A SMALL NATION IN THE TURMOIL OF THE SECOND WORLD WAR 
STUDIES IN SOCIAL AND ECONOMIC HISTORY

Volume 35 


\title{
A Small Nation in the Turmoil of the Second World War
}

\author{
Money, Finance and Occupation \\ (Belgium, its Enemies, its Friends, 1939-1945)
}

HERMAN VAN DER WEE \& MONIQUE VERBREYT 


\section{FUS}

Uitgegeven met de steun van de Universitaire Stichting van België.

Published with the support of the Research Fund of Leuven University.

Original title: De Nationale Bank van België 1939-1971. Boekdeel 1 - Oorlog en monetaire politiek: de Nationale Bank van België, de Emissiebank te Brussel en de Belgische regering, 1939-1945.

(c) 2005 Dutch language edition by Nationale Bank van België.

(C) 2009 revised and translated edition by Leuven University Press / Presses Universitaires de Louvain / Universitaire Pers Leuven. Minderbroedersstraat 4, B-30oo Leuven (Belgium).

All rights reserved. Except in those cases expressly determined by law, no part of this publication may be multiplied, saved in an automated datafile or made public in any way whatsoever without the express prior written consent of the publishers.

ISBN 9789058677594

$\mathrm{D} / 2009 / 1869 / 30$

NUR: 696-688

Translation from Dutch: Frank Parker

Lay-out: Typeface n.v., Leuven

Cover: Jurgen Leemans

Illustration cover: detail of Otto Dix, Der Krieg (Das Geschütz), 1914

(“museum kunst palast” Düsseldorf - C SABAM, Belgium 2009) 
To our grandchildren:

Gillis and Tuur Van der Wee

Elisa and Laura Lievevrouw

That their lives may never be overshadowed by war.

'Je reste troublé par l'inquiétant spectacle que donnent le trop de mémoire ici, le trop d'oubli ailleurs, pour ne rien dire de l'influence des commémorations et des abus de mémoire - et d’oubli. L'idée d'une politique de la juste mémoire est à cet égard un de mes thèmes civiques avoués'

Paul Ricoeur, La mémoire, l'histoire, l'oubli. 



\section{Contents}

PREFACE

CHAPTER 1

PRELUDE TO A NEW WORLD CONFLICT 17

The policy of neutrality under discussion $\quad 17$

The problem of governing under occupation $\quad 21$

Getting the gold stock to safety $\quad 25$

CHAPTER 2

THE BLITZKRIEG AND THE BANQUE NATIONALE DE BELGIQUE 33

The German invasion 33

Rising war panic $\quad 38$

Ostend, a confused episode $\quad 40$

The peregrination through France $\quad 43$

CHAPTER 3

FRANCE AND THE MONETARY CRISIS

The capitulation and its monetary consequences $\quad 47$

The search for scapegoats 50

Emotion and frustration among the Belgian refugees 53

$\begin{array}{ll}\text { The Bank under tutelage } & 59\end{array}$

CHAPTER 4

$\begin{array}{ll}\text { A RUDDERLESS BELGIAN GOVERNMENT } & 61\end{array}$

$\begin{array}{ll}\text { The evacuation of Belgian gold from France } & 61\end{array}$

The dramatic discussion of 18 June 1940 at Bordeaux 65

A Belgian government in its death throes 72

The Bank's return to Brussels $\quad 74$ 
CHAPTER 5

IN THE AFTERMATH OF BELGIUM'S WAR DRAMA IN FRANCE 79

$\begin{array}{ll}\text { Ingenbleek's 'finest hour' } & 79\end{array}$

Theunis's despair $\quad 82$

Final efforts to evacuate the gold $\quad 85$

The cost of the peregrination in France 92

CHAPTER 6

THE INSTALLATION OF THE GERMAN ADMINISTRATION 93

Dislocation and the 'new order' 93

'Le temps des notables' 100

The bankers' initiative for a bank of issue 103

CHAPTER 7

THE ESTABLISHMENT OF THE BANQUE D'EMISSION 109

$\begin{array}{ll}\text { The decisive negotiations } & 109\end{array}$

The Bank and the Banque d'Emission $\quad 115$

$\begin{array}{ll}\text { The principal actors of the two banks } & 118\end{array}$

CHAPTER 8

THE POLITICS OF ACCOMMODATION IN DAILY REALITY 127

$\begin{array}{ll}\text { The distribution of responsibilities } & 127\end{array}$

$\begin{array}{ll}\text { The challenge to legal competence } & 129\end{array}$

The economic, social and political context in 1940 and 1941

Money circulation 139

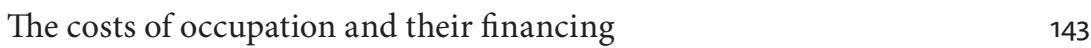

CHAPTER 9

THE POLICY OF ACCOMMODATION PUT TO THE TEST 149

$\begin{array}{ll}\text { The commandeering of gold and foreign currency } & 149\end{array}$

$\begin{array}{ll}\text { The fraudulent clearing system } & 155\end{array}$

$\begin{array}{ll}\text { The first crisis of the clearing system } & 160\end{array}$

Janssen and the German occupier 164 
CHAPTER 10

$\begin{array}{ll}\text { THE LOOTING OF GOLD } & 167\end{array}$

$\begin{array}{ll}\text { The prelude } & 167\end{array}$

$\begin{array}{ll}\text { Janssen misled } & 169\end{array}$

The Wiesbaden Convention (29 October 1940) 176

The supplementary protocol of 11 December $1940 \quad 179$

The aftermath of the repatriation 186

$\begin{array}{ll}\text { The restoration of Luxembourg's gold } & 191\end{array}$

CHAPTER 11

IN THE SHADOW OF JANSSEN'S DEATH 195

The problem of the succession $\quad 195$

$\begin{array}{ll}\text { A new administration } & 197\end{array}$

The first great disillusions 200

Occupation and economy (May 1940-May 1942) 205

CHAPTER 12

THE GOLD COVER AND THE CLEARING SYSTEM

$\begin{array}{ll}\text { UNDER DISCUSSION } & 207\end{array}$

The dilemma concerning cover for the note issue 207

Towards a confrontation with the Ministry of Finance 210

The clearing system in discredit 213

The motion of 24 September 1941

The motion of 7 January 1942

The mission to Berlin (24-28 March 1942) 225

CHAPTER 13

THE INSTALLATION OF THE BANQUE NATIONALE DE BELGIQUE

IN LONDON 231

The establishment of a Belgian government in London 231

The financing of the Belgian government in London 233

The Bank in London and its protagonists 237

Baudewyn's difficulties at his installation in London $\quad 239$ 
CHAPTER 14

THE BANQUE NATIONALE DE BELGIQUE IN LONDON IN THE MAELSTROM OF WAR

The loan of gold to Great Britain 243

The decrees of 27 November $1941 \quad 249$

The reactions in Belgium 253

Goffin's appointment and the outside world 257

CHAPTER 15

THE PROCEEDINGS AGAINST THE BANQUE DE FRANCE

IN NEW YORK $\quad 263$

$\begin{array}{ll}\text { The cause } & 263\end{array}$

The French attempts to achieve an amicable solution $\quad 269$

The problem of the Luxembourg gold 274

The legal proceedings: worth the candle? 280

CHAPTER 16

THE PAYMENT ORDERS 'LAUT BESONDERER MITTEILUNG' 283

Incorporation into the German war economy 283

Towards the agreement of 5 May $1942 \quad 287$

The reappearance of the Reichskreditkassenscheine 290

Cracco's memorandum and its consequences 291

CHAPTER 17

THE CREATION OF A UNITED FRONT

The resolutions of 16 October 1942

$\begin{array}{ll}\text { The dramatic interview with Reeder } & 301\end{array}$

Reeder's order for immediate payment $\quad 305$

CHAPTER 18

THE RUPTURE OF THE UNITED FRONT 311

Preparations for the negotiations of 18 November 1942

The negotiations of 18 November 1942

The arrangement of 25 November 1942

The question of successors for Berger and Van Nieuwenhuyse 323 
CHAPTER 19

TOWARDS THE END OF THE OCCUPATION

The turn of the tide in military affairs 327

The Belgian economy at the end of the occupation 331

Anxious years for the staff and for the Bank 335

$\begin{array}{ll}\text { Cracco's Emissiebank certificates } & 340\end{array}$

CHAPTER 20

THE LIBERATION IN SIGHT

The final skirmishes with the Bankaufsichtamt 345

The export of banknotes to France 349

Monetary differences and disputes with the Netherlands and Germany 352

The preparations for post-war monetary reform 355

The final days of the occupation 359

CHAPTER 21

PREPARATION IN LONDON FOR POST-WAR BELGIUM 361

$\begin{array}{ll}\text { The establishment and start of the CEPAG } & 361\end{array}$

Baudewyns' proposal becomes the Gutt plan 364

The Belgian discussions about the exchange rate and currency reform $\quad 368$

CHAPTER 22

THE BUILD-UP TO POST-WAR INTERNATIONAL COOPERATION 375

From the Dutch-Belgian-Luxembourg monetary agreement to BENELUX 375

The Franco-Belgian and the Anglo-Belgian monetary agreements $\quad 379$

CHAPTER 23

BELGIUM AND THE NEW ECONOMIC WORLD ORDER 385

Belgium and the Bretton Woods agreements of 22 July 1944

The banknotes for the army of liberation and for the currency reform 391

The organization of the Bank's return to Belgium 393

CHAPTER 24

THE RETURN FROM LONDON 395

The great settling of scores $\quad 395$

$\begin{array}{ll}\text { Governor Theunis in Brussels } & 401\end{array}$

The closure of the Belgo-French gold dossier 403 
CHAPTER 25

BACK TO NORMALITY 413

The completion of the Belgo-French reconciliation 413

The Gutt Operation (6 October 1944) 417

CHAPTER 26

THE END OF AN ERA

The currency reform in action $\quad 425$

Criticism and evaluation $\quad 432$

CHAPTER 27

THE COMMISSION OF ENQUIRY AND THE LEGAL INVESTIGATION 441

$\begin{array}{ll}\text { Installation and start } & 441\end{array}$

The Commission's report 443

Reactions $\quad 445$

The prosecutor's decision and its aftermath $\quad 449$

$\begin{array}{ll}\text { EPILOGUE } & 453\end{array}$

$\begin{array}{ll}\text { SOURCES } & 461\end{array}$

1. Public Archives $\quad 461$

2. Private Archives 463

3. Interviews 464

$\begin{array}{ll}\text { BIBLIOGRAPHY } & 465\end{array}$

$\begin{array}{ll}\text { LIST OF ABBREVIATIONS } & 479\end{array}$

$\begin{array}{ll}\text { INDEX } & 481\end{array}$ 


\section{Preface}

War, occupation and liberation are phenomena that have a very specific character. In the first place, minor incidents are experienced much more intensely and self-consciously than similar incidents in peacetime. Indeed, a population caught up in them has the sense of being involved in 'the making of history', following the unfolding drama of war with acute interest, bearing the attendant misery with courage, sometimes being wracked by fear, and not infrequently - through resistance or collaboration - playing an active part in the exceptional circumstances.

In the second place, the unfolding of events in war conceals a certain paradox. On the one hand, military action and occupation disrupt normal communication and consequently reduce daily life to the microlevel of village or town, causing social life to turn in on itself and concentrate on the bare essentials. On the other, they generate complexity at macro-level. The normal interaction of necessity, coincidence and freedom in the historical process is, in fact, seriously compromised: during a war, the predictable, structured element in the course of history appears weaker; in contrast, coincidence plays a greater part and there is increased scope for the creative, unpredictable contribution of strong personalities. All this leads to a new and more complex combination of driving forces on the macro-stage of history.

The history of Belgian central banking during the period from 1939 to 1945 reflects this paradox, making the writing of this narrative an enthralling task and at the same time posing a great challenge for the authors. To this was added the serious problem of the source material. The archives that have been preserved in Belgium and abroad are unusually rich and the general writings on the Second World War - a necessary source if the history of Belgian central banking was to be placed in its correct, historical context - are myriad. As a result, selection was the order of the day, but the question remained of whether the information processed was representative. In fact, ensuring representativeness was the constant and guiding principle for the authors in their 
choice of what to include. Lastly, there was the fact that, during the war, the Banque Nationale de Belgique and the Banque d'Emission were under great pressure and had to cope with tense relationships with all kinds of bodies in both occupied and unoccupied territories. In order to ascertain the true circumstances of all these tensions, it was often necessary to dig deep, the aim always being to unravel as fully as possible the complexity of the situations examined and to take account of all the variables that came into play. This proved to be no simple task and goes to explain the book's substantial size. In the English edition, there has been a degree of pruning: detailed explanations about internal developments in Belgium have been shortened and a large number of notes - chiefly in respect of quotations that served only to underpin the text - have been excised.

As far as we know, few academic works see the light of day just in consequence of the merits of their authors. In writing this particular book, we, too, have been able to count on the cooperation of a wide circle of people and on the confidence that they have placed in our work. It will surprise no-one that our thanks go first to Guy Quaden, Governor of the Banque Nationale de Belgique, and in particular to Luc Coene, Deputy-governor: not only were they, together with Alfons Verplaetse, former governor of the Bank, the originators of the project, but they also secured us the unvaluable support of Luc Ghékiere, Secretarygeneral, aided by Ivo Maes and Jean-Percey Cassiers. Coordinating the overall project - which, besides our book, included a further three volumes that take the story up to 1971 - was Walter Pluym, ever assiduous and willing. Olivier Boehme, and in particular Joseph Makart, made our archive research within and outside the Banque Nationale a great deal more effective.

We were also able to rely on excellent help in our research into foreign archives: guiding us through the Dutch archives were Dr. Sierk Platinga, Dr. Christiaan Rupert, Geert Lamfers, Corry van Renselaer and Hélène De Muy-Fleurke; through the American archives, the late Dr. Milton Gustafson; and through the archives of the Bank of England, Dr. Anne Fremault, Archivist Sarah Miljard and Deputy-Archivist Jenny Ulph. The fact that we did not lose the thread in the endless 
documentation of the French archives we owe to Michel Margairaz, Olivier Feiertag, Fabrice Reuzé, and Jean Quinet, and to mesdames Bordogna, Pagès, Cueille and Bouttier. For our research into the German archives, we were able to turn to Professor Manfred Pohl and Dr. Martin Müller. In our home country, we had the unconditional support of Madeleine Jacquemin, Françoise d'Arras d'Haudrecy, Françoise Peemans and Caroline Six, as well as their colleagues Dr. Dirk Luyten, René Brion, Jean-Louis Moreau and Mark Van Pottelberghe. A special word of thanks goes to Tony Vandeputte, who spoke to us about his father, Robert Vandeputte, a former governor of the Banque Nationale.

We are deeply indebted to the Research Fund of Leuven University, in particular to its Vicerector Research Policy Professor Dr. Paul De Boeck and its Senior staff member Research Policy and secretary of the Research Council Ms. Josée Houben, and to the University Foundation at Brussels, in particular Ms. Hilde Garmyn, for their generous help for the English edition. Our warmest thanks also to Mrs. An Delva for sharing with us her rich experience in the world of book illustrations, and to Leuven University Press, its Chairman and Board of Directors, and in particular Ms. Marike Schipper, Director, Ms. Beatrice Van Eeghem and Ms. Nienke van Schaverbeke, who assisted us most friendly and efficiently with the publication of the book. Finally, we owe a great debt to Professor Peter Mathias, who was so kind to go over the English manuscript. We all know that he is un homme de lettres as well as un homme de science: his critical reading and relevant annotations of the translation, indeed, enhanced style and transparency of the text substantially. We are most grateful to him for this invaluable help.

Researching sources over a period of more than five years can be a lonely task, even when two people are doing the work together. For this reason, the authors are particularly grateful for the months of hospitality they received at various institutions, where staff and colleagues demonstrated an interest in their work and encouraged them in their research. Delightful months were spent at the Netherlands Institute for Advanced Study in the Humanities (NIAs) at Wassenaar, at the Wissenschaftskolleg zu Berlin (Institute for Advanced Study), and at the Wissenschaftszentrum Berlin für Sozialforschung. In this respect, the authors 
owe a very substantial debt of gratitude to Professor Emeritus Henk L. Wesseling and Dr. Wouter Hugenholtz, respectively Honorary Rector and Director of the NiAs, to Professor Dieter Grimm and Dr. Joachim Nettelbeck, respectively Rector and Director of the Wissenschaftskolleg zu Berlin, and to Professor Jürgen Kocka and Dr. Dagmar Simon, respectively President and Director of the Wissenschaftszentrum. Our debt of gratitude also extends to the staff of those institutions for the outstanding technical and administrative help that they provided.

The authors also wish to thank a number of institutions that kindly made available their rich collections of archives and documentation on the war period: firstly, the Banque Nationale de Belgique in Brussels; then the Algemeen Rijksarchief in Brussels, the archives of the Royal Palace, the Studie- en Documentatiecentrum 'Oorlog en Hedendaagse Maatschappij' (CEgesoma), the Ministry of Foreign Affairs, the Generale Maatschappij van België, the Krijgsauditoraat, the Université Catholique de Louvain (Louvain-la-Neuve) and the Kredietbank (now квС Group). They also greatly valued the access they were allowed to the private archives of the Ansiaux, Baudewyns and Berger families.

Abroad, they were extremely hospitably and efficiently received at the Algemeen Rijksarchief, the Ministry of Foreign Affairs and the Ministry of Finance in The Hague, the Nederlandsche Bank in Amsterdam, the National Archives in Washington, D.C., the Herbert Hoover Institute on the campus of Stanford University at Palo Alto (California), the Bank of England in London, the Banque de France in Paris and the Deutsche Bank in Frankfurt-am-Main.

Heartfelt thanks go to Mr. and Mrs. William and Livine Van de Velde and Mr. and Mrs. Theo and Nicole Erauw, who gave us unrestricted use of their holiday home, a place where we could work undisturbed, as if on an uninhabited island, and where we could live in the peace of nature. Finally, and with sadness, the authors thank the late Ms. Simone Verbreyt for the invaluable help she gave in organizing the documentation for the book: she expected so much of the book, but, alas, she was not destined to see it in print.

Herman Van der Wee and Monique Verbreyt 'De Hettinghe', 4 May 2009 


\title{
Prelude to a New World Conflict
}

\author{
THE POLICY OF NEUTRALITY UNDER DISCUSSION
}

The inter-war years (1918-1939) proved to be a very difficult period for one Belgian institution in particular; this was the National Bank of Belgium (referred to simply as 'the Bank' in what follows). A chaotic government policy failed to curb war inflation after peace was concluded in 1918. The Belgian franc therefore remained under pressure, progressively losing ground on both the domestic and international exchange markets against the American dollar and the pound sterling, the two international reserve currencies at the time. The Bank took action and used its powers of persuasion in an effort to reverse the situation, but to no avail; the cause appeared to be lost.

Moreover, during the last years before the Second World War, Belgian politics were characterized by contradictions, confusion and impotent drift. Within the span of less than four years - from June 1936 to the outbreak of war in September 1939 - six different governments took office ${ }^{1}$. Each of them was plagued by sharp tension between the two main language communities and by fierce discussions on the monetary policy to be pursued. Monetary policy even to become one of the major themes in the parliamentary elections of April 1939. In those elections, Camille Gutt, who in February had become Minister of Finance in the first Pierlot government (1939), continued his opposition to an eventual new devaluation of the Belgian franc, the previous one having been de-

1 For a comprehensive analysis of the activities of the Bank during the inter-war years, see: H. Van der Wee and K. Tavernier, La Banque Nationale de Belgique et l'histoire monétaire entre les deux guerres mondiales, Brussels, 1975, Chapters 1-7. For two excellent surveys of Belgian politics during the inter-war period, see: T. Luyckx, Politieke geschiedenis van België van 1789 tot heden, Brussels, 1973, and more recently, E. Witte, J. Craeybeckx, and A. Meynen, Politieke geschiedenis van België van 1830 tot heden, Brussels, 2000. 
cided in 1935. At the same time, Gutt rejected the franc being pegged to sterling, as that would in fact represent an implicit, albeit concealed, devaluation; moreover, it would undermine the country's policy of neutrality, which, in the uncertain international climate then prevailing, could be detrimental to a small country like Belgium. However, the retention of a stable franc required a deflationary policy that, in his opinion, could only be effectively accomplished through higher taxation².

In the new, second Pierlot government (1939), Gutt was again Minister of Finance. Intelligent and active, Gutt was, above all, thorough, efficient and resolute ${ }^{3}$. He did not easily forget when he felt his pride had been injured by someone, the clearest illustration of this being the rancour he harboured against former Prime Minister Van Zeeland, who in 1935 had devalued the Belgian franc by 28 per cent, against the policy of Gutt. In ideology, Gutt was a conservative liberal, with clear-cut ideas that he defended obstinately ${ }^{4}$. His public image was of a stoic and selfconfident technocrat, and hinted at a vigorous and committed personality ${ }^{5}$. Without doubt, he was the strong man - the dominant figure, even - in the Belgian government in exile in London, though that was not yet the case in 1939 .

Besides the monetary question, a further point of sharp difference within the Belgian government during 1938 and 1939 was the policy of neutrality, a question that arose from the increasing concern in international circles about a possible second world war. King Leopold III deemed it his duty to keep Belgium out of any new world conflict and consistently pursued a policy of strict neutrality ${ }^{6}$. This policy was energetically supported by Spaak, a personal friend of the King ${ }^{7}$ and by

2 In this respect, see the important contribution of: J.-Fr. Crombois, 'Finance, économie et politique en Belgique à la veille de la Seconde Guerre Mondiale, 1933-1940', in: Bijdragen tot de Eigentijdse Geschiedenis, 1998, 5, pp. 171-206.

3 A. Van de Voorde, De penningmeesters van de Wetstraat, Tielt, 1993, pp. 140-142.

4 Charles de Gaulle was to describe Gutt's efforts in London during the Second World War as 'l'ardeur de Gutt' (Dumoulin, Spaak, pp. 213-214).

5 De Staercke, Memoires, pp. 143-144.

6 In this respect, see particularly: J. Velaers and H. Van Goethem, Leopold III. De koning, het land, de oorlog, Tielt, 2001, pp. 44-66.

7 Memorandum of 09.10.1944 from J. Webb Benton, United States Consul-general in Leopoldville, with an account of a conversation between Edwin W. Martin, Viceconsul, and Leopold Lowy, a journalist active in Belgium before the war and at the 
then already an influential politician. He headed the government from May 1938 to February 1939 and thereafter, until the outbreak of the Second World War, was Minister of Foreign Affairs in the successive Pierlot governments. However, not all his colleagues shared Leopold and Spaak's views: certain members of the Pierlot cabinets were, indeed, bitter opponents of the neutrality policy. The ensuing differences of opinion were one cause of the dilatory, inadequate and uncoordinated character of preparations for the looming onset of war.

The King and the government continued officially to hold to the neutrality policy after the German invasion of Poland and the outbreak of the Second World War on 3 September $1939^{8}$. However, everyone was now convinced that, with any broadening of the conflict, Belgium would more than likely become one of the next victims. In an ultimate attempt to save his neutrality policy, the King appointed expremier Theunis, a close friend of Gutt, as ambassador extraordinary to the United States, with the dual task of firstly seeking support from a sister spirit, one that also regarded independence and neutrality as top priorities, and secondly of organizing the procurement of armaments and food for Belgium, should the situation get out of hand and she be drawn into the conflict 9 .

The government, on its part, proceeded to a general mobilization. Army strength was raised to about 600 ooo men, efforts were made to modernize military equipment and to increase its production, public

time agent in Leopoldville for the Bunge Corporation of New York; the conversation concerned the pre-war political situation in Belgium (Washington, National Archives, fonds Belgium).

8 French requests for military contacts to be organized and, later, for permission to send troops to Belgium's south-eastern border were refused. In September 1939, however, Spaak began cautiously to adjust his attitude towards Belgium's policy of neutrality to the new circumstances: 'Notre intérêt belge rejoint ici nos sentiments. Il faut rester, malgré notre neutralité, du côté franco-anglais' (Dumoulin, Spaak, Brussels, 1999, p. 136).

9 Writing about this in 1966, Gutt stated: 'Dès septembre 1939....nous sentîmes le besoin de renforcer notre représentation diplomatique. Nous songeâmes au rôle qu'avaient joué les Etats-Unis dès avant leur intervention militaire par la création de la "Commission for Relief", puis par leur formidable contribution en hommes et en matériel à la victoire finale. Or, notre représentation à Washington était, pour employer un mot modéré, faible' (вNB, Archives, Diverse documenten: 'Georges Theunis (Souvenirs de Camille Gutt)', 11.07.1966, p. 45). 
works to reinforce the country's defences were carried out at an accelerated tempo. The question now arose of how the government was to finance the sudden and considerable increase in public expenditure. Oscar Plisnier, Secretary-general of the Ministry of Finance ${ }^{10}$, and the members of the Economic Committee that had been set up within the Bank during the first month of hostilities ${ }^{11}$, were unanimous in their opinion that the only possible solution to the problem was a combination of additional government loans (with the logistical support of the Bank), new or higher taxes and direct advances from the Bank to the State. In their view, the advances would inevitably have the side effect of fuelling inflation, but that could be neutralized by loans and taxation ${ }^{12}$.

Notwithstanding the pressure on public finances the Belgian franc, even after the outbreak of the war, held its own on foreign exchange markets, as indeed did the American dollar, unlike the French franc and sterling, both of which did less well. There was thus no reason for disquiet on that front, but there was a question about what would happen to the link between the Belgian and the Congolese franc, should Germany occupy Belgium. The latest report of the Banque du Congo Belge had indicated to the Bank that this problem was being discussed in the colony, as well; it even tentatively asked whether it would not be better in that circumstance for the link to be abandoned. The Bank became concerned about the future of the national currency and consulted Léon-Hugo Dupriez, Professor at the University of Leuven and economic adviser to the Bank since 1938.

10 See the text of a lecture given by Plisnier at the Université Libre de Bruxelles on 18.01.1940: S. Brutsaert, Oscar Plisnier, Louvain-la-Neuve, 1993, pp. $119 \mathrm{ff}$.

11 The economic committee consisted of the members of the Bank's board of directors plus J. Van Nieuwenhuyse, Secretary of the Bank, P. Kauch, Private Secretary to the Governor, leading officials of the Bank - more particularly J.-J. Vincent, head of the Economic Research Department, and F. Cracco, a member of that department - and a number of external experts, more particularly Professors L.-H. Dupriez, economic adviser to the Bank since 1938, and B.S. Chlepner; as well as F. De Voghel (the then Secretary of the Banking Commission): BNB, Archives, SD, Malaise Papers, dossier 11: P. Kauch, La Banque Nationale pendant la seconde guerre mondiale (unpublished text), Part 1, Chapter.1, $\$ 2$. See also: De toestand en de verrichtingen der Emissiebank te Brussel tijdens de Duitsche bezetting. Verslag van het Onderzoekscomité, opgericht bij Besluitwet van 11 december 1944. Eerste deel (published text), Brussels, 1946, p. 7.

12 Van der Wee and Tavernier, De Nationale Bank, pp. 334-335. 
Dupriez submitted his report in early $1940^{13}$. He deemed it most undesirable and - particularly for Belgium - highly disadvantageous for the link between two currencies that had always had the same parity to be dropped, and put forward two arguments in support of this. The first was monetary in that, should hostilities escalate, the colony would enjoy an unprecedented economic boom, a consequence of its favourable location and its wealth of raw materials. In the colony, national income would rise quickly and the trade balance would record results never previously seen. The financial world would regard the uncoupling of the two currencies at such a time as indicating a lack of confidence on the part of the Belgian government in the national currency. The second argument had a colonialist undertone: 'It's perfectly legitimate that Belgium would take advantage of the colony's gains to overcome its present difficulties : it's just a compensation for all the sacrifices Belgium made in favour of its colonies'.

\section{THE PROBLEM OF GOVERNING UNDER OCCUPATION}

But how was the country to be governed under an occupation? For the government, and indeed for the Bank, too, this was a much more insistent question and caused great confusion within government circles ${ }^{14}$. Led by Minister Marcel-Henri Jaspar, certain members of the government advocated implacable opposition ('opposition irréductible'), taking the view that, should the Germans invade, central, provincial and local authorities ought to move to an unoccupied area or even abroad. This would confront the enemy with a complete administrative vacuum, hindering him in his attempts to plunder the country. However, the majority of government members felt that such a strategy was unrealistic and declared for rolling resistance ('résistance mobile'), arguing that a complete evacuation of the authorities would be impossible were the enemy to advance as quickly as had been the case in Poland.

The international crisis around the German annexation of the Sudetenland in September 1938 had led to discussions in the Bank concern-

13 BNB, Archives, Studiedienst, dossier 01.02.02.70.

14 BNB, Archives, $S D$, dossier 11: Kauch, La Banque Nationale (unpublished text), Part 1, Chapter. 1, pp. 17-18. 
ing the organization of the administration should there be war. Governor Janssen had then already requested the members of the board of directors to draw up suggestions for this eventuality. In the opinion of the board, one of the essential tasks of the Bank was to underpin the national economy; consequently, the Bank ought to pursue its normal activity in Belgium, were the country to be occupied. At the same time, however, the Bank would also continue to fulfil two other essential functions. In the first place, it would carry on supporting the government, even if it was forced to leave the country: in other words, the Bank would provide help to the government in exile through its material presence. Secondly, the Bank would have its possessions and assets abroad managed and safeguarded autonomously through a presence in unoccupied territory.

Upon the outbreak of the Second World War on 3 September 1939, the board of directors began to alter its original strategy; from January 1940, indeed, the Bank took a pronouncedly combative stance. Voicing its views through its Economic Committee, it now fell closely in line with the ideas of Jaspar ${ }^{15}$. An important reason was the disturbing news filtering through from Poland, which awoke memories of the brutality of the German invasion in Belgium during the summer of 1914, barely a quarter of a century earlier. However, it was in all likelihood the growing tension between the King and the Cabinet that proved to be the decisive factor in the changing attitude of the Bank ${ }^{16}$. Leopold's continuing pursuit of a policy of strict neutrality and his simultaneous obstinate and personal intervention behind the scenes was a source of intense irritation to the government and resulted in Jaspar and the other ministers that advocated a 'scorched earth' policy gaining a great deal of influence. The pressure that they brought to bear led to a government decree being issued on 2 February 1940, whereby, in case of war and for the duration of hostilities, Belgian trading companies (of which the Bank was one by definition), were permitted to transfer their registered office and the administration of their company or institution abroad. Should the country be occupied, directors who remained in the

15 In this respect, see the minutes of the meeting of 29.02.1940 (quoted by Kauch: BNB, Archives, $S D$, Malaise Papers, dossier 11: Kauch, La Banque Nationale (unpublished text), Part 1, Chapter. 1, p. 16, footnote 14).

16 D’Ydewalle, De Memoires, pp. 168-169. 
occupied areas would cease to have any authority whatsoever in respect of assets in the unoccupied areas and would no longer be competent to perform any executive act, even in the occupied area. ${ }^{17}$. Taking its cue from this, the Economic Committee drew up a detailed administrative regulation on 29 February $1940^{18}$.

A policy of implacable opposition was now adopted by the Economic Committee, too. The Governor and all directors but one, the supervisory council and the board of scrutineers would follow the government into exile where they would continue to function as normal. The Postal Cheque Office would follow suit, as indeed would all the country's semi-public credit institutions. The Bank would give a limited trust commission to one or more members of the staff remaining in Belgium and those persons would represent the Bank in respect of the occupier and protect the Bank's interests still in Belgium ${ }^{19}$. Counters would be closed in both Brussels and the provinces. All the stock of banknotes and the entire equipment for producing them would be evacuated to safety, as would the Bank's currency reserves and securities, as well as all securities deposited with the Bank by third parties.

The Bank's changing stance had been viewed with increasing disquiet by the private bankers and on 18 January 1940 Willy de Munck, Chairman of the Banque de la Société Générale, and Max-Léo Gérard, Chairman of the Banque de Bruxelles, had an initial discussion about it with Governor Janssen ${ }^{20}$. By then, it had already become clear that, should the country be occupied, the head-office services of the Bank would follow the government abroad, although it was still thought in financial circles that the Bank's local branches in occupied territory would continue to operate.

When, shortly afterwards, the regulation of 29 February was made known, and it was seen that the Bank's 'master plan' included the closure of all the Bank's branches in the occupied areas, the private bank-

17 Belgian Official Gazette, 7.02.1940, No. 38.

18 BNB, Archives, sD, Malaise Papers, dossier 11: Kauch, La Banque Nationale (unpublished text), Part 1, Chapter. 1, pp. 14-16.

19 'Entretiens avec Hubert Ansiaux, I. L'or et les valeurs de la Banque Nationale dans la tourmente de 1940', in: Revue Générale, February 1985, p. 7.

20 BNB, Archives, Dossiers officiels après 1945, dossier 13: letter of 08.02.1940 from Janssen to Gérard and de Munck. 
ers deemed it a matter of the utmost urgency to talk with the Bank again. They came, not only to express their concern, but also to air their indignation at such a deficient view of reality. Furthermore, they stated that, were the country to be occupied, they could not abandon their essential function of providing support for the Belgian economy. How could they go on with their task if the Bank were to evacuate the stock of banknotes and, moreover, to suspend all the activities of its branches in occupied territory? The consequence of such a policy could be nothing less than a general moratorium on payments ${ }^{21}$.

Janssen, Gutt and Dupriez appreciated that such a hopeless situation could arise and proposed a solution whereby the Bank's branches in occupied territory would not be closed, though without being able to supply the private banks with new banknotes ${ }^{22}$. Janssen and Dupriez felt that they could assume that there were sufficient liquid resources in the country - private income generated by recent, high government expenditure and the mass withdrawals of cash from the banks had been largely tucked away in the face of the threat of war, but would in time resurface and normalize the day-to-day circulation of money ${ }^{23}$. The private bankers regarded this as an unrealistic assumption; for them, it was a question of having the additional cash available during the emergency and not after it. As a result, no definitive agreement was reached ${ }^{24}$. All that Janssen and Gutt did was advise the private bankers to provide

21 BNB, Archives, Dossiers officiels après 1945, dossier 13: letter of 08.02.1940 from Janssen to Gérard and de Munck.

22 No minutes were taken, but Dupriez made a summary of the conversations, which Kauch quoted in a footnote in his historical review: 'Afin d'éviter toute équivoque à cet égard, la Banque ne peut laisser du côté de l'occupant des organes pouvant avoir l'apparence de comité de direction ou de conseil de régence. L'organisation de la Banque en territoire occupé devrait reposer: a) sur des délégations de pouvoirs assez larges accordées aux agents locaux, en vue de faire face aux besoins financiers du pays occupé, ce système étant d'application aussi bien à Bruxelles qu'en province; $b$ ) sur une coordination de l'action des agences occupées, sous l'égide de personnalités compétentes, se réunissant en comité de surveillance' (BNB, Archives, SD, Malaise Papers, dossier 11: Kauch, La Banque Nationale (unpublished text), Part 1, Chapter. 1, p. 42, footnote 56 ).

23 BNB, Archives, Dossiers officiels après 1945, dossier 13: note résumant l'entretien du mardi 24 septembre 1940 entre M. le Gouverneur et M. Henri Rolin (première atténuation de la solution radicale de l'évacuation).

24 Van der Wee and Verbreyt, De Generale Bank, p. 243. 
their branches with an additional stock of banknotes and state that the Bank would give them all possible help ${ }^{25}$.

\section{GETTING THE GOLD STOCK TO SAFETY}

Besides taking these administrative measures, the Bank began in 1938 to make additional provisions to secure its buildings, protect its staff and transfer the gold stock and other assets. The idea of evacuation was not new, as people in Belgian government circles had already given thought to getting the Bank's stock of gold to safety at the time Hitler came to power in 1933 in Germany. Governor Georges Janssen, however, now went a step further: not just the gold stock of the Bank needed to be evacuated, but also the other securities which the Bank held on its own behalf or in safe custody on behalf of the State and other third parties.

Director Louis-Jean Mahieu, was charged with preparing and organizing the transfer abroad and was aided by Henri Sontag, Treasurer of the Bank, and Hubert Ansiaux, an inspector at the Bank. By 31 March 1938 already, Sontag was able to put forward a proposal for the organization of the evacuation, were the armed forces to be mobilized ${ }^{26}$. For his part, Janssen contacted the Bank of England and paid a visit to London on 12 March 1938, i.e. shortly after becoming governor. He raised the question whether the Bank of England would be prepared to take into safe custody the gold, government funds and other securities belonging or entrusted to the Bank. The answer, albeit with a few peripheral conditions, was yes and the first gold ingots began to be transferred from Brussels and Antwerp to London as early as the following $J_{u l y}{ }^{27}$.

25 BNB, Archives, SD, Malaise Papers, dossier 11: Kauch, La Banque Nationale (unpublished text), Part 1, Chapter. 1. See also: SD, dossier 11bis (preparatory measures and studies). See also: BNB, Archives, Studiedienst, dossier 01.02.01.70 (A 247/6): quelques rétroactes relatifs aux circonstances qui ont provoqué la création de la Banque d'Emission à Bruxelles; NBB, Dossiers officiels après 1945, dossier 13: note résumant l'entretien du mardi 24 septembre 1940 entre M. le Gouverneur et Henri Rolin.

26 BNB, Archives, Schatbewaarder, 1, dossier 02.01.02.04 (D 536/7): note du 31.03.1938.

27 BNB, Archives, Schatbewaarder, 1, dossier 02.01.02.04 (D 536/7): note du trésorier Sontag, 26.09.1938. 
By 24 September 1938, 151,00o kilograms of Belgian gold, valued at 7,323 million Belgian francs, had already been deposited in the vaults of the Bank of England in London; it represented 22 per cent of the total stock, which amounted to 686,000 kilograms ${ }^{28}$. The Governor of the Bank viewed this as only a first step and in the following December contacted the Minister of Finance Albert-Edouard Janssen and discussed with him the Bank's plan to amend the geographical distribution of the gold stock as follows: one-third of the stock would remain in Belgium, one-third would be deposited in safe custody in Great Britain and one-third would be transferred to North America (the United States or Canada, or both) ${ }^{29}$.

The minister agreed with the proposal, but requested further information in order to have well-grounded arguments to convince his government colleagues, who would not be in favour of such a substantial transfer abroad. In his supplementary memorandum, the Governor pointed out that, with a world war in prospect, all the major central banks of Western Europe, including those of Great Britain, France, the Netherlands and Switzerland, had spread their gold stocks geographically and had already sent much of them overseas to safety. For Belgium, the best overseas option was North America, either the United States or Canada. In each case, there were advantages and disadvantages. Should there be war, the United States would undoubtedly be the prime supplier of all types of goods, ranging from military stores and materials to food for the population, and New York was a focal point for international payments. The big disadvantage lay in the fact that Belgium had ceased to service the debts she had incurred in the United States during the First World War and the government in Washington could well retaliate by freezing or even confiscating the Bank's gold. No such risk existed were the gold to be deposited in Canada, more particularly Ottawa, although Canada at that time did not boast an important financial centre. The Governor's personal opinion was that the United States was the better option, but he demanded that the gov-

28 BNB, Archives, Schatbewaarder, 1, dossier 02.01.02.04 (D 536/7): note du trésorier Sontag, 26.09.1938, pp. 2-3.

29 BNB, Archives, Boekhouding, 1, dossier 601/1: minutes of the board of directors, 17.12.1938; minutes of the supervisory council, 21.12.1938. 
ernment absolve the Bank from any responsibility should there be any freezing or confiscation of these assets ${ }^{30}$.

Albert-Edouard Janssen gave the Governor's proposal his full support, but he was unable to convince the government to adopt it. Discussion dragged on and no definitive decision was reached. When, upon the formation in February 1939 of the first Pierlot government, Gutt assumed office as Minister of Finance, the Governor immediately renewed his offensive, in order to win the new minister over to his plan. The two reached an agreement fairly rapidly and it was now only a matter of convincing the other members of the government. Again, this proved to be no easy matter. The resistance apparent in the previous government was still in evidence in the new cabinet ${ }^{31}$ and the same arguments - monetary and political in nature - were once more deployed against moving part of the gold stock to the United States. The monetary argument rested on the fact that the Bank's bye-laws laid down that, to ensure confidence and security, at least 40 per cent of the money in circulation be covered by gold, of which a minimum 30 per cent had to be in metallic gold, the rest eventually in currencies convertible to gold. In a system of convertibility like the one still applied in Belgium, this requirement implied the actual material presence of the supportive assets in the country. In uncertain times like the present, how was one to respond to a massive demand for gold in exchange for cash if a substantial proportion of the gold stock had been evacuated overseas? The political argument concerned the policy of strict neutrality that Belgium was pursuing. Evacuation of two-thirds of the gold stock to the United States and Great Britain would be interpreted by Germany as a violation of that neutrality, as a hostile act against Germany, a highly desirable pretext for the Nazis to invade Belgium ${ }^{32}$.

To escape from this impasse, Governor Janssen altered his original idea $^{33}$ and proposed to Gutt to halve the amount of gold to be sent to

$30 \mathrm{BNB}$, Archives, $S D$, 56, dossier 0.1, 'or' (généralités): note sur la répartition géographique de l'or, 31.12.1938.

31 BNB, Archives, Boekhouding, 1, dossier 601/1: letter of 22.03.1939 from Gutt to Janssen.

32 'Entretiens avec Hubert Ansiaux, I. L'or et les valeurs de la Banque Nationale dans la tourmente de 1940', in: Revue Générale, February 1985, p. 7.

33 BNB, Archives, Boekhouding, 1, dossier 601/1: letter of 20.03 .1939 from Janssen to Gutt, p. 1. 
North America to about 3 billion Belgian francs' worth and add the balance to the Bank's stock in Brussels; in this way, the 30 per cent quota required by the bye-laws would be respected ${ }^{34}$. However, he continued to insist that a deposit of gold in the United States and in Great Britain was of crucial importance for the protection of the national currency, and he put forward two arguments to underpin his view. The first was that, as Belgium was holding fast to the gold standard, it was not unthinkable that, in the uncertain political situation of the time, the franc would come under pressure in New York and London; a local deposit of gold could relieve that pressure, as indeed had recently happened in Great Britain. The second was that, if war broke out, the Belgian government could well find itself needing the deposits in order to have access to foreign currency and credit abroad. It was clear that the latter argument was of a confidential nature. Indeed, the supervisory council would never countenance such an initiative, as the purpose of the stock of gold was to enable the Bank to carry out its statutory tasks. A final obstacle was the cost of transport and insurance to transfer the gold to the United States, a cost that had become prohibitive as a result of the political situation. The Bank had already requested the previous government to intervene with the Compagnie Maritime Belge to insist on special, favourable rates, but the government had not responded. The Bank would be able to count on greater cooperation from Gutt ${ }^{35}$.

Seeking to break the resistance of a section of the government, Gutt suggested that, for the moment, the transfer be limited to what the Bank deemed technically necessary for the adequate defence of the Belgian franc on the New York money market ${ }^{36}$. At the same time, he proposed that the transfer of gold to Great Britain be temporarily increased, so that, in effect, the stock of gold in Belgium would be reduced to one-third of the total and the transfers to the United States and Great

34 BNB, Archives, SD, 56, 1, dossier 0.1, 'or' (généralités): letter of 20.03.1939 from Janssen to Gutt, p. 2: 'Ultérieurement il avait été envisagé de conserver en Belgique la couverture métallique nécessaire à assurer une circulation de trente milliards. Cela réduisait le dépôt d'or à constituer aux Etats-Unis à quelques trois milliards'.

35 BNB, Archives, SD, 56, dossier 0.1, 'or' (généralités): letter of 20.03.1939 from Janssen to Gutt, pp. 2-3.

36 BNB, Archives, SD, 56, dossier 0.1, 'or' (généralités): letter of 22.03.1939 from Gutt to Janssen. 
Britain would together amount to two-thirds of it ${ }^{37}$. Thanks to Gutt, the transfer of gold resumed at the end of March 1939: to London by aeroplane and by packet boat, to New York by packet boat.

As the international situation worsened, however, Belgium felt increasingly threatened, especially when, at the beginning of November 1939, there were signals from Berlin indicating an imminent attack ${ }^{38}$. On 8 November, Gutt - still Minister of Finance, but now in the third Pierlot government (1939-1940) - contacted Governor Janssen for additional precautionary measures to be taken regarding the gold still at the Bank, including the gold entrusted to the Bank by third parties, in particular by the Banque du Congo Belge, the Treasury and the Caisse d'Epargne du Grand-Duché de Luxembourg. On 9 November, it was agreed that gold to the value of about 4,00o million Belgian francs be entrusted for safe keeping to the French central bank (Banque de France) ${ }^{39}$. Two days later, on 11 November, Gutt requested the Bank to evacuate a further 2,00o million Belgian francs' worth of gold to France ${ }^{40}$. Nine days later, Governor Janssens was able to report to him that gold pieces and ingots valued at 5,938 million Belgian francs and packed in crates had been deposited in the vaults of the Banque de France at Bordeaux and Libourne ${ }^{41}$.

Pierre Fournier, the Governor of the Banque de France, had accepted the deposit, but not according to the formula Janssen had requested, namely that it would be 'earmarked', the customary procedure for

37 This can be deduced from the minutes of the meeting of the supervisory council, 29.03.1939 (BNB, Archives, Boekhouding, 1, dossier 601/1).

38 Dumoulin, Spaak, pp. 140-142.

39 BNB, Archives, Boekhouding, 1, dossier 601/1: letter of 10.11 .1939 from Janssen to Gutt.

40 BNB, Archives, Boekhouding, 1, dossier 601/1: letter of 11.11.1939 from Gutt to Janssen.

41 BNB, Archives, Boekhouding, 1, dossier 601/1: letter of 20.11 .1939 from Janssen to Gutt. The breakdown was as follows: $1^{\circ}$ securities belonging to the Bank: 9,640 gold bars (weight: 116,360.8 kg; value: 3,862,422,285 Belgian francs) and sundry gold pieces (joint value: $1,905,085,500$ Belgian francs); $2^{\circ}$ securities belonging to the Banque du Congo Belge: 410 gold bars (weight: 5,147.8 kg; value: $170,872,357$ Belgian francs). See also: BNB, Archives, Hoofdkas, dossier 25.02.04.00 (G 503 and G 504); BNB, Archives, Inspectie, dossier 22.00.00.00 (G 373/3). See also: G. Cornu, L'or monétaire au vingtième siècle. En marge de l'histoire de la Banque de France: aventures de l'or monétaire, Paris, 1981, p. 164. 
transactions between central banks ${ }^{42}$. Fournier could not accept that procedure, as the urgency of the matter precluded a detailed verification of the contents of the sealed crates. The Banque de France was prepared officially to acknowledge only the 'number' of crates delivered with the seals intact, and further to accept the declaration of the depositor regarding the content of the crates and its value.

On 18 April, Gutt pressed the Bank to evacuate the remaining stock of gold in Belgium to France. Janssen promptly agreed, but the supervisory council was unresponsive and asked whether it would not be safer to evacuate all the gold to the United States. Janssen pointed out that it was now much too late to put forward such a suggestion: transport and insurance costs for shipping gold from Europe to North America had meanwhile become prohibitive, thereby completely precluding the option, and the risk of freezing these assets, and even confiscation, remained a vexed question in the United States. According to information received by Janssen, Danish and Norwegian gold had been frozen there as soon as the two countries were in a state of war $^{43}$.

Table 1.1: Geographic spread abroad of the gold stock of the BNB (10 May 1940) (value in Belgian francs)

Deposited in safe custody with the Bank of England, London:

Placed in bond with the Banque de France:

$10,662,955,799.85$

Deposited in safe custody with the Federal Reserve Bank, New York: $7,323,429,547.14$

Deposited in safe custody with the South African Reserve Bank:

$5,106,797,796.85$

$289,775,512.77$

Total:

$23,382,958,656.61$

Source: BNB, Archives, Boekhouding, 2, file 88.02.02.00 (B 608/14)

The measures taken meant that, on the eve of the German invasion, there was virtually no further gold of the Bank in the strong-rooms at

42 The term 'earmarked gold' used by central bankers in gold transactions between themselves referred to the certainty regarding the perfect quality of the gold traded, as officially laid down by the central banks. Certainty was arrived at through a detailed and guaranteed control of the gold bars in respect of their number, weight, fine-gold content and the like, upon delivery to one of the central banks.

43 BNB, Archives, $R R, 24.04 .1940$. 
Brussels or elsewhere in Belgium ${ }^{44}$. However, the situation was totally different in respect of the mass of banknotes, bank paper and securities that, at the moment of invasion, was still held in the Bank's vaults and that likewise had to be evacuated ${ }^{45}$. To evacuate this mass, too, out of the country also proved to be no mean task.

44 According to a memorandum drawn up in 1950, the final fifty-four crates of gold bars and nineteen crates of gold coins were transferred by the Bank to France on 11.05.1940: the delivery was valued at 104.6 million Belgian francs, of which 69.4 million for gold belonging to the Bank, 33.2 million for gold sold to the Bank by the Reichsbank on 9 May, 1.2 million for gold belonging to the BIS and 0.8 million for gold belonging to the Banque du Congo Belge. On 12 May, a further ninety crates were evacuated to France from Ostend: these concerned gold bars belonging to the Caisse d'Epargne du Grand Duché de Luxembourg (BNB, Archives, Schatbewaarder, 1, dossier 02.01.02.06 (536/8.2): étude relative à l'évacuation éventuelle des encaisses et valeurs essentielles, 1950).

45 Of relevance here was the stock of coins of the Bank and the Mint, the stock of banknotes at the main cash office and at the branches, the banknotes laying ready for issue, the banknotes being printed and the stock of banknote paper, the plates and dies and other printing equipment, the securities of the State funds and othe securities belonging to the Bank, the securities in respect of the various accounts held by the State at the Bank, and the securities belonging to various public institutions (twenty in total), but deposited in safe custody or in pledge at the Bank: BNB, Archives, Schatbewaarder, 1, dossier 02.01.02.06 (536/8.2): étude relative à l'évacuation éventuelle des encaisses et valeurs essentielles, 1950). 



\section{CHAPTER 2 \\ The Blitzkrieg and the Banque Nationale de Belgique}

\section{THE GERMAN INVASION}

In the small hours of 10 May 1940, a spring day that brought the sun with it, German fighting units poured across the south-eastern border of Belgium: the feared attack was under way. For Hitler, it was a new phase in his obsessive plan to reorganize the political and socioeconomic face of Europe into a Groszraum under German hegemony. The time of European nation states - in his view, a time of destructive, mutual conflicts and murderous economic competition - was dead and gone. What the Führer proposed in their place was a new entity, a unified Europe under German leadership that, by means of a well considered dirigiste policy, would grow to become a zone of organized autarchy, thereby regaining Europe's status as a dominant world power ${ }^{1}$. A necessary first step in the realization of this grand idea was war, but not a long war of attrition like that of 1914-1918, which would only give the enemy the opportunity to regroup and catch up in the arms race. In Hitler's strategy, it would be a short and successful Blitzkrieg, a war that would have the great advantage of sparing German territory and the German population, with an army committing itself effortlessly to an ultimate deployment of power; to paraphrase Mussolini: 'War alone brings to its highest tension all human energy and puts the stamp of nobility upon the peoples who have the courage to meet it'.

The German ground attack between Liège and Malmédy was supported by a massive air attack all over the country. A wave of panic swept over the population. Schools were closed and, except for anxious

1 A. Milward, War, Economy and Society, 1939-1945, London, 1975, pp. 1-17.

2 Milward, War, Economy and Society, p. 6. 
listening to the radio's continuous stream of alarming news, the activity of most citizens was restricted to frenetic hoarding and to queuing at the private banks to withdraw their deposits. The banks, however, were closed over the Whitsun weekend of Saturday 11 May and did not open again until the following Tuesday morning, May 14. Although the private banks had a stock of approximately 2 billion Belgian francs in banknotes on the eve of the German invasion, they awaited the reopening of their counters after the weekend with trepidation. The panic withdrawals, in fact, continued and cash reserves became exhausted in some private banks ${ }^{3}$.

In order to prevent the situation descending into chaos, the government, in consultation with the bankers, had, by decree of 13 May, issued a moratorium on paying out bank deposits; withdrawals were thenceforth limited to a maximum of 5,000 Belgian francs per account per fortnight, though the banks were allowed to make exceptions under certain conditions. On 15 May, a moratorium was also instituted on paying-out commercial paper ${ }^{4}$.

Prior to this, the Belgian government had already taken other measures in response to the crisis. At an emergency meeting on 10 May, it had promulgated a series of important decrees, including a number bearing on monetary and financial matters 5 . The gold convertibility of the franc was suspended and a mandatory rate of exchange set for paper money in circulation; nothing was done in respect of the Bank's obligation to maintain a minimum gold cover of $40 \%$. The control on foreign exchange transactions- set in place for the first time on 17 March 1935 and suspended in April of the following year - was reinstated ${ }^{6}$ and the

3 At the meeting of the executive committee of the Bank van de Société Générale on 15 May, for example, the chairman de Munck reported that there was a shortage of banknotes in the branches of Charleroi and Mons: SG, Archives, DC, 15.05.1940.

4 Janssens, De Belgische frank, pp. 285-286.

5 BNB, Archives, AV, 30.06.1945, report by the board of scrutineers for the 1940-1944 financial years, prepared on behalf of the supervisory council, p. 10. See also: Janssens, De Belgische frank, pp. 285-286.

6 In connection with this, a decree of 14 May was to impose an obligation on all inhabitants to declare all their holdings of gold and foreign currency to the Exchange Institute (BNB, Archives, $S D$, Malaise Papers, dossier 9.5.11/ s. f. 4: Kauch, rapport au Roi, 20.12.1943, p. 5). See also: BNB, Archives, AV, 30.06.1945: report by the board of scrutineers for the 1940-1944 financial years, prepared on behalf of the supervisory council, p. 11. 
stock markets were closed until further notice'. Lastly, the government authorized the Minister of Finance to conclude with the Bank all regulations that might be necessary to obtain additional credit.

As was to be expected, the renewal of the control on foreign exchange transactions brought problems in its wake. On 11 or 12 May, the Banque de France in Paris informed Governor Janssen by telephone that Belgian refugees who had crossed the border in the Ardennes were trying to exchange Belgian banknotes for French, and requested a regulation in that respect ${ }^{8}$. Moreover, it wanted the arrangements with Belgium to be linked to the Franco-British Reynaud-Simon monetary agreement of 4 December 1939. In that agreement, France and Great Britain had determined a fixed rate of exchange for their two currencies for the duration of the war and, as allies, had undertaken to grant each other lines of credit to promote and underpin mutual economic cooperation'.

At the beginning of May 1940 free market rates of up to 173.04 French francs to 100 Belgian were being quoted on the Brussels Exchange and in Northern France, compared to the then official rate of 143.425 French francs to 100 Belgian $^{10}$. In the telephone discussion of 11 or 12 May with Janssen, the Governor of the Banque de France, Fournier, declared that he was prepared to accept the exchange of banknotes at the official rate of exchange; now that Belgium had called on the French army for help and French troops operating in Belgium would necessarily need Belgian money, there would be an offset between the money requirements of the French army in Belgium and those of Belgian refugees in France, so that the exchange rate risk for the Bank had become virtually non-

7 H. Willems and F. Buelens, 'De Tweede Wereldoorlog en de Belgische Beurzen', in: M. de Keizer et al., eds., Thuisfront, Oorlog en Economie in de twintigste eeuw, 2003, p. $149 \mathrm{ff}$.

8 BNB, Archives, $D C$ : 12.12.1944: memorandum from Baudewyns. Due to the advance of French and British troops to the Belgo-Dutch front, the borders remained officially closed to non-military traffic until 13 May inclusive: BdFr, Archives, Secrétariat Général, dossier 1060.2001.01/38, 'or belge': letter of 13.08.1940 from A. de Brouckère ( $\mathrm{Pau}$ ) to the Banque de France (Châtelguyon); note sur les opérations traitées aux guichets de la Banque de France par les réfugiés belges, 29.08.1940).

9 BNB, Archives, $S D$ : P. Kauch, note sur les opérations de change de francs belges et de francs français lors de la fuite des belges en France et de leur rapatriement (unpublished text), Chapter. 1, pp. 1-3.

10 BNB, Archives, Boekhouding, Dossier 88.02.02.00 - B 610/1-5 
existent $^{11}$. In order to resolve this thorny question, Gutt and Spaak on 13 May travelled to the French Ministry of Finance in Paris.

The Belgian and French ministers rapidly reached an accommodation and, after consultation with London, it was also accepted that Belgium would accede to the Reynaud-Simon monetary agreement of 4 December 1939. On the following day, 14 May, Gutt and his French counterpart Félicien Lamoureux signed an interim Franco-Belgian monetary agreement whereby the two countries declared themselves prepared to grant credits to each other: the French Treasury opened an interest-free line of credit in the amount of 500 million French francs in favour of the Belgian Treasury, which in turn opened an interest-free line of credit in the amount of 340 million Belgian francs in favour of the French. Further details would be included in a subsequent, definitive agreement and a similar agreement would be signed with Great Britain in the near future. Debts arising out of the credit lines granted would be settled at exchange rates of 147.2 French francs to 100 Belgian francs and 1 pound sterling to 120 Belgian francs ${ }^{12}$; the rates would remain in force for the duration of the war and could be changed only by mutual agreement ${ }^{13}$.

11 BNB, Archives, DC, 12.12.1944: memorandum from Baudewyns.

12 According to an indication by Hubert Ansiaux, it was only from 17.05.1940 on that there was any extensive exchange of Belgian money into sterling in Great Britain: exchange was at a rate of 1 pound sterling to 120 Belgian francs, with a maximum permissible amount of 10 pounds per person per week: BNB, Archives, Studiedienst, dossier 01.02.01.70 (A 247/6): memorandum of 28.08.1942 from Dussart to Kauch. Although the French pushed for a rapid conclusion of a provisional Anglo-Belgian monetary and financial agreement on the same lines as the Franco-Belgian agreement, and although the Bank of England indicated that it would have no objection, there was opposition from the British Treasury. Sir David Waley, while agreeing in principle, wanted first thoroughly to examine the text of the Franco-Belgian agreement, which is why assent to an Anglo-Belgian agreement came only later, probably on 16 May (BEngl, Archives, Belgium, dossier OV88/3: telephone conversation of 14.05.1940 with Philips (Paris); letter of 14.05.1940 from Waley to Cobbold).

13 BNB, Archives, SD: Kauch, note sur les opérations de change, Chapter.1, p. 7. The agreement regarding the mutual granting of credit lines never came into force, due to the changed military circumstances, and was in fact superseded in this respect by the Franco-Belgian agreement of 7 June (BNB, Archives, SD: Kauch, note sur les opérations de change, Chapter. 2, p. 11, footnote 28). See also: V. Janssens, De Belgische frank, p. 287. 
However, the exchange rate that the ministers had set between the French and Belgian francs proved unacceptable to the Banque de France, which, on 15 May, notified its branches that the rate of 144.4 French francs to 100 Belgian it had announced on 9 May remained in force ${ }^{14}$. The Belgian government made a vague protest, but to no avail ${ }^{15}$. The Bank appeared to accept neither of the rates, as, that same day, the board of directors resolved that only small quantities of banknotes presented by French soldiers would be exchanged, and then only at the pre-war free market rate of 172.4 French francs to 100 Belgian. At Gutt's express request, the Bank fairly quickly relaxed its stance ${ }^{16}$ and on 16 May announced that French military personnel could exchange banknotes up to an amount of 25,000 French francs per person at a rate of 144.4 French francs to 100 Belgian, but that the rate of 172.4 French francs to 100 Belgian would remain in force for private individuals. On the other hand, and with chiefly the safeguarding of the Bank's gold reserves in mind, the board of directors urged the Banque de France to restrict the exchange of Belgian banknotes for French to the maximum of 5,000 Belgian francs per account per fortnight ${ }^{17}$.

The provisional arrangement of 16 May with Great Britain was also received with a certain degree of displeasure on the part of the Bank. In the same way as France had supported Belgium militarily, Great Britain had sent a great number of troops to the continent and, again like France, looked to obtain as favourable an exchange rate as possible for her military forces' spending in Belgium. In consequence, the Bank of England was not prepared to accept the unfavourable free market rate of 1 pound sterling to 101.675 Belgian francs that had been quoted on the Brussels Exchange just prior to its closure. It wanted the official rate of 1 pound sterling to 120 Belgian francs to be applied. On 11 May, it notified

14 BNB, Archives, Studiedienst, dossier 01.02.01.70 (A 247/6): letter of 28.08.1942 from Dussart to Kauch; Janssens, De Belgische frank, p. 287.

15 BNB, Archives, SD, 36, Service étranger, dossier 8.11.30/1: activité du service des changes et du service étranger, 10 mai 1940-31 décembre 1941 (rapport au comité de direction); Janssens, De Belgische frank, p. 287.

16 BNB, Archives, $S D$, 49, dossier 8.13.11/ s. f. 1: 'période de guerre, correspondance 20 mai 1940-30 mai 1940': letter of 28.05.1940 from Janssen to Gutt.

17 BNB, Archives, Studiedienst, dossier 01.02.01.70 (A 247/6): letter of 28.08.1942 from Dussart to Kauch. 
the Bank by telephone that British forces would exchange their pounds at the official rate, but that there would be a limit of two pounds per soldier $^{18}$. After discussion with Governor Janssen, Gutt declared himself in agreement with the rate proposed by the Bank of England ${ }^{19}$.

\section{RISING WAR PANIC}

Since the invasion, a rising sense of unease about the course of military operations had prevailed at the Bank in Brussels. The management of the Bank, therefore, judged it wise to make all haste to complete the evacuation of Bank's holdings of gold, as well as all other valuables it held $^{20}$. On 15 May, the government decided to leave Brussels and establish itself at Ostend. Gutt requested the Bank to transfer its registered office to where the government was retreating and to carry out its monetary tasks there. The Bank decided that Governor Janssen, Deputygovernor Ingenbleek and Director Baudewyns would follow the government to Ostend. Director Goffin and the Treasurer Sontag were to remain in Brussels. Thirty-three members of the head office staff were detailed by the board of directors to follow the management to where it was decamping ${ }^{21}$. Various semi-public institutions, including the Postal Cheque Office and other public services such as the Banking Commission were to follow, as were a number of secretaries-general, or their representatives, with part of their administration.

Once the government had resolved to quit Brussels, it invited leading figures from the world of banking to the Ministry of Finance to discuss with Gutt and the Minister of Foreign Affairs Spaak how affairs were to be managed in the occupied area of the country after the government's departure. Only Alexandre Galopin, Governor of the Société Générale, Max-Léo Gérard, Chairman of the Banque de Bruxelles, and Fernand Collin, Chairman of the Kredietbank, were in a position

18 BNB, Archives, $S D$ : Kauch, La Banque Nationale (unpublished text), Part 1, Chapter. 2, p. 32, footnote 40. See also: BNB, Archives, sD: Kauch, note sur les opérations de change, Chapter. 1, pp. 6-7.

19 BNB, Archives, SD: Kauch, note sur les opérations de change, Chapter. 1, pp. 6-7.

20 Between 11 and 14 May gold was sent to France by Ansiaux under rail convoy (BNB, Archives, Boekhouding, dossier 88.02.02.00 - B 610/1-5).

21 BNB, Archives, DC, 15.05.1940. 
to participate in the discussion. Gutt notified the three of the decision regarding the imminent departure of the government and added that a substantial proportion of government institutions and the central administrative framework would follow the government to Ostend and, in the event, abroad. Because a departure on this scale would create a large administrative vacuum in the occupied territory, particularly in respect of public finances, Gutt requested the bankers to assume responsibility for the payment of the wages and salaries of the public sector employees who remained behind, and, to that end, handed Galopin a blank cheque from the Treasury ${ }^{22}$.

The discussion in Gutt's bureau revealed once again with what incomprehensible ignorance the Belgian government faced the war. Galopin sought in vain for a guiding principle among those in authority remaining in Belgium, whether in the public or the private sector. What attitude was he and his colleagues to adopt toward the German occupier, he asked, now that the departing government had resolved to pursue a scorched earth policy as regards politics and administration ('stratégie de vide politique et administrative')? Surely it was not the government's intention to abandon the population unprotected to the occupier or, as Galopin put it, 'You don't want us, after all, to turn Belgium into a cemetery?' That was certainly not what was wanted by the ministers, who accepted that concessions had to be made to the occupier, but gave no indication as to what they were. How this thorny question was to be dealt with they left to the wisdom and courage of those in authority remaining behind ${ }^{23}$. Spaak ended the discussion with the rhetorical declaration that was later to cause so much controversy, 'Gentlemen, we entrust you with Belgium'²4.

22 Van der Wee and Verbreyt, De Generale Bank, pp. 243-246.

23 Quoted by R. Brion and J.-L. Moreau, La Société Générale, 1822-1997, p. 333.

24 UCL, Archives, fonds A.-E. Janssen, dossier 200B/10: letter of 30.08 .1946 from Collin to A.-E. Janssen and letter of 11.07.1946 from Gérard to A.-E. Janssen. See also: UCL, Archives, fonds A.-E. Janssen, dossier 200B/11: letter of 05.01.1947 from Velge to A.-E. Janssen. A great deal has been written about the exact scope of the request by Gutt and Spaak to the three bankers to follow-up the economic development of the country prudently. It is very certain that no details were discussed - indeed, there was no time for that - and nothing was set down in writing. The discussion nevertheless followed the direction indicated above. For more details of the entire debate, see particularly: M. Van den Wijngaert, L'économie belge sous l'occupation. La politique d'Alexandre Galopin, gouverneur de la Société Générale, Brussels, 1990. 


\section{OSTEND, A CONFUSED EPISODE}

Governor Janssen and Baudewyns left for Ostend on 16 May, together with the government, and Ostend automatically became the place where the Bank's registered office was established ${ }^{25}$. The very next day, the Germans marched into Brussels. Before this happened, Sontag and Ansiaux had worked feverishly at head office to move the last securities and the printing equipment out of the capital, and to safeguard the cash stocks and securities of the branches that, in accordance with the evacuation plan, had in an initial phase been transferred to Brussels from the south and east of the country ${ }^{26}$.

The evacuation of the branches went far from according to plan. In many cases, the transfer was a chaotic affair, even though, miraculously, it was completed successfully ${ }^{27}$. In the final instructions from head office before the German invasion, the branch managers had been told to stay at their posts for as long as possible before bringing their cash stocks and securities to Brussels or Ostend under escort from the local gendarmes. The rapid advance of the German troops stymied that flow, as did the fact that, in certain cases, the gendarmes withdrew without alerting the local branch. Thus, abandoned totally to their own devices, the managers had to find secure transport. They could call on the local military commandant to requisition the necessary lorries. Where that was not possible, they had to get out as best they could, using whatever means of transport they could lay their hands on. Once transport was secured, they then had to make their way between the advancing or retreating armies and the swarms of refugees that clogged the roads everywhere. On top of that, they had to run the gauntlet of German fighter planes in search of military convoys. They arrived sporadically at head office in Brussels, some of them, including the managers from

25 BNB, Archives, Boekhouding, dossier 88.02.02.00 (B 608/12): France 1940. Inventaires, évacuation, rapatriement (ordre de service du 17 mai, signé par Goffin).

26 In this respect, see the reports of the agents about their evacuation: BNB, Archives, Inspectie, dossier 22.00.00.00 ( $\mathrm{G}$ 373/4): rapports d'évacuation des agences de la BNB.

27 The agents' reports contain interesting details about this: BNB, Archives, Inspectie, dossier 22.00.00.00 (G 373/4): rapports d'évacuation des agences de la BNB. 
Tongres, Nivelles and Mons, having had to abandon branch premises destroyed or damaged by bombardment ${ }^{28}$.

In the early afternoon of 15 May, Ansiaux left Brussels for Ostend for the last time, accompanied by a few lorries packed chiefly with unissued banknotes and the stocks of cash that had arrived from the local branch managers in the south of the country ${ }^{29}$. It was only in the early morning of the following day that he arrived with his consignment at the branch in Ostend. Confusion reigned there, too. Considerable quantities of cash were arriving from the branches in the north and centre of the country, that from Antwerp even in a number of commandeered hearses, for want of other means of transport. There was naturally insufficient manpower to inventory everything accurately and, moreover, the labels of many sacks and crates had been torn or lost.

Governor Janssen was in a sombre mood. He had learned from Gutt that the military situation was hopeless and that the government would soon decamp: in Gutt's words, "It's a disaster, the government will leave for France, either to Le Havre, or further south ${ }^{30}$. Following this bad news, Janssen convened an emergency meeting of the board of directors at the Ostend branch on the morning of Friday 17 May, in order to discuss what course of action the Bank ought now to take ${ }^{31}$. It was resolved that the Governor should follow the Minister of Finance and that Baudewyns should leave immediately for Paris and there contact the Banque de France. In the early morning of 18 May, the government resolved to leave forthwith for Le Havre, its departure from Ostend having been hastened by a night bombardment of the town. The following day, Gutt and Governor Janssen arrived in Paris, where Janssen accepted the hospitality of the Banque de France, in whose premises he established the Bank's registered office ${ }^{32}$.

28 BNB, Archives, $R R$, review of 1940. See also: Tijdschrift voor het personeel van de $N B B, 1958,6$, pp. $1-6$.

29 'Entretiens avec Hubert Ansiaux, I. L'or et les valeurs de la Banque Nationale dans la tourmente de 1940', in: Revue Générale, February, 1985, p. 10; Ansiaux, Souvenirs, 1990, pp. 48-50.

$30 \mathrm{KP}$, Archives, fonds Leopold III, 58: Ingenbleek, mon journal de guerre, p. 2.

31 BNB, Archives, DC, 17.05.1940.

32 BNB, Archives, $S D$, 36, Foreign Department, dossier 8.11.30/1: activité du service des changes et du service étranger, 10 mai 1940 - 31 décembre 1941 (rapport au comité de direction, Chapter. 1). 
When Ostend came under renewed bombardment later in the day, Ingenbleek deemed it time to get the staff and most of the cash stocks deposited at the branch there to safety in Le Havre. Greater urgency was given to his decision by the news, just received, that the German army was successfully forcing a breakthrough to the north French coast, so that Belgium would probably very soon be cut off from France. The task now facing Ansiaux, left behind in Ostend, was hopeless ${ }^{33}$. The load still to be evacuated consisted of 281 crates, weighing approximately forty tonnes. Apart from a few staff from head office, he had virtually no one left; much worse was the fact that he had only one lorry with which to transport the entire load. The day before, 17 May, he had been in contact with the port authority, which was then in the hands of the French military, and had found a willingness to help; but the port lay deserted and no further ships were expected to arrive, so that no salvation could be expected from that quarter.

With Sunday 19 May dawning, the situation had become hopeless. By amazing good fortune, however, a Belgian coastguard vessel bearing the number A4 sailed into Ostend from Dunkirk at around six o' clock that evening and Ansiaux was able to convince the local Belgian Naval commander to make the ship available. Initially, the A4 hugged the Belgian coast. As it approached Nieuwpoort, however, the port of Dunkirk came into sight, ablaze; the rudder was thrown over and the vessel headed out into the open sea. The following morning, the A4 reached the Thames estuary, where the British Admiralty instructed it to sail on to Folkestone. From Folkestone, the A4 was directed to Dartmouth and from there to Plymouth, where transport to London would be provided ${ }^{34}$. At last, on the morning of 26 May, the vessel tied up in Plymouth harbour. Under the watchful eye of Ansiaux, the valuable crates were unloaded onto the quay and transported to the vaults of the Bank of England. Ansiaux had carried out his remit with flying colours.

33 For what follows, see: 'Entretiens avec Hubert Ansiaux, I. L'or et les valeurs de la Banque Nationale dans la tourmente de 1940', in: Revue Générale, February, 1985, pp. 11-12. See also: Ansiaux, Souvenirs, pp. 53-55; J. Pluym, 'Geld aan boord', in: Connect (NBB staff magazine), May 2002, pp. 21-22. See also: Private Archives of Ansiaux Jr.: 'Evacuation de l'encaisse à Ostende'.

34 BNB, Archives, Studiedienst, dossier 01.02.00.10 (A 230/4): quelques renseignements recueillis concernant les évacuations des encaisses de la Banque Nationale. 


\section{THE PEREGRINATION THROUGH FRANCE}

The evacuation of the cash stocks and valuables of the local branches to France was a very tortuous affair, particularly the first stage to Le Havre. Once again, progress was hindered by clogged roads, numerous diversions and incessant bombardment. Furthermore, the convoy assembled in Ostend lost some of its cohesion, so that a number of branch managers were thrown onto their own resources and had to resort to a great deal of improvisation in order to reach Le Havre. The majority of the convoy finally reached the agreed place of assembly at Sainte-Adresse near Le Havre around 21 May; there they were awaited by Ingenbleek and directed further to $\mathrm{Caen}^{35}$, where they met Bastiné, a deputy-general manager of the Bank, and Pierre Kauch, the Governor's private secretary. These two organized convoys destined for Tarbes in southwest France ${ }^{36}$, where the Banque de France had placed the strong-room of its branch there at the Bank's disposal to deposit the cash stocks; between 21 and 29 May, no less than thirty of the Bank's forty-two branch managers made use of this facility ${ }^{37}$. This brought the number of staff and family members in Tarbes and its surroundings to $240^{38}$. Fortunately, the staff had received three months' pay in advance upon their departure from Belgium, a gesture that was repeated on the instructions of Bastiné in Caen ${ }^{39}$.

35 For a detailed account of the wandering of a large number of these agents, see their reports in: BNB, Archives, Inspectie, dossier 22.00.00.00 (G 373/4): rapports d'évacuation des agences de la BNB mai-juin 1940. See also: the diary of a member of staff, Walter Patoor (NBB, war diary of Walter Patoor).

36 BNB, Archives, Inspectie, dossier 22.00.00.00 (G 373/4): rapports d'évacuation des agences de la BNB, mai-juin 1940.

37 BNB, Archives, Inspectie, dossier 22.00.00.00 (G 374/4): rapport consécutif à l'évacuation de l'encaisse de nos agences, 10.06.1940; BNB, Archives, $S D$, Ingenbleek Papers: le problème de la vie sous l'occupation, Chapter. 4, p. 11.

38 BNB, Archives, Boekhouding, dossier 88.02.02.00 (B 608/12): France 1940. Inventaires, évacuation, rapatriement (these figures also included the staff in Toulouse, but not the staff at Mont-de-Marsan; in total, 344 members of staff were repatriated in July-August to Belgium: see below).

39 BNB, Archives, Inspectie, dossier 22.00.00.00 (G 373/4): rapports d'évacuation des agences de la BNB, mai-juin 1940 (report of the agent J. Leleux of the Ath branch, 30.05.1940). See also: BNB, Archives, $S D$, 49, dossier 8.13.11/ s. f. 3, 'période de guerre, correspondance du 6 au 10 juin 1940': letter of 06.06.1940 from Baudewyns (Paris) to Van Nieuwenhuyse (Mont-de-Marsan)). 
As already mentioned, Janssen, accompanying Gutt, had left Ostend for Paris on 18 May, in order to establish the Bank's registered office there. No less important, though, was the matter of the provisional monetary agreement of 14 May, which now had to be given definitive form. The matter had become exceptionally urgent, as the number of Belgian refugees in France was now enormous, the government putting it at nearly two million ${ }^{40}$. It was probable that there were, in fact, only about a million or somewhat more Belgian refugees actually in France and that the government estimate wrongly included the approximately 800,000 Belgian refugees in West Flanders and a part of East Flanders ${ }^{41}$, but this still meant that more than one million refugees in France were looking to exchange Belgian francs for French.

Consequently, the French banks were inundated with requests to convert Belgian money into French, something that gave Janssen and Baudewyns extreme cause for concern about the future of the gold reserves that had been deposited with the Banque de France. Conversion on a massive scale would result in a sharp increase in the quantity of Belgian banknotes in the hands of the Banque de France. Buying them in with gold, the only method normally permitted, would severely diminish the Belgian gold deposit in France or even jeopardize it completely.

For his part, Gutt was well aware that he would be in sore need of French $\mathrm{credit}^{42}$. In the first place, he had to finance the expenditure of

40 BNB, Archives, Boekhouding, dossier 88.02.02.00 (B 608/11): memorandum concerning the expenditure of the Pierlot government in Belgium and in France, 10 May-15 August 1940, p. 1. This figure was endorsed by the Dutch envoy in Brussels, who had kept a close track of the Belgian government during its peregrination through France: Ndl.Bz, London Archives 1940-1945, GA, G II, België ${ }^{\circ}$ 2: letter of 29.05.1940 from van Harinxma thoe Slooten (Poitiers) to van Kleffens (London). In 1941, the French authorities were even speaking of between two and three million Belgian refugees (BdFr, Archives, Direction de la documentation, dossier 1397.1994.01/71: séance du 4 octobre 1940, relative à l'or belge.

41 Robert Vauchez, 'Le Drame belge', an article published in the newspaper Le Soir at the end of 1940, in which he wrote: 'Aujourd'hui, le rapatriement (de France) de plus d'un million de belges est presque terminé' (Ndl.Bz, Archives, dossier 'London': Belgium).

42 According to a memorandum drawn up during the summer of 1940, the Bank, as State cashier paid out a total of 1,692,142, 547.27 Belgian francs for account of the government between 10 May and 15 August: BNB, Archives, Boekhouding, 88.02.02.00 (B 608/11). 
the armed forces in France and also provide for the maintenance of the reserve of recruits, the tens of thousands of young men between the ages of sixteen and thirty-five who were not yet in the armed forces, but whom, during the first days of the invasion, the government had sent to the south of France, pending their joining the Belgian troops. Moreover, the government had granted the refugees a subsistence benefit and had to pay the salaries of the numerous officials who had fled to France. The government had also agreed to provide cash advances to persons who could prove that they had money in their post office account, and continued to pay pensions and invalidity benefits to refugees qualifying for them ${ }^{43}$. Lastly, it had to build up an administrative structure in France, continue to maintain the diplomatic services abroad and continue to service foreign debt ${ }^{44}$.

In fact, the only major assets that the government could use as collateral for credit were the gold deposit of the Bank and the quantity of foreign currency, gold pieces, securities and other valuables that refugees and businesses had brought to France. There was, thus, a dual concern of not allowing the gold deposit to shrink too much and of keeping private assets out of the hands of the French government.

The government and the Bank had also to take account of the financial interests of the refugees, who were very unhappy about the exchange rate that had been accepted with the Franco-Belgian agreement of 14 May, i.e. 144.4 French francs to 100 Belgian, a parity considerably different to the market rate of 9 May, which was 173.04 French francs to 100 Belgian. The new situation, whereby the decrees of 10 May had abolished transactions on the free market, so that only the official rate continued to apply, was perceived by the refugees as a drastic devaluation of the Belgian currency. As a result, they felt that they were suffering a considerable loss every time they exchanged money and that their government had let them down. On top of that, the Bank had agreed with the Banque de France on 18 May that, with effect from the follow-

43 ARA, fonds ministerie van Financiën, Plisnier Papers, dossier 2 b: note de M. Gutt sur l'activité financière du gouvernement belge, summer 1940.

44 ARA, fonds ministerie van Financiën, Plisnier Papers, dossier 2 b: letter of 27.07 .1940 from Smeers (Vichy) to Plisnier (Brussels). In this respect, see also: BNB, Archives, $S D$, London Archives: note de M. Janssen sur son activité entre le 10 mai et le 9 juillet $1940, \mathrm{n}^{\circ} 14$. 
ing day, the conversion of Belgian money into French would be limited to 2,00o Belgian francs per person per fortnight, with a maximum of 5,000 Belgian francs per household ${ }^{45}$.

Quite simply, Gutt and Janssen were between hammer and anvil. On the one hand, their aim was to keep the Bank's gold deposit as intact as possible ${ }^{46}$ and to do that by keeping the conversion of Belgian money to a minimum. On the other, their unwillingness to ignore the interests of the refugees meant that the exchange rate of the Belgian franc had to be maintained, while scope had to be left regarding the amount of money to be converted. Neither of the two men was at the time fully aware of the extraordinarily high feelings and emotion that the government's manipulation of the exchange rate was arousing among the refugees. It was an ignorance that later came to haunt them.

45 BNB, Archives, Studiedienst, dossier 01.02.01.70 (A 247/6): memorandum of 28.08.1942 from Dussart to Kauch. See also: BNB, Archives, SD: Kauch, note sur les opérations de change, Chapter. 2, p. 3.

46 BNB, Archives, $S D$ : Kauch, note sur les opérations de change, Chapter. 2, p. 2. 


\title{
CHAPTER 3 \\ France and the Monetary Crisis
}

\author{
THE CAPITULATION AND ITS MONETARY CONSEQUENCES
}

The negotiations between France and Belgium to give definitive form to the provisional monetary agreement of 14 May were resumed on 20 May $^{1}$. Progress was slow and difficult, especially as Great Britain had to be taken into account in the three-country agreement conceived in Paris. Communication worsened by the day, particularly cross-Channel communication, and this decided Gutt to leave for London on 23 May. He hoped for fruitful consultation there regarding the half-finished discussions in Paris over that agreement, but also wanted to take advantage of the occasion to conclude an Anglo-Belgian agreement, already hinted at during the Paris meetings.

The discussion in London went unexpectedly smoothly and on 24 May, the day after his arrival, Gutt and Kingsley Wood, Chancellor of the Exchequer, were able to sign a provisional Anglo-Belgian agreement. This was a carbon copy of the provisional Franco-Belgian agreement: the British government granted Belgium an interest-free line of credit of three million pounds sterling and the Belgian government granted Great Britain a reciprocal line of 360 million Belgian francs; the official exchange rate was to be that set in Paris, i.e. 1 pound sterling to 120 Belgian francs ${ }^{2}$.

During the night of 27/28 May, the Belgian armed forces capitulated. The news was announced over the radio by the French Prime Minister, Paul Reynaud, who branded the capitulation an act of treachery on the part of the King and, in virulent language, berated both him and the Belgian armed forces, sparing neither. In a radio address following this,

1 BNB, Archives, SD: Kauch, note sur les opérations de change, Chapter. 2, p. 3.

2 BNB, Archives, $S D$ : Kauch, note sur les opérations de change, Chapter. 2, p. 11, footnote 28 . 
Pierlot, deeply stricken by the hostile attitude of his hosts, gave support to the French position, albeit adopting a somewhat more moderate tone, but nevertheless took the view that the King should be deposed ${ }^{3}$. The two radio addresses, particularly Reynaud's, unleashed a wave of anger - generally verbal - throughout France against the Belgian refugees ${ }^{4}$.

On 25 May, already, the French government had issued a decree freezing all the assets of Belgian companies that had taken refuge in France, a measure whose application extended to the assets (banknotes and securities) of the Bank placed in safe custody in the branches of the Banque de France at Mont-de-Marsan, Tarbes and Toulouses. In consequence, nothing further could be withdrawn from the reserve of banknotes, a catastrophic situation for both the Bank and the Treasury.

On 28 May worse was to follow. Following the news of the Belgian capitulation, the Governor of the Banque de France, Fournier, decided unilaterally that, with effect from the next day, Belgian refugees would be permitted to exchange no more than 500 Belgian francs per person per fortnight (with a maximum of 1,00o Belgian francs per household) 6 . Likewise on 28 May, he informed Janssen that, according to available figures, the Belgian refugees had so far presented 1.2 billion Belgian francs' worth of banknotes for exchange and in return had received an amount of 1,732.8 million French francs at the official exchange rate. The Banque de France was now demanding immediate settlement in gold and had decided to withdraw approximately 36,397 kilograms of fine gold from the Belgian gold reserves deposited in its branches at Libourne and Bordeaux.

3 According to constitutional experts, the King had not violated the constitution, because - as Commander-in-Chief of the army - he was not obliged to request a ministerial counter-signature: Ndl.Bz, London Archives, 1940-1945, GA G II, België, $\mathrm{n}^{\circ}$ 2: letter of 29.05.1940 from van Harinxma thoe Slooten (Poitiers) to van Kleffens (London).

4 Velaers and Van Goethem, Leopold III, pp. 264-269.

5 BNB, Archives, SD: Kauch, La Banque Nationale (unpublished text), Part 1, pp. 2930, and particularly: Kauch, note sur les opérations de change, Chapter. 2, pp. 4-5, footnote 16.

6 BNB, Archives, Studiedienst, dossier 01.02.01.70 (A 247/ 6): memorandum of 28.08.1942 from Dussart to Kauch. 
Janssen was seized by panic. He feared even tougher action on the part of the French in the immediate days ahead and, in this uncertain monetary situation, looked to see responsibility shared. That same day, 28 May, he sent a telegram to the Belgian embassy in London, which read, 'For Minister Gutt - stop - confirm: your presence here, with the briefest delay, appears to be indispensable'? Gutt returned to Paris on 29 May and negotiations began the following day, promising to be hard. There were three main points on the agenda: the currency parity, the mutual granting of credit and the disposition of the valuables, which the refugees had brought with them. It was clear from the outset that the French would be dictating the terms and would be giving little ground to the Belgians. 'Evidently', wrote Gutt to Theunis, 'no more presents, no more declarations of Saint-Adresse, about war reparations's. The French took the view that the capitulation had put Belgium in an extremely weak position: she had lost the war and was now an occupied territory; her economy was in ruins and, under the occupation, would as a matter of course no longer be able to contribute to the Allies' war effort ${ }^{9}$; lastly, the value of the Belgian franc no longer had an economic foundation and the currency was, in any case, overvalued against the French currency ${ }^{10}$.

The French therefore demanded that the value of the Belgian and French francs be equalized, which meant an exchange rate of 100 (no longer 144.4) French francs to 100 Belgian, a 30.75 per cent devaluation of the Belgian currency against the French. In accordance with the provisional Franco-British-Belgian agreement of 14 May, sterling was required to be associated with this arrangement, so that there would

7 BNB, Archives, SD, 49, dossier 8.13.11/ s. f. 1: telegrams of 30.05 .1940 and 01.06.1940 from Baudewyns to Ansiaux.

8 Quoted by J.-Fr. Crombois, Camille Gutt. Les finances et la guerre, 1940-1945, Brussels, 2000, p. 75. The reference to the declaration of Saint-Adresse refers to the French government's promise during the peace negotiations after the First World War to support the Belgian position regarding German war reparations.

9 This point of view was shared by Janssen: BNB, Archives, $S D$, London Archives: note de M. Janssen sur son activité entre le 10 mai et le 9 juillet 1940, $\mathrm{n}^{\circ}$ 17. See also: BNB, Archives, $A V, 26.08 .1940$ (memorandum of 26.08.1940 for Governor Janssen to use in his reply to Senator Van Dieren's interpellation at the meeting of the general assembly in August 1940).

10 BNB, Archives, $S D$ : Kauch, note sur les opérations de change, Chapter. 2, p. 6. 
also be a proportional devaluation of the Belgian franc against sterling from 120 to 176.625 Belgian francs to the pound. Conversion against these official rates would be conducted via the bodies or institutions authorized for that purpose: for France, the Fonds de Stabilisation; for Great Britain, the Exchange Equalization Fund; and for Belgium, the Bank in its capacity of State exchequer ${ }^{11}$.

\section{THE SEARCH FOR SCAPEGOATS}

Who, in fact, was behind this demand for devaluation? Some members of the Banque de France insinuated that it was Gutt and Janssen. The devaluation, they said, would make the French franc much more expensive for the Belgian refugees, discouraging them from buying French francs and thus contributing to limit the loss of Belgian gold. The insinuation, however, does not seem close to the truth. It is more than likely that the French imposed the adjustment of the currency parity on the Belgians and that the Belgians were unable to summon up any resistance to such an agreement. From both an ideological and a theoretical point of view, Gutt and Janssen were great champions of a stable currency and opposed as a matter of principle any form of devaluation. It is also very revealing that, immediately after the defeat of France, barely three weeks after the devaluation of 9 June, Gutt and Janssen attempted to have the devaluation declared void and, indeed, succeeded in their efforts.

As regards the provision of credit, it was agreed during the negotiations that, for the duration of the war, the respective governments would grant each other interest-free lines of credit of respectively one billion French francs and one billion Belgian francs for purchases within France or the French empire and within Belgium or the Belgian Congo. Any overrun would be offset by the transfer of Treasury bonds at 3 per cent for the amount of the overrun ${ }^{12}$. Similar conditions would apply between Great Britain and Belgium in respect of purchases within Great Britain and the British empire and within Belgium or the

11 See article 3 of the Franco-Belgian and the Anglo-Belgian financial agreements of 07.06.1940.

12 Article 4 of the Franco-Belgian financial agreement of 07.06.1940 (see below). 
Belgian Congo ${ }^{13}$. It was also agreed that the Belgian government would make a fair contribution to the financing of the war effort, whether with gold, dollars or foreign currency convertible to dollars ${ }^{14}$.

Belgium also agreed with France that half of all Belgian government debt would be settled at the end of each month in gold, dollars or foreign currency convertible to dollars, the remaining half to be set against the agreed line of $\mathrm{credit}^{15}$. A similar arrangement was laid down in a separate agreement in respect of the cooperation between Belgium and Great Britain and both arrangements would be reciprocal.

Additionally, article 3 of the Franco-Belgian monetary agreement carried a hidden sting by way of a clause inserted stating that the conversion of Belgian money into French by refugees fell outside the credit facility arrangement; in consequence, the Bank's repurchases of Belgian banknotes had to be funded entirely with gold ${ }^{16}$. In principle, there should also have been reciprocity in this matter, but the reciprocity clause was omitted from the implementing protocol signed by the two central-bank governors on 7 June 1940, with the result that the Banque de France was not later to feel itself bound by any such reciprocity ${ }^{17}$. Lastly, the Belgian government had to accept that Belgian banks should suspend their activities on French soil ${ }^{18}$.

When Deputy-governor Ingenbleek came to read the text of the agreements of 7 June, he was fiercely critical. In his view, the formulation of the general clause was so vague and its practical application so

13 BNB, Archives, SD, Malaise Papers, dossier 9.5.11/ s. f. 4: Kauch, rapport au Roi, 20.12.1943, p. 18.

14 Article 9 of the Franco-Belgian and the Anglo-Belgian financial agreements of 07.06.1940 (see below).

15 BNB, Archives, Boekhouding, dossier 88.02.02.00 (B 608/9): letter of 07.06.1940 from Bouthillier to Gutt.

16 The Franco-Belgian agreements of 7 June regarding the exchange of money by Belgian refugees in France and regarding Belgium's contribution in gold, dollars and assimilated foreign currency to the war effort, insofar as settled before 25 June, were recognized as legal by the German occupiers in Brussels (Freiburg im Breisgau, Militär Archiv, Militärverwaltung, dossier Rw 37/277: Hofrichter, Abschluszbericht der Militärverwaltung in Belgien und Nord-Frankreich, p. 85).

17 BNB, Archives, Boekhouding, dossier 88.02.02.00 (B 608/9): BEB, DC, 09.07.1942 (extract for manager Bastiné).

18 BNB, Archives, SD: Kauch, note sur les opérations de change, Chapter 2, p. 7. 
broad that it threw open the door to downright plundering of the gold reserves by the French or British government, or even both. ${ }^{19}$.

In respect of the final point of the agenda, i.e. the disposition of the refugees' valuables, Belgium was able to score a degree of success in that both France and Great Britain declared that they would make no claim on them, indicating that the valuables could eventually be confiscated by the Belgian government ${ }^{20}$. Gutt attempted, unsuccessfully, to have the agreement extended to include the gold reserves frozen in France and Great Britain. He also demanded the unfreezing of the Bank's assets in the branches of the Banque de France at Tarbes, Toulouse and Mont-de-Marsan ${ }^{21}$, but to no immediate avail.

By 30 May, the major lines of the agreement had already become fairly clear ${ }^{22}$. All that had to be done immediately thereafter was to fill in the details, so that it would quickly be ready for signing. However, two unforeseen events now occurred to throw a spanner in the works. The first was the totally unexpected declaration by the Minister for the Colonies, Albert De Vleeschauwer, that he was opposed to the agreed exchange rates. He argued that the Belgian Congo was not a territory under military occupation and that, in consequence, there was no reason for discussing a weakening of the international position of the Congolese currency. ${ }^{23}$.

The minister had contacted representatives of the Belgian colonial companies, many of whom had fled from Brussels to Bordeaux ${ }^{24}$. He

19 ... On a été jusqu'à permettre au Ministre des Finances, dans une convention qu'il fit avec son collègue de France, de disposer de l'or de la Banque, sans que le Comité de Direction... eût été consulté': KP, Archives, fonds Leopold III, 58: Ingenbleek, mon journal de guerre, pp. 30-31.

20 BNB, Archives, $S D$ : Kauch, note sur les opérations de change, Chapter. 2, pp. 7-8, 15 and annex 17. See also: BNB, Archives, SD, Malaise Papers, dossier 9.5.11/ s. f. 4: Kauch, rapport au Roi, 20.12.1943, p. 14.

21 BNB, Archives, $S D$ : Kauch, note sur les opérations de change, Chapter. 2, p. 12, footnote 30 , and p. 5 , footnote 16 .

22 BNB, Archives, Studiedienst, dossier 01.02.01.70 (A 247/3): précisions sur les négociations économiques et financières entre la France et la Belgique émigrée, mai-juin 1940.

23 Janssens, De Belgische frank, p. 289.

24 In his war diary, Minister De Schryver speaks of the representatives and managements of 'hundreds' of colonial companies, all of whom had fled to Bordeaux: De Schryver, Oorlogsdagboeken, 1940-1942, p. 73. 
had also consulted the representatives of the Banque du Congo Belge. The reaction was unanimous: no-one could agree to a devaluation of the Congolese franc. For the Banque du Congo Belge, a devaluation would lead to a drastic reduction in its operating funds in respect of its purchases abroad; for the colonial companies, it would mean a sudden increase in the price of the foodstuffs that needed to be imported, thereby pushing up the cost of living for the indigenous workers. Against this, of course, was the fact that a lower value for the Congolese franc would help to boost exports, but this argument carried no real weight because international demand for raw materials was certain to rise in prevailing circumstances.

After a great deal of discussion, Gutt and Spaak won over De Vleeschauwer, who promised not to break the exchange-rate parity between the Congolese and Belgian currencies. The colony was thus set to fall in line with the motherland. It was at this moment that the second event occurred to prevent the agreement being concluded, namely the change of government in France that took place on 4-5 June. This necessitated a fresh round of talks, so that it was only by the evening of 7 June that the drafting of the Franco-Belgian and the Anglo-Belgian monetary agreements could be completed.

The Franco-Belgian agreement was signed in Paris by Gutt and by the new French Minister of Finance, Yves Bouthillier. The AngloBelgian agreement was signed the next day, also in Paris, by Belgium's ambassador to France, acting for the Belgian government, and by Sir Ronald Campbell, Great Britain's ambassador to France, for the British government ${ }^{25}$.

\section{EMOTION AND FRUSTRATION AMONG THE BELGIAN REFUGEES}

The Belgian refugees, many of whom were in any case not well off, reacted angrily to the new monetary measures ('the turmoil was considerable' $)^{26}$. They not only had to suffer the distress of their exile and the hostile attitude of the French since the capitulation of the

25 Janssens, De Belgische frank, p. 289.

26 BNB, Archives, SD, Malaise Papers, dossier 9.5.11/s. f. 4: Kauch, rapport au Roi, 20.12.1943, p. 17. 
Belgian armed forces, but were now faced for the second time with a drastic fall in the exchange rate. Complaints from people in financial difficulties poured in $^{27}$ and everyone felt mounting disillusion with the authorities responsible. Ingenbleek, then in Mont-de-Marsan, spoke of a general consternation among Belgians, the devaluation being regarded as 'a war tax of 44 (sic) per cent', imposed on all refugees by the unilateral decision of government ${ }^{28}$.

The government and the Bank were shocked at the enormous emotional reaction that the devaluation unleashed among the Belgians in France, and Gutt and Janssen set to work at once to undo its consequences $^{29}$. Their chance came after the defeat of France and the subsequent armistice arranged between France and Germany on 22 June. On 25 June, Janssen and Gutt conferred about the strategy to be pursued in order to annul the devaluation of $7 \mathrm{June}^{30}$. Both felt that there were convincing arguments for annulment. The French had posited that a devaluation of the Belgian franc was inevitable, because the German occupation of Belgium meant that the currency no longer had a sound economic and political basis. The same line of argument could now be used against France, as the French economy was in ruins. A second important line of argument was the French assumption that Belgium would for a long time remain economically and politically dependent on her if Belgian war efforts were to be continued from French territory had now likewise been overtaken by events.

The next day, 26 June, Janssen met Fournier at Bordeaux to elucidate the Belgian position, discussions being continued on 27 June by Smeers and $\mathrm{Kauch}^{31}$. The reasons why the parity agreed on 7 June had to be revoked were abundantly clear. It was a question not just of personal pres-

27 Numerous of these complaints can be found in: BNB, Archives, SD, 'période de guerre' (Mont-de-Marsan).

$28 \mathrm{KP}$, Archives, fonds Leopold III, dossier 58: Ingenbleek, mon journal de guerre, pp. 17-18.

29 This can be clearly inferred from a letter of Gutt to Theunis, in which Gutt speaks of his satisfaction over the reversal of the devaluation of 7 June (ARA, Theunis Papers, 'correspondance Theunis-Gutt': letter of 28.08.1940 from Gutt to Theunis).

30 BNB, Archives, $S D$ : Kauch, note sur les opérations de change, Chapter. 2, p. 18, footnote 41.

31 вNB, Archives, $S D$, Malaise Papers, dossier 9.5.11/ s. f. 4: Kauch, rapport au Roi, 20.12.1943, p. 20. 
tige, but also of money: if the previous exchange rate of 144.4 French francs to 100 Belgian was reinstated, the Bank would have to pay out not 100, but only 69.25 Belgian francs for every 100 French francs that Belgian refugees presented for conversion on their return from France.

After major concessions from the Belgian side, the Banque de France was able to give its accord to the proposal to reinstate the previous parit ${ }^{32}$. The agreement was signed by the respective Ministers of Finance, Bouthillier and Gutt, on 9 July as an appendix to the Franco-Belgian agreement of 7 June. By its terms, the Franco-Belgian exchange rate parity was restored to its level of 14 May, i.e. 144.4 French francs to 100 Belgian. Refugees and officials returning to Belgium were permitted to exchange French money for Belgian, provided that the exchange took place in French banks in France ${ }^{33}$ and upon the simultaneous presentation of the declaration form, either completed at the time of crossing the border into France or regularized within eight days thereafter, as agreed at the time between the governments. That form was the necessary proof that the French money had been purchased with Belgian banknotes or other foreign currency at the time of entry into France. Those unable to present such a declaration form were allowed to exchange up to a fixed maximum of 4,00o French francs per person (with a maximum of 10,000 French francs per household). A further stipulation was that no more than two thirds of the quantity of French currency presented could be converted into Belgian banknotes; the balance had to be deposited in a frozen bank account in France. Lastly, it was also agreed that the Banque de France had the right to call an

32 BNB, Archives, $S D$, Malaise Papers, dossier 9.5.11 / s. f. 8, échange de FF contre FB: letter of 03.07.1940 from Fournier to Janssen.

33 The re-exchange of French money in Belgium would be regarded as illegal and consequently that money would not qualify for repurchase by the Banque de France through the cession of gold (BNB, Archives, SD, Janssen Papers: letter of 30.07 .1940 from Janssen to Ingenbleek). The obligation to submit an application form came up against enormous difficulties. During the first weeks of en masse flight, and in the great confusion of the moment, very few refugees thought to request an application form: in the first place, because people were not aware of the obligation and, in the second, because only the branches of the Banque de France held forms and such branches were few and far between in the border zone: BdFr, Archives, Secrétariat Général, dossier 1060.2001.01/38, 'or belge': letter of 13.08.1940 from A. de Brouckère (Pau) to the Banque de France (Châtelguyon). 
immediate halt to the conversion. It can be seen from all this just how substantial the concessions to the French were.

The actual instructions for implementing the agreement first appeared on 21 July in the French Official Gazette, so that it was only then that a start was made in applying the new rate, with the emphasis on 'a start': practice was to show that, despite the instructions, it was applied only slowly and unevenly. France was now split into two zones: one occupied, the other unoccupied. Contacts between the two were subject to strict formalities and were consequently restricted. Moreover, the Germans were opposed to banknotes being brought over from the occupied to the unoccupied zone. On the instruction of the Banque de France, a large proportion of the Belgian banknotes exchanged by the refugees on entering France had been sent from all the various locations in France to its main branch in Bordeaux, a town later to be incorporated into the occupied zone. As those banknotes could then no longer be returned to branches in the unoccupied zone, there was now a severe shortage of Belgian banknotes for the exchange of French for Belgian money there ${ }^{34}$.

The matter of re-exchanging French money was thrown into chaos by all these factors. Generally there were no Belgian banknotes available, so that many refugees simply had to take their French money home with them. In Belgium, however, the conditions for re-exchange were downright poor, with an exchange rate of 200 French francs to 100 Belgian initially being applied. It is true that the rate improved considerably to 160 French francs to 100 Belgian with effect from 24 July, but it never became really favourable ${ }^{35}$.

34 BNB, Archives, SD: Kauch, note sur les opérations de change, annex 76 (letter of 17.07.1940 from Rueff to Janssen).

35 Initially, only the Reichskreditkasse was authorized to exchange French money into Belgian, but this institution applied the Berlin Reichsmark rates for the French and Belgian currencies, i.e. 1 Reichsmark to 20 French francs and 1 Reichsmark to 10 Belgian francs, which gave a cross-rate of 200 French francs to 100 Belgian francs (the actual rate was 200 French francs to 99.80 Belgian). With effect from 24 July, the re-exchange operation was taken over by the Banque d'Emission and by the banks licensed to deal in foreign currency for account of the Banque d'Emission, which, from then on, applied a rate of 160 French francs to 100 Belgian (BNB, Archives, SD: Kauch, note sur les opérations de change, Chapter. 2, pp. 24-25). 
In this final stage of exchange-rate operations, which had gradually turned into a nightmare, the refugees felt that, yet again, they had been shamelessly duped. When, on their repatriation from France, they looked to exchange their remaining French money, they found that the Belgian franc had now become much more expensive. For the third time, they were losing money on an exchange transaction between the two currencies and, for the third time, they blamed the government and the Bank. When the President of the Belgian Red Cross arrived in France to help organize the repatriation and was asked what public opinion thought about the Belgian government in France, his answer was short and sharp: 'Messieurs, on les vômit' ${ }^{6}$.

In part, from the point of view of the repatriated, the accusations levelled at the government and the Bank were probably justified, but the Bank, too, had suffered a considerable loss during the tragic adventure of the Belgian refugees in France. A provisional estimate drawn up on 28 June 1940 by Bastiné indicated that, for the Franco-Belgian money exchange operations of May-June alone, the Bank had had to transfer a total of about 2,308 million Belgian francs' worth of gold to the Banque de France ${ }^{37}$. The situation was further compounded by the fact that there would be no settlement in gold by the Banque de France when the substantial amount of French banknotes from returning refugees was presented to it by the Bank.

Adjustment of the exchange rates for sterling and the Congolese franc to the new rate between the French and Belgian francs likewise led to difficulties. The Bank of England accepted the new rate of 1 pound sterling to 120 Belgian francs, but was not at all happy with this upward valuation of the Belgian currency, regarding it as 'a thorn in the flesh' ${ }^{38}$.

36 Dumoulin, Spaak, p. 198.

37 Bastiné estimated that, as at 28 June, 1,732.8 million French francs had been drawn down at a rate of 144.4 French francs to 100 Belgian. The Banque de France had set aside two provisions at the same rate, the first for an amount of 300 million French francs, and the second for 100 million French francs. On 18 June, two additional provisions were set aside, one for 200 million and the other for 800 million French francs, both at a rate of 100 French francs to 100 Belgian. This brought the total to $2,932,800$, ooo French francs in exchange for 2,307,750,00o Belgian (BNB, Archives, SD: Kauch, note sur les opérations de change, annex 60).

38 ARA, Theunis Papers, 'correspondance Theunis-Gutt': letter of 17.08.1940 from Gutt to Theunis. 
The adjustment of the Congolese franc simply did not take place. De Vleeschauwer speedily refused to apply the agreement of 9 July to the Congolese franc and stuck to the equalization of the French and Congolese currencies and to the rate of 1 pound sterling to 176.625 Congolese francs between the British and Congolese currencies, as fixed in the agreement of 7 June. Both rates were to be maintained for the duration of the war ${ }^{39}$.

De Vleeschauwer's insistence on sticking to the devalued Congolese franc appeared at first sight to be totally at odds with the hard line he had taken a few weeks previously, when he had fiercely resisted a devaluation. However, since then the situation had changed. According to Ansiaux, the main reason for De Vleeschauwer's refusal to accept an upward revaluation of the Congolese franc was the divergence of the exchange rate between the French and British currencies. After 7 June, the exchange rate that the two countries had fixed for their currencies could no longer be maintained on the free international market and, after the armistice, the French franc depreciated even further against sterling. The Belgian colonial companies feared being the dupe of this depreciation, which would undoubtedly have been to the advantage of their French competitors on the international markets, which is why they wanted the Congolese franc to continue to be held at parity with the French franc ${ }^{40}$.

Similar considerations played a part in respect of Great Britain. As things now stood, Belgian colonial companies viewed their export prospects with gloom. Great Britain, the only one of the Allies still fighting the Germans, would certainly block the import of raw materials to the continent and would thereby seal off the traditional export markets for Belgian colonial goods. Exports to Great Britain were an option, and to

39 Janssens, De Belgische frank, p. 293.

40 At the beginning of August 1940, the cross-rate of the Belgian franc against sterling on the basis of the free rate of the French franc at Geneva resulted in a value of 1 pound sterling to 250 Belgian francs. The colonial government and the colonial companies in the Belgian Congo felt that, under these circumstances, they could not justify a revaluation of the Congolese franc, as officially agreed for the Belgian franc on 9 July by the Belgian and French governments, namely back to 100 Belgian francs to 144.44 French or 1 pound sterling to 120 Belgian francs: BNB, Archives, $S D$, Ansiaux Papers, dossier A1: letter of 03.08.1940 from Ansiaux (Vichy) to Janssen (Brussels). 
be able to compete against British colonial companies, which enjoyed a range of privileges in the mother country, there was only one weapon that the Belgian colony could wield: very low prices. A weak Congolese currency would thus underpin exports.

\section{THE BANK UNDER TUTELAGE}

While Governor Janssen was in Paris with Gutt on 20 May, negotiating a definitive Franco-Belgian monetary agreement, he also conducted talks with his counterpart at the Banque de France, Fournier, on the practical organization of the Bank's operation during its exile in France. As mentioned in the previous chapter, the initial contacts had taken place within a collegial atmosphere of mutual helpfulness, as was normal among central bankers. However, when it became clear that military reverses were being suffered and that Belgium, following the Netherlands, would be obliged to lay down her arms, the mood changed. On 25 May, without giving the slightest indication to the Belgian government, the French government issued a decree whereby all deposits of money and other assets made in France by Belgian companies were frozen ${ }^{41}$. For the Bank, the decree came like a bolt from the blue. Without the slightest warning, it was placed under the tutelage of the French government and no longer had the power to dispose of its own assets; it was even denied access to its reserve of banknotes in the strongrooms of the Banque de France's branches at Mont-de-Marsan, Tarbes and Toulouse.

It was a decision that came wholly unexpectedly, too, for the Belgian government, which relied on the Bank and on its services as State exchequer and as State banker. Immediately after the signing of the Franco-Belgian agreement of 7 June, Gutt consequently felt himself obliged to request the French government for a loan of 400 million French francs in favour of the Belgian Treasury ${ }^{42}$. However, not only did the Belgian government find itself in an impasse, there was also a complete cessation of the services provided by the Bank to semi-public institutions, whose heads were now advised to approach the Treasury for fi-

$41 \mathrm{KP}$, Archives, fonds Leopold III, 58: Ingenbleek, mon journal de guerre, pp. 12-13. 42 BNB, Archives, $S D$ : Kauch, note sur les opérations de change, Chapter. 2, pp. 13-20. 
nancing. Shorn of its fundamental functions, the Bank was left with no more than its contact with the Banque de France and with finding a solution to the problems of converting Belgian money into French.

The French decree did, in fact, make provision for the freezing to be lifted, but for this to happen the special authorization of both the French and Belgian governments was required. Quite naturally, Gutt did all in his power to have it lifted as soon as possible for the Bank ${ }^{43}$, but it was not until 19 June that the matter was settled and the Bank regained the right to dispose of its assets. The reasons for this were the obvious ones of extremely poor communications, the chaotic military and political situation in the country and no doubt the irritation that was still felt by certain French authorities at the Belgian capitulation. At that time, there was no surplus of goodwill towards Belgium on the part of her southern neighbour.

43 BNB, Archives, SD: Kauch, La Banque Nationale (unpublished text), Part 1, Chapter 2, p. 26. 


\title{
A Rudderless Belgian Government
}

\author{
THE EVACUATION OF BELGIAN GOLD FROM FRANCE
}

The French government's headlong flight from Paris on 10 June triggered an immediate and chaotic dash southward of all French central administrative services. The government installed itself provisionally at Bordeaux and in the vicinity, and was joined there a short time later by the Banque de France. By then, the Belgian government and its two to three thousand officials had already experienced a substantial peregrination. It had arrived at Poitiers on 23 May, hoping to be able to organize itself suitably there, but scarcely three weeks later had been requested to move on to Sauveterre-en-Guyenne, a small village of barely 750 souls in the region of the Gironde that lacked even the most rudimentary infrastructure. The Treasury immediately commandeered the small village school, among whose benches it installed its payment office. As agreed in the monetary convention of 7 June, it ceased making payments in Belgian francs and for the first time began to execute its transactions in French money'.

When the Belgian government had left Poitiers, Baudewyns had transferred the Bank's services to Mont-de-Marsan². As soon as the Banque de France moved on to Bordeaux, however, he followed. Janssen himself, after departing from Paris, settled at Mont-de-Marsan and from 15 June on was making almost desperate attempts by telephone, telegraph and letter to contact Fournier at Saumur, in order to gain a

1 ARA, fonds ministerie van Financiën, Plisnier Papers, dossier 2b: letter of 27.07.1940 from Smeers (Vichy) to Plisnier.

2 KP, Archives, fonds Leopold III, 58: Ingenbleek, mon journal de guerre, p. 21. The Exchange Institute, which had been transferred on 10 June from Paris to Poitiers, left Poitiers on 19 June (BNB, Archives, $S D$, 36, Foreign Department, dossier 8.11.30/1: activité du service des changes et du service étranger, 10.05.1940 - 31.12.1941). 
degree of certainty about safeguarding the Belgian gold with the French central bank. Fournier could not be reached ${ }^{3}$.

At the beginning of June in Paris - before being evacuated - Fournier had informed Janssen that the French government proposed to bring the Belgian gold to safety outside France ${ }^{4}$ and had asked him whether he could agree to this. Janssen gave his approval as a matter of course, but, as was later to appear, details of the transfer were not discussed at the time and there was seemingly even no mention of a country of destination. Janssen must later have wondered about this summary treatment of what was an extremely important matter and on 15 June sent Fournier a telegram on the subject's. By then, the Banque de France, in consultation with the French Ministry of Defence, had already decided to go ahead with evacuation and to move the Belgian gold abroad to safety, together with the Polish gold that had been deposited at the Angoulème branch, and with a proportion of the French gold reserves that were still at Brest.

The French Navy had been entrusted with the task of taking the gold abroad, but was prepared to accept the responsibility only if the gold was delivered to a naval port with a protected arsenal. Lorient had been selected and on 9 June, the Belgian and Polish gold (weighing about 275 tonnes in $\operatorname{total}^{6}$ ) had been transported there by rail. The responsibility for the evacuation was formally accepted by the French Navy on 16 June and the gold was put on board the light cruiser Victor Schoelcher, loading taking from the morning of 17 June to the evening of 18 June, when anchor was weighed?

3 BNB, Archives, SD, London Archives: note de M. Janssen sur son activité entre le 10 mai et le 9 juillet 1940, $\mathrm{n}^{\circ} 25$.

4 BNB, Archives, $S D$, London Archives: note de M. Janssen sur son activité entre le 10 mai et le 9 juillet $1940, n^{\circ} 21$.

5 BNB, Archives, SD, London Archives, dossier 'or': note relative au dépôt d'or, 19391940, annexes 25 and 26 (telegram and letter of 15.06.1940 from Janssen to Fournier).

6 On 18.06.1940, Captain Moevus confirmed in writing that he had taken 6,152 crates of gold on board: 4,944 Belgian and 1,208 Polish: BNB, Archives, $S D$, London Archives, dossier 'or', s. f.: chargements et transfert de l'or, Lorient-Dakar, note of 18.06.1940.

7 The details of the various stages of the handling of the gold cargo can be found in the report of the vice-admiral of the squadron in the port of Lorient, in the 
On leaving harbour, the captain of the Victor Schoelcher was instructed to set course for the open sea and await further instructions; according to him, he was at that time still unaware of the final destination of his voyage ${ }^{8}$. When, the next day, he enquired about it, he received the order to head south to Casablanca and en route to join up with the convoy that had left Brest with 736 tonnes of French gold on board9. From Casablanca, the combined flotilla was to continue to Dakar in West Africa. It was here, on 28 June, that the cargo of gold was discharged $^{10}$.

Why was the Victor Schoelcher ordered to sail to West Africa and not to the United States or Canada? Was it as a result of the discussions that took place in the French government on 14-15 June about a possible move to North Africa, in order to continue the struggle from there? Was there a connection with the victory of the Pétainistes on 16 June within the government and the announcement the next day by Marshal Pétain that an armistice had been sought? Did the Pétainistes hope to be able to maintain an autonomous France, oriented more to the Afro-Asiatic empire than to the European continent: in other words, to achieve what they termed 'paix en dignité'? Put in this context, it was certainly more interesting for the Minister of Finance, Bouthillier, and the Chief of the Naval Staff, Admiral Darlan, two convinced Pétain-

report of Marot, manager of the Banque de France branch at Lorient, and in the report of the captain of the Victor Schoelcher (BNB, Archives, SD, London Archives, dossier 'or': chargements et transfert de l'or, Lorient-Dakar, reports of 14.06.1940, 18.06.1940, 31.10.1940). See also: Lepotier, La bataille de l'or, pp. 181-199.

8 Th.G.J.M. van de Burgt, 'Nazi-goud: een tussenstand', in: Bank- en Effectenbedrijf, January-February 1998, pp. 10-12. According to Van de Burgt, Captain Moevus and the crew thought that, on putting to sea, their final destination would be the island of Martinique in the Caribbean, then part of the French empire. According to Moevus' later testimony, he was unaware of the final destination until the morning of 19 June; it was only then that the captain was informed by the French Admiralty that he was to set course for Casablanca (Lepotier, La bataille de l'or, pp. 200-201.

9 France had already evacuated a large proportion of her own gold reserves to New York, London, Martinique and Casablanca. The French gold that had been transferred from Brest to Dakar was also said to include gold that had been deposited in safe custody at the Banque de France by the central banks of Latvia, Lithuania, Norway and Czechoslovakia: Th.G.J.M. van de Burgt, 'Nazi-goud: een tussenstand', in: Bank- en Effectenbedrijf, January-February 1998, p. 11.

10 Cornu, L'or monétaire au vingtième siècle, p. 165; and ARA, Theunis Papers, 'correspondance Theunis-Gutt': letter of 29.12.1941 from De Schryver to Theunis. 
istes, to have the gold brought to safety in the African hinterland than sent to the United States. If that was the case, Fournier would no longer have been able on 18 June to send the gold to the United States, even if he had wanted to, because - with effect from 16 June - he had devolved full responsibility for the operation to the French Navy. Furthermore, he was not a member of the new core group making the decisions in France and, as was generally known, his relationship with Bouthillier was very strained. Indeed, he was relieved of his office by Bouthillier on 31 August, although it is not known whether that had anything to do with the evacuation of the gold.

As soon as the Belgian government had moved from Poitiers to Sauveterre-en-Guyenne, Janssen left for Bordeaux with Gutt, to reestablish contact with the French government and the Banque de France, from which they had heard virtually nothing since the flight from Paris on 10 June $^{11}$. Tracking down the French government in a Bordeaux in chaos was no easy matter and time was pressing, because Gutt had not yet received the loan of 400 million French francs requested on 9 June. It was only on 17 June, more than a week later, that he was able to reach the competent authorities and effectively obtain it; the loan was granted that same day: half to be made available as a line of credit and half to be settled in gold at the end of the month ${ }^{12}$. The amount was transferred immediately to the Bank's account with the Fonds de Stabilisation. On that same day, too, Gutt and Janssen were able to agree with their French counterparts that the embargo on the Bank's assets would be lifted, though this took effect only on 19 June $^{13}$.

The most important question to be resolved was, naturally, the evacuation of the gold deposited in safe custody. Oddly enough, this question was not addressed on 17 June, but on the following day. Had Gutt and Janssen been informed of the imminent arrival of Ansiaux by air from London, accompanied by a high-ranking British naval officer, and had they been informed of the instructions and powers that the two

11 BNB, Archives, SD, Malaise Papers: Kauch, La Banque Nationale (unpublished text), Part 1, Chapter. 2, p. 27, footnote 37.

12 ARA, fonds ministerie van Financiën, Plisnier Papers, dossier 2 b, letter of 27.07.1940 from Smeers to Plisnier.

13 BNB, Archives, $S D$, Malaise Papers: Kauch, La Banque Nationale (unpublished text), Part 1, Chapter. 2, p. 26. 
were bringing with them? It is likely, but no tangible proof that this was the case has been found. The question nevertheless remains of what prompted Ansiaux' sudden appearance. His eventful journey certainly requires some explanation ${ }^{14}$.

\section{THE DRAMATIC DISCUSSION OF 18 JUNE 1940 AT BORDEAUX}

As soon as Ansiaux had arrived in London on 26 May, after his perilous crossing in the coastguard vessel A4 from Ostend to Plymouth, he reported to the Belgian embassy. In company with the Belgian ambassador Cartier de Marchienne and the Head of the Belgian Economic Mission to London, René Boël, Ansiaux conferred with the English government and the Bank of England ${ }^{15}$ and in joint discussions they concocted a plan to spirit the gold out of France. Ansiaux, provided with written authorization from the Belgian ambassador, was to fly to Bordeaux in a private aeroplane with the British naval officer, Onslow. Once there, he was to contact Janssen and Gutt to obtain their help in getting the gold out of France. Onslow had been authorized by the British Navy to requisition the British cruiser Arethusa, then moored at Le Verdon at the mouth of the Gironde, or any other British ship in the vicinity to transport the Belgian gold to Great Britain or the United States.

Ansiaux and Onslow arrived at Bordeaux on 18 June at 6 a.m. Onslow at once reported to the British embassy, where the financial at-

14 Ansiaux's journey from London to Bordeaux and his negotiations with the Banque de France and the French Ministry of Finance are given full coverage in his book (Ansiaux, Souvenirs) and in his interview ('Entretiens avec Hubert Ansiaux; I. L'or et les valeurs de la Banque Nationale dans la tourmente de 1940', in: Revue Générale, March 1985, pp. 13-14). More precise details are to be found in the memorandum he drew up for the Bank's legal proceedings against the Banque de France in New York (a memorandum intended for Theunis): BNB, Archives, Studiedienst, 13, (A 320/6): Ansiaux, note relative à l'or de la Banque Nationale de Belgique, confié en dépôt à la Banque de France, 1939-1940, March 1942.

15 Initially, Boël considered allowing one or more Belgian mailboats to leave for Bordeaux under the command of Commander Grisar, but the idea was quickly abandoned (BNB, Archives, SD, London Archives, dossier 'or', 1942, letter of 01.03 .1942 from Ansiaux to Theunis). 
taché, Norman Young, was seconded to him as assistant ${ }^{16}$. Ansiaux, for his part, reached the branch of the Banque de France around 8 a.m., there meeting d'Ambrière, who held responsibility for the Belgian gold. Ansiaux knew this man fairly well, as he had worked with him from November 1939 in respect of the evacuation of gold from Belgium to Bordeaux and Libourne. He briefed d'Ambrière about his mission, but to his astonishment was told that the gold was no longer being held in the strongrooms at Bordeaux and Libourne, but had been sent to a port other than Bordeaux, from where it was to be shipped overseas to safety. D'Ambrière would give no details of the port of loading, the name of the ship or the destination, and referred Ansiaux to the French Ministry of Finance.

After his meeting with Janssen and Gutt, Ansiaux went in search of Onslow, finding him shortly thereafter in company with Young. Consultation followed and it was decided to go to the French Ministry of Finance and to submit both an explicit request for the custody of the Belgian gold to be lifted and authorization for it to be shipped, perhaps via Great Britain, to the United States by the British Navy. Minister Bouthillier was unable to receive them himself and had the matter dealt with by Deroy, one of his collaborators. Deroy claimed that he had no knowledge of any details of the evacuation, but that he had heard that no order to sail had yet been given; this would not occur before the Bank had given its formal agreement to its debt vis-à-vis the Banque de France being settled in gold. As indicated above, Fournier had, at the time of the Belgian capitulation of 28 May, obtained immediate settlement in gold of the 1,733 million French francs that, according to his figures, had up to that moment been paid out in exchange for the Belgian francs presented by Belgian refugees, and for 300 million French francs by way of a provision (the exact details of which had not yet been reported to the central services). During the subsequent monetary negotiations, he had added an additional provision of 100 million French francs, likewise to be settled immediately in gold ${ }^{17}$. Now, Deroy announced that Bouthillier was prepared to consider the Belgian re-

16 For N. E. Young's part in the negotiations, see his written testimony of 26.02.1942, also annexed to Ansiaux's memorandum (see above).

17 In respect of the discussions concerning the monetary agreement of 09.06.1940, see above. 
quest to evacuate its gold only if, firstly, the Bank formally agreed to the 'immediate' settlement in gold of half of the loan of 400 million French francs just taken up by the Belgian government (according to the convention, settlement was required only at the end of each month) and, secondly, if the Bank gave instructions for an additional amount of 800 million French francs to be paid immediately in gold as provision for any further exchange of Belgian francs for French and for any further loans drawn down by the Belgian government ${ }^{18}$.

Janssen viewed this gravely, but ultimately assented; too much was at stake and he felt himself to be totally boxed in. Early that afternoon, Baudewyns handed the Deputy-governor of the Banque de France, Rueff, the official documents of cession for the release of the gold to that bank in accordance with the details already listed. This brought the total amount of gold ceded to the Banque de France by the Bank between 28 May and 18 June from its reserves in France to about 65,000 kilograms, in large measure to cover provisions ${ }^{19}$. During a new meeting, Deroy stated that Bouthillier was satisfied with the instructions and authorization given by Janssen ${ }^{20}$. This would have been welcomed as good news, had it not been for Deroy adding that he had been notified by the French Navy that the ship with the cargo of Belgian gold had just weighed anchor. He also said that the evacuation was now definitively in the hands of the French Navy. Further questioning proved fruitless: neither the name of the ship nor her route or ultimate destination could be given; the entire operation fell within the scope of 'le secret militaire' ${ }^{21}$.

Gutt would not admit defeat and went the same day to speak to Bouthillier personally. However, the French minister was nowhere to be found, upon which Gutt decided to go with Ansiaux to the restaurant where Bouthillier was accustomed to dine. They found him there

18 вNB, Archives, SD, London Archives, dossier 'or': chargements et transfert de l'or, Lorient-Dakar, letter of 18.06.1940 from Janssen to Fournier at Bordeaux.

19 BNB, Archives, SD, London Archives, dossier 'or': chargements et transfert de l'or, Lorient-Dakar, letter of 18.06.1940 from Janssen to Fournier at Bordeaux.

20 In this respect, see the testimony of Young, 26.02.1942 (BNB, Archives, SD, London Archives, dossier 'or': annex).

21 See the testimony of Onslow, 26.02.1942 (BNB, Archives, SD, London Archives, dossier 'or': annex). 
at table with a few of his staff. The discussion was short and tense, and Bouthillier did not even take the trouble to invite them to sit down. In a few words, Gutt once again outlined the matter and Bouthillier promised to contact Admiral Darlan the following day and request him to give Onslow a full briefing ${ }^{22}$. The next morning, Onslow went once more to the French naval headquarters to obtain the promised information, but was received extremely coldly and was given no details whatever. The same day, the naval attaché at the British embassy made a further attempt to obtain information, but he, too, came back emptyhanded from Admiral Darlan's headquarters. Greatly disheartened, Onslow returned that day to England and the British cruiser left port the day after ${ }^{23}$. The whole matter had proved to be a serious disappointment to all who had devoted themselves to the task. Writing to Theunis a few weeks later, Gutt was very bitter about his negotiations with the French authorities during the period from mid-May to the end of July: 'I had to discuss with them endlessly, for weeks, their government negotiating in bad faith ${ }^{24}$.

The shifts on the political and military chessboard now followed each other with increasing rapidity. On 17 June, Marshal Pétain had announced over the radio that he had begun negotiations with Germany for an armistice and a declaration of peace between their two countries. The question now concerned what path Great Britain would take. Would she continue the struggle or seek a compromise? This latter option was not totally excluded and the question was discussed at length during a meeting of the Belgian Cabinet on 18 June. It was known that there was a strong pacifist faction in the House of Lords in Great Britain, whose activity had led to a sharp exchange of words between Churchill and Halifax a few weeks earlier at the end of May ${ }^{25}$. Were the struggle to be continued, Great Britain would be standing alone, facing

22 Gutt: interview in the newspaper Le Soir, 20.09.1970. See also: BNB, Archives, SD, Ansiaux Papers, dossier 9.1/32: correspondance avec Gutt.

23 See the testimonies of Onslow and Young, 26.02.1941 (BNB, Archives, $S D$, London Archives, dossier 'or': letter of March 1942 from Ansiaux to Theunis, annexes).

24 ARA, Theunis Papers, 'correspondance Theunis-Gutt': letter of 18.08 .1940 from Gutt to Theunis.

25 Velaers and Van Goethem, Leopold III, pp. 309-312 and 362-363; De Schryver, Oorlogsdagboeken, pp. 95-98. 
an enormous task that would also make extreme financial demands on her. Would this have repercussions for the safety of the gold that the Bank had deposited in safe custody with the Bank of England?

Janssen and Gutt felt a degree of unease about the situation - particularly because of the surprisingly bad treatment that Belgium had received at the hands of her French ally - and consequently deemed it opportune to dispatch Baudewyns and Ansiaux also on 18 June on a special mission to London. The task of these two emissaries was to secure the Bank's assets abroad and, in particular, the gold that had been deposited with the Bank of England, the Banque de France, the Federal Reserve Bank of New York and the South African Reserve Bank. Indeed, it was still in the minds of Gutt and Janssen to have the entire Belgian gold reserves taken to New York ${ }^{26}$. With a view to this, the emissaries were authorized to take all necessary protective and administrative measures, but only when the management of the Bank found itself unable to issue instructions ${ }^{27}$.

On 18 June, too, Janssen wrote to Fournier, reminding him of the arrangement that they had made together regarding the safety of the gold: 'If the circumstances permit it, the Banque de France may follow the instructions of the British Admiralty to transfer to the United States the gold which the Bank put into safe custody in the Banque de France. I also gave a mandate to the Bank of England for participating in these operations in view of concentrating in the Federal Reserve Bank of New York all the Belgian gold, put into safe custody in France and in England as well' ${ }^{28}$. At that moment, thus, it was clearly Janssen's intention to transfer the Belgian gold held by the Banque de France and

26 At Laken on 26.06.1940, unaware of the decisions taken at Bordeaux, King Leopold requested colonel Kiewitz, Hitler's adjutant to the King, to send a telegram to the Führer, requesting that, among other things: 'it be immediately demanded of France that the Belgian State treasure (several billions in gold), in probably not an unknown hiding-place in France south of Bordeaux, be restored forthwith to Belgian hands': d'Ydewalle, De Memoires, pp. 397-398.

27 BNB, Archives, SD, London Archives, dossier 'or', annex 30: appointment of Baudewyns, Ansiaux and Theunis, 18.06.1940. See also: BNB, Archives, SD, London Archives: note de M. Janssen sur son activité entre le 10 mai et le 9 juillet 1940, $\mathrm{n}^{\circ}$ 30.

28 BNB, Archives, $S D$, London Archives, dossier 'or': annex 28: letter of 18.06.1940 from Janssen to Fournier. 
by the Bank of England to the United States ${ }^{29}$. In the event, the gold at the Bank of England did not go to New York, as Janssen had wished, but to Ottawa (Canada) ${ }^{30}$. Baudewyns later wrote to Janssen that Montague Norman, the Governor of the Bank of England, was not keen for the gold to go to the Federal Reserve Bank of New York, preferring a partner from the Commonwealth, which is why he ignored Janssen's instructions and had the gold transported to Canada ${ }^{31}$.

Fournier, was later always to deny that Janssen had 'formally' requested him on 7 June to lift the embargo on the Belgian gold and have the gold sent to New York. Once - on 18 June - Fournier became aware of the Bank's 'express' wish for the gold to be evacuated to the United States, and once - a few days later - information reached him that the French Navy was transporting the gold to a destination within the French empire, he attempted, in consultation with Janssen, to break the deadlock. According to the testimony he gave in 1941, he informed Janssen immediately of where the Belgian gold was now headed and together they sought a way of still meeting Janssen's wish ${ }^{32}$. Fournier first proposed that a portion of the earmarked gold held under the Banque de France dossier at the Bank of Montreal be transferred to the Federal Reserve Bank dossier at Montreal, in the name of the Bank, and that it then be transported to New York at the first opportunity. After consult-

29 BNB, Archives, SD, London Archives, dossier 'or': annex 37: telegram of 07.07.1940 from Janssen (Vichy) to Baudewyns (London): 'Usez de votre mandat pour assurer transfert fedreserve dépôts confiés Norman conformément ma lettre du 18 juin et éventuellement Fournier'. See also a letter of 09.07.1940 from Janssen to Baudewyns (вNB, Archives, $S D$, Malaise Papers: Kauch, note relative au dépôt de l'or, $\mathrm{n}^{\circ} 16$ ). See also: BNB, Archives, DC (Mont-de-Marsan), 19.06.1940.

30 BNB, Archives, $S D$, Ansiaux Papers, A 1: letter of 03.08.1940 from Ansiaux (Vichy) to Janssen (Brussels).

31 BNB, Archives, SD, London Archives, 'correspondance, 1940-1941': letter of 26.04.1941 from Baudewyns (London) to Janssen (Brussels).

32 Fournier was formal in his statement: as soon as he was informed a few days after 18 June of the final destination of the gold transfer, he notified Janssen and together they looked for a solution. Fournier strenuously denied Ansiaux's allegation during the legal proceedings in New York that, during the days following the meeting of 18 June, Janssen did not know where the gold was being taken to ( BdFr, Archives, Secrétariat Général, dossier 1060.2001.01/38, 'or belge': observations de M. Fournier sur les allégations formulées à l'encontre de la Banque de France à l'occasion de l'instance engagée à New York, 27.11.1941, and BdFr., Archives, Direction de la documentation, dossier 1397.1994.01/83: rapport Janssen, $\mathrm{n}^{\circ} 28$ ). 
ing Gutt, Janssen agreed. The Federal Reserve Bank would naturally have to be asked whether it would accept such an arrangement and on 26 June, via the American embassy, Janssen dispatched a telegram with such a request to New York ${ }^{33}$.

The American reply arrived on 5 July, but unfortunately was negative: 'it is contrary to our policy to hold any of our own gold abroad and we would not wish to earmark gold belonging to other parties ${ }^{34}$. The roundabout route via the Federal Reserve Bank dossier was necessary, because the Bank lacked its own dossier at Montreal. The creation of a dossier demanded a great deal of time and Janssen's imminent departure from France for Belgium meant that the procedure could no longer be introduced. Other solutions proved to be equally unviable, including a transfer of gold under French dossier at the Federal Reserve Bank of New York to the Bank dossier there, because the French gold there was embargoed ${ }^{35}$.

A final attempt to solve the problem also failed. Fournier had ordered one of his directors, Moreton, to join the convoy with the French, Belgian and Polish gold in the port of Casablanca, hoping to be able to maintain some sort of control to ensure the safe outcome of the expedition. He now contacted Moreton and instructed him explicitly to separate the Belgian gold from the rest of the cargo and at the first opportunity to conduct it to New York. With this aim, Moreton flew from Casablanca to Dakar on 6 July, but very soon telegraphed to announce that the Belgian gold could no longer be separated, as all the gold had become mixed. There matters remained for the time being ${ }^{36}$.

33 BNB, Archives, Studiedienst, 13, dossier A 320/6: Ansiaux, note relatieve à l'or de la BNB confié en dépôt à la Banque de France, 1939-1940, March 1942.

34 BNB, Archives, SD, London Archives, dossier 'or': annex 36, telegram of 05.07.1940 from Cariguel (Banque de France, Clermont-Ferrand) to Janssen (Tarbes). See also: Cornu, L'or monétaire au vingtième siècle, pp. 166-167.

35 BNB, Archives, $S D$, Ansiaux Papers: letter of 03.08.1940 from Ansiaux (Vichy) to Janssen. The Germans asked the American government also to freeze the Belgian gold reserve deposited in New York. According to Plisnier, there was no response to the request: Plisnier, 'L'or belge livré aux Allemands en 1940', in: Revue Générale Belge, 52, February 1950, pp. 1-3.

36 BdFr, Archives, Secrétariat Général, dossier 1060.2001.01/42: letter of 18.07.1940 from Favre-Gilly (Paris) to Bélin (Paris). See also: Plisnier, 'Lor belge livré aux Allemands en 1940', in: Revue Générale Belge, 52, February 1950, p. 16. That it was actually Fournier's intention to have the Belgian gold transferred from Dakar to 


\section{A BELGIAN GOVERNMENT IN ITS DEATH THROES}

The day the problem of the evacuation of the gold came to a head, i.e. on 18 June, France had just been defeated and negotiations for an armistice had already been announced. The French government faced the greatest crisis in its history and was divided, but the situation in the Belgian government was also far from one of 'in unity, strength'. Discussion was being conducted in a depressed atmosphere of frustration, indecision and discord; ministers were having quickly to take a series of extremely important decisions regarding the future, but were apparently not able to do so. The situation was little better within the Bank and there were differences of opinion between the Governor and his Deputy-governor. The French embargo of 25 May had paralysed all activity at the Bank for weeks, resulting in the staff becoming listless and discontented, and looking to return home; the little news that reached them from Belgium appeared to be less pessimistic than feared and many were saying that they had heard that the situation there would fairly rapidly return to normal.

The armistice announced by Marshal Pétain on 17 June hit the French public like a bombshell. and its effect on the Belgian government was equally dramatic. Discussion about leaving for Great Britain appeared to have been swept aside for good. At the Cabinet meeting on that day, the only person, even if a very convinced one, to advocate continuing the struggle from London was Jaspar, Minister of Public Health. The question was raised again the next day. The Prime Minister, Pierlot, took the line that, in the circumstances, Belgium did not have the resources to continue the war. It did not make sense, therefore, to move to London. With the exception of three ministers - Jaspar, De Vleeschauwer and Gutt, the entire Cabinet agreed with Pierlot's point of view. After the vote, not wishing to break ranks at such a crucial moment, De Vleeschauwer and Gutt declared themselves ready to ac-

the United States can be inferred from his instruction to Moreton to withdraw 1,100 million French francs' worth of gold in advance from the consignment, as settlement for the commission approved by Janssen, but not yet paid: BdFr, Archives, Direction de la documentation, dossier 1397.1994.01/83, 'or belge': note pour le Secrétariat à Paris (Clermont-Ferrand, 25.09.1940). 
cept the majority decision ${ }^{37}$. That same day, a telegram to the King and the Belgian ambassador in London was prepared, in order to announce that the Belgian government was breaking off hostilities, as the French had done. The telegram to the King also notified him that the ministers were placing their portfolios at his disposal, so as to give him the necessary scope to negotiate a peace deal between Belgium and Germany ${ }^{38}$. The ambassador in London was required to notify the British government of the telegram's contents.

At this juncture, abandoning their readiness to follow the majority decision, De Vleeschauwer and Gutt adopted the view taken by Jaspar that the struggle should be continued. One of the reasons that prompted them to do this may have been connected to the contacts that they had in Bordeaux during those days with representatives of the most important companies in the Belgian Congo. It was being rumoured that, were Belgium to drop out of the fight, Great Britain might well take control of the Belgian Congo. Was this being discussed with those contacts? The colonial leaders were far from happy about such a prospect: they wanted no foreign rule, but for most of them, there was absolutely no question of Belgium continuing to fight Germany from the Congo, though this was nonetheless the standpoint that Pierre Ryckmans, Governor-general of the Congo, defended in a radio broadcast.

The representatives of the colonial companies suggested that the Minister for the Colonies, perhaps together with a few other ministers, should go to Great Britain with a view to safeguarding Belgian sovereignty over the Congo. Pierlot responded by proposing that De Vleeschauwer be appointed Administrator-general of the colony and in that capacity go to London to defend the Congo's status as a Belgian colony. The fact that De Vleeschauwer could not simply go to London in his capacity of Minister for the Colonies and apparently needed a new status for the mission had everything to do with the fear that, in the un-

37 After the defeat of France, the British government requested the Belgian government to place the Belgian Navy and its ship's crews at Great Britain's disposal; no immediate response was given to the request, and it was later explicitly refused. Belgian pilots who fled with their planes to Great Britain were even condemned in their absence for desertion and theft by Belgian courts-martial in France: De Schryver, Oorlogsdagboeken, p. 115.

38 Velaers and Van Goethem, Leopold III, pp. 361-365. 
certainty of the times, the solidarity of the government would somehow or other be broken. The government approved Pierlot's proposal unanimously and De Vleeschauwer was able to leave for the British capital the following day, travelling via Lisbon ${ }^{39}$. During the subsequent days, the Belgian government returned repeatedly to the question of whether it should escape to Great Britain ${ }^{40}$, before at last definitely rejecting the idea.

\section{THE BANK'S RETURN TO BRUSSELS}

As soon as the armistice between France and Germany was signed on 22 June and the Belgian government had decided not to decamp to Great Britain, but to remain in France in the hope of returning to Belgium, Gutt again sought contact with the Bank. He wished to discuss a number of urgent problems regarding the Treasury and was particularly concerned about the problem of the conversion of French money to Belgian, a problem that had become very acute, now that the Belgian refugees were seeking to return home. However, due to the general chaos at Bordeaux and probably also to Janssen's uncertain health at that time, the meeting between Gutt and the Governor did not take place until 26 June. In respect of the money conversion, Janssen was required to begin negotiations as quickly as possible with the Banque de France and, moreover, to use the occasion to reverse the humiliating devaluation of the Belgian franc on 7 June. Janssen met Fournier that same day. An agreement in principle to the restoration of the previous rate of exchange was not ruled out and, concerning the gold, Fournier had even worked out the very attractive proposal involving Canada, as mentioned above ${ }^{41}$.

After the conclusion of the Franco-German armistice, the government wished in any case to return as quickly as possible to Belgium and, in the absence of any reaction from the Court to its telegrams of 19

39 J. Stengers, Léopold III et le gouvernement: les deux politiques belges de 1940, Brussels, 1980, pp. 84-95.

$40 \mathrm{KP}$, Archives, fonds Leopold III: Ingenbleek, mon journal de guerre, pp. 34-35.

41 BNB, Archives, $S D$, London Archives, 67: note de M. Janssen sur son activité du 10 mai au 9 juillet 1940, Nos. 35, 36 and 37 . 
and 24 June, delegated the diplomat Viscount Berryer to go to Brussels to investigate to what degree a return was possible and whether contact with the King could be restored ${ }^{42}$. When Janssen was informed of this, he thought it appropriate that a representative of the Bank also be sent and charged his private secretary, Kauch, with the task.

Meanwhile, Janssen sent a telegram to Thomas H. McKittrick, Chairman of the Bank for International Settlements (BIS) at Basel, requesting him to sound out the Reichsbank about the Bank's possible return to Brussels $^{43}$. At the same time, Ingenbleek contacted the German Kommandatur at Mont-de-Marsan and at Bordeaux to arrange the organization of a possible repatriation of the Bank's operations and its assets to Belgium, but the German authorities in both places felt themselves unable to co-operate in such a matter ${ }^{44}$.

On 2 July, Janssen received a message from the Belgian embassy at Bordeaux saying that Bemelmans had come as the representative of the Société Générale de Belgique to sound out the situation and had brought a letter for him, enclosing the text of the ordinance for the establishment of a temporary note issue institution, the Banque d'Emission à Bruxelles. The minutes of a meeting of the board of directors that same day recorded that, in a conversation with Gutt at Bordeaux, Bemelmans had made it clear that Galopin, Governor of the Société Générale, and de Munck, Chairman of the Banque de la Société Générale, would welcome Janssen's return to Brussels, particularly in view of the imminent establishment of the Banque d'Emission. On his conversation with Gutt, Bemelmans was later to note: 'The Minister was of the opinion that Janssen had to return to Brussels the moment his health would allow ${ }^{45}$. At a meeting of the board of directors on 4 July, Janssen reported on the meeting with Gutt and Bemelmans, which had probably taken place the day previously. The major points discussed were the return of the Governor and the transfer of the Bank's registered office, central

42 Velaers and Van Goethem, Leopold III, pp. 419-320.

43 BNB, Archives, Studiedienst, 5, dossier 01.02.01.70 (A267): letter of 03.06.1945 from Ingenbleek to the chairman of the Commission of Enquiry (Banque d'Emission). See also: BNB, Archives, SD, Ingenbleek Papers, La Banque Nationale pendant la guerre, pp. 11-12.

$44 \mathrm{KP}$, Archives, fonds Leopold III, 58: Ingenbleek, mon journal de guerre, p. 38. 45 BNB, Archives, DC (Mont-de-Marsan), 02.07.1940. 
services and assets to Brussels, to all of which Gutt gave his approval, on condition that the government also agreed ${ }^{46}$.

It is manifestly clear that Janssen was impatient to return to Belgium; indeed, he had every reason to be impatient. The events of the preceding weeks had served to reduce the Bank's activities in France and the role played there by its governor to virtually nothing ${ }^{47}$; moreover, he had enjoyed little cooperation from the French, rather the opposite. Whenever he turned to his government, he was confronted with a group of rudderless, often quarrelsome ministers, who gave more attention to their personal household problems than to the interests of their country ${ }^{48}$. Against such a background, the prospect of a return to Brussels and the resumption of responsibility for such a respected institution as the Bank must have seemed irresistibly attractive: 'I consider it my duty to return to Belgium, where I can be much more useful than here $^{249}$. Janssen realized that a heavy task awaited him under the German occupation. It may also be that the heroic chord had been touched in him, as he ended his report to Ingenbleek on his latest meeting with Gutt half ironically: 'I am going to be executed!'so.

It was agreed that, on Saturday 6 July, before his departure for Brussels, Janssen would meet Gutt at Vichy, where the Belgian government had meanwhile established itself. During this last consultation, the details of the journey were arranged and ideas exchanged about the negotiations still taking place on the monetary agreement with the Banque de France. Janssen requested Gutt to put the final touches to

46 Janssen omitted to have the approval for his return confirmed in writing by Gutt and the entire government. In a letter of 17 July, he asked Ingenbleek to arrrange for this 'pour la bonne forme', but there was no response: BNB, Archives, $S D$, Janssen Papers, 'correspondance 1939-1941': letter of 17.07.1940 from Janssen to Ingenbleek (Mont-de-Marsan).

47 BNB, Archives, SD, dossier 'enquête BEB': report of the Commission of Enquiry: letter of 03.06.1946 from Ingenbleek to the chairman of the Commission of Enquiry.

48 Gutt's letters to Theunis from this period constantly refer to the wretched situation within the government (ARA, Theunis Papers, 'correspondance Theunis-Gutt': letters of June and July 1940).

49 BNB, Archives, SD, 40, liquidation of the Banque d'Emission, dossier 8.11.40/ 2 a: letter of 04.07.1940 from Janssen (Bordeaux) to Galopin (Brussels).

50 According to Ingenbleek, it was with these words that Janssen closed the account of his conversation with Gutt: KP, Archives, fonds Leopold III, 58: Ingenbleek, mon journal de guerre, p. 24. 
it and particularly to review the matter with his opposite number, the French Minister of Finance ${ }^{51}$. It was agreed that all Belgian government expenditure in the territories of the French and the British empires would be covered by loans granted by the French and British Treasuries respectively, half of which were to be settled in gold at the end of each month, as laid down in the monetary agreements of early June between France, Great Britain and Belgium. Servicing foreign debt in the United States and in Switzerland, as well as remunerating Belgian diplomats outside the French and British empires, would be by way of ceding gold to the Federal Reserve Bank of New York ${ }^{52}$. For his part, Janssen would, from Belgium, continue his efforts to have the Belgian gold deposits in France and Great Britain transferred to the Federal Reserve Bank of New York.

The responsibilities of Deputy-governor Ingenbleek had also to be discussed. Provisionally, he would head the services at Montde-Marsan. He would be responsible for the conversion in France of French money into Belgian for the Belgians who were returning to their country and would organize the repatriation of the Bank's staff and its assets. Lastly, it was his approval that would be required for transactions carried out on behalf of the Treasury at Vichy ${ }^{53}$, meaning that all important Treasury transactions to be conducted by the Bank as State exchequer in 'unoccupied' territories were dependent on Ingenbleek's approval, even though he remained in 'occupied' France. This was a faulty arrangement that was to lead to great difficulties during the ensuing months.

While the discussions between Janssen and Gutt at Vichy were being pursued, Kauch returned from Brussels. He arrived at Montde-Marsan on 6 July, accompanied by two German officers, and left that same evening for Vichy in order to report to Janssen and Gutt on his talks with Goffin, Galopin and Louis Frédéricq, Secretary to the King, about the general situation in Belgium. On 8 July, in the name of the head of the military supreme command, General Alexander von

51 See above.

52 BNB, Archives, SD, Janssen Papers, 'correspondance 1939-1941': letter of 17.07.1940 from Janssen to Plisnier. See also: BNB, Archives, $S D$, Malaise Papers: Kauch, note sur les opérations de change, p. 14, footnote 33.

53 вNB, Archives, DC (Mont-de-Marsan), 04.07.1940. 
Falkenhausen, the German officers asked Janssen if he wished to go back with them to Belgium, whether as governor of the Bank or as a private individual being entirely up to him. Janssen's preference was to return as governor and he left for Belgium on 9 July under German escort, arriving at Brussels the following day ${ }^{54}$. The organization of the repatriation of the Bank's staff and its assets was no trifling matter, but the entire operation was conducted without a hitch and represented an impressive effort on the part of all those involved 5 .

54 BNB, Archives, SD, London Archives, 67: note de M. le Gouverneur sur son activité entre le 10 mai et le 9 juillet 1940, Nos. 49, 50 and 51. See also: KP, Archives, fonds Leopold III: Ingenbleek, mon journal de guerre, pp. 40-42.

55 BdFr, Archives, Secrétariat Général, dossier 1060.2001.01/36: letter of 22.08.1940 from Janssen (Brussels) to Fournier (Paris). 


\section{CHAPTER 5 \\ In the Aftermath of Belgium's War Drama in France}

\section{INGENBLEEK'S 'FINEST HOUR'}

As stated in the previous chapter, Janssen transferred broad areas of competence to his deputy Ingenbleek, before he left for Brussels. The first concerned the conversion in France of French money into Belgian by Belgian refugees returning to their own country. Additionally, he was to act as State treasurer and State banker to the Belgian government at Vichy. Lastly, he was given responsibility for repatriating the Bank's assets.

The conversion of French money into Belgian was beset by many difficulties to which both the refugees and the Bank fell victim. Confronted by the virtually insuperable difficulties in exchanging their money and at last wearied by their sojourn in France, many refugees took their remaining French money to Belgium, as mentioned in the previous chapter, in the hope of being able to convert it there. That hope was initially fulfilled by the Reichskreditkasse, even though conversion was at a very unfavourable rate. The task of conversion was soon taken over by the Banque d'Emission of Brussels and the accredited Belgian exchange banks, which at the same time improved somewhat the rate of exchange. However, the Banque de France deemed the transactions not to be in conformity with the monetary convention of 9 July signed by Gutt and Bouthillier, and therefore labelled them as illegal; on these grounds, it then refused to settle in gold with the Bank for the repurchase of the French banknotes involved ${ }^{1}$.

1 BNB, Archives, SD, Janssen Papers, dossier 2, 'correspondance 1939-1941': letters of 30.07.1940 and 11.08.1940 from Janssen to Ingenbleek (Mont-de-Marsan). 
Janssen and Ingenbleek were severely dismayed and put out by the small-mindedness of the Banque de France, but had their backs to the wall - not for the first time in this perilous course of events - and wondered if the setbacks would never end. Ingenbleek requested Gutt to contact Bouthillier and find out whether he could induce the Banque de France to adopt a more flexible stance ${ }^{2}$, but there was no reaction to this. The exchange operation in France left the Bank with the frustrating feeling of having been duped by its friends, a feeling compounded by the heavy losses that the institution had sustained, which left deep scars, both financial and psychological.

The competence exercised by Ingenbleek as State treasurer and State banker to the Belgian government at Vichy was equally fraught with problems and was called into question by Kauch, among others, though rather in respect of a mistaken organizational measure than of criticism of him as a person. To allow Ingenbleek and the central services of the Bank to remain in the occupied zone at Mont-de-Marsan while the government moved to Vichy in the unoccupied zone was asking for trouble. Kauch claimed that, since 29 June, when Mont-de-Marsan had come under occupation, Ingenbleek was no longer in a position to carry out the function he had been charged with. It was clearly laid down in law that, in times of war, the Bank should follow the government into unoccupied territory.

Ingenbleek, Janssen, Gutt and the entire Belgian government viewed the matter differently. The Belgian government had approved the return of the Bank's registered office to Brussels, implying that the Bank was relieved of the obligation to establish its registered office at the place where the government found itself; indeed, that approval was in line with the government's own intention to make a speedy return to Belgium 3 . The representation at Mont-de-Marsan, accredited to the lawful French and Belgian governments at Vichy, was therefore competent to continue to perform all acts of administration and even to take safeguarding and administrative measures regarding the Belgian gold

2 BNB, Archives, SD, Janssen Papers, 'correspondance 1939-1941': letter of 01.08.1940 from Janssen to Ingenbleek (Mont-de-Marsan).

3 BNB, Archives, SD, Janssen Papers, 'correspondance 1939-1941': letter of 17.07.1940 from Janssen to Plisnier. See also: BNB, Archives, $S D$, Malaise Papers: Kauch, note sur les opérations de change, p. 14, footnote 33 . 
deposited with the Banque de France in West Africa. The Banque de France in the unoccupied area of Clermont-Ferrand and the Reichsbank in Berlin shared this view and would continue to regard the Bank in Brussels as their partner in discussion at all times.

The Federal Reserve Bank of New York, in what was at the time still a neutral United States, was more equivocal in its attitude towards the Bank. Initially, it refused to accept Baudewyns's signature in London for foreign payment orders as, in its opinion, his mandate of 18 June did not extend to that domain. Basing itself on Janssen's decision on his return to Belgium at the beginning of July, it was nevertheless prepared to accept the signature of Ingenbleek, who remained at Mont-de-Marsan. However, when in mid-August the Deputy-governor also returned to Belgium, it began demanding the signature of Janssen himself. Shortly thereafter, it changed tack again, now no longer accepting the Governor's signature, its argument being that the board of directors of the Bank was no longer represented at the seat of government ${ }^{4}$.

The manner in which Ingenbleek in practice fulfilled his functions as State treasurer and State banker to the Belgian government likewise gave rise to serious problems. He did, indeed, adopt a very formal approach to procedure. In his view, the return of the Bank to Brussels implied the reinstatement in Brussels of the board of directors in its original competences; however, the occupation meant that recognition had to be given both to the Bank's subjection to German tutelage and to the authority of Oscar Plisnier as Secretary-general of the Ministry of Finance. Consequently, Ingenbleek felt duty-bound to subject every major act of administration to the prior approval of not only the board of directors in Brussels - thus of Janssen and Goffin - but also to that of the German commissioner appointed for the Bank, as well as to that of the Secretary-generals.

4 On 21 August, via Fournier of the Banque de France, the Federal Reserve Bank asked Janssen whether he wished to confirm his payment order of 8 July in favour of the Chase National Bank in New York, so that payment could be made: BdFr, Archives, Direction de la Documentation, dossier 1397.1994.01/71: letter of 21.08.1940 from Fournier (Vichy) to Janssen (Brussels).

5 BNB, Archives, $S D$, Ingenbleek Papers, dossier 'direction Mont-de-Marsan': letter of 17.07.1940 from Ingenbleek (Mont-de-Marsan) to Janssen, 17.07.1940; KP, Archives, fonds Leopold III, 58: Ingenbleek, mon journal de guerre, pp. 45-46. 
Janssen agreed, certainly as regards his own role. Gutt was explicit about this, stating that Janssen thought he could organize everything from Brussels ${ }^{6}$. For their part, the German commissioner and the Secretary-general took a fairly relaxed view of the matter, but their involvement in any case implied a bureaucratic procedure. With the added complication of the difficulty of communication at that time between Brussels, Mont-de-Marsan, Vichy and London, the exercise of the function of State treasurer and State banker to the Belgian government at Vichy was reduced to a painful exercise of inertia and frustration for all concerned.

\section{THEUNIS'S DESPAIR}

Besides the responsibility he held regarding the financing of Belgian government expenditure in France, Ingenbleek also felt responsible for his government's expenditure in foreign countries outside France. In this respect, too, the impossible stance he adopted led to serious friction that threatened the smooth operation of the Bank. On 16 July, he had telegraphed to Baudewyns and Theunis to inform them that the Bank could execute foreign payments in London and New York for the State only on instructions from himself, from Janssen, from Plisnier and from the German commissioner at the Bank.

In London, Baudewyns had been attempting since the beginning of July to implement the Anglo-Belgian monetary convention of 7 June and the financial agreement of 8 June between the Bank of England and the Bank, but without success 7 . Indeed, implementing the convention was never even started, indicating that it had been a miscalculation to count on a loan from the British government within its framework. Meanwhile, the situation regarding unsettled foreign debt had reached a critical stage. In the United States, the reserve of dollars previously set aside for the procurement of five aircraft had been released by Theunis to pay off part of the interest due on foreign debt, but that was a one-off

6 ARA, Theunis Papers, 'correspondance Theunis-Gutt': letter of 18.08.1940 from Gutt (London) to Theunis (New York).

7 BNB, Archives, SD, London Archives, 'correspondance 1940', s. f. 7: letters of 10.07.1940 and 12.07.1940 from Baudewyns (London) to Janssen. 
operation that could do nothing in the future to solve the problem of outstanding debt and current costs ${ }^{8}$. Complaints, indeed, were coming in thick and fast from the diplomatic and consular corps at the failure to pay salaries and representation costs9.

For Theunis, the responsibility for the financial disarray confronting the Belgian government since its move to France lay with the Bank ${ }^{10}$. The return of Janssen to Brussels, moreover, was viewed by Theunis as a great mistake, as he had thereby left the government in the lurch at a dramatic moment. Theunis further accused him of not having prepared his departure with sufficient care and of not having made appropriate arrangements for payments. He wondered what had possessed Janssen to return to Brussels. His view was that the decisive factor in Janssen's fatal choice had been the government's decision at the end of June to give up the struggle and to return as quickly as possible to Belgium after the repatriation of the refugees. Gutt concurred with this opinion, but could not ignore the fact that he, too, bore a certain responsibility in the matter. After all, it was he who, as Minister of Finance, had authorized Janssen to return and re-establish the Bank's registered office in Brussels and had convinced the government to approve the decision to return. Gutt was later to qualify his stance by emphasizing the role played by Galopin in this matter, but to state that Galopin's 'express' request was of decisive significance ${ }^{11}$, is to put a gloss on the facts that was not universally shared and that was emphatically rejected by Galopin himself ${ }^{12}$.

The British government had been following the evolving Belgian stance with increasing distrust. It was extremely sceptical about the Bank's return to Brussels and was downright hostile to the Belgian government's decision to sue for peace. For the British, Janssen's idea of

8 ARA, Theunis Papers, 'correspondance Theunis-Gutt': letter of 18.08 .1940 from Gutt (London) to Theunis (New York); BNB, Archives, $s D$, London Archives, 'correspondance 1940', s. f. 7: letter of 10.07.1940 from Baudewyns to Janssen.

9 BNB, Archives, SD, London Archives, 'correspondance 1940', s .f. 7: letter of 03.08.1940 from Baudewyns (London) to Theunis (New York) and Gutt (?).

10 ARA, Theunis Papers, 'correspondance Theunis-Gutt': letter of 20.08.1940 from Theunis (New York) to Gutt (London).

11 ARA, Theunis Papers, 'correspondance Theunis-Gutt': letter of 29.08.1940 from Gutt (London) to Theunis (New York).

12 See above. 
continuing the foreign activity of the Bank from Brussels and Mont-deMarsan was simply unacceptable: 'It is evident', wrote Ansiaux to Janssen on 3 August 1940, 'that your interventions can have effect only outside the dollar- and the sterling area; in both areas orders from Brussels, and even from unoccupied France, will not be executed. I have received already a warning about it from the Bank of England, which is increasingly suspicious about our contacts with Mont-de-Marsan and Vichy. Soon we will have to choose between not following your instructions or being interned ${ }^{13}$. It was only after the formation of a Belgian Government in London that there was a glimmer of a solution to this problem.

Ingenbleek's third task at Mont-de-Marsan was to organise the repatriation of the Bank's assets from France to Belgium. Initially, everything went fairly smoothly, the majority of them being returned to Belgium during the month of July. In early August, however, it was found that repatriation of the last part of the assets at Tarbes and Toulouse was prohibited. What lay behind this odd measure? According to insiders, the German authorities had got wind at the end of July of the intention of Gutt, Pierlot and Spaak to set out for the Franco-Spanish border and to cross to England via Portugal. With that knowledge, it was but a short step to assuming that the purpose was to form a government in London and perhaps continue the struggle. Was this the real reason or was it rather the German authorities' request to the French government not to recognize, with effect from the end of July, any foreign government in exile at Vichy? The presumption is that both factors played a part. In any case, the Paris radio was announcing at the beginning of August that the three Belgian ministers had left for the Franco-Spanish border and the prohibition was therefore interpreted by many as being an immediate sanction aimed against their action ${ }^{14}$.

Following the advice of Deputy-governor Ingenbleek and Secretary Van Nieuwenhuyse, Janssen submitted a request on 22 August to the Banque de France and to the German commissioner at the Bank in Brussels for repatriation of the assets and holdings from Toulouse and Tarbes. On 29 August, Fournier, Governor of the Banque de France,

13 BNB, Archives, SD, Ansiaux Papers, A 1: letter of 03.08.1940 from Ansiaux (Vichy) to Janssen.

14 KP, Archives, fonds Leopold III, 58: Ingenbleek, mon journal de guerre, pp. 55-56; BNB, Archives, Boekhouding, dossier 88.02.02.00 (B 608/13): letter of 10.08.1940 from Smeers (Vichy) to Sibille (Tarbes). 
indicated that there would be no further objection to repatriation, provided certain conditions were accepted. Ultimately, these concerned a few minor points in the dossier, so that Janssen was quickly able to put things to rights and official permission was received a few days later on 15 October. Ingenbleek played no part in this closing phase of the repatriation. Since the German authorities had requested the Pétain government to no longer recognize the Belgian government at Vichy ${ }^{15}$, French control over Belgian government expenditure had tightened by the day until finally it became virtually impossible to have orders executed in the dollar and sterling zones. Ingenbleek therefore perceived that his role at Mont-de-Marsan was played out and he returned to Brussels on 12 August. Van Nieuwenhuyse was left to handle this last phase of the repatriation.

\section{FINAL EFFORTS TO EVACUATE THE GOLD (AUGUST-SEPTEMBER 1940)}

On 5 July 1940, in London Baudewyns learnt that the Belgian gold deposited with the Banque de France was under military guard in the harbour of Dakar, news that was soon confirmed by British sources ${ }^{16}$. In London, it was known that most of those in authority in French West Africa recognized the Vichy government as legal or were at least positively inclined towards it. It could not therefore be excluded that, via Vichy, the Belgian gold might in time end up in German hands, and various ideas about how to prevent that happening were floated.

Ansiaux, in consultation with Baudewyns, Cartier de Marchienne and René Boël, came to the conclusion that the best course was for him to travel to Vichy, where, with the help of the Belgian government, he would attempt to persuade the Banque de France to return to the Bank's instruction of 18 June and evacuate the Belgian gold deposit to the United States ${ }^{17}$. If the attempt were to fail, Ansiaux would then demand

15 BNB, Archives, SD, dossier 8.11.43, Commission of Enquiry (Banque d'Emission): letter of 03.06.1946 from Ingenbleek to the chairman of the Commission of Enquiry.

16 BNB, Archives, Studiedienst, 13, dossier A 320/6: Ansiaux, note relative à l'or (New York, 17.04.1941), p. 11.

17 'Eté 1940. Les vagabondages de l'or et du gouvernement belge. Entretiens avec Hubert Ansiaux, II', in: Revue Générale, March 1985, pp. 3-15. 
restitution of the deposit and himself take it to the United States ${ }^{18}$. As Head of the Belgian Economic Mission in London, Boël had the Belgian Navy within his jurisdiction and would ensure that a ship was available in the Lisbon Roads, ready to take the gold to England or the United States ${ }^{19}$. For his part, Ansiaux, assumed that, with authorization from Baudewyns, he would have the requisite authority to carry out the plan successfully.

Ansiaux left London for Lisbon on 14 July, but difficulties in obtaining a travel visa for France meant that he arrived at Vichy only on 29 July, around midnight ${ }^{20}$. The next day, together with Gutt, he had a personal meeting with Fournier at the headquarters of the Banque de France at Clermont-Ferrand. Fournier acknowledged that, on 18 June, Gutt, Janssen and Ansiaux had given instructions that the Belgian gold be taken to the United States, but said that the French Navy was no longer 'in a position' on that date to observe those instructions, as an armistice had been requested the day before and military etiquette had not permitted the situation then existing to be changed while negotiations were being conducted; it had happened that, just before the request for an armistice had been submitted, an order had been given to transport the gold to a French territory overseas, and Admiral Darlan had no longer been able to reverse that order. Ansiaux replied by asking whether, as the authorized agent of the Bank, he could not himself take charge of the Belgian gold deposit at Dakar and, at the Bank's cost and risk, take it to the United States. In Fournier's opinion, the Banque de France would have no objection to that proposal, but the indisputably political nature of such an operation meant that the French government, too, would have to give permission.

Gutt and Ansiaux immediately demanded a meeting with the French Minister of Finance, Bouthillier, at Vichy, but that proved to be impossible, because the presence of the Belgian Minister of Finance there would be contrary to the Germans' request on 27 July to the French

18 BNB, Archives, Studiedienst, 13, dossier A 320/6: Ansiaux, note relative à l'or (New York, 17.04.1941), p. 12.

19 BNB, Archives, SD, London Archives, 2, 'correspondance 1940', s. f. 7: letter of 23.08.1940 from Ansiaux (Vichy) to Baudewyns (London).

20 BNB, Archives, Studiedienst, 13, dossier A 320/6: Ansiaux, note relative à l'or (New York, 17.04.1941), p. 11-19. 
government to sever all contacts with governments in exile at Vichy, including the Belgian. To add to this, Ansiaux found out on 31 July, a day after the meeting with Fournier, that Bouthillier had given written instructions for all French and foreign gold assets in French overseas territories to be frozen ${ }^{21}$. That same day, accompanied by Spaak and Pierlot, Gutt travelled to Le Perthus on the Franco-Spanish border to meet De Vleeschauwer, who had come over especially to persuade them to move as a government to Great Britain. Gutt declared himself willing to go immediately; indeed, he had already prepared for this decision, having on 30 July requested and obtained the authorization of the Cabinet to leave - even alone - for London as a member of the government.

On 2 August, Bouthillier received Ansiaux and notified him that, for political reasons (almost certainly because of German pressure), the French government could not accede to his request for the restitution of the Belgian gold and his proposal for its transfer to the United States at the Bank's cost and risk ${ }^{22}$. Undaunted, Ansiaux insisted on a second meeting, in order to pursue the matter further. Bouthillier agreed, but left the discussion to two of his officials. These sympathized to a certain degree with Ansiaux and suggested that he involve the Minister of Foreign Affairs, Paul Baudouin, in the discussion. Ansiaux followed their suggestion and his persistence was rewarded by Baudouin instructing his political director, Rochat, to study the dossier.

A few days later, Rochat made known via his deputy that the French government had authorized the Banque de France to return the gold, but only under specific conditions. Because the Bank had now removed its registered office to Brussels, Ansiaux's current mandate was deemed inadequate, both the French government and the Banque de France believing that the authority to request restitution now lay with the Bank in Brussels and not with Baudewyns in London. Authorization for restitution could thus be given only if Janssen directed an official letter to the Head of State, Marshal Pétain, in which (i) he requested restitution of the Belgian gold being held at Dakar, (ii) gave explicit authorization

21 Cornu, L’or monétaire au vingtième siècle, p. 168.

22 For an account of these negotiations, see: BNB, Archives, Studiedienst, 13, dossier A 320/6: Ansiaux, note relative à l'or (New York, 17.04.1941), pp. 14-18. See also: the supplementary memorandum 'démarches faites à Vichy et Clermont-Ferrand, 19.07.1940 - 15.12.1940'. 
to Ansiaux to take receipt of that gold and (iii) guaranteed that the gold would be transported to Argentina or to another neutral country. From Vichy on 11 August, Ansiaux wrote to Janssen in Brussels requesting his agreement with these conditions ${ }^{23}$, but letting Janssen know in strict confidence by courier that, once the gold was in his possession, he would ensure that it got to the United States ${ }^{24}$.

There was no immediate answer from Janssen and events conspired to ensure that an answer would not arrive in time. In fact, it never came. On 12 September, realizing that his permit to reside in unoccupied France was due to expire, Ansiaux undertook a last effort with Rueff, now Acting Governor of the Banque de France, following the dismissal of Fournier, but their meeting was brief and negative. It was, in fact, to be the final official meeting between representatives of the two central banks, aiming at an amicable settlement of the gold question. On 16 September, Ansiaux sent a registered letter to the Banque de France, declaring that institution officially in default in the matter of restitution of the deposit of gold to the Bank, the legitimate owner. That same evening, he left Vichy and returned to London ${ }^{25}$.

Current events were now prompting a change of strategy. In a raid on Mers-el-Kébir at the beginning of July, the British had destroyed a number of French warships and merchantmen under the command of men faithful to the Vichy regime. An attempted landing in the vicinity of Dakar at the same time had come to nothing, but had sown great unrest in colonial government circles, the more so as British propaganda had achieved a degree of success in convincing French colonists in Senegal to distance themselves from the defeatist Vichy regime and ally themselves with the British struggle against Germany. Moreover, the crisis had induced the authorities immediately to unload the French,

23 вNB, Archives, SD, Ansiaux Papers, dossier A 1, pp. 36-37: letter of 11.08.1940 from Ansiaux (Vichy) to Janssen.

24 BNB, Archives, SD, London Archives, 2, 'correspondance 1940-1941', s. f. 7: letter of 23.08.1940 from Ansiaux (Vichy) to Baudewyns (London).

25 BNB, Archives, Studiedienst, 13, dossier A 320/6: Ansiaux, note relative à l'or (New York, 17.04.1940), pp. 16-17; Lepotier, La bataille de l'or, pp. 235-246. For a good and detailed survey of the transfer of the French, Polish and Belgian gold by convoy from Brest and Lorient to Casablanca-Dakar and from Dakar to Thiès and Kayes, see: BdFr, Archives, Secrétariat Général, dossier 1060.2001.01/42: report of 18.01.1941 from Gontier (Clermont-Ferrand) to Favre-Gilly (Paris). 
Belgian and Polish gold (about 1,130 tonnes) from the convoy that had just arrived at the port of Dakar and take it to the military base of Thiès, about seventy kilometres from Dakar, on the Dakar-Bamako railway line.

Internal tensions had kept the situation in the colonies agitated and confused. In the meantime, and together with the British, General de Gaulle had been preparing a large-scale attack on Dakar, with the intention of bringing the whole of French West Africa under Allied con$\operatorname{trol}^{26}$. The French authorities had then found it safer to send the gold along the same railway line to the bastion at Kayes, 500 kilometres further inland, on the border with Senegal and French Sudan ${ }^{27}$.

In July, three members of the Belgian armed forces, Captain Georges J. Truffaut, Second Lieutenant Floor and Sergeant Van den Eynden, had journeyed by ship from West Africa to Great Britain to join the Allied armed forces ${ }^{28}$. From their Polish companions on board, they had heard the details of the evacuation of the French, Belgian and Polish gold, and had given that information to the Belgian authorities in London, additionally offering their services to help attempt to move the gold from a French African to a British African territory. Gutt had only just arrived in London when he heard that the Polish government in exile - with the help, or at least with the cooperation of the British Navy - was organizing an expedition to recover the Polish gold in Africa. Gutt's thoughts had turned immediately to the Belgian gold there and he had obtained

26 The idea came from Churchill. He had foreseen that Great Britain would rapidly be facing a shortage of gold, because British purchases of war material in the United States were on the basis of the 'cash and carry' system applied by the Americans. Churchill asked de Gaulle to devise a concrete plan and de Gaulle came up with Opération Menace. Churchill approved it and ordered British cooperation. However, talks were accompanied by a sharp discussion about how, once it was recovered, the gold could be used. Would France, Poland and Belgium be able to use it for their own ends or would Great Britain be able to have recourse to it for use in the Allied cause, under her leadership? Ultimately, Allied solidarity won the day: J. De Launay, Histoire de la diplomatie secrète de 1914 à 1945, Verviers, 1966. See also: W. Churchill, The Second World War. Vol. 2; Ch. de Gaulle, Mémoires, Part I, p. 2oo; Lepotier, La bataille de l'or, pp. 242-245.

27 Cornu, L’or monétaire au vingtième siècle, p. 167; BNB, Archives, $S D$, Malaise Papers: Kauch, note relative au dépôt d'or, $\mathrm{n}^{\circ} 13$.

28 E.C. Truffaut, Sauver l'or belge. La mission du capitaine Georges Truffaut en Afrique occidentale (aô̂t-septembre 1940), Tubize, 1997. 
permission from Churchill and Halifax for the three Belgians to join the Polish expedition ${ }^{29}$. These three he had charged with getting the gold to Bathurst in Gambia; at the same time, he had asked Baudewyns whether the Bank could not finance the attempt, with a little extra added on 'to buy a conscience or two, if necessary' in West Africa ${ }^{30}$.

The Polish-Belgian expedition had sailed on 22 August 1940 and on 6 September had reached Bathurst, where the Belgians had attempted to work out an initial strategy. During the following days, Truffaut and Floor had been able to lay their hands on a copy of the bills of lading regarding the Belgian gold, a major first step, but thereafter the three had made no further progress ${ }^{31}$. Ultimately, they had decided that it would be better for them to link up with the expeditionary force that, under the command of de Gaulle and with the help of a Franco-British fleet, was preparing to launch an attack from Freetown (Sierra Leone) to seize Dakar; once at Dakar, the three would carry out their mission from there ${ }^{32}$. The attack took place on 23 September, but was completely beaten off. From a conversation with de Gaulle on 1 October at Freetown, the Belgians inferred that they ought not to count on a fresh attack for the time being ${ }^{33}$. During their visit to de Gaulle, they also learnt to their surprise that, with the support of the British Treasury and the Bank of England - and probably behind the backs of Gutt and Baudewyns - another Belgian officer, Louis Franck, had accompanied the expeditionary force, with the aim of getting the Belgian gold to a British African territory ${ }^{34}$. Confusion reigned and on 8 October Truffaut let

29 ARA, fonds ministerie van Financiën, kabinetsraad: letter of 19.08.1940 from Gutt to (Baudewyns?); letter of 20.08.1940 from Gutt (London) to Halifax (London). See also: De Lovinfosse, Au service de Leurs Majestés, p. 119.

30 ARA, fonds ministerie van Financiën, kabinetsraad: letter of 21.08.1940 from Gutt to Baudewyns (London); letter of 28.08.1940 from Gutt (London) to de Lantsheere (London).

31 De Lovinfosse, Au service de Leurs Majestés, p. 118.

32 ARA, fonds ministerie van Financiën, kabinetsraad: letter of 24.09.1940 from Floor (Bathurst) to Gutt (London).

33 De Lovinfosse, Au service de Leurs Majestés, p. 118.

34 ARA, fonds ministerie van Financiën, kabinetsraad: message of o8.10.1940 from Truffaut to Gutt via the British governor of Sierra Leone and to Waley of the Bank of England. See also: BNB, Archives, SD, London Archives, 2, 'correspondance 19401941': memorandum of 22.08 .1940 by Baudewyns on the Truffaut mission; report 
Table 5.1: Geographic breakdown of the BNB's gold reserve and of the gold of third parties, held by the BNB in safe custody (situation as at 1 August 1940, in millions of Belgian francs)

1) BNB's own gold reserve (estimate):

Gold reserve in Brussels

Gold reserve deposited with the Federal Reserve Bank (New York)

Gold reserve deposited with the South African Reserve Bank (Pretoria)

Gold reserve deposited with the Bank of England (London)

Gold reserve deposited with the Banque de France (West Africa)

Total: $\quad 21,088$

2) Gold of third parties, held by the BNB in safe custody (estimate):

Gold of third parties at the Banque de France:

- belonging to the Banque du Congo Belge

- belonging to the Caisse d'Epargne du Luxembourg

- belonging to the Postal Cheque Office

Gold of third parties at the Bank of England:

- belonging to the Banque du Congo Belge

Total:

826

Total amount of gold of the BNB and third parties, deposited by the BNB in safe custody with foreign central banks (less the reserve in Brussels): circa 21,906 million Belgian francs

Sources: BNB, Archives, Boekhouding, file 88.02.02.00 (B 608/11 and 14, D 609/1). Freiburg im Breisgau, Military Archives, Militärverwaltung, file R.W. 36/277: Hofrichter, Abschluszbericht der Militärverwaltung in Belgien und Nord-Frankreich, Part 1, pp.87-88.

it be known from Freetown that he regarded his mission as failed ${ }^{35}$. Of Franck, nothing more was heard. The grand dream of recovering the Belgian gold had thus fairly quickly come to an inglorious end.

of 03.10.1940 from Floor to Gutt; general Truffaut-Floor report of 08.10.1940 (Freetown) to Gutt.

35 ARA, fonds ministerie van Financiën, kabinetsraad: general Truffaut-Floor report of 08.10.1940 (Freetown) to Gutt. See also ARA, fonds ministerie van Financiën, kabinetsraad: letter of 13.12 .1940 from Gutt (London) to De Vleeschauwer (Leopoldville). 


\section{THE COST OF THE PEREGRINATION IN FRANCE}

What picture did the financial balance sheet reveal for the Bank once hostilities had ceased? On an interim estimate by the Bank, the gold reserve shrank by about 2,380 million Belgian francs between 10 May and 1 August 1940, namely from 23,469 million Belgian francs to 21,088 million, the reduction concerning chiefly the exchange of Belgian money into French by the refugees and by the government. Advances made by the Bank to the government between 10 May and 15 August totalled 1,693 million Belgian francs, according to a provisional estimate by Smeers, the representative of the Treasury at the Bank, who transferred sixteen Treasury certificates for 100 million Belgian francs each to the Bank for the purpose. 


\section{CHAPTER 6 \\ The Installation of the German Administration}

\section{DISLOCATION AND THE 'NEW ORDER'}

As indicated above, the evacuation of government departments had been poorly planned, if indeed there was any planning at all. Soon after the German invasion not only had the parliamentary representatives and the government quit the country, but they had been followed by many officers of the central administration, the sole exception being the magistrates, most of whom, both locally and centrally, remained at their posts ${ }^{1}$. The situation was repeated at the Bank and among the other semi-public institutions: many officials and white-collar workers had slipped across the border to join their institution in France. The officials of the Postal Cheque Office had even taken their book-keeping and other documents with them, but were forced to abandon everything at a school in Kortrijk and hide them there before getting across the border just in time ${ }^{2}$.

The Belgian army by implementing the 'scorched earth' policy had destroyed many bridges, viaducts, tunnels and other infrastructural works all over the country. Rivers and canals had been made unnavigable by the collapsed bridges and various public utility installations, such as telephone and telegraph networks, and even gasworks and electricity generating stations had been put out of action ${ }^{3}$. If it was not over-

1 BIS (Basel), Archives, dossier 7.18 (6), AUB 4/21: Struye, l'opinion publique de Belgique, p. 11.

2 It was only shortly before 13 June that the documents were recovered: SG, Archives, $D C, 04.06 .1940$ and 13.06.1940.

3 BIS (Basel), Archives, dossier 7.18 (6), AUB 4/21: Struye, l'opinion publique de Belgique, p. 2; SG, Archives, DC, 22.05.1940 and 27.05.1940. 
whelming, the amount of material damage done during the Eighteendays Campaign nevertheless was still fairly substantial ${ }^{4}$.

The situation was aggravated by the lack of public administration and particularly by the acute shortage of money. It is true that the government had given local and provincial authorities additional powers to take emergency measures ${ }^{5}$, but the Committees for Public Assistance fairly quickly found themselves with no cash to provide support ${ }^{6}$. The evacuation of the Postal Cheque Office posed an even greater problem: because of the absence of the account books and a large proportion of the staff, the 442,00o account-holders were no longer able to make transfers, withdraw deposits or cash cheques?. When the Liège coal mines gradually resumed their activity, they found themselves obliged to pay their workers with their own emergency money ${ }^{8}$.

The discipline of the German army of occupation contrasted sharply with the chaos and anarchy rife among Belgian public authorities during the first weeks of the war. The Germans did not behave arrogantly, but sought to give the impression that they wanted strictly to observe the international rule of law and more particularly the 1907 Hague Convention'. German attempts to build up a favourable image among the population received an indirect boost from an unexpected quarter after the armistice of 28 May. The disgraceful accusations levelled by the French government at Leopold III and the Belgian army, followed by a somewhat toned-down repetition of them over the radio by the Belgian Prime Minister, Pierlot, deeply offended Belgian people both at home and scattered abroad. Their view of matters was that the King had not committed any treasonable act and, in capitulating, had avoided a

4 BNB, Archives, Studiedienst, dossier 01.02.01.70 (A 238/2, s. f. 4 a): estimation des dommages de guerre subis par la Belgique.

5 BNB, Archives, Studiedienst, 2, dossier 01.02.01.70 (A 247/6, s. f. 9): quelques rétroactes relatifs aux circonstances qui ont provoqué la création de la BEB (note de la Société Générale), 26.03.1943, pp. 3-4.

6 SG, Archives, DC, 15.05.1940.

7 BNB, Archives, Studiedienst, 2, dossier 01.02.01.70 (A 247/6, s. f. 9): quelques rétroactes relatifs aux circonstances qui ont provoqué la création de la вEв (note de la Société Générale), 26.03.1943, pp. 4-5.

8 SG, Archives, DC, 21.05.1940.

9 BNB, Archives, SD, 41, Commission of Enquiry (Banque d'Emission), dossier 8.11.43 $\left(\mathrm{n}^{\circ} 33\right)$ : letter of 01.10.1940 from Rolin to Janssen. 
needless bloodbath; they stood four square behind him and against the government. Even greater castigation was heaped on the Belgian government by the refugees returning from France, who attributed their losses in the currency exchange operations to their government's 'monetary manipulations ${ }^{10}$.

Meanwhile, the feeling grew that the war would be of short duration and that Germany would in any case dominate the European continent for some time to come. Public opinion in Belgium, which included a number of prominent people in the country, hesitated between two possible outcomes: either total victory for Germany or a compromise peace between the two remaining belligerents ${ }^{11}$. Writing from Lisbon on 3 July to his minister in London, the Dutch envoy Bennert Philip van Harinxma thoe Slooten, who had kept close to the Belgian government from mid-May to the end of June, observed 'I continue to look for a ray of hope for the British cause, but can find none and feel that there are few chances of England winning this war' ${ }^{12}$. Somewhat later, from Vichy, Ansiaux wrote to Baudewyns in London: 'Prevailing Belgian opinion is strongly in favour of the Germans....Everyone is taken with the idea of a «European Peace»...Whatever happens, the old regime is finished, because the revolution, which has overtaken hearts and minds, is already too far advanced. Everyone is coming back - the rush to return to Brussels is as great as was the rush to leave it ${ }^{{ }^{13}}$.

The occupation of Belgium, the Netherlands and France had been well prepared by Germany ${ }^{14}$. On 19 October 1939, with the experiences

10 See above.

11 The German Luftwaffe's failure in September-October 1940 to win control of British skies and thereby the Battle of Britain had already then raised serious doubts about the possibility of total German victory, though the possibility of a compromise peace was still alive: P. Nefors, Industriële collaboratie in België. De Galopin-doctrine, de Emissiebank en de Belgische industrie in de Tweede Wereldoorlog, Leuven, 2000, pp. 31-32; BIS (Basel), Archives, dossier 7.18 (6), AUB 4/21: Struye, l'opinion publique de Belgique, pp. 7-8.

12 Ndl.BZ, London Archives, 1940-1945, GA GII, België, n 4: letter of 03.07.1940 from van Harinxma thoe Slooten (Lisbon) to Van Kleffens (London).

13 BNB, Archives, $S D$, London Archives: letter of 23.08.1940 from Ansiaux (Vichy) to Baudewyns (London).

14 P.F. Klemm, German Economic Policies in Belgium from 1940 to 1944, Ann Arbor (Michigan), 1973, pp. 29-33. For Himmler's unavailing attempts to install a Civil Government in Belgium, see: Velaers and Van Goethem, Leopold III, pp. 329-330. 
in Poland in mind, Hitler had ordered the army to draw up a general plan for military administration in the occupied territories to the west. The plan worked out was twofold: governance would be strictly centralized and would not aim at any annexation. It would be geared to reviving the individual economies; scarce strategic raw materials, however, would be requisitioned and transferred to the German war economy ${ }^{15}$. Hitler approved the plan and on 5 November of that year a special commission was set up under the presidency of the district president of Rhineland-Westphalia, Eggert Reeder, with the task of fleshing out the plan; the commission completed its work in January 1940.

On 14 May 1940, Hitler appointed Alexander von Falkenhausen as military commander for Belgium, Northern France and Luxembourg, though this last was removed from his authority a few weeks later on its annexation to the Reich in July-August 1940. Reeder was appointed as head of the Military Government and Harry von Craushaar as Deputypresident ${ }^{16}$. The Military Government had various departments, including an important economic department (Abteilung Wirtschaft). Within a sub-department for monetary and financial affairs (Gruppe VIII), a unit (the Bankaufsichtamt) was created to supervise private banking and the central bank; this sub-department was headed by Hans von Becker, with Dr. Helmuth Hofrichter as his deputy.

Von Falkenhausen $\left({ }^{\circ} 1878\right)$ belonged to the old German aristocracy and had had a distinguished military career that had taken him to the Middle East, Japan and China. He was a highly cultivated man, openminded, correct and had an international outlook ('ein ausserordentlich anständig denkender Mann ${ }^{17}$ ). Conservative in his opinions, but nevertheless with an independent spirit, he also steadfastly refused to join the Nazi Party. He was certainly not ill-disposed towards Belgium and, insofar as he could, attempted to defend Belgian interests, but could not and would not run foul of instructions from the Nazi government in

15 Velaers and Van Goethem, Leopold III, p. 44; Milward, Economy and Society, 19391945, p. 132.

16 Velaers and Van Goethem, Leopold III, pp. 38-39; BNB, Archives, Studiedienst, 2, dossier 01.02.01.70 (A 247/6, s. f. 7): indications relatives à certains membres du commissariat allemand, annex.

17 SOMA, Archives, Prack Papers, dossier JP 965: Vier Jahre Besatzungszeit in Belgien. Persönliche Erinnerungen von Herbert Prack, p. 43. 
Berlin. He was dismissed on 18 July 1944 and shortly thereafter arrested by the Gestapo ${ }^{18}$.

Reeder $\left({ }^{\circ} 1894\right)$ was a lawyer from Schleswig and had been a member of the Nazi Party since 1933. He, too, was independent-minded and, for example, never gave up his friendship with well-known non-Nazis, despite pressure from the party. Prior to his appointment as head of the Military Government in Belgium, Northern France and Luxembourg, he, as a Prussian official, had occupied high office in Rhineland-Westphalia. He was the epitome of the traditional Prussian bureaucrat: intelligent, purposeful, sober, demanding of himself and his colleagues, honourable and fundamentally honest. Standing by hierarchy and authority, he deemed it his duty to mobilize the Belgian economy to the fullest in the service of the German war effort. However, he never lost sight of the original purpose of the special commission that he had presided over in 1939, namely to promote the development of national economies in the occupied territories in order that a certain degree of prosperity should be maintained. Naturally enough, and indeed as a matter of priority, all efforts had to be in the service of the Reich ${ }^{19}$ The attitude of Reeder and von Falkenhausen thus contrasted clearly with that of the Nazis, whose purpose was simply a systematic plundering of conquered territories ${ }^{20}$.

Von Becker was made commissioner of the Banque d'Emission on 26 June $194 \mathrm{O}^{21}$. During the First World War, he had been deputy to the then German commissioner at the Bank, Karl von Lumm, in Brussels, and during the inter-war years had worked in a Berlin private bank. Despite these credentials, he was not regarded in the banking world

18 M. De Vlaminck and L. De Vos, 'De Belgische industriëlen tijdens de bezetting, 1940-1944. Collaboreren om de bezetter te schaden, produceren met het oog op de naoorlogse periode', in: Belgisch tijdschrift voor militaire geschiedenis, XXvI, 2 (June 1985), p. 114.

19 J. Gérard-Libois and J. Gotovitch, L'An 40. La Belgique occupée, 1971, p. 151.

20 P.F. Klemm, German Economic Policies in Belgium, pp. 34-37; M. Rehm, Eggert Reeder (22 Juli 1894 - 22 November 1959): Preuszischer Regierungspräsident, Militärverwaltungschef, Staatsburger, $13 \mathrm{p}$.

21 BNB, Archives, Prack Papers, dossier JP 965: Das Währungs-, Geld- und Bankwesen in Belgien, Part 1; SG, Archives, DC, 14.06.1940; BNB, Archives, Studiedienst, 2, dossier 01.02.01.70 (A 247/6 s. f. 7): Basyn, note relative à certains membres du commissariat allemand, pp. 1-2. 
as being professionally competent. What he lacked in intelligence, he more than made up for in arrogance. He was, in the worst sense of the term, the bon vivant type and was chiefly out for money and honour. In August 1943, he was dismissed as commissioner at the Bank and the Banque d'Emission. A year later, in 1944, he was convicted of currency smuggling by a Berlin court and demoted ${ }^{22}$. With effect from 1 December 1943, he was succeeded by Reichsbank director Jost, a rather weak figure, suspicious and secretive.

Von Becker's deputy, Hofrichter, was cast in an entirely different mould. He was the driving force behind the control of the private banks, the strong man in the supervision of the Bank and the Banque d'Emission ${ }^{23}$. During the autumn of 1939, he had been involved in the reorganization of central banking in Poland, and this experience had led to his appointment in Brussels. A confirmed party member, with a number of typically Prussian traits, he was intelligent and well grounded, not to say thoroughly expert, in banking matters. To cap that, he was a workaholic and a tough negotiator.

Hofrichter was thus anything but well liked in Belgian banking circles or indeed among his own people, and was feared by all, a regular comment of his to his staff being, 'One should not be loved, but feared ${ }^{24}$. On the other hand, it was said of him that, aside with a few exceptions, he was fundamentally correct in his dealings with people and that, as the war progressed, he became less acerbic. He was in any case upright, although it undoubtedly took courage and intelligence to oppose him; in fact, the only persons in the Bank who could face up to him were governor Janssen, the chief inspector François Cracco, and later also the director Robert Vandeputte.

A man of action and tenacious, Hofrichter was to play an important part in 1940-1941 in getting the Belgian gold from Dakar to Berlin. At

22 BNB, Archives, $S D$, service étranger, dossier 8.11/32, 'rapports sur l'activité de la BEB, 1940-1944' (September 1944): création de la BEB, texte revu par Basyn, passage sur von Becker.

23 SOMA, Archives, Prack Papers, dossier JP 965: Vier Jahre Besatzungszeit in Belgien. Persönliche Erinnerungen von Herbert Prack, pp. 28-29. See also: BNB, Archives, Studiedienst, 2, dossier 01.02.01.70 (A247/6, s. f. 7): Basyn, note relative à certains membres du commissariat allemand, pp. 2-5.

24 SOMA, Archives, Prack Papers, dossier JP 965: Vier Jahre Besatzungszeit in Belgien. Persönliche Erinnerungen von Herbert Prack, p. 29. 
the end of 1943, however, he fell out of favour, the victim, probably, of an internal German power struggle. He was sent to Poland, where he died $^{25}$. His dominant role in Brussels was taken over by a Reichsbank director, Dr. Hoppe, a competent jurist. Unlike Hofrichter, however, he was cunning and untrustworthy, maintaining close relations with the Gestapo in Brussels. A sinister figure, the Bank had great difficulty in dealing with him.

Another member of the Bankaufsichtamt, Dr. Herbert Prack, was something of an odd-man-out. He had been born in Austria and before the war - as secretary to the governor of the Austrian central bank had got to know the Belgian financial expert, Maurice Frère, whom the League of Nations had sent to Vienna. The friendship they had struck up at first meeting was continued during the war, when Frère was Chairman of the Banking Commission and a member of the board of directors of the Banque d'Emission. Prack was an Austrian nationalist, who had a great deal of sympathy for Belgium and was clearly antiNazi. However, he was not a fighter and was chary about any strategy of direct confrontation, seeing more benefit in serious negotiation and cautious, but obstinate, obstruction. His function in Gruppe VIII was a subordinate one, but he spoke reasonable French, which resulted in him attending most meetings of the Bank and the Banque d'Emission ${ }^{26}$. As staff numbers thinned in the course of the occupation, so his influence grew, as did his nerve. Through him, the management of the Bank were made more and more aware of affairs within the Gruppe and of its strategy, intentions and ulterior motives.

Although ruling over a population of at least 11.5 million, the Military Government was poorly manned. At its peak, in September 1941, the German staff numbered no more than $1,166^{27}$, a sharp contrast with the figure of about 10,000 during the First World War. In December 1940, if the low-ranking staff who carried out purely clerical tasks are excluded, there were barely 700 . Later, numbers were reinforced a little, but they began to fall again from the autumn of 1941 to the point where,

25 These final details are drawn from later conversations with von Falkenhausen, extracts of which have been published by Jo Gérard.

26 BNB, Archives, $S D, 30, \mathrm{BEB}$, dossier 8.11.24/ 1 and 2: travaux préparatoires à la création de la вев (comptes-rendus).

27 P. Nefors, Industriële collaboratie in België, p. 62. 
in 1942, the Military Government in Belgium and Northern France was being run by a staff of just $47 \mathrm{O}^{28}$. This low level helps to explain the rather limited deployment of the Military Government and its reliance on the cooperation of the country's civil service, the world of business and banking in order to be able to function effectively ${ }^{29}$.

\section{‘LE TEMPS DES NOTABLES'30}

On 16 May 1940, the doors of the Bank were closed, the only persons left at their posts by Goffin being the conciërge, the chauffeur and a team of security guards. The following day - Friday, 17 May - Brussels was occupied by the Germans and on 20 May, the bank specialists of the Military Government Dr. Möckel and Dr. Heppert, two former officials of the Reichsbank, started discussions with Goffin ${ }^{31}$. Right from the start, the Germans made Goffin reopen the Bank and resume all its normal activities $^{32}$. For both legal and practical reasons, Goffin was not able to comply. Legally, his authority was limited to taking conservatory measures $^{33}$, while, in practice, the Bank no longer had the necessary materials, its banknotes, printing presses and dies having been sent abroad ${ }^{34}$.

As soon as Goffin heard what the two representatives of the Military Government had to say, he informed the top man of the Société Générale, Alexander Galopin, who from 19 May had begun to have daily meetings with Max-Léo Gérard, Chairman of the Banque de Bruxelles and, later, with Fernand Collin, Chairman of the Kredietbank. Acting at the request of Ministers Gutt and Spaak, Galopin extended the small group, inviting prominent people from various fields to join; together they would consult about the decisions to be taken, which promised to

28 Klemm, German Economic Policies in Belgium, p. 82.

29 M.G. Haupt, Der 'Arbeitseinsatz' der belgischen Bevölkerung während des Zweiten Weltkrieges, 1970, p. 12.

30 Term applied by Gérard-Libois and Gotovitch in their book L'An 40 .

31 BNB, Archives, SD, BEB, dossier 8.11.24/11: mémoranda des réunions, 12.06.1940, 19.06.1940, 03.07.1940 and 10.07.1940. See also: BNB, Archives, SD, 30, BEB, dossier 8.11.24/f. 13: protocole allemand du 21.05.1940.

32 BNB, Archives, SD, 30, ВEB, dossier 8.11.24/11: memorandum of 12.06.1940.

33 ARA, fonds ministerie van Financiën, As, dossier 14-15, a: conversation (de Goffin) avec Heppner, 11.06.1940.

34 BNB, Archives, $S D$, Malaise Papers: Kauch, La Banque Nationale (unpublished text), Part 1, Chapter 3, p. 37. 
be very tough, and share the consequences. Among those brought into the trusted circle were ex-minister Paul Tschoffen, a lawyer practising at Liège, Baron Raymond Vaxelaire, a Brussels businessman, Willy de Munck and Albert Goffin, Albert-Edouard Janssen, Chairman of the Société Générale de Banque, and, from 16 June, Léon Bekaert, a Flemish industrialist. Occasionally, ex-minister Emile Van Dievoet, professor of Civil Law at Leuven, was invited to join them ${ }^{35}$. The group itself came to be known as the 'Galopin Committee', Galopin indeed being its driving force and dominant figure.

The bankers' immediate focus of attention was the general shortage of hard cash. During the initial days of the occupation, the Banque de la Société Générale (the only private bank still with a cash reserve) advanced more than 200 million Belgian francs to municipalities and various public services, to enable them to pay benefits to the needy and the unemployed. On 29 May, moreover, in cooperation with the Caisse Générale d'Epargne et de Retraite and a number of other private banks, it also created an Association Nationale d'Assistance to organize bank help more systematically. Lastly, pushed by Galopin, the bankers, in collaboration with the business world, set up a Société Coopérative $d^{\prime}$ Avances et de Prêts to facilitate the financing of industrial recover $y^{36}$.

Galopin quickly became convinced that the passive resistance that had determined Belgium's stance, when occupied during the First World War, would now be inappropriate ${ }^{37}$. He had heard from his Deputy-governor who had attended meetings at the American embassy between 20 and 24 May, that large-scale food aid from the United States on the lines organized by Hoover during the First World War would face virtually insurmountable problems ${ }^{38}$. Churchill was determined to keep the blockade of the continent watertight; any aid to civilians in occupied territory being aid to the enemy. In consequence, in the absence of outside help, Belgium would have to find food stocks as best she could.

35 Brion and Moreau, La Société Générale, 1822-1997, p. 334; Nefors, Economische collaboratie in België, p. 40.

36 LLN, Archives, A.-E. Janssen Papers, dossier 200 B, 11: BEB, letter of February 1947 from H. Velghe to A.-E. Janssen. See also: Van der Wee and Verbreyt, De Generale Bank, p. 253 (the CAP project was set up, but the establishment of the Banque d'Emission prevented the institution from ever playing an important part).

37 SG, Archives, CD, 24.05.1940.

38 Van der Wee and Verbreyt, De Generale Bank, pp. 246-247. 
Furthermore, industrial recovery had not simply become a necessity as regards employment, it was also being demanded by the Germans. As soon as the Military Government had been installed, the managing directors of the Société Générale heard that the Germans were planning to get work under way again in the mining and metalworking sectors in the Provinces of Liège, Hainault and Limburg39. In early June, the chief engineer of the metal works at Hoboken reported on his recent visit to the Netherlands, a report that Galopin summarized in the committee of managing directors as follows: 'In the Netherlands the administration is functioning normally, although the government is based in London... The private banks and even the central bank (with its gold outside the country) are at work. All industries are operating....and you have to take a very long view to understand whether their work is legal or illicit' ${ }^{\prime 0}$. All the information coming in contained just one message: work had to be resumed.

What the preceding comments indicate is that, even before the occupation became total, Belgian bankers and holding companies did not question the policy of passive resistance. For them, the linkage between stocks, employment and exporting to Germany was all part of a logical whole. Of course, aid to the enemy, which was what 'exporting' implied, would be kept to a minimum, but it was acceptable in principle. This was an attitude on which everyone, including the members of the Galopin Committee, was agreed; at this moment, although it was to lead to enormous problems in the four years to come, the attitude dovetailed easily with the policy of 'accommodation' that, it was claimed, was working reasonably well in the Netherlands ${ }^{41}$. Nevertheless, in order to relieve any unease in people's minds, additional opinions were requested from the lawyer Paul Struye and from Professor Léon-Hugo Dupriez on 18 and 28 June respectively; both opinions were positive

39 SG, Archives, DC, 27.05.1940.

40 SG, Archives, DC, 04.06.1940.

41 H.A.M. Klemann, Nederland, 1938-1948. Economie en samenleving in jaren van oorlog en bezetting, Amsterdam, 2002, pp. 67-70; J.C.H. Blom, Crisis, bezetting, herstel. Tien studies over Nederland, 1930-1950, The Hague, 1989, pp. 67-69; Joh. de Vries, De Nederlandsche Bank van 1914 tot 1948. Trips tijdvak, 1931-1948, onderbroken door de Tweede Wereldoorlog, The Hague, 1994, pp. $238 \mathrm{ff}$. 
about the acceptance of a policy of economic accommodation ${ }^{42}$. In fact, there was no real rational choice open to Belgium.

Certain historians, among them the American, John Gillingham, have asserted that the leaders of the Belgian holding companies and banks were impatiently lining up to collaborate with the Germans, in order, with their help, to reduce the influence of the trade unions, but no proof of this is provided by the minutes of meetings from that period; if anything, the contrary was the case. It is true that the bankers and industrialists were fairly quick to agree to resume work; for most of them, however, 6o per cent of pre-war production appeared to be an acceptable level of output ${ }^{43}$. Furthermore, they were initially hesitant about exporting to Germany and it was only gradually that they reached agreement on that point. There were naturally many factors to be considered in the decisions, which had to be taken: among these were keeping their businesses going, ensuring employment, and the fear of reprisals both on the part of the occupier and on account of article 115 of the Belgian Penal Code, which decreed severe punishment for economic collaboration. In the summer of 1940, they were all faced with the hardest decision of their professional careers, and they approached it with different priorities. It is not for the historian, however, to make a judgment on their motives.

\section{THE BANKERS' INITIATIVE FOR A BANK OF ISSUE}

The initiative of the bankers in setting up an institution for new issues during the first weeks of the occupation has, in the first place, to be seen within the context of public opinion at the time, which was gradually coming round to the idea of a policy of accommodation as this was

42 SOMA, Archives, V 16 (dossier 1375), politique de production en Belgique occupée, $\mathrm{n}^{\circ} 1$ : consultation de M. Struye du 18.06.1940; étude de L.-H. Dupriez du 28.06.1940.

43 BNB, Archives, SD, enquête BEB, dossier 1-2, g, 'Société Générale memorandum': observations relatives à la création éventuelle d'une Banque d'Emission, 27.06.1940. In respect of Gillingham's hypothesis, see. J. Gillingham, Belgian Business in the Nazi New Order, Ghent, 1977. For a refutation of this hypothesis, see: H. Van der Wee, 'L'économie belge au cours de la Seconde Guerre Mondiale et le problème de la collaboration industrielle', in: Revue Belge de Philologie et d'Histoire, 57, 2 (1979), pp. 397-409. 
being crystallized within the Galopin Committee. A look back at the pre-war years may throw some light on the influences and motives that, while not being prominent, were nevertheless present in the obscure background to this extremely complex event. During the 1930s, the bankers had taken a few hard knocks, and their image had not been improved by the bank crisis in the early part of that decade, the attendant insolvencies in the bank sector and the disastrous 'government of the bankers' (1934-1935). In addition, the influence of the private banks in the public sphere had been seriously curtailed by the establishment of the Banking Commission in 1935 and the restriction in 1937 of the powers of the supervisory council of the Bank. The dirigisme of the Minister of Finance De Man and the vigilance exercised by Janssen, Chairman of the Banking Commission until he became Governor of the Bank, over the strict application of the new banking regulations had, to put it mildly, often irritated the bankers ${ }^{44}$. Consequently, there might have been a whiff of revenge in the air, now that the bankers found themselves being called upon to take an active part in the public sector once again, something that they did not entirely shy away from.

Shortly after the occupation of Brussels on 17 May, de Munck, Chairman of the Banque de la Société Générale contacted Director Goffin to discuss the problem of issuing money ${ }^{45}$. The idea of reactivating issues via the Bank - one that the Military Government had been pushing from the outset of the occupation - was not considered, as the Bank at that moment was officially still established in France. The Germans could, of course, set up a new issue institution themselves and in fact, in the opinion of the jurists Paul Tschoffen and Henri Rolin, had the right as an occupying power to do so on the basis of the Hague Convention ${ }^{46}$. Such a solution would be all the worse, because control of monetary policy in Belgium would then become solely a German affair ${ }^{47}$.

44 Van der Wee and Verbreyt, De Generale Bank, p. 237.

45 BNB, Archives, $S D$, Malaise Papers, 3, dossier 9.5.11/ s. f. 4: Kauch, rapport au Roi, 20.12.1943, pp. $26 \mathrm{ff}$.

46 Krijgsauditoraat, Archives, CI 47/44, dossier 3: rapports sur l'activité de la BEB, farde 4 (dépositions, 15 décembre $1944-28$ novembre 1945: declaration $n^{\circ} 9$ de W. de Munck). See also: KB, Archives, Collin Papers, dossiers B, 'banques (BEB 19401945)': note sur la Banque d'Emission, 30.01.1945, p. 5; BNB, Archives, SD, Malaise Papers, dossier 9.5.11/ s. f. 4: Kauch, rapport au Roi, 20.12.1943, p. 32, $\mathrm{n}^{\circ} 32$.

47 Van der Wee and Verbreyt, De Generale Bank, p. 250. 
Also excluded was any tolerance of the Reichskreditkassenscheine that were circulating. These were cash credit vouchers denominated in German marks, paper money that was used by the German army as a temporary means of payment in occupied territories. They were not legal tender in Germany and, even if introduced as a temporary measure, could seriously affect the circulation of money in Belgium and generate a feared spiral of inflation. The spectre of the German marks circulating during the First World War and the baleful consequences of this after the conclusion of peace were still very much alive in many people's memory $y^{48}$. For the German occupier, the system naturally had the advantage of an almost hidden war tax, but, from a Belgian point of view, the system was to be condemned; indeed, the quantity of marks brought into circulation would not be fixed and the increasing volume would, as a 'subterfuge money' ('une monnaie anesthésiante'), encourage the country's plundering ${ }^{49}$.

De Munck and Goffin felt that, ultimately, there was only one viable solution, which was for the Belgians themselves to establish a new issue institution as an autonomous private bank according to Belgian law and with Belgian capital, in which all other Belgian private banks would participate ${ }^{50}$. Once the idea was accepted, Goffin immediately gave instructions to the Bank's research department to work out a plan on these lines.

A first version of the plan was presented to de Munck and Goffin on 20 May by two members of that research department, Jean-Jacques Vincent and Ferdinand Aspeslagh ${ }^{51}$. The plan proposed the establishment of an office belge d'émission in the form of a Belgian limited company with share capital, to be subscribed by private banks and private individuals. The institution would be headed by a director and a deputy director, under the supervision of an auditor whose appointment and dismissal would be subject to the approval of the military commander.

48 BNB, Archives, $S D$, enquête BEB, dossier 3-4, a: Th. Basyn, note relative à l'origine de la Banque d'Emission à Bruxelles, o8.11.1944.

49 BNB, Archives, $S D$, enquête BEB, dossier 1-2, g, 'Société Générale memorandum': observations relatives à la création éventuelle d'une Banque d'Emission, 27.05.1940.

50 Krijgsauditoraat, Archives, CI 47/44, enquête $\mathrm{BEB}$, dossier 3: rapports sur l'activité de la вЕв, farde 4 (dépositions, 15 décembre 1944-28 novembre 1945: declaration $n^{\circ}$ 9 de W. de Munck).

51 NBB., Archives, $S D$, 30, création de la BEB, dossier 8.11.24/2: office belge d'émission. 
However, it is noticeable that, probably at the suggestion of the bankers and of the Bank itself, no supervision on the part of the Ministry of Finance was envisaged in the plan; apparently there was a fear that the Belgian government would be too dirigiste, which suggests that the points of difference of the pre-war years between the private and public financial sectors were still in evidence.

The new issue institution was to take over the Bank's traditional activity in Belgium for the duration of the war and integrate the activity of the Postal Cheque Office. This second task was wholly to the advantage of the private banks, as the Postal Cheque Office had become a formidable competitor through its giro payment system. Moreover, that system had given the government free access to an appreciable mass of money on deposit, money that could be used for the government's short-term credit requirements; it had also entailed the private banks missing out on a potential market at a time when lending in the private sector was at a low ebb. Another question dealt with in the plan was that of backing for the issues. They would be covered by instruments of debt arising from discounting, loans and advances; four fifths of uncovered circulation would have to be covered by banknotes of the Bank, withdrawn from circulation.

During the ensuing discussions with the Germans the impression prevailed that they had been won over to the idea of a Belgian issue institution. A few days later, however, during a meeting with de Munck on 5 June, Heppner was saying something entirely different. According to him, there was no question of a new Belgian issue institute being set up, it was the issue activity of the Bank itself that had to be restored. This made it patently clear that there were serious differences of opinion within the Military Government about the matter and that no-one had so far been able to resolve them ${ }^{52}$.

Meanwhile, something of a commotion had been created at the Ministry of Finance. During a meeting there, Regierungsdirektor Dr. Witt had reminded Secretary-general Plisnier of his duty to assume responsibility for the note issues ${ }^{53}$. Shortly afterwards Plisnier contacted

52 BNB, Archives, $S D$, 'enquête BEB': report of the Commission of Enquiry (published text, 1946), Part 1, p. 13.

53 ARA, fonds ministerie van Financiën, Secretariat-general, dossier 417, farde 12/13. 
Goffin, asking to have a look at the outlines of the plan for the new institution.

The request took the bankers somewhat by surprise and in their haste during the meeting of the Galopin Committee on 4 June they approved the insertion of a special article reading as follows: 'The Secretary-general...will be present, when he judges this to be appropriate, at the meetings of the Board of Directors and of the General Assemblies. His voice will be consultative'. Plisnier received the amended text from Goffin the following day. His reaction was immediate and indignant. He demanded unlimited control of all activities of the institution, as well as a right of veto on all decisions that might contravene Belgian law and be against the interests of the country. The bankers acquiesced and on 7 June, in Plisnier's office, de Munck, Goffin, M.-L. Gérard and A.-E. Janssen approved a new text that not only met Plisnier's demands, but also considerably reduced the authority of the representative of the Military Government ${ }^{54}$.

54 BNB, Archives, SD, 30, BEB, dossier 8.11.24/ 2: office belge d'émission (3e et 4e projet). The competence of the Bankaufsichtamt was redrafted as follows: Art. 12, 'Un délégué du pouvoir d'occupation reçoit à l'intervention du Secrétaire général...tous renseignements, états ou copies des documents que ce déléguéjugera nécessaires pour exercer une surveillance sur l'office belge d'émission'. 



\section{CHAPTER 7 \\ The Establishment of the Banque d'Emission}

\section{THE DECISIVE NEGOTIATIONS}

In retrospect, the negotiations with Möckel and Heppner appear to have been no more than an initial exploration of the terrain on the part of the Germans, pending the long-term organization of the Bankaufsichtamt that was to be set up at Brussels. Instructions for this were being awaited from the Reichsbank in Berlin and finally arrived on 9 June, the Reichsbank also announcing the leadership of the new body. It was to be headed by von Becker, with Hofrichter as his deputy. The two had received concrete instructions from the Reichsbank ${ }^{2}$ which they laid before a delegation of Belgian bankers on 13 June. Central to the discussions was the establishment of a new issue institution at Brussels, on the lines envisaged by the German authorities ${ }^{3}$. Von Becker and Hofrichter invited the bankers to study the text and submit any comments at a meeting planned for 15 June$^{4}$.

The fact that Hofrichter was involved in the setting-up of a new bank of issue in Poland suggests that the bank of issue in Brussels was designed on the Polish model, with many points of similarity. The plan

1 The ordinance setting up the Bankaufsichtamt and confirming the appointment of von Becker and Hofrichter dated from 14.06.1940: BNB, Archives, $S D$, 'enquête BEB': report of the Commission of Enquiry (published text, 1946), Part 1, p. 13.

2 Nefors, Economische collaboratie in België, p. 53.

3 BNB, Archives, $S D, 30, \mathrm{BEB}$, dossier 8.11.24, f. 1 and 2: travaux préparatoires relatifs à la création de la $\mathrm{BEB}$, minutes of the meeting of 13.06.1940.

4 BNB, Archives, SD, Malaise Papers: Kauch, La Banque Nationale (unpublished text), Part 1, Chapter. 3, p. 39.

5 BNB, Archives, $S D$, 'enquête BEB': report of the Commission of Enquiry (published text, 1946), Part 1, pp. 17-18; BNB, Archives, $S D$, 30, BEB, dossier 8.11.24, f. 3: ordonnance relative à la Banque d'émission en Belgique. 
was nevertheless for it to be established in the form of a Belgian limited company with a large capital, to be subscribed by the private banks, a concession to the proposals of the Belgian bankers. However, the actual organizational structure was very different. The bank was to be managed by a chairman who would wield practically all the power and who would be assisted by two managing directors. The board of directors would in principle be reduced to an advisory body, its power of decision limited to approving the balance sheet and the management of discounting transactions.

Clearly, underlying the entire organization chart was the Führer principle. The competence of the general meeting was kept to a minimum and was in fact limited to the appointment of the main office holders; those appointments were further subject to the approval of the military commander, who also had the right to dismiss office holders. Additionally, a German commissioner at the new institution was to be kept fully informed of its activity and his authorization was required for all important decisions, authorization that he could retract as and when he thought fit. The proposed bank of issue was also removed from the control of the Belgian Banking Commission and there was thus no place in the organizational structure for a Belgian government commissioner.

It was the intention that the Bank should place its premises, staff and printing equipment at the disposal of the new institution and that the banknotes of this institution should be the only legal tender circulating in the country. The banknotes of the Bank would have to be exchanged and the Reichskreditkassenscheine would have to be taken out of circulation ${ }^{6}$. Besides these two activities of exchange and withdrawal, the bank of issue would also be empowered to discount commercial paper, but not government paper, such as Treasury certificates issued by the State, the provinces, the municipalities or other public institutions; nor would it be authorized to grant loans or advances with such government securities as collateral. Note issues would thus be covered by claims arising from commercial discounting transactions, by banknotes exchanged, by Reichskreditkassenscheine and by other assets at the Reichskreditkasse, the Reichsbank and the Verrechnungskasse in

6 BNB, Archives, $S D$, enquête BEB, dossier 3 - 4: Th. Basyn, note relative à l'origine de la BEB et aux résultats de son activité, p. 2. 
Berlin. An additional guarantee would be provided by a general mortgage on real estate in Belgium.

The spokesmen of the Belgian banks at the meeting of 15 June were Goffin, Galopin, de Munck, A.-E. Janssen, M.-L. Gérard and Collin? They had many points to raise about the German proposal. In the first place, in their opinion, the proposed legal structure was unacceptable: the entire procedure of nomination and granting virtually exclusive power to the chairman were in fact irreconcilable with Belgian legislation on limited companies. Moreover, the bye-laws ought to make no reference to regulations in the law on limited companies, but to regulations in the bye-laws of the Bank, which was an institution sui generis ${ }^{8}$. Finally, the capital of the new bank of issue did not need to be as large as proposed by the Germans and no more than 20 per cent needed to be paid up on the bank's formation. In their original project, the bankers had proposed a figure of 100 million Belgian francs by way of capital, but were nevertheless prepared to increase this to 150 million.

There followed a discussion about the constitutionality and the extent of the proposed mortgage: the imposition of a mortgage on the population was contrary to articles 6 and 11 of the Belgian Constitution. The Belgian bankers also argued that the extent of the mortgage was too great, but were unable to persuade the Germans of this. The suggestion that the Bank's premises, staff and printing equipment be placed at the disposal of the new bank of issue also ran into a legal problem. Goffin had, in fact, no authority to take any decision in this respect, but it was thought that a solution could be provided by a requisition order from the Secretary-general of the Ministry of Finance; consequently, von Becker arranged to speak to Plisnier on 17 June about the matter.

The big stumbling-block for the bankers was the article prohibiting the new bank of issue from granting advances against government securities or discounting them. Ultimately, the payment of salaries and pensions by the central, provincial, municipal and other public authorities, compensation for war damage, and benefits paid out to the unemployed, the families of military personnel and those on poor relief

7 BNB, Archives, $S D, 30, \mathrm{BEB}$, dossier 8.11.24, f. 1: travaux préparatoires relatifs à la création de la BEB, minutes of the meeting of 15.06.1940.

8 BNB, Archives, SD, 30, BEB, dossier 8.11.24 / 15: consultation de maître Tschoffen, 25.06.1940. 
- were financed by the banks on the basis of government debt instruments. Moreover, there would be no less need for cash by the public sector - on the contrary - and tax income would lag behind government expenditure for some time to come, certainly with the costs of occupation, an alarming prospect. The banks simply could not raise sufficient cash to continue to finance all this. The only way to solve the problem was to allow them to mobilize government securities at the new bank of issue. Von Becker understood the problem, but wished to consult the Reichsbank about whether he could grant this concession?.

The final major point concerned the circulation of the Reichskreditkassenscheine. In the German project, they formed one of the assets acting as backing for the new banknotes. In his comments, von Becker stated that their issue had been provisionally set at 1 billion Reichsmarks, although that figure could, of course, be increased as necessary. Galopin and de Munck immediately saw the danger: an uncontrollable issue of banknotes would prompt a spiral of inflation. Moreover, the Scheine were circulating as legal tender in Norway, Denmark, the Netherlands, and Northern France besides Belgium, and it was not unthinkable that masses of this paper money would flow in from those countries, particularly as the Germans were concentrating troops in Belgium and Northern France, with a view to an invasion of Great Britain. The spokesmen of the Belgian banks therefore enquired about the terms and conditions that would accompany the withdrawal of the Scheine; but von Becker declined to answer, as there was a political aspect to this question that was outside his remit. Together with Hofrichter, he was leaving for Berlin on 17 June to report to the Reichsbank on the discussions and hoped on his return to be able to present new instructions that would take account of Belgian proposals.

On 27 June, Goffin, Galopin, de Munck, A.-E. Janssen and M.-L. Gérard convened at von Becker's invitation at his offices at the Bank, being joined towards the end of the meeting by Plisnier. The new plan, as approved by Berlin, was laid before the bankers ${ }^{10}$ and it took some account of the objections raised at the meeting of 15 June. The concept of a simple limited company in Belgian law had been adopted; capital was

9 SG, Archives, DC, 26.06.1940.

10 BNB, Archives, $S D$, Malaise Papers: Kauch, La Banque Nationale (unpublished text), Part 1, Chapter. 3, p. 40. 
set at 150 million Belgian francs, with 20 per cent to be paid up immediately. The idea of a general mortgage on real estate in Belgium as a supplementary guarantee had been dropped; and discounting government paper, including its negotiation, as well as granting advances against such paper, had been accepted as a normal activity for the new institution, although time to maturity was not to exceed one year ${ }^{11}$. For both the bankers and Plisnier, these amendments represented an important concession on the part of the German authorities.

Against this, not an inch had been yielded on the matter of the conditions regarding cover. German means of payment and Reichsmark credit balances with German institutions remained as valid backing, as did commercial and public securities and other claims by the Bank. The Germans were nevertheless prepared to do their best to withdraw the Reichskreditkassenscheine from circulation, perhaps in exchange for Belgian banknotes ${ }^{12}$. No account was taken of Plisnier's demand for inclusion of a right of control for the Ministry of Finance ${ }^{13}$. All that the secretary-general gained was authorization to attend the meetings of the board of directors, at which he could obtain information and give advice. Lastly, the new institution would not be established as the 'Banque d'Emission de Belgique', the name originally previewed, but as the 'Banque d'Emission de Bruxelles', in order to avoid any confusion with the Banque Nationale de Belgique (the Bank) ${ }^{14}$.

The spokesmen of the Belgian bankers were given a quarter of an hour to consult with one another, but it was now a question of taking the text as it stood or leaving it. There was thus no option but to accept it, the alternative being a note-issuing institution under full German control. The order for establishment was signed and promulgated that same day, and was published in the German Official Gazette of 6 July 1940, the deed of incorporation being executed before notarypublic Hubert Scheyven at Brussels on 13 July 1940. The Bank's premises and staff, as well as its equipment for printing the new banknotes were

11 BNB, Archives, $S D$, 'enquête BEB': report of the Commission of Enquiry (published text, 1946), Part 1, pp. 17-18. See also: SG, Archives, DC, 27.06.1940.

12 SG, Archives, DC, 27.06.1940.

13 BNB, Archives, $S D$, Malaise Papers: Kauch, La Banque Nationale (unpublished text), Part 1, Chapter. 3, p. 40.

14 SG, Archives, DC, 27.06.1940. 
requisitioned by Plisnier on 27 June and all placed at the disposal of the Banque d'Emission ${ }^{15}$. Goffin was appointed as chairman of the new institution, and the Bank's Treasurer, Sontag, and the head of the staff department, Deputy General Manager Pirsoul, were appointed as its managing directors ${ }^{16}$.

It appeared that all parties believed that they had done well out of the final arrangement. The Germans felt that the Banque d'Emission could not be regarded as the product of German coercion (eine deutsche Zwangmasznahme). At the same time, they were convinced that the adjustments made in Berlin would enable them to bend the new institution to their will ${ }^{17}$. For his part, Goffin was satisfied that the Bank itself had been able to steer clear of direct German interference ${ }^{18}$. Plisnier was relieved that a solution had been found to finance the costs of occupation and the government deficits. Lastly, the bankers felt that their caution had won the Banque d'Emission a certain degree of independence from both the occupier and the Belgian government ${ }^{19}$. Emile Puhl, Deputy-chairman of the Reichsbank, had travelled to Brussels from Berlin to give added lustre to the occasion of the Banque d'Emission's establishment and had been reassuring in his language ${ }^{20}$.

What the bankers found very significant was the German concession in accepting government paper as cover for the banknotes. Since the crisis of the 1930s, income from credit to the private sector had been at a low ebb and this situation was most unlikely to change in the immediate future. Consequently, the banks had to turn to income from

15 BNB, Archives, SD, 30, BEB, dossier 8.11.24/ 14, 'réquisition du personnel et des locaux de la BNB': letters of 17.06.1940, 26.06.1940 and 27.06.1940 from Plisnier and Tschoffen.

16 SG, Archives, DC, 27.06.1940; BNB, Archives, SD, Malaise Papers: Kauch, La Banque Nationale (unpublished text), Part 1, pp. 40-41; ARA, fonds ministerie van Financiën, Secretariat-general 1914-1945, dossier 11/ 7, 'banques (вев)': letters of 06.07.1940 and 13.07.1940 from Goffin to Plisnier.

17 BNB, Archives, $S D$, Malaise Papers: Kauch, La Banque Nationale (unpublished text), Part 1, Chapter. 3, p. 43.

$18 \mathrm{NBB}, \mathrm{SD}, 3 \mathrm{O}, \mathrm{BEB}$, dossier 8.11.24/11: memorandum of 03.07.1940.

19 BNB, Archives, Studiedienst, dossier 01.02.01.70 (A 247/6, s.f. 9), 'Société Générale memorandum': quelques rétroactes relatifs aux circonstances qui ont provoqué la création de la BEB, 26.03.1943.

20 SG, Archives, $D C$, 29.06.1940; BNB, Archives, SD, 30, BEB, dossier 8.11.24/ s. f. 5, 'correspondance diverse': letter of 28.06.1940 from von Becker to Goffin. 
the provision of credit to the various government bodies; in this respect, interesting prospects were offered by the purchase of Treasury certificates and their possible mobilization at the Banque d'Emission. From France, on 4 July, Janssen declared his agreement with the setting-up of a bank of issue, but saw it solely as a means to provide the country with cash resources until the Bank's return ${ }^{21}$.

\section{THE BANK AND THE BANQUE D'EMISSION}

Shortly after his return to Brussels, on 11 July, Janssen was received by von Becker, head of the Bankaufsichtamt, who indicated that Janssen could resume his function in Brussels as Governor and even offered him the chairmanship of the Banque d'Emission. Von Becker also had no objection to the Banque d'Emission making way for the Bank, as Janssen envisaged, provided that the Bank returned to Brussels quickly, though dissolving the newly established bank would naturally depend on authorization from Berlin ${ }^{22}$. Janssen, on his part, was looking to chair the meeting of the general council of the Bank, fixed for 15 July to give consent to the re-establishment of the Bank's registered office at Brussels, but von Becker indicated that this would not be possible. He pointed out that officials and prominent persons who had fled abroad at the time of the invasion could resume their functions in Belgium or exercise new functions there only on the authorization of the competent reintegration committee of the Belgian administration and the Military Government, following investigation of their dossiers. Goffin would chair the meeting. This was a first disappointment for Janssen and a clear sign that times had changed in Brussels ${ }^{23}$.

The general council of the Bank, which comprised the board of directors, the supervisory council and the board of scrutineers, met in Brussels on 15 July as planned. Goffin opened the meeting by announc-

21 BNB, Archives, Studiedienst, dossier 01.02.01.70 (A 243/4), 'inspection générale': letter of 04.07.1940 from Janssen (Bordeaux) to Galopin (Brussels).

22 Krijgsauditoraat, Archives, CI 47/44, dossier 3: rapports sur l'activité de la BEB, farde 4 (dépositions, 15 décembre 1944 - 28 novembre 1945: declarations Nos. 37 and 47 of P. Kauch).

23 BNB, Archives, Studiedienst, dossier 01.02.01.70 (A 243/ 4), 'inspection générale': meeting of 13.07 .1940 between von Becker, Hofrichter and Janssen. 
ing that the board of directors at Mont-de-Marsan had resolved to return the Bank's registered office to Brussels, to return there itself and to restore all the Bank's administrative, management, supervisory and advisory bodies to their normal operations. With the exception of the gold reserves, which remained beyond the Bank's control, the repatriation of the Bank's assets was in full swing. Goffin also indicated that the Minister of Finance and the entire Belgian government at Vichy had approved the transfer and repatriation. The general council took note of the return and ratified the resolutions passed. Goffin also notified the council of the establishment on 13 July of the Banque d'Emission, under his chairmanship. Its establishment would be no obstacle to the Bank continuing to pursue all its traditional activities, as long as they did not impinge on the exercise of the right of issue $e^{24}$. The two institutions would exist side by side, but would be able to co-operate to the full, as the management was in joint hands.

Before the banknotes of the new Banque d'Emission got into circulation, the Bank's important stock of their own notes had arrived in Brussels from Mont-de-Marsan and consumers had begun spending the money that they had been hoarding. On July 15 Janssen was able to obtain from the German authorities a suspension of the plan for the immediate exchange of banknotes: for the time being, those of the Bank would remain in circulation and only when the time came for a new issue would those of the Banque d'Emission be called into use ${ }^{25}$.

On 23 July, Janssen informed the governors of the Bank of England and the Banque de France that the registered office and the management of the Bank were once again established in Brussels and that the decision of 15 May concerning the transfer of the registered office and the move of the management abroad was annulled. He also contacted McKittrick, Chairman of the Bank for International Settlements (BIs) at Basel, to request him likewise to notify the change to the other central banks that were members of that institution ${ }^{26}$.

\footnotetext{
$24 \mathrm{BNB}$, Archives, AR, 15.07.1940.

25 BNB, Archives, $S D$, 'enquête BEB': report of the Commission of Enquiry (published text, 1946), Part 1, pp. 25 ff.: letter of 15.07.1940 from Janssen to Galopin. See also: BNB, Archives, $S D$, dossier 03.00.00 (G 792/5): Association belge des banques, minutes, 01.08.1940.

26 Janssens, De beheerders van ons geld, p. 136; BNB, Archives, Studiedienst, dossier
} 
When Janssen effectively resumed the leadership of the Bank - until his official reinstatement, the governorship had been exercised by von Becker ad interim ${ }^{27}$ - he was faced with a depleted board of directors consisting solely of himself and Goffin. Baudewyns was to remain in London for the duration of the war and Ingenbleek was still operating at Mont-de-Marsan. The fourth place on this committee, previously held by Mahieu, who died on april 1940, was left open. In addition, there was Van Nieuwenhuyse who, on his return from France in August, resumed his function as Secretary to the Bank.

During their meeting with Janssen on 20 July, von Becker and Hofrichter indicated that changes had to be made to the composition of the Bank's board of directors and particularly to the Banque d'Emission's management, as there was too great an imbalance between the Dutch-speaking members and the French-speaking members. Attention turned first to the Banque d'Emission. The bankers who were behind its founding and who had subscribed to its capital were, in any case, members of the board of directors and no objection to them was raised by the Military Government. The bank's bye-laws envisaged a twenty-member board; to the nine founder-bankers, thus, a further eleven members had to be added. Names suggested by the bankers were Plisnier, Secretary-general of the Ministry of Finance, Leon Bekaert, Robert Brasseur, Jacques Desoer, Léopold Dumont de Chassart, Leopold Frateur, Lucien Graux, André Huyssens, Georges Laloux, Arthur Mulier, Leopold Nuyens and Fernand Van Goethem ${ }^{28}$. To provide a flexible way of increasing the number of Dutch-speaking members, the Germans issued an ordinance on 19 August increasing the membership of the board of directors to thirty.

The management of the Banque d'Emission was exclusively Frenchspeaking and the Military Government felt that change was required here too. On a unanimous vote in the board of directors, the Secretary to the Bank, Van Nieuwenhuyse, was chosen as Dutch-speaking candidate. He seemed the perfect choice: he came originally from Bruges and

01.02.01.70 (A 320/6).

27 BNB, Archives, Prack Papers, 2: Das Währungs-, Geld- und Bankwesen in Belgien, 10 Mai 1940 - 31 Dezember 1940. B: Die Notenbanken.

28 BNB, Archives, $S D$, 'enquête BEB': report of the Commission of Enquiry (published text, 1946), Part 1, passim. 
had served the Bank extremely well before the war and especially during the invasion and the flight to France; he was 'in-house' and knew the techniques of the business. His candidacy was supported unconditionally by Janssen and all the bankers. The Military Government, too, appeared to be in agreement, but at the last moment withdrew its support for him in favour of a candidate from outside the Bank: it preferred a deutschfreundliche candidate and its choice fell on Pierre Berger, manager of the Kredietbank branch at Antwerp. It was he who, at an extraordinary general meeting of the Banque d'Emission held on 25 November 1940, was appointed managing director.

\section{THE PRINCIPAL ACTORS OF THE TWO BANKS}

Before detailing the confrontations between the German and Belgian authorities, it is perhaps appropriate to introduce the chief actors on the Belgian side, the previous chapter having briefly discussed the main personalities on the German side. Those persons naturally include the directors and managing directors of the two banks, but mention should also be made of the bankers who, as founders of the Banque d'Emission, were to play a prominent part in events, particularly after the death of Janssen, as well as of the most important advisers, members of the supervisory council and secretaries-general.

Until his death on 9 June 1941, Janssen remained the inspired leader of the two banks. Once he had returned from France and resumed the governorship of the Bank in Belgium, adding to that the chairmanship of the new issue institution, he identified himself wholeheartedly with the problems of daily life in a country under occupation ${ }^{29}$. He worked energetically for the resumption of economic activity; in doing so, he won for himself a dominant role in shaping the country's monetary policy. He was, nevertheless, well aware of the limits the new situation imposed on him, writing on 17 July to Ingenbleek: 'I resumed my activities, without claiming, however, that I am again in full control of everything that I controlled before $10 \mathrm{May}^{30}$.

29 ARA, Theunis Papers, 'correspondance Theunis-Gutt': letter of 28.07.1940 from Gutt (Vichy) to Theunis (New York).

30 BNB, Archives, SD, Janssen Papers, f. 2 j: letter of 30.07.1940 from Janssen (Brussels) to Ingenbleek (Mont-de-Marsan). 
Through his intelligence and single-mindedness, authoritarian manner, boldness of action, courage and genuine patriotism, Janssen overshadowed the other members of the two managements, who were only too happy to leave things to his judgement when it came to taking decisions $^{31}$. Even the bankers who, as founders of the Banque d'Emission, dominated its board of directors seldom took a leading part in decisionmaking, generally preferring to leave initiatives to the chairman ${ }^{32}$.

Janssen also gained the respect of the German administration. Prack, in his memoirs, wrote frankly that Janssen was the most important and strongest personality he had come across in Belgium during the occupation. Hofrichter, with whom Janssen had numerous momentous confrontations, likewise respected him. Their meetings could become pretty heated and on one occasion, when Hofrichter spoke threateningly to the Governor and in the same breath also opposed all the leaders of the two banks, Janssen answered that it was he alone who bore responsibility for monetary policy in Belgium and that, if anyone should hang for it, that person could only be him, adding somewhat cynically: 'I can lose only one head ${ }^{33}$. On the other hand, Janssen could be very charming and circumspect in his dealings with the Military Government, besides exhibiting great diplomatic skill. His intuition (Fingerspitzengefühl) found an admirer in Prack $^{34}$ and often enabled Janssen to score a success when arguing a point.

The others in the management - Deputy-governor, Ingenbleek, Directors Goffin and Berger and Secretary Van Nieuwenhuyse - came across less strongly. Ingenbleek had hoped to be appointed a managing director of the Banque d'Emission, which was what Janssen had in fact suggested in a letter to him at Mont-de-Marsan ${ }^{35}$, but the appointment had been vetoed by the Germans ${ }^{36}$. During the initial years of the

31 BNB, Archives, RR, 12.06.1941: addresses by A. Goffin and L. Smeers on the occasion of Janssen's death on 09.06.1941.

32 BNB, Archives, $S D, 37$, enquête BEB, dossier 8.11.34: note des fondateurs relative à l'origine de la BEB et à ses résultats (1943).

33 BNB, Archives, Prack Papers: letter of 24.01.1986 from Prack (Vienna) to Cracco.

34 SOMA, Archives, Prack Papers, dossier JP 965: Vier Jahre Besatzungszeit in Belgien. Persönliche Erinnerungen von Herbert Prack, pp. 13-14.

35 вNB, Archives, SD, 37, Janssen Papers, f. 2 j: letter of 30.07.1940 from Janssen (Brussels) to Ingenbleek (Mont-de-Marsan).

36 BNB, Archives, Prack Papers: Das Währungs-, Geld- und Bankwesen in Belgien. B: Notenbanken, 1a. Direktion. 
occupation, Ingenbleek, in conversations with Germans, allowed it to be seen that 'he tried to understand the German point of view', while also showing little, if any, sympathy with the British ${ }^{37}$. This stance gave him access to Military Government circles and enabled him to mediate behind the scenes when conflicts arose. He also maintained good relations with Plisnier, with whom he had been a friend for years ${ }^{38}$.

Goffin was a conscientious official of both banks. Somewhat taciturn, he displayed little decisiveness; even when Governor of the Bank, in succession to Janssen, he was unable to put his stamp on policy. He shrank from taking responsibility and, lacking a firm personality, came increasingly to rely on Galopin, the strong man in the board of directors of the Banque d'Emission ${ }^{39}$. As director of the Bank and managing director of the Banque d'Emission, Berger carried greater clout. Berger certainly had a more forceful character than Goffin; moreover, he owed his appointment to the direct intervention of the Military Government and was thus able to count on German goodwill, which gave him a degree of leverage in matters of monetary policy ${ }^{40}$. However, the longer the occupation lasted and the more acute the problems became, the more it became clear that he was not equal to the task or capable of actually standing up to the German authorities ${ }^{41}$.

37 Soma, Archives, Prack Papers, dossier JP 965: Vier Jahre Besatzungszeit in Belgien. Persönliche Erinnerungen von Herbert Prack, p. 19. Ingenbleek was also branded as an anglophobe in the documents of Belgian State Security in London: BNB, Archives, $S D$, London Archives, dossier 9.1/25, 'période de guerre', s. f. 1, documents du haut Commissariat à la sécurité de l'Etat: Banque Nationale de Belgique, 1943-1944.

38 Brutsaert, La nuit ne durera pas toujours. Oscar Plisnier, passim.

39 Prack himself claimed that he had several times urged Goffin to adopt a somewhat harder attitude towards the Military Government: soma, Archives, Prack Papers, dossier JP 965: Vier Jahre Besatzungszeit in Belgien. Persönliche Erinnerungen von Herbert Prack, p. 19.

40 soma, Archives, Prack Papers, dossier JP 965: Vier Jahre Besatzungszeit in Belgien. Persönliche Erinnerungen von Herbert Prack, p. 21. Belgian State Security in London described Berger as follows: 'Esprit réactionnaire qui, au début de l'occupation, ne câchat pas ses sympathies pour un régime autoritaire semblable à celui de l'occupant. N'a cependant pas tardé à modifier son attitude, lorsqu'il a pu en apprécier les inconvénients': BNB, Archives, SD, London Archives, dossier 9.1/25, documents de guerre, s.f.a, documents du haut Commissariat à la sécurité de l'Etat: Banque Nationale de Belgique, 1943-1944.

41 BNB, Archives, Prack Papers: Das Währungs-, Geld- und Bankwesen in Belgien. B: Notenbanken, 1a. Direktion. 
A few top officials likewise played a major part in the affairs of the two institutions during the Second World War. The most remarkable of them were Kauch and Cracco. Kauch, an excellent legal historian, trained at the Université Libre de Bruxelles, was the private secretary and confidant of Janssen, who entrusted him with a number of delicate tasks. He put his influence down chiefly to the large number of analytic and advisory memoranda that he prepared for Janssen, in which he showed himself a shrewd jurist and a well documented and forceful writer, exhibiting however a Francophile bias and a priori distrust of the private bankers. Janssen's confidence in Kauch was not shared by the other members of the management. Baudewyns spoke scathingly of him and he was no more persona grata with the rest of the management. The private bankers disliked him, too; their distrust of him was so strong that, after the death of Janssen, he was removed from the Banque d'Emission as private secretary to the chairman.

The second of these remarkable men, Cracco, was a civil engineer and economist of the Leuven School, who began his career at the Bank in the research department. When the clearing system imposed by the German administration came into effect on 10 July 1940, he was charged with its management, insofar as the Bank was involved. At the end of 1940, he was appointed by Janssen to head a foreign department to be set up within the Banque d'Emission. Until then, he had not attracted any particular notice in the Bank, but in this new function he became an authoritative senior official. Through his intelligence, technical knowledge, force of argument and self-confidence, his authority influenced both the management and the German Bankaufsichtamt. Following Janssen's death, it was the memoranda and reports of Cracco that set the tone in the determination of Bank policy. Hofrichter and his staff were impressed by him, finding him to be a formidable debater. Vandeputte joined Cracco as managing director at the beginning of 1943, to replace Berger and Van Nieuwenhuyse. Vandeputte, a jurist, was appointed on the recommendation of the bankers, who had come to appreciate him as secretary of their association. A hard worker, very efficient, making demands both on himself and on those around him, he displayed right from the start an exceptional talent for organization. After Cracco's arrest by the Germans he became the central figure in the Bank and the Banque d'Emission in contacts and negotiations with 
the Bankaufsichtamt. He knew his briefs thoroughly, and this, combined with his correct, but firm, attitude, made him a difficult person for the occupier to deal with, even though they held him in the greatest respect ${ }^{42}$.

The board of directors of the Banque d'Emission was dominated by the big Belgian bankers and industrialists, with Galopin the undisputed leader. After Janssen's death, he virtually drove decision-making at the Banque d'Emission and, via Goffin, drove much of that at the Bank, too. Galopin was a civil engineer by training and immediately after the First World War had successfully accomplished the reorganization of the Liège metalworking industry and the modernization of the entire heavy industry sector ${ }^{43}$. He had served as deputy-governor of the Société Générale de Belgique from the beginning of the 1930s, and had been made governor in 1935; in those two functions, moreover, he had piloted the most powerful of Belgium's holding companies safely through the world depression. Not only in Belgium, but far beyond, too, he was recognized as one of the country's most prominent figures.

Galopin's prestige rose even further when, as chairman of the committee bearing his name, he succeeded, with his policy of resuming work and getting the Belgian economy restarted during the general confusion of the first months of the occupation. Until mid-1942, he enjoyed the confidence of the Belgian government in London ${ }^{44}$, which, with good reason, regarded him as a confirmed and authoritative patriot $^{45}$. Thereafter, doubt arose in Belgian government circles in London about the policy he was pursuing, even though he had always regarded the government at Vichy and subsequently in London as the sole, legitimate government of Belgium and had always acted accordingly ${ }^{46}$. Galopin never favoured the acerbic or aggressive approach in discussion, preferring instead to argue logically in the belief that, although some-

42 BNB, Archives, Prack Papers: Das Währungs-, Geld- und Bankwesen in Belgien. B: Notenbanken. 1a Direktion.

43 Van der Wee and Verbreyt, De Generale Bank, p. 132.

44 Van de Voorde, De penningmeesters van de Wetstraat, pp. 142-145.

45 See the testimony of Goetz, directeur of the Dresdner Bank, regarding his request to the bankers in August 1940 for close economic cooperation with Germany: ' $j e$ sentais un vif et incontestable sentiment de résistance chez Galopin, au contraire chez de Launoit' (Krijgsauditoraat, Archives, CI 47/44, BEB dossier, 1).

46 Nefors, Industriële collaboratie in België, pp. 43-45. 
times demanding great patience, this would lead to persuasion and consensus ${ }^{47}$. He was nevertheless conscious of his prestige and was not altogether free from authoritarian and even dictatorial traits ${ }^{48}$. Where problems arose at the meetings of the board of directors of the Banque d'Emission, he generally allowed everyone to have their say, before himself concluding with a short and pertinent intervention that was more often than not approved by all members present ${ }^{49}$. After his assassination in February 1944, the strenght of the board was broken.

Deputy-governor of the Société Générale de Belgique and Chairman of the Banque de la Société Générale, de Munck, was a jurist by training and was, in fact, Galopin's right hand, his expert and adviser in financial matters. He was a cultivated, calm and discerning man who never lost sight of the interests of his bank and holding company ${ }^{50}$. Undeniably a heavyweight, he was highly respected by the German authorities ${ }^{51}$.

A.-E. Janssen, Chairman of the Société Belge de Banque, was less in the limelight, but no less active for all that. The great authority that he wielded as former Minister of Finance, as the central figure in the resolution of the crisis surrounding the Farmers' League (Boerenbond) in 1934-1935 and as banker of the Antwerp diamond trade gave him the necessary authority to mediate in reconciling differences of opinion ${ }^{52}$. With Galopin, moreover, he was the only member of the board to maintain contact with the Belgian government in London; the fact that he

47 BNB, Archives, SD, Basyn Papers, s. f. 6: note sur la réunion du comité de rédaction de la вEB, 19.09.1941.

48 See the testimony of Goetz, director of the Dresdner Bank, Krijgsauditoraat, Archives, CI 47/44, BEB dossier, 1.

49 See the testimony of Prack, who attended most meetings of the board of directors: 'Im Verwaltungsrat der BEB entschied seine Stellungnahme, die er in der Regel nach anhören der Debatte kürz abgab, das Votum des Gremiums ziemlich diktatorisch' (BNB, Archives, Prack Papers: Das Währungs-, Geld- und Bankwesen. B: Notenbanken. 1 a. Direktion.).

50 Van der Wee and Verbreyt, De Generale Bank, p. 228.

51 soma, Archives, Prack Papers, dossier JP 965: Vier Jahre Besatzungszeit in Belgien. Persönliche Erinneringen von Herbert Prack.

52 Comtesse Plater-Zyberk, Albert-Edouard Janssen, raconté par sa fille, 1976. See also: Van der Wee and Verbreyt, Mensen maken geschiedenis. De Kredietbank en de economische opgang van Vlaanderen, 1935-1985, 1985, pp. 71-112; SOMA, Archives, Prack Papers, dossier JP 965: Vier Jahre Besatzungszeit in Belgien. Persönliche Erinnerungen von Herbert Prack, p. 22. 
was able to do so throughout the war and at the same time retain the government's confidence enabled him to give the board useful advice ${ }^{53}$.

M.-L. Gérard, Chairman of the Banque de Bruxelles and also a former Minister of Finance, was likewise an active and influential member of the board of directors, his effectiveness being enhanced by his long friendship with Galopin. His most important contribution was as mediator between the Banque d'Emission and the Ministry of Finance at times of tension between the two. Plisnier, the Secretarygeneral of the Ministry, and Gérard were old friends and it was, in fact, partly through Gérard's support that Plisnier owed his appointment to that post in $1937^{54}$.

Collin, a Dutch-speaking jurist, Chairman of the Kredietbank and professor at the University of Louvain, was initially distrusted by Galopin; very quickly, however, the two bankers came to appreciate each other ${ }^{55}$. In 1941, as an expert in penal law and at Galopin's request, Collin prepared an opinion on the application of article 115 of the Penal Code to economic collaboration, an opinion that contributed substantially to the reformulation of the Galopin doctrine on the politics of accommodation ${ }^{56}$. Of other figures, Maurice Frère, Chairman of the Banking Commission, had become a member of the board at Janssen's insistence ${ }^{57}$; apart from the occasional foray, he kept himself in the background. He resigned at the end of 1942. Much more active was Léon Bekaert, an important industrialist from West Flanders, who was also a member of the supervisory council of the Bank. He was a strong personality and came from the circles of the General Christian Association of Employers; his businesslike and pertinent interventions exercised an unmistakable influence on discussions in the council ${ }^{58}$.

53 A.-E. Janssen was also active in the financing of the Resistance and, via that avenue, had additional contacts with the government in London (see below).

54 Brutsaert, La nuit ne durera pas toujours. Oscar Plisnier, pp. $35 \mathrm{ff}$.

55 Nefors, Industriële collaboratie in België, p. 41.

56 A. Collin, 'De politiek van tewerkstelling tijdens de bezetting', in: Mededelingen van de Koninklijke Academie voor Wetenschappen, Letteren en Schone Kunsten van België, Klasse der Letteren, xxxix, 1977, $\mathrm{n}^{\circ} 1$.

57 Krijgsauditoraat, Archives, CI 47/44, BEB dossier, $\mathrm{n}^{\circ}$ 3: rapports sur l'activité de la BEB (déclarations 15 décembre $1944-28$ novembre 1945: testimony No. 50 of M. Frère).

58 sомA, Archives, Prack Papers, dossier JP 965: Vier Jahre Besatzungszeit in Belgien. Persönliche Erinnerungen von Herbert Prack, p. 23. 
Lastly, Oscar Plisnier and Victor Leemans were the two secretariesgeneral having most dealings with the Banque d'Emission and the Bank during the war. Plisnier was an economist and held a doctorate in administrative sciences from the Université Libre de Bruxelles, where he subsequently held the chair in public finances ${ }^{59}$. He was a cultivated man and had a sense of social responsibility; a hard worker and selfassured, he was rather stand-offish and authoritarian towards his staff. Throughout the war, he showed great devotion to duty and was tolerated by the Military Government at Brussels, but not really highly regarded. In Berlin, he was held in even less esteem and there was pressure for him to be replaced, although this was not pursued by the Military Government for fear of resistance within the Belgian administration. Oddly enough, Plisnier also had a poor reputation in London as well as among the Belgian magistracy, being accused of being too accommodating to the occupier. His cooperation with the Banque d'Emission and the Bank was at first smooth, but ultimately ended in dramatic conflict ${ }^{60}$.

Leemans was cut from altogether different cloth and the two secretaries-general did not have a comfortable relationship, Plisnier regarding him as a rival who undermined his authority and actions. Leemans was a self-made man from East Flanders who had gained a teaching diploma and then gone on to study in Paris, Berlin and Munich, finally obtaining a doctorate in sociology in Paris ${ }^{61}$. A young conservative, with a Christian-corporatist ideology, he was a moderate Flemish nationalist, a Germanophile and was initially convinced of a German victory. He had been appointed Secretary-general of the Ministry of Economic Affairs by the Military Government, taking the place of Baron Snoy et d'Oppuers who had fled to France at the time of the invasion.

As Secretary-general, Leemans played an important part in settingup the production centres (Warenstellen) that the Military Government established from July 1940 for organising industrial production, which gave him easy access to Reeder and other top German officials.

59 Brutsaert, La nuit ne durera pas toujours. Oscar Plisnier, passim.

60 See Chapter 13.

61 O. Boehme, 'Tussen de fronten. Het jong-conservatisme van Victor Leemans', in: Wetenschappelijke Tijdingen, 58 (1999), 3, pp. 131-153; O. Boehme, 'Academici en de revolutie van rechts tijdens het Interbellum', in: Wetenschappelijke Tijdingen, 57 (1998), 1, pp. 45-58; Nefors, Industriële collaboratie in België, pp. 57-61. 
Galopin distrusted him at first, but came increasingly to value him as the occupation continued. Experience showed that he took a moderate and even fairly independent line with the German administration and never lost sight of the interests of his country. He was, consequently, a valued intermediary for the bankers, the industrialists and the Banque d'Emission alike when tension with the Military Government led to deadlock or threatened to erupt in conflict. 


\section{CHAPTER 8 \\ The Politics of Accommodation in Daily Reality}

\section{THE DISTRIBUTION OF RESPONSIBILITIES}

At its establishment on 27 June 1940, the Banque d'Emission was given a wide range of competences, in line with the view of the German administration and the founding fathers, who envisaged it as Belgium's central bank for the duration of the war. However, the return of the governor of the Bank from France on 10 July and the repatriation of the substantial stocks of banknotes of the Bank from the strongroom at Mont-de-Marsan placed a check on the original plan for the Banque d'Emission. As the Banque d'Emission was not wholly ready with its new banknotes by the time its deed of incorporation was executed on 13 July $^{1}$, Janssen, as was already said before, was able to persuade the Military Government to allow it to make provisional use of the notes of the Bank.

One of Janssen's first moves was to try to get the Banque d'Emission rapidly liquidated, but the German authorities rejected his proposal; according to the Bankaufsichtamt in Brussels, the veto came from Berlin, the Reichsbank being unwilling to go back on its original decision. Janssen consulted the jurist Rolin about the matter, but Rolin's assessment was formal: the Banque d'Emission had been validly established and the return of the Bank from France did nothing to change the situation $^{2}$. The only course in Rolin's view was to adopt a pragmatic stance: accept the co-existence of the two institutions and search for a division of responsibilities that was as much in the Bank's favour as possible.

1 W. Pluym, 'Jaarverslagen', in: Tijdschrift voor het personeel NBB, 2001, pp. 3-10.

2 BNB, Archives, $S D$, dossiers officiels après 1945, dossier 13: note résumant l'entretien du 24 septembre 1940 entre M. le Gouverneur et M. Henri Rolin; consultation de M. Henri Rolin (undated). 
Janssen drew up a general proposal for the distribution of tasks and presented it to the Military Government in a memorandum of 29 July. Now that the Bank had returned to Brussels and the dire shortage of banknotes and coins had been resolved, the Bank should resume its traditional competences and functions. The Banque d'Emission, however, ought not to disappear, as legally it had broader powers than the Bank and could focus its activity on those areas for which it had legal competence and the Bank did not.

At the time of the Banque d'Emission's establishment, nothing had been formally settled concerning the notes of the Bank being made available to the new institution. Janssen wanted to have this matter sorted out and suggested that the Banque d'Emission employ credit operations with the Bank to ensure itself of the requisite banknotes. However, he was unable to present any concrete proposals regarding an arrangement for clearing and for resolving the issue of dual circulation; these were matters that the Germans would have to decide.

It took until 20 August 1940 for the Military Government to respond to Janssen's general proposal ${ }^{3}$, but the situation was made immediately clear when it did. Janssen was not to think that he could treat the Banque d'Emission as a subordinate department of the Bank; the Banque d'Emission was and remained the country's sole issue institution: it was true that, to that end, it was using the notes of the Bank, but this was purely a temporary arrangement that had a psychological purpose, namely to ensure the confidence of the population in the fiduciary money4. Moreover, the Banque d'Emission was competent to pursue a fully open-market policy and, of its own accord, to conduct all credit operations permitted by its bye-laws; consequently, it was not obliged to go through the Bank, as Janssen proposed.

Lastly, the Military Government confirmed the allocation of other important tasks to the Banque d'Emission. The Belgo-German clearing account at the Deutsche Verrechnungskasse in Berlin would remain in its name, meaning that the management and the pre-financing of all

3 BNB, Archives, $S D$, 30, вEB, dossier 8.11.24. 7, and SD, 41, 'enquête BEB', dossier 8.11.43/31: memorandum, adressé par le commissaire allemand au président de la $\mathrm{BEB}$, définissant les attributions respectives des deux instituts d'émission, 20.08.1940.

4 BNB, Archives, SD, Malaise Papers: Kauch, La Banque Nationale, (unpublished text), Part 1, Chapter. 5, pp. 68-70; 
clearing operations would fall within its responsibility. It would also continue to manage third-party deposits at the Postal Cheque Office and would henceforth assume in full the function of State exchequer; in addition, it would be required to expand its activities in the provinces and advertise its presence clearly to the public by means of explicit notice-boards in all the Bank's branches.

The German memorandum of 20 August thus threw Janssen's suggestions into total confusion. In the opinion of the Bankaufsichtamt, the Bank's chief task was ultimately to make its reserve of banknotes available to the Banque d'Emission. The Bank was also to concentrate on securing the repatriation of the gold it had placed in safe custody abroad. It would be permitted to manage its other assets and settle its current transactions, but no longer to attract new deposits or undertake new transactions.

\section{THE CHALLENGE TO LEGAL COMPETENCE}

The reorganization of the Postal Cheque Office was, in fact, the result of a long and exhaustive discussion set in train by the private bankers, a discussion prompted by the great confusion that arose from the flight of that public institution's management abroad at the time of the German invasion and from the temporary misplacing of documentation. The situation was made use of by the private bankers to begin a campaign for rearranging the functions of the Office. Their most important arguments were psychological and financial. In their opinion, during the preceding months the population had lost confidence in it ${ }^{5}$. Furthermore, it was procedurally unacceptable for the Treasury to have a right of free and unlimited access to the third-party deposits of the Office; consequently, there was an urgent need for a clean split between State and private accounts. In an agreement of 3 August between the Ministry of Finance, the Bank and the Banque d'Emission, the Military Government closed the discussion by transferring the management of the third-party deposits to the Banque d'Emission.

5 BNB, Archives, Prack Papers: Das Währungs-, Geld- und Bankwesen, 10 Mai 1940 - 31 Dezember 1943, A. Grundlagen. II, 7: Ingangsetzung des Postcheckamtes. 
The ensuing months saw a new and acute problem in connection with competences. On the Banque d'Emission's establishment in June, the Military Government had included the function of German commissioner in the bye-laws and had clearly defined his area of competence. However, nothing had been determined with regard to a commissioner at the Bank. In the discussions at Wiesbaden in the autumn in respect of the gold deposited with the Banque de France, von Becker had acted as the Bank's representative, but did so wrongly, claimed Janssen, because he did not have the authority to do so, as his competence was limited to the Banque d'Emission. This problem was resolved on 16 December by the Military Government issuing an ordinance declaring that the competences of the commissioner at the Banque d'Emission extended to the Bank. It was announced at the same time that the commissioner could legally represent the two institutions both at home and abroad, and on behalf of both could perform all legal acts and take measures of disposition ${ }^{6}$.

A similar dispute with regard to competence emerged in respect of the Weisungsrecht. Did the occupying power have the right to direct the Banque d'Emission to execute certain transactions? According to the bye-laws, the military commander was entitled to make use of that right where a conflict between the Military Government and the Banque d'Emission led to a deadlock. Such situations actually occurred occasionally from 1941 on, but when the commissioner at the Banque d'Emission looked to apply the Weisungsrecht, the management each time refused to fall in line, arguing that the bye-laws laid down that only the military commander or his representative, Reeder, had that right, and then exclusively in an actual situation of deadlock; in formal terms, the commissioner had no competence in the matter. The Military Government was extremely irritated by this stance on the part of the management, but never directly quarrelled with it and - reluctantly needless to say - always respected the procedure laid down. Application of the Weisungsrecht was to remain a bone of contention for both parties throughout the period of the occupation?

6 BNB, Archives, RR, 23.12.1940. See also: BNB, Archives, Prack Papers: Das Währungs-, Geld- und Bankwesen in Belgien, 10 Mai 1940 - 31 Dezember 1943.

7 BNB, Archives, Prack Papers: Das Währungs-, Geld- und Bankwesen in Belgien, 10 Mai 1940 - 31 Dezember 1943. See also: BNB, Archives, SD, Malaise Papers: Kauch, La Banque Nationale (unpublished text), Part 1, Chapter. 3, pp. 43-45. 
The distribution of tasks between the two institutions, as officially restated by the occupying power on 20 August 1940, continued to rankle with Janssen, who could not accept the subsidiary role thereby accorded to the Bank. Meanwhile, though, in the autumn public opinion had begun visibly to turn against the occupier, whose true face was gradually being revealed by the requisitioning of all types of goods, the imposition of mandatory declaration of holdings of gold and foreign currency, the burden of billeting, the high costs of occupation, the increasing shortage of food, rationing, the restriction of freedom, the introduction of the curfew and other wartime measures. The German 'New Order' was losing its initial attraction. Furthermore, the idea of German military superiority was being undermined by the Germans' failure to prevail in the Battle of Britain and tenacious British resistance. The depression felt by the conquered was giving way to optimism, albeit cautious. The Belgian people had begun to rediscover their ostensibly lost patriotism and their solidarity in the struggle against a common enemy, the hated occupier.

The Bank, too, was not unsusceptible to a similar change of mentality, though that is not to say that Janssen's patriotism had ever wavered; right from the moment of his return, it had been central to everything he undertook and to all his decisions. During the summer of 1940, however, it was expressed chiefly in leaning towards the policy of accommodation, which was initially directed at the recovery of the economy and the expansion of employment.

As a result of the first sharp disagreements with the Military Government and the realization that a compromise peace was becoming increasingly unlikely, Janssen came to fear - intuitively, perhaps - that, however honourable the intentions, the policy of accommodation involved great risks for the Bank's future. Certain competences could, in fact, lead to activities that were contrary to the institution's purpose, an instance of this being cooperation in obtaining the repatriation of the Belgian gold from France, which the German authorities insisted on. Consequently, in the autumn of 1940 Janssen began to work even harder to protect the Bank from German interference, making a fresh effort to adjust the distribution of tasks between the Bank and the Banque d'Emission. He submitted a proposal to bring the distribution

8 BIS (Basel), Archives, dossier 7.18 (6), AUB 4/ 21: Struye, l'opinion publique de Belgique après sept mois d'occupation, February 1941. 
more into line with the way the war economy was actually evolving 9 The Military Government approved the proposal on 28 February $1941^{10}$.

In accordance with the new arrangement, the Banque d'Emission would make use of the notes of the Bank for the duration of the war; there was thus no further prospect of it issuing its own banknotes, so that the Bank need have no worries about its own issue privilege, and the danger of having both types of banknote in circulation in Belgium was averted. The Banque d'Emission would continue to be responsible for all foreign transactions: more particularly, clearing operations and their pre-financing in Belgium, the purchase of foreign currency and gold belonging to private individuals, and all financial and monetary transactions with German authorities, German organizations and German banks active in Belgium. Lastly, it would continue to manage third-party deposits at the Postal Cheque Office ${ }^{11}$. For its part, the Bank would take care of all credit operations in respect of the Belgian private sector, State, provincial and local authorities, public bodies and all other public institutions; it would also continue carry out its traditional function of State exchequer ${ }^{12}$.

This new distribution of tasks represented a substantial victory for Janssen. The Bank regained virtually all its pre-war functions and at the same time was able to shed all activities linked to the occupying power and pass them to an institution set up solely for the duration of the war. In this way, Janssen hoped to protect the Bank against any direct relationship with the enemy, as it had been during the First World War, and be able to pilot it safely through the war, without its role being compromised ${ }^{13}$. The comparison with the First World War was not entirely correct, as - during that conflict - the Bank had ceased its issue activity and the Société Générale de Belgique had used one of its

9 BNB, Archives, DC, 28.02.1941.

10 BNB, Archives, DC BEB, 28.02.1941.

11 The distribution of general costs between the two institutions was to be settled at the end of each year. Each institution would bear the costs regarded as specific to itself and a set formula would be applied to the distribution of other common general costs: BNB, Archives, $D C$ BEB, 02.01.1942.

12 BNB, Archives, $S D$, Malaise Papers: Kauch, La Banque Nationale (unpublished text), Part 1, Chapter. 2, pp. 46-48.

13 BNB, Archives, $S D$, enquête BEB, dossier 3-4: Basyn, note relative à l'origine de la BEB et aux résultats de son activité (o8.11.1944). 
own departments to issue banknotes of its own. Now, the Bank was making its banknotes available to the Banque d'Emission. However, the arrangement had not been settled in law. In fact, it could be regarded as granting advances by the Bank to the Banque d'Emission for financing the costs of occupation, the clearing operations and German purchases in Belgium on the black market and elsewhere. The Bank thus remained involved in all these transactions with the occupier and could not entirely escape the implications ensuing from the Belgian policy of accommodation ${ }^{14}$.

On the side of the Military Government, there was satisfaction with the outcome. The use of the notes of the Bank exerted a favourable psychological effect on circulation. Moreover, it gave the Military Government much greater influence over the Banque d'Emission. It also enabled the Belgian economy to be more easily involved financially in the German planned economy and in the German war effort ${ }^{15}$. The bankers and big industrialists were naturally aware of the unfavourable implications for them of the compromise that had been reached, but they lodged no protest: Janssen was not used to sharing his authority with others. For that reason, the bankers sensibly held themselves aloof at meetings of the board of directors. Furthermore, Janssen had the reputation of being a confirmed patriot, which was an excellent guarantee of the Banque d'Emission's political integrity. At the same time, he displayed a very co-operative attitude towards the matter of financing clearing operation $\mathrm{s}^{16}$, which was the essential component of the policy of accommodation and the employment policy being pursued by the bankers and the big industrialists.

14 BNB, Archives, $S D$, Malaise Papers: Kauch, La Banque Nationale (unpublished text), Part 1, Chapter. 2, p. 48.

15 BNB, Archives, SD, Malaise Papers: Kauch, La Banque Nationale (unpublished text), Part 1, Chapter. 2, p. 43. BNB, Archives, Studiedienst, 2, dossier 01.02.01.70 (A 247/6, s.f. 9): H. von Becker, L'évolution du crédit en Belgique depuis l'occupation allemande (address at Cologne in 1941). See also: H. von Becker, 'Die Kreditwirtschaftliche Entwicklung in Belgien seit der Deutschen Besatzung', in: Bank-Archiv, 1941, 1, pp. 11-13.

16 BNB, Archives, $S D$, enquête BEB, dossier 3-4: Basyn, note relative à l'origine de la BEB et aux résultats de ses activités (08.11.1944). 
When they invaded Belgium in 1940, the Germans were well aware that the country boasted a progressive economy and that half of the active population was employed in industry and mining, and could thus be of great service to the German war machine. The Nazi doctrine of a European Groszraumwirtschaft, however, was one directed towards concentrating all major industries in the fatherland and leaving the production of raw materials and of any simple or half-finished manufactured goods to the periphery. For the exploitation of Belgium, this meant steppingup the production of coal with a view to its direct export to Germany or indirect export in the form of the electricity it could generate. In other industrial sectors, the German Ministry of Economic Affairs immediately went in search of stocks of scarce raw materials necessary for the conduct of war; when identified, these were requisitioned forthwith and transferred to Germany ${ }^{17}$. The occupier's hand was felt even more heavily in the transport sector, where, during the first two years of the occupation, about 1,000 locomotives and more than 50,000 railway wagons were seized and sent to Germany ${ }^{18}$.

The Military Government had totally different ideas about how Belgian industry was to be incorporated into the German war effort. The intention of von Falkenhausen and Reeder was to use a vigorous, dirigiste policy to get the Belgian economy working efficiently again and to give the Belgian population a tangible share in the economic recovery. A certain degree of prosperity in an occupied territory could serve only to encourage the commitment of the population and ultimately enable a greater contribution to be made to German war production. Designed to be the cornerstone of this policy were the twelve (subsequently increased to sixteen) Warenstellen for the organization of industrial production, under the direction of the Belgian Ministry of Economic Affairs ${ }^{19}$.

With his decree of 26 August 1940, Goering, who was directing the Four-year Plan for the German economy, more or less went along

17 Klemm, German Economic Policies in Belgium from 1940 to 1944, pp. 12-25.

18 Klemm, German Economic Policies in Belgium from 1940 to 1944, p. 29.

19 Nefors, Industriële collaboratie in België, pp. 57-66. 
with the Military Government's strategy. In his view, Belgian industry should contribute to the German war economy by way of orders from Germany. Furthermore, there should be merging of capital (Kapitalverflechtung) between big German and Belgian companies, which would give an additional boost to the contribution from Belgian industry.

In formal terms, the Military Government was the highest authority in the occupied territory of Belgium and Northern France. In practice, however, its authority in economic matters was compromised by the action of all types of other German bodies. The resulting tendency towards a fragmentation of economic authority did nothing to make the incorporation of the Belgian economy into the German war effort more efficient ${ }^{20}$.

According to its advocates - the members of Belgium's financial and industrial establishment - the policy of accommodation was the best way in which to get the economy in Belgium back on the rails, following the military defeat, and particularly to get employment back to a proper level. However, this general programme concealed other aims, which included maintaining the management of business in Belgian hands, preventing the dismantling of the factories (as happened during the First World War) and opposing the deportation of labour (particularly of the unemployed in the secondary sector) to Germany. Likewise a priority concern was the import of food and raw materials; this could be resolved only by exporting coal, electricity and manufactured goods to Germany and her satellites. Conceived at a time when many still anticipated or feared a compromise peace and German dominance of continental Europe, the policy of accommodation certainly had a degree of common ground with the ideas of the Military Government about how the Belgian economy could best be incorporated into the German war effort.

The key question, however, concerned the extent to which that policy could stretch. With not only the interests of his group in mind, but also, as a confirmed patriot, feeling responsible for the general interest, Galopin initially took a very cautious line in his pronouncements about this problem. His memorandum of 15 July 1940 indicates that a recovery of industrial production to 60 per cent of its pre-war level ought to be

20 Klemm, German Economic Policies in Belgium from 1940 to 1944, pp. 43 and 82. 
sufficient to keep the policy of accommodation within safe limits ${ }^{21}$. This view was endorsed by the Christian employers' organizations, which also emphasized that, in any case, the production of arms had to be excluded, as had any expansion of production in no matter what firm. Making extra profit was equally excluded and production was required to be directed as much as possible towards supplying the Belgian market. Lastly, employers were not to take advantage of the dissolution of the trade unions to reverse the social progress made during the preceding decades ${ }^{22}$.

Speaking for the Belgian government in London, Gutt, with certain reservations, agreed with the doctrine of the Galopin Committee. On 22 February 1941, he could still write to Cattier, who had met Ansiaux in Lisbon: 'que quand on a faim, il fallait manger; que pour manger il fallait acheter de la nourriture; que quand on n'en avait pas assez à l'intérieur, il fallait l'acheter à l'extérieur; que pour l'acheter à l'extérieur, il fallait des devises; que pour avoir des devises, il fallait vendre à l'extérieur' ('when you are hungry, you have to eat; for eating you need food; if the country does not produce enough food, you have to buy it abroad; buying abroad has to be done with foreign currency, which can only be obtained by exporting goods'. However, his assent to the policy of a resumption of work and exporting to Germany was conditional. In a letter to Hannecart, Gutt expressed his reservation as follows: 'le tout est dans la façon dont on le fait et dans les rapports avec les Allemands' ('Crucial is the way how your exports to Germany and how your relations with the Germans are organized') ${ }^{23}$.

Not all Belgian industrialists behaved moderately. Some chose to co-operate as closely as possible with German industry and at first appeared little inclined to take much notice of the advice of the Galopin Committee $^{24}$. This contrasted with the attitude of the big industrialists from the Société Générale de Belgique group and many others, who observed strict restraint. Attitudes among medium-sized enterprises were similarly divided: many held to the Committee's view, others used the

21 Nefors, Industriële collaboratie in België, pp. 46-48.

22 De Vlaminck and De Vos, 'De Belgische industriëlen tijdens de bezetting, 19401944', pp. 117-122.

23 BNB, Archives, SD, Ansiaux Papers, 9. 1/32: letter of 23.12.1946 from Gutt to Ansiaux. 24 E. Verhoeyen, Les grands industriels belges entre collaboration et résistance, passim. 
occasion to restore their finances ${ }^{25}$. Numerous Belgian industrial firms had suffered heavy losses during the world depression of the 1930 and were still in a precarious position on the eve of the German invasion; for some of them, there was a great temptation to use collaboration to regain their place in the sun.

The picture of fragile recovery was confirmed by industrial production figures. Despite the special attention given by the occupier to coalmining, coal output in 1940 and 1941 was $10-15$ per cent below its level for 1939. The situation was much worse in the iron and steel industry, as only half of the forty-four blast furnaces operating in 1939 were still active in 1940 and 1941, and things were little better in the metalworking, non-ferrous and textile sectors, due chiefly to the lack of raw materials.

In agriculture, adjusting the acreage under cultivation led to a considerable increase in the production of rye and potatoes, at the expense of the production of meat and dairy. After a time, it proved possible to cover the full requirement for potatoes and three-quarters of that for bread, although this result was achieved to the detriment of other agricultural products, such as meat and dairy produce, and the calculations were made on the basis of poor, insufficient rations. The country was thus still dependent on the import of grain ${ }^{26}$. In this respect, Germany was anything but co-operative, the autumn of 1941 even seeing a temporary stop being placed on the export of grain to Belgium ${ }^{27}$. Prices on the black market rocketed and there was a great deal of hunger in the winter of 1940-1941, especially in the towns. The situation of wageearners was made hopeless by the prohibition on wages being adjusted and all this led to widespread strikes in May 1941. By then, already, the members of the Galopin Committee and their supporters had realized that, as regards the provision of supplies, the fragile policy of accommodation, from which they had hoped for so much, had failed. Simply, the export of manufactured goods to Germany had not been offset by adequate imports of foodstuffs and raw materials, as had been agreed ${ }^{28}$.

25 D. Luyten, Burgers boven elke verdenking? Vervolging van economische collaboratie in België na de Tweede Wereldoorlog, Brussels, 1996.

26 BNB, Archives, AV, 30.06.1945: report by the board of scrutineers for the 1940-1944 financial years, prepared on behalf of the supervisory council, pp. 27-33.

27 Klemm, German Economic Policies in Belgium from 1940 to 1944, pp. 69-72.

28 Nefors, De industriële collaboratie in België, pp. 92-93. 
No real progress was made as regards unemployment either. It is true that there was a resumption of work, but between 1 July 1940 and 31 May 1941 something like 15,000 workers a month left voluntarily for Germany $^{29}$, attracted by higher wages and particularly by better rations. Indeed, moving to Germany became even more attractive after the revaluation of the Reichsmark against the Belgian franc on 22 July 1940 (from 1 Reichsmark to 10 Belgian francs to 1 Reichsmark to 12.50 Belgian francs).

These negative developments created a sense of malaise within the Galopin Committee. It was all very well that the policy could be justified on legal and ethical grounds, but it had not served its purpose in those early months: insufficient food had been brought into the country in exchange for Belgian exports, and the resumption of work had proved unable to prevent the exodus of workers to Germany. The Committee was faced with finding a means to change the situation and Galopin saw only one possibility, i.e. raising industrial production from 60 to 80 per cent of its previous level; this would improve Belgium's hand in negotiations with Germany regarding food imports and immediately create more jobs on the domestic market ${ }^{30}$.

The German ordinance of 1 August 1940 had prohibited any increase in salaries and wages, ostensibly to stabilize the cost of living. On 29 May 1941, however, following the hard winter of 1940-1941 and the strikes in that same month, the Military Government authorized an 8 per cent rise, though this was far from what was required. At this time, like all wage-earners in Belgium, the staff of the Bank and the Banque d'Emission were finding it extremely difficult to get by on their income, which is why both institutions put various social measures in place that were to prove successful in the longer run. In the first place, they themselves made an adjustment to salaries and wages, albeit indirectly. Additionally, they gave help in kind ${ }^{31}$, the most important instance of this being a mid-day meal, provided six times a week on the premises of the Bank at a minimum price and without ration coupons having to be surrendered.

29 Klemm, German Economic Policies in Belgium from 1940 to 1944, pp. 140-141.

30 De Vlaminck and De Vos, 'De Belgische industriëlen tijdens de bezetting, 19401944', pp. 123-127: Galopin, note relative au comportement de l'industrie belge pendant l'occupation du pays (30.06.1940).

31 See, among others: BNB, Archives, DC, 20.11.1941. 


\section{MONEY CIRCULATION}

The policy of bringing about a resumption of work gradually reduced the payment difficulties experienced during the initial months of the occupation. June 1940 saw the lifting of the restrictions of 13 May on the withdrawal of deposits from the private banks and, at the end of July, the clearing houses began to operate again, under the leadership of the Bank. The moratorium on the payment of due invoices and matured securities was ended on 19 August and the Brussels, Antwerp and Liège Stock Exchanges opened their doors again with effect from 21 Augus $^{32}$. The Postal Cheque Office, too, resumed normal operations: more particularly from 22 July for giro transactions and from 8 August for the withdrawal of deposits.

Together with the scarcity of goods, the increase in the overall money supply formed a breeding-ground for feared price inflation. That inflation had no effect on rationed goods, as the price of these was set by the government and was stable. On the parallel black market, however, prices went up sharply, although major regional differences and a lack of information make it virtually impossible to give accurate figures.

The withdrawal of the Reichskreditkassenscheine from circulation was without doubt the biggest monetary problem faced by the Banque d'Emission at the beginning of the occupation. The central administration of the Reichskreditkasse, set up in September 1939, had created

Table 8.1: Total money supply, 10 May 1940 to 1 January 1942 (in millions of Belgian francs)

\begin{tabular}{lrrrrrrrr}
\hline & & & Notes and \\
coins in & Treasury \\
notes & circulation & Palances & $\begin{array}{r}\text { Postal Cheque } \\
\text { Office transfer } \\
\text { account balances }\end{array}$ & $\begin{array}{r}\text { Demand } \\
\text { accounts at } \\
\text { private banks }\end{array}$ & Total \\
\hline bate & 29,806 & 1,607 & 31,413 & 909 & 4,668 & 13,620 & 50,610 \\
10.05 .40 & 35,453 & 2,302 & 37,755 & 1,779 & 5,311 & 14,151 & 58,610 \\
01.01 .41 & 48,942 & 3,420 & 52,362 & 2,348 & 7,401 & 17,788 & 79,899 \\
\hline
\end{tabular}

Source: BNB Archives, AV, 30.06.1945: general report prepared on behalf of the supervisory council by the board of scrutineers for the 1940-1944 financial years, p. 11.

32 Freiburg im Breisgau, Militärarchiv, Militärverwaltung, dossier Rw 36/277: Hofrichter, Abschluszbericht der Militärverwaltung in Belgien und Nord-Frankreich, pp. 46-48. 
local cashier offices in the occupied territories, whose purpose was to provide the armies in the field with money. In fact, they operated as mini central banks in their particular areas, using their Scheine to provide the soldiery with cash and also to finance army requisitioning and procurement.

The Scheine were not at all welcome in Belgium ${ }^{33}$. Fresh in everyone's mind were the bad memories of the mass circulation of Reichsmarks during the First World War. In Janssen's view, the Reichskreditkassenscheine in 1940 represented a similar danger. First and foremost, their issue was totally uncontrollable and could result in the country falling prey to inflation; secondly, they were an instrument of plunder on a massive scale, to which Belgium had no defence; thirdly, there was no guarantee whatsoever that there would be a proper financial settlement after the war. From the moment of his return from France, therefore, Janssen gave the elimination of the dual currency circulation priority in his negotiations with the occupying power ${ }^{34}$.

On 26 July 1940 Plisnier, Secretary-general of the Ministry of Finance, received a request from the Military Government to transfer 3 billion Belgian francs to its account at the Banque d'Emission, as prepayment for occupation costs, yet to be agreed. Janssen viewed this as an opportunity to request the withdrawal of the Reichskreditkassenscheine from circulation $^{35}$. He accepted Plisnier's proposal to join him in discussion on the occupation costs, to be held on 9 August with Reeder, President of the Military Government; this would give Janssen the opportunity to raise the question ${ }^{36}$. During the discussion with Reeder, Janssen argued that Belgium had the right to demand the withdrawal of the Scheine, as the Belgian government had agreed in principle to pay occupation costs

33 BNB, Archives, $S D$, Malaise Papers: Ingenbleek, La vie en Belgique sous l'occupation, pp. 16-17.

34 BNB, Archives, $S D$, 36, Foreign Department, dossier 8.11/32 (RKKs): la question des Reichskreditkassenscheine.

35 The chairman of the Nederlandsche Bank, Trip, had already received an undertaking in July 1940 from the army that it would not disburse any more Reichskreditkassenscheine in the Netherlands: Klemann, Nederland 1938-1948, p. 132.

36 вNB, Archives, AR, 17.08,1940. See also: BNB, Archives, SD, 33, dossier 8.11.27/4, 'divers': Plisnier, mémoire relatif à l'indemnité réclamée à la Belgique au titre des frais d'occupation, 20.12.1940. 
to the German authority. Failure to withdraw them would in fact mean Belgium paying twice for the same purpose.

Janssen went on to emphasize the monetary disadvantages of a dual circulation; no conditions had been fixed for the size of the issue, which could cause inflation. In accordance with article 49 of the Hague Convention, moreover, the Reichskreditkassenscheine, and indeed the occupation costs, were required to be used exclusively for the maintenance of the local occupying power. The costs for troops concentrated in Belgium and Northern France in preparation for an invasion of Great Britain or for army divisions passing through or resting in Belgium did not qualify as occupation costs to be paid by Belgium ${ }^{37}$; those extra costs could be financed with Belgian francs in exchange for Reichsmarks that Belgium could use to purchase foodstuffs and raw materials in Germany. Janssen set out his arguments in two memoranda of 28 September and 21 October 1940 respectively, and ensured that, in each case, they were delivered to Commissioner von Becker just before he left for Berlin to conduct discussions with his superiors ${ }^{38}$.

The memoranda produced results. With effect from the end of September 1940 already, the local Reichskreditkassen ceased to place new Scheine in circulation. On 3 February 1941 Janssen proposed that the Banque d'Emission would assume responsibility for the withdrawal of the Scheine still in circulation, provided that there was an agreed ceiling of 3-4 billion Belgian francs; any balance above that would have to be financed by the Kassen themselves. It was also proposed that the Scheine cease to be legal tender not only in Belgium, but also in Northern France and in the Netherlands, and, lastly, that the Scheine acquired

37 Reeder disagreed with the first argument. In his view, the Reichskreditkassenscheine represented a claim on Germany for the disbursement of the pay of the 'conquering' troops and for the purchases of equipment by the army: consequently, they had nothing to do with the costs of occupation. However, Reeder and von Becker were able to agree with the second argument and eventually with the third. For the reasons stated, they regarded the withdrawal of the Scheine even desirable, but withdrawal had to be gradual: BNB, Archives, $S D$, 'Association des Banques Belges' Papers, dossier 08.00.00.00 (C 783/4): circulaires, Plisnier, frais d'occupation (memorandum of 17.08.1940 from Plisnier concerning the meeting with Reeder and von Craushaar on 09.08.1940); BNB, Archives, BR BEB.

38 BNB, Archives, SD, 36, Foreign Department, dossier 8.11/32 (RKKs): la question des Reichskreditkassenscheine. See also: BNB, Archives, $S D$, 14, dossier 8.11/4, s. f. 3 (RKKS): retrait des Reichskreditkassenscheine (période 21 octobre 1940 à mars 1941). 
by the Banque d'Emission be used in Germany for the purchase of food and raw materials ${ }^{39}$.

The Military Government reacted to Janssen's proposals during a meeting on 26 February 1941 and a month later in a memorandum of $25 \mathrm{March}$, saying that it was prepared to accede to the request for the Scheine to be withdrawn from circulation, on condition that the Banque d'Emission grant an unlimited and interest-free line of credit to the central administration of the Reichskreditkassen. Janssen viewed the proviso with scepticism and consulted the jurists Marcq, Rolin and Struye. Their opinion was unanimously negative ${ }^{40}$ : the free granting of an unlimited line of credit to the Kassen would be in contravention of article 115 of the Penal Code, which formally prohibited financial help being given to the enemy.

Janssen refused to comply and total deadlock ensued. However, the Bank continued to accept the Scheine presented at its counters and exchange them for their full value. It also transferred the Scheine it received to the central administration of the Reichskreditkassen, which withdrew them from circulation in exchange for Belgian money. By the beginning of September 1941, 3,566 million Belgian francs' worth of Scheine (the equivalent of 249,323,812 Reichsmarks) had been transferred and taken out of circulation ${ }^{41}$. On 1 August 1941, meanwhile, an agreement had been concluded between the Military Government and the Ministry of Finance, whereby the value of Scheine subsequently presented to the Bank would be offset against the occupation costs to be paid of 50 million Belgian francs per month. However, few further Scheine were presented and the problem of dual circulation seemed to have disappeared. On 5 November 1941, Plisnier concluded the matter by granting the Banque d'Emission a State guarantee for the amount of what the withdrawal of the Scheine had cost ${ }^{42}$.

39 вNв, Archives, SD, 36, Foreign Department, dossier 8.11/32 (RKкs): la question des Reichskreditkassenscheine.

40 Soma, Archives, Paul Struye Papers, dossier 4: consultations BNB et Finances (crédit à l'occupant).

41 BNB, Archives, Boekhouding, 1, dossier 88.02.01.00 (B 608/4): retrait des Reichskreditkassenscheine.

42 BNB, Archives, SD, 36, Foreign Department, dossier 8.11/32 (RKKs): la question des Reichskreditkassenscheine. 


\section{THE COSTS OF OCCUPATION AND THEIR FINANCING}

The costs of occupation were yet another bone of contention between the Belgian administration and the Military Government. They also concerned the Bank, as they exerted a direct effect on public finances and thereby on the Bank's provision of credit to the government. When, on 26 July 1940, Plisnier was requested to transfer 3 billion Belgian francs by way of prepayment of prospective occupation costs, he immediately turned to the jurists Marcq, Rolin and Struye for advice. Their opinion was that the Hague Convention entitled the Germans to demand such costs from Belgium, but that the extent and terms of those costs were subject to strict conditions; only the costs of administrating the occupied territory and of maintaining the local occupation authority were admissible. As Belgium continued to be responsible for the administration of the country and for maintaining public order, only the maintenance costs for the occupying troops could be taken into account. The jurists concluded that the amount demanded by the Military Government was excessive and not to be accepted ${ }^{43}$.

Accompanied by Janssen ${ }^{44}$, on 9 August Plisnier went to discuss the matter with Reeder, basing his arguments on the opinion of the three jurists. He accepted the 'principle' of occupation costs, but wanted to come to a fixed agreement with Reeder about their extent. He also had a number of pertinent questions to ask regarding the term that would be covered by the prepayment demanded, whether a detailed list of costs could be provided and what the estimate was for overall occupation costs. Furthermore, he pointed out to Reeder that excessive occupation costs would totally derail the Belgian economy, while it was precisely the German administration's express intention to get that economy up

43 BNB, Archives, SD, 'Association Belge des Banques' Papers, dossier 08.00.00.00 (C 783/4): AV, minutes, 17.08.1940 (see also the letter of 05.08.1940 from Plisnier to A.-E. Janssen, chairman of the association).

44 Plisnier valued Janssen's cooperation extremely highly:.....tous mes remerciements pour l'aide précieuse que vous m’avez apportée en les moments difficiles que l'Administration des Finances vient de traverser. J'en profite....de vous dire....combien j'apprécie les sentiments de patriotisme éclairé et de dévouement à la chose publique qui vous ont guidé en ces circonstances' (BNB, Archives, SD, 33, dossier 8.11.27/4, 'divers': letter of 20.08.1940 from Plisnier to Janssen). 
and running again. Reeder took the point, but nevertheless demanded that the amount demanded be paid by 20 August ${ }^{45}$.

Plisnier had little choice but to accede to Reeder's demand and immediately began consultations with Janssen and the private bankers to arrange the financing. By 20 August, the Banque d'Emission would discount 3 billion Belgian francs' worth of renewable Treasury bonds at four months and the private banks would subscribe for a total of 500 million Belgian francs. To consolidate the resulting debt, the Treasury would, from the end of September, issue a ten-year government loan of 3 billion Belgian francs at 4 per cent per year, to be organized by the Bank. In a consortium, the banks immediately underwrote 500 million Belgian francs ${ }^{46}$. At the request of the Military Government, Plisnier agreed to increase fiscal pressure in order to finance the interest charges and to redeem the debt, and new taxes set to bring in about 2.5 billion Belgian francs were imposed in October 1940 and at the beginning of 1941. The fact that agreement was reached so smoothly suggests that everyone, i.e. Plisnier, Janssen and the bankers, were convinced that the occupation would be short-lived and that the problem of occupation costs would be resolved in the not too distant future.

However, the dust had barely settled around the prepayment of 3 billion Belgian francs when, in a letter of 27 November 1940, the Military Government demanded a further prepayment of 2.5 billion Belgian francs, to be transferred before 10 December. In his letter, Reeder added that, after consultation with the government in Berlin, a long-term arrangement would be worked out, with fixed amounts per month. Plisnier was furious and requested a meeting. This took place on 11 December and again Plisnier was accompanied by Janssen. From what was said, both could infer that the new demand was intended as cover for the occupation costs for November and December. If an arrangement for a fixed amount was put in place in January, as was more or less being mooted, a monthly payment of about 1.25 billion Belgian francs could be expected.

45 BNB, Archives, SD, 33, dossier 8.11.27/4, 'divers': Plisnier, mémoire relatif à l'indemnité réclamée à la Belgique au titre de couverture des frais d'occupation, 20.12.1940. See also: BNB, Archives, $B R$ BEB, 17.08.1940.

46 вNв, Archives, SD, 'Association Belge des Banques' Papers, dossier 08.00.00.00 (C 783/4): AV, minutes, 17.08.1940. 
Plisnier and Janssen were shaken by such exorbitant demands and put forward several counter-arguments, in order to move Reeder to take a more reasonable line. The new demands, they argued, were clearly beyond the country's budgetary and fiscal capacity. In addition to the occupation costs, the government had to finance the costs of economic recovery and of reconstruction; at the same time, it had to cope with the gap in tax income during the first months of the invasion, as well as with the weak growth of that income thereafter. Furthermore, the government was faced with claims from towns and municipalities for providing extra services to the occupier, such as billeting. Finally, there was the gloomy outlook for government income; the government loan issued in September had been a downright fiasco, with barely 1.4 billion of the projected 3 billion Belgian francs being subscribed to and, despite an extension of the subscription period, little more could be expected. With a winter of hunger in prospect, it was certainly not the moment to introduce new tax levies, as suggested by the Military Government. Nor was anything to be expected from windfall taxing of war profits, as these generally stemmed from illegal transactions on the black market and thus completely escaped tax.

However real the arguments, they had no effect whatsoever on the Military Government, which stood by its demand for a further 2.5 billion Belgian francs. Plisnier and Janssen nevertheless received an undertaking that the monthly amount for the costs of occupation would be set in January 1941 and that there would be no further issue of Reichskreditkassenscheine. Plisnier resigned himself to the decision and an initial tranche of 500 million Belgian francs was transferred on 12 December, the balance being paid in four equal tranches every ten days from 20 December ${ }^{47}$. Over time, however, the strongly founded arguments of Plisnier and Janssen bore fruit. In January 1941, the monthly amount for the costs of occupation were at last fixed at 1 billion Belgian francs, lower than originally feared, and payable with effect from 1 February.

47 In January 1941, Plisnier invited twenty prominent figures from the world of finance, administration and politics and from the magistrature to exchange ideas on this question. The meeting approved Plisnier's stance (BNB, Archives, $S D$, dossier 8.11.27/ 4, 'divers': report of the meeting, 22.01.1941). 
Where was the Belgian administration to get those enormous sums? Because of the war it could not count much on rising tax income. In 1938, 63 per cent of government expenditure was covered by tax receipts, but that figure fell to 36.6 per cent in 1940 and was to fall further to a low of 29.3 per cent in $1943^{48}$. In fact, the only way to bridge the rising deficit of the administration's budget was by loans and the issue of paper money.

As already mentioned, long-term government loans, such as that launched in September 1940, failed to attract the public ${ }^{49}$. The preference was clearly for short-term investment and it was this preference that the management of the Bank, as well as the private bankers, urged the Treasury to exploit by offering short-term Treasury certificates to the wider public ${ }^{50}$. The Treasury declined to take that step, arguing that the wider public was too fickle; it preferred to keep its short-term certificates exclusively for the banks, with which it had a more rational business relationship and which were more susceptible to pressure ${ }^{51}$.

The private banks, for their part, became increasingly interested in Treasury paper. In a surprisingly short time, they had gone from a situation of tight liquidity to an equally unhealthy one of a growing surplus of deposits that were bringing no return. Demand from business for investment funds was at a virtual standstill and, in the uncertainty of the war years, few private individuals were prepared to risk taking up consumer credit from their banker. It was a situation where the Treasury's need of money and the bankers' search for profitable investments came together. By the autumn of 1941, the private banks had 12.7 billion Belgian francs' worth of 4-month Treasury certificates at 2.75 per cent in portfolio.

48 вNB, Archives, SD, Goffin Papers, f. 2: considérations relatives à la politique d'emprunt, memorandum of January 1944.

49 A comprehensive analysis can be found in a memorandum prepared by Dupriez, Vincent and Kauch: BNB, Archives, $S D$, Goffin Papers, f. 2: considérations relatives à la politique d'emprunt. See also: BNB, Archives, $S D$, Malaise Papers: Kauch, La Banque Nationale (unpublished text), Part 1, Chapter. 5, p. 86.

50 BNB, Archives, SD, Goffin Papers, dossier 2: Société Générale, memorandum of 21.10.1940; memorandum of 02.09.1941 from Kauch.

51 BNB, Archives, SD, Goffin Papers, dossier 2: report of the meeting of governor Goffin with government commissioner Smeers, 10.09.1941. 
Table 8.2: Development of the BNB's portfolio of government paper, 1940-1941 (in millions of Belgian francs)

\begin{tabular}{l|r|r|r|r|r|r}
\hline & \multirow{2}{*}{$\begin{array}{r}\text { Short-term Treasury } \\
\text { Date }\end{array}$} & Assimilated & \multicolumn{3}{|c|}{ Government paper } & \multirow{2}{*}{ Total } \\
\cline { 4 - 6 } & certificates, up to 4 months & securities & max.1 year & max.5 years & more than 5 years & \\
\hline 1940 & & & & & & \\
30.06 & $5,060.4$ & 808.7 & - & - & 930.5 & $\mathbf{6 , 7 9 9 . 6}$ \\
30.09 & $8,548.3$ & 180.0 & - & - & 866.9 & $\mathbf{9 , 5 9 5 . 2}$ \\
31.12 & $9,218.7$ & 179.3 & 19.6 & - & $1,279.3$ & $\mathbf{1 0 , 6 9 6 . 9}$ \\
\hline 1941 & & & & & & \\
31.03 & $10,415.2$ & 206.2 & 44.3 & - & $1,231.7$ & $\mathbf{1 1 , 8 9 7 . 4}$ \\
30.06 & $10,575.7$ & 199.6 & 107.1 & - & $1,139.9$ & $\mathbf{1 2 , 0 2 2 . 3}$ \\
30.09 & $11,196.2$ & 199.2 & 228.4 & 399.6 & $1,155.5$ & $\mathbf{1 3 , 1 1 8 . 9}$ \\
\hline
\end{tabular}

Source: BNB Archives, sD, Malaise papers, 2, file 9.5.6.: Aspeslagh, de Nationale Bank van België en haar monetaire functie, 24.12.1941, p. 24. 



\section{CHAPTER 9 \\ The Policy of Accommodation Put to the Test}

\section{THE COMMANDEERING OF GOLD AND FOREIGN CURRENCY}

The Currency Protection Office (Devisenschutzkommando) was notifying the Belgian civilian population as early as 21 May 1940 that free access to the hired safe-deposit boxes in the strong-rooms of the private banks was temporarily suspended. The hirers were requested to present themselves and, by appointment, to open their safe-deposit box in the presence of a representative of the Kommando, who would verify the contents and list them. Should the hirers not appear, members of the Kommando would force the boxes and, after verification, draw up an authenticated inventory of the contents. Gold, foreign currency and securities would be deposited in safe custody with the bank in question, cash placed on a blocked current account and jewellery placed in an envelope that would then be sealed and entrusted to that bank ${ }^{1}$.

However, the occupier's search for gold, foreign currency and foreign securities went further than the inspection of safe-deposit boxes in banks. On 17 June 1940, the Military Government issued an ordinance prohibiting the population and other authorised persons in the occupied territory from having free disposition of gold, foreign currency or foreign securities; anyone in possession of them was required to declare them to the nearest local office of the Reichskreditkasse. Further instructions were to follow in an eventual total of twelve decrees that were promulgated subsequently ${ }^{2}$.

1 вNB, Archives, Hoofdkas, dossier 'Вев': ordonnances en matière de devises: réglementation relative aux coffres-forts, annex 4.

2 BNB, Archives, SD, Malaise Papers, 3, dossier 9.5.11, s. f. 4: Kauch, rapport au Roi (20.12.1943), p. 100. 
On 2 August, in a first decree, gold, gold coins, us dollars, Swiss francs and Swedish kronor were required to be declared and offered for sale to the Banque d'Emission, from where they would be transferred on a weekly basis to the Reichsbank in Berlin. It is to be noted that in the decree nothing was formally 'assessed', but great pressure was exercised on owners to sell ${ }^{3}$. Later, this requirement was expanded to include other metals, such as platinum and silver. A decree of 27 August, concerning all foreign shares, bonds and government securities, as well as other assets held abroad, explicitly emphasized that Congolese shares and securities were also to be regarded as 'foreign'. Lastly, the requirement was extended to include virtually all European and Latin-American currencies, plus the Canadian dollar and the Japanese yen ${ }^{4}$. Apparently, and somewhat oddly, there was no interest in sterling holdings, though this situation was to change in February 1943, when these, too, had to be declared and offered for sales.

It was not only the numerous holders of precious metals, hard currency and foreign shares who were affected by the decrees; the Bank, too, felt itself targeted. Janssen informed von Becker that the decree of 17 June and the implementing decree of 2 August had hit the Bank hard, as it removed any possibility for the Bank in the future to build up a gold reserve or a portfolio of foreign reserve currencies, over and above its holdings of Reichsmarks; the country was in desperate need of such reserves to buy foodstuffs and raw materials. Further, he asked whether it would not be better to allow the Banque d'Emission to keep the gold and foreign currency it had purchased and use them as an exchange reserve, rather than sending them to the Reichsbank in Berlin ${ }^{6}$.

3 BNB, Archives, SD, Malaise Papers, 3, dossier 9.5.11, s. f. 4: Kauch, rapport au Roi (20.12.1943), pp. 101-107. See also: Freiburg im Breisgau, Militärarchiv, Militärverwaltung, dossier RW 36/281: Hofrichter, Abschluszbericht, Militärverwaltung in Belgien und Nord-Frankreich, pp. 26-28.

4 BNB, Archives, $S D$, 'enquête BEB': report of the Commission of Enquiry (unpublished text, 1946), Part 1, pp. 158 and 160. See also: BNB, Archives, $B R B E B, 02.10 .1940$ and 16.10.1940.

5 Freiburg im Breisgau, Militärarchiv, Militärverwaltung, dossier Rw 36/281: Hofrichter, Abschluszbericht, Militärverwaltung in Belgien und Nord-Frankreich, pp. 2627.

6 BNB, Archives, Studiedienst, 9, dossier 01.02.01.70 (A 240/6): letter of 29.08.1940 from Janssen to von Becker. 
In its answer of 11 September, the Bankaufsichtamt rejected this suggestion, arguing that the general centralization of these assets in Berlin was necessary in order to secure their efficient use in the interests of the 'European' economy'.

Bad blood was likewise created by the ordinance of 27 August concerning the declaring and offering for sale of foreign shares, bonds and government securities. Janssen turned again to Rolin for advice ${ }^{8}$. The centralization of foreign currency in a special Banque d'Emission account at the Reichsbank and the refusal to allow the Banque d'Emission, to dispose of it, were in Rolins view against art. 52 and 53 of the Hague Convention: the Reichsbank could, if deemed necessary, always commandeer the contents of the account, thereby giving the occupier the disposition of some private Belgian assets in the event of a European emergency. The Bank and the Banque d'Emission therefore ought not to acquiesce in this disguised confiscation or actively participate in voluntary or compulsory purchase operations, nor in the centralization of the purchased items, nor in their transfer to Berlin. Any active participation would imply giving financial assistance to the enemy and would fall under article 115 of the Belgian Penal Code?.

Janssen, Plisnier and the private bankers brought a great deal of pressure to bear on the Bankaufsichtamt to tone down the measures. Their efforts produced a response: the Military Government agreed to exempt colonial shares and securities from the obligation to declare and offer them for sale. This came as a great relief, particularly for the Société Générale de Belgique, though also for the many Belgian private individuals, holding companies, businesses and institutions that had traditionally invested in such valuables ${ }^{10}$. There was also a second con-

7 BNB, Archives, $B R$ BEB, 16.10.1940. See also: BNB, Archives, SD, 'enquête BEB': report of the Commission of Enquiry (published 1946), Part 1, p. 159.

8 BNB, Archives, SD, 30, BEB, dossier 8.11.24 s. f. 16: note de L.H. Dupriez (sur la quatrième ordonnance relative aux devises étrangères du 27 août 1940), 09.09.1940; BNB, Archives, $S D$, dossiers officiels après 1945, dossier 13: note résumant l'entretien du mardi 24 septembre 1940 entre M. le Gouverneur et M. Henri Rolin, 01.10.1940.

9 BNB, Archives, $S D$, dossiers officiels après 1945, dossier 13: note résumant l'entretien du 24 septembre entre M. le Gouverneur et M. Henri Rolin, 1 octobre 1940 (in addendum: letter of 08.10.1940 from Rolin to Janssen).

10 BNB, Archives, Contentieux: nota, 12.09.1940; BNB, Archives, SD, Malaise Papers, dossier 9.5.11, s. f. 4: Kauch, rapport au Roi (20.12.1943), pp. 107-109. 
cession concerning foreign securities, which now were no longer required to be offered for sale, though they still had to be declared ${ }^{11}$.

However, neither of the two concessions was mentioned in a new implementing decree; rather, they were communicated verbally and Janssen took it upon himself to use the press to announce them to the public. It was also a fact that no further mention of the two original obligations was made on the declaration forms. Privately, and aside from any ordinance, transactions in foreign shares and securities were still taking place between Belgian and German civilians and institutions, this period seeing numerous Belgian assets in Eastern and Central Europe being sold to German firms and private individuals. In general, these arose from participating in banks, companies and buildings that had given Belgian investors little satisfaction, particularly during the 1930's, when profits were frozen for years or the repatriation of invested capital prohibited. The Germans, looking to increase their sphere of influence in those regions, were very avid buyers. The transactions also fitted in extraordinarily well with Goering's policy of economic integration, which was only gradually under way in the rest of the occupied territories ${ }^{12}$.

For precious metals and foreign currency, the obligatory declaration and offer for sale remained in force. Janssen ultimately assented to the measure and was also prepared to accept the role of the Banque d'Emission in centralizing the purchases and in transferring them to Berlin. It is probable that he still nurtured the hope that his good personal relationship with Puhl, Deputy-chairman of the Reichsbank, would lead to the Banque d'Emission retaining some say in whether the valuables could be used for the purchase of foodstuffs and raw materials $^{13}$.

Rolin was not happy with the accommodating stance adopted by Janssen in the planned announcement on the matter, and particularly with the acceptance of the role of the Banque d'Emission in centralizing

11 BNB, Archives, SD, Malaise Papers, dossier 9.5.11, s. f. 4: Kauch, rapport au Roi (20.12.1943), pp. 104-105.

12 H. James, 'The Deutsche Bank and the Dictatorship, 1933-1945', in: L. Gall et al., The Deutsche Bank, 1870-1995, London, 1995, pp. 330-333. See also: Van der Wee and Verbreyt, De Generale Bank, 1822-1997, pp. 254-256.

13 BNB, Archives, $B R$ BEB, 16.10.1940. 
and transferring gold and foreign currency to Germany. Janssen took account of Rolin's opinion and corrected his original text, the new version of which he submitted to the board of directors. There was unanimous agreement for the role of the Banque d'Emission in transferring gold and foreign currency to Berlin, but under the explicit condition that the value they represented be used solely for financing the import of foodstuffs and raw materials to Belgium.

What prompted the Military Government to go some way to meeting the demands from the Bank, the Ministry of Finance and the private banks for the ordinance of 27 August to be watered down? It may well have been that it was sensitive to the argument that the measures contravened the norms of international law: during the Second World War, the German authorities, indeed, tried as much as possible to keep their actions legitimate within national legislation and within the international arrangements and conventions then in force ${ }^{14}$. The Belgian leadership was often struck by the occupier's concern with legality and had learned to use it to their own advantage: if German demands were thought to be excessive, the leadership argued against them on the basis of legal principles and attempted first to demonstrate that the proposed measures contravened national or international law.

The Bank also attempted to take a more subtle line in resisting the dictates imposed on it and to incorporate a certain 'leisureliness' into its cooperation, which proved relatively successful in dealing with the declarations about foreign assets ${ }^{15}$. Declarations and offers for sale poured in during the summer and autumn of 1940. The declarations led to a total of about 400,000 dossiers being created, but no additional help to those who had to handle them was forthcoming from the Bank. The Bankaufsichtamt became impatient and indeed suspicious, and laid down that priority be given to the declarations concerning gold and foreign currencies. Between July 1940 and August 1944, the Banque d'Emission transferred to the Reichsbank 210.9 million Belgian francs'

14 Commission d'études sur le sort des biens des membres de la communauté juive de Belgique, final report (final evaluation, conclusions and proposals), Brussels, 2002, p. 455.

15 In respect of what follows, see the memorandum from R. Simonis regarding the interview granted to W. Pluym in 1998: 'Quelques souvenirs de la période de guerre à la Banque'. 
worth of gold and 94.7 million Belgian francs' worth of foreign currency, the greater part before the end of $1940^{16}$.

Another aspect of the commandeering of gold, money and other valuables, one in which both the Bank and the Banque d'Emission were involved, concerned the persecution of the Jews ${ }^{17}$. Belgian Jews and Jewish firms had to open their safe-deposit boxes in the same way as all other Belgians, but from October 1940 they were subject to a series of additional measures. With effect from 28 October, for example, all Jews were required to have their names recorded in the Jewish register and all Jewish firms were required to enrol with a special registration service. It was then but a short while before the Military Government focused its attention on the Jewish community's financial assets, an ordinance of 31 May 1941 obliging all Jews and Jewish firms to notify their banking institution that they were Jewish, to transfer their deposits to an account at one of the recognized exchange banks and to deposit their holdings of Belgian and foreign securities with that same exchange bank.

The Bank found itself caught up in this measure, as fifty or so of its clients - individuals and firms - holding a current or a custody account gave notification that they were Jewish. Not having the legal status of a recognized exchange bank, the Bank was consequently obliged in principle to transfer their credit balances. It nevertheless obtained the right to retain the accounts. In the autumn of 1942, however, the Military Government decided to centralize all Jewish bank and custody accounts at the Brüsseler Treuhandgesellschaft, a management company in Belgian law, under German control; this company in turn demanded that all those accounts be transferred before 31 January 1943 to its account at a French institution under German control, the Société française de banque et de dépôts in Brussels. The Bank allowed the investigations into the exact amount of the balances to drag on and

16 Freiburg im Breisgau, Militärarchiv, Militärverwaltung, dossier RW 36/281: Hofrichter, Abschluszbericht der Militärverwaltung in Belgien und Nord-Frankreich, pp. 27-28; BNB, Archives, $S D$, 'enquête BEB': report of the Commission of Enquiry (published 1946), Part 1, pp. 162-169.

17 In respect of what follows, see: J. Makart, 'Les avoirs des Juifs pendant la guerre, 1940-1945' (memorandum of 21.01.2002 from Makart, provided to the authors). See also: W. Pluym, 'Rekeningen van verdwenen mensen. De Bank stelt de joodse gemeenschap schadeloos voor verloren tegoeden tijdens Wereldoorlog II', in: Connect (NBB staff magazine), July-August 2002, pp.10-13. 
it was only in the spring of 1943 that the credit balances of seventeen accounts were transferred, most of which did not even amount to 300 Belgian francs; all the other accounts showed a negative balance which precluded any transfer.

\section{THE FRAUDULENT CLEARING SYSTEM}

By the time the Second World War broke out, the monetary world order had already moved a long way from the gold standard. During the depression of the 1930s, many countries had scrapped not only their currency's gold convertibility, but also its linkage to gold. Most of them had then introduced a system of floating currencies, sometimes with the national currency floating against all other currencies and sometimes with the national currency as part of a group of currencies - as in the case of the sterling zone - with fixed exchange rates against each other, but floating against all other currencies. Other countries that had abandoned the gold standard introduced a bilateral system of fixed exchange rates, linked to a strict commercial policy.

Until the German invasion, the Belgian government maintained the gold convertibility of the Belgian franc and foreign payments remained in principle unrestricted. Clearing accounts were nevertheless opened at the Bank for countries that officially permitted foreign transactions only on that basis. With the occupation of Belgium, the situation changed: the Belgian franc was now in the German Reichsmark zone and Belgian foreign payments would consequently be integrated into the German clearing system. On 10 June 1940, immediately after the occupation had become a fact, an official of the Bankaufsichtamt met Goffin to discuss the situation, but Goffin pointed out that such arrangements fell within the competence of the Ministry of Finance. Plisnier was then brought into the matter and authorized the Bank to co-operate in the implementation of the German clearing system ${ }^{18}$.

The definitive arrangement was published in a notice of 10 July 1940 in the German Official Gazette. All payments from Belgium to German creditors were required to be transferred to an account in the name of

18 BNB, Archives, SD, 31, Malaise Papers, dossier 8.11.25, s. f. 10, 'entretiens' (meeting between Goffin and Flad, 10.06.1940). 
the Deutsche Verrechnungskasse at the Bank in Brussels; conversely, all payments from Germany to Belgian creditors would be transferred to an account in the name of the Bank at the Deutsche Verrechnungskasse in Berlin; payments would be at a fixed exchange rate of 1 Reichsmark to 12.50 Belgian francs. The arrangement was, in fact, similar to the method current during the 1930 s in the countries within the German sphere of influence, as indicated above; it was no longer the market, but the government, in cooperation with the central banks, that would ensure bilateral equilibrium in international payment transactions within the zone.

On his return from France on 10 July, Janssen had no choice but to accept the German arrangement just announced, as it was simply imposed on Belgium by the occupier. He found nevertheless that the system also offered certain advantages, creating an institutional framework for both the export of Belgian manufactured goods to Germany and the import of what to Belgium were essential foodstuffs and raw materials. Furthermore, the centralization of all Belgian international payments ought normally to give the Bank the opportunity to control them. However, Janssen was undoubtedly aware of the difficulties that cooperation in clearing could create for the Bank, should it later have to justify its wartime activities. Shortly after his return, therefore, he negotiated with the Bankaufsichtamt to have the Bank relieved of its clearing task and to transfer this to the Banque d'Emission. On 4 August 1940, the Military Government acceded to Janssen's request ${ }^{19}$, but the change was greeted with mixed feelings by the founder-bankers of the Banque d'Emission. On the one hand, they were satisfied that they now had a direct say in the country's foreign transactions. On the other, they feared unfavourable implications in the longer term, though against this was Janssen's integrity and their own 'patriotic caution'20.

Janssen was also able to convince Plisnier that the financing of exports was in fact linked to the import of foodstuffs and raw materials so vital for the country, and that the general and the private interest

19 BNB, Archives, SD, Malaise Papers, 2, dossier 9.5.11, s. f. 2, 'renseignements BEB, $\mathrm{n}^{\circ} 4$ ': the decision of 4 August was published as a notice in the Verordnungsblatt (German Official Gazette), 07.08.1940.

20 BNB, Archives, $S D$, 41, dossier 8.11.42 b, 'enquête BEB': memorandum of 22.01.1945 from Plisnier. 
thereby coincided. Consequently, providing a State guarantee against the risks involved in clearing was in the general interest. Plisnier accepted this reasoning and on 19 July authorized the Treasury to issue Treasury certificates for the purpose, up to a maximum amount of 1 billion Belgian francs, and to pass them to the Bank ${ }^{21}$. From 4 August on, the certificates were handed over to the Banque d'Emission.

Janssen found this procedure too complicated and suggested a simplification. The Bank would make the necessary banknotes available to the Banque d'Emission, the Ministry of Finance granting the latter a State guarantee up to an amount of 1 billion Belgian francs for any losses that it might incur ${ }^{22}$. On 20 November 1940, at Janssen's insistence and after a great deal of quibbling, the guarantee was raised to 1.5 billion Belgian francs ${ }^{23}$; almost a year later, on 5 November 1941, an unlimited State guarantee was granted ${ }^{24}$.

Although Janssen had accepted the clearing system as such, he was not happy with the conditions that the arrangement of 10 July $1940 \mathrm{im}-$ posed on Belgium. In accordance with the pre-war procedure, putting a clearing system in place was a matter of a voluntary agreement between two sovereign states and had to be based on full equilibrium between mutual imports and exports in terms of value; no imbalance could be tolerated for more than a limited period. The system imposed on Bel-

21 BNB, Archives, SD, 31, dossier 8.11.25, s. f. 10, 'divers': entretiens. See also: BNB, Archives, Studiedienst, 6, dossier 01.02.01.70 (A 237/ 1, s. f. 11): projets d'arrêté ministériel relatif à la garantie de l'Etat (memorandum of 31.07.1940 from Smeers to Plisnier).

22 Published in the Belgian Official Gazette of 12-13.09.1940: BNB, Archives, $B R$ BEB, 18.09.1940; Brutsaert, Oscar Plisnier, pp. 84-85. See also: Krijgsauditoraat, enquête BEB, dossier 3-4: A. Heilporn, E. Guyot, E. Desutter, rapport d'expertise en cause de la BEB, Part 1, pp. 14-16.

23 Krijgsauditoraat, enquête BEB, dossier 3-4: A. Heilporn, E. Guyot, E. Desutter, rapport d'expertise en cause de la BEB, Part 1, pp. 15-17. See also: BNB, Archives, $R R$, 20.11.1940; BNB, Archives, $S D$, 12, notes (conférences), dossier 8.11.25.

24 Krijgsauditoraat, enquête BEB, dossier 3-4: A. Heilporn, E. Guyot, E. Desutter, rapport d'expertise en cause de la BEB, Part 1, pp. 15-18. In Plisnier's opinion, the State guarantee nevertheless remained subject to certain conditions: 'Si cette garantie couvrait le risque global que l'Institut d'Emission courait, elle ne couvrait aucune opération individualisée du clearing...' For Plisnier, it was also clear that the ultimate beneficiary of the State guarantee was the Bank, and not the Banque d'Emission (NBB, SD, 41, dossier 8.11.42 b, 'enquête BEB': memorandum of 22.01.1945 from Plisnier). 
gium ignored those elementary pre-war rules ${ }^{25}$; it was established by unilateral decision of the Germans, leaving Belgium unable to make any suggestions to amend it. Worse, the arrangement of 10 July 1940 stated that Belgian exports of goods and services to Germany were not subject to any limitation and that there was no compulsion for there to be countervailing exports from Germany to Belgium ${ }^{26}$, a regulation that was to give rise to insurmountable problems in the future.

Belgian exporters were able to demand payment as soon as the amount due had been transferred to the Banque d'Emission's account at the Verrechnungskasse in Berlin. Should the Banque d'Emission refuse financing, the German commissioner, and indeed the German Minister of Finance in Berlin, were empowered to order payment. By this arrangement, the Banque d'Emission was put entirely at the mercy of the occupier's whim; it could, in principle, be forced to finance every claim on Germany, without being able to exercise any 'prior' verification of the legality of that claim. Its competence was, in fact, limited to $a$ posteriori verification of the documents submitted ${ }^{27}$. The arrangement was not at all to Janssen's liking and though he still nurtured a faint hope that the Germans would not abuse the arrangement, he felt no certainty about this.

Janssen turned to seeking a way of circumventing the disadvantages of the system and to that end contacted the Reichsbank in Berlin with the intention of concluding a separate agreement between the respective German and Belgian issue institutions, in order to counter the danger of having to comply with arbitrary instructions from the authorities in Berlin. It was in that spirit that, on 16 August 1940, on behalf of the Banque d'Emission, he signed a convention that was endorsed a day later by the Reichsbank. The Banque d'Emission undertook to exchange into Belgian francs, without let or hindrance, all Reichsmarks presented by the Reichsbank; for its part, the Reichsbank undertook to exchange into Reichsmarks, without let or hindrance, all Belgian francs presented by the Banque d'Emission.

25 BNB, Archives, $S D$, Malaise Papers, 2, dossier 9.5.11, s. f. 2: 'clearing'.

26 BNB, Archives, Studiedienst, 5, dossier 01.02.01.70 (A 409/ 2): mémorandum relatif à l'accord du 16-17 août 1940 (20.05.1941).

27 BNB, Archives, SD, Malaise Papers, 3, dossier 9.5.11, s. f. 4,: Kauch, rapport au Roi (20.12.1943), pp. 65- 76. 
The convention harked back to the method introduced by Germany in the 1930s to have all international payments pass compulsory and exclusively via the central banks, the purpose being to enable those banks to control all financial operations with other countries and thereby maintain full equilibrium in bilateral payment transactions. In Janssen's view, the convention would be to Belgium's advantage ${ }^{28}$, as it would give the Banque d'Emission autonomous scope to use the receipts from Belgian exports to Germany for purchases of German foodstuffs and raw materials, and to gear those purchases to Belgium's import requirements. Moreover, the two central banks would constantly monitor equilibrium in the clearing system between the two countries: the convention thus was, in his view, 'an instrument to counter any abuse, which could arise from the arbitrary and unilateral character of the system, imposed on 10 July' ${ }^{29}$.

Janssen's hope proved idle. The convention of 16-17 August was a non-starter and was even to be used by the German authorities against the Bank. In the first place, it was not with the Reichsbank that German customers were required to settle their debts, but with the Verrechnungskasse in Berlin, which was in no way accountable to the Reichsbank. Consequently, the Reichsbank had no authority to interfere in respect of the growing imbalance in clearing between Germany and Belgium. Furthermore, the freedom of action of both the Reichsbank and the Banque d'Emission was restricted by the German regulations governing the import and export of goods, services and capital; there were no restrictions whatever on exports from Belgium - the more, the better - but exports from Germany were limited to such an extent as to amount to virtually a complete embargo on them. Lastly, the Banque d'Emission had neither free disposition of its foreign currency account at the Reichsbank, in order to be able to purchase foodstuffs and raw materials in Germany or elsewhere abroad, nor free access to its credit balances at the Verrechnungskasse. Janssen quickly realized that what was seen as a German concession in the convention remained a dead

28 BNB, Archives, $S D$, 'enquête BEB': report of the Commission of Enquiry (published 1946), Part 1, p. 174.

29 BNB, Archives, SD, Malaise Papers, 2, dossier 9.5.11, s. f. 2, 'renseignements BEB': report of the Commission of Enquiry, Part I: Clearing. Chapter 1: La réglementation allemande. 
letter as far as Belgium was concerned. During a meeting in September 1941, Collin was even to claim that the convention was a weapon the Germans authorities could use to force the Bank to co-operate in the inflationary monetary policy ${ }^{30}$.

The clearing system put in place on 10 July 1940 between Germany and Belgium was followed by similar bilateral agreements between Belgium and a number of other countries ${ }^{31}$, but these were concluded by the Military Government, not by the Belgian administration. The agreements were fairly quickly integrated into a multilateral system, the hub of which was the Verrechnungskasse in Berlin. The measure was justified by the theoretical argument that multilateralization would remove the limitations inherent in the requirement for bilateral equilibria. In the prevailing circumstances, however, the measure was simply a pretext to lay hands on foreign currency: 'a one way system, imposed upon all occupied countries in Europe and even upon a neutral country such as Switserland'32.

\section{THE FIRST CRISIS OF THE CLEARING SYSTEM}

Towards the end of the exceptionally harsh winter of 1940-1941, famine, especially in the towns, became a feature of daily life. Janssen, the Galopin Committee and many other people in authority rightly looked for recourse to the clearing agreement, asking why, if the Banque d'Emission had such an exceptionally positive credit balance at the Ver-

30 BNB, Archives, $S D$, Basyn Papers, s. f. 6: minutes of the meeting of the editorial committee for the drafting of the motion of 24.09.1941.

31 In 1940, clearing agreements were signed on 2 August with the Netherlands, on 24 September with Italy, on 27 September with Sweden, on 1 October with the Protectorate of Bohemia-Moravia, on 7 October with Switzerland, on 1 November with Finland, on 13 November with Yugoslavia, on 9 December with Bulgaria, on 18 December with Norway, on 23 December with Hungary, on 9 December with Greece; and in 1941, on 21 January with Denmark, on 27 January with France, on 28 February with Rumania, on 11 June with Slovakia, on 23 April (until 22 June) with the Soviet Union, on 18 September with Serbia and on 20 October with Croatia.

32 BNB, Archives, $S D$, Malaise Papers: Kauch, La Banque Nationale (unpublished text), Part 1, Chapter. 7, pp. 5-6. See also: BNB, Archives, $S D$, Malaise Papers, 2, dossier 9.5.11, s. f. 2, 'renseignements BEB': report of the Commission of Enquiry, Part I: Clearing. Chapter 1: La réglementation allemande. See also: BIs (Basel), Archives, jaarverslag, 1943, p. 285. 
rechnungskasse in Berlin, the promised supply of food had not materialized. At the meeting of the Bank's supervisory council on 13 November 1940, indeed, Janssen had already indicated that the credit balance had risen to nearly 1 billion Belgian francs ${ }^{33}$.

However, the Germans showed little willingness to supply foodstuffs, something that put Janssen severely out of countenance: he had, after all, invested a great deal of his energy and even prestige in the clearing system's operation. On top of this came the news that, at the beginning of March 1941, the Banque d'Emission's credit balance has suddenly increased by about 700 million Belgian francs ${ }^{34}$. During a meeting of the institution's board of directors on 5 March, Commissioner von Becker let slip that the increase was due mainly to financial transactions, namely to payments made by German private individuals and institutions for participations they had taken in Belgian companies and, most of all, to payments for German purchases of Belgian foreign investments ${ }^{35}$. Belgian holding companies and banks had, in fact, been able to rid themselves of their Central and Eastern European assets, blocked since the 1930s, by selling them to German banks. Additionally, German law obliged holding companies and banks to divest themselves of their assets in Luxembourg - now German territory - through sales to German residents or companies ${ }^{36}$. Those who had sold shares, whether under compulsion or not, were now looking to use the clearing mechanism of the Verrechnungskasse and the Banque d'Emission to convert their Reichsmark receipts into Belgian money.

This was not the first time that payment for financial transactions had been made in Belgium to the beneficiaries, and Janssen, who had taken complete control of the clearing operations since July $194 \mathrm{O}^{37}$, had indeed always sanctioned the payments ${ }^{38}$. Now, however, exception-

33 BNB, Archives, RR, 13.11.1940.

34 BNB, Archives, BR BEB, 05.03.1941.

35 BNB, Archives, $S D$, 'enquête BEB': report of the Commission of Enquiry (published 1946), Part 1, Chapter. viI, p. 175.

36 Van der Wee and Verbreyt, De Generale Bank 1822-1997, pp. 255-256; Van der Wee and Verbreyt, Mensen maken geschiedenis. De Kredietbank 1935-1985, pp. 171-178.

37 BNB, Archives, DC, 10.07.1941.

38 BNB, Archives, $B R B E B, 14.03 .1941$; BNB, Archives, SD, 'enquête BEB': report of the Commission of Enquiry (published 1946), Part 1, Chapter. viI, pp. 174-176. 
ally high amounts were involved, so that even the maximum limit of the State guarantee was exceeded. Certain members of the Banque d'Emission's board of directors also found it unacceptable that the increase was the result not of commercial activities, but of purely financial transactions, and many among them could not help but feel uneasy about such operations.

There was no room here for the argument that the operations were necessary for imports of foodstuffs, because the credit balance from commercial activities was more than sufficient to ensure food imports for Belgium. What made matters worse, however, was that the sale of Belgian assets abroad served to increase the economic power of Germany; any Banque d'Emission involvement would be punishable in Belgian law. These considerations prompted the board to call a temporary halt to payments in respect of financial transactions and to contact Secretary-general Plisnier to obtain his advice and cooperation in finding a solution ${ }^{39}$.

On 7 March 1941, Janssen and certain members of the board, gathered together with Plisnier and two representatives of the Ministry of Economic Affairs, to discuss the problem of payments regarding financial transactions and to determine the extent to which, in this context, the State guarantee could be extended. Plisnier was formal: payment for financial transactions could not be advanced as an argument for increasing the amount of the State guarantee. He was nevertheless prepared to cover an overrun of the limit, provided it was temporary and the consequence of payments for commercial transactions ${ }^{40}$.

The next day, on 8 March, the board of directors, taking into account the results of the meeting with Plisnier, decided to maintain the suspension of payments regarding financial transactions. Von Becker reacted by issuing the same day a formal payment order (Weisung) of 275 million Belgian francs. After long discussions the board, in the end, decided to execute the order, acknowledging that at that very moment a fair amount of foodstuffs and raw materials had been sent from Germany to Belgium, or were to be sent shortly. Consequently the disequilibrium in the clearing account was reduced substantially.

39 BNB, Archives, $S D$, 'enquête BEB': report of the Commission of Enquiry (published 1946), Part 1, Chapter. vil, pp. 174-176.

40 BNB, Archives, BR BEB, 14.03.1941. 
Meanwhile, von Becker had left for Berlin, in order to explore the possibility of finding a satisfying solution for the Belgians with respect to the problem of payments for financial transactions. He returned with some positive results. In a letter of 21 March 1941 he set out a concrete proposal for the separation of commercial and financial transactions with Germany. Belgian claims from commercial transactions would continue to be regulated by transfer to the Banque d'Emission's account at the Verrechnungskasse and those transactions would be covered by the State guarantee. However, Belgian claims from financial transactions would be regulated within the framework of the convention of 1617 August 1940, signed by the Reichsbank and the Banque d'Emission, and would be entered on the Banque d'Emission's special account at the Reichsbank in Berlin, opened a few days later on 20 August. These transactions would cease to be covered by the State guarantee. According to this proposal, equilibrium in respect of that special account would be secured by the Banque d'Emission investing in German securities, as was the case at the Nederlandsche Bank ${ }^{41}$.

Janssen and the directors of the Banque d'Emission accepted von Becker's idea of separating transactions, but not his proposal that the credit balances of the special account at the Reichsbank be invested in German government paper. Intensive negotiations therefore followed and it was not before 22 April 1941 that a final agreement was reached. The separation of the two types of transaction was approved and came into effect on 1 May 1941; additionally, the Banque d'Emission was permitted to decide autonomously for what financial transactions it would pay, as well as the form the payouts would take. The suggestion that credit balances on the special account be invested in German government paper was set aside ${ }^{42}$.

41 BNB, Archives, SD, 14, dossier 8.11/ 4, 'Reichskreditkassenscheine': memorandum of 21.03.1941. See also: BNB, Archives, Studiedienst, 5, dossier 01.02.01.70 (A 409/ 2): mémorandum relatif à l'accord du 16-17 août 1940 (20.05.1941).

42 BNB, Archives, Studiedienst, 5, dossier 01.02.01.70 (A 409/2): mémorandum relatif à l'accord du 16-17 août 1940 (20.05.1941). 


\section{JANSSEN AND THE GERMAN OCCUPIER}

In an a posteriori assessment of the first crisis of the clearing system, the questions arise of why Janssen accepted the German order of 8 March 1941 to pay out 275 million Belgian francs, why he requested the board of directors of the Banque d'Emission to approve the payments and why he did not choose that moment to resign. It must already have been crystal clear to him that the wartime clearing system was collapsing and that the German occupier would not hesitate to bend the convention of 16-17 August 1940 to its own advantage, even - displaying great arrogance - to legitimizing its own abuse of power ${ }^{43}$.

The reasons behind the stance he adopted are complex. In the first place, he was well aware that the arrangement of 10 July 1940 gave von Becker the right, in case of refusal, to compel the Banque d'Emission to make payment. Janssen had hoped that, if the refusal could be justified, the occupier would not have recourse to that right, but that was a first miscalculation. Secondly, he was convinced that his own personality and authority were the best guarantees for the continued protection of the interests of the Bank, the Banque d'Emission and the country. His conviction would have been reinforced by events in the Netherlands, where the President of the Nederlandsche Bank, L.J.A. Trip, had resigned in March 1941 and had been promptly replaced by the Nazi sympathizer Rost van Tonningen ${ }^{44}$. In Janssen's opinion, something similar would befall Belgium were he to follow Trip's example and resign.

Thirdly, he was extremely concerned about Belgian food supplies and, above all, feared that famine would strike, which is why he had subscribed to the Galopin Committee's policy of a resumption of work and had accepted the clearing system imposed in July 1940. In all this, it should not be forgotten that the Banque d'Emission's credit balance at the Verrechnungskasse remained relatively modest until the summer of 1941, with the imbalance remaining more or less within acceptable

43 BNB, Archives, SD, Malaise Papers, 3, dossier 9.5.11, s. f. 4: Kauch, rapport au Roi (20.12.1943), p. 74. BNB, Archives, SD, Malaise Papers, 2, dossier 9.5.11, s. f. 2: 'renseignements BEB': report of the Commission of Enquiry, Part I: Clearing. Chapter 1. La réglementation allemande.

44 Joh. de Vries, De Nederlandsche Bank van 1914 tot 1948, pp. 278-28o. 
limits; in the spring of 1941 , moreover, there was the fact, and future prospect, of major imports of foodstuffs and raw materials ${ }^{45}$.

In the same way as Plisnier, Janssen attempted to obtain the maximum from his constant negotiations and compromises with the occupier. Inevitably, it was a thankless task that brought failure and disappointment with it, but Janssen was undoubtedly convinced, as was Plisnier, that they were patriotic and courageous in their behaviour ${ }^{46}$.

45 BNB, Archives, $S D$, 'enquête BEB': report of the Commission of Enquiry (published 1946), Part 1, Chapter.1, p. 82.

46 BNB, Archives, SD, 41, dossier 8.11.42, 'Comité d'Enquête': memorandum of 22.01.1945 from Plisnier. 



\section{CHAPTER 10}

\section{The Looting of Gold}

\section{THE PRELUDE}

On 20 August 1940, during the negotiations of the Franco-German Armistice Commission at Wiesbaden, Richard Hemmen, head of the German delegation for economic affairs, found out that the Belgian gold had been evacuated to Dakar in Senegal' ${ }^{1}$ He immediately signalled the news to Brussels and Paris, and requested that steps be taken to have the gold repatriated as soon as possible ${ }^{2}$. In this, the Germans skillfully played the safety card, touching the Bank's governor in one of his most sensitive spots. At that time, no-one could doubt that Europe was a safer place than Senegal, as the situation in French West Africa had become very tense since the attack on Mers-el-Kébir on 3 July.

On 6 September von Becker wrote Yves Bréart de Boisanger, the new governor of the Banque de France, to have the gold transported from Dakar to Brussels ${ }^{3}$. The demand tallied entirely with the German strategy of getting control of gold, wherever it was, but the determination with which the German authorities attempted to chase down the Bank's gold, even before they were in total control of the territories they

1 BNB, Archives, SD, London Archives, dossier 'or': note relative au dépôt d'or confié par la BNB à la Banque de France, 1939-1940 (annex 49: letter of 02.09.1940 from Schäfer, Commissioner at the Banque de France, to the secretary-general). See also: BdFr, Archives, Sécrétariat Général, dossier 1060.2001.01/37: 'or belge': letters of 02.09.1940 and 06.09.1940 from Favre-Gilly (Paris) to Schäfer (Paris).

2 Freiburg im Breisgau, Militärarchiv, Militärverwaltung, dossier RW 36/277: Hofrichter, Abschluszbericht der Militärverwaltung in Belgien und Nord-Frankreich, 1940-1944, Part 1, pp. 88-89.

3 BdFr, Archives, Direction de la documentation, dossier 1397.1994.01/83, 'or belge': copy of a letter of 05.09.1940 from Janssen (Brussels) to de Boisanger (ClermontFerrand); copy of a letter of 05.09.1940 from Janssen (Brussels) to von Becker (Brussels); memorandum of 24.09.1940 from Jost. 
had just conquered, suggests that they feared being thwarted. The uncertain political situation in West Africa and Ansiaux's negotiations at Vichy and Clermont-Ferrand were two very disquieting signals and it is therefore not surprising that von Becker was already asking Janssen on 3 September to provide him with a letter addressed to the Banque de France and requesting the restoration of the Belgian gold to the Bank ${ }^{4}$.

Janssen acquiesced, but not without reservations. He stated that it was on the instructions of the Belgian government that the gold had been deposited in safe custody with the Banque de France and that, in consequence, he could not act on his own authority in the matter: more particularly, he required authority from the government, in this case from the Secretary-general of the Ministry of Finances.

Janssen contacted Plisnier forthwith. Both were minded to approve von Becker's demand, provided that two conditions were satisfied. First, that repatriation be under the responsibility of the Banque de France; second, that the Bank should have free and autonomous disposition of the repatriated gold. In fact, this was a matter for the Belgian government to approve, but at that moment the government was in complete disarray at Vichy ${ }^{6}$ and, since the end of July, had ceased to be recognized by the French as a government. Plisnier therefore felt himself competent to give approval on behalf of the government, particularly as the matter was one on which the occupier was demanding a rapid ruling. The provisional text was put before the supervisory council of the Bank on 4 September and approved as such?

Janssen, no doubt, was so ready to accede to von Becker's demand because he had stipulated free disposition of the gold as a conditio sine qua non. Since his return from France, he had been extremely concerned about the problem of food and raw material supplies in the country, which also explains the affinity he felt with the Galopin Committee

4 Freiburg im Breisgau, Militär Archiv, Militärverwaltung, dossier RW 36/277: Hofrichter, Abschluszbericht der Militärverwaltung in Belgien und Nord-Frankreich, 1940-1944, Part 1, p. 88.

5 NBB, Archives, $S D$, London Archives, dossier 'or': note relative au depot d'or confié par la BNB à la Banque de France, 1939-1940 (annexes 61-62).

6 ARA, Theunis Papers, 'correspondance Theunis-Gutt': letters of 26.07.1940, 28.07.1940, 08.08.1940 and 29.08.1940 from Gutt to Theunis.

7 BNB, Archives, RR, 04. 09.1940 
and with the secretaries-general ${ }^{8}$. 'Gold' was the only reliable weapon against shortages of foodstuffs and raw materials, and the only weapon against hunger and unemployment. In that context, it was understandable that he reacted positively, albeit conditionally, to von Becker's demand.

At that moment of extreme tension, the question of whether Janssen was competent to submit a request for the gold's repatriation was not really relevant. He himself was convinced that he was and Ansiaux's letter of 11 August to Janssen requesting authorization for transferring the Belgian gold to the United States likewise implied recognition of his competence. Ansiaux was, in fact, to confirm this later in a letter to Baudewyns?.

\section{JANSSEN MISLED}

The conditions set by Janssen for the repatriation of the gold - i.e. that the Banque de France remain responsible for the gold and for its restoration to Brussels, and that the Bank have free disposition of that gold - were not well received by the German authorities. They had wanted the request to the Banque de France to be unconditional ${ }^{10}$.

The question of responsibility was not a difficult one and the Germans would solve it themselves ${ }^{11}$. There remained the condition of free disposition. Von Becker thought that here, too, a solution could be found and argued that the matter should be discussed between the Military Government and the Bank, and not between the Bank and the Banque de France. Moreover, he gave the impression that, in principle, the German authorities would have no objection to it. Using these arguments, he was able to persuade Janssen to write two separate letters.

8 Van der Wee and Verbreyt, De Generale Bank 1822-1997, pp. 246-248.

9 BNB, Archives, SD, London Archives, 2, 'correspondance 1940', s. f. 7: letter of 23.08.1940 from Ansiaux (Vichy) to Baudewyns (London).

10 Freiburg im Breisgau, Militär Archiv, Militärverwaltung, dossier RW 36/277: Hofrichter, Abschluszbericht der Militärverwalting in Belgien und Nord-Frankreich, 1940-1944, Part 1, p. 89.

11 Plisnier, 'Lor belge livré aux allemands en 1940', in: Revue Générale Belge, 52, February 1950, p. 4. 
In a first letter of 5 September, Janssen requested the Banque de France to repatriate, under its own responsibility, the Belgian gold from Dakar to Brussels. In a second letter of the same day to von Becker, he set out his two conditions, expressly adding that the letter to the Banque de France could be sent only after the German authorities had accepted the second condition ${ }^{12}$. Besides writing to von Becker, Janssen also entrusted his letter to the Banque de France to him.

After the war, the Chief Military Prosecutor was to condemn Janssen for writing the letters and having entrusted them to von Becker ${ }^{13}$. Did the Bank at that time have a similar perception of the question? Not at all. Janssen had clearly made his conditions known to the occupier and felt completely covered. Furthermore, Plisnier and the supervisory council were in immediate agreement with the content of the letters. The entrusting of the letters to a man like von Becker was, equally, not regarded at the time as being wrong: postal services in Europe were so disorganized that correspondence with other countries could be conducted safely only via the German authorities.

Von Becker's intrigues during that September served to show the Germans in their true light, which was not at all the credible image of disciplined and correctly behaved occupiers that they had sought to project during the first months after the invasion, even in contacts with the Bank. It was von Becker who conceived the ingenious plan of sending only copies of Janssen's two letters to Paris, the first one, addressed to the Banque de France, containing the full text of the original, but the second one, addressed to him, deleting the passage stating that the first letter could be handed to the Banque de France only after the German authorities had officially recognized that the Bank should have free disposition of the gold ${ }^{14}$. Von Becker then approached Hemmen to

12 BNB, Archives, $S D$, London Archives, dossier 'or': note relative au dépôt d'or confié par la BNB à la Banque de France, 1939-1940 (annex 57 and annex 58); BNB, Archives, SD, Malaise Papers, dossier 9.5.11, s. f. 4: Kauch, rapport au Roi, 20.12.1943, p. 42.

13 BNB, Archives, Studiedienst, 13, dossier A 320/6: letter of 18.07.1956 from the military prosecutor Ganshof-van der Meersch to Kauch. See also: P.Kauch, Le vol de l'or de la Banque Nationale par les nazis (1940-1943), Brussels, 1956.

14 BdFr, Archives, Direction de la documentation, dossier 1397.1994.01/83, 'or belge': letter of 05.09.1940 from Janssen (Brussels) to de Boisanger (Clermont-Ferrand) (copy doctored by the Germans, with German annotations, and a full copy, probably provided later to Bolgert by Kauch). 
put pressure on Governor de Boisanger, who was chairing the French delegation at the Wiesbaden negotiations, for having the Belgian gold at Dakar returned to Europe with all haste, given the unsettled situation in West Africa ${ }^{15}$. In this roundabout way, the matter of the repatriation of Belgian gold landed on the negotiating table ${ }^{16}$. On 13 September, von Becker returned the two original letters to Janssen and announced that the Military Government could not accept the conditions that had been set ${ }^{17}$, adding that the question would be discussed at Wiesbaden and that Janssen would have an opportunity there to defend his standpoint ${ }^{18}$.

The Banque de France was now caught between two fires. Ansiaux had returned to Vichy during the first half of September, still looking to bring about the evacuation of the Belgian gold, but Janssen had meanwhile requested that the gold be repatriated to Brussels. Which course was to be followed? Into the bargain was the delicate position that de Boisanger personally found himself in, as he owed his recent appointment as governor to Bouthillier, the Vichy Minister of Finance, who, with most of his colleagues, wished to do as much as possible to go along with the Germans.

The dilemma was resolved the day after Ansiaux's departure from Vichy to England on 17 September (see supra), the French government now authorizing the Banque de France to accede to Janssen's request to repatriate the gold to Brussels ${ }^{19}$. In its answer of 23 September to Janssen, the Banque de France agreed to restore the gold, but refused any

15 Freiburg im Breisgau, Archives, Militärverwaltung, dossier RW 36/277: Hofrichter, Abschluszbericht der Militärverwaltung in Belgien und Frankreich, 1940-1944, p. 89.

16 R. Aron, Histoire de Vichy, 1940-1944. Parijs 1954, pp. 315-316. In this respect, see also: BdFr, Archives, Direction de la documentation, dossier 1397.1994.01/83, 'or belge': telegram of 10.09.1940 from Wiehl (Ministry of Foreign Affairs, Berlin) to Hemmen (Wiesbaden).

17 BNB, Archives, $S D$, London Archives, dossier 'or': note relative au dépôt d'or confié par la BNB à la Banque de France (annex 63)

18 Krijgsauditoraat, Plisnier, fonds 77, depot 3.033: letter of 14.09.1940 from Janssen to Plisnier; Plisnier, 'L'or belge livré aux allemands en 1940' in: Revue Générale Belge, 52, February 1956, p. 5.

19 Cornu, L’or monétaire au vingtième siècle, pp. 171-17; BdFr, Archives, Sécrétariat Général, dossier 1060.2001.01.37, 'or belge': note pour Monsieur le Sécrétaire Général, 19.09.1940. 
liability for the risk in transporting it from Dakar to Brussels and demanded settlement in advance of its outstanding gold claims against the Bank ${ }^{20}$.

Janssen prepared himself for his visit to Wiesbaden to defend his standpoint regarding the gold, but the visit never took place. Without informing him, von Becker and Hofrichter themselves travelled to Wiesbaden and there, on 4 and 5 October, negotiated on behalf of the Bank about all the questions still pending between the two central banks ${ }^{21}$. The German delegation found it normal for the Bank to be represented by the commissioner and his deputy during the Franco-German negotiations, and not by the governor; after all, Belgium had capitulated and consequently did not fall under the system of a contractual armistice. In Hemmen's opinion, in those circumstances the Military Government in Brussels had the right to undertake the representation ${ }^{22}$.

However, the governor of the Banque de France was, indeed, at the negotiations and, as the chairman of the French delegation, was able to set out his position in detail. It was a discrepancy that apparently prompted reactions in the corridors, which would explain why, at the opening of the second day of negotiations, Hemmen explained that Janssen would normally have been present, but that illness prevented him. At the same time he declared that the ongoing negotiations were only 'preparatory' discussions and that Janssen would certainly be present in mid-October at their conclusion and the definitive signing of the agreement.

On the opening day, 4 October, Hemmen stated that the discussions would be limited to three matters: 1) the amount of gold to be restored; 2) the exchange of banknotes, irrespective of whether they were French or Belgian; and 3) the repatriation of the Belgian assets stored at Tou-

20 BdFr, Archives, Direction de la documentation, dossier 1397.1994.01/83, 'or belge': note pour M. le Sécrétaire Général, 21.09.1940; dossier 1397.1994.01/84, 'or belge': letter of 23.09.1940 from Favre-Gilly to Schäfer; letter of 23.09.1940 from FavreGilly (Paris) to Janssen (Brussels).

21 BdFr, Archives, Direction de la documentation, dossier 1397.1994.01/83, 'or belge': note pour M. le Sécrétaire Général 21.09.1940; dossier 1397.1994.01/84, 'or belge': letter of 23.09.1940 from Favre-Gilly to Schäfer; letter of 23.09.1940 from Favre-Gilly to Janssen.

22 Cornu, L’or monétaire au vingtième siècle, pp. 172. 
louse and Tarbes. This last matter was sorted out immediately, everyone agreeing to an immediate repatriation, but negotiations on the first two proved difficult ${ }^{23}$.

Acting as representatives of the Bank, von Becker and Hofrichter naturally had every interest in repatriating as much gold as possible to Belgium and therefore obstructed the French demand to add a further 27,307.8 kilos of fine gold to what was already being withheld from the Belgian deposit in settlement of the provisions charged in June and July 1940 (as referred to above). Von Becker and Hofrichter contended that those provisions had never been transposed into real transactions and had never been entered into the Bank's accounts. The French replied that Janssen had given a signature of endorsement and had agreed that their value should be deducted from the deposited gold ${ }^{24}$.

The discussion about the exchange of French banknotes was equally sharp. At the outset, von Becker and Hofrichter demanded that settlement for the French money that had been exchanged back into Belgian francs on the return of the refugees should be made fully in gold by the Banque de France. In this respect, they referred to what had happened in a similar situation in the spring and summer of 1940, when the exchange of Belgian into French francs by Belgian refugees had at all times been honoured in gold by the Bank. The Banque de France had no intention of acceding to this demand: one of its directors at Clermont-Ferrand had in fact entered 'A exclure' in the margin of an internal memorandum, next to the paragraph raising the question of a possible settlement in gold ${ }^{25}$.

The first line of argument adopted by the French representatives was that Banque de France had scrapped the reciprocity clause from the implementing protocol of the Franco-Belgian monetary convention of 7 June 1940. The second was that Belgian refugees had brought a great

23 BdFr, Archives, Direction de la documentation, dossier 1397.1994.01/71, 'or belge': convention de Wiesbaden, comptes-rendus des séances du 4 et 5 octobre relatives à l'or belge, 04.10.1940, 05.10.1940. See also: BdFr, Archives, Sécrétariat Général, dossier 1060.2001.01/36, 'or belge': projet germano-belge remis à la délégation française, 05.10.1940.

24 BdFr, Archives, Direction de la documentation, dossier 1397.1994.01/83, 'or belge': note pour M le Sécrétaire-Général, Paris (Clermont-Ferrand), 25.09.1940.

25 BdFr, Archives, Direction de la documentation, dossier 1397.1994.01/83, 'or belge': note pour M. le Sécrétaire-Général, 21.09.1940. 
quantity of French banknotes into France in May 1940 which they had acquired on the free market at a rate of around 170 French francs to 100 Belgian, whereas the official rate was 144.4 French francs. At that time, the currency controls instituted by the French government prohibited the import of banknotes purchased on the free market; to bring them in amounted to a fraudulent, illegal import that absolutely precluded any settlement in gold.

The final matter for discussion was the restoration of the Belgian gold by the Banque de France. There is no trace of any discussion to be found in the minutes, probably because both parties had assumed that the Bank endorsed the restoration. Von Becker informed Janssen on 7 October about the result of the negotiations and asked him to give his overall opinion as soon as possible, after viewing the document $\mathrm{s}^{26}$.

Jansen disapproved of the way in which the preliminary negotiations had been handled and was not prepared to accept a number of the French proposals. He wished, therefore, to go in person to Wiesbaden to argue his case with the French delegation, but his health let him down. Via Kauch, he asked whether the final negotiations might not be postponed, only to be informed by von Becker on 9 October that Hemmen had refused the request, on grounds of urgency. Von Becker nevertheless assured Janssen that he and Hofrichter would work strenuously to defend Belgian interests ${ }^{27}$.

Janssen submitted his comments on the draft texts on 10 October in a four-page memorandum ${ }^{28}$, but during the final round of negotiations on 14-16 October, no account was taken of his remarks. The French were later to claim that they had never even been shown the memorandum ${ }^{29}$. First up for discussion were the Franco-Belgian exchange rates, with von Becker and Hofrichter tabling a demand for a rate of 160 French francs to 100 Belgian. This was unacceptable to the French: a devalu-

26 BNB, Archives, Studiedienst, 13, dossier 01.04.04, s. f. 2 (A 320/12): letter of 07.10.1940 from von Becker to Janssen.

27 BNB, Archives, Studiedienst, 13, dossier 01.04.04, s. f. (A320/ 12): letter of 09.10.1940 from von Becker to Janssen.

28 BNB, Archives, Boekhouding, 2, dossier 88.02.02.00 (B 610/7), 'convention de Wiesbaden': remarques du gouverneur Janssen, 10.10.1940.

29 BNB, Archives, $S D$, London Archives, dossier 'or': note relative au dépôt confié par la BNB à la Banque de France (annex 81, letter of 23.10.1940 from Kauch to Janssen). 
ation against the Belgian franc would further dent France's already battered image and would not be good in economic terms, either. It would inter alia push up the price of coal, large quantities of which were imported at that moment from Belgium. A solution acceptable to both parties was ultimately arrived at, whereby the exchange rate would remain at 144.4 French francs to 100 Belgian until 1o December, after which a rate of 160 French francs would apply.

The main focus of discussion was the amount of gold that was to be returned to Belgium ${ }^{30}$. Three points remained to be resolved. Were the provisions endorsed by Janssen on 28 May and 18 June effectively to be settled in gold or not? Were the French banknotes held by the Banque d'Emission to be honoured in gold by the Banque de France or not? Were the loans of the French and Belgian governments to each other, and registered at the two central banks via a current account, to be settled in gold or not? Discussion became heated, but here, too, both parties relaxed their demands until a compromise was reached. Von Becker and Hofrichter acknowledged the Bank's endorsement of 28 May for a provision of 100 million French francs to be settled in gold. For its part, the Banque de France accepted that the provision of 800 million French francs conceded on 18 June be scrapped from the list of French demands; it also agreed to a compromise arrangement whereby the loan of 400 million French francs granted to the Belgian Treasury and effectively drawn down was to be repaid in banknotes and not settled in gold.

There was no further discussion of the principle of repatriation and restoration of the gold, but the French held stubbornly to their position on certain points regarding the actual implementation of what had been agreed. One example was the refusal to accept the proposal for German planes to be used to transport the gold from Kayes and Algiers to Marseilles. Another was the Banque de France's insistence that the gold be transferred into the hands of legally accredited Belgian representatives of the Bank, to which Hofrichter replied that the German commissioner at the Bank had the requisite authority to accept

30 BdFr, Archives, Direction de la documentation, dossier 1397.1994.01/71, 'or belge': convention de Wiesbaden, comptes-rendus des séances, 13.10.1940, 15.10.1940, 16.10.1940; dossier 1397.1994.02/13: convention de Wiesbaden, compte-rendu de la séance, 14.10.1940. 
the transfer. Nonetheless, the Banque de France continued to assert that legal considerations prevented any change in its position and the Germans apparently resigned themselves to this.

A draft agreement was initialled on 17 October by Heinrich Hartlieb and Maurice Couve de Murville on behalf of the German and French governments respectively, and by Hofrichter and Bolgert on behalf of the two central banks ${ }^{31}$. It was officially signed on 29 October as the Wiesbaden Convention, on behalf of the German and French governments respectively by Hemmen and de Boisanger, the chairmen of the delegations, and on behalf of the two central banks respectively by von Becker and Schäfer, the German commissioners at Brussels and at Paris respectively ${ }^{32}$.

The convention was favourably received among the new French leaders as a whole and a gesture of goodwill towards the occupier was soon forthcoming. At the request of the Banque de France, therefore, a first aircraft with 2,400 kilos of the Bank's gold left Kayes on 4 November less than a week after the official signing of the convention - bound for Marseilles; a second, carrying approximately the same weight, followed in mid-November ${ }^{33}$.

\section{THE WIESBADEN CONVENTION (29 OCTOBER 1940)}

The Wiesbaden Convention of 29 October was an attempt to achieve, under German supervision, a general compromise that would resolve all the Franco-Belgian problems that had arisen in monetary and public finance affairs since the German invasion. With some of the arrangements Janssen could agree, such as the repatriation of the banknotes and securities, which the Bank had been left behind in Toulouse and

31 BNB, Archives, $S D$, Malaise Papers: Kauch, La Banque Nationale (unpublished text), Part 1, Chapter. 4, p. 60.

32 BNB, Archives, AR, notulen, 30.10.1940; SOMA, Archives, Prack Papers, dossier JP 965: Vier Jahre Besatzungszeit in Belgien. Persönliche Erinnerungen von Herbert Prack.

33 BdFr, Archives, Sécrétariat Général, dossier 1060.2001.01/42: letter of 09.11.1940 from the Minister for the Colonies to the Banque de France, 09.11.1940; telegram of 14.11.1940 from Rousseau (Clermont-Ferrand) to Lacroix (Dakar). See also Kauch, Le vol de l'or, p. 39. 
Tarbes, but the big stumbling-block remained the repatriation and restoration of the gold.

The convention's sting, indeed, was in the tail. Article vin stated that the Banque de France 'accepted' to restore the deposited gold to the Bank, but that the cost of repatriation was to be borne by the Bank. Moreover, restoration would completely release the Banque de France from its responsibility as custodian. ${ }^{34}$.

Janssen could not understand that the Banque de France would have given its fiat without taking account of the conditions set by the Bank on 5 September. Without informing the Germans, he therefore sent his private secretary, Kauch, on 21 October to Paris and ClermontFerrand to inform the Banque de France personally about the Belgian point of view. Kauch had difficulty in convincing the few directors he could meet that, in fact, Janssen had requested the Banque de France not to restore the gold, unless his conditions had been accepted by the Germans. The French reacted in astonishment ${ }^{35}$. They acknowledged that Janssen's absence during the negotiations at Wiesbaden had raised eyebrows, but the reference to his health had been taken at face value; furthermore, the French delegation had even insisted on the presence of a Belgian representative of the Bank.

The directors of the French central bank explained why they had not made any effort to contact the Bank directly to discuss what, after all, was a very serious matter: they had accepted the copy of Janssen's letter of 5 September in good faith and had regarded it as a valid and normal request for the gold to be restored. They showed Kauch the copy, which, as he wrote to Janssen in his report of 22 October, left him dumbfounded: 'And what did I learn and see? In a letter of 5 September you yourself asked the governor of the Banque de France to repatriate the Belgian gold from Dakar'.

The directors also explained to Kauch that they could not retract their signature of 17 October, but promised that it would not automatically lead to repatriation and restoration. Indeed, their acceptance of the French government's request for restoration had been only on the

34 BNB, Archives, $S D$, London Archives, dossier 'or': note relative au dépôt d'or confié par la BNB à la Banque de France (annex 86).

35 BNB, Archives, SD, London Archives, dossier 'or': note relative au dépôt d'or confié par la BNB à la Banque de France (annex 81: letter of 22.10.1940 from Kauch to Janssen). 
understanding that certain conditions were met: the convention had to be signed by the governors of the two central banks (on 29 October, the Banque de France nonetheless accepted the signature of von Becker, who 'claimed' to have Janssen's authorization) and restoration had to be into the hands of the legal representatives of the Bank. Furthermore, German aircraft would not be allowed to pick up the gold at Dakar and this would allow delaying tactics to be employed. There would also be strict adherence to the normal procedure of placement in safe custody and restoration. Lastly, the French gave a verbal undertaking - repeated on 30 October - that the Banque de France would proceed to restoration of the gold only when the Bank expressly requested it ${ }^{36}$.

Janssen was now fully informed of how von Becker, Hofrichter and Hemmen had abused his trust and completely misled him, but he was in an extremely delicate position. He baulked at offending von Becker by accusing him of an abuse of trust, deeming it the wrong time to get caught up in an open conflict with the occupying power. For Janssen, too, there was a personal and somewhat painful aspect to the breach of trust, in that he could hardly accuse von Becker openly without admitting that he himself had been unforgivably and even incomprehensibly naïve and imprudent in his approach to the entire question. For this reason, he resolved to use legal arguments in attacking the provisional convention of 17 October.

To this end, Janssen had already submitted two critical memoranda to von Becker on 21 and 25 October. He declared his acceptance of the repatriation and restoration of the gold, now deemed inevitable, but at the same time attempted to demonstrate that the occupier had no legal grounds for laying claim to the Belgian gold. After all, the Bank's gold was itself inviolable, as it served as cover for the issue of Belgian banknotes $^{37}$.

Janssen had also enlisted the help of the jurists Marcq and Rolin, whose opinion of 28 October put the Bank's arguments on a different

36 BNB, Archives, SD, Malaise Papers: Kauch, rapport au Roi (20.12.1943), pp. 45-46; see also BdFr, Archives, Direction de la documentation, dossier 1497.1994.01/83, 'or belge': letter of 24.10.1940 from Bolgert to Couve de Murville.

37 BNB, Archives, $S D$, London Archives, dossier 'or': note relative au dépôt confié par la BNB à la Banque de France (annex 89: letter of 30.10.1940 from Janssen to Frédéricq, private secretary to the King). 
tack $^{38}$. Their view was that von Becker could make no claim to having competence to act in the Bank's name in initialling the draft convention of 17 October and signing the convention itself. It was true that, in accordance with the original German decree, the commissioner of the Bankaufsichtamt had been granted an extraordinary power of control over the Banque d'Emission, but that did not apply to the Bank. As a result, the Bank was subject to the normal German supervision to which all Belgian banks were subject. That normal supervision excluded the German authorities from exercising any power of disposition. A second argument put forward by Marcq and Rolin was that the Military Government had entrusted the administration of occupied Belgium to the national administrative bodies and that this excluded the Bankaufsichtamt from any interference in matters regarding the management of the Bank. Yet a third argument stated that, as the gold reserves and the assets belonged to the Bank, whose incorporation under private law was not in question, it could be concluded that the occupier was precluded by the Hague Convention from disposing them.

The opinion of the jurists was formal: the Bank had the fullest right to regard the Wiesbaden Convention as not binding. Basing himself on the opinion of the jurists and on his own arguments, Janssen wrote to von Becker on 18 November to notify him officially that the Bank could not recognize the Wiesbaden Convention ${ }^{39}$.

\section{THE SUPPLEMENTARY PROTOCOL OF 11 DECEMBER 1940}

Concerned always to cloak its illegal actions in a guise of legality, the Military Government found itself totally stymied. To escape from the impasse, new initiatives were required, not just for Belgium, but also for France ${ }^{40}$. From Berlin at the beginning of November, a new strategy was rapidly developed, whose aim was to transfer the contract for safe

38 BNB, Archives, SD, London Archives, dossier 'or': note relative au dépôt d'or confié par la BNB à la Banque de France (annex 84 and annex 85, opinions of 28.10.1940 from R. Marcq and H. Rolin).

39 BNB, Archives, SD, London Archives, dossier 'or': note relative au dépôt confié par la BNB à la Banque de France (annex 91: letter of 18.11.1940 from Janssen von Becker).

40 In respect of the French impasse, see: BdFr, Archives, Direction de la documentation, dossier 1397.1994.01/71, 'or belge': letter of 06.11.1940 from Schäfer (Paris) to the embassy adviser von Campe (Wiesbaden). 
custody from the Banque de France to the Reichsbank and to ensure that the Belgian government would authorize the Bank to accept the transfer ${ }^{41}$.

The new strategy was explained to von Falkenhausen by von Becker on 16 November. Direct negotiations with the Belgian secretariesgeneral would be set in train and an accommodation on the costs of occupation would be used to persuade the Belgian administration to come to an agreement on the question of the gold ${ }^{42}$. It took little time for the military commander to give the go-ahead and on 19 November Reeder wrote to Alexandre Delmer, Chairman of the Belgian Committee of Secretaries-general, requesting that Janssen be authorized to release the Banque de France from its responsibility for the Belgian gold. The Banque de France would undertake to transfer the gold as quickly as possible to Marseilles, where the Reichsbank would receive it on behalf of the Bank. Reeder added that Janssen had agreed to assist in the operation, provided he received authorization from the secretariesgeneral ${ }^{43}$.

The Committee of Secretaries-general met on 21 November. Asked to clarify the problem, Plisnier stated that the committee was not competent to grant that authorization to the governor: the committee did not, in fact, replace the Belgian government and it was only in their own particular domain that the secretaries-general had been authorized to take necessary decisions of a current nature, as was also the case for him as secretary-general of the Ministry of Finance. Moreover, the law of 10 May 1940 forbad him to act against a decision of the legal government of Belgium, and it was the government that had decided to

41 Soma, Archives, Prack Papers, dossier JP 965: Vier Jahre Besatzungszeit in Belgien. Persönliche Erinnerungen von Herbert Prack, p. 44.

42 Freiburg im Breisgau, Militär Archiv, Militärverwaltung, dossier Rw 36/277: Hofrichter, Abschluszbericht der Militärverwaltung in Belgien und Nord-Frankreich, 1940-1944, p. 9o. See also: Soma, Archives, Prack Papers, dossier JP 965: Vier Jahre Besatzungszeit in Belgien. Persönliche Erinnerungen von Herbert Prack, p. 44.

43 BNB, Archives, Studiedienst, 13, dossier A 320/12: letter of 19.11.1940 from Reeder to Delmer; BNB, Archives, $S D$, London Archives, dossier 'or': note relative au dépôt d'or confié par la BNB à la Banque de France (annex 93: letter of 19.11.1940 from Reeder to Delmer, chairman of the Committee of Secretaries-general). In a letter to Reeder, Janssen had written: 'Si l'autorité belge compétente en décide ainsi, il (Janssen) ne ferait pas d'opposition à la rentrée de l'or') (quoted by Plisnier: ARA, Krijgsauditoraat, Plisnier, 1, dossier c: Committee of Secretaries-general, minutes, 30.11.1940). 
evacuate the gold to prevent it falling into the hands of the enemy. All members of the committee present declared their agreement with this position ${ }^{44}$.

As all means to prompt the Banque de France to restore the gold via the normal procedure now appeared to be exhausted, the German Ministry of Foreign Affairs in Berlin resolved to switch action to the political front and on 23 November instructed Hemmen to travel to Vichy to put pressure on Minister Laval and the French government ${ }^{45}$. At their meeting, which took place on 29-30 November ${ }^{46}$, Hemmen pointed out that, in return for its cooperation, the French delegation at Wiesbaden had already received a reduction in the costs of occupation and added that new concessions in that respect were being mooted. Even the release of 150,000 French prisoners of war was being considered, as was - utopian as it may have seemed - the formal return of Alsace-Lorraine and permission to rearm. A gesture on the part of the French government over the Belgian gold would be, if not decisive, at least a welcome signal in efforts to achieve positive cooperation between France and Germany ${ }^{47}$.

The ministers Laval, Bouthillier and Baudouin went along with the German proposals, promising to persuade the Banque de France to repatriate the Belgian gold to Marseilles and then transfer it to the Reichsbank. Hemmen was able on 30 November to telegraph von Ribbentrop, the Minister of Foreign Affairs in Berlin, that Laval and the French government had accepted the German proposals ${ }^{48}$.

Schäfer now went to Bolgert in Paris to inform him about that acceptance and to submit the attendant draft protocol. Immediately thereafter, Bolgert left for Clermont-Ferrand to discuss the text with

44 ARA, Krijgsauditoraat, Plisnier, 1, dossier c: Committee of Secretaries-general, minutes, 30.11.1940.

45 BdFr, Archives, Direction de la documentation, dossier 1397.1994.01/7, 'or belge': entretien de M. Hemmen et M. de Boisanger, 23.11.1940.

46 BdFr, Archives, Direction de la documentation, dossier 1397.994.01/71, 'or belge': note pour le gouverneur (négotiations relatives à l'or belge, 12.02.1941).

47 Cornu, L'or monétaire au vingtième siècle, pp. 176-177; M. Margairaz, 'Introduction. 1. La Banque de France et l'occupation; 2. La Banque de France et ses partenaires', in: M. Margairaz, ed., Banques, Banque de France et Seconde Guerre Mondiale, Paris, 2002, pp. 1-37. In this respect, see also: Velaers and Van Goethem, Leopold III, pp. 553-554.

48 Cornu, L’or monétaire au vingtième siècle, pp. 178-181 
Governor de Boisanger and the other directors of the Banque de France. $\mathrm{He}$ also addressed an accompanying memorandum to the Governor, in which he expressed his great unease about the entire situation. In the Wiesbaden Convention, the Banque de France had made its agreement concerning the restoration of the Belgian gold conditional on that gold being transferred into the hands of the accredited Belgian representatives of the Bank. The agreement between Laval and Hemmen simply ignored the existence of that clause. Bolgert found that the entire construction was degrading for the Banque de France. His suggestion, therefore, was that the Banque de France should demand that the government bring in a special law whereby the institution would be 'forced' to implement the restoration ${ }^{49}$.

De Boisanger was not prepared to take that step. However, the board of directors of the Banque de France resolved to submit a letter of protest to the French Minister of Finance, which again emphasized that the institution could accept to restore the gold only if a 'voluntary' request for restoration was received from the Bank. In reply, Bouthillier said that he could subscribe entirely to the board's legal arguments, but that there were greater interests at stake at the moment. The board submitted, but nevertheless sought to give itself additional cover. In the first place, it demanded that the transfer take the legal form of a 'substitution of depositary' ('substitution de dépositaire'), a formula whereby they hoped to envelop the transfer in the tradition of loyalty among central banks and thereby exert moral pressure on the Reichsbank to honour its obligations vis-à-vis the Bank and the Banque de France. Secondly, it demanded a State guarantee for the risks it was exposed to; this was granted by letter of 12 December from Bouthillier. The supplementary protocol was signed on 11 December by Hemmen and de Boisanger, representing the German and French governments respectively, and by Schäfer and von Becker, representing respectively the Banque de France and the Bank $k^{50}$.

49 BdFr, Archives, Direction de la documentation, dossier 1397.1994.02/13, 'or belge': Bolgert, note pour le Gouverneur, 30.11.1940.

50 BNB, Archives, DC, 11.12.1940: additional memorandum on the protocol of 11.12.1940. See also: Freiburg im Breisgau, Militär Archiv, Militärverwaltung, dossier RW 36/277: Hofrichter, Abschluszbericht der Militärverwaltung in Belgien und Nord-Frankreich, 1940-1943, Part 1, p. 90. 
In Belgium, meanwhile, the Military Government was also resorting to political means to gain its end. On 14 December, von Becker informed Janssen of the content of the supplementary protocol, as well as that of the text of an ordinance to be issued by von Falkenhausen two days later. The ordinance stated that, besides his function as commissioner of the Banque d'Emission, von Becker would exercise an identical function at the Bank. During this meeting von Becker asked Janssen whether the Bank would accept the supplementary protocol or refuse all cooperation regarding the repatriation of the gold. He demanded an answer by 6 p.m. and threatened dismissal should Janssen continue to resist ${ }^{5}$.

After taking fresh advice from the jurists Marcq and Rolin, Janssen wrote to von Becker on 18 December stating that the supplementary protocol was unacceptable to the Bank and explaining why ${ }^{52}$. The protocol did not supplement the Wiesbaden Convention, but fundamentally changed it: now, the gold would be handed over not to the accredited representatives of the Bank, but to representatives of the Reichsbank; from a legal point of view, such a change was even less admissible than what had been laid down in the convention.

Under private law, furthermore, there was no justification whatsoever for the substitution: the Bank had neither been involved, nor legally represented, in the drawing-up of the protocol. There was also no justification under international law for the transfer of the gold to Germany. All that could be commandeered were State securities held in the occupied territory, and then only insofar as that was urgently necessary for the maintenance of the army of occupation. This was not the case here, and transferring the gold to Germany was consequently unlawful.

While all this was unfolding, repatriation of the Belgian gold had actually got under way. An initial consignment of 1,199 crates with a combined weight of approximately 60 tonnes was to be transported by

51 BNB, Archives, SD, London Archives, dossier 'or': note relatif au dépôt d'or confié par la BNB à la Banque de France (annex 103: ordonnance du 16 décembre 1940). See also: BNB, Archives, SD, 12, dossier 8.11/2: note confidentielle sur l'entretien d'Ingenbleek avec Hayoit de Termicourt, 10.04.1942.

52 BNB, Archives, SD, London Archives, dossier 'or': note relatif au dépôt confié par la BNB à la Banque de France (annex 108: letter of 18.12.1940 from Janssen to von Becker). 
train from the military base at Kayes to Dakar. From there, it would be shipped to Casablanca, freighted by train to Oujda in Marocco, on to Oran and then on to Algiers ${ }^{53}$. Transporting the remaining 3,652 crates proved even more difficult and in fact turned into a spectacular adventure. Patrolling British and American ships had made the sea route unsafe, so that a land route had to be sought. The crates left Kayes by train in April 1941, bound for Bamako, from where they were to be transported upstream on the Niger in three separate convoys to Bourem in what was then the French Sudan. However, persistent drought had substantially lowered the water level, so that keeping the boats afloat proved to be a feat of strength requiring the enlistment of 160 local men. In consequence, it was three weeks before all the convoys reached Bourem. Once there, the crates were loaded on to trucks of the Compagnie Transsaharienne, which, in scorching heat, had then to work their way right across the Sahara to Colomb-Béchar in Algeria. The journey was a nightmare, burst tyres having to be repaired with whatever was to hand, and failed engines requiring enormous ingenuity to be coaxed back to life; in comparison with this, the present-day Paris-to-Dakar rally is little more than a school run for teenagers. At Colomb-Béchar, the crates were transferred to rail for Algiers.

By the end of November 1941, no more than 2,013 out of the 4,944 crates had arrived in Berlin. Becoming impatient, Hemmen insisted in December that the French take more effective measures, but there was little positive that he could draw from the reaction to his criticism. In the first place, they had no more than a few old bomber aircraft available, to carry the gold and for these they no longer had any stock of spare parts. Moreover, fuel had now become a problem, though this was to be taken care of by the occupier ${ }^{54}$. Much worse, however, was the danger of flying over the Mediterranean Sea, where the airspace was constantly alive with Allied aircraft. It was only at night that any flying could be undertaken without too great a risk, but this meant that no more than

53 BdFr, Archives, Direction de la documentation, dossier 1397.1994.01/71, 'or belge': note pour le gouverneur (négociations relatives à l'or belge, 12.02.1941). BNB, Archives, Boekhouding, 2, dossier 88.02.02.00 (A 610/7), 'convention de Wiesbaden': Kauch, note pour M. le Gouverneur, 03.02.1941.

54 Archives, Sécrétariat Général, dossier 1060.2001.01/42, 'or belge': transport de 1292 caisses de Kayès à Marseille. 
five tonnes of gold per week could be flown from Algiers to Marseilles. The task was completed on 26 May 1942. Under pressure from Berlin, the Vichy government had meanwhile given the order for the Polish gold also to be delivered to Germany. This left Kayes in the autumn of 1941, but was intercepted en route by the Allies and transported to the United States ${ }^{55}$.

Because a number of the crates in the first convoy of Belgian gold had been damaged in transport, the Reichsbank decided to verify the entire delivery ${ }^{56}$. To that end, the Bankaufsichtamt requested Janssen on 6 January 1941 for further cooperation, though on a more limited scale, with just a few of the Bank's officials travelling to Berlin to act as simple 'witnesses'. However, the tone of the request was again threatening, the formulation being that of an order: a new refusal would be regarded as an act of sabotage and the Military Government would have the Governor court-martialled and request the judges to condemn him to deportation ${ }^{57}$.

Janssen consulted the jurist Marcq who gave his opinion that there was nothing against complying with the order, as this could in no way derogate from the Bank's refusal to recognize the legality of the convention and the protocol. Furthermore, it involved no more than a material presence in Berlin, not active cooperation, and responsibility for the gold in any case rested with the Banque de France ${ }^{58}$. Initially, Janssen felt that he should stick by his refusal, but the other members of the board of directors were able to persuade him otherwise ${ }^{59}$.

55 BdFr, Archives, Direction de la documentation, dossier 1397.1994.01/78, 'or belge': communiqués from Algiers and Marseille, February 1941; Secrétariat Général, dossier 1060.2001.01/42, 'or belge': reports on the transportation of the gold through the Sahara, 1941-1942.

56 Freiburg im Breisgau, Militär Archiv, Militärverwaltung, dossier Rw 36/277: Hofrichter, Abschluszbericht der Militärverwaltung in Belgien und Nord-Frankreich, 1940-1944, Part 1, p. 92.

57 BNB, Archives, SD, 12, dossier 8.11/2: note confidentielle sur l'entretien d'Ingenbleek avec Hayoit de Termicourt, 10.04.1942.

58 Plisnier, 'L’or belge livré aux allemands en 1940', in: Revue Générale Belge, 52, February 1950, pp. 12-13.

59 BNB, Archives, $S D$, 12, dossier 8.11/ 2: note confidentielle sur l'entretien d'Ingenbleek avec Hayoit de Termicourt, 10. 04.1942 


\section{THE AFTERMATH OF THE REPATRIATION}

Meanwhile Janssen was taking steps to obtain certainty about the Banque de France's continuing liability regarding the Belgian gold. His first chance to find out more came at the end of December 1940. Auguste Callens, a director of the Société Générale de Belgique, was travelling to France on business and, at Janssen's request, contacted the directors of the French central bank. Its governor, de Boisanger, formally declared to Callens that the Banque de France still regarded itself liable for the Belgian gold ${ }^{60}$.

A little later, Janssen had an opportunity to go deeper into the question of liability, making use of a trip by Kauch to France in January 1941 to have him deliver a letter to de Boisanger, in which Janssen explicitly underlined that, in accordance with the rules of acceptance into safe custody, and notwithstanding the transfer of the gold to Berlin, the Banque de France remained responsible for the deposit vis-à-vis the Bank $^{61}$.

However, there was more to Kauch's mission than simply delivering a letter to de Boisanger. His main purpose was to obtain a 'written' declaration from de Boisanger, officially confirming the Banque de France's continuing liability vis-à-vis the gold ${ }^{62}$. Kauch returned to Brussels on 1 February and the day after reported on his meeting with de Boisanger ${ }^{63}$. With the approval of the French government, the Banque de France was prepared - should Janssen request it in a letter or a memorandum - to give a written declaration that it remained fully liable vis-à-vis the Bank in respect of the Belgian gold.

6o Cornu, L'or monétaire au vingtième siècle, p. 185.

61 BNB, Archives, SD, London Archives, dossier 'or': note relative au dépôt d'or confié par la BNB à la Banque de France (annex 116: letter of 15.01.1941 from Janssen to de Boisanger).

62 BNB, Archives, SD, London Archives, dossier 'or': note relative au dépôt d'or confié par la BNB à la Banque de France (annex 117: letter of 18.01.1941 from Kauch to Janssen).

63 'M. de Boisanger se déclare prêt à nous remettre un écrit ...précisant les responsabilités de la Banque de France, à condition que la BNB lui adresse une lettre ou une note sollicitant directement ou indirectement cette déclaration'...: BNB, Archives, SD, London Archives, dossier 'or': note relative au dépôt confié par la BNB à la Banque de France (annex 120, memorandum of 02.02.1941 from Kauch to Janssen). 
Kauch went back to Paris on 5 February and, during his visit to the Banque de France on the following day, handed over Janssen's written request. De Boisanger stated that he wished to fulfil the agreement of the previous week and they discussed a draft text of the declaration, agreeing that Kauch should return the next day to pick up the document. However, his reception was not what he expected when he announced himself at the Banque de France in the afternoon of 7 February. That same morning, the Pariser Zeitung and several foreign newspapers had carried news about the question of the Belgian gold, reporting that, in the Bank's name, Theunis, minister plenipotentiary of Belgium in the United States, had obtained a Supreme Court order for sequestration of the Banque de France's gold in deposit and registered under dossier at the Federal Reserve Bank of New York.

The news of the action taken in New York had barely been made known before de Boisanger went back on his concessions of the previous days. No written declaration could be given to Kauch as agreed. According to de Boisanger, the text had to be amended in any case, as the institution could not risk having to restore the gold twice: once in New York and again in Europe ${ }^{64}$.

What prompted Theunis to apply to the American court on 5 February in the Bank's name and with the authorization of the Belgian government in London was a telegram to him in New York sent on 26 January from Toulouse by Kauch: 'Santé Janssen bonne; situation mauvaise. Famille Jaunet (Belgian gold) en route de Cayès par Alger et Oran via Marseille vers famille Germain (Berlin) par Air France. Il faudrait retenir branche française famille Jaunet (French gold registered under dossier) à New York. Espoir en vous. Kauch (Banque de France, Toulouse) ${ }^{\prime 65}$. The question is whether the telegram was sent by Kauch on his own initiative or on Janssen's instructions.

Cattier, another director of the Société Générale de Belgique, who in February had a conversation with Ansiaux in Lisbon, could not believe that Janssen would have charged Kauch with sending the telegram.

64 BNB, Archives, Studiedienst, 2, dossier 01.02.01.70 (A247/6, s. f. 4): Kauch, note pour gouverneur, 09.02.1941; BdFr, Archives, Direction de la documentation, dossier 1397.1994.01/83, 'or belge': Bolgert, entretiens avec M.K., 20.03.1941.

65 ARA, Theunis Papers, 'correspondance Theunis-Gutt': letter of 27.01.1941 from Theunis (New York) to Gutt (London). 
In his opinion, Kauch had acted on his own initiative ${ }^{66}$. However, Baudewyns, who knew the structure of authority at the Bank intimately, was convinced that Janssen was the person responsible ${ }^{67}$.

Why would Janssen have decided to send the telegram? Why, after the telegram had been sent, would he have allowed Kauch to push ahead with negotiations in Paris about obtaining the written declaration? These are difficult questions and their answers can only be guessed at.

The first is probably the less difficult. The initial major delivery of Belgian gold had arrived in Berlin at the beginning of January 1941 and a last-ditch proposal from Janssen to the Reichsbank for the gold to be transferred to the BIs in Basle, made during the same month, had been ignored. Furthermore, the attempt to use an amended version of that proposal to obtain some sort of power of decision over the Belgian gold in Berlin was likewise appearing to be a hopeless rearguard action. By involving the United States, which was then still neutral, Janssen would thus have been looking to hedge his bets.

As to the second question, Janssen probably allowed his secretary to continue negotiating in order to obtain an additional guarantee. There was no a priori certainty that there would be legal proceedings in the United States or that any such proceedings would succeed, and it is therefore likely that Janssen regarded the telegram as a means of putting pressure on the Banque de France to obtain the written declaration and even to move it to make further concessions.

Despite the proceedings that had been instituted in New York, or even perhaps because of them, the Banque de France indeed continued to push for an amicable settlement. Everything points to Janssen also thinking along those lines. He now proposed reconsideration of a suggestion put forward on 10 July 1940 by Fournier, the former governor of the Banque de France, namely a transfer of gold registered under dossier, this time from the account of the Banque de France to an account of the Bank or to a joint Bank-Banque de France account at the Federal Reserve Bank of New York. In exchange, the Bank would suspend the proceedings in New York. The fact that the accounts there were frozen

66 BNB, Archives, SD, London Archives, 2: report from Ansiaux on his meeting with Cattier in Lisbon, 26-27.02.1941.

67 BNB, Archives, SD, London Archives: letters of 06.03.1941, 14.03.1941 and 24.03.1941 from Baudewyns (London) to Ansiaux (Lisbon). 
ought not to be an obstacle, because the arrangement applied to both central banks and would resolve itself after the war ${ }^{68}$.

Fresh negotiations were set in train by Kauch and, at the end of February, Cattier was informing Ansiaux in Lisbon that the prospects for a settlement were not developing unfavourably ${ }^{69}$. The Banque de France remained prepared - insofar as French government agreement was forthcoming - to give a written declaration of its continuing liability, in exchange for the halting of the proceedings initiated in New York. However, it insisted that the written declaration would be given only after the action had been withdrawn and the proceedings stopped. The 'New York transfer' proposed by Janssen was a step too far for the French, though discussions continued. Janssen then suggested that the 'transfer' be replaced by the French gold being 'given in pledge' in New York, but this suggestion, too, was rejected, the Banque de France refusing to go any further than a general written declaration of its obligation to the Bank regarding the gold.

Viewed from London, the discussions on the continent appeared to be too much of an uphill struggle and to be progressing too slowly. Baudewyns and the Belgian government remained suspicious ${ }^{7^{\circ}}$, fearing that the long-drawn-out series of proposals and counter-proposals between the Belgian and French central banks would compromise the legal proceedings in New York $^{71}$. Were that to happen and the negotiations on the continent to end in nothing, Belgium would be left emptyhanded. It is probable, too, that the Belgian government was being influenced by its financial and monetary entourage in London, which was extremely distrustful of anything French and thus of the French central bank, as well. When, furthermore, Baudewyns and the Belgian gov-

68 вNB, Archives, $S D$, London Archives, dossier 'or': note relative au dépôt d'or confié par la BNB à la Banque de France (annexes 123 and 124).

69 BNB, Archives, $S D$, London Archives, 2: report from Ansiaux on his meeting with Cattier in Lisbon, 26-27.02.1941.

70 Janssen regretted the suspicion of Gutt, Baudewyns and Theunis, and hoped that his negotiations with Paris, via Kauch, would normalize relations. BdFr, Archives, Direction de la documentation, dossier 1397.1994.01/84, 'or belge': letter of 02.04.1941 from Kauch to Bolgert, memorandum of 02.04.1941, with 'suggestions de M. Janssen'.

71 BNB, Archives, SD, London Archives, 1941, 2: letters of 06.03.1941 from Baudewyns and Spaak (London) to Ansiaux (Lisbon). 
ernment heard at the beginning of March 1941 that a delegation from the Banque de France had taken ship for New York ${ }^{72}$, their minds were made up and they went ahead with the legal action ${ }^{73}$.

Even then, as Kauch was to testify, negotiations did not cease ${ }^{74}$. Without the knowledge of the board of directors, he continued his discussions and involvement even after Janssen's death. Ansiaux and Baudewyns, Bank people to the core, also continued to hope that Kauch would achieve an acceptable agreement with the French central bank, so that legal proceedings could ultimately be avoided ${ }^{75}$. Via Kauch, the Banque de France did, in fact, later contact Goffin, the new Governor of the Bank, to try to reach an amicable settlement, now declaring itself prepared to give written confirmation of its liability regarding the Belgian gold and even agreeing to give French gold in pledge in New York, in return for the legal proceedings to be halted ${ }^{76}$.

In Brussels, the board of directors - never enthusiastic about the efforts of Janssen and Kauch to negotiate a solution - resolved to consult the jurist Marcq about the new proposal. His opinion, submitted on 15 November, was clear: the proposal could not be accepted by the Bank's management in Brussels, as such matters now were outside its competence, that competence lying with the appointed members of the Bank abroad ${ }^{7}$. Endorsing Marcq's opinion, the Bank wrote to the Banque de France on 17 November 1941 that both the legal proceedings and the proposed pledging arrangement implied decisions being made in unoccupied territory and that, pursuant to the Law of 2 February 1940, such decisions did not fall within the competence of the board of directors

72 ARA, Pierlot Papers, 'correspondance': letter of 04.03.1941 from Theunis to Gutt.

73 BNB, Archives, SD, London Archives (p. 40): letter of 20.03.1941 from Baudewyns (London) to Ansiaux (Lisbon).

74 BNB, Archives, SD, London Archives, 1941, 2: letter of 15.04.1941 from Kauch (Paris?) to Baudewyns (London).

75 BNB, Archives, SD, London Archives, 1941, 2: letters of 24.03.1941, 15.04.1941, and 30.05.1941 from Ansiaux (New York) to Baudewyns (London).

76 BNB, Archives, SD, London Archives, dossier 'or': note relative au dépôt de l'or confié par la BNB à la Banque de France (annexes 127 and 128: draft of 31.10.1941 of a letter and of a pledging by the Banque de France to the Bank).

77 BNB, Archives, Contentieux, dossier 'Miomandre': letter of 15.11 .1941 from Marcq to Goffin. 
in Brussels ${ }^{78}$. With this, the matter of the gold was closed for the Bank in the occupied area.

\section{THE RESTORATION OF LUXEMBOURG'S GOLD}

Within the context of the Belgo-Luxembourg Economic Union (established on 25 July 1921), and following the Belgo-Luxembourg monetary convention of 23 May 1935, the Caisse d'Epargne du Grand-Duché de Luxembourg had deposited 357 gold bars in safe custody at the Bank during the immediate years before the German invasion. The gold, 143.3 million Belgian francs' worth, together with a number of Luxembourg securities, in fact acted as security for the drawdown of advances from the Bank. In May 1940, the Bank evacuated that gold to France, along with the final shipment of Belgian gold. In legal terms, however, the Bank was, and remained, the sole depositary of the Luxembourg gold; all that the Banque de France was responsible for was the Belgian gold ${ }^{79}$.

With the incorporation of the Grand Duchy of Luxembourg into the German Reich in the course of August 1940 came a Luxembourg Civil Administration. On 27 August, it issued an ordinance requiring all residents and legal persons of the Grand Duchy - including the Caisse d'Epargne - to declare the gold they possessed and offer it for sale to the Reichsbank, and to do so before 15 September $^{80}$. On 30 August, consequently, the Caisse d'Epargne requested the Bank for the return of its gold. Janssen replied that the Bank was in neither a practical nor a legal position to comply, since the gold was overseas, beyond the Bank's reach. Additionally, he pointed out that article 7 of the Belgian decree of 7 February 1940 had, in any case, deprived the board of directors in

78 вNB, Archives, Contentieux, dossier 'Miomandre', annex 130: letter of 17.11.1941 from Goffin to de Boisanger.

79 Freiburg im Breisgau, Militär Archiv, Militärverwaltung, dossier Rw 36/277: Hofrichter, Abschluszbericht der Militärverwaltung in Belgien und Nord-Frankreich, 1940-1944, Part 1, p. 96.

80 In respect of what follows, see the detailed review of P. Kauch: BNB, Archives, Studiedienst, 8, dossier 01.02.01.70 (A 240/5, s.f. 1): note relative aux rapports entre la BNB et le Grand-Duché et principalement au dépôt d'or confié à la première par la Caisse d'Epargne du Grand-Duché de Luxembourg. 
Brussels of the authority to take executive measures, such as the return of the Luxembourg gold ${ }^{81}$.

In a letter of 5 February 1941, the Caisse d'Epargne authorized or, rather, instructed the Bank to transfer the gold bars it had deposited with the Belgian central bank to the Reichsbank in Berlin under the same legal formula, i.e. as a deposit in safe custody. It added that, once the instruction had been carried out, the Bank could demand from the Reichsbank a certificate of full discharge from its responsibility as depositary. The German commissioner acting as intermediary in the negotiations left no doubt that the instruction was not a simple request, but a formal order implying immediate execution. Janssen wondered whether he was, in fact, empowered to comply with the order without the express authorization of the Luxembourg government in exile in London. But he had to take account of the ordinance of 16 December 1940 issued by the Military Government in Brussels, whereby the commissioner had been given the authority to take all such measures on behalf of the Bank ${ }^{82}$.

In weighing up the various arguments, Janssen apparently decided that he could not ignore the Brussels ordinance and consequently could no longer hinder the transfer to Berlin, responsibility for which he felt he could shift onto the Banque de France ${ }^{8_{3}}$. In a letter of 17 April 1941 to the French central bank, Janssen declared that the Bank had no objection to the Caisse d'Epargne approaching the Banque de France directly for restoration of the Luxembourg gold ${ }^{84}$.

The Banque de France realized which way the wind was blowing and knocked the ball back into the Belgian camp, informing the Bank on 13 May that any withdrawal of gold from the deposit and its transfer to the Reichsbank was a matter for the Bank. The Bank therefore had to give the Banque de France the necessary instructions and authorizations to

$81 \mathrm{Ib}$., note de Kauch: letter of 05.09.1940 from Janssen to the Caisse d'Epargne du Grand-Duché de Luxembourg.

82 BNB, Archives, $S D$, Malaise Papers, dossier 9.5.5./ s.f. 2: note de E. Miomandre (livraison de l'or détenu pour compte de la Caisse d'Epargne du Grand-Duché de Luxembourg), memorandum of 21.02.1941.

83 BNB, Archives, SD, Ingenbleek Papers, rapports 1.1, s. f. 1: letter of 28.09.1944 from Ingenbleek to Theunis.

84 BNB, Archives, SD, Ingenbleek Papers, rapports 1.1, s. f. 1: letter of 28.09.1944 from Theunis to Ingenbleek. 
identify the gold bars in question and, moreover, explicitly mandate it to execute the transfer to Berlin.

The Caisse d'Epargne drew no benefit from the dispute between the Belgian and French central banks and consequently changed its tack. In a letter of 11 June 1941, it requested the Bank to have the gold transferred directly to itself and not made available to the Reichsbank. A reply stated that the requisite signatures from the Luxembourg side were lacking for the instruction to be given to France. These were promptly forwarded, in conformity with the institution's bye-laws, but were found to be of directors who at the time were managing the institution with the approval and under the control of the Germans. Consequently, they had not acted of their own free will. Pursuant to a decree of the Luxembourg government in exile in London, issued on 5 February 1941, they no longer even had dispositional power ${ }^{85}$. The Bank, nonetheless, acknowledged the signatures and, in a letter of 11 July, signed by the acting governor Ingenbleek ${ }^{86}$ after Janssen's death in June, instructed the Banque de France to place the 357 Luxembourg gold bars at the Caisse d'Epargne's disposition and to discharge the Bank from its responsibility for the deposit. The Banque de France promised to execute the instruction as quickly as possible after the necessary identification process, not forgetting to add that it was not the Banque de France, that should discharge the Bank from its responsibility, but the Caisse d'Epargne, since the Bank and not the Banque de France was legally the depositary of the Luxembourg gold ${ }^{87}$.

In September 1941, the Banque de France received and immediately executed an order from the Caisse d'Epargne to place the gold at its disposition. The beginning of 1942 saw the Bank repeatedly requesting the Caisse d'Epargne to be discharged of its responsibility as depositary. Discharge was finally granted on 16 June of that year, bringing all the necessary formalities to an end.

85 BNB, Archives, Studiedienst, 13, dossier 01.02.01.70 (A 320/5): memorandum of 29.05.1943 from Rolin.

86 BNB, Archives, SD, Ingenbleek Papers, rapports 1.1, s. f. 1: letter of 26.09.1944 from Kauch to an unnamed director of the Bank.

87 BdFr, Archives, Secrétariat Général, dossier 1060.2001.01/41, 'or belge': entretien avec M. Schroeder (Luxembourg) à la Banque de France, 21.07.1941; Direction de la documentation, dossier 1397.1994.01/79, 'or belge': visite de M.K., 25.07.1941. 



\section{CHAPTER 11}

\section{In the Shadow of Janssen's Death}

\section{THE PROBLEM OF THE SUCCESSION}

Janssen's death on 6 June 1941 thoroughly dislocated the operation of the Bank and the Banque d'Emission, of which he was respectively governor and chairman. Although Belgian government circles in London certainly valued him as a person, they, nevertheless, had become increasingly critical of his policy and had taken particular exception to the stance he had taken in the question of the gold, which they regarded as a very grave error ${ }^{1}$. After the war, because of the courage he had shown and his old friendship with Gutt, all these errors, however, were to be treated tactfully.

The death of Janssen immediately prompted a wave of speculation about the succession, the Dutch-language newspapers in particular circulating the names of a series of former ministers, university professors and leading figures in banking ${ }^{2}$. All the while, busy discussions were taking place in Brussels behind the scenes. Playing a central role in the discussions was the Deputy-governor, Ingenbleek, now acting governor, whose chief concern was to prevent an outsider predisposed towards the Germans being appointed to the vacant governorship. In normal circumstances, the governor of the Bank would be appointed by the King, on the proposal of the Minister of Finance, but Ingenbleek took the view that the current circumstances of war required the new governor to be appointed by the Secretary-general of the Ministry of Finance, with the approval of the military commander of the occupying forces ${ }^{3}$. Secretary-general Plisnier took the same line ${ }^{4}$.

1 In this respect, see: BNB, Archives, Studiedienst, 13, dossier A 320/6: letter of 18.07.1956 from the military prosecutor Walter Ganshof-van der Meersch to Kauch. .

KP, Archives, fonds Leopold III, farde 243: note (de Capelle) pour le Roi, 10.06.1941.

4 BNB, Archives, SD, Ingenbleek Papers: letter of 12.06.1941 from Ingenbleek to Plisnier. In respect of the special competences of the secretaries-general during the 
For Plisnier, the obvious candidate was Ingenbleek. However, he declined the invitation, stating health grounds ${ }^{5}$. In turn, he proposed the French-speaking Goffin, who was from Brussels and a director of the Bank. This meant that the governorship would again be in the hands of a French speaker, though that imbalance would be offset by the Dutch-speaking Van Nieuwenhuyse, succeeding Goffin in the board of directors. This arrangement found consensus within the Bank and ultimately Plisnier, too, gave it his blessing. Galopin found it an acceptable proposal, having no liking for the idea of a Dutch-speaking governor and even less for a banker drawn from the competition ${ }^{6}$.

Von Becker and Hofrichter felt that Ingenbleek was the proper candidate for the governorship. Should he decline, however, the Military Government's choice would fall on the recently appointed director, Berger, above Goffin'. Ingenbleek vigorously opposed that choice, arguing that Berger's appointment would leave a bad impression among leading circles of the country and that his earlier appointment as director, against the candidate of the Bank and the entire financial and industrial world, had been forced on the Bank by the occupier. Now to appoint him as governor would be unacceptable and be regarded as a 'coup de force' on the part of the occupying authority. With that, the Germans dropped their candidacy of Berger and accepted Ingenbleek's suggestions.

On 16 July 1941, by order of Secretary-general Plisnier, and with the approval of General von Falkenhausen, Goffin was appointed governor $^{8}$. The general meeting of 23 August appointed Van Nieuwenhuyse as director $^{9}$ and, on 25 August, Basyn as secretary ${ }^{10}$. Finally, on 3 Septem-

war, see also: SOMA, Archives, CRE, 7 B5: Commission d'enquête des secrétaires généraux (Commission Tschoffen), rapport Plisnier, dossier 44, p. 60 ff. See also: ARA, fonds ministerie van Financiën, Secretariat-general, 1940-1945, dossier 725: letter of 17.12.1945 from Plisnier to J. Duquesne de la Vinelle, chairman of the BEB Commission of Enquiry. BNB, Archives, $S D$, Ingenbleek Papers: letter of 12.06 .1941 from Ingenbleek to Plisnier.

6 See the newspaper Le nouveau journal, 19.06.1941.

7 KP, Archives, fonds Leopold III, farde 243: note (de Capelle) pour le Roi, 10.06.1941. See also: Nefors, Industriële collaboratie in België, pp. 112-113.

8 BNB, Archives, RR, 23.07.1941.

9 BNB, Archives, AV, 25.08.1941.

10 BNB, Archives, $S D$, Basyn Papers, s. f. 6: note de Basyn relative à sa nomination de secrétaire de la BNB, 01.09.1941. 
ber during an extraordinary general meeting of the Banque d'Emission, Goffin was chosen as that institution's chairman, Van Nieuwenhuyse being appointed as managing-director to replace him, and Basyn as secretary $y^{11}$. This settled the question of Janssen's succession.

\section{A NEW ADMINISTRATION}

Following his return to Brussels in July 1940, Janssen had taken virtually sole control of both the Bank and the Banque d'Emission, the other leaders having practically no part of any significance to play, but Janssen's death brought a total turnaround in the way the Bank was led. Goffin, the new governor was the very opposite of his predecessor, eschewing leadership and decision-making, and feeling secure in a resolution only if it had been reached collectively by the board of directors $^{12}$. In addition, Goffin accepted as a matter of course the tutelage of Galopin, who, via the board of directors of the Banque d'Emission, now clearly asserted his dominating influence ${ }^{13}$. Ingenbleek, who, as acting governor, had come more to the fore during the interregnum, now opted to act chiefly behind the scenes as an éminence grise ${ }^{14}$.

From Janssen, Berger had inherited the portfolio of foreign relations. This heavy responsibility reinforced his authority and made him a key player in the management of the Bank and the Banque d'Emission. Van Nieuwenhuyse initially kept himself in the background, but after a brief period of settling in to his task, he became more active in matters of general management and even took the lead in the hard position adopted against the excessive demands of the occupier.

Kauch became Goffin's private secretary, but only in respect of the Bank, not the Banque d'Emission ${ }^{15}$. Whether this was a sign of distrust

11 BNB, Archives, $A V$ BEB, 03.09.1941.

12 BNB, Archives, London Archives, dossier 9.1 /25, s. f. 1: documents du Haut Commissariat à la sécurité de l'Etat, Banque Nationale de Belgique.

13 SOMA, Archives, Prack Papers, dossier JP 965: Vier Jahre Besatzungszeit in Belgien. Persönliche Erinnerungen von Herbert Prack, p. 18.

14 Belgian State Security in London described Ingenbleek as follows: 'Appartient à la catégorie de ceux qui depuis 1940 se sont cantonnés dans une attitude prudente et expectative. Anglophobe.' (BNB, Archives, London Archives, dossier 9.1 /25, s. f. 1: documents du Haut Commissariat à la sécurité de l'Etat, Banque Nationale de Belgique).

15 Krijgsauditoraat, dossier CI 47/44, 'BEB', 3, farde 4: 64 dépositions entre le 15 décembre 1944 et le 28 novembre 1945 ( $n^{\circ} 25$ : Kauch). 
on the part of the bankers and industrialists or of Goffin himself is difficult to say, but the argument could be made for both possibilities. On the one hand, the bankers and industrialists on the board of directors of the Banque d'Emission considered Kauch as a Bank man who was not really behind them ${ }^{16}$; on the other, Goffin and the members of the Bank's board of directors felt that Janssen had placed too implicit a trust in a person that did not entirely merit $\mathrm{it}^{17}$. Whatever the truth of the matter, Kauch's influence on the management and his impact on the policy of the Bank and the Banque d'Emission clearly waned after Janssen's death ${ }^{18}$. This contrasted with the substantial rise in the prestige and authority of Cracco, head of the Foreign Department ${ }^{19}$, whose impressive memoranda on the development of clearing and its monetary implications served as a guideline for the management.

Janssen's death also brought considerable changes in the power and management structures of the Bank and the Banque d'Emission. The banker-founders of the Banque d'Emission now abandoned their policy of standing aloof and took control of the institution, as well as of the Bank. Henceforth, they - Galopin, M.-L. Gérard, A.-E. Janssen, de Munck, Collin and Paul de Launoit - regularly convened separate meetings with the directors of the Bank and managing directors of the Banque d'Emission, where they set out the guidelines for policy that were later submitted for discussion and approval by the supervisory council of the Bank and the full board of directors of the Banque d'Emission, on which body the German commissioner von Becker and Secretary-general Plisnier also sat. The strong man in the new power structure was Galopin, while Goffin, in spite of being respectively governor and chairman, clearly played second fiddle ${ }^{20}$.

16 BNB, Archives, $S D$, Malaise Papers: Kauch, La Banque Nationale (unpublished text).

17 Baudewyns Family Archives: letter of 16.06.1941 from Baudewyns (London) to his son (Oxford).

18 BNB, Archives, London Archives, dossier 34: letter of 21.08.1941 from Ansiaux (New York) to Baudewyns (London); BNB, Archives, Studiedienst, 13, dossier A 320/12: note de Kauch du 15 mai 1942, relative aux documents demandés par Ansiaux.

19 Baudewyns Family Archives: letter of 16.06 .1941 from Baudewyns (London) to his son (Oxford).

20 SOMA, Archives, Prack Papers, dossier JP 965: Vier Jahre Besatzungszeit in Belgien. Persönliche Erinnerungen von Herbert Prack, pp. 18-19. See also: BNB, Archives, $S D$, 12, dossier 8.11/1, s. f. 5, 'période de guerre': note de couverture, 04.12.1941 (la Banque Nationale...sa soumission aux banques privées est lamentable). 
Cooperation between the Banque d'Emission and the Ministry of Finance languished and the focus of attention diverged. Plisnier felt less concern about the policy of resuming work, as his main concern was to reduce the costs of occupation, even if that meant getting them shifted to the area of clearing. The priorities of Galopin and the Banque d'Emission were precisely the opposite, being increasingly to limit payments via the clearing system to the settlement of solely bona fide commercial transactions and to get all payments of a political nature and of a more doubtful commercial character transferred to occupation costs. The mutual understanding and solidarity between the Ministry of Finance and the Banque d'Emission, therefore, began to show cracks that would ultimately become a dramatic rift between what were two of the country's key bodies ${ }^{21}$.

The change was no less fundamental at a second level. Among the secretaries-general Plisnier lost influence to his colleague Leemans, Secretary-general of the Ministry of Economic Affairs ${ }^{22}$. As soon as the administrative organization of the country began to operate more or less reasonably again, the Military Government evinced greater interest in the economy, looking to integrate Belgian industry as fully as possible into the German war effort. Leemans had successfully organized the German system of the Warenstellen and their Gruppen in Belgium: it made him very much 'their man' in the eyes of the Military Government.

The new organizations that came into being under the aegis of the Warenstellen-system began to share out the industrial orders for Germany among Belgian companies, at the same time providing them with the necessary raw materials. Initially, Galopin and his colleagues viewed this new, Germany-oriented industrial dirigisme with great suspicion, but gradually came to realize that they could hardly disregard it if they were to achieve their own economic agenda. They also saw that here was a means of shifting responsibility for possible economic collaboration by 'individual' companies' onto impersonal organizations within the system of the Warenstellen. Maybe this was an answer to why, even though initially shunned, Leemans eventually became less distrusted by the Brussels financial establishment?

21 See Chapters 18-19.

22 Nefors, Industriële collaboratie in België, pp. 57-59. 
The increasing influence exercised by the founder-bankers on Banque d'Emission and Bank policy created a sense of unease suspicion, even - among the members of the board of directors and supervisory council, respectively, who did not belong to the closed circle of the founders-bankers. One of the first to ask the pertinent questions that were in the minds of many of his colleagues was Maurice Frère, Chairman of the Banking Commission since 1938 and - on Janssen's proposal - appointed director at the Banque d'Emission at the end of 1940. Although the Bankaufsichtamt had assumed many of the Banking Commission's tasks, Frère had been able to maintain his authority in the financial world, thanks to his strong personality and, in part, to his contact with his friend Prack, who fed him vital inside information.

During a meeting of the board of directors of the Banque d'Emission on 20 August 1941, Frère raised certain important questions about the responsibility of the directors ${ }^{23}$. Pursuant to the bye-laws, the directors were required to 'advise' the managing directors. In order to carry out their task properly, however, the directors had to have comprehensive and correct information. According to Frère, this was not the case, though this was a deficiency not so difficult to repair. The main problem, however, lay in the limits and the content of the responsibility. Where did the advisory task of the directors begin and where did it end? How was their responsibility to be understood? In Frère's opinion, the responsibility was not clearly set out in the bye-laws and consequently more clarity was needed. Galopin and M.-L. Gérard, the two leaders of the bank's founder-bankers, felt they had to respond to this. Galopin himself spoke mainly about the question of responsibility, stating that there was no split between board of directors and managing directors: responsibility had to be borne in a spirit of cooperation between the two.

\section{THE FIRST GREAT DISILLUSIONS}

In early 1941, it was rumoured that certain government circles in Berlin were planning to integrate Belgium, the Netherlands and Northern France fully into the German economy by means of a customs union

23 BNB, Archives, $B R B E B, 20.08 .1941$. 
linked with, or followed by, a monetary union ${ }^{24}$. It was also being said that Hofrichter was completely won over by the $\operatorname{plan}^{25}$. In the opinion of the bankers, such a policy of Gleichschaltung would be catastrophic for the country, destroying entirely its monetary, industrial and financial autonomy.

At the beginning of April, Galopin made a secret trip to Berlin, hoping to use his contacts in the banking world to find out more about the plan and to halt its implementation insofar as Belgium was concerned ${ }^{26}$. He knew that he had a fair amount of backing at home, in that he could count on the support of the Military Government: both von Falkenhausen and Reeder were marked opponents of any form of customs or monetary union, and the secretaries-general were likewise against; indeed, Leemans himself had gone to Berlin at the end of March to get the German government to drop the idea. In Berlin, the two Belgians were reassured by their hosts that the decision rested for the time being with the Military Government, which was their partner in the matter. Galopin and Leemans made use of their visit to set out the advantages of a policy of contract work (Auftragsverlagerung), whereby German industrial orders would be placed increasingly in Belgium; in return, the German authorities would undertake to discourage the emigration of Belgian labour to Germany and to ensure a better supply of food and raw materials from Germany to Belgium ${ }^{27}$.

The argument for a policy of Auftragsverlagerung was not an easy one to make; there was indeed a major pitfall, such a policy requiring a readiness to increase Belgian industrial production in favour of Germany. Galopin realized that he could not take responsibility for such a major decision alone, but Gutt's letter of the end of February - sent via Lisbon to the Société Générale de Belgique and expressing the minis-

24 Joh. de Vries, De Nederlandsche Bank van 1914 tot 1948. Trips tijdvak, 1931-1948, pp. 244-255 and 273. See also, Klemann, Nederland, 1938-1948, pp. 143-145.

25 BNB, Archives, Studiedienst, dossier 01.02.01.70 (A 237/ 1, s. f. 10): memorandum of 24.03.1941 from Leemans for the secretaries-general (report: journey to Berlin, 1923.03.1941).

26 ARA, fonds Société Générale de Belgique, Direction, Galopin Papers, letter of 30.08.1945 from Dubois-Pélerin to the Military prosecutor Wilmart.

27 Nefors, Industriële collaboratie in België, pp. 92-95; BNB, Archives, Studiedienst, dossier 01.02.01.70 (A 237/1, s. f. 10): memorandum of 24.03.1941 from Leemans for the secretaries-general (report: journey to Berlin, 19-23.03.1941). 
ter's understanding for the export of industrial products to Germany in exchange for food - perhaps gave him the courage to take on the challenge of getting the policy introduced, in the conviction that he had sufficient, though vague, approval from the Belgian government in London ${ }^{28}$.

On 1 April 1941, reassured by this, Galopin convened a meeting at the Société Générale de Belgique in Brussels of leading figures from the magistracy and the legal profession, as well as from the monetary, financial and industrial world, to discuss the problem of economic collaboration. How was Belgian business to react to Germany's unwillingness during the previous winter months to give help of any substance in solving the problem of food shortages in Belgium? Ought the export of industrial goods from Belgium to Germany consequently be halted or scaled back? Or ought the exports to be continued so as to hinder the emigration of labour to Germany and to put greater pressure on Germany to supply more food and raw materials ${ }^{29}$ ?

In preparation for that meeting, Galopin had obtained the legal opinion of the jurists Marcq and Hermans, and had also asked Collin, who combined his chairmanship of the Kredietbank with a professorship in penal law, to prepare a memorandum on the scope of article 115 of the Penal Code, in respect of economic collaboration ${ }^{30}$. In strict terms, according to the three jurists, any exports to Germany, and $a$ fortiori any increase in them, was regarded as a form of economic help to the enemy; all exports, thus, fell within the scope of application of article 115. However, its application could be escaped through the introduction of the 'state of emergency' and in view of the concept of 'the policy of the least evil'. Galopin had the impression that, in light of the state of emergency, there was sufficient consensus in the meeting for the policy of work resumption to be retained as acceptable and even to be continued. In a memorandum of 24 June 1941 he suggested that the

28 LLN, Archives, A.-E. Janssen Papers, dossier 5: letter of 22.02.1941 from Gutt (London) to Cattier (via Ansiaux at Lisbon).

29 Van der Wee and Verbreyt, De Generale Bank, 1822-1997, pp. 270-271. See also: Nefors, Industriële collaboratie in België, pp. 99-100.

30 Collin, 'De politiek van tewerkstelling tijdens de bezetting', in: Mededelingen van de Koninklijke Academie van België. Klasse der Letteren, 39/1, 1977, pp. 3-10. See also: Nefors, Industriële collaboratie in België, p. 99. 
country's total industrial production be raised from 60 to 80 per cent of the pre-war level ${ }^{31}$.

The sense of crisis and unease during the spring of 1941 was fed further by the alarming development regarding the costs of occupation. From the outset, they had been high - too high, even - and had given Plisnier, as Secretary-general for the Ministry of Finance, responsible for their payment, nightmares. To be able to finance them, he regularly called on the Bank for the necessary resources, which were provided in the form of advances to the Treasury. In the beginning, according to the Military Government, there were particular reasons for the costs of occupation and billeting to be high. In June 1940, Belgium and Northern France represented the springboard for the German army's further conquest of France and, after this had been completed, for the planned conquest of England, for which a million soldiers had been assembled in the territory. Plisnier and Janssen had argued that assault troops could not be classified as part of the army of occupation and that, in accordance with the Hague Convention, their costs could not be charged. Studies made by the Ministry of Finance, the Bank and the Société Générale put the monthly cost of the occupation at a maximum of 400 million Belgian francs, but much more than double that amount was being demanded ${ }^{32}$. Resistance, however, was in vain, as von Falkenhausen and Reeder argued that they could not go against formal orders from Berlin.

The definitive abandonment of the invasion of England (Operation Sea Lion) in the spring of 1941 and the preparations for the attack on the Soviet Union (Operation Barbarossa) reduced the number of German troops quartered on Belgian soil to about $40,000^{33}$. During talks with

31 Nefors, Industriële collaboratie in België, pp. 94-95; De Vlaminck and De Vos, 'De Belgische industriëlen tijdens de bezetting, 1940-1944', in: Belgisch Tijdschrift voor Militaire Geschiedenis, 26, 2 (June 1985), pp. 117-122.

32 SG, Archives, Direction, Galopin Papers, dossier 64: aide-mémoire pour la réunion restreinte du 7 janvier $1942 \mathrm{chez} \mathrm{Mr}$. Plisnier (rappel à la réunion du 12 novembre $1941 \mathrm{chez}$ Mr. Plisnier).

33 Ndl.Bz, Archives, dossier 5512 GA: letter of 04.10.1941 from the Dutch agent at Lisbon to his Minister of Foreign Affairs (London) (account of a conversation at Lisbon of Luns, attaché to the legation, with P. Heymans, chairman of the Belgian food aid campaign Winterhulp). 
Plisnier ${ }^{34}$, the Military Government now indicated that it was looking ${ }^{35}$ to be able to grant a reduction in the occupation costs and at the same time set a ceiling for them ${ }^{36}$, but nothing came of either initiative. All that resulted from Plisnier's efforts was that the costs imposed were stabilized at 1 billion Belgian francs for the third quarter of $1941^{37}$; even so, this did not stop the Military Government from feeling obliged to demand an additional 250 million Belgian francs for that quarter, as an advance on subsequent monthly charges.

All this left Plisnier utterly disillusioned. On 1 August 1941, following Galopin's example, he invited a number of leading Belgian figures to the Ministry of Finance for consultations about the question of occupation $\operatorname{costs}^{38}$. At the meeting, he asked whether they would agree to his using his resignation as a means of obtaining a reduction in the costs. Those present advised him most strongly against adopting such a course: resignation would achieve nothing and serve only to exacerbate the problem; furthermore, the German authorities would simply appoint someone tractable to their measures in his place. Galopin felt that Plisnier ought to continue to argue for a reduction, but to use strong and concrete arguments, such as a comparison with the costs of the FrancoBelgian occupation of the Rhine during the 1920s. Plisnier ought also to point out that the occupation costs were putting the economy under so much pressure that ultimately there could be no question of any further industrial help being given to Germany by Belgium.

Plisnier set to work and produced a memorandum on 9 August. In this, he forecast that the costs of occupation and billeting for 1941 would exceed 14 billion Belgian francs. This was a higher amount than the country's tax receipts, estimated at 13 billion Belgian francs, which naturally had to serve to finance not only the occupation costs, but also

34 BNB, Archives, RR, 09.07.1941; BNB, Archives, BR BEB, 17.09.1941.

35 BNB, Archives, Prack Papers, dossier 1: Zweiter Jahresbericht des Kommissars bei der Nationalbank von Belgien (Mai 1941-Mai 1942), Brussels, 26.05.1942, p. 3.

36 Freiburg im Breisgau, Militärarchiv, dossier Rw 36/277: Hofrichter, Abschluszbericht der Militärverwaltung in Belgien und Nord-Frankreich, Part 1, pp. 11-12.

37 BNB, Archives, $S D$, 12, dossier 8.11/2: notes confidentielles diverses (memorandum of 09.08.1941 from Plisnier).

38 At the meeting were Jamar, Davignon, Gesche, Goffin, Heymans, Hayoit de Termicourt, Galopin, Ingenbleek, A.- E. Janssen, de Launoit, M.-L. Gérard, Lippens and O. Gérard. 
normal State expenditure. Quite simply, Belgium's public finances were in a pitiable state. According to Plisnier, the distress caused by the war virtually excluded any increase in taxation, so that the Treasury would necessarily have to turn to advances from the Bank and to loans from the banks and the public ${ }^{39}$.

The Military Government was uncomfortable with the occupation costs. Both von Falkenhausen and Reeder, in fact, also considered them to be excessive and hoped to be able to have them reduced, following the move of military activity to the Eastern front. However, Berlin decided otherwise. With operations on the Eastern front demanding so much more additional resources, German needs were rising spectacularly and a range of specialized German procurement agencies began to purchase goods in Belgium on an increasing scale, even unashamedly scouring the parallel or 'black' market there ${ }^{40}$. All those purchases were initially entered as occupation costs, which is why, instead of declining, those costs went up in the course of 1941 and why the Military Government found itself obliged to raise them by 50 per cent with effect from 1 October, i.e. from 1 billion to 1.5 billion Belgian francs per month ${ }^{41}$.

\section{OCCUPATION AND ECONOMY (MAY 1940-MAY 1942)}

The high costs of the occupation and the payment of the clearing balances were chief factors in a spectacular expansion of the money supply, as Table 11.1 shows clearly.

The expansion of the money supply naturally had an effect on the economy as a whole. Industrial companies, retail businesses and small tradesmen were now swimming in cash, but cash that could not be invested in either stocks or technical equipment ${ }^{42}$, so that much of it was

39 вNв, Archives, Studiedienst, 8, dossier 01.02.01.70 (A 240/5, s. f. 5): situation financière, économique, alimentaire et sanitaire de la Belgique après 20 mois d'occupation (beginning of 1942).

40 BNB, Archives, SD, Prack Papers: Zweites Jahresbericht des Kommissars bei der Nationalbank von Belgien (Mai 1941-Mai 1942), Brussels, 26.05.1942, p. 3.

41 BNB, Archives, DC, 01.10.1941.

42 BNB, Archives, Studiedienst, 4, dossier 01.02.01.70 (A 239/7): notes de Kauch pour M. le Directeur Berger, 04.08.1941. 
Table 11.1: Development of the money supply in Belgium (10.5.1940-31.12.1942) (in millions of Belgian francs)

\begin{tabular}{lrrrrrr}
\hline Date & $\begin{array}{r}\text { Banknotes in } \\
\text { circulation }\end{array}$ & $\begin{array}{r}\text { Coins in } \\
\text { circulation }\end{array}$ & $\begin{array}{r}\text { Balances in } \\
\text { current account }\end{array}$ & $\begin{array}{r}\text { Postal cheque } \\
\text { account }\end{array}$ & $\begin{array}{r}\text { Demand accounts } \\
\text { at private banks }\end{array}$ & $\begin{array}{r}\text { Total } \\
\text { (appr.) }\end{array}$ \\
\hline 10.05 .40 & 29,806 & 1,607 & 909 & 4,668 & 13,620 & 50,600 \\
31.12 .40 & 35,453 & 2,302 & 1,799 & 5,311 & 14,151 & 59,000 \\
31.12 .41 & 48,942 & 3,420 & 2,348 & 7,401 & 17,788 & 80,000 \\
31.12 .42 & 68,636 & 3,918 & 4,563 & 7,714 & 22,283 & 107,000 \\
\hline
\end{tabular}

Source: V. Janssens, De Belgische frank, p. 293.

simply deposited with the banks. At the time, however, there was no private-sector demand for bank credit and so the banks saw the massive credit requirements of the State as a welcome investment alternative, even though they had to be satisfied with low rates of interest: for example, 1 15/16 per cent per year for 4-month Treasury certificates ${ }^{43}$.

Together with a general shortage of goods, the expansion had a clear effect on the level of prices. Officially, these were subject to strict regulation and remained stable, but they soared on the parallel or 'black' market, particularly from 1942 on. As already mentioned, German procurement agencies were active on a large scale on the Belgian black market, but they were not alone, because much of the population was necessarily also having recourse to it. The Belgian ration of barely 1,300 calories per adult per day (compared to 2,00o calories in Germany and 1,750 calories in the Netherlands) was clearly inadequate, so that every household, within the limits of what it could afford, was obliged to resort to an alternative source ${ }^{44}$.

43 BNB, Archives, Prack Papers: Zweiter Jahresbericht des Kommissars bei der National Bank von Belgien (Mai 1941-Mai 1942), Brussels, 26.05.1942, p. 28.

44 BNB, Archives, Studiedienst, 8, dossier 01.02.01.70 (A 240/5 s. f. 5): situation financière, économique, alimentaire et sanitaire de la Belgique après 20 mois d'occupation (beginning of 1942), pp. 8-12. 


\section{The Gold Cover and the Clearing System under Discussion}

\section{THE DILEMMA CONCERNING COVER FOR THE NOTE ISSUE}

The growing circulation of banknotes during 1941 placed the Bank in a dilemma regarding the legal requirement to hold a minimum quantity of gold - 40 per cent - as cover for its direct obligations to pay cash. That requirement dated back to 1850 , the date of the institution's establishment, when the minimum quantity was set at 30 per cent. That minimum had been raised to 40 per cent in 1926 and had been reaffirmed in article 7 of royal decree of 24 August $1939^{1}$.

With the occupation, the question of the cover requirement surfaced again. Within a very short time, the issue of banknotes had expanded to an unprecedented degree. A prime reason for this was the enormous amounts that the Bank was advancing to the Treasury to pay the costs of occupation; another lay in the fact that the clearing balances and the conversion of Reichskreditkassenscheine had to be settled in Belgian francs. As a result, the Bank was forced to provide a continuous flow of banknotes, thereby skewing the cover percentage ${ }^{2}$. With the outlook for the months ahead certainly offering no improvement, Goffin, the new governor, decided to place the problem on the agenda of a meeting of the board of directors ${ }^{3}$.

The board found the matter too complicated and its implications too far-reaching for an immediate decision to be made ${ }^{4}$, deferring the decision until it had obtained opinions from the jurists Marcq and Van

1 Van der Wee and Tavernier, De Nationale Bank van België, pp. 198-199, 308.

2 BNB, Archives, AR, 24.09.1941.

3 BNB, Archives, DC, 27.08.1941.

4 BNB, Archives, DC, 06.09.1941. 
Dievoet, as well as from economists, in this instance Professor Dupriez and Jean-Jacques Vincent, head of the Bank's Economic Research Department. Furthermore, the director Berger would consult the Bankaufsichtamt and Ingenbleek would take up the question with Raoul Hayoit de Termicourt, Advocate-general of the Court of Cassation.

Three aspects of the problem were examined during the consultations: legal, economic and ethical. The legal aspect could itself be viewed from a logical or from a formal standpoint. Logically, following the suspension of the Belgian franc's gold convertibility on 10 May 1940, the Bank was no longer subject to the cover requirement; indeed, convertibility was the raison d'être for the requirement: suspension of one meant that there was no sense in the other. In May 1940, however, the government had omitted to abolish the cover requirement. Thus, in formal terms the requirement was still in force. Insofar as it was considered possible for the Bank to continue to issue banknotes, it was up to the administration to find a legal measure to solve the problem. The economic aspect involved the threat of inflation: whether the Bank continued to issue banknotes or if the issue was taken over by another institution, money circulation would continue to expand, and price inflation with it. The ethical aspect, finally, involved criminal law and centred on the question of whether the continued issue of banknotes by the Bank or their issue by another institution did not imply the provision of financial aid to the enemy; again, article 115 of the Penal Code was hauled out for examination'.

There were three possible options to be explored, following a decision to halt the issue of banknotes by the Bank and to have that issue continued by another institution ${ }^{6}$. The first was a reintroduction of the Reichskreditkassenscheine: the board was chary of this, feeling that it left the door wide open for an uncontrolled plundering of the country. The second was for a proposal to the Military Government that it reintroduce the Reichsmark as legal tender. The reaction of the Board was also unanimously negative?.

5 BNB, Archives, Studiedienst, 1, dossier 01.02.01.70 (A 242/ 6), 'circulation': Kauch, note relative à la couverture légale, December 1942, pp. 5-6.

6 BNB, Archives, DC, 10.09.1941.

7 BNB, Archives, $S D, 12$, dossier 8.11/ 1, 'période de guerre', s. f. 5: la situation financière et monétaire aux Pays-Bas (memorandums of 08.12.1941 and 12.12.1941). 
The third option was to bring into circulation the banknotes of another Belgian institution, one that was not subject to the legal requirement of the cover percentage. Ingenbleek ${ }^{8}$ initially appeared to be in favour of this option and certain members of the supervisory council were definitely so. They continued to defend the idea, arguing that the issue function would thereby remain in Belgian hands and thus ensure Belgium of at least some control. It would also enable the Bank to meet its legal obligations and maintain intact its image as an independent institution'. Furthermore, a separate note issue agency within the Société Générale de Belgique had brought similar banknotes into circulation during the First World War and the formula had not led to any criticism after hostilities had ended.

If at first there was no immediate agreement within the Bank's board of directors about whether to accept or reject the third option, a clear consensus to reject it emerged, nevertheless, after far-reaching discussion and at Berger's prompting ${ }^{10}$. The board took the view that to have the Banque d'Emission issuing banknotes would create a situation of dual currency circulation, something that had more than once been proved to lead to monetary chaos.

The position adopted by the board of directors found support in the advice of the economists. Dupriez was very explicit: the population would regard Banque d'Emission banknotes or, as the case might be, Reichsmarks, as being inferior wartime money and that, in accordance with Gresham's Law (bad money drives out good), their circulation would encourage people to hoard the notes of the Bank. To keep the circulation of banknotes at a proper level, hoarding would have to be countered by additional quantities of banknotes of other origin being brought into circulation. After the war, that additional issue would represent a potential danger of inflation and give rise to psychological

8 BNB, Archives, SD, Ingenbleek Papers: Ingenbleek, problèmes de la vie sous l'occupation (X: La dépêche de M. Gutt à Galopin), p. 35.

9 BNB, Archives, $R R$, 14.01.1942; BNB, Archives, $S D$, 13, dossier 8.11/ 3, 'couverture': memorandum from the supervisory council, incorporating a report of two informal meetings of the board of directors and a few members of the supervisory council, 23.02.1942 and 25.02.1942.

10 BNB, Archives, Studiedienst, 1, dossier 01.02.01.70 (A 242/ 6), 'circulation': Kauch, note relative à la couverture légale, December 1942, p. 11-12. 
confusion and monetary chaos, thereby seriously hindering currency reform ${ }^{11}$.

The legal aspect of the matter was discussed during a meeting between Berger and Hofrichter on 10 September 1941. Both were agreed that, as the cover percentage had been imposed by law, it was only by a new law that it could be abolished, lowered or suspended. In the circumstances of war, with the Belgian government abroad, the measure would normally have to be taken by the Secretary-general of the Ministry of Finance.

In his opinion of 20 September 1941, the jurist Marcq assessed the competence of the Secretary-general to act as legislator in this matter in the place of the Belgian government in London. Basing himself on the arguments stated in the Court of Cassation's judgement (arrêt) of 7 April 1941, Marcq felt that the Secretary-general did indeed have that competence: 'si l'on reconnait aux secrétaires généraux un pouvoir législatif limité, l'on peut reconnaître au secrétaire général des finances le pouvoir de prendre la mesure envisagée, pour autant qu'il y ait urgence ${ }^{12}$. Consulted by Ingenbleek in December 1941, Hayoit de Termicourt spoke in similar terms ${ }^{13}$.

\section{TOWARDS A CONFRONTATION WITH THE MINISTRY OF FINANCE}

The option for a single currency in circulation implied shifting responsibility onto the Secretary-general's shoulders. Contacts with the Ministry indicated that Plisnier could in no way reconcile himself to the Bank's option. He certainly regarded himself as having the legal competence to suspend the article on coverage by decree, but considerations of professional ethics prevented him from doing $\mathrm{so}^{14}$.

In Plisnier's view, there was, first of all, no economic argument whatsoever to justify such a measure: economic production and activity had

11 BNB, Archives, DC, 12.09.1941 (Basyn, annexe au procès-verbal du comité de direction).

12 BNB, Archives, Contentieux, Miomandre Papers, dossier 'Marcq b': letter of 20.09.1941 from Marcq to Goffin.

13 BNB, Archives, SD, Basyn Papers, dossier 6: opinion of 03.11.1941, Hayoit de Termicourt.

14 Archives, SD, 13, dossier 8.11/ 3, 'couverture': annexes 3, 17 and 18. 
slowed to such a degree that the amount of currency in circulation ought to be reduced rather than increased, if it was to be commensurate with economic development. Secondly, there was a social argument to justify his refusal, in that suspension would open the floodgates for inflation and the hardest hit by it would again be salaried staff, wageearners and pensioners: in short, all those people on a limited and fixed income.

Plisnier had a third, more tactical reason for refusing, one that for him was very pertinent. In the run-up to the opening of the Eastern front, the Military Government had held out the prospect of a reduction in the costs of occupation and he was looking to open discussions in order to tie that reduction to a concrete figure; maintaining the cover percentage appeared to him to be a valuable means of applying pressure in his confrontation with the German authorities.

By the end of November 1941, the cover percentage had fallen to about 45 per cent and was being projected to fall to the minimum level of 40 per cent within a further three months. At this point, Goffin wrote officially to Plisnier to inform him of the alarming situation and to request him after all to promulgate the measure suspending the cover percentage $^{15}$. Plisnier answered that, until the occupier granted a reduction in the costs of occupation, he would refuse to proceed with the measure ${ }^{16}$.

The Bank, having initially thought that mutual discussion could iron out the difference of opinion with the Secretary-general, now began to see that Plisnier was not prepared to give way: not only was there no prospect of a reduction in the costs of occupation; on the contrary, they had just been increased. Thus, for the Bank only one option remained, i.e. the issue of banknotes by the Banque d'Emission. On 9 January, the Bank therefore resolved to propose that the Banque d'Emission begin printing its own banknotes under the signature of Goffin ${ }^{17}$.

The Military Government was very put out by Plisnier's continued refusal and the government in Berlin even more so, regarding his stance as a sign of unacceptable obstruction and even considering his

15 BNB, Archives, $D C$, 21.11.1941. See also: BNB, Archives, $S D$, 13, dossier 8.11/ 3, 'couverture': letter of 26.11.1941 from Goffin to Plisnier.

16 BNB, Archives, Studiedienst, 1, dossier 01.02.01.70 (A242/ 6), 'circulation': Kauch, note relative à la couverture légale, December 1942, p. 13. See also: BNB, Archives, DC, 08.01.1942.

17 BNB, Archives, DC, 09.01.1942. See also: BNB, Archives, $D C$, 31.01.1942. 
dismissal. Von Falkenhausen and Reeder did not wish to go that far, as they feared that revoking his appointment would provoke a wave of resistance in Belgian public circles; as always, they were against stirring up public opinion, preferring order and calm, and no friction or tension in the occupied territory that could have a negative effect on economic cooperation with Germany and fuel fresh criticism from Berlin of the Military Government's handling of policy in Belgium: increasingly they came to favour the idea of an ordinance obliging the Bank to continue issuing banknotes ${ }^{18}$. By 5 February 1942, the cover percentage had fallen to 42.48 per cent and two days later the Bank decided to make a final attempt to persuade Plisnier to revise his stance ${ }^{19}$.

Goffin put a clear choice before Plisnier. Both the Bank and the Ministry of Finance preferred a single currency to remain in circulation. For that principle to be maintained in the circumstances, article 7 of the royal decree of 1939 had to be amended or suspended and that could be done only by a decree of the Secretary-general or a by German ordinance. It was for the Secretary-general to decide. At the same time Goffin proposed that a number of leading figures from the Bank, the Banque d'Emission and the Ministry of Finance should meet to make a final attempt to reach a compromise ${ }^{20}$. Plisnier agreed to a meeting on 27 February.

During the intervening period, Plisnier was besieged by various prominent figures, each attempting to break the deadlock by personal discussion. The gulf, at first, appeared to be unbridgeable, but time that indefatigable ally of compromise - accomplished its work. The negotiators, indeed, did manage to extract a not unimportant compromise from the Secretary-general: at an informal meeting of the board of directors with members of the supervisory council on 25 February 1942 Smeers, the Government Commissioner at the Bank, let a few words drop that came as an enormous relief to all of them and opened the door to a solution: 'le refus de M. Plisnier d'intervenir lui-même par un arrêté n'exclut pas une autorisation accordée à la Banque d'obtemperer à

18 Soma, Archives, Prack Papers, dossier JP 965: Die Besatzungszeit in Belgien. Persönliche Erinnerungen von Herbert Prack.

19 BNB, Archives, Studiedienst, 1, dossier 01.02.01.70 (A 242/6), 'circulation': Kauch, note relative à la couverture légale, December 1942, pp. 15-18.

20 BNB, Archives, DC, 17.02.1942. 
une ordonnance allemande...' ('the refusal by Mr. Plisnier to issue a decree him self, does not exclude a consent, given to the Bank for complying to a German order' ${ }^{21}$. Now, at the formal meeting of 27 February, Goffin and Plisnier were able to declare without loss of face that, in the higher interest of the country, they were both prepared to accept a possible German ordinance suspending the cover requirement. Responsibility for implementing the ordinance would rest with the Bank ${ }^{22}$. The jurist Marcq also allied himself with this consensus ${ }^{23}$.

At its meeting of 5 March 1942, the supervisory council endorsed the agreement that been reached and authorized the board of directors to continue to issue banknotes. Next day, the cover requirement of 40 per cent was suspended by order of the military commander, von Falkenhausen ${ }^{24}$. On 9 April, the cover percentage fell below that requirement, but the Bank nevertheless continued to issue its banknotes ${ }^{25}$. The incident was closed. The wound probably healed, but the scar remained.

\section{THE CLEARING SYSTEM IN DISCREDIT}

Over and above the questions of the occupation costs and the cover percentage, a third and by no means minor problem confronted the Bank and the Banque d'Emission in the summer of 1941. It concerned the rapidly growing imbalance in the clearing operations with Germany and, to a less extent, with France and the Netherlands.

With the German attack on the Soviet Union on 22 June 1941, the war entered a new phase, one of total war, with German propaganda

21 BNB, Archives, SD, 13, dossier 8.11/ 3, 'couverture': RR, 25.02.1942 (report of two informal meetings, 23.02.1942 and 25.02 1942).

22 BNB, Archives, Studiedienst, 1, dossier 01.02.01.70 (A 242/ 6), 'circulation': Kauch, note relative à la couverture légale, December 1942, pp. 19-20.

23 BNB, Archives, SD, 13, dossier 8.11/ 3, 'couverture': letter of 28.02.1942 from Goffin to Plisnier; letter of 03.03.1942 from Plisnier to Goffin; supervisory council decision, 05.03.1942 (with a report of the meeting between Ingenbleek and Marcq concerning the agreement reached).

24 BNB, Archives, SD, 13, dossier 8.11/3, 'couverture': decision of the supervisory council, 05.03.1942; ordinance of 06.03.1942 of the military commander.

25 BNB, Archives, Studiedienst, 1, dossier 01.02.01.70 (A 242/ 6), 'circulation': Kauch, note relative à la couverture légale, December 1942, p. 20. 
claiming that the opening of the Eastern front ought to be recognized by the entire civilized world as a 'crusade against evil': who would want to avoid the sacrifices necessary to defend the 'values of the West' against such a pernicious soviet regime? Convinced or not, occupied Europe would be obliged to contribute to the struggle. For Belgium in particular, this had serious consequences for the flow of payments between her and Germany.

Plisnier saw the opening of the Eastern front differently. For him, it meant a considerable reduction in the number of German troops in Belgium ${ }^{26}$; consequently, there could be a sharp cut in the costs of occupation. Even the Military Government had to concede - reluctantly, it is true - that he was right ${ }^{27}$. Moreover, Reeder had been offering the prospect of a reduction since the spring of 1941. Aware of Belgian discontent at the high costs of occupation, in August 1941 the government in Berlin began to insist that certain transactions for the Wehrmacht be withdrawn from the sphere of occupation costs and be settled via the clearing system ${ }^{28}$.

Belgian exports to Germany were not subject to the normal requirement of a licence from the Clearing Office at the Ministry of Economic Affairs. As a result, control of what was being exported was possible only a posteriori, after the Verrechnungskasse in Berlin had demanded payment by the Banque d'Emission and invoices had been presented. Verification of the whole process was the responsibility of the inspection service at the Bank's Foreign Department, headed by Cracco.

In a memorandum of 1 August, Cracco drew the attention to the 'alarming' development within the Belgian clearing system and to the 'plundering' - there was no other word for it - of occupied Belgium ${ }^{29}$. He submitted a further memorandum on the same subject on $25 \mathrm{Au}-$ gust, together with a statistical review of clearing operations from July

26 Ndl.BZ, Archives, dossier 5512 GA: letter of 04.10 .1941 from the envoy in Lisbon to the Minister of Foreign Affairs (London).

27 Ndl.BZ, Archives, dossier 5512 GA: letter of 04.10.1941 from the envoy in Lisbon to the Minister of Foreign Affairs (London).

28 BNB, Archives, DC, 29.07.1941. See also: Krijgsauditoraat, dossier GI 47/44 (BEB, 1): Hopchet, note au sujet des banques allemandes, 25.06.1945.

29 BNB, Archives, SD, 32, Cracco Papers, dossier 8.11.26/ 2: Cracco, note relative aux clearings, 01.08.1941. 
1940 to July 1941. He emphasized that the Belgo-German clearing system in force no longer had anything to do with the system of traditional offsetting agreements, which did not permit long-term imbalances. Clearing operations were now taking on the form of the provision of a line of credit 'de telle manière que la mesure du crédit est fixée non plus par le donneur, mais par le preneur de crédit'. Moreover, the attendant risk was no longer being borne by the original private creditors, but by the entire community, which made the clearing system: 'un véritable complément de contribution de guerre ${ }^{30}$.

Table 12.1: Development of Belgian clearing accounts (total of Belgian balances) (in millions of Belgian francs)

\begin{tabular}{lr}
\hline Balance as at 31 October 1940 & 886 \\
Balance as at 30 November 1940 & 1,066 \\
Balance as at 31 January 1941 & 1,209 \\
Balance as at 31 March 1941 & 1,465 \\
Balance as at 31 May 1941 & 1,900 \\
Balance as at 31 July 1941 & 2,768 \\
Balance as at 2 August 1941 & 2,881 \\
Balance as at 17 August 1941 & 3,820 \\
Balance as at 27 August 1941 & 4,579 \\
\hline
\end{tabular}

Source: BNB, Archives, SD, Cracco Papers, file 8.11.26/2: memorandum of 25.08.1941; BNB, Archives, DC, 04.09.1941.

Analysis of the credit balance as at 31 July 1941 enabled Cracco to conclude that just 37 per cent of the total stemmed from visible trade, 24 per cent from invisible trade and 32 percent from capital transactions. This last figure was extremely disquieting. Initially, the balance had resulted from the transfers of gold and foreign currency from the Banque d'Emission to the Reichsbank. Since November 1940, however, the increasing balance was due chiefly to the proceeds from the sale of Belgian and foreign shares by Belgian companies to German buyers: the foreign securities apart, much of the sale had to do with the disposal of Belgian assets in South-eastern Europe, in the Balkans and in the Grand Duchy of Luxembourg, now annexed by Germany.

30 BNB, Archives, SD, 32, Cracco Papers, dossier 8.11.26/ 2: Cracco, quelques observations fondamentales sur le clearing (les enseignements d'une année d'expérience), 25.08.1941. 
The credit balance in the sector of invisible trade resulted primarily from the transfer of savings by Belgians working in Germany to their families in Belgium. That in the sector of visible trade was the largest in absolute figures, but in fact fairly modest in relative figures, due to the large volume of both imports and exports at the time. Heading exports were textile products, coal, crude steel, semi-finished steel products, and goods from the metalworking industry, including locomotives, railway wagons and ships. Heading imports until July 1941 were grain and other foodstuffs, followed by raw materials for the textile and metal industries ${ }^{31}$.

In the course of August 1941, the imbalance in the Belgo-German clearing system took a new and very inauspicious turn. The direct cause was the derailing of an agreement that Janssen had concluded on 17 April 1941 with the central administration of the Reichskreditkassen in connection with the settlement of credit balances in Reichsmarks held by the Banque d'Emission at the Reichskreditkasse in Brussels. The credit balances originated largely from transfers in Reichsmarks made by branches of German banks in Belgium that were looking to receive Belgian francs in return. The banks wanted to pass on those francs to German procurement agencies, who had purchased goods or services in Belgium for the armed forces and who needed Belgian money to pay their Belgian suppliers ${ }^{32}$. At first, Janssen had not opposed this practice ${ }^{33}$. After all, it provided the Banque d'Emission with foreign currency in the form of Reichsmarks that he felt could be used eventually to purchase foodstuffs and raw materials abroad. In addition, the payments concerned were deductible from the costs of occupation.

The arrangement had already begun to go wrong in the summer of 1941. As indicated above, there was a rapid increase particularly in

31 BNB, Archives, $B R$ BEB, 03.09.1941. See also: BNB, Archives, $S D$, 15, dossier 8.11/ 5, 'clearing': commandes en carnets à destination de l'Allemagne, 26.09.1941 (' $\mathrm{La}$ cadence actuelle dans le secteur de la construction métallique laisse prévoir une moyenne annuelle de 5 à 6 milliards de francs de commandes ( 36 pourcent locomotives, 43 pourcent bataux, 21 pourcent matériel de chemin de fer), dans le secteur de l'industrie de la sidérurgie, grosso modo 1 milliard de francs, dans l'industrie des charbonnages approximativement 1,5 milliard de francs').

32 BNB, Archives, $B R$ BEB, 03.09.1941; BNB, Archives, RR, 06.08.1941, 04.09.1941.

33 BNB, Archives, $S D, 15$, dossier 8.11./ 5, 'clearing': extrait du procès-verbal de la séance du CD, 17.04.1941. 
German procurement for the Eastern front, generating an alarming rise in the Banque d'Emission's credit balance at the Reichskreditkasse in Brussels. When, on 5 August, it came to settling the transactions for July (valued at 461 million Belgian francs in favour of the Banque d'Emission), Hofrichter notified Berger, who was responsible for foreign operations since Janssen's death, that the Reichskreditkasse was no longer in a position to settle such credit balances from the proceeds of occupation cost payments $\mathrm{s}^{34}$ and therefore demanded that the procedure be revised. He pointed out that most purchase transactions were not for procurement for the German army of occupation in Belgium stricto sensu, but for the army in general and for the army on the Eastern front in particular. In consequence, those transactions could no longer be offset against occupation costs, but ought to be settled via the clearing system.

Berger had no option but to accept both the logic of Hofrichter's argument and its consequences. The Banque d'Emission was now faced with taking immediate action to curb any increase in its credit balance at the Reichskreditkasse and to prevent any further derailing of the clearing system.

\section{THE MOTION OF 24 SEPTEMBER 1941}

In his discussions of 5 and 6 August, Hofrichter indicated that the financial administration of the Military Government was checking to see what past expenditure, entered as occupation costs, was in fact to be regarded as reimbursement for German purchases made in Belgium, but with a foreign destination. On 11 August, the Reichskreditkasse informed the Banque d'Emission that, in accordance with the new arrangement, 40 million Reichsmarks had been transferred to its account $^{35}$, soon followed by two more transfers of respectively 25 and 40 million Reichsmarks (for an overall equivalent of 1,312.5 million Belgian francs $)^{36}$.

34 BNB, Archives, DC, 05.08.1941.

35 BNB, Archives, $D C B E B$, 11.08.1943.

36 BNB, Archives, $D C B E B, 25.08 .1941$. 
The managing directors now felt that matters were getting out of hand and refused to make payment in Belgian francs for the last transfer, even after von Becker's threatening telephone call of 25 August demanding payment before noon the following day ${ }^{37}$. The management remained resolute, arguing that the transfer of part of the costs of occupation to the clearing system had a political bearing and that the Commissioner's demand could be acted upon only after consultation with and authorization from the Ministry of Finance.

Plisnier feared that an outright refusal would weaken his position in the negotiations then being conducted with von Falkenhausen on a possible reduction of the occupation costs, and therefore advised the managing directors to bite the bullet and make the payment ${ }^{38}$. Nevertheless, he pointed out that the amounts in question should be reimbursed by the Military Government to the Ministry of Finance, since Belgium would otherwise be paying twice: once as a part of the occupation costs paid by the Ministry and now again via the clearing system in Berlin. But he agreed with the management that the Banque d'Emission could make payment to the Reichskreditkasse only if ordered in writing to do so and - also importantly - provided the operation did not recurr ${ }^{39}$.

The supervisory council of the Bank and the board of directors of the Banque d'Emission had followed the adverse development of Belgium's clearing balance in Berlin intently. Some of their members had already been sharply critical when Cracco's memorandum of 1 August revealed that, since November 1940, the distortion of the balance had been due mainly to the sale of Belgian foreign assets to German buyers. The council and the board were even more shocked when the operations to purge the occupation costs resulted in a new sudden rise in the clearing balance in Berlin ${ }^{40}$, implying an increase in the payments to be made by the Banque d'Emission in Belgium. In a fresh memorandum on 11 September, Cracco wrote that concrete measures were required

37 BNB, Archives, RR, 04.09.1941.

38 BNB, Archives, $D C B E B, 26.08 .1941$ : report of the midday session, at which Ingenbleek set out the result of his discussions with Plisnier (in the morning).

39 BNB, Archives, RR, 04.09.1941.

4O BNB, Archives, BR BEB, 03.09.1941. 
from the Banque d'Emission ${ }^{41}$. Three demands should be put to the occupying power: 1) that a clear distinction be made between occupation costs and clearing operations; 2) that all imports and exports of goods be subject to approval by the Ministry of Economic Affairs or the Ministry of Agriculture and Supply; and 3) that, in respect of capital transactions, transfers be subject to a licence from the Clearing Office of the Ministry of Economic Affairs. This office would determine whether there could be any offsetting and, if not, reimbursement would be in Belgian government paper.

One of directors, A.-E. Janssen, proposed that, in line with Cracco's suggestion, a motion should be drawn up for submission to the Military Government. In that motion, the board of directors would set out its view on the measures to be taken to curb inflation and to achieve a reduction in occupation costs.

The directors convened on 24 September to approve the definitive text of the motion. This referred in the first place to the inflationary effect of many measures taken by the occupier. It went on to say that the occupying power was shamelessly abusing article 13 of the bye-laws by obliging the Banque d'Emission to accept German Reichsmarks without distinction and with no limit as cover for the issue of banknotes by the Bank. Belgian law had laid down that only foreign currency freely convertible into gold could be considered as alternative cover to gold. The occupier was required to respect that law. In the same way as the Bank, the Banque d'Emission was a Belgian institution whose specific public task was to pursue a sound monetary policy. Demands by the German authorities that led directly to uncheckable inflation prevented the Banque d'Emission from fulfilling that task adequately ${ }^{42}$.

The motion also demanded a clear and absolute separation of occupation costs from clearing operations. To guarantee that separation, a mixed committee was proposed that would have executive powers and in which the occupying power, the Ministry of Finance, the Ministry of Economic Affairs and the Banque d'Emission would be represented. The motion also proposed that Belgo-German goods trade be subject to

41 BNB, Archives, $D T$, 1, dossier 02.02.01.03 (D. 537/ 8), 'notes': Cracco, addendum à la note du 25 août 1941, relative aux clearings, 11.09.1941.

42 BNB, Archives, $B R B E B$, 24.09.1941. 
a system of quota restrictions and licences, and that government securities be used to settle payments in respect of capital movements ${ }^{43}$.

The Military Government was impressed by the motion. There was therefore no coincidence in Reeder inviting Leemans, Secretary-general of the Ministry of Economic Affairs, for a discussion on 25 September with Dr. Landfried, State Secretary for Economic Affairs in Berlin, who was visiting Brussels ${ }^{44}$. Landfried opened the discussion with an assurance that the heavy burden of costs laid on Belgium would only be temporary and was dictated by the exceptional circumstances of the moment.

Leemans aired Belgian unhappiness about the state of affairs during the preceding months and, as regards Belgo-German trade, pointed to the contrast between the sharp increase in the Belgian clearing balance and the recently announced export embargo in Germany. He added that Belgium could not even obtain authorization to import freely from other countries and that all these restrictions placed a heavy burden on the development of Belgium's clearing balance. He asked for counter measures: exports to Germany and the Netherlands (at that moment accounting for 95 per cent of Belgian exports) to be subject to prior licensing by the Clearing Office at the Ministry of Economic Affairs, so that the credit balance in favour of Belgium could be brought down to normal proportions. Furthermore, Belgium should be allowed to trade freely with other countries. Lastly, there ought now to be compensatory imports of foodstuffs from France for the imposed export of coal to that country - without any compensation - which had caused a lot of resentment, the more so as it had led to coal-rationing in Belgium.

Landfried adopted a placatory approach. Reeder would work out a system with Leemans to improve Belgian control of foreign trade and would also commence discussions with France to ensure that, in future, Belgian exports of coal would be offset by imports of grain. Time proved Landfried's fine words hollow, as nothing ever came of them.

43 BNB, Archives, $B R B E B$, 24.09.1941.

44 BNB, Archives, SD, 15, dossier 8.11/ 5, 'clearing': report of 25.09 .1941 by Leemans on his meeting with Landfried (see also: letter of 29.09.1941 from Leemans to Goffin, concerning the dispatch of the report). 


\section{THE MOTION OF 7 JANUARY 1942}

On 29 September 1941, the Banque d'Emission was notified that the government in Berlin had transferred a fresh amount of 30 million Reichsmarks to the Banque d'Emission's account at the Verrechnungskasse, as settlement for purchases in Belgium destined for Germany and wrongly charged to occupation costs. The notification was accompanied by a request for the equivalent amount in Belgian francs to be transferred to the Reichskreditkasse in Brussels. It was stated in addition that a final transfer amounting to 35 million Reichsmarks would follow, completing the regularization of the erroneous charging of occupation costs to the value of 145 million Reichsmarks, the equivalent of 2,182.5 million Belgian francs ${ }^{45}$. The leaders of the Banque d'Emission were upset by the news and suggested that the managing directors should respond: a limit had to be placed on the provision of banknotes to the Banque d'Emission; for the time being, however, this remained just a suggestion $^{46}$.

The month of October brought a new disenchantment, this time regarding Franco-Belgian payment flows. For as long as men could remember, Belgian seasonal labourers had worked on the big farms in Northern France and later as frontier workers in industry, but their numbers had of late begun to increase, particularly since the Wehrmacht's recruitment of labourers in Belgium to build fortifications along the French coast. At the same time, the Wehrmacht had commenced purchasing goods in Belgium for use in France. So far, the Reichskreditkasse in Paris had financed all expenditure in this respect, recouping it from the Reichskreditkasse in Brussels via mutual offsetting. For its part, the Reichskreditkasse in Brussels financed its payments to Paris with receipts from the Ministry of Finance for settling occupation costs.

On 8 October the Bankaufsichtamt informed the Banque d'Emission that the mutual offsetting arrangement between the Paris and the Brussels Reichskreditkasse was abolished ${ }^{47}$ and that, henceforth, the Franco-

45 BNB, Archives, $D C$ BEB, 29.09.1941 and 01.10.1940. See also: BNB, Archives, $S D, 15$, dossier 8.11/ 5, s. f. 7: ordres de paiements, 29.09.1941, 01.10.1941.

46 в в, Archives, RR, 01.10.1941. See also: Nefors, Industriële collaboratie in België, p. 112.

47 BNB, Archives, SD, 15, dossier 8.11.5/ s. f. 9, 'virement des RKK': letter of 08.10.1941 from von Becker to Goffin, 08.10.1941. 
Belgian clearing agreement concluded at Wiesbaden on 18 December 1940 and ratified by the protocol of 11 January 1941 would apply. That agreement laid down that all Franco-Belgian payments were to be conducted via the clearing system in Berlin, so that all remuneration for purchases in Belgium by the Wehrmacht that were destined for France and all payments for the provision of Belgian services in France ${ }^{48}$ were now required to be settled by means of transfers to the Banque d'Emission's account at the Verrechnungskasse in Berlin ${ }^{49}$.

The letter also announced that the new arrangement would be applied retroactively and that, in consequence, the German government had transferred 43.25 million Reichsmarks to the Banque d'Emission's account at the Verrechnungskasse, with the request that the equivalent, amounting to 540 million Belgian francs, be paid to the Reichskreditkasse in Brussels.

The managing directors were outraged. In their reply they declared their agreement with an arrangement via the clearing system in Berlin limited to purely commercial transactions with France. However, to apply the arrangement not only to remuneration for goods purchased by the Wehrmacht in Belgium and destined for France, but also to remuneration for work performed by Belgians in France, on behalf of the Wehrmacht, was going too far. Such remuneration, the managing directors argued, should be regarded as coming under occupation costs and consequently should be borne by the country where those costs were incurred, in this case by France and certainly not by Belgium. They therefore proposed a different, more suitable arrangement, whereby the Banque de France would open a special French franc account in the name of the Banque d'Emission, in exchange for Belgian franc payments by the Banque d'Emission. The Belgian government would be able to use that account to purchase food and other goods in France, free of quota restrictions. If the proposal was not accepted, the Banque d'Emission would refuse to pay out the amount of 540 million Belgian francs to the Reichskreditkasse in Brussels ${ }^{50}$.

48 BNB, Archives, $S D$, 15, dossier 8.11.5/ s. f. 13, 'main d'oeuvre belge en France': letter of 03.11.1941 from Hofrichter to Goffin, 03.11.1941.

49 BNB, Archives, DC BEB, 21.01.1942.

50 BNB, Archives, SD, 15, dossier 8.11/ 5, 'clearing': note sur les virements des RKK en Belgique et en France, 23.09.1942. 
The Vice-president of the Military Government, General Harry von Craushaar, now invited Plisnier and Goffin to a meeting with Hofrichter and a number of other German members of the Military Government, in order to have an open discussion about these difficulties ${ }^{51}$. Von Craushaar first addressed the question of the occupation costs and repeated the proposal that had already been aired with Plisnier on 10 October: if the announced increase in occupation costs from 1 billion to 1.5 billion Belgian francs a month was unacceptable to the Belgian population, those costs could be reduced to 1.25 billion Belgian francs, provided that the Bank granted the Reichskreditkasse in Brussels a credit line of 250 million Belgian francs a month. Goffin immediately replied that the Bank could not accept that solution. Providing credit in that form was contrary to the bye-laws and moreover came within the scope of article 115 of the Penal Code ${ }^{52}$. Von Craushaar therefore left the matter at 1.5 billion Belgian francs a month.

As regards the Franco-Belgian payment flows, von Craushaar stated that the Banque d'Emission's repayment of the amount of 540 million Belgian francs to the Reichskreditkasse in Brussels was a non-recurring operation to rectify what had happened in the past and that there would be no recurrence. What happened in the future would be governed by the arrangement of 8 October 1941. This arrangement would remain in force until 30 April 1942, after which the situation would be reviewed. The Military Government nevertheless indicated that it would make a particular effort to keep Franco-Belgian transactions for the Wehrmacht to a minimum and even completely eliminate them, if possible. In the event of any new requests for payment in this respect, the Banque d'Emission could ultimately charge the amount against Belgian occupation costs ${ }^{53}$.

Plisnier sought to play safe regarding the acceptance of the increase in the occupation costs. In the first place, he drew up a memorandum to be sent to Reeder that summed up the grievances in respect of those

51 BNB, Archives, SD, 15, dossier 8.11.6, 'clearing': entretien avec von Craushaar, 04.11.1941.

52 BNB, Archives, SD, Malaise Papers, dossier 9.5.5 / s. f. 2: résumé des consultations juridiques, relatives au clearing (in this respect, see particularly the opinion of 23.10.1941).

53 BNB, Archives, DC BEB, 21.01.1942, 11.02.1942. 
costs and bluntly set out the Belgian protest against them. Then, on 12 November, he invited a number of leading figures to a meeting at the ministry to examine whether it was better to reject the increase and resign or to accept it, while voicing strong protest. With the exception of a few hardliners, most of those present opted for the second course, some also declaring their approval of the Military Government's proposal that Plisnier go himself to Berlin to argue the case ${ }^{54}$. Galopin and the other founder-bankers of the Banque d'Emission were rather distrustful of Plisnier's strategy and his planned journey to Berlin, fearing that his arguments there for a reduction in the costs of occupation would be at the Banque d'Emission's expense, i.e. through transfers of a political or military nature being foisted onto the clearing system 55 .

The question of the payment of the 540 million Belgian francs to setthe the problem of Franco-Belgian payments dragged on, the stumbling block appearing to be the opening of a special account at the Banque de France in the name of the Banque d'Emission. Op 23 December, von Becker issued an 'order' for the Banque d'Emission to make the payment, bringing tension to a peak. Among the managing directors, Van Nieuwenhuyse and Berger argued for refusal: in their view, Belgium could not be forced to assume a part of French occupation costs and they threatened resignation if this happened ${ }^{56}$. Ingenbleek and Galopin found this stance too extreme and talked Van Nieuwenhuyse and Berger out of their planned action ${ }^{57}$. At the meeting of the board of directors on 24 December, the majority of the members indicated that they felt it preferable to obey the order. Nevertheless, everyone was agreed that payment should be accompanied by a new motion even more resolute than that of 24 September. It was also resolved that Cracco's statistical memorandum concerning the recent development of the Belgian clearing balance should be appended to the motion ${ }^{58}$.

54 Nefors, Industriële collaboratie in België, pp. 111-112.

55 SG, Archives, Direction, Galopin Papers, dossier 50: remarks of Galopin on Plisnier's memorandum of 14.11.1941.

56 SG, Archives, Direction, Galopin Papers, dossier 64: aide-mémoire pour la réunion restreinte du 7 janvier 1942 chez M. Plisnier, p. 3. See also: Général Van Overstraeten, Léopold III, prisonnier de guerre, pp. 166-167.

57 SG, Archives, Direction, Galopin Papers, dossier 64: aide-mémoire pour la réunion restreinte du 7 janvier $1942 \mathrm{chez}$ M. Plisnier, p. 3; BNB, Archives, $D C B E B, 23.12 .1941$.

58 BNB, Archives, $D C B E B, 23.12 .1941$; $B R B E B, 24.12 .1941$; $D C B E B, 27.12 .1941$. 
The new motion was submitted to the Military Government on 7 January $1942^{59}$. It stated that, between the end of August and the end of December 1941, the war taxes imposed by the Germans had gone up by 8.9 billion Belgian francs from 22.2 billion to a total of 31.1 billion. From the beginning of June 1940 to the end of August 1941, the average monthly charge for those taxes was 1.48 billion Belgian francs; from the beginning of September to the end of December, 2.21 billion, an average monthly rise of 730 million that was due not only to the increase in the occupation costs imposed, but also to the expanding clearing balance.

According to the motion, the growth of the clearing imbalance was the result primarily of higher exports and a gradual decline in imports, a divergence that concerned chiefly Belgo-German flows of goods, but increasingly Belgo-French and Belgo-Dutch flows, as well ${ }^{60}$. A second reason was that it was caused by ever increasing numbers of Belgians working in Germany, France and the Netherlands, whose savings deposited in German, French and Dutch currencies and credited to the Banque d'Emission's account at the Verrechnungskasse in Berlin - the Banque d'Emission was obliged to pay out in Belgian francs.

The motion emphasized that all the costs destined for France and the Netherlands, were in most cases on behalf of the Wehrmacht and consequently ought to be considered as French and Dutch occupation costs. In conclusion, the motion pressed for urgent work to be made of implementing the motion of 24 September of the previous year.

THE MISSION TO BERLIN (24-28 MARCH 1942)

The ink was barely dry on the motion of 7 January 1942 before a new row broke out over Franco-Belgian payment flows. It concerned the Military Government's demand on 8 January for the Banque d'Emission to pay out once again 86.25 million Belgian francs for Belgian transactions on behalf of the Wehrmacht in France. This was promptly rejected by the Banque d'Emission, which based its action on the meeting of 4 November with von Craushaar.

59 BNB, Archives, $S D$, 15, dossier 8.11/ 5, 'clearing': motion of 07.01 .1942 (with a statistical annex from Cracco: note relative à l'évolution des clearings, 01.01.1942).

60 BNB, Archives, $B R B E B, 24.12 .1941$. 
Both the demand and the reaction appeared to make an impression, causing the Military Government to cast around to see what concessions could be made to calm the situation. In the first place, these consisted of the Bankaufsichtamt announcing that the 86.25 million Belgian francs could be charged against Belgian occupation costs ${ }^{61}$ and of Reeder notifying Plisnier on 16 January that the visit to Berlin, planned in the previous autumn, would now definitely take place and that he should make concrete preparations for it ${ }^{62}$.

The motion of 7 January 1942 also had an auspicious effect on the problem of financial transfers. In September 1941, acting on the advice of the Banque d'Emission, Plisnier had submitted a draft decree to the German authorities for approval: its substance being that the proceeds from sales of Belgian shares and of Belgian participations abroad, as well as the proceeds from sales of other assets of a financial nature, should be paid out in the form of a special type of Treasury certificate, to be held at the Ministry of Finance for account of the Banque d'Emission and payable no earlier than three months after the conclusion of peace ${ }^{63}$. At the end of January, the Military Government informed Plisnier that his draft decree concerning financial transfers had been approved (on 3 February 1942 the decree was promulgated) ${ }^{64}$.

All attention now passed to the preparations for Plisnier's trip to Berlin. As the natural head of the Belgian delegation these preparations centred on Plisnier. The Bank and the Banque d'Emission immediately realized that they had been sidelined; indeed, the Military Government initially spoke only of a three-man delegation: Plisnier, Leemans and Galopin; no leader from either bank was included ${ }^{65}$. The conclusion was very quickly drawn that the Bank and the Banque d'Emission would have to seek closer contacts with the Ministry of Finance, even at the cost of some autonomy. They would have to co-operate more with the Secretary-general and form a united front ${ }^{66}$. The changed attitude on

61 BNB, Archives, DC BEB, 21.01.1941.

62 Nefors, Industriële collaboratie in België, p. 111.

63 BNB, Archives, DC BEB, 06.09.1941, 25.10.1941.

64 Published in the Belgian Official Gazette, 06.02.1942

65 BNB, Archives, $D C B E B, 03.02 .1942$.

66 вNB, Archives, DS, Malaise Papers: Kauch, La Banque Nationale (unpublished text),

Part 1, Chapter. 7, p. 17. 
the part of the two institutions had its first result in the inclusion of Goffin in the delegation.

Plisnier had drawn up a guideline for the delegation's negotiations and a first version was circulated on 4 February; second and third revised versions followed on 25 and 27 February. The core of the text comprised recommendations to the German government on ways to help Belgium financially and economically, and to make an additional effort in respect of supplies ${ }^{67}$. Unbeknown to anyone, however, at the end of December 1941 Ingenbleek had reported fully to the Court about the tensions between the Belgians and the Military Government, as well as about the possible resignation of an entire swathe of leading Belgian figures. When further tension arose after the Military Government's demand of 8 January, Ingenbleek was able to persuade the King, via his aides, to address a personal letter to Hitler, setting out the problems of the country and particularly the great need for food and coal, and also urging that special measures be taken to provide relief for Belgium. The letter was delivered personally to Hitler on 9 February by Werner Kiewitz, German adjutant to the King ${ }^{68}$.

Hitler was incensed by the royal letter. He found the tone arrogant, felt humiliated by the reference to the hunger being suffered, and made the government in Berlin aware of his anger at the letter's contents. The upshot was an order from the Fuhrer's headquarters that the Belgians' planned trip was to be put off indefinitely. In the end, however, ruffled feathers were smoothed and the trip was once again placed on the agenda, though not for February, as originally planned, but for the end of March ${ }^{69}$.

In the meantime, Galopin met the Advocate-general of the Court of Cassation, Hayoit de Termicourt, to examine whether the visit to Berlin could actually be justified in the given circumstances, bearing in mind that few, if any, results could be expected. Hayoit de Termi-

67 BNB, Archives, $S D$, 17a, dossier 8.11/ 7, 'clearing', (sous-farde 5): voyage à Berlin, 2428.03.1942 (letters of 04.02.1942, 25.02.1942 and 27.02.1942 from Plisnier to Goffin).

68 Général Van Overstraeten, Léopold III prisonnier de guerre, pp. 160, 167-168, 173. See also: KP, Archives, fonds Leopold III, secretariat (Capelle Papers), dossier XVG.A, 232 band 296 .

69 Krijgsauditoraat, Plisnier, dossier 36: letter of 12.02.1942 from Plisnier to Reeder. 
court thought it was a patriotic necessity and demanded 'une politique de présence active aux postes de commandes ${ }^{30}$.

The managing directors and the board of directors of the Banque d'Emission were now also looking - though somewhat late in the day - to contribute to the success of the Berlin trip. They provided Goffin with the motions of 24 September 1941 and 7 January 1942, adding a third, which had been approved the day before the delegation's departure. This pressed the German government to set a monthly maximum in respect of both clearing transfer payments and occupation costs; moreover, it urged that those maxima should take account of Belgium's economic potential. Finally, as regards the clearing transfers, it requested that a detailed description of the type of transaction be given, as well as the names of the 'real' beneficiaries ${ }^{71}$.

The delegation departed for Berlin on 24 March, taking the night train and being accompanied by a number of top officials from the Military Government. Schlumprecht, head of the Gruppe Wirtschaft, sought out the members of the delegation on the train, advising them not to argue for more food aid from Germany, as such a request would be badly received. The Russian conquests had not, as expected, resulted in greater imports of grain; on the contrary, food shortages in Germany had increased sharply in recent months. Hitler abhorred anything, exports included, that might exacerbate the shortages, which would demoralize the German population - a risk that had absolutely to be avoided. Schlumprecht stated that it would be better to press for the food supply systems in France, Belgium and the Netherlands to be equalized, which could be brought about by internal redistribution. On industrial matters, he thought it advisable to argue for an extension of the Auftragsverlagerung or contract work system. In respect of financial matters, his advice was not to insist on a simultaneous reduction in occupation costs and clearing operations, as that would stand no chance

70 SG, Archives, Direction, Galopin Papers, dossier 50: conversation Galopin-Hayoit de Termicourt sur le voyage de Berlin, 15.01.1942. Galopin had surmised correctly. At the beginning of March, Funck, Minister of Economic Affairs in Berlin, wrote to von Falkenhausen: 'je dois de toute nécessité décevoir leurs espérances dans le domaine des frais d'occupation et de monnaie ... je les recevrai donc seulement pour des motifs psychologiques' (Krijgsauditoraat, Plisnier and Crispiels, 1: French translation of German documents, letter of 09.03.1942 from Funck (Berlin) to von Falkenhausen (Brussels)).

71 BNB, Archives, BR, 24.03.1942. 
and would create bad feeling. A positive result was more likely from talking solely about a reduction in occupation costs and by dropping the matter of cutting clearing balances. In fact, those balances represented a claim, whereas occupation costs could be regarded as being lost $^{72}$.

The delegation's reception in Berlin was courteous, but the refusal of the Minister of Supply to meet some of the members was a clear signal that nothing was to be expected from Germany as regards food aid. Even the attempt to obtain an internal redistribution for the available food supplies between France, Belgium and the Netherlands met with a refusal on political grounds. The proposal to increase the export of Belgian manufactured goods to third countries in exchange for foodstuffs also aroused suspicion; the proposal was accepted in principle, though hesitantly and on the express condition that Germany should in no way be disadvantaged by such exports.

Somewhat more success was gained over financial matters. During a meeting at the Reichsbank, Dr. Puhl, Deputy-president, told Goffin that an effort would be made to achieve a better separation between occupation costs and clearing operations. As far as clearing operations were concerned he would do his best to exclude the use of the clause 'laut besonderer Mitteilung', although adding in confidence that the Reichsbank had little say in that particular matter. ${ }^{73}$.

The Belgian delegation returned to Brussels on 29 March and convened the following day at the Ministry of Finance to evaluate its mis$\operatorname{sion}^{74}$. Everyone was agreed that little positive, if anything, had come out of the visit. Nevertheless, Galopin praised the spirit of solidarity shown by the delegation members on both the government and the banking side; the united front had apparently had its effect. That there was a united front was not entirely true. During the journey back from Berlin, Goffin, Galopin and M.-L. Gerard held a confidential discussion

72 ARA, fonds ministerie van Financiën, Plisnier Papers, dossier 2, f: entretien avec M. Schlumprecht, 24.03.1942.

73 ARA, fonds ministerie van Financiën, Plisnier Papers, dossier 2, g: note de synthèse du voyage de la délégation belge à Berlin, mars 1942. For more precision on the clause "laut besonderer Mitteilung", see Chapter 16.

74 ARA, fonds ministerie van Financiën, Plisnier Papers, dossier 2, j: réunion au cabinet de M. Plisnier, 30.03.1942. 
with Hofrichter and Schlumprecht ${ }^{75}$. In that discussion, the bankers stated flatly that the systematic use of the description 'laut besonderer Mitteilung' had prevented the clearing system working properly. They suggested that all non-commercial and unjustified commercial transactions be filtered out from the system, even if that meant higher occupation costs.

During the delegation's meeting on 30 March, Galopin made two interesting remarks. The first concerned the general situation in Germany. Although the delegation was greatly disillusioned by the German refusal to offer any concession on food aid, the reason for that refusal had become obvious to all during the trip. Within a span of just a few months, to everyone's surprise, the food supply and the psychological climate in Germany had manifestly worsened and it was therefore no wonder that the German authorities were not keen to augment food rations in the occupied territories. The second remark was focused on the Military Government, which had so often appeared demanding and intransigent during discussions in Brussels. It was now very clear to all members of the delegation how correctly and impartially the Military Government had been informing the German government in Berlin about the actual situation in Belgium and about the justified complaints against the regime of occupation. Von Falkenhausen and Reeder had consistently defended Belgian interests with the Nazi government in Berlin. Although this had generally been in vain, it put the leaders of the Military Government in Belgium in a new light. At the same time, suspicion was strengthened within the delegation that tension between the Military Government in Belgium and the Nazi government in Berlin was sharp and that Belgium could easily be affected by the fallout from any open conflict between the two.

Lastly, M.-L. Gérard brought up the question of 'filtering' the clearing system. This drew a rapid and curt response from Plisnier, who declared that, although he was also in favour of purging the clearing system of inappropriate transactions, this could not be done at the expense of his own ministry, which was responsible for paying the occupation costs. Very slowly, dangerous cracks in the united front began to appear.

75 BNB, Archives, $S D$, 17, dossier 8.11/ 7, 'clearing': entretien de M. Goffin avec M. Puhl à Berlin pendant les journées du 24 au 29 mars 1942. 


\section{The Installation of the Banque Nationale de Belgique in London}

\section{THE ESTABLISHMENT OF A BELGIAN GOVERNMENT IN LONDON}

After the French defeat in June 1940, the British government was greatly disappointed by the decision of the Belgian ministers to give up the struggle against Germany and to return to Belgium, if possible. The British had few illusions about the help that could be expected from occupied Belgium and her vacillating government, but were concerned about the Belgian Congo. No later than 20 June, the British Foreign Secretary, Lord Halifax, had informed the Belgian ambassador, Cartier de Marchienne, that Great Britain could not countenance the Belgian Congo falling within the German sphere of influence. Was this a warning shot across the bows? A memorandum from J.G. Ward, a senior official at the Foreign Office, left nothing to the imagination about the mood in certain British circles: 'It is of crucial importance to maintain Belgian Congo in a state of war against Germany... We must... envisage to intervene in the Congo to safeguard our vital interests, even at the cost of a correct constitutional procedure".

The Governor-general of the Belgian Congo, Pierre Ryckmans, shared the British view and announced his intention of continuing the struggle against Germany in a radio broadcast. In doing so, he put himself in opposition to his own government and sent an unmistakeable signal. Now that Belgian sovereignty over the Congo was at stake, the

1 J.C. Williame, 'Le Congo dans la guerre: la cooperation économique belge-alliée de 1940 à 1944, in: Le Congo Belge Durant la Seconde Guerre Mondiale. Receuil d'Etudes, Brussels, 1983, p. 214. 
Minister for the Colonies, Albert De Vleeschauwer, requested the Cabinet to send him to the Congo and was allowed to go as 'Administrator of the Belgian Congo', but not as a minister, in case the government were to resign and he were thereby to lose his ministerial competence ${ }^{2}$.

He set out for Lisbon, arriving there on 24 June 1940, only to be advised by various prominent people not to travel immediately to the Congo, but to go first to London to take stock of the situation ${ }^{3}$. On his arrival there on 4 July, his path having been smoothed by the Belgian ambassador, he gained direct access to Churchill and other members of the British government. In his capacity as Minister for the Colonies and as Administrator-general of the Belgian Congo, he placed the entire production of all raw materials at the disposition of Great Britain in her fight against Nazi Germany $y^{4}$ This gesture was certainly appreciated, but the British felt that it was not wholly adequate for a government to be represented by just a single minister and asked whether he could not persuade some of his colleagues to join him. If that were not possible, the British government would feel itself obliged to recognise an alternative government eventually led by Van Zeeland 5 .

At the end of July, De Vleeschauwer left for Barcelona and from there to Le Perthus, at the Spanish-French border, in the hope of being able to convince some of his colleagues at Vichy to make the move to London. Meanwhile, Gutt had been able to convince his fellow ministers to allow him to leave for England in his capacity as Minister of Finance. He had completed his task in France, he argued, and was now eager to tackle the problems in unoccupied territory, which could only be properly dealt with by a minister of Finance, ensuring the servicing of foreign debt, the payment of the salaries and expenses of the diplomatic corps, and securing the gold reserves of the Bank in unoccupied territory.

2 De Schryver, Oorlogsdagboeken, pp. 96-98.

3 Schepens, De Belgen in Groot-Brittannië, pp. 25-26.

4 Williame, 'Le Congo dans la guerre', p. 216.

5 Among other things, during a meeting with Churchill (J. Stengers, Léopold III et le gouvernement. Les deux politiques belges de 1940, Paris-Gembloux, pp. 117-118). See also: V. Dujardin and M. Dumoulin, Paul Van Zeeland, 1893-1973, Brussels, 1998, pp. 115-116. In this respect, see also: Schepens, De Belgen in Groot-Brittannië, pp. 25-26. 
Gutt left for Le Perthus, firmly determined to cross to London with De Vleeschauwer. He and De Vleeschauwer arrived in London on 8 August. Pierlot and Spaak accompanied Gutt to Le Perthus. They had given their word to return to Vichy, but after their meeting with De Vleeschauwer they were convinced that the government's future lay in London. They soon left Vichy. The other eight members of the government refused to consider leaving and it was only after endless discussion that they gave their assent for Pierlot and Spaak to go, opting themselves to remain in France and agreeing to declare that they were willing to resign ${ }^{6}$.

Pierlot and Spaak reached London only on 22 October 1940, having escaped from two months of résidence surveillée imposed by the Spanish authorities after they arrived from France. Now, at last, a Belgian government could be formed in London, even though it boasted only four members. It was recognized by the British, but without any great enthusiasm.

\section{THE FINANCING OF THE BELGIAN GOVERNMENT IN LONDON}

Although the Belgian government was now back in harness and officially recognized by the British government, there was the immediate question of who was to finance its operation. Tax income was virtually non-existent and little could be expected from Baudewyns, who had been sent to London with the express instruction just to take care of the Bank's gold reserves.

The financing of Belgian activities in unoccupied territories had been examined by Baudewyns, with the help of inspector Ansiaux, even before Gutt's arrival in London. Ansiaux, when discussing the question with Baeseleer, a director of the Banque du Congo Belge in Leopoldville, who was on a fact-finding trip to London, found out that De Vleeschauwer had contacted the Congolese administration in order to gain priority for Great Britain in the supply of goods, and particularly raw materials, from the colony. When Ansiaux heard that payment was to be in sterling, he felt at once that a solution to the problem of the government

6 BNB, Archives, $S D$, dossier 'documents divers': Georges Theunis (Souvenirs de Camille Gutt), Ostend, 11.07.1966. 
budget deficit was at hand and began to press for a convention that the colony would use its sterling portfolio to provide financial support to the Belgian government for the duration of the war. In De Vleeschauwer's plans, there would be a considerable increase in that portfolio in the near future ${ }^{7}$. However, this did not square with De Vleeschauwer's own view, which was that the colony's income was to be applied to its own requirements and to supporting England, which was already an enormous undertaking. To cover its costs, the Belgian government in exile would simply have to call on the Bank and its gold reserves ${ }^{8}$.

Gutt, however, was taken with Ansiaux's idea and contacted Jaspar Wauters, the London representative of the Banque du Congo Belge ${ }^{9}$, proposing that the Congolese bank grant the Belgian government a loan of 1-2 million pounds sterling in exchange for short-term Treasury bonds at an annual interest of 1.75 per cent, half to be redeemed in sterling and half in Congolese francs. In Gutt's opinion, this would certainly be no bad thing for the Banque du Congo Belge. If everything went according to plan, the colony would have a sterling surplus at its disposition within the foreseeable future and, since that surplus could not be used outside the sterling zone, the colony could transfer it to the Belgian government, recouping it in part in Congolese francs ${ }^{10}$.

The Governor-general of the colony, Ryckmans, intervened to reject the proposal ${ }^{11}$. It was not that he was against a loan to the Belgian government. Nevertheless, he felt that such a loan ought to be issued exclusively in Congolese francs, which the Belgian government could then use to purchase sterling from the Banque du Congo Belge. Ansiaux argued that this was unreasonable and even to the colony's detriment ${ }^{12}$, as

7 BNB, Archives, SD, Ansiaux Papers, 1: letter of 03.08.1940 from Ansiaux (Vichy) to Janssen (Brussels).

8 BNB, Archives, SD, London Archives, 2 (1940), s. f. avances de trésorerie à De Vleeschauwer: juillet 1940: letters and texts of 8, 9 and 11.07.1940.

9 J. Vanderlinden, Pierre Ryckmans, 1891-1959. Coloniser dans l'honneur, Brussels, 1994, p. 463.

10 BNB, Archives, SD, London Archives, 2 (1941): letter of March 1941 from Ansiaux (London) to De Vleeschauwer (London); Ansiaux, Souvenirs, pp. 81-82.

11 Williame, 'Le Congo dans la guerre', pp. 213-218; Vanderlinden, Pierre Ryckmans, 1891-1859, p. 463.

12 BNB, Archives, $S D$, Ansiaux Papers, 3, dossier 'Londres': letter of 21.03.1941 from Ansiaux (London) to De Vleeschauwer. 
it would mean the colony shouldering the entire exchange rate risk for the sterling balances it received, whereas the Belgian proposal meant that the risk would be shared by both partners.

The discussion dragged on, but the British government had not lost sight of De Vleeschauwer's proposal regarding supplies from the Belgian Congo and had sent Lord Hailey with a delegation to Leopoldville in September 1940 to examine the matter. Negotiations were initially conducted with the Governor-general and the management of the Banque du Congo Belge, but were continued at government level between Great Britain and Belgium, once the Belgian government was established in London. This led to the agreement of 21 January 1941, signed in London by the new British Foreign Secretary, Anthony Eden, and Spaak ${ }^{13}$. By its terms, the Congolese franc was included in the sterling zone, thereby bringing Congolese imports of goods, and Congolese exports of gold, coins and foreign currency within the control of the British monetary authorities. Additionally, there was official confirmation of the exchange rate of 176.625 Congolese francs to the pound, which consolidated a remarkable paradox: with a strong economy for the colony in prospect, the Congolese franc remained officially undervalued, whereas the Belgian franc, shorn of its economic base, officially retained its overvalued rate of exchange of 123 Belgian francs to the pound. It was an artificial situation and one that cost the Belgian government dear. If it had been able to finance its expenditure in England with Belgian francs at the official rate, the government would have had to give out just 123 Belgian francs to the pound. Gutt subsequently attempted to have the Congolese franc revalued to the level of the Belgian franc, but the British government naturally would have none of it.

Great Britain made use of the agreement of January 1941 to buy chiefly copper, cobalt, cotton, groundnuts, palm nuts and palm oil at fixed and favourable prices. However, the most important clause in the agreement concerned Congolese gold production, the Belgian government and the colony having undertaken to cede both the balance of gold production over and above their own requirements and any receipts in gold currency to the Bank of England for the duration of the war.

13 Williame, 'Le Congo dans la guerre', pp. 217-220. 
The agreement of January 1941 was not well received by the Bank. It was true that the integration of the colony into the sterling zone, was widely praised. It ensured a guaranteed export market, but this was at prices that were far too low. The agreement also set a geographical limit for imports, as goods could be bought only within the sterling zone, thereby making free trade a dead letter for the colony; moreover, the exclusive link to sterling could also entail a dangerous exchange rate risk ${ }^{14}$. Virtually identical critical comment was to be heard in the colony itself. Indeed, dissatisfaction there with the agreement was extreme and felt by everyone, specifically by the Governor-general and the Banque du Congo Belge, but no less by the business world. As always, however, businessmen managed to find a way around the restrictive clauses, bumping up the production of goods that fell outside the scope of the agreement, which could be sold to the United States at prevailing world prices ${ }^{15}$.

On 21 March 1941, within the framework of the Anglo-Congolese agreement, Gutt was at last able to conclude a convention between the Belgian government and the colony to secure the government's financing for the duration of the $\mathrm{war}^{16}$. The convention itself was the outcome of the original idea from Ansiaux and the subsequent discussions between Gutt, on the one hand, and Ryckmans and the Banque du Congo Belge, on the other, the ground having been prepared by Ansiaux during his mission to Lisbon in February $1941^{17}$.

In order to provide cover for the financial needs of the Belgian government in London, the Banque du Congo Belge undertook to make the requisite foreign currency available and to do this by means of loans, for which the colonial government would stand surety. In exchange

14 BNB, Archives, SD, Ansiaux Papers, A 2, dossier 9, 1/24: agreement of 21.01.1941 between Great Britain and the Belgian Congo.

15 Ndl.ARA, Ministry of Foreign Affairs, London Archives, A, 1940-1945 (diplomatieke zaken $\mathrm{CH}$ Z): memorandum of 02.05.1945 from the Dutch legation.

16 BNB, Archives, $S D$, Malaise Papers: Kauch, La Banque Nationale (unpublished text), Part 1, Chapter. 9, pp. 51-53 and 59-60.

17 BNB, Archives, SD, London Archives: letter of 30.07.1940 from Janssen (Brussels) to Baudewyns (London) and particularly letter of 03.08.1940 from Ansiaux (Vichy) to Janssen (Brussels)). See also: BNB, Archives, SD, London Archives, dossier 1 (1941), s. f. mission d'Ansiaux à Lisbonne: projet de convention entre l'Etat belge et la colonie (rédigé par Ansiaux). 
for the loans, the Belgian government would issue short-term Treasury certificates at 1.75 per cent per year, payable in Congolese francs. In its turn, the Bank guaranteed to discount those certificates, should the Banque du Congo Belge require them to be paid out at maturity, rather than renewed. With this, the problem of financing the Belgian government during the war was resolved. In the event, the loans from the Banque du Congo Belge provided the greater part of the financing.

\section{THE BANK IN LONDON AND ITS PROTAGONISTS}

The formation in London at the end of October 1940 of a legal government in exile came also as a great relief to Baudewyns and Ansiaux, the two persons heading the Bank in the British capital. At last, after months of uncertainty, there was now a government again, which was recognized by the British and the Belgians as the only legitimate government of Belgium. For Baudewyns and Ansiaux, this also cleared the situation with their British counterparts.

The four ministers forming the government in London were Pierlot, Gutt, Spaak and De Vleeschauwer, but what type of people were they and what were the power relationships among them? In his memoirs, de Gaulle praised the Belgian government: 'Pierlot, Gutt and Spaak made together an excellent team, combining wisdom, diligence and dexterity in the service of Belgium ${ }^{18}$, but did the reality fully reflect these fine words? The prime minister was held in universal esteem for his integrity and his perfectionism, but, in fact, he had no leadership qualities and his manifest difficulty in coming to a decision often led to tension within the government ${ }^{19}$. The British assessment of Spaak was not wholly positive either. According to some he was not free of a degree of opportunism and was not exactly eager for work. The latter point was one on which Gutt, himself a workaholic, could get extremely exercised ${ }^{20}$. De Vleeschauwer was virtually sidelined politically by Gutt, once the financing of the Belgian government in London had been settled. De

18 Quoted by Dujardin and Dumoulin, Spaak, p. 213.

19 BNB, Archives, SD, London Archives, dossier 2 (1941): letter of 08.07.1941 from Ansiaux (New York) to Baudewyns (London).

20 Gutt alluded to this regularly in his letters to Theunis. 
Gaulle did not even mention De Vleeschauwer in his memoirs when he spoke of the Belgian government in London.

As indicated above, and disputed by no-one, Gutt was the dominant figure in the Belgian government in London. Adroit and charming when necessary, he achieved his goals through unflagging drive. His intelligence and command of briefs enabled him to neutralize all criticism with just a few words, whether it came from within the government or from the circle of members of parliament, former ministers and other prominent figures who had fled to London ${ }^{21}$. Baudewyns, who often suffered at his hands, wrote of him: 'an exceptional mind: Gutt surpasses by far his colleagues... his English is impeccable ${ }^{22}$.

Of the Bank's protagonists, Baudewyns was not a fighter. However hard he struggled to defend the interests of the Bank, he had to knuckle under when it came to the point and follow the Finance Minister's instructions. In fact, Gutt underestimated Baudewyns' intellectual qualities. Although not a man for public debate, Baudewyns, nevertheless, demonstrated an acute understanding of current problems, as he demonstrated during the monetary negotiations in preparation for post-war monetary policy ${ }^{23}$. Ansiaux was from a different mould, a man more on the lines of Gutt. From their first contacts, Gutt described the young inspector as: 'outstanding, courageous and smart'24. As time went on, Baudewyns felt himself overshadowed and even overtaken - not altogether without reason - by Ansiaux, who had, meanwhile, been appointed a director. Occasionally, Baudewyns had to call him to order ${ }^{25}$.

Theunis, a member of the supervisory council and Ambassador Extraordinary in New York, was a very striking figure, very intelligent, a man of integrity, able and blessed with a particularly keen memory. He had been closely involved in the Bank's activities since the beginning of the war and, holding the Bank's mandate, it was his task to act for the

21 See, among others: Schepens, De Belgen in Groot-Brittannië, passim.

22 Baudewyns Family Archives: letter of 17.02.1941 from Baudewyns (London) to his son (Oxford).

23 See below.

24 ARA, Theunis Papers, 'correspondance Theunis-Gutt': letter of 06.01.1941 from Gutt (London) to Theunis (New York).

25 Baudewyns Family Archives: letters of 02.12.1941 and 06.02.1942 from Baudewyns (London) to his son (Oxford). 
Bank in New York in its function of State exchequer. In that capacity, he also introduced the legal proceedings against the Banque de France before the Court in New York. His long connection with Gutt explained why he followed the affairs of the Belgian government in London with more than ordinary interest. In his letters to Baudewyns from this period, Ansiaux pointed to the enormous influence exerted by Theunis, behind the scenes via Gutt, on the decision-making of the Belgian government in London. On 7 June 1941 he wrote: 'Theunis...is, in fact, the real leader of the State ${ }^{26}$.

\section{BAUDEWYN'S DIFFICULTIES AT HIS INSTALLATION IN LONDON}

Baudewyns arrived in London four days after having taken his leave of Janssen at Bordeaux on 18 June 1940. By 24 June, he was ensconced in a comfortable office in the Bank of England, as indeed was Ansiaux. Getting the Bank installed in London may have gone smoothly, but getting on with its task of acting as State exchequer proved much more tricky. At their leave-taking in Bordeaux, Janssen had impressed on Baudewyns that the Bank's three officers in unoccupied territory - Baudewyns, Ansiaux and Theunis - were on no account to exceed the authority delegated to them on 18 June, which was no more than to take measures to conserve the Bank's gold stocks abroad. Only Ingenbleek, staying at Mont-de-Marsan after Janssen had left for Brussels, was given authority to execute payment orders on behalf of the Bank in unoccupied areas.

Baudewyns looked to obey Janssen's formal order to the letter and informed Ansiaux and Theunis of his intention ${ }^{27}$. However, he was no sooner installed in London before requests for money and advances came pouring in. Boël needed money to find somewhere to house the Belgian Navy, which had moved to England. The ambassador, Cartier de Marchienne, requested money to support the Belgian embassy's ex-

26 вNB, Archives, SD, London Archives, dossier 2 (1941): letter of 07.06.1941 from Ansiaux (New York) to Baudewyns (London).

27 BNB, Archives, $S D$, London Archives, dossier 2 (1940), s. f. 'difficultés de disposition à la Federal Reserve Bank': letter of 12.07.1940 from Theunis (New York) to Baudewyns (London). 
ceptionally busy rôle in London, to pay the salaries and costs of the other diplomatic and consular services within the sterling zone and to provide material help to the Belgian military personnel, politicians, officials and the like who had also fled to England. Baudewyns had himself to provide financial support for the twenty-eight members of the Bank's staff who were in London. Over and above this, Baring, the London bank, was asking for instructions, to ensure the servicing of the State loan of 1936. Lastly, Theunis was urgently demanding money to be able to finance the servicing of the loan taken out in New York by the Belgian State, which matured on 1 July 1940. He also needed money to pay the oversees diplomatic services outside the sterling zone, for which he was responsible. Caught on the back foot by all these requests, Baudewyns was now fully convinced that the Bank in London ought to be represented by someone with power of decision, someone who, in the capacity of State cashier, could make specific payments on account of the State ${ }^{28}$. Moreover, driven to distraction by Ingenbleek's irrational conduct, he sent a telegram to Theunis, requesting him to contact the Federal Reserve Bank of New York and ask, as a matter of urgency, whether it would be willing to execute a few more payment orders for the Bank if they came from London and were signed by Baudewyns ${ }^{29}$. However, the Federal Reserve Bank refused to recognize Baudewyns' signature, keeping strictly to the instructions issued by Janssen ${ }^{30}$. At that point Theunis wrote to Baudewyns: 'Janssen's instructions to the Federal Reserve Bank tie my hands completely ${ }^{31}$. Theunis found it incomprehensible that Janssen, on his departure for Brussels, had not ensured that Baudewyns would have the same authority to make pay-

28 BNB, Archives, SD, London Archives, dossier 2 (1940), s. f. 'avances de trésorerie' (De Vleeschauwer: juillet 1940): report of a meeting of 08.07.1947 at the Belgian embassy; letters of 9 and 11.07.1940.

29 ARA, Theunis Papers, 'correspondance Theunis-Baudewyns': letter of 15.07.1940 from Baudewyns (London) to Theunis (New York).

30 BNB, Archives, $S D$, London Archives, dossier 2 (1940), s. f. 'difficultés de disposition à la Federal Reserve Bank': letter of 18.07.1940 from the Federal Reserve Bank (New York) to Baudewyns (London).

31 BNB, Archives, SD, London Archives, dossier 2 (1940), s. f. 'difficultés de disposition à la Federal Reserve Bank': letter of 20.08.1940 from Baudewyns (London) to Theunis (New York); letter of 19.09.1940 from Theunis (New York) to Baudewyns (London). 
ments in the dollar and sterling zones as Ingenbleek for the French franc zone. Had he done so, all problems would have been eliminated ${ }^{32}$.

Even Janssen received no response when, as Governor, he attempted to authorise payments to the Federal Reserve Bank from Brussels ${ }^{33}$. That institution now invoked Belgian law, which stated that, in times of war, the registered office of the Bank was required to be established where the government had chosen to be domiciled. The legal Belgian government was now in London and the registered office of the Bank had meanwhile been transferred to Brussels, a situation which was not in conformity with the law. Because of this, the Federal Reserve Bank refused to accept payment orders from Brussels.

Baudewyns, for his part, had more to contend with than the Federal Reserve Bank's refusal to recognize his signature, as his position in London as representative of the Bank was hotly disputed during the initial months after his arrival. At first, he concentrated on activating the Anglo-Belgian financial agreement of 24 May-7 June 1940 and the accompanying memorandum endorsed in Paris by Janssen and Cobbold for the Bank and the Bank of England respectively.

That agreement laid down that the British and Belgian governments would grant each other, for the duration of the war, a credit line of up to 3 million pounds sterling at an interest rate of 3 per cent; accounts would be squared each month and half of any credit drawn down would be settled in gold ${ }^{34}$. In France, the Belgians were convinced that the British delegates were totally behind the agreement and that official ratification was no more than a pure formality. Once in London, however, Baudewyns could persuade neither the British government nor the Bank of England to have the necessary signatures appended to the agreement and its stipulations implemented ${ }^{35}$. Ultimately, a financial arrangement was set up by roundabout means: more particularly, a temporary agreement between the Banque du Congo Belge and the

32 ARA, Theunis Papers, 'correspondance Theunis-Gutt': letter of 20.08.1940 from Theunis (New York) Gutt (Lisbon).

33 BNB, Archives, SD, Ansiaux Papers, 1: letter of 03.08.1940 from Ansiaux (Vichy) to Janssen (Brussels).

34 See above.

35 BNB, Archives, $S D$, Ansiaux Papers, 1: letter of 03.08.1940 from Ansiaux (Vichy) to Janssen (Brussels): 'l'accord anglo-belge n'a pas joué'. 
Bank of England whereby, among other things, each granted the other a line of credit, from which the Banque du Congo Belge could lend sterling to the Belgian government ${ }^{36}$.

Another difficulty concerned payment or transfer orders to the Bank of England on behalf of the Belgian government. Janssen had informed the Bank of England that, after the return of the Bank's registered office to Brussels, he had resumed his authority as Governor. Next to Ingenbleek at Mont-de-Marsan, he would also, among other things, issue international payment orders from Brussels on behalf of the government. Following a policy of its own, however, the Bank of England declared that it could not accept orders from Janssen nor from Ingenbleek, since, for the duration of the war, it would not, as a matter of principle, execute orders issued from within German-occupied territories or even from unoccupied France. The fact that these were not just idle words was born out by the feeling Baudewyns and Ansiaux had of being in the firing line because of their contacts with Brussels and Mont-de Marsan, as detailed in Chapter 5. This unpalatable situation was resolved by a decree issued by the Belgian government on 31 October 1940, shortly after its establishment in London. This substantially increased the administrative authority of all directors of Belgian companies who were resident in unoccupied territory, whatever their previous status. This immediately normalized the situation of Baudewyns and Theunis, both of whom could now act effectively in the direction of the Bank within the sterling and dollar zones ${ }^{37}$.

36 вNB, Archives, Boekhouding, 1, dossier D 606/4: letter of 04.07.1940 from Baudewyns (London) to Janssen (Mont-de-Marsan).

37 BNB, Archives, SD, Ansiaux Papers, 1: letter of 03.08.1940 from Ansiaux (Vichy) to Janssen (Brussels). See also: BNB, Archives, $S D$, Malaise Papers: Kauch, note relative à l'or, $n^{\circ} 23$. 


\section{The Banque Nationale de Belgique in London in the Maelstrom of War}

\section{THE LOAN OF GOLD TO GREAT BRITAIN}

Just before leaving France for Belgium in early July 1940 Jannsen had asked Montagu Norman, Governor of the Bank of England, what he was doing about the instruction to transfer the Belgian gold from London to the Federal Reserve Bank of New York ${ }^{1}$. Norman replied with the vague words: '... we are taking steps to deal with the gold held here for the National Bank of Belgium on the lines set out in the memorandum (of ) $8^{\text {th }} J u n e^{2}$. In a letter of 18 July, Baudewyns also asked Norman what progress had been made with the transfer ${ }^{3}$. Norman again answered in sibylline terms: 'You may assume, for all practical purposes, that the whole amount of gold which we hold for the National Bank of Belgium, is now on the other side of the Atlantic ${ }^{4}$.

However, more details were provided by Siepmann of the Bank of England, who stated that the gold had not been transferred to the Fed-

1 BNB, Archives, Boekhouding, 1, dossier D 606/4, 'correspondance avec la Bank of England': letter of 08.07.1940 from Baudewyns (London) to Norman (London).

2 BNB, Archives, Boekhouding, 1, dossier D 606/4: letter of 09.07.1940 from Norman (London) to Baudewyns (London). Article 8 of the memorandum of 8 June reads as follows: 'Dès à présent, il a été demandé à $M$. Cobbold que les mesures conservatoires que la Banque d'Angleterre pourrait prendre en ce qui concerne ses réserves métalliques soient étendues, dans la mesure du possible, aux réserves métalliques de la Banque Nationale de Belgique. M. Cobbold examinera la possibilité de donner suite à cette demande, étant évidemment entendu que les transports se feraient aux frais et risques de la Banque Nationale de Belgique(BNB, Archives, SD, London Archives, 2 (1940), dossier 'Janssen': memorandum of 08.06.1940 from Janssen to Cobbold).

3 BNB, Archives, Boekhouding, 1, dossier D 606/4: letter of 18.07.1940 from Baudewyns (London) to Norman (London).

4 BNB, Archives, Boekhouding, 1, dossier D 606/4: letter of 24.07.1940 from Norman (London) to Baudewyns (London). 
eral Reserve Bank of New York, under Bank dossier, as requested by Janssen, but had been sent to Ottawa, where it had been deposited in safe custody at the Canadian central bank. Siepmann warned that any further insistence on the gold being taken to New York could result in the deposit being confiscated and would, in any case, be regarded as a hostile act against Great Britain 5 . Even before the gold had been moved to Canada, however, it had already been under a form of embargo, as the Bank had no access to it without the authorization of the British government. Baudewyns' comment, made a few months later, was therefore correct: 'Since the capitulation of the French army our gold deposit in London has been the prisoner of Great Britain'.

It was clear that Great Britain was not keen for the Belgian gold to be transferred. If it had to be, however, Britain preferred to send it to safety in Canada, one of the Dominions, and not to New York, outside Britain's field of influence, where there was a risk of the gold being frozen for the duration of the war. Nevertheless, the evasive and misleading answers by the highest British authority - particularly ignoring Janssen's instructions - did not really accord with the notion of fair play. The times were, of course, exceptionally difficult. During the late summer and autumn of 1940, Britain stood alone to face what proved to be the decisive battle against the Luftwaffe. The country needed many weapons, and needed them immediately. For the British, the only possible supplier was the United States, but the United States still applied the 'cash and carry' principle for all procurement: settlement for all purchases had to be immediate and in gold, which spelt catastrophe for the British Treasury.

Gutt saw in the gold affair an opportunity to rehabilitate the Belgian government in the eyes of the British authorities. He had already worked out for himself that, sooner or later, the British would request the Belgian government to cede its gold to them; should he refuse, he risked the gold being confiscated as enemy property'. But when complying with the request, Gutt intended to stipulate that the Belgian gov-

5 BNB, Archives, Boekhouding, 1, dossier D 606/4: memorandum of 24.07.1940 from Baudewyns.

6 BNB, Archives, SD, London Archives, 2 (1941): memorandum of 26.04.1941 from Baudewyns.

7 ARA, Theunis Papers, 'correspondance Theunis-Gutt': letter of 10.08.1940 from Gutt (London) to Theunis (New York). 
ernment would make that gesture only if the other governments in exile - including the Dutch, the Norwegian and the Polish - were to do the same.

On 11 October 1940, Gutt was invited by the Chancellor of the Exchequer, Kingsley Wood, to discuss the financial difficulties the Belgian government in London was experiencing as a result of its lack of foreign currency $^{8}$. Gutt stated that its chief need was for sterling, as only one quarter of its total expenditure was required to be in us dollars. He went further, to suggest that the shortage of sterling could be solved largely by exports from the Belgian Congo to Great Britain. If the balance of trade in the Congo's favour was found to be insufficient, then the Belgian government could always have recourse to the line of credit granted by the British, as laid down in the Anglo-Belgian financial agreement of 24 May-7 June 1940, although that agreement had not yet formally come into operation. us dollars could be purchased against gold from the Belgian cache at the Federal Reserve Bank of New York. If that were frozen, Gutt felt that recourse could always be had to the Belgian gold deposited with the Bank of England.

Wood used this last suggestion of Gutt to make his own proposal, which was for the Bank of England to purchase against payment in sterling all the Belgian gold deposited in London. Gutt could hardly say straight out that he found such a proposal unacceptable because he had insufficient confidence in the future of sterling. He therefore answered that the Belgian government was certainly prepared to help, but could do so only within the limits of what was possible. Legally, the gold was owned by the Bank and not by the government so that he would have to consult Baudewyns and Theunis. However, he emphasized that the gold reserve was an 'essential' element of the Belgian central banking system, acting as a guarantee for the value of Belgian banknotes, as required by the Bank's bye-laws; hence, the Bank could not 'sell' the gold, though it could, in Gutt's opinion, 'lend' it.

The British minister was unhappy about Gutt's negative reaction and, in a series of discussions involving both the Bank and the Bank of

8 ARA, Administrative services of the Prime Minister: letter of 16.10.1940 from Gutt (London) to Kingsley Wood; letter of 22.10.1940 from Gutt (London) to Waley (London); report of the meeting between Waley, Gutt and De Vleeschauwer at the British Treasury in London, 06.11.1940. 
England, continued to press Gutt to revise his standpoint ${ }^{9}$. Nevertheless, Gutt refused to budge. All the members of the Belgian government and all representatives of the Bank in London and New York gave their support to Gutt's statement of principle. Moreover, Baudewyns required, in case of the gold being lent, concrete guarantees for its return, demanding to know where, when and how the gold - the foundation of the Belgian monetary system - would be returned to the Bank ${ }^{10}$.

Baudewyns now found himself caught between two fires. He saw clearly that, as a loyal ally, Belgium was duty-bound to support Great Britain in the struggle against Germany, but this conflicted with his own loyalty and duty to the Bank. It was a dilemma that he could not solve by himself and he therefore resolved to obtain Janssen's counsel, hatching a plan to send Ansiaux (perhaps under a false passport) to unoccupied France to find a way of getting in touch with Janssen to ask his advice ${ }^{11}$. Gutt was not at all pleased with Baudewyns' initiative and opposed the plan ${ }^{12}$.

Gutt got his way and Ansiaux did not leave for France. However, Baudewyns did not give up, but waited for a more opportune moment. This came shortly afterwards when, in February 1941, Ansiaux was sent not to France, but to Lisbon on behalf of both the government and Baudewyns. There, he was to meet Félicien Cattier of the Société Générale de Belgique, who was bringing the latest news from Belgium. Ansiaux also had to hand him instructions from the government and the Bank in London for Galopin and Janssen in Brussels. In his memorandum, Baudewyns dealt extensively with the current discussions with the British government, clearly setting out the advantages and disadvantages of a possible loan of the gold. Cattier said that he was convinced that Janssen would endorse the operation, on condition that the other small countries would agree to do the same ${ }^{13}$.

9 ARA, Administrative services of the Prime Minister: letter of 18.10.1940 from Waley (London) to Gutt (London).

1O ARA, Theunis Papers, 'correspondance Theunis-Gutt': letter of 12.02.1941 from Gutt (London) to Theunis (New York).

11 BNB, Archives, SD, London Archives, 1 (1940): memorandum of 22.02.1941 sent by Baudewyns (London) to Janssen (Brussels) via Ansiaux and Cattier (Lisbon).

12 ARA, Theunis Papers, 'correspondance Theunis-Gutt': letter of 06.01.1941 from Gutt (London) to Theunis (New York).

13 BNB, Archives, SD, Ansiaux Papers, dossier 'Cattier': letter of 03.03.1941 from Ansiaux (Lisbon) to Baudewyns (London). 
In asking for special guarantees Baudewyns' purpose was not only to protect the interests of the Bank but also to gain time until he received an answer from Janssen. Gutt saw things differently. His aim was to accelerate the loan of the gold, so that he would have something in hand for his negotiations with the British about the post-war position of Belgium and her colony, the gold loan being his bargaining counter. Moreover, he feared that long-drawn-out negotiations would give the loan greater publicity in Belgium and lead to questions about it. He was therefore outraged when he heard that Baudewyns had given a detailed memorandum about the matter to Ansiaux to pass on to Janssen ${ }^{14}$.

Relations between the Bank and the government did not improve when, in February 1941, the British Chancellor of the Exchequer, Kingsley Wood, abandoned the idea of purchasing the gold and opted for a loan. This required a concrete proposal to be prepared and necessarily required Baudewyns' presence. Gutt, would have preferred to arrange the matter at government level, since he realized that Baudewyns' 'cooperation' would not make his task any easier, which proved to be the case. Baudewyns regarded the loan not as one between two governments, as originally conceived, but as one from the Belgian government to the Bank of England. The Bank would not itself lend the gold, but, in response to a formal request, transfer it to the Belgian government. In this way, as far as the Bank was concerned, the loan would be guaranteed not only by the Bank of England, but also by the Belgian government ${ }^{15}$, thereby giving the Bank dual cover.

On 17 February 1941 Wood organized a lunch at the Treasury, to which he invited forty guests. These included all the ministers of finance of the governments in exile in London and the representatives of the respective central banks. Also present were top officials from the Treasury, the Foreign Office and the Bank of England. In his speech of introduction, Wood stated bluntly that Great Britain was in need of help, appealing to their solidarity as allies and requesting financial help in the struggle against Germany.

A few days later, Wood asked Gutt round to the Treasury. There, he came straight to the point, saying to an astounded Gutt: 'We need gold and we don't have any gold left. Without waiting for a signed agree-

14 ARA, Theunis Papers, 'correspondance Theunis-Gutt': letter of 12.02.1941 from Gutt (London) to Theunis (New York).

15 Ansiaux, Souvenirs, pp. 82-83. 
ment, could you lend us some immediately?'. Gutt called the moment unforgettable and dramatic: 'I will always remember the day when Great Britain was asking me for gold to an amount of 25 million pound sterling, because she did not have any gold anymore'. Gutt answered that he was always ready to oblige, but that he could do no more than have the loan granted within the framework of the agreement being prepared, nevertheless promising to do everything in his power to expedite matters. He kept his word and, together with Baudewyns, was invited back to the Treasury on 1 and 2 March to work with Arthur Siepmann of the Treasury, Sir David Waley of the Foreign Office, and Harry Lloyd Hopkins, President Roosevelt's envoy in London, to drawing the agreement ${ }^{16}$.

On 4 March an agreement was hammered out and signed that same day ${ }^{17}$. By its terms, the Belgian government declared itself prepared to lend three quarters of the Bank's gold deposited in London to the Bank of England, i.e. 7 million ounces or about 60 million pounds' worth. The Bank of England subscribed to the loan with gold certificates, thus undertaking to repay the loan in gold. Repayment would commence six months after the cessation of hostilities and be in monthly instalments of 1 million pounds ${ }^{18}$. The Belgian government immediately asked the Bank for an initial tranche of 3 million ounces of gold - 25 million pounds' worth - which was lent to the Bank of England on 6 March. The agreement also made provision for the Belgian government to have free access to a line of credit in sterling, should the Belgian Congo at any time be unable to make sufficient amounts of sterling available; furthermore, that line of credit was not required to be settled in gold but could be in pounds ${ }^{19}$.

Even Gutt had to admit that Baudewyns' obstinacy - a trait that had so often annoyed him - had not been without its uses during the preparation of the agreement. After the tough discussions and the con-

16 ARA, Theunis Papers, 'correspondance Theunis-Gutt': letter of 03.03.1941 from Gutt (London) to Theunis (New York).

17 Baudewyns Family Archives: letter of 04.03.1941 from Baudewyns (London) to his son (Oxford).

18 BNB, Archives, $S D$, Ansiaux Papers, 2, lettres de Baudewyns à Ansiaux: letter of 04.03.1941 from Baudewyns (London) to Ansiaux (Lisbon).

19 ARA, Theunis Papers, 'correspondance Theunis-Gutt': letter of 03.03.1941 from Gutt (London) to Theunis (New York). 
clusion of an auspicious agreement, all obstacles to the gold loan appeared to have been overcome. Yet appearances can, of course, deceive. The conditio sine qua non for winning the Belgians over in the first place had been that all the small-country allies should follow suit. In fact, they all agreed to do so, until 11 March 1941, when the Lend Lease Act was passed in the United States. Then, every one of them, with the Netherlands in the lead, retracted their promise, assuming that Great Britain would now be able to survive without their help. Gutt judged that Belgium would be treated unfairly if the British insisted on holding the Belgians to their undertaking. Kingsley Wood fully recognized the merit of Gutt's argument and on 30 August waived his option to take up the 35 million pounds' worth of gold remaining ${ }^{20}$. The 25 million pounds' worth of gold that had already been borrowed was restored in its entirety to the Bank on 3 March 1943, well before the end of hostilities $^{21}$.

\section{THE DECREES OF 27 NOVEMBER 1941}

When Gutt saw all the difficulties that the Bank had to cope with in London, he realized that he had been wrong in allowing Janssen to return to Belgium and re-establish the Bank's registered office in Brussels. Plisnier's appointment of a new governor of the Bank on 16 July 1941 therefore was not at all well received in London. The government had certainly hoped that, following Janssen's death, the office of governor would remain vacant for the duration of the war ${ }^{22}$. It was hard enough to swallow the fact that an appointment had been made, but that the choice should have fallen on Goffin was the last straw.

An interview given by Goffin to the newspaper le Soir immediately after his appointment as governor did nothing to smooth things between London and Brussels. On the contrary: when asked whether

20 ARA, Administrative services of the Prime Minister, dossier 'Angleterre': letter of 03.07.1941 from Gutt (London) to Pierlot (London), memorandum of 26.07.1941 from Gutt (London) for Pierlot (London).

21 BNB, Archives, DC, 28.12.1944; BNB, Archives, SD, Malaise Papers: Kauch, La Banque Nationale (unpublished text), Part 1, Chapter. 9, p. 61.

22 BNB, Archives, SD, London Archives, 2 (1941): letter of 29.07.1941 from Ansiaux (New York) to Baudewyns (London). 
the Bank's gold in unoccupied territory was really safe, Goffin had replied that he trusted that the 'so-called' Belgian government in London would not use the Bank's gold deposits for its own ends and would not cede it to third parties ${ }^{23}$. Gutt took this answer as a reproachful allusion to his recent loan of Belgian gold to the Bank of England and felt himself targeted and criticised personally.

Arguments other than personal criticism also raised questions about Goffin's appointment. One of them concerned whether, as a secretarygeneral, Plisnier was actually competent to make such an appointment, and this immediately put the spotlight on the scope of the legitimacy of all secretaries-general. By law of 10 May 1940, the government had delegated ministerial authority to them or their deputies, to be exercised in the event of the country being occupied. The government in London, however, had never favoured a broad interpretation of the ministerial authority granted to the secretaries-general. In a radio broadcast barely two days after Goffin's appointment, Pierlot returned explicitly to the limited character of the delegated authority ${ }^{24}$.

Another reason why the government regretted allowing Janssen to return to Brussels and re-establish the Bank's registered office there was the difficulty experienced by the Bank in introducing legal proceedings against the Banque de France before the court in New York. Normally, the proceedings ought to have been introduced from the Bank's registered office, but this was no longer a practical option, now that the registered office was in occupied territory. However, the American judges had great difficulty in regarding Baudewyns in London and - even more - Theunis in New York as representatives of the Bank, empowered to take legal proceedings on behalf of the Bank, but without having received an explicit mandate from Brussels to do $\mathrm{so}^{25}$.

There were thus too many problems as long as the Bank was based in Brussels. Once Janssen was dead, however, Gutt set about finding a solution, transferring the Bank's registered office to London, declaring Goffin's appointment in Brussels illegal and appointing a new governor in London. Before making decrees to effect this, however, he needed

23 Newspaper Le Soir, 23.07.1941: interview with Governor Goffin.

24 Belgian Official Gazette, London, 17.07.1941: text of Pierlot's radio broadcast.

25 See above. 
to be sure of having the right man for the office. Objectively, the most obvious candidate to become governor was Paul Van Zeeland. He had for years been a director of the Bank, thereafter its deputy-governor; and although not felt by all to be irreproachable, he was seen by many as being the most expert in monetary matters. Moreover, he was in unoccupied territory and was highly regarded by both the British and the American governments. Gutt's personal rancour against him, however, was too great for his candidature to be acceptable. In Gutt's view, the only other person in unoccupied territory who had the standing necessary for the position was Theunis, who eventually agreed to his name being put forward, although only after a great deal of correspondence ${ }^{26}$.

In fact, Theunis was not overjoyed at the prospect of becoming governor of the Bank. In no circumstances did he wish to leave New York and his wife was even more adamant about staying there. Furthermore, he had passed the legal age limit to be considered for the appointment, that had been set by law at 67 and Theunis was then 68 . Gutt regarded it the job of the lawyers to smooth away such difficulties and that is what they did. Joseph Nisot, Theunis' legal adviser, argued that the law applied only to governors who had not yet reached the age of 67 at the time of their appointment, and, as Theunis had already passed it, he could thus be appointed ${ }^{27}$.

On 20 October 1941, Gutt began discussions with Baudewyns in order to gain his support for the planned reforms. Baudewyns had no objections in principle; he found it a good idea for the Bank's registered office to be transferred to London, having always been in favour of the original arrangement, which laid down that, during time of war, the Bank's registered office should be established where the government was in residence. He was also able to live with the appointment of Theunis and with his somewhat astonishing decision not to elect domicile in London, where the Bank's registered office was now established, but to remain in New York. Moreover, this decision would allow Baudewyns himself to chair the board of directors in London, as well as permitting him to present the official report on the Bank's activities in

26 ARA, Theunis Papers, 'correspondance Theunis-Gutt': letters of the summer and early autumn 1941 between Gutt (London) and Theunis (New York).

27 BNB, Archives, $S D$, Ansiaux Papers, A2: memorandum of 10.12.1943 from Nisot. 
unoccupied territories during the war to the Bank and to Belgian public bodies on his return to Belgium ${ }^{28}$.

However, there was one point in the plan that Baudewyns was not prepared to go accept. Gutt's idea was to have a four-strong board of directors in London, consisting of Baudewyns, the director already in situ, Ansiaux, to be promoted to director, and two outsiders yet to be appointed. There would thus be seven directors in total, including the three in Belgium. It was the appointment of two outsiders that was the sticking-point for Baudewyns. He feared that they would threaten his authority within the board in London, and also that their appointment would lead to an unhealthy interference from private banking taking root in the Bank. In this respect, he referred to what had happened in Belgium during the 1920 s and, indeed, until late in the 1930s. Gutt conceded the point: the Bank's board of directors in London would consist of no more than two directors, Baudewyns and Ansiaux.

Gutt's plan for reform was submitted to the National Committee for its opinion. On that committee sat Belgian parliamentarians and prominent political figures who had fled to London. It met on 16 November 1941 and found no difficulty in declaring its approval of the project as such. However, it reacted very negatively to Gutt's suggestion that Theunis be appointed governor and put forward Baudewyns or Van Zeeland as being the only feasible candidates. Used, as he was, to having his ideas accepted, Gutt left the meeting beside himself with indignation. For his part, Baudewyns saw the Bank's future threatened by an unprecedented rift between government and the National Committee. Nevertheless, Gutt was to get his way, but only after he had promised to ensure that Theunis' appointment would be only for the duration of the war.

On 27 November 1941, the government in London issued two decrees $^{29}$. The first replaced royal decrees of 24 August and 2 October 1939 on the operation, organization, competence and bye-laws of the Bank, and, for the duration of the war, granted the Minister of Finance power to appoint or dismiss up to seven directors. In addition, it specified that,

28 Baudewyns Family Archives: letters of October-November 1941 from Baudewyns (London) to his son (Oxford).

29 Belgian Official Gazette, London, 10.12.1941. 
for the duration of the war, the governor and the board of directors were the sole management bodies of the Bank: business was to be conducted at the registered office established in London. The board of directors had a quorum when at least two members were present and should the governor be prevented from attending, he was to be replaced as chairman by the eldest of the directors present; it specified further that the amendments to the bye-laws were justified by the exceptional circumstances of the moment and that the board of directors in Brussels, the supervisory council, the board of scrutineers, the general council and the general meeting of shareholders were no longer competent to take administrative measures and to represent the Bank in law.

The second decree appointed Theunis as governor of the Bank for the duration of the war. Because only one director was present in unoccupied territory and because this might threaten the Bank's proper operation, Ansiaux was appointed director on 12 December. This followed Gutt's message on radio 'Free Belgium', in which he had explained the reforms and made it clear that the government in London regarded Goffin's appointment as illegal and, moreover, had relieved the leaders of the Bank still active in Brussels of every administrative and executive competence.

\section{THE REACTIONS IN BELGIUM}

As was only to be expected, the news from London came as a bombshell to those in occupied Belgium, creating confusion and uncertainty among the leaders of both the Bank and the country ${ }^{30}$. At the Royal Court in Brussels, the decrees were interpreted as the opening salvo in a wider campaign by the government in London to curb any autonomous exercise of power in the occupied territory and to reinforce its own political influence in Belgium ${ }^{31}$. In industrial circles, many did not worry too much about the changes; they were regarded as an unnecessary and

30 SG, Archives, Direction, Galopin, 94: message of 05.01.1942 from Galopin (Brussels) to Gutt (London) via Bemelmans (Berne).

$31 \mathrm{KP}$, Archives, fonds Leopold III, cabinet du roi, dossier 232 b: réactions aux arrêtésloi du 27 novembre 1941 (03.12.1941). 
inappropriate interference on the part of the government in London in the internal administration of occupied Belgium ${ }^{32}$.

At the Bank, too, there were some who thought that the second decree could be taken with a pinch of salt. However, the board of directors in Brussels was not entirely at ease with the tone of Gutt's radio broadcast. The board therefore resolved to consult the jurist Marcq ${ }^{33}$, who gave it as his firm opinion that the Bank's registered office was validly transferred in July 1940 from Mont-de-Marsan back to Brussels. Additionally, Marcq recognized Goffin's appointment as governor, contradicting Gutt's claim: the appointment by Plisnier was in conformity with the transfer of ministerial authority to the secretaries-general by the law of 10 May 1940 and fully respected the necessary conditions of urgency for that authority to be exercised.

Marcq also examined the scope of the two decrees. In his opinion, they had been validly promulgated and consequently had the force of law; thus, with effect from 27 November 1941, Goffin was no longer the governor of the Bank and was replaced by Theunis. With effect from that date, too, the Bank's registered office was transferred from Brussels to London. Marcq nevertheless stated that the decree reorganizing the Bank did not provide for closure of the Bank in Belgium ${ }^{34}$; nor did it remove from office the four members of the board of directors in Brussels, Ingenbleek, Goffin, Berger and Van Nieuwenhuyse. Although they no longer had any power to take administrative and executive decisions, their competence was now governed by article 1375 of the Civil Code, whereby their activities were required to be in line with what was expected of scrupulous and diligent caretakers ${ }^{35}$.

32 According to the Court, the reaction of many industrialists was: 'Qu'ils nous fichent la paix!': KP, Archives, fonds Leopold III, cabinet du roi, dossier 232 b: réactions aux arrêtés-loi du 27 novembre 1941 (03.12.1941).

33 BNB, Archives, SD, Malaise Papers, 1, dossier 9.5.5/ s. f. 1: maître Marcq, questions soulevées par la communication radiophonique de Londres, 01.12.1941.

34 Gutt later wrote that he would have liked to close the Bank in Brussels on 27 November, but that Pierlot and the other members of the government had advised him against doing so: ARA, Theunis Papers, 'correspondance Theunis-Gutt': letters of 20.03.1942 and 29.04.1942 from Gutt (London) to Theunis (New York).

35 The government in London attached great importance to the opinion of the jurist Marcq, who had stated that Goffin was no longer governor and that, with effect from 27.11.1941, the function was legally held by Theunis: ('Gutt est aux anges!', 
The board of directors in Brussels concurred with Marcq's opinion and resolved to remain in post, not wishing to be accused after the war of desertion ${ }^{36}$. The German commissioner at the Bank, for his part, thought that the moment had come to force a break with the Bank in London and attempted to convince the board to inform the Federal Reserve Bank of New York that Theunis, Baudewyns and Ansiaux were no longer part of the Bank. However, the board refused to countenance this, stating that only the general assembly was competent to pass a resolution of that nature ${ }^{37}$.

Galopin and the limited circle of leading bankers were apparently much more on the qui vive than the Brussels board of directors and, in order to gain a better insight into the actual scope of the decrees, Galopin attempted to contact the government in London. Arthur Bemelmans, a director of the Société Générale de Belgique, had obtained a passport to travel to Switzerland and, at Galopin's request, he sent a telegram to Gutt from there in December 1941 to ask for an elucidation of the measures of 27 November $^{38}$. The telegram pointed out that Gutt's radio broadcast had caused a great deal of turmoil in Belgium and that it was very difficult to gauge the intentions behind the measures. It asked whether the decrees were intended solely to provide a more solid legal basis for the proceedings in New York or whether the decisions taken were really in earnest: more particularly, whether Goffin and Plisnier were to resign as governor and secretary-general respectively, and whether the Bank in Brussels and its branches throughout the country were to be closed. The telegram also underlined that both the group around Galopin and other leading figures in business and public authorities wished to follow the government's directives, but desired further information about the exact nature of the matter.

wrote Baudewyns to Ansiaux, when the opinion became known in London): BNB, Archives, SD, London Archives, 1 (1942), 'correspondance': letter of 16.03.1942 from Baudewyns (London) to Ansiaux (New York). In a memorandum of 29.05.1943, drawn up in London, Henri Rolin declared his agreement with Marcq's opinion (BNB, Archives, Studiedienst, 13, dossier 01.02.01.70 (A 320/ 5): memorandum of 29.05.1943 from Henri Rolin).

36 BNB, Archives, DC, 05.12.1941.

37 BNB, Archives, DC, 09.12.1941.

38 BNB, Archives, $S D$, 'enquête BEB': report of the Commission of Enquiry (published text, 1947), Part 1, pp. 39-42. 
Gutt telegraphed his reply to Bemelmans via the British embassy. The text, indeed, indicated clearly that important motives for the decrees being issued were to secure the deposits of Belgian gold abroad, to strengthen Belgium's legal position in the proceedings in New York against the Banque de France; and finally to use the decrees for underpinning the governmengt's image as an active participant in the allied camp. However, Gutt went much further in explaining the reasons for the decrees. He claimed that the removal of the Bank's registered office from Mont-de-Marsan to Brussels had been illegal, as had been Goffin's appointment as governor by Plisnier. All this, coupled with the regrettable interview of Goffin in the newspaper Le Soir, meant that Goffin had to resign as governor. Gutt also stated that he did not wish to make a final statement about Plisnier, but that there was no doubt that the secretary-general had committed a number of grave errors. In respect of the Bank's closure, Gutt said that he was not prepared to make an unequivocal judgement, but the Bank could probably consider scaling down its activities and having recourse to another issue institution, as had been the case during the First World War. The directors of the Bank, including Goffin, could remain, but could no longer exercise any management authority as a board of directors.

Insufficient care was taken by the British diplomatic authorities to deliver Gutt's telegram safely to Bemelmans, who was handed it in the middle of a meeting at a Swiss bank with his German counterparts. Feeling certain that they had noticed something suspicious and probably suspected him of espionage, he destroyed the document, conveying its contents verbally to Galopin on his return to Brussels. For fear of the Germans, Galopin and Bemelmans agreed to keep the telegram's existence secret, which is why, although he realized how important Gutt's message was, Galopin never explicitly mentioned the telegram to Goffin.

Galopin nevertheless made several attempts to bring the attitude of the Bank's leaders in Brussels more into line with the political decision-making of the government in London. In February 1942 he invited Goffin several times to exchange thoughts on the matter. During those personal discussions, Galopin placed the question of the gold cover in the wider context of Gutt's radio broadcast of 28 November of the previous year, in which the validity of Goffin's appointment was disputed 
and displeasure expressed with Goffin's interview in Le Soir. He also asked whether the question of the gold cover was perhaps not a good opportunity to scale down the Bank's activities and for Goffin himself to resign as governor of the Bank and as chairman of the Banque d'Emission.

Goffin declared that he was prepared to follow the government's instructions as far as possible, but that he would not resign as governor, as this would give the Germans a free hand to do what they had done in the Netherlands and appoint a Belgian puppet governor. Nevertheless, he gave an undertaking to Galopin that he would continue as governor only in a caretaker capacity ${ }^{39}$.

During that February, Galopin also emphatically defended his position to the board of directors of the Banque d'Emission, suggesting that, to scale down its operations, the Bank ought to cease to issue notes; in this way it would be acting in the spirit both of the decrees (of which it had been sent a copy from Basel to Brussels via the BIs) and of Gutt's radio broadcast. If necessary, the Banque d'Emission could undertake the issue of new banknotes. This view was supported by de Munck, Collin, Bekaert and Peltzer, but not by most members of the board, who felt that a dual circulation of banknotes had to be avoided at all cost. It was this argument that proved decisive in the rejection of Galopin's proposal.

\section{GOFFIN'S APPOINTMENT AND THE OUTSIDE WORLD}

The London decree likewise led to confusion at the Bank of International Settlements (BIS) in Basel. That institution had been set up in 1930 in the wake of the Young Plan agreements to manage the financial

39 BNB, Archives, SD, 31, dossier 8.11.25/ s. f. 10, 'divers': report of the Galopin-Goffin meeting of 19.02.1942. On the relations between the Bank for International Settlements at Basel (BIs), the government in exile in London, the Bank in Brussels and in London, as far as analyzed in the next subchapter, we were able to draw on a comprehensive memorandum that Dr. Piet Clement, archivist of the BIs, prepared for us on the basis of the BIS archives at Basel, for which our heartfelt thanks. The main BIs file used was: BIs, Archives, dossier 7.18 (5), descriptive catalogue, Hechler Papers, Belgian Treasury Bills. We also used: ARA, Theunis Papers, dossier 22; BNB, Archives, SD, Goffin Papers, dossier 3, 'Banque des Règlements Internationaux'. 
operations linked to the rescheduling of German war reparations. The BIS was required to operate in currencies that satisfied the conditions of the gold standard or of the gold exchange standard. By the end of the 1930's, few currencies still met those conditions, but one of those few was the Belgian franc. In consequence, the BIs began to invest a proportion of its liquid resources in short-term Belgian Treasury certificates, which went by the name of 'Mendelssohn bonds', payable and repayable in Dutch guilders, since they were issued through the mediation of the Amsterdam house, Mendelssohn. Subsequently, there were further investments in Belgian Treasury certificates, also denominated in Dutch guilders, but issued through the mediation of the houses Pierson and Beyersdorf-Terlinck. At the end of August 1939 - on the eve of the Second World War - the portfolio of the BIS contained a considerable quantity of Belgian Treasury certificates for a total of 12.65 million Dutch guilders, redeemable on 29 May 1940.

In the meantime, the German armed forces had invaded Belgium, the Belgian government had fled to France, and the country had come under total occupation. From France, the Minister of Finance, Gutt, informed the BIS that the government was prevented from redeeming the Treasury certificates on maturity and paying the interest, due to the exceptional circumstances of war. Because of this, the maturity date would be postponed for three months. It so happened that, at the end of the period, Gutt was in London, together with the Minister for the Colonies, but at that time, not the rest of the government. Redemption or the payment of interest was once again excluded. Even after the Belgian government had regrouped in London, the redemption and interest payments on the Mendelssohn bonds had to be postponed further; in fact, the government went so far as to suspend all redemptions of Belgian foreign debt until after the war. In his letter of 22 October 1940 to the BIs, Gutt also made it known that the government would make no exception, and certainly not 'when an institution dominated by enemy interests is concerned'. He was clearly not particularly well disposed towards the BIs.

For its part, the BIS was not pleased with the Belgian decision. Its investments in short-term Belgian government paper represented a substantial proportion of its liquid resources, and these were now frozen or perhaps lost for good. The insinuation in Gutt's letter was not well 
received either, and the irritation felt on both sides shows all too clearly in the further correspondence. However, the BIs did not give up and in December 1940, its chairman, McKittrick, attempted via American mediation to achieve a compromise solution, whereby the BIS would accept consolidation of the Treasury certificates until after the war, but expected that the interest due would be paid regularly during the duration of the war, taken from the stock of gold that the Bank had deposited under dossier with the Federal Reserve Bank of New York. McKittrick's efforts came to nothing. Gutt then proposed that the BIs should cease to pay dividends to Belgian shareholders, i.e. to the Bank and the few private bank-shareholders in Brussels, but this was rejected, as the BIs felt obliged to meet its obligations towards its shareholders, even in time of war. At a complete loss, McKittrick decided on 15 May 1941 to address himself to Janssen in Brussels, who, with the government's legal approval, had returned the Bank's registered office to Belgium.

The BIs had logic on its side in the change of approach. It had obligations towards the Bank and towards certain private Belgian banks, because together they held 19,772 BIS shares out of a total of 200,400. The governor of the Bank sat ex officio in the board of directors of the BIS and, as representative of the private shareholders, Galopin was also a member. The Belgian shareholders were entitled to a dividend in a gold-convertible currency and all of them currently had their registered office in Belgium. It was therefore normal that the BIs should seek a solution in that country.

When McKittrick wrote to Janssen, he asked whether, via an offsetting formula, the obligation to pay out dividends could not be applied to settling the Belgian Treasury's debt to the BIs. He sent a similar letter to Plisnier. Janssen and Plisnier apparently responded positively, but wished to link any approval - in Janssen's case in consultation with Galopin - to a number of conditions: among these were a reduction in the rate of interest from 4 to 3 per cent, the integration of the question of the Mendelssohn bonds into an overall arrangement for Belgium's outstanding foreign debt and free disposition of the amount of goldconvertible currency to be paid out at Basel, to the extent that it exceeded the amount involved in the offsetting arrangement.

The conditions appeared to be over-ambitious and, to find a solution, the BIs requested the Reichsbank and the German Ministry of 
Finance to mediate. Negotiations proved laborious. Galopin, Janssen and his successor, Goffin, initially held to their original demand that Belgian shareholders have free disposition of the gold-convertible foreign currency accruing to them in Switzerland. Ultimately, however, they were unable to succeed. The eventual agreement of 22 August 1941 was totally in line with the wishes of the BIs: the Ministry of Finance in Brussels declared itself prepared to pay to the Bank in Belgian francs the interest due on the outstanding Treasury certificates held by the BIs; in exchange, the Bank was prepared to use those receipts to pay, in Belgian francs and on behalf of the BIs, the dividends due to Belgian shareholders.

However, a new element was introduced by the decree of 27 November 1941, whereby the Belgian government in exile in London had transferred the Bank's registered office from Brussels to London, declared Goffin's appointment as governor void and designated Theunis in his place. Indeed, Gutt had already informed McKittrick two weeks previously that the question of interest on the Belgian Treasury certificates or Mendelssohn bonds and the dividends due by the BIs to the Bank was to be discussed and settled exclusively with the Belgian government and the Bank in London.

On 5 December, McKittrick answered that he was prepared to resume discussion of the two questions with Gutt, preferably in Portugal, but reiterated his proposal made a year earlier that the certificates be consolidated until after the war and that the payment of interest be made from the Belgian gold deposited in New York. Furthermore, he stated that the BIS could not sever its contacts with Belgium completely, as dividends had to be paid out to the private shareholders in Belgium and that, as members of the board of directors of the BIs, Goffin and Galopin had to be consulted where Belgian interests were involved. As far as the BIS was concerned, the transfer of the registered office to London and the latest appointments at the Bank were primarily inspired by political considerations, in respect of which the BIs could not adopt a definite position, given its neutrality during the war and the fragmentary information available at the time. At first sight the arguments put forward by the Bank in Brussels and the Bank in London to prove their legitimacy appeared to be valid. The BIs therefore proposed to solve the problem for itself by henceforth sending all documents to both gov- 
ernors and by suspending its decisions about appointments and other measures regarding the Bank until the question of legitimacy had been resolved.

Gutt did not accept McKittrick's proposals and allowed the BIs dossier to gather dust until he was informed in the spring of 1942 of the arrangements of 22 August 1941 between the BIS and the Bank in Brussels, whereby the dividend payments to the Bank and the private shareholders, and payment of interest to the BIS would be organized via reciprocal offsetting in Brussels. Gutt now changed his tune and insisted on an agreement between the BIS and the Belgian government and the Bank in London. After an exchange of letters, Gutt concluded that the solution of the problem posed two alternatives: the BIS and the Belgian government (the latter via the Bank in London) would have all dividends and interest due since 1940 transferred in dollars to the respective gold accounts of the BIS and the Bank at the Federal Reserve Bank of New York, either without account being taken of the Brussels offsetting arrangement of 22 August 1941 (Gutt's standpoint), or with account being taken of that arrangement (the BIs standpoint).

Only in the course of 1943, after McKittrick's personal negotiations with Theunis in February in New York, was a solution found that both Theunis, Gutt, and McKittrick could accept. It consisted of the Belgian Mendelssohn bonds being consolidated until after the war and payment of interest to the BIS, as well as BIs dividends to the Bank, being executed in us dollars via the Federal Reserve Bank of New York, without account being taken of the Brussels offsetting arrangement of 22 August 1941. For their part, Theunis and Gutt agreed that the BIS would continue to pay dividends to the private shareholders in Belgium. On 29 October 1943, they gave the green light for a transfer of 331,512 us dollars from the Bank's gold account to the Bis gold account at the Federal Reserve Bank: from the 543,328 us dollars due to the BIs in accrued interest (since 1940), 211,816 us dollars were deducted for dividends due to the Bank from the BIs (since 1940). At the same time, in order to pay dividend to the private shareholders, the BIs offered a small number of Mendelssohn bonds for sale in Brussels, which reduced the total number in the BIS portfolio from 12.65 million to 12.1 million Dutch guilders' worth. After the liberation of Belgium a satisfactory solution was found for the redemption of the bonds and for the double payment 
of dividends and interest for the years 1940-1941. Maurice Frère, who had meanwhile been appointed governor of the Bank, was instrumental in bringing about this arrangement and reconciliation. 


\section{The Proceedings against the Banque de France in New York}

\section{THE CAUSE}

The telegram Kauch sent from Toulouse to New York on 26 January 1941 to inform Theunis, Belgian Ambassador Extraordinary to the United States, of the transfer to Germany of the Belgian gold entrusted to the Banque de France was couched in somewhat cryptic terms: Theunis was told that it was now up to him to undertake action in New York against the Banque de France. Exactly why these instructions were not more explicit and why it was not clearly stated who was giving them are questions that still remain unanswered ${ }^{1}$. But it was clear that Theunis had to decide on the course of action to be taken, i.e. whether legal proceedings should be begun against the Banque de France or a threat of sequestration be made as a means of putting pressure on it to achieve an amicable settlement.

Baudewyns and Ansiaux did not desire a legal confrontation with the Banque de France and supposed that this was not Janssen's intention either. In any case, an action in law was a highly unusual manner in which to solve a difference of opinion between European central banks. Moreover, when Ansiaux travelled to Lisbon in January 1941 he was informed by Cattier that Janssen was in the midst of negotiations with the Banque de France to achieve a settlement regarding recognition of its responsibility for the Belgian gold and that the prospects for a settlement were favourable. This was good news for Baudewyns and Ansiaux who also wanted an amicable arrangement. The fact that the idea of a compromise was rejected and legal proceedings begun in New York, indicates that it was not the people of the Bank in London who were

1 BNB, Archives, Studiedienst, SD 1, dossier 01.02.00.10 (A 230/1): or monétaire (memorandum of 07.01.1944 from J. Nisot, New York). 
pulling the strings, but rather Gutt and Theunis, both of whom were bent on confrontation and felt that they had sound reason for seeking it.

Upon lodging the complaint, Theunis had been permitted by the judge in New York to have the French gold in the strong-rooms of the Federal Reserve Bank provisionally sequetrated. In an interview with the New York Times on 6 February 1941, Theunis declared that, on 17-18 June 1940, the Banque de France had declined to respond to the Bank's request for the contract of deposit in safe custody to be cancelled, that it had refused to evacuate the Belgian gold to the United States, and even worse - had transferred it to the Reichsbank, against the express will of the Bank ${ }^{2}$.

In a memorandum from Jean Sancery, head of the Disputes Department in Paris, received on 27 February 1941 by Jean Martial, the Banque de France's representative in New York, the French central bank, supported in this by the French Ministry of Finance, put forward three arguments disputing the legal action taken by the Bank3. In the first place, it claimed that neither the Belgian government in exile nor the Bank's representatives in London were competent to initiate legal proceedings. It was true that the British and American governments had recognized the Belgian government and the Bank's office in London, but there were no clear legal grounds either for the Belgian government to be recognized as the 'legal government' or for the office to call itself 'the National Bank of Belgium'. Since July 1940, and with the approval of the legal Belgian government, then in Vichy, the registered office of the Bank had been brought back to Brussels. Pursuant to the Bank's byelaws, only the governor or, in his absence, the deputy-governor could take executive decisions on behalf of the Bank and both were now in Brussels. Consequently, the Bank's office in London was not competent to conduct legal proceedings in New York.

2 BdFr, Archives, Direction de la documentation, dossier 1397.1994.01/73, 'or belge': Martial, mon câble d'hier, 07.02.1940 (reçu à la Banque de France, Clermont-Ferrand, 10.02.1941); dossier 1397.1994.01/79: report of 29.04.1941 from Martial (Clermont-Ferrand) to de Boisanger.

3 SOMA, Archives, MBz, dossier 200/F.2: memorandum of 20.02.1941 from Arnal. See also: BdFr, Archives, Direction de la documentation, dossier 1397.1994.01/78, 'or belge': note Sancery pour la Banque de France au sujet de l'instance engagée contre elle par la BNB, reçue 27.02.1941; dossier 1397.1994.01/79, 'or belge': note pour le contentieux (Paris), 28.02.1941. 
Secondly, New York State law itself disqualified the Bank's office in London from taking legal action, as it stated that a foreign company could institute such proceedings there against another foreign company only if one of them did business in that State, which was not the case in this instance. The Banque de France's third argument was that there were no grounds for the complaint as such; on 18 June 1940 it had not 'refused' to cancel the contract of deposit in safe custody, as it had not been 'formally' requested to do so. Furthermore, it had always declared, and was always prepared to reaffirm, that it continued to regard itself responsible for the Belgian gold, even if that gold had for the moment been entrusted to the Reichsbank in the form of a subordinate deposit in safe custody. In any case, the Banque de France would restore the gold to the Bank forthwith on being officially requested to do so by the legally recognized representatives of the Bank and when it was in a position to do so. In the Banque de France's eyes, thus, there was no reason for legal proceedings ${ }^{4}$.

Theunis resolved to engage an eminent lawyer to refute the French arguments and turned to John Foster Dulles, who, at the time, was a senior partner in the well known law firm of Sullivan \& Cromwell (after the Second World War he was to be appointed Secretary of State in Eisenhower's presidency). Dulles had studied at the Sorbonne before the First World War. Theunis had got to know him immediately after the war, as they both served on the Reparations Commission in Paris, Dulles as a junior member of the American delegation and Theunis as head of the Belgian delegation. Theunis had already learnt to appreciate Dulles' talents and now considered that he would be an excellent defender of Belgian interests.

For its defence, the Banque de France turned to the equally well known law firm of Coudert Brothers and Co. The partners of this firm were initially reluctant to take the case, regarding the surrender of the gold to the Reichsbank as a breach of contract that would be difficult to defend before an American court. Coupled with this was the very negative reaction of the American press and public opinion to the news of the surrender, which prompted one of the Coudert brothers to object strongly to becoming involved, as he was a senator for New York State

4 BdFr, Archives, Secrétariat Général, dossier 1060.2001.01.41, 'or belge': note pour la Banque de France, 02.04.1941. 
and, with elections in prospect, was not keen for his name to be linked to a matter that had been subject to such sharp criticism. However, the oldest partner, the father, an ardent francophile, had the final word and accepted the commission from the Banque de France. Paul Fuller, nephew and partner of the brothers, would support the dossier, assisted by a junior partner, Manlon B. Doing 5 . Sancery was sent to New York to appear, together with Martial, for the defence before the American courts, the requisite powers of attorney for both having been signed on 4 March 1941 by the French central bank's governor, de Boisanger ${ }^{6}$.

Sancery left for New York on 15 March, sailing from Lisbon and carrying the documents that Martial needed to prepare the case for the defence. The Portuguese authorities had assured the Banque de France that his ship would sail directly to New York, but en route it was intercepted by British ships and conducted to a port in Bermuda, where it had to remain at anchor for two days. With British agents subjecting the baggage of all travellers to a close search, Sancery made a quick decision to destroy a number of confidential documents 7 . After the war, Ansiaux would claim that these agents had had the documents photographed at night and had forwarded the photographs to the British Intelligence Service and to the State Department in Washington. Whatever the truth of the matter, Theunis was effectively informed of the situation by a State Department official and allowed access to the documents. This was extremely important in respect of the completion of the dossier'.

In his first statement, on 7 April 1941, Martial argued that the American courts were not competent to judge a dispute between two foreign companies, neither of which was active in New York State. Dulles had warned Theunis that the judge could well accept this argument as decisive $^{9}$. He advised the Bank to cede its assets at the Banque de France

5 BdFr, Archives, Direction de la documentation, dossier 1397.1994.01/78, 'or belge': report of 29.04.1941 from Sancery (Clermont-Ferrand) to de Boisanger.

6 BdFr, Archives, Secrétariat Général, dossier 1060.2001.01/41, 'or belge’: pouvoirs donnés à Sancéry et Martial, 04.03.1941.

7 BdFr, Archives, Secrétariat Général, dossier 1060.2001.01/41, 'or belge': mission à New York de M. Sancery, chef du Service du Contentieux, février-avril 1941.

8 Ansiaux, 'L'or belge', III, in Revue Générale, April 1985, p. 4.

9 BdFr, Archives, Direction de la documentation, dossier 1397.1994.01/73, 'or belge': on 20.02.1941, the French Navy (Vichy) passed Martial's letter of 17.02.1941 (New York) to the French Minister of Finance (Vichy). 
to two residents of New York State who would demand restitution from the Banque de France on behalf of the Bank. Acting on this advice, on 14 March the Bank had ceded its claim to Daniel de Gorter and Henri Wild, both residents of New York State, the former being chairman of the Belgo-American Chamber of Commerce and the latter a director of the Banque belge pour l'Etranger. On 24 April, de Gorter and Wild summoned the Banque de France to appear in first instance before the Supreme Court of the State of New York, which sat in the State capital, Albany. Their brief was to recover the Belgian gold that had been deposited with the French central bank, but they also requested that a sequestration order be placed on the Banque de France's assets at the Federal Reserve Bank of New York. The Court granted their request and the State sheriff had the order executed the following day ${ }^{10}$.

Meanwhile, the Belgian government had decided that Gutt should go to New York to keep a close watch on the proceedings. He showed himself prepared to talk informally about possible alternatives to legal proceedings. At Dulles' suggestion, he even accepted an invitation to lunch with Fuller from the law firm Coudert Brothers. Their discussion was friendly and Gutt made it clear that Belgium was not necessarily looking to pursue the legal action to the bitter end, but would be prepared to accept an amicable settlement, as long as that put the Bank back in possession of its gold ${ }^{11}$.

Words like that were music to Fuller's ears. He was convinced that only an amicable settlement offered a way to avoid what would almost certainly be a judgement against the Banque de France. Following his conversation with Gutt he did all in his power, in consultation with Martial and Sancery, to achieve a compromise. His only ally was time, hence his strategy of questioning the competence of the American courts and of exhausting all other procedural means, in order to postpone indefinitely discussion of the core of the matter. This fitted well within de Boisanger's scheme of things, because he, too, favoured an amicable settlement.

10 BNB, Archives, Studiedienst, DS 1, dossier 01.02.00.10 (A 230/ 1): or monétaire, memorandum of 07.01.1944 from J. Nisot (New York).

11 BdFr, Archives, Direction de la documentation, dossier 1397.1994.01/78, 'or belge': report of 29.04.1941 from Martial (Clermont-Ferrand) to de Boisanger. 
The defence's game, thus, became a legal sparring match that lasted for months. Now that, legally, the competence of the American courts could no longer be challenged, Fuller turned to a new point of procedure, stating that, according to the contract of deposit in safe custody, only the Paris courts were competent to judge a dispute concerning it. This argument was rejected by the Supreme Court of the State of New York on 3 July, but the Banque de France then challenged that decision and laid the matter before the Appelate Division, a body of second instance at the Supreme Court of the State of New York. On 12 August, this body unanimously confirmed the verdict, to which the Banque de France replied by requesting the Appelate Division to allow it to place the matter in third instance before the Court of Appeals, a request that was again rejected unanimously.

The Banque de France now changed tack and on 3 November submitted a number of conclusions to the Appelate Division, the purpose of which was to challenge the competence of the Supreme Court of New York; these conclusions were in turn rejected. Then, on 10 November, the central bank requested a further delay, only for the Appelate Division to refuse to allow any prolongation. On 17 November, the Banque de France approached Chief Justice Lehman to obtain the requested prolongation, but he, too, refused to grant it. The next day, however, both admitted a procedural error and on 18 November granted the prolongation of delay. That same day, the Banque de France submitted an appeal to the Court of Appeals against the judgment of 3 November, which had rejected a request for the competence of the American courts to be limited ${ }^{12}$.

In tandem with his strategy of using all the legal tricks to postpone the case, Fuller had been continuing to work for an amicable settlement between the two central banks and in June-July had already produced a text that both his client, the Banque de France, and the French Ministry of Finance could agree to ${ }^{13}$, no mean feat. By the terms of the text, the Banque de France declared itself prepared to make restitution of the Belgian gold and to do so against the guarantee of its own gold deposited in New York, with restitution obviously devolving to the 'legal'

12 BNB, Archives, Studiedienst, DS 1, dossier 01.02.00.10 (A 230/ 1): or monétaire (memorandum of 07.01.1944 from J. Nisot (New York).

13 BdFr, Archives, Direction de la documentation, dossier 1397.1994.01/79, 'or belge': letter of 09.10.1941 from Cathala (Paris) to de Boisanger (Clermont-Ferrand). 
representatives of the Bank and not to those in London who 'claimed' to be the legal representatives ${ }^{14}$.

Naturally enough, the Bank in London, receiving the proposal in November 1941, was unable to agree. For his part, Dulles found it too vague and, to put it mildly, too bruising for the representatives of the Bank in London. From the Banque de France's point of view, there was good reason for it to continue to refuse to recognize the Bank in London as being legally the National Bank of Belgium, because, from Paris, it was still negotiating with Brussels to achieve an accommodation ${ }^{15}$. In furtherance of this, in October the Banque de France submitted Fuller's proposal to Goffin. However, advised by the jurist Marcq, the board of directors of the Bank replied that it had no competence in respect of measures taken in unoccupied territory and that the Bank in Brussels could therefore not respond to the French proposal. From that point on, the Banque de France saw no purpose in continuing to negotiate with Brussels and now turned exclusively to the Belgian government and the Bank in London for further attempts at an accommodation.

\section{THE FRENCH ATTEMPTS TO ACHIEVE AN AMICABLE SOLUTION}

Fuller did not down tools after his failed attempt to achieve a compromise. In November 1941, he contacted Dulles again to see whether an arrangement of that sort could be worked out. Dulles answered that he would consult his client on the matter and informed the American Treasury and the State Department of what was happening ${ }^{16}$; thereafter, both departments took a close interest in the case ${ }^{17}$.

14 BdFr, Archives, Direction de la documentation, dossier 1397.1994.01/73, 'or belge': telegram of 07.06.1941 from Martial (New York) to the Banque de France (Clermont-Ferrand); dossier 1397.1994.01/71, 'or belge': letter of 20.06.1941 from de Boisanger (Clermont-Ferrand) to Bouthillier (Vichy); Secrétariat Général, dossier 1060.2001.01/40, 'or belge': meetings of 20.06.1941 and 27.06.1941 between de Boisanger and Schäfer in Paris, meeting of 04.07.1941 between Bolgert and Schäfer, letter of 10.07.1941 from Schäfer (Paris) to de Boisanger (Clermont-Ferrand).

15 See above.

16 Washington, National Archives, Belgium, dossier 855.515/73: letter of 07.11.1941 from Bernstein (us Treasury, Washington) to Foley (us Treasury, Washington).

17 Washington, National Archives, Belgium, dossier 855.515/69: memorandum of 17.12.1941 (us Treasury) to Dean Acheson (Secretary of State, us State Department). 
The discussion between the two lawyers ultimately took place midDecember on the telephone ${ }^{18}$. Prompted by the Banque de France at Clermont-Ferrand, Fuller again suggested a settlement. He stated that the Banque de France remained prepared to put its name to an official document recognizing its obligation to make restitution of the gold received in deposit, but that it still refused to make an immediate transfer to the Bank of the monetary gold it held under dossier with the Federal Reserve Bank of New York, because of the continuing uncertainty about whether restitution was to be made to the Bank in London or the Bank in Brussels. The Banque de France therefore promised to make restitution as soon as doubt about the Bank's status had been dispelled or - if the circumstances of war prevented this - as soon as hostilities ceased. In the latter case, it would make restitution to the institution then recognized by American jurisprudence as being officially the Bank. Lastly, the Banque de France was also prepared to use the gold it held under dossier at the Federal Reserve Bank of New York as a guarantee for the restitution.

Dulles informed Theunis of the conversation, pointing out that it would be in the Bank's interest to answer that it found the proposal attractive and wanted to examine it: the proposal was indeed to the Bank's advantage, as it did not serve to halt the legal proceedings and at the same time implied fresh recognition by the Banque de France of the Bank's rights ${ }^{19}$. Dulles also advised that the Bank itself should delay the legal proceedings somewhat, because, following the Japanese attack on Pearl Harbor on 7 December 1941, the United States had declared war on the Axis Powers and joined the ranks of the Western Allies. Rumours were now circulating in Washington that the American government would freeze, or even confiscate, the assets of civilians and companies from occupied countries. Freezing or confiscation, it was argued, should be regarded as a guarantee against possible damage or loss that the American government or American citizens might suffer in consequence of the country's entry into the war on the side of the Allies ${ }^{20}$.

18 вNB, Archives, Studiedienst, DS 13, dossier A 320/6: letter of 12.12.1941 from Dulles (New York) to Bernstein (Washington).

19 вNB, Archives, Studiedienst, DS 13, dossier A 320/6: letter of 15.12.1941 from Theunis (New York) to Gutt (London).

20 BNB, Archives, Studiedienst, Ds 13, dossier A 320/6: secret supplementary letter 
A further argument was that not to freeze or confiscate the assets could be seen as discriminating between the Allied countries. With its policy of 'cash and carry', the American government had forced Great Britain to liquidate all her domestic gold reserves and all her assets abroad, in order to finance the purchase of war materials. She was not only using those materials to defend herself, but would also be using them for the eventual liberation of the occupied territories. It would, therefore, be unfair to Great Britain if the governments, citizens and companies of those occupied territories had free disposition of their assets in the United States and did not commit them to liberating their own territories, whereas the British had committed their assets to just that purpose. Dulles indicated that the planned measure would have repercussions on the dispute between the two central banks, his reasoning being that, were the American president to eliminate the discrimination against Great Britain, gold that Belgium had demanded and received could be frozen or confiscated as a Belgian asset. Were no restitution to have yet taken place, the gold would be frozen or confiscated as French gold and the Bank would retain its claim against the Banque de France. In Dulles' view it was now better for the Bank to attempt to defer the restitution for as long as possible ${ }^{21}$.

In a letter of 4 March 1942, Theunis therefore pressed Gutt to follow Dulles' advice, stating his own opinion that the Bank should reply to the Banque de France that it was prepared to accept the French proposal as the basis for a possible settlement ${ }^{22}$. Gutt was unhappy at Theunis' suggestion. He had taken a hard line right from the first French overtures in the course of 1941, when he was insisting on a transfer of the French monetary gold at the Federal Reserve Bank of New York to the gold in the Belgian account ${ }^{23}$.

The Banque de France nevertheless continued to hold out hopes of a settlement and had meanwhile again attempted to delay legal proceedings. On 5 March, the Court of Appeals of the State of New York

of 15.12.1941 from Theunis (New York) to Gutt (London), with an account of the Dulles-Boël meeting.

21 ARA, Pierlot Papers, dossier 'London': letters of 15.12 .1941 and 31.12.1941 from Theunis (New York) to Gutt (London).

22 BNB, Archives, Malaise Papers: letter of 04.03 .1942 from Theunis (New York) to Gutt (London).

23 BNB, Archives, Studiedienst, DS 13, dossier A 320/6: letter of 16.12.1941 from Gutt (London) to Theunis (New York). 
granted permission for the question of the competence of the American courts to be laid before the Supreme Court in Washington. Two days later, the French central bank went to that federal court with the request that it annul the verdicts of the Appelate Division and of the Court of Appeals of the State of New York ${ }^{24}$. By the end of the month, however, these two French initiatives had proved unsuccessful, so that Dulles was able to notify Theunis that the opposing party was required to submit its response to the charges within ten days and that, at last, the core of the matter could be argued ${ }^{25}$.

Ultimately, Dulles' optimism appeared to be somewhat premature, as the Banque de France launched a fresh campaign in April 1942 to have the case postponed. Referring to the court case concerning the Bank of Rumania, it lodged a request with the Supreme Court in Albany on 6 April for the sequestration order placed on its gold with the Federal Reserve Bank of New York to be lifted. The same day, it requested that same court for a new prolongation of delay, in order to be able to respond to the action brought by de Gorter and Wild, since no verdict had yet been given on the lifting of the sequestration order. Both requests met the same fate as their predecessors and were rejected, as was the appeal the Banque de France lodged on 27 April with the Appelate Division against those two verdicts. The next day, a review of the verdict on the request for a prolongation of delay was sought, but this, too, was rejected. At the end of June, finally, the Supreme Court in Washington handed down its verdict, which was likewise in favour of the $\mathrm{Bank}^{26}$, and with this, the possibilities of gaining a further delay in arguing the core of the matter were now exhausted. In the meantime, however - more particularly on 5 May - Fuller had tabled a new proposal for an amicable settlement.

According to this new proposal, the Banque de France would go a step further than the compromise it had offered the previous year. It would be prepared to hold a specific sum in gold under dossier at the

24 BdFr, Archives, Direction de la documentation, dossier 1397.1994.01/72, 'or belge': letter of 11.03.1942 from Martial (New York) to Gargam (Clermont-Ferrand).

25 ARA, Theunis Papers, 'correspondance Theunis-Gutt': letter of 25.03.1942 from Gutt (London) to Theunis (New York).

26 BNB, Archives, SD, Ansiaux Papers, A 2, dossier 9.1/26, s. f. 1: letter of 15.06 .1942 from Ansiaux (London) to Theunis (New York). 
Federal Reserve Bank of New York as a guarantee in favour of the Bank and to give a formal undertaking that, once hostilities had ceased, it would restore the gold to the Bank at whatever location the Bank indicated: New York, Brussels or Paris. During the term of the agreement, the Banque de France would recognize the representatives of the Bank in London as the legal representatives of the Bank, but only within the context of this operation; in the case of dispute, the matter would be referred to an American court of law. In return, the Bank and de Gorter and Wild would halt legal proceedings and request that the sequestration order be lifted ${ }^{27}$.

Martial gave this proposal his full endorsement, supported by the management of the Banque de France: Fuller and Martial could now go ahead $^{28}$. The proposal was received fairly positively in London, and both Dulles and Theunis were in favour, because they thought that a solution was now in sight ${ }^{29}$. However, new difficulties arose and, once again, nothing came of the hoped-for amicable settlement.

The Bank had indeed ceded its claim to de Gorter and Wild, but essentially it remained the claimant. Regulating the relationship between the American government and central banks in exile was American decree No. 31 of 19 May 1941, especially article 25, which laid down that the Secretary of State was empowered to indicate who, on behalf of those central banks, would have power of disposal over their assets. In June 1941, Spaak had submitted a request to that end, with respect to Baudewyns and Theunis, but the request had been declared inadmissible and the Belgian government had left the matter at that. In March 1942, however, with the prospect of the main issue being pleaded in New York, the recognition of the right of disposition for Baudewyns and Theunis became relevant again, as the opposing party or even the court

27 BdFr, Archives, Direction de la documentation, dossier 1397.1994.01/72, 'or belge': telegram of 03.07.1942 (delivered 19.07.1942) from Martial (New York) to the Banque de France (Clermont-Ferrand), Secrétariat Général, dossier 1060.2001.01/42, 'or belge': note sur le projet d'accord élaboré à New York, 02.09.1942.

28 BdFr, Archives, Direction de la documentation, dossier 1397.1994.01/72, 'or belge': letter of 09.10.1942 from Cathala (Vichy) to de Boisanger (Clermont-Ferrand); Secrétariat Général, dossier 1060.2001.01/41, 'or belge': projet d'accord amiable en vue de mettre fin au procès relatif à l'or belge, 13.10.1942.

29 BNB, Archives, Studiedienst, DS 13, dossier A 320/6: letter from Nisot (New York) to Dulles (New York). 
could use the refusal of the Secretary of State to admit Spaak's request as an argument against the Bank's claim for the gold. Legitimizing the decrees of 27 November 1941 on the transfer of the Bank's registered office from Brussels to London became a first step in negating such a line of argument. With that purpose in mind, the Belgian government in London lodged a request with the Supreme Court in Albany to be officially recognized as the sole legal government of Belgium. Recognition was given on 7 March 1942, thereby automatically legitimizing the decrees $^{30}$. On 25 May, Theunis, as governor, was licensed to take individual decisions in the United States on behalf of the Bank; Baudewyns, as director, and Ansiaux, as nominal secretary, were granted the same authority, but could exercise it only in tandem ${ }^{31}$.

An estimate had meanwhile been made of the sheriff's fee, the amount the plaintiff was required to pay to the Department of Justice as cover the State's legal costs: the total was 2,560,00o us dollars. For the times, this was an enormous amount. Dulles and Fuller immediately lodged a protest against it and also had a bill introduced by members of the New York State Assembly in Albany to have payment of the sheriff's fee deferred until after the final court ruling. The bill was approved. Dulles and Fuller then attempted to go a step further and had a second bill introduced that would limit the sheriff's fee in the future to a maximum amount of 10,000 us dollars per complaint. This bill, too, was approved by the Assembly, but was vetoed by the New York State governor $^{32}$.

\section{THE PROBLEM OF THE LUXEMBOURG GOLD}

The question of the gold deposited with the Bank by the Caisse d'Epargne du Luxembourg was even more sensitive. At the end of March 1942, in a two-fold approach, the prime minister of the Luxembourg govern-

30 BNB, Archives, SD, Malaise Papers: letter of 07.03.1942 from Theunis (New York) to Gutt (London).

31 ARA, fonds ministerie van Financiën, dossier 'London': report of the Cabinet meeting of 25.05.1942.

32 ARA, Theunis Papers, 'correspondance Theunis-Gutt': letter of 21.04 .1942 from Theunis (New York) to Gutt (London). 
ment in exile, Pierre Dupong, contacted Theunis in Washington and the Luxembourg Minister of Foreign Affairs, Joseph Bech, sought out Gutt in London. Both came with the same disquieting account of how the Bank in Brussels had instructed the Banque de France to restore to Luxembourg the gold that the French central bank had accepted in safe custody together with the Belgian gold. Theunis and Gutt refused to commit themselves, replying that the Bank in Brussels had no authority to make any arrangements regarding that gold and that the present directors of the Caisse d'Epargne du Luxembourg had been appointed by the Germans and consequently had no competence in the matter: only the Bank in London and the pre-war directors of the Caisse d'Epargne $d u$ Luxembourg could legitimately take action in that respect ${ }^{33}$.

It was, nevertheless, pretty clear that both the Bank in London and Theunis were embarrassed by the question. As early as the beginning of May 1942, Baudewyns was informing Theunis that the Luxembourg gold threatened to become an issue in the Bank's legal action in New York. Baudewyns was so shocked by the conduct of the Bank in Brussels that he again wondered whether it would not be better to move in the direction of an amicable settlement ${ }^{34}$.

The question of the Luxembourg gold became extremely acute when, in early September, the Banque de France, via its lawyer, Fuller, submitted its response to the charges of de Gorter and Wild to the court ${ }^{35}$. Among other things, it was explicitly stated that, in 1940, the then governor of the Bank, Georges Janssen, had himself directed that the Belgian gold be repatriated to Brussels and, in 1941, the deputy-governor, Ingenbleek had signed the letter instructing the Banque de France to restore the Luxembourg gold to the Caisse d'Epargne du Luxembourg. In its argument, the French defence did not miss the opportunity to underline that the Bank in Brussels knew very well at the time that the Caisse d'Epargne du Luxembourg - now managed by puppets of the Nazi regime, although this was not stated in so many words - would

33 ARA, Theunis Papers, 'correspondance Theunis-Gutt': letter of 31.03 .1942 from Theunis (New York) to Gutt (London).

34 BNB, Archives, SD, Ansiaux Papers A 3, dossier 9.1/31 s. f. 1: letters of 02.05.1942 and 05.05.1942 from Baudewyns (London) to Theunis (New York).

35 BNB, Archives, Studiedienst, DS 1, dossier 01.02.00.10 (A 230/1): note, Nisot, 07.01.1944. 
transfer the gold from Luxembourg to the Reichsbank. This being so, the defence wondered how the Bank could bring charges against the Banque de France for transferring the Belgian gold to the Reichsbank, when the Bank itself was responsible for the Luxembourg gold being transferred to Berlin.

The French response to the Bank's charge came as a shock to Baudewyns and Ansiaux, as they confessed at the end of September $1942^{36}$. Dulles suggested that there should be no further mention of the decrees of 27 November 1941, since it would give the American judge the impression that the government and the Bank in London had something to hide and that it was for this reason that, in consultation with the government, the Bank had decided to transfer its registered office to London. In Dulles' opinion, such an impression would not be conducive to a favourable verdict, particularly now that the core of the matter could be discussed. After consulting his lawyer Nisot, Theunis chose to differ from this argument ${ }^{37}$. From a legal point of view, Ingenbleek's signature in July 1941 was worthless, as the Luxembourg gold was at that time still outside occupied territory, meaning that, according to Belgian law, Ingenbleek had no power of disposition over it. Furthermore, the officials of the Caisse d'Epargne du Luxembourg had no authority to request the gold's restitution, since they had been appointed under the occupation and a Grand-Duché de Luxembourg ordinance issued from London on 5 February 1941 had declared their appointments illegal ${ }^{38}$. Theunis and Nisot therefore argued that the Belgian plaintiffs could go ahead with their action. However, such reasoning smacked more of an exercise in legal cleverness than a realistic approach to the problem.

Dulles stuck to his guns. Since Dupong's visit to Theunis at the end of March 1942, he had had a presentiment that the question of the Luxembourg gold would weigh on the action in New York. He had, in fact, favoured an amicable settlement right from the outset, but his clients had never agreed to it. He now decided not to wait until the beginning

36 вNB, Archives, London Archives, 1942, dossier 'or': letter of 22.09 .1942 from Baudewyns (London) to Theunis (New York).

37 BNB, Archives, SD, Ansiaux Papers, A 2, dossier 9.1/26: letter of 25.09.1942 from Ansiaux (London) to Theunis (New York).

38 BNB, Archives, Studiedienst, DS 13, dossier A 320/6: opinion of 13.10.1942 from Nisot (New York) to Theunis (New York). 
of September, when the main action was due to be determined, but to react immediately and favourably to the new French proposal of 5 May 1942 seeking an amicable settlement.

In June, together with Fuller, Dulles had cast around for a formula that, taking account of the complications that had arisen, could meet with the approval of both parties ${ }^{39}$. However, all indications are that the two lawyers' efforts were ultimately brought to grief by the inflexibility of the Bank and the government in London ${ }^{4}$. In any case, the action continued and, on 4 November, Dulles submitted a 'motion for particulars' to the Supreme Court in Albany, with seventeen questions about the replies that, via Fuller, the Banque de France had submitted to the court at the beginning of September ${ }^{41}$. Among other things, the motion contained a request for more information about how the Reichsbank had been able to take the place of the Banque de France as custodian of the Belgian gold. How strong had been the pressure from the Vichy government on the Banque de France, to transfer the gold to Berlin? Additional information was also requested about the restitution of the Luxembourg gold, about the competence of Ingenbleek and the current directors of the Caisse d'Epargne du Luxembourg, about whether the registered office of the Banque de France was in Paris or at ClermontFerrand, and more besides. Dulles' conclusion was that the Banque de France's response of September 1942 was wholly unsatisfactory: there were not only gaps, but also a great many inconsistencies.

On 13 January 1943, Judge Bernstein ruled that the Banque de France must submit its reply to Dulles' motion to the court within thirty days ${ }^{42}$, and this duly occurred shortly thereafter. The Banque de France admitted that the Bank had deposited gold in safe custody with it and also admitted that it had transferred the custodianship to the Reichsbank

39 Washington, National Archives, Belgium, dossier 855.515/72: Department of State, Financial Division, memorandum of 11.06 .1942 from Berle.

40 BNB, Archives, SD, Ansiaux Papers, A 2, dossier 9.1/26 s. f. 1: letter of 15.06 .1942 from Ansiaux (London) to Theunis (New York).

41 Washington, National Archives, Belgium, dossier 855.515/75: motion of particulars by Dulles to Supreme Court of New York, 04.11.1942.

42 Washington, National Archives, Belgium, dossier 855.515/82: Dulles (New York) to Luxford (us Treasury), 14.01.1943; BNB, Archives, $S D$, Ansiaux Papers, A 2, dossier 9.1/26: memorandum of 12.01.1943. 
without consulting the Bank. It maintained, however, that the transfer released it from its obligation to make restitution of the gold to the Bank, justifying this position by submitting that French law permitted one custodian to be replaced by another. The principle of replacement, it argued further, had been effectively established in December 1940 in the Wiesbaden Protocol, an agreement between the Reichsbank and the Banque de France, two institutions that had been recognized by the American government as legal central banks. Consequently, the transfer of the gold to the Reichsbank was totally legal. Furthermore, the Vichy government had forced the Banque de France to make the transfer, so that the central bank could rightly invoke a cas de force majeure and could no longer be held liable. If the Bank desired restitution, it should address itself to the Reichsbank or to the French government at Vichy.

The Banque de France stated further that, on the instructions of the Bank in Brussels, a portion of the gold deposited in safe custody had already been restored to the Caisse d'Epargne du Luxembourg and that a considerable portion had been transferred to its own gold reserve, in settlement of the exchange of Belgian banknotes and in repayment of the State loans to the Belgian government during the months of MayJune 1940. It also stated that, according to the original contract of deposit in safe custody, any dispute with the Banque de France regarding this matter was required to be adjudicated by a court at the place where the head office of the custodian was established, in this case at Clermont-Ferrand. Finally, the Banque de France was unable to give any additional information, since Martial, its representative in New York, was deprived of any further contact with France. Dulles' answer to this was that Martial had had a year and a half to collect the necessary information from France and that, in consequence, he could be assumed to have everything to hand to provide the answers requested ${ }^{43}$.

The pleading of the core matter from April 1943 onward, which the Belgian party had for so long insisted on, did not go all that smoothly. In the first place, embarrassing questions were asked by Martial about the role played by the Bank's governor, Janssen, in the repatriation of the Belgian gold from West Africa to Europe. A negative assessment was also given of Janssen's attitude regarding the restitution of gold to

43 Washington, National Archives, Belgium, dossier 855.515/ 82 and 85: memorandums of 12.01.1943 and 26.01.1943. 
the Caisse d'Epargne du Luxembourg. At the same time the New York Times, in a stark banner headline, trumpeted: 'Belgian Quislings invited the Vichy government to transfer the Belgian gold to Brussels ${ }^{44}$. In a counter article in the same newspaper, Gutt gave a spirited rebuttal of the imputation, but the original report continued to reverberate in the United States ${ }^{45}$.

Theunis now began to have doubts about a successful outcome to the action, writing to Baudewyns on 30 June that he saw little chance of a satisfactory solution in the short term ${ }^{46}$. Gutt nevertheless remained obstinately wedded to continuing the action, writing to Boël in November 1943: 'Do you think that I am going to let them (the Banque de France) get away with murder? Not me!' ${ }^{17}$. The same month, however, Theunis notified Gutt that Dulles, although he was now in a position to argue the main issue, chose not to, since American jurisprudence provided for such cases to be postponed until four months after the cessation of hostilities, in order to enable the defending party to call its witnesses; with the total occupation of France since the beginning of 1943 there was no question of calling them now ${ }^{48}$. Gutt at last gave in, but only on condition that the temporary suspension of the court proceedings could in no way be construed as bringing an end to the action ${ }^{49}$. Baudewyns, and everyone in New York, including Dulles, agreed with the condition.

However, Gutt was not one to let the grass grow under his feet. Now that the action in New York had been temporarily suspended, he set about adjusting his strategy to make use of changed circumstances. The Comité Français de la Libération Nationale, whose registered office was

44 ARA, Theunis Papers, 'correspondance Theunis-Rolin': letter of 15.06.1943 from Rolin (London) to Theunis (New York).

45 Washington, National Archives, Belgium, 855.515/ 86: Gutt's reply to an article in the newspaper The New York Times of 08.06.1943.

46 вNв, Archives, Studiedienst, DS 1, dossier 01.02.00.10 (A 230/1): or monétaire (memorandum of 07.01.1944 from J. Nisot, New York, p. 5).

47 ARA, Theunis Papers, 'correspondance Theunis-Gutt': letter of 17-18.11.1943 from Gutt (London) to Boël (?).

48 ARA, Theunis Papers, 'correspondance Theunis-Gutt': letter of 18.11.1943 from Theunis (New York) to Gutt (London).

49 ARA, Theunis Papers, 'correspondance Theunis-Baudewyns': letter of 29.11.1943 from Baudewyns (London) to Theunis (Washington). 
in Algiers, had little by little been gaining in status with the Allies since their successful landing in North Africa in November 1942, and during 1943 the prospect of France and Belgium being liberated was improving. Gutt therefore decided to open negotiations with the Comité, with a view to finding a solution to the Franco-Belgian dispute about the gold. He wanted the conflict out of the way before the liberation and hoped to use the action in New York as a means of pressure. By the end of November, he was already having talks in New York with Jean Monnet about the gold. His move proved to be the initial impetus for the fresh negotiations that would lead to an amicable settlement after the liberation.

\section{THE LEGAL PROCEEDINGS: WORTH THE CANDLE?}

Attempting to provide an objective evaluation of the legal proceedings in New York is fraught with pitfalls. From the order and calm of good archives, it is no easy matter to form an unbiased picture of how the protagonists in the affair were to hold a straight course in the chaotic circumstances into which they were cast. One problem confronting them was communication. Our generation finds it difficult to comprehend the fact that, barely sixty-five or so years ago, leaders in very critical circumstances did not even have a telephone to hand. In consequence, rumour and misunderstanding were rife and nobody appeared to be immune. A first point of reference in constructing a narrative has therefore to be the written sources, even though they require a critical examination. What they show in this case is that it was certainly not the original intention of the Bank's governor, Janssen, to resort to open conflict in order to obtain restitution of the Bank's gold from the Banque de France. On the contrary. The then governor of the Banque de France, Fournier, also wanted to find a solution acceptable to both parties.

Who, then, set the legal action in New York in train? Ultimately, the finger points to Theunis and Gutt as the instigators. Theunis was an impulsive man and showed himself to be extremely irritated about the difficulties placed in his way in the United States about the measures he was trying to take on behalf of the Bank, difficulties that he attrib- 
uted to the hybrid status of an occupied and an unoccupied France. For him, a court case would clarify the situation. In addition, he was an authoritarian man who, once set on a course of action, was difficult to persuade to stop and reflect whether means other than a confrontation could serve his purpose.

Despite his vigorous approach in the run-up to the court case and during its first months, Theunis, in fact, appeared willing to consider proposals from the Banque de France for an amicable settlement. Those proposals were warmly recommended by Dulles, as we have seen, and Theunis had come to value his New York lawyer very highly during the negotiations and increasingly took notice of his opinion, which may go some way to explaining, why, in time, he was to abandon his aggressive attitude towards the French central bank.

There remains Gutt. Was he the central figure - the hardliner - who, in all the labyrinthine procedures, never lost sight of the goal of getting the Banque de France formally to admit that it had been gravely at fault? As the court action progressed, it became clear that the driving force behind the stubborn refusal to come to a compromise was, indeed, Gutt and continued to be so, even after it had become apparent that the Bank's case was not so conclusive as originally thought. Gutt's distrust of the French authorities was long-standing. He could not forget the dramatic journey in March 1935 to Paris, where he had asked in vain for help to save Belgium from a severe devaluation of its currency. What grieved him most, however, was the reception given to the Belgian government by the French authorities in May-June 1940, if this could in any way be described as a reception. He was a single-minded statesman who did not allow himself to be diverted by emotion. Even for him, though, there were limits; the humiliation brought by the arrogance of the French politicians and monetary leaders towards the Belgian government were a little too hard to take, a bridge too far. A confidential and, for Gutt, very emotional letter to Spaak in 1944 shows him giving vent to his deepest suspicions of the French political and financial world ${ }^{50}$.

How are the entire proceedings to be evaluated? The Banque de France continued to maintain that it bore no responsibility for the 
transfer of the Belgian gold to Berlin, as it had been forced into that action. The legal proceedings led unfortunately to souring the relationship between the two central banks. Even before the question of a court case had come up, the Banque de France had agreed formally to make restitution of the gold. In the event, the court action was halted in 1943 at a moment when the prospect of a favourable outcome for Belgium was no longer looking so rosy. The costs rocketed, particularly when the sheriff's fee had to be settled, and the question is whether such an investment of public money was justified in such a cause at such a time. The invasion of Europe was imminent and the occupied territories had more to worry about than who was responsible for the Bank's gold. A judgement boils down to the question of whether the legal proceedings were really worth the candle. 


\title{
CHAPTER 16 \\ The Payment Orders 'Laut besonderer Mitteilung'
}

\author{
INCORPORATION INTO THE GERMAN WAR ECONOMY
}

The winter of 1941-1942 proved to be the turning-point in the fortunes of the belligerents. For Nazi Germany, it was a period of reverses. The failure of the 'Barbarossa' Blitzkrieg offensive in the Soviet Union and the enormous loss of men and material during the overwintering of the German army in the bitter cold of the Russian steppes, capped by the United States' entry into the war on the side of the Western Allies in December 1941, represented major setbacks for a regime that had thus far gone from one victory to another. The reverses also had unmistakable repercussions on public opinion in Belgium, where, for many, it was at last no longer utopian to believe in an Allied victory and where renewed hope fed resistance to the occupier ${ }^{1}$.

The shifts in the overall aspect of the war inevitably also had an impact on German war strategy, smoothing the way for those at the top to pursuit a policy of total war. The driving force behind it was Dr. Fritz Todt, Minister of Armaments and Munitions. In his view, not just the German economy, but also the economies of the occupied territories, had to be more intensively geared to supporting the war machine $e^{2}$ A second aspect of the new strategy was one that also affected Belgium, this time through the labour market. Special premiums were offered to attract Belgian workers to Germany, in order to replace Germans mobilized to make up the huge losses on the eastern front ${ }^{3}$. Parallel with this

1 SG, Archives, Direction, Galopin Papers: Struye, l'opinion publique en Belgique après 24 mois d'occupation.

2 Klemm, German Economic Policies in Belgium, pp. 44-102.

3 The estimates of the number of Belgian workers who went voluntarily to Germany during the first years of the war vary enormously. An official statistic puts the number of jobs created in Germany for Belgian workers between July 1940 and 
was the employment of more and more Belgian contractors to build the Atlantic Wall, a solid line of fortifications along the Dutch, Belgian and French coastlines against a possible military invasion launched from across the Channel. Priority was given to this project, as the German General Staff thought that such an attack could be expected in the course of 1942.

The incorporation of Belgium and all occupied territories into the new strategy was given strong ideological underpinning by the Berlin government. Official propaganda proclaimed that it was all about the protection of European civilization from the 'Bolshevik threat', no less than the 'salvation of Europe' under the leadership of Germany. It was therefore the duty of all European countries to contribute unconditionally to that cause ${ }^{4}$.

In line with the new strategy the Berlin government wrote secretly to von Falkenhausen on 16 January and 21 February 1942, giving instructions that the details of certain deliveries of goods and services from Belgium to Germany of a military or political character were not to be revealed'. Instead, the German Ministry of Economic Affairs would issue a 'blanket' payment order in Belgian francs to the Banque d'Emission, with the statement 'laut besonderer Mitteilung' ('according to special notification') $)^{6}$. In this way, the anonymity of Belgian suppliers vis-à-vis the Banque d'Emission would be ensured and the nature of the transactions remain concealed.

September 1941 inclusive at 205, 305 (BNB, Archives, SD, 15, clearing, dossier 8.11/5: placements des ouvriers belges en Allemagne. Source: Office National du Travail). The number of new voluntary applications was to rise further during the cold winter of 1941-1942, due to the parlous situation in Belgium at the time regarding food and to the fact that high recruitment premiums were offered from the beginning of 1942 on.

4 BNB, Archives, $S D$, 17bis, clearing, dossier 8.11/7: visite du Dr. Landfried, compte rendu des entretiens, 30.06.1942.

5 Freiburg im Breisgau, Militärarchiv, Militärverwaltung: Hofrichter, Abschluszbericht der Militärverwaltung in Belgien und Nord-Frankreich, Part 1, pp. 132-133.

6 In 1940 Dr. Hjalmar Schacht, President of the Reichsbank, had already called for the establishment in Belgium of German-controlled banks, in order to take BelgoGerman economic relations out of the hands of the big Belgian banks. The establishment of the Hansa-bank, the Commerzbank and the Continental Bank has to be seen in this light. The reference to these banks in the secret instructions is in line with Schacht's call; the Banque d'Emission was, in fact, regarded by the Germans as an institution dominated by the big Belgian banks. 
At the meeting of the managing directors of the Banque d'Emission on 28 January 1942, mention was made of two important payment orders already bearing the statement 'laut besonderer Mitteilung' and similar orders were received in quick succession. From communications with Hofrichter of the Bankaufsichtamt, it appeared that the orders were for non-commercial transactions or services. Berger therefore contacted the Secretary-general of the Ministry of Finance and the Banque d'Emission's board of directors. During the subsequent discussions, it was decided that, for the moment, the orders should be executed, since this was no time to be contesting the instructions of the Bankaufsichtamt: in the immediate offing, more explicitly, was the journey of the Belgian delegation to Berlin to discuss a reduction of the overall costs of occupation and an increase in food aid, and that could not be compromised.

The discussions in the board of directors about the matter were not at all tranquil. In the Belgo-German balance of payments, the clearing operations were already skewed and the formula of 'laut besonderer Mitteilung' would serve only to skew them further ${ }^{8}$. In 1941, payment or transfer orders with detailed information about the beneficiaries and the nature of the transactions concerned accounted for some 98 per cent of the total. By the end of March 1942, nearly 70 per cent of the total was being accounted for by blanket orders without indication of the actual beneficiaries or the nature of the transactions involved ${ }^{9}$. This was unacceptable, the more so as independent German agencies were systematically buying up goods on the black market in Belgium at prices four or five times the official tariffs.

On 3 April 1942, the management of the Banque d'Emission notified Commissioner von Becker that it would no longer execute blanket payment orders for amounts above 40,00o Reichsmarks ${ }^{10}$. At the same time, the management wrote to Plisnier and Leemans, requesting them

7 BNB, Archives, $D C B E B$, 28.01.1942.

8 BNB, Archives, $B R B E B, 12.02 .1942$.

9 BNB, Archives, DC, 23.04.1942: note verbale.

10 On 20 April, the board of directors also decided to suspend payment orders for smaller amounts, if they were not accompanied by the necessary precise details, although the decision was cancelled the next day at the request of the members of the delegation to Berlin (BNB, Archives, SD, $17 \mathrm{~A}$, clearing, dossier 8.11/7 (Berlin): paiements laut besonderer Mitteilung). 
to explain to the German authorities why some payments were being suspended and to insist on a solution being found acceptable to the Banque d'Emission ${ }^{11}$.

Goffin and Berger met Leemans on 9 April to discuss the problem ${ }^{12}$. The Secretary-general agreed to write a letter to Reeder, President of the Military Administration, to expose the abuses regarding the blanket payment orders and German purchases on the black market, and also to insist on a reorganization of the export trade to Germany. Exports of Belgian products to every country except Germany were subject to prior licensing by the Clearing Office at the Ministry of Economic Affairs. Extending the requirement to cover exports to Germany as well would be a means of curbing the growing imbalance in the clearing system, which would be to everyone's advantage ${ }^{13}$.

Reeder appreciated the Banque d'Emission's arguments and suggested to Leemans that the suspended payments be transferred to occupation costs. Moreover, he would try to ensure that in future only exceptional payment orders submitted to the Banque d'Emission would carry the statement 'laut besonderer Mitteilung'14. The Bankaufsichtamt, however, was totally opposed to Reeder's proposal. On Hofrichter's instructions, von Becker wrote to the Banque d'Emission that Reeder's undertaking was based on a misunderstanding. The details required for the payments suspended by the Banque d'Emission could not be provided and it would not be possible to give details for a large number of orders in the future. Von Becker's letter consequently contained a 'formal order' for the twenty-four blanket payment orders involved to be executed forthwith ${ }^{15}$. A few days later, Hofrichter made it clear to Berger that, when it came to important decisions, it was the Berlin government and not the Military Government in Brussels that had the last word. If the orders in question were not executed immediately, serious sanctions could be expected from Berlin ${ }^{16}$. This clearly brought into the light the

11 BNB, Archives, DC, 03.04.1942.

12 BNB, Archives, SD, 17 A, clearing, dossier 8.11/7 (Berlin): paiements laut besonderer Mitteilung (négociations janvier-mai 1942).

13 BNB, Archives, SD, 17 A, clearing, dossier 8.11/7 (Berlin): paiements laut besonderer Mitteilung (letter of 09.04.1942 from Leemans to von Falkenhausen).

14 BNB, Archives, SD, 17 A, clearing, dossier 8.11/7 (Berlin): paiements laut besonderer Mitteilung (letter of 13.04.1942 from Leemans to Goffin).

15 BNB, Archives, DC BEB, 16.04.1942.

16 BNB, Archives, DC BEB, 18.04.1942. 
tension between the Bankaufsichtamt, which followed the instructions of the Nazi government in Berlin to the letter, and the Military Government in Brussels, which pursued a more moderate course.

During the deliberations about whether or not to execute the blanket payment orders, the managing directors had felt it advisable to obtain the opinion of the jurist Marcq, who advised that a formal order could effectively be regarded as a coercive measure, but added that after the liberation public opinion could interprete the managing director's passive attitude as 'de facto' financial aid to the enemy ${ }^{17}$. This warning strengthened the management in their determination to continue to resist executing the blanket payment orders and to use the threat of suspension as a means of obtaining more detailed information.

TOWARDS THE AGREEMENT OF 5 MAY 1942

As already mentioned, the members of the delegation to Berlin (Plisnier, Galopin, M.-L. Gérard, Goffin, Leemans and De Winter) met on 3o March 1942 in Plisnier's private office to evaluate the results of their visit. There was little for them to do but admit that the initiative had been a complete failure but they felt that the delegation's display of solidarity during the visit had been exemplary and justified its seeking a mandate from the Bank's supervisory council and the Banque d'Emission's board of directors to continue negotiations ${ }^{18}$.

The thought of giving a mandate to the 'Berlin delegation' made the managing directors and board of directors of the Banque d'Emission uneasy, but they ultimately acquiesced in the proposal, probably because they had no arguments to hand to counter it ${ }^{19}$. On 21 April the delegation met again in Plisnier's private office to work out the guidelines for the strategy to be followed ${ }^{20}$. The first item on the agenda was a proposal to establish a joint committee of German and Belgian experts to examine the question of the suspended payments - the total amount

17 BNB, Archives, Contentieux, Miomandre Papers: opinion of 16.04 .1942 from R. Marcq.

18 BNB, Archives, $S D, 17$ A, clearing, dossier 8.11/7: réunion chez M. Plisnier, 30.03.1942.

19 BNB, Archives, DC BEB, 02.04.1942.

20 BNB, Archives, SD, 17 A, clearing, dossier 8.11/7 (Berlin): paiements laut besonderer Mitteilung (aide-mémoire de la réunion chez M. Plisnier, 21.04.1942). 
of which had meanwhile risen to nearly 700 million Belgian francs and to determine whether they could be executed, provided more detailed information was submitted. Another proposal was that Leemans should submit a memorandum to Reeder, which would contain a series of measures to reform the clearing system, but this reckoned without Plisnier, who immediately opposed the idea. He had no intention of being the dupe of any reform operation and realized what was afoot: anything that would not pass muster for the clearing system would be shifted onto occupation costs. Galopin and M.-L. Gérard pointed to the strategic character of the proposals: with the clearing system reformed, efforts could be concentrated on getting the occupation costs reduced. Plisnier recognized the logic of the proposal, but accepted only with great difficulty and on certain conditions.

On 23 April, Leemans submitted a memorandum to Reeder, containing the following proposals: payment orders of a political nature should be withdrawn from the clearing system; those without details should not amount to more than 2 per cent of total monthly payments; normal payment orders should carry adequate details about the actual beneficiaries and the nature of the transactions concerned; and payment orders from France in favour of German agencies or other organizations should be executed only where offset by French exports of foodstuffs. The memorandum also floated the idea of the establishment of a joint committee of experts ${ }^{21}$.

Reeder accepted the idea of a joint committee that would look at both the problem of the pending payment orders and the proposals to reform the clearing system. With the first meeting of the committee taking place the next day, 24 April, the Belgo-German negotiations appeared at last to be gathering momentum. But Hofrichter, who headed the German experts on the committee, immediately stated that all payment orders, both pending and future, were to be executed, the Belgians having the choice of the channel to be used. The Bankaufsichtamt had no objection to the clearing system not being used for some of the orders, but would in those cases demand that payment be by means of a charge on occupation costs. In principle Hofrichter favoured Leemans' proposal regarding payment orders from France, but suggested that it

21 BNB, Archives, BR BEB, 06.05.1942. 
be dealt with separately, since the French authorities needed to be involved in the matter.

The Belgians protested against the automatic linking of the German clearing deficit to an increase in occupation costs: Plisnier would never accept it. Hofrichter appreciated the point and, after taking time to ponder the question, came back on 27 April with counter-proposals. The first concerned the blanket payment orders by German banks having branches in Belgium. These, in fact, were orders from the five biggest German purchasing agencies in Belgium, four of which were prepared to give details for between two thirds and three quarters of their payment orders; the fifth and largest agency, the Todt Organization, refused to co-operate and its payment orders would be charged to occupation costs. For non-blanket payment orders a difference was to be made between those of a political nature, which would be taken out of the clearing system, and those being economic, which would remain in it. Nevertheless, for the last category of orders, a limit of 50 million Belgian francs' worth per month would also be set for payment orders registered as 'laut besonderer Mitteilung'. Payment orders from France would be regulated by a Franco-Belgian clearing agreement and, in this respect, the Military Government would seek an agreement from Berlin. Finally, in order to hold down the costs of occupation, purchases of goods by troops in transit and remittances from German families to their menfolk serving in Belgium would no longer be settled through occupation costs, but through the clearing system ${ }^{22}$.

The delegation was able to accept all Hofrichter's counter-proposals, save the last. In the delegation's view, purchases by troops in transit and remittances from Germany should continue to be charged to occupation costs. Failing that, the German clearing deficit would soar again ${ }^{23}$. In a letter of 5 May to Leemans, von Falkenhausen confirmed the overall agreement, but reserved the right to increase the level of occupation costs, if necessary ${ }^{24}$.

22 BNB, Archives, SD, 17 A, clearing, dossier 8.11/7: réunion des techniciens, 27.04.1942. 23 BNB, Archives, $S D, 17 \mathrm{~A}$, clearing, dossier 8.11/7: réunions au cabinet de M. Leemans, 28.04.1942; BNB, Archives, $B R B E B$, 06.05.1942.

$24 \mathrm{BNB}$, Archives, $S D, 17 \mathrm{~A}$, clearing, dossier 8.11/7: letter of 05.05 .1942 from von Falkenhausen to Leemans. 


\section{THE REAPPEARANCE OF THE REICHSKREDITKASSENSCHEINE}

Most of the board of directors and the entire management of the Banque d'Emission appeared satisfied with the results of the discussions and the agreement. A few new concessions made by the Military Government in May and June strengthened the impression that its relationship with financial circles in Belgium had become more relaxed.

Unexpectedly, however, Reichskreditkassenscheine had begun to circulate again in Belgium in March 1942. This was certainly not in accordance with the cooperation being enjoyed with the Military Government. By the beginning of June the Bank already had 549 million Belgian francs' worth in hand. Investigation showed that Scheine were being fraudulently introduced into Belgium by troops resting from the eastern front, although this could not account for the large amounts involved. It transpired that certain purchasing agencies of the armed forces, particularly those linked to the Luftwaffe, were making use of the Scheine to finance their transactions on the black market ${ }^{25}$. To make things worse, on 9 June the Military Government requested the Bank to transfer 500 million Belgian francs' worth of Scheine to the Brussels Reichskreditkasse in exchange for a credit there in favour of the Bank ${ }^{26}$.

As in 1940, the Bank again demanded that the Scheine cease to be used as legal tender and be withdrawn from circulation. During negotiations with the Military Government, a choice of two solutions was tabled: either discredit the Scheine among the population, whereby they would automatically cease to circulate, or officially demonetize them. The Belgians opted for the second ${ }^{27}$. In a circular of 7 July 1942, the Military Government forbad the private banks to accept or use Reichskreditkassenscheine in the future; Belgian nationals could exchange them at the Bank, German nationals at the Reichskreditkasse. The population at large was requested to cease accepting Scheine. The Bank was dissatisfied with the arrangement. It feared being the victim of malpractice,

25 Freiburg im Breisgau, Militärarchiv, Militärverwaltung: Hofrichter, Abschluszbericht der Militärverwaltung in Belgien und Nord-Frankreich, Part 1, p. 113.

26 BNB, Archives, SD, Malaise Papers, 3, dossier 9.5.11/ s. f. 4: Reichskreditkassenscheine.

27 BNB, Archives, SD, 36, service étranger, dossier 8.11.32: les entrées frauduleuses de RKK-scheine en 1942. 
given that the administration and the semi-public institutions were not included in the operation, and therefore insisted on a cut-off date, after which no further exchange would be possible for everyone. Moreover, it requested that a ceiling be set for the Scheine to be exchanged. On 21 July, the end of that month was set by the Military Government as the cut-off date, though this was later shifted to 17 August. A ceiling was set at 1,800 million Belgian francs: in the event this was slightly exceeded and 1,812 million Belgian francs' worth of Scheine were ultimately exchanged.

\section{CRACCO'S MEMORANDUM AND ITS CONSEQUENCES}

The relaxation in the relationship between the Military Government and the Banque d'Emission was also quickly overshadowed by other problems and tensions. In the first place, no satisfactory solution was forthcoming for the elimination of the respective clearing deficits of France and the Netherlands vis-à-vis Belgium. The French deficit continued to grow, because the French obstinately refused to deliver food to Belgium in exchange for the payment of wages to Belgian workers employed in France or for French purchases of goods - particularly various types of coke - in Belgium.

Even worse, during the summer of 1942, negotiations started between the French and German authorities to transfer the Belgian credit balance in the Franco-Belgian clearing system - a matter of 1,250 million Belgian francs - to the Belgo-German clearing system. The Germans declared themselves prepared to assume the French clearing deficit visà-vis Belgium and to enter it in the books of the Verrechnungskasse in Berlin as a liability in favour of Belgium, provided that France supplied certain goods to Germany as compensation. Germany would thus receive goods that Belgium had demanded in vain from France during the preceding months, and the Banque d'Emission would have to content itself with an additional increase in its clearing credit balance at the Verrechnungskasse ${ }^{28}$. Settlement of the Dutch clearing deficit vis-àvis Belgium likewise led to serious difficulties during the summer of 1942. Requiring ever increasing amounts in Belgian banknotes in order 
to pay Belgian workers employed in the Netherlands, the Nederlandsche Bank was asking to have the resulting liability entered on the BelgoDutch clearing account, but, in return, the Banque d'Emission was demanding delivery of foodstuffs to Belgium. In the same way as the French, however, the Dutch authorities refused to comply ${ }^{29}$. The Banque d'Emission then proposed that payment for the Belgian banknotes be in Belgian Treasury certificates held by the Nederlandsche Bank ${ }^{30}$. The Dutch initially rejected the proposal, but in September, under pressure from the Military Government in Brussels, found themselves forced to accept it.

A second major concern for the Bank and the Banque d'Emission during the summer of 1942 was the marked expansion of transactions on the black market in Belgium. The fresh increase in the German clearing deficit vis-à-vis Belgium in July, after two months of reasonable stability, was due chiefly to payment orders for transactions on the black market under the blanket cover of 'laut besonderer Mitteilung'31.

Table 16.1: Total Belgian clearing balance per sector (June 1941-June 1942) (in millions of Belgian francs)

\begin{tabular}{lrrrrr}
\hline Date & Goods & Services & Capital & Unspecified & Total \\
\hline 30.06 .1941 & 642 & 580 & 758 & 312 & $\mathbf{2 , 2 9 2}$ \\
30.09 .1941 & 3,009 & 1,011 & 1,129 & 120 & $\mathbf{5 , 2 6 9}$ \\
31.12 .1941 & 4,913 & 1,392 & 1,209 & 338 & $\mathbf{7 , 8 5 2}$ \\
31.03 .1942 & 6,284 & 2,011 & 1,429 & 443 & $\mathbf{1 0 , 1 6 7}$ \\
30.06 .1942 & 7,885 & 2,817 & 2,103 & 586 & $\mathbf{1 3 , 3 9 1}$ \\
\hline
\end{tabular}

Source: BNB, Archives, $S D$, 18, clearing, file 8.11.8/3: report F. Cracco, 24.07.1942.

A report of 24 July 1942 by Cracco, Head of the Foreign Department, stated that the occupier was abusing the system on such a large scale that the international credit system had become thoroughly dislocated and had, in fact, been turned on its head, with the debtor now dictating to the creditor. The report went further, declaring that the lack of con-

\footnotetext{
29 BNB, Archives, $B R$ BEB, 02.09.1942, 16.09.1942.

30 BNB, Archives, DC BEB, 08.07.1942, 16.08.1942, 30.09.1942.

31 BNB, Archives, $S D$, 18, clearing, dossier 8.11.8/3: rapport de M. F. Cracco, 24.07.1942.
} 
trol had served to increase abuse of the system by the Belgian business world. By selling frozen shares and assets in Central and South-eastern Europe to German investors, for example, certain holding companies had been able to recoup the value of their erstwhile foreign holdings via the clearing system. That recoupment had, in fact, been on the back of the Belgian people, as the risk in respect of the Belgian clearing balance at the Verrechnungskasse in Berlin was covered by the State guarantee. The report did not spare the industrialists and their middlemen either: however justified in social and economic terms the Galopin Committee's policy of work resumption had initially been, and in fact still was, there was no denying that abuses had generated unjustified war profits right across the board ${ }^{32}$.

As was to be expected, Cracco's report was not well received by the founder-bankers of the Banque d'Emission. The furore led to them devoting an extraordinary meeting to the report, which took place on 8 September, monitored by Galopin. From a preliminary analysis of the figures Galopin concluded that only a limited proportion of the Belgian clearing balance could be imputed to the export of goods by the big industrial groups. The greater part of it concerned the payment orders marked 'laut besonderer Mitteilung' and thus referred largely to transactions in which those groups took no part. Galopin, nevertheless, did not duck the question of industry's responsibility. In his view, the question had become so serious, given the present situation of the clearing system, that it demanded resolution ${ }^{33}$.

At another meeting two days later, Galopin expanded on what he had said on 8 September. First of all, he suggested that Cracco's statistical analysis be examined more deeply: this would enable the sectors and social categories guilty of abusing the clearing system to be identified more clearly. His second point was that the Bank and the Banque d'Emission had to take responsibility in the alarming development in the clearing system. He therefore requested the managements to prepare a memorandum clearly setting out their position ${ }^{34}$.

32 BNB, Archives, SD, 18, clearing, dossier 8.11.8/3: note justificative (de Cracco) relative aux conclusions du rapport, 17.08.1942.

33 BNB, Archives, SD, 18, clearing, dossier 8.11.8/5: réunion des banquiers fondateurs, 08.09.1942.

34 BNB, Archives, $S D$, 18, clearing, dossier 8.11.8/ 10: procès-verbaux du comité de di- 
The allegations of Cracco and the reaction to them among the founder-bankers made a strong impression on Berger and Van Nieuwenhuyse ${ }^{35}$, both of whom now took the lead in getting the stance of their institutions adapted to the changed circumstances. Their first move was to request Leemans to address a letter to Reeder, complaining about the violation of the agreement of 5 May: during the summer the orders marked 'laut besonderer Mitteilung' had increased substantially.

The Military Government's reply of 29 September to Leeman's letter was very disturbing, as its main thrust was to emphasize the necessity of incorporating Belgian industry more efficiently into the German war economy. Of course, it also stated that the Military Government would attempt to provide the information required on the orders marked 'laut besonderer Mitteilung', but in Berger and Van Nieuwenhuyse's view the reply was no more than an exercise in vague promises from which nothing much was to be expected.

At the same time, the management was looking to address the recommendations made by Galopin on 8 and 10 September. The task of dealing with the first recommendation - namely that there should be additional statistical analysis - was given to Cracco. To Van Nieuwenhuyse went the difficult task of preparing a comprehensive memorandum placing the stance of the Bank and the Banque d'Emission towards the clearing problem in its proper context and setting it out clearly. An initial draft of this memorandum was ready by the end of September and was discussed thoroughly by the other managing directors during the days that followed ${ }^{36}$.

The document took a fairly aggressive line and illustrated the management's frustrations with the other Belgian partners in the clearing crisis. It stated that there was no longer any contact with the Ministry of Finance. Following the discussions in April about reforming the clearing system at the expense of occupation costs, Plisnier had with-

rection (discussion du mémorandum).

35 When, during a meeting of the board of directors on 07.09.1942, Deputy-governor Ingenbleek asked whether it was indeed, advisable to approve the report, given the blunt complaint against the industrialists, Berger responded by saying: 'le rapport...dit strictement la vérité...un jour nous nous féliciterons d’avoir approuvé ce document et nous reconnaîtrons les effets heureux de l'émotion qu'il a pu soulever dans certains milieux': BNB, Archives, DC BEB, 07.09.1942.

36 BNB, Archives, $S D$, 18, clearing, dossier 8.11.8/10: procès-verbaux du comité de direction, September 1942. 
drawn, disillusioned, from joint action. Within the Belgian administration, only Leemans now remained as a valid contact. Furthermore, the managing directors' distrust of the Banque d'Emission's founderbankers began to take on a sharper edge, with Berger feeling that they were attempting to shift responsibility for the clearing system onto the management. Van Nieuwenhuyse agreed ${ }^{37}$. The previous spirit of cooperation appeared now largely to have evaporated.

The conclusion drawn in Van Nieuwenhuyse's memorandum was that the Banque d'Emission should unilaterally terminate the convention that it had concluded with the Reichsbank on 16-17 August 1940. This would provide the Banque d'Emission with a legal basis for refusing to execute any more payment orders lacking justification. Deputygovernor Ingenbleek, however, argued that a much better course would be to form a common front against the occupier ${ }^{38}$.

Van Nieuwenhuyse and Berger were open to the suggestion of a common front, but stood by their idea of taking a hard line. Once a few sharp edges had been smoothed, the other members of the management, Governor Goffin and Deputy-governer Ingenbleek, acquiesced in the memorandum and on 3 October they all approved it. It was also agreed that the text be submitted not only to the Bank's supervisory council and the board of directors of the Banque d'Emission, but also to Plisnier ${ }^{39}$.

37 BNB, Archives, $D C B E B$, 30.09.1942.

38 BNB, Archives, DC BEB, 01.10.1942.

39 BNB, Archives, DC BEB, 02.10.1942, 05.10.1942. 



\section{CHAPTER 17 \\ The Creation of a United Front}

THE RESOLUTIONS OF 16 OCTOBER 1942

The memorandum approved unanimously by the management on 3 October 1942 was submitted to the Bank's supervisory council and the Banque d'Emission's board of directors on 8 October. The next day the supervisory council examined it ${ }^{1}$. Bekaert declared that the Bank should refuse to co-operate in financing German purchases on the black market and, to that end, should develop a supervisory system that would examine every transaction. Berger and Van Nieuwenhuyse, present at the meeting, demurred, unconvinced of its viability and preferring a general measure, more particularly the abandonment of the 1940 convention. Bekaert, an experienced and pragmatic businessman, and supported by Peltzer, another businessman, stated his conviction that the Germans had to be confronted at every turn and that a general and radical measure would inevitably fail, because of German opposition.

The jurists Marcq and De Visscher had been invited to the meeting and attempted to place the opposing standpoints within a realistic context. They pointed out that, to abandon the 1940 convention, would be to invite a series of measures from the Military Government, aimed at obtaining execution of the payment orders; once things reached that pass, the management could either bow to orders or refuse to accept them and consequently resign; acceptance meant no lightening of responsibility and, in the present circumstances, resignation was clearly not in the interest of the country. The suggestion of the two jurists, therefore, was that it might be wiser to demand concrete concessions from the Military Government, before terminating the convention; a feasible goal put forward by De Visscher was for a ceiling to be agreed for the charges being imposed.

1 BNB, Archives, RR, 09.10.1942. 
Initially, Berger and Van Nieuwenhuyse stuck to their guns, but ultimately allowed themselves to be convinced by the arguments of the jurists; in consequence, the renunciation of the convention was scrapped from the conclusion of the memorandum and replaced by a demand for a ceiling to be set for the payment orders ${ }^{2}$.

The meeting of the founder-bankers of the Banque d'Emission to discuss the memorandum was likewise attended by Marcq and De Visscher. Discussion proved to be more tense than within the supervisory council ${ }^{3}$ and, as always, the proceedings were dominated by Galopin. He stated that the occupier had not respected the agreement of 5 May and that the Banque d'Emission and the Bank had therefore to react forcefully and together. However, it was less clear how this might be done. Here, Galopin favoured Bekaert's proposal to the supervisory council: the managements of the two institutions should fight to gain more control over the payment orders; once they had succeeded in this, it would be easier for them to identify abuses in the clearing system, expose them and attempt to eliminate them.

Goffin and Ingenbleek saw no salvation in Galopin's strategy and remained in favour of the management's proposals. They were convinced that efficient supervision was impossible: the 135-strong staff of the Foreign Department were handling an average of 2,500 dossiers a day and there was a major problem in separating the legitimate transactions from the illegitimate. Because the information supplied by the Germans was so scant, tracking down irregularities was like looking for a needle in a haystack. In Van Nieuwenhuyse's view, there could be only one solution: to obtain a joint ceiling for the clearing deficit and the occupation costs.

Galopin realized immediately that the proposal of the managing directors would place a curb on Belgian exports, thereby threatening his policy of maintaining employment in Belgium. Since the Germans refused to admit the word 'unemployed' in their vocabulary, any reduction in industrial activity would be accompanied by large-scale deportation of Belgian workers to Germany, the more so since the Ger-

2 BNB, Archives, Studiedienst, 4, dossier 01.02.01.70 (A 239/8): relations des négociations consécutives au mémorandum du 3 octobre.

3 BNB, Archives, $S D$, 19, clearing, dossier, 8.11.9/2: réunion des banquiers fondateurs, 12.10.1942. 
man ordinance of 6 October 1942 envisaged 'forced' labour, involving such deportation. De Munck noted that the danger was increased by the 'fixed' ceiling that Berger and Van Nieuwenhuyse had proposed. Indeed, because the sole aim was to set a fixed ceiling for the total costs, the Germans could spread those costs at will. If they judged it better to deploy Belgian workers in the service of war industry in Germany, they could shift all costs in respect of Belgium onto occupation costs and thus allow the clearing system to atrophy. Exports from Belgium to Germany would then automatically cease and the labour thereby released be fully available for deportation.

Berger and Van Nieuwenhuyse responded by suggesting that the ceiling be embedded in a system of control, whereby exports to Germany would be accompanied by a licence issued by a Belgian authority. This $a$ priori control would eliminate irregular transactions from the clearing system and be an effective replacement for the ex post facto control of the agreement of 5 May. Pragmatists as they were, the founder-bankers of the Banque d'Emission were extremely sceptical of any such concept: the idea that the Germans would accept a ceiling demonstrated a poor sense of reality and to couple the obligation of a Belgian licence to the ceiling was totally unrealistic.

The bankers, for their part, stated that there were valid arguments to justify de facto collaboration. Supplying the population with food, avoiding the mass deportation of workers to Germany, maintaining an industrial infrastructure in the country, with a view to post-war recovery, were all overriding arguments in their opinion. Moreover, during the preceding two years of war, nearly 40 per cent of total Belgian exports had been offset by imports of foodstuffs and raw materials; undoubtedly, therefore, the policy of the least evil had produced a number of positive results, however unsatisfactory in general.

In De Visscher's opinion the arguments put forward by the founder-bankers were not valid for those heading the Bank and the Banque d'Emission, who had their own monetary responsibility to bear that even German enforcement orders could not remove. Moreover, for the Bank's leaders the situation was not to get any better, because the problem of financing was made all the more acute by the transfers of savings from workers deported to Germany.

4 BNB, Archives, DC BEB, 14.10.1942. 
Following the discussion, De Visscher and Marcq were given the task of working out a number of resolutions with Berger and Van Nieuwenhuyse, that would take account of the remarks and criticisms that had been made. Since both directors were by now so firmly rooted in their ideas, there was little scope for compromise between them and the two jurists. The two managing directors, in fact, dictated the content of the texts, and they proposed six resolutions ${ }^{5}$. The first included De Visscher's suggestion of a ceiling, meaning that henceforth there would be a monthly maximum for the burden of costs imposed by the occupier, including occupation costs, clearing payment orders, requisitions and the conversion of Reichskreditkassenscheine. Furthermore, Belgium needed to exert control over how the costs were broken down according to the various categories. The second stated that the agreement of 5 May had not been respected by the occupier and was therefore deemed to have lapsed; payment orders bearing the inscription 'laut besonderer Mitteilung' would no longer be automatically executed. The third was that all transactions with other countries, including Germany, should be subject to prior control and approval by the Clearing Office at the Ministry of Economic Affairs.

The three following resolutions were not so comprehensive and thus less essential. The first declared that transfers to Belgium of money by workers employed in German war industry could not be accepted and would not be executed in future; the needs of families in Belgium would be supplied by Belgian poor-relief services. The second was for Belgian credit balances in the clearing system between the French and Belgian Reichskreditkasse to be deducted from occupation costs. The third was for the Bank and the Banque d'Emission to refuse to transfer 1 billion Belgian francs' worth of Reichskreditkassenscheine from their portfolios to the Reichskreditkasse, recently requested by the Military Government.

The six resolutions were submitted to the founder-bankers of the Banque d'Emission ${ }^{6}$. Goffin ensured that they had the support of the Bank's supervisory council, even though they were exacting in their demands and aggressive in tone. Unusually, the bankers found them-

5 BNB, Archives, SD, 19, clearing, dossier 8.11.9/3: résolutions du 16 octobre 1942.

6 BNB, Archives, SD, 19, clearing, dossier 8.11.9/2: réunion des banquiers fondateurs, 14.10.1942. 
selves thrown entirely on the defensive. They had always pressed the management of the Bank and the Banque d'Emission to act vigorously to combat abuses. Now that vigorous action was being taken, how could they back down? On the other hand, they realized all too well that the demands being made were not feasible. If this went ahead, they would be on course for a serious clash with the Military Government, which they wanted to avoid.

A.-E. Janssen made a dramatic call for everyone to support the policy of accommodation and for new negotiations with the occupier, the sole purpose being to increase the effectiveness of Belgian control of the clearing transactions. Only if this proved to be impossible could consideration be given to the proposals of Berger and Van Nieuwenhuyse.

In the end, however, the founder-bankers lined up behind the resolutions and on 16 October, together with the directors and supervisory council of the Bank, as they put their signatures to the text. However, the agreement that was reached was not quite what it purported to be: the founder-bankers regarded the resolutions as maximum bargaining demands to be used in negotiations with the Military Government and eventually to be scaled down in exchange for German concessions. Berger and Van Nieuwenhuyse, with the backing of Goffin, demanded that the resolutions be accepted in toto by the Germans as a conditio sine qua non for any agreement, otherwise they would resign?. However, neither standpoint was made explicit in the text, apparently in order to gain the support of the secretaries-general of the Belgian administration.

\section{THE DRAMATIC INTERVIEW WITH REEDER}

The text of the resolutions was sent to Plisnier and Leemans, with a request for them to join the action ${ }^{8}$. Plisnier reacted positively to the text. Wanting first to hear how the two parties interpreted it - because he suspected that their versions might differ - he invited those involved

7 BNB, Archives, SD, Malaise Papers, 'enquête BEB': report of the Commission of Enquiry (published text, 1946), Chapter. 3, pp. 105-107.

8 BNB, Archives, $S D$, 32, dossier 8.11.26/8: divers (difficultés actuelles de la BEB), 20.10.1942. 
to a joint meeting in his private office. He was not mistaken. According to Galopin, the resolutions were not to be taken as an ultimatum to the Germans, but as a basis for negotiations. For Van Nieuwenhuyse and Berger, however, they had indeed to be regarded as an ultimatum: if the Military Government could not agree with the entire package, then the board of directors of the Bank (most of them also managing directors of the Banque d'Emission) would resign. Plisnier declared that, if that were the case, he would align support their decision. The representatives of the Banque d'Emission's board of directors and the Bank's supervisory council had no wish to break ranks; they stated that they, too, would resign, if the respective managements did so 'for justified reasons'. As individuals, however, they would remain at their posts in their companies, 'not wanting to abandon their workers to be deported to Germany ${ }^{10}$.

It became clear as the meeting drew to a close that there was still uncertainty about a considerable number of points, particularly about the strategy to be adopted in arguing the case for the memorandum with Reeder and about who should be delegated to argue it. On this last issue quick agreement was reached: Plisnier and Leemans would act for the country's administration, Goffin and Berger for the Banque d'Emission, and Galopin and M.-L. Gérard for the founder-bankers. It was also decided that these delegates would coordinate their strategy in a preparatory meeting.

The intense preparations for the planned action had naturally not gone unnoticed by the Bankaufsichtamt and, on 21 October 1942, von Becker asked Ingenbleek for more information. It appeared from what was said that von Becker was particularly well informed. He warned Ingenbleek that too aggressive an approach would have severe consequences: 'you will have government by the ss', and there would be very unpleasant sanctions. After these threats, he introduced a note of disappointment, asking whether the Belgians had no appreciation of the efforts of the Military Government to make the occupation as bearable as possible. He was certainly honest in stating that: 'general von Falkenhausen sometimes risks being considered too lenient by the Nazi-gov-

9 BNB, Archives, $S D$, 'enquête BEB': report of the Commission of Enquiry (published text, 1946), Chapter. 3, p. 107 (footnote 1).

10 BNB, Archives, $S D$, 19, clearing, dossier 8.11.9/5: préparation de la réunion chez M. Reeder. 
ernment in Berlin, by going out of his way to alleviate the burden of occupation on Belgium"1.1.

The meeting with Reeder was initially set for 27 and then for 28 October. After intensive discussions during their preparatory meeting the Belgian delegates resolved to abandon the idea of presenting the six resolutions as a straightforward ultimatum ${ }^{12}$. First would come the demand for the Banque d'Emission to have effective control of the global payment orders, which from the end of the summer 1942 were again increasing dramatically. The main argument for this was the fact that German purchases on the black market were no longer exceptional occurrences, but common practice. Such abuses could no longer be tolerated and only effective control by the Belgian authorities could stop them.

The second point to be addressed would be the question of the clearing system as such, and here the emphasis would be chiefly on determining what transactions qualified for the system. The third point would be the matter of the ceiling, though this would be presented as only a secondary problem. Lastly, in order of importance, would come the questions of the wage transfers, the offsetting between the French and Belgian Reichskreditkassen and the refusal to transfer the Reichskreditkassenscheine to the Reichskreditkasse in Brussels. Van Nieuwenhuyse was quite disillusioned about the direction things were taking, but the opportunity for a united front demanded a readiness to accept a degree of compromise ${ }^{13}$.

The actual meeting with Reeder took place at the headquarters of the Military Government ${ }^{14}$. In his introductory remarks, Reeder immediately set the tone by stating that the Military Government did not like requests for negotiations. The fact that it had agreed to receive the delegation had therefore to be seen as an exceptional gesture of courtesy on the part of the Germans.

11 BNB, Archives, DC BEB, 21.10.1942.

12 ARA, fonds Société Générale de Belgique, dossier кв 1: note relative à la crise traversée par la BEB au cours du quatrième trimestre 1942, 04.02.1943.

13 In this respect, see the allusions in: BNB, Archives, SD, Basyn Papers, dossier 6 g: letter of 12.01.1943 from Kauch to Basyn, p. 6.

14 BNB, Archives, SD, 19, clearing, dossier 8.11.9/ s. f. 6: réunion chez le Président Reeder, 28.10.1942; BNB, Archives, $S D$, Basyn Papers, dossier 6 e: Basyn, relation des négociations consécutives au mémorandum du 3 octobre 1942 (17.12.1942). 
Reeder's discouraging introduction did not deter Plisnier from taking the bull by the horns and declaring that, as the Germans were not respecting the agreement of 5 May 1942, the arrangements it contained had to be reviewed and improved: 'Belgian' control over clearing transactions had to be built into a new agreement and steps had to be taken to curb German purchases on the Belgian black market. He concluded with an urgent call for a reduction in overall occupation costs.

In his response, Reeder reduced the entire matter to Plisnier's comments regarding the problem of the black market and claimed that he would be the first to act vigorously to stamp out such malpractice. In an aside, however, he remarked that there were two parties in the market: without the Belgian black-marketeers, the German purchasing agencies could not operate. He then proposed that a special commission be set up to control all that Belgians were offering on that market to German buyers. In future, moreover, all payments within the clearing system would be concentrated and executed via an account opened at the Wehrmachtverrechnungskasse (WVK), in order to impose effective control by the Military Government and thereby eliminate the abuses and irregularities.

Galopin perceived positive elements in Reeder's proposals, but doubted whether they were sufficient to resolve all the questions that had been tabled. He was convinced that, if the intention was really to eliminate payment orders carrying the reference 'laut besonderer Mitteilung', German control would have to be matched by a system of control set up within the Belgian administration.

Reeder declared his readiness to examine the demands of the Belgian delegation and the degree to which the Military Government could meet them. However, the effect of these positive noises was dampened when, just before ending, he mentioned, as if in passing, that the coming months could well see new requests for lump-sum payments, without any details being offered. Surprised by this unexpected statement, the Belgian delegation asked what precisely it meant, whereupon Reeder gave the floor to Hofrichter. The explanation was businesslike, curt, even imperious, immediately cancelling the sense of conciliation to reveal how big was the gap within the Military Government between the moderates around Reeder and the Hofrichter coterie, which looked to follow Berlin's strict line ${ }^{15}$.

15 BNB, Archives, SD, 20, clearing, dossier 8.10.10/ s. f.15: réunion des banquiers fondateurs, 03.11.1942, p. 5. 
Hofrichter then set out a complete financial programme that would fundamentally reorganize the clearing system. The Banque d'Emission was to accept the concentration of all payments in the Wehrmachtverrechnungskasse. It also had to execute immediately the suspended payments, which already amounted to about 750 million Belgian francs. Furthermore, the Banque d'Emission was required to transfer a lump sum of 500 million Belgian francs each month, for which no details would be provided; however, details would be given for $90-100 \%$ of blanket payment orders exceeding that monthly sum. Lastly, and contrary to what had been laid down in the agreement of 5 May, no further details would be given about the payments made between May and October 1942, amounting to $1,512.5$ million Belgian francs.

Hofrichter's words and arrogant manner came as a violent shock to the delegation. Goffin reacted immediately and said that Hofrichter's programme had not taken the least account of the Belgian delegation's proposals. Now it appeared that, with their unacceptable demands, the Geman authorities were leaving the managers of the Bank and the Banque d'Emission no option but to tender their resignations ${ }^{16}$. Reeder had not expected such a sharp reply and reacted rapidly and drastically. He found Goffin's intervention unseemly and declared that acceptance of Hofrichter's four-point programme - which would also be set out in a letter to be circulated - was the conditio sine qua non for Belgian request to be considered. He then suspended the meeting and stormed out.

\section{REEDER'S ORDER FOR IMMEDIATE PAYMENT}

The letter Reeder had referred to was delivered on 29 October. It repeated the demands set out by Hofrichter, but reformulated them, making them in part more imperative and in part more flexible ${ }^{17}$. The demand for execution of the suspended payments amounting to about 750 million Belgian francs was translated in the letter into a formal order; payment was required to be made by no later than 4 p.m. on 30 October and was an unconditional requirement for negotiations to be

$16 \mathrm{BNB}$, Archives, $S D$, clearing, dossier 8.11.9/s. f.10: réunion tenue le vendredi 30 octobre 1942 à 19 heures chez M. le Bâtonnier René Marcq, p. 12.

17 BNB, Archives, SD, 19, clearing, dossier 8.11.9/ s. f. 7: lettre du Président Reeder, 29.10.1942. 
resumed. Furthermore, Reeder explicitly confirmed that the agreement of 5 May remained in force, with the difference that the details agreed upon would no longer be supplied by the German purchasing agencies, but by the Wehrmachtverrechnungskasse. A more flexible stance was taken towards execution of future blanket payment orders, with Reeder offering two options.

The first (option A) was for the monthly payment of a lump sum of 500 million Belgian francs to the Wehrmachtverrechnungskasse: in principle, no details would be provided, although the Military Government promised to make an effort to supply the names of the Belgian sellers, as well as the amounts paid to them and the nature of the goods involved in the transactions; in any case details would be given in respect of virtually all blanket payment orders exceeding the monthly lump sum.

The second option (option B) was for all purchases of goods in Belgium made by German agencies or by troops in transit, and destined for use outside Belgium, to be financed via the clearing system and no longer via occupation costs; details would be provided for at least 90 per cent of the transactions concerned. Were the Banque d'Emission to reject this option, financing would continue to be via occupation costs. If the first option was also rejected, occupation costs would be increased by the amount of the monthly lump sum.

The order for immediate payment of 750 million Belgian francs required a rapid decision about the course of action to be followed. The managing directors of the Banque d'Emission met the same day ${ }^{18}$. In a first draft of the reply they refused to comply with Reeder's order. Their argument was that the money would largely be applied to finance purchases on the black market; but since both German ordinances and Belgian decrees prohibited such transactions, the Banque d'Emission was bound to refuse to execute the payment.

The draft reply was submitted to Plisnier who the following morning invited Galopin and M.-L. Gérard, together with Goffin and Berger, to discuss it ${ }^{19}$. Galopin and M.-L. Gérard disapproved of the text, believing the refusal to pay was pointless and irresponsible, since it would

18 BNB, Archives, DC NBB-BEB, 30.10.1942.

19 BNB, Archives, $S D$, Basyn Papers, dossier 6 e: Basyn, relation des négociations consécutives au mémorandum du 3 octobre 1942 (17.12.1942). 
block the future negotiations. They also found the tone of the reply too aggressive. No-one wanted a breach with the Military Government, but breach there would be if the reply was sent in its present form. The draft was therefore revised in Plisnier's office and its tone moderated. The new form stated that the Banque d'Emission was prepared to execute the payment, but only on condition that the Bankaufsichtamt give a prior assurance that the money would not be used to finance purchases on the black market.

The revised text was ready by 1 p.m. and in principle could be handed in due time to the Bankaufsichtamt. However, Berger wished to submit it first to the other managing directors. They disagreed with the revised text and decided to work on a new and harsher version that partly reflected the original draft ${ }^{20}$. The founder-bankers, in their turn, saw themselves unable to accept the new version and sent it back to the managing directors with the request that everything possible be done to moderate it. By now, however, the lengthy discussions and arguments over the text had overrun the deadline of 4 p.m. Half an hour late, Goffin reported to the Bankaufsichtamt and asked whether he could submit the text on the following Tuesday morning, a delay of four days, on the excuse that the Banque d'Emission's leaders had not finished discussing on it and that some members could not be reached, because 'All Saints' fell on that weekend ${ }^{21}$. Hofrichter asked whether the payment had been made. When Goffin replied that it had not, he was told to remain at the Bank until further notice.

The intense discussion that had been taking place all the while among the managing dirctors centred on how the reply could be amended to bring it more into line with what had been proposed by Galopin and M.-L. Gérard. Ultimately, it was the more moderate version that was chosen as the agreed text, i.e. the one on which consensus had been reached around midday in Plisnier's office ${ }^{22}$.

Around 6 p.m., Goffin was summoned to the Bankaufsichtamt. He was now able to present the reply, but when he drew the attention of von

20 BNB, Archives, $D C$ NBB-BEB, 30.10.1942, p. 5.

21 BNB, Archives, $S D$, 'enquête BEB': report of the Commission of Enquiry (published text, 1946), Chapter. 3, p. 112.

22 BNB, Archives, $D C$ NBB-BEB, 30.10.1942, p. 6. See also, BNB, Archives, $S D$, 2O, clearing, dossier 8.10.11/ s. f. 15: réunion des banquiers fondateurs, 04.11.1942, p. 6 . 
Becker and Hofrichter the payment being conditional, the Germans refused to accept the reply ${ }^{23}$ : they said that an official of the Bankaufsichtamt would be at the Bank at 10 a.m. the following morning to verify that the payment had been made. The memorandum also contained certain unmistakable threats: for example, before 7 p.m. that evening Goffin was required to confirm that the Bank's equipment - particularly its printing presses - were in good condition and that all the Bank's valuables were immediately available. Any slip-up in these respects would be regarded as an act of sabotage. Furthermore, not only the managements of both banks, but also the members of the Bank's supervisory council and board of scrutineers, as well as the members of the Banque d'Emission's board of directors, would be held responsible for a refusal to execute the payment ${ }^{24}$.

The managing directors were at their wits' end and therefore sought external help. They found the jurist Marcq prepared to receive them in his office that evening and there they were joined by De Visscher and Plisnier $^{25}$. De Visscher and Marcq judged that the threats had reached such a pitch that they had to be regarded in a new light. Manifestly, the Military Government now saw the execution of an order as a matter of prestige and felt that there could be no further discussion. The two jurists took the view that, if, in spite of everything, the Germans still appeared ready to negotiate further, this was an important reason to justify immediate and unconditional payment. Plisnier took the same line.

The managing directors resolved to do this. Berger agreed, but with 'rage in his heart'. Van Nieuwenhuyse, too, declared his support for the majority, but not without reservation: on the assumption that negotiations would lead to nothing and that the plundering of the country would continue and ultimately result in ruin, he wanted to decide whether he would remain as a director or resign ${ }^{26}$.

23 BNB, Archives, $D C$ NBB-BEB, 30.10.1942, p. 7.

24 BNB, Archives, SD, 19, clearing, dossier 8.11.9/ s. f. 9: sommation des autorités allemandes, 30.10.1942.

25 BNB, Archives, SD, 19, clearing, dossier 8.11.9/ s. f. 10: réunion tenue le vendredi 30 octobre 1942 à 19 heures chez M. le Bâtonnier René Marcq.

26 The two jurists gave their opinion in writing and submitted the letter to Goffin on 3 November 1942: BNB, Archives, SD, 19, clearing, dossier 8.11.9/s. f. 11: consultation de Me Marcq et du Prof. De Visscher. 
The payment was made the next morning. During the night of 30/31 October, German police in plain clothes surrounded the Bank and at 10 a.m. burst into the cashiers' hall. Meanwhile, two members of the Bankaufsichtamt, dressed in army uniform, presented themselves to Goffin to check whether the instruction to transfer the money had been handed to Cracco and if the transfer had actually taken place ${ }^{27}$.

27 BNB, Archives, $S D$, 19, clearing, dossier 8.11.9/s. f. 12: exécution de la sommation, 31.10.1942. 



\title{
CHAPTER 18 \\ The Rupture of the United Front
}

\author{
PREPARATIONS FOR THE NEGOTIATIONS OF 18 NOVEMBER 1942
}

On 3 November, the dramatic events of the 'All Saints' weekend were revealed to the founder-bankers and the Bank's supervisory council. Galopin, in his personal notes, regarded making the payment as 'unconditional surrender' that severely weakened the Belgian negotiating position and consequently boded ill for the future. He was also critical of the opinion given by the two jurists, who had recommended that the payment be executed so that negotiations could be continued. But how were they to be continued? By hostages? The Bank and the Banque d'Emission now had to get agreement to the unacceptable demands of 16 October. In the face of this, any negotiation was doomed to failure. What would happen then? Collective resignation? If this was to be accepted, then the only course was also to abandon the policy of accommodation.

At the meetings of the leaders of the Bank and the Banque d'Emission on 3 and 4 November, Galopin referred only vaguely to his personal evaluation of the drama played out over the weekend. M.-L. Gérard was more explicit and regretted that he had not been involved in the deliberations, even though, unlike Galopin, he had been in Brussels over the weekend. However, both endorsed the decision that had been taken, accepting that the managing directors had allowed themselves to be guided by the opinion of two competent and reliable jurists ${ }^{1}$.

During the meetings, there was also thorough discussion of the choice between the two options that Reeder had proposed in his letter of 29 October, regarding reorganization of the clearing system. As mentioned in the previous chapter, option A would require the Banque

1 BNB, Archives, $S D$, 20, clearing, dossier 8.11.10/ s. f. 15: réunion des banquiers fondateurs, 03.11.1942 and 04.11.1942. 
d'Emission to accept to pay an additional lump-sum amount of 500 million Belgian francs a month via the clearing system, without the Military Government being obliged to provide any details for the payment; option B would require the goods and services purchased by troops in transit to be financed by the Banque d'Emission via the clearing system, and no longer be charged to occupation costs. Should the Banque d'Emission reject both options, everything would remain as it had been, i.e. with purchases by troops in transit being charged to occupation costs, but with the addition of the 500 million Belgian francs of option A to the present monthly amount of occupation costs.

For those present, option A was unacceptable: to sanction it would be to invite a further increase in the risk of the Banque d'Emission finding itself financing doubtful transactions. After great hesitation, it was also decided to reject $\mathrm{B}$, as this also concerned transactions of a military character. However, the rejection of both options meant that the Ministry of Finance was now saddled with an additional charge of 500 million Belgian francs a month, which Ingenbleek, supported by Galopin, de Munck and Berger, felt could not be permitted ${ }^{2}$. The question then was to find a way out of the impasse. According to Berger and others, some of the purchases of troops in transit were clearly commercial transactions and could therefore be financed without any objection via the clearing system; consequently, Reeder's additional charge of 500 million Belgian francs could be reduced in proportion, thereby spreading it over the clearing system and occupation costs. This suggestion met with approval.

Berger then brought the expenditure of the Feldpost into the equation. This institution was used by German troops in Belgium to obtain certain sums of money from Germany each month to buy goods to send back home. Until now, the expenditure of the Feldpost had been financed via occupation costs, but, as Berger pointed out, the expenditure chiefly concerned commercial transactions and could therefore also be financed via the clearing system, which would naturally result in a further reduction in occupation costs and bring about an even better distribution of the additional charge of 500 million Belgian francs.

2 BNB, Archives, SD, Basyn Papers, dossier 6 G: letter of 12.01.1943 from Kauch to Basyn. 
Naturally enough, the suggestions had to be put to Plisnier, whose agreement was necessary if the united front was to be maintained ${ }^{3}$.

The managing directors had put the proposals in a draft reply to Reeder that was intended to serve as the basis for talks with Plisnier, taking place on 6 November. The Secretary-general showed no interest in the proposals and was unwilling to commit himself. In the end the draft was reduced to a vague text that everyone, including Plisnier, could accept. By and large, it indicated a preference for option B, but also included a reference to option A. It stated that, as regards blanket payment orders, the Banque d'Emission was prepared to transfer a maximum monthly sum of 500 million Belgian francs to the Wehrmachtverrechnungskasse, provided that the money was applied to financing normal commercial transactions and that payments would be made directly to the Belgian sellers concerned and after each transaction. The nature of the transactions would also be notified in detail to the Banque d'Emission.

Meanwhile, during his encounter with Leemans, Reeder had indicated that the discussion about his two options could be integrated into overall negotiations on the many questions that had remained unresolved since the suspension of the meeting at the end of October. Reeder set 18 November as the date for the negotiations. The news, however, did not change the disillusion of the managing directors about Plisnier's negative attitude during the discussion of 6 November. Van Nieuwenhuyse, in particular, was highly resentful of Plisnier's apparent lack of interest - his indifference, even - during the discussion. Plisnier had shown clearly that he had not moved a jot from his previous position: 'direct cooperation' in purging the clearing operations implied 'direct cooperation' in increasing occupation costs and he had no intention of becoming involved. During their meeting the next day the managing directors resolved to reject both options in Reeder's letter and to shift the entire charge of 500 million Belgian francs onto occupation costs, thereby returning to their previous resolution to pursue a policy of monetary and financial orthodoxy, even at the cost of the collapse of the united front. Berger went to Galopin to inform him of the management's new position and mentioned a possible collective resignation.

3 BNB, Archives, SD, 20, clearing, dossier 8.11.10/ s. f. 15: réunion tenue chez M. Plisnier, 06.11.1942. 
This sudden about-turn of the managing directors left Plisnier once again facing the spectre of higher occupation costs. He was unsure of how to react. Should he resign as secretary-general, because of the higher costs? Or should he accept the increase as 'cas de force majeure'? It was a difficult dilemma. For advice, he turned to De Visscher and on 11 November convened a meeting of a number of former ministers in whom he had confidence ${ }^{4}$.

For De Visscher, there could be no doubt: the united front had to be maintained at all cost. The former ministers were more down-toearth in their response, though their opinion was far from unanimous. Joseph Pholien and Octave Dierckx suggested resignation. Most of the other former ministers insisted on not resigning, expressing their fullest confidence in the wisdom of the secretary-general's judgement, even if some new concessions had to be made. The words were very flattering, but contained little effective advice. However, all those present were agreed on one thing, namely that the clearing system had to be purged of all suspect transactions, both political and military. On 13 November, A.-E. Janssen and M.-L. Gérard reported to the managing directors and board of directors of the Banque d'Emission on what had taken place at the meeting of former ministers ${ }^{5}$. They emphasized that all those present were agreed that dubious transactions should be kept out of the clearing system.

The Banque d'Emission's leaders then set about drawing up the strategy to be followed at the coming meeting with the Germans on 18 November, the managing directors repeating that they wished to keep entirely to the resolutions of 16 October and to their position on 7 November. Galopin agreed, but felt that Plisnier could not be left in the lurch. Turning next to the composition of the Belgian delegation to the meeting, it was decided that it would consist of Berger, Van Nieuwenhuyse and Cracco, for the Banque d'Emission, and Smeers and Olivier Gérard respectively for the Ministries of Finance and Economic Affairs.

The delegates met on 16 November. Those from the Banque d'Emission proposed that a monthly ceiling of 2.5 billion Belgian francs

4 BNB, Archives, $S D$, enquête BEB: réunion du 11 novembre 1942 des anciens ministres chez M. Plisnier, 11.11.1942.

5 BNB, Archives, $S D$, 20, clearing, dossier 8.11.10/15: réunion des banquiers fondateurs, 13.11.1942. 
be demanded for total charges (actual charges during October had risen to 3.7 billion) ${ }^{6}$, spread as follows: 1.5 billion for orthodox occupation costs and 1 billion for additional charges, 400 million of which to be financed via the clearing system, since that amount could be regarded as concerning normal commercial transactions. Half the remaining 600 million related to wage transfers from Belgian workers employed abroad, in respect of which the German authorities had at one time declared themselves prepared to work out a formula acceptable to the Belgians. What were termed 'dubious transactions' thus accounted for no more than 300 million Belgian francs and would have to be borne by the Ministry of Finance as additional occupation costs.

The proposal was not well received by the ministry's delegate, Smeers. He immediately pointed out that Plisnier never would agree to it. Upon this, the managing directors convened an emergency meeting with the founder-bankers, Plisnier, Smeers and the jurists Marcq and De Visscher on 17 November. The meeting proved to be dramatic with Plisnier sticking obstinately to his guns: he repeated that, when the Banque d'Emission had refused to have the lump sum of 500 million Belgian francs financed via the clearing system, as proposed by Reeder in his first option, he had never assented to that amount being shifted onto occupation costs. Although he showed understanding for the Banque d'Emission's decision, he could not accept that, in consequence of that refusal, he was required to approve being saddled with the additional charge.

In this, Plisnier was following the advice of De Visscher, who judged that, once a joint refusal had been made, no further reproach could be levelled at the Belgians: they had resisted strongly and courageously, and the fact that they had nevertheless had to submit to the increase in charges - charges imposed by order of the occupier - was not now a matter of their voluntary cooperation. De Visscher, moreover, had a strong suspicion that the consequences of such a strategy would not necessarily be dramatic: the Germans would not react by dismissing the top people in Belgium, because they had need of them. Approximately 700 German officials could not administer the country ade-

6 BNB, Archives, $S D$, enquête BEB: réunion à la BEB, 17.11.1942; BNB, Archives, $S D, 20$, clearing, dossier 8.11.10/15: réunion tenue au cabinet de M. Plisnier, 18.11.1942.

7 BNB, Archives, $S D$, enquête BEB: réunion à la $\mathrm{BEB}, 17.11 .1942$. 
quately without the cooperation of competent Belgians, which was the underlying reason why, throughout the occupation, major instruments of administrative control had remained in Belgian hands ${ }^{8}$.

Plisnier was able to associate himself with De Visscher's opinion when he stated that the Banque d'Emission and the Ministry of Finance should act in solidarity. In line with that, Plisnier accepted that payments in respect of dubious transactions be split, deciding - now against De Visscher's advice - to do so voluntarily as a logical consequence of the state of emergency. But what did 'solidarity' actually mean for those involved? For the Banque d'Emission, which felt itself for ethical reasons no longer able to finance dubious transactions via the clearing system, solidarity meant the Ministry of Finance accepting to finance them via occupation costs. For Plisnier, on the contrary, it meant precisely that the burden and the responsibility should be shared.

Ultimately, it was Galopin who provided the breakthrough 9 . He pointed out that much of the discussion with the German authorities would concern Belgian control of the transactions that fell under Reeder's demand for an additional 500 million Belgian francs a month. As it could be assumed that most of the transactions would be justifiable, they could be financed by the Banque d'Emission via the clearing system. The transactions that remained as dubious would probably account for no more than 100 million Belgian francs a month. Which institution took on that residual amount was now a matter of indifference and he urged the management of the Banque d'Emission to finance that too.

Ingenbleek noted the consensus and Plisnier declared that this was a conclusion he could accept. The clouds seemed suddenly to have disappeared, but what had been missed in the tense discussion and the ensuing euphoria was that the solution accepted turned De Visscher's original and vital idea on its head. What Plisnier had done was to get the Banque d'Emission and its founder-bankers voluntarily to agree -

8 ARA, fonds Société Générale de Belgique, BeB dossier nº 9: visite à M. De Visscher 20.11.1942 (text probably from de Munck, who went to De Visscher after the crisis and on 04.01.1945 requested him to confirm the content of that conversation). See also: ARA, Archives, SD, 20, clearing, dossier 8.11.10/16: note sur l'état de nécessité par le prof. De Visscher, 10.11.1942.

9 BNB, Archives, $S D$, 20, clearing, dossier 8.11.10/15: réunion tenue au cabinet de M. Plisnier, 18.11.1942. 
for the sake of maintaining the united front - to finance a number of dubious transactions.

It quickly became clear that Goffin, Berger and Van Nieuwenhuyse would not agree to Galopin's proposed compromise. Ultimately, they decided among themselves to stick to De Visscher's original advice and reject the proposal for the Banque d'Emission to assume voluntary payment of the additional charge.

\section{THE NEGOTIATIONS OF 18 NOVEMBER 1942}

The negotiations with the Germans took place in the afternoon of 18 November at the premises of the Bankaufsichtamt, as agreed the previous week ${ }^{10}$. The first point tabled by the Belgian delegation concerned the demand for a priori control of transactions through the use of a licence and, yet again, the Germans declared that they could not comply. However, they were prepared to provide prior details for transactions up to 375 million Belgian francs a month for payment orders issued by German banks in Belgium.

The demand for an upper limit on total occupation costs was likewise refused. Reeder's letter of 29 October came up for discussion and the Germans stated their readiness to provide as many details as they could regarding the additional charge of 500 million Belgian francs. Information about all purchases by German agencies would be provided six to eight weeks after payment ${ }^{11}$. However, if the Banque d'Emission still aimed to keep a totally checked clearing system, the Military Government would be obliged to increase the current level of occupation costs by between two thirds and three quarters.

$10 \mathrm{BNB}$, Archives, $S D, 20$, clearing, dossier $8.11 .10 / 17$ : procès-verbal succinct de la séance au commissariat allemand, 18.11.1942.

11 During a meeting with de Launoit, Leemans said that the Military Government was highly irritated by the activities of the German purchasing agencies, which, on the instructions of Berlin and without the knowledge of the Military Government, were creaming off the markets in Belgium and demanding payment via the clearing system on the basis of joint orders. Reeder had given Leemans an angry letter to read from Hofrichter to the Berlin government, in which the abuses were sharply attacked: ARA, Plisnier Papers, dossier 1: Banque d'Emission, aide-mémoire, 23-26.11.1942. 
The Germans were prepared to accept the conditions set by the delegation for the wage transfers from Belgian workers employed in France and the Netherlands, and the amounts in question would be credited to a special Banque d'Emission account at the Banque de France and De Nederlandsche Bank ${ }^{12}$. However, the demand for goods - in other words, food - to be given in exchange for goods and services delivered from Belgium to France and the Netherlands on behalf of the occupier could not be met, as the two neighbouring countries refused to comply. However, the resulting credit balances could be applied to repaying Belgian public debt in France and the Netherlands: an agreement in this sense had already been concluded with the Netherlands and the German authorities were looking for a similar agreement with France.

The day after, at a meeting of the founder-bankers, attended by certain members of the Bank's supervisory council, the delegates reported on their previous day's encounter with the Germans. Goffin, Berger and Van Nieuwenhuyse noted that, with the exception of the wage transfers, no account at all had been taken of Belgian demands. Consequently they had resolved to resign from both the Banque d'Emission and the Bank. Solvay and A.-E. Janssen felt that this decision could well be defended from a strictly monetary point of view, but not on the higher grounds of the common interest. Galopin agreed entirely with Solvay and Janssen's statement. Plisnier, too, regretted the resignation, wanting the negotiations to be continued, and requesting forty-eight hours for reflection ${ }^{13}$. After a great deal of discussion, Goffin withdrew his resignation and asked Berger and Van Nieuwenhuyse to reconsider their decision. Berger answered by posing a counter question: would Plisnier maintain his decision not to include any dubious transactions in the package of 500 million Belgian francs as additional occupation costs or was he prepared to concede on this? Plisnier answered that he had to refuse.

The two jurists Marcq and De Visscher, who were also present, shared Plisnier's view. They had, in fact, gained their point: both sides had refused to accept voluntarily the additional increase in charges.

12 BNB, Archives, SD, 2obis, clearing, dossier 8.11.10/27: lettre du Président Reeder, 07.12.1942 (report of the meeting of 14.12.1942 at the Bankaufsichtamt).

13 BNB, Archives, SD, Basyn Papers, dossier 6 e: Basyn, relation des négociations consécutives au mémorandum du 3 octobre 1942 (o1.12.1942), p. 37. 
However, their success was tempered by the refusal of Berger and Van Nieuwenhuyse to accept their advice not to resign. As long as there was a chance of keeping control of monetary and financial events in reliable Belgian hands, they argued, however fragile and inadequate that control was, resignation was not the path to follow.

Finally, the meeting requested Ingenbleek to make contact with Plisnier personally in order to examine whether a compromise, which could satisfy the two resigning managing directors, was still possible. Meanwhile Ingenbleek had contacted the former ministers Pholien and Dierckx, who, during the meeting of 11 November, had advised the secretary-general to resign. After a long exchange, Ingenbleek was able to convince the two ministers to reverse their decision and give their support to the policy of accommodation. In a memorandum of 22 November, they stated that Plisnier now found himself in a 'cas de force majeure' situation and could legitimately accept the dubious transactions as part of occupation costs ${ }^{14}$. The three then visited Plisnier, who promised to make a conciliatory statement at the meeting of the Banque d'Emission's board of directors the next day, 23 November ${ }^{15}$. However, during the meeting, Plisnier failed to make the statement he had promised, and from this Galopin inferred that there could be no further papering over the cracks in the united front. Henceforth, each group would have to act on its own responsibility. Taking its cue from this assessment, the board of directors resolved to continue negotiations with the Military Government ${ }^{16}$.

Was Plisnier's attitude determined by wounded pride, willfulness and a lack of resolve, as the Banque d'Emission's founder-bankers always claimed later? Was the advice of Marcq, and especially De Visscher, to continue to resist the occupier decisive or were there at play more personal feelings of repressed antipathy towards the founderbankers, whom Plisnier had never really trusted? Was he thinking that,

14 Quoted by F. Maerten, 'Pholien face à la seconde occupation du pays', in: F. Carton de Wiart and G. Janssens, eds., Joseph Pholien. Un homme d'état pour une Belgique en crise, Brussels, 2003, pp. 175-176.

15 BNB, Archives, $S D$, clearing, 2obis, dossier 8.11.10/23: nouvelles propositions du Commissariat (communication de M. le Vice-Gouverneur, 26.11.1942).

16 BNB, Archives, $S D$, 'enquête BEB': report of the Commission of Enquiry (published text, 1946), Chapter. 3, p. 117. 
as always, they were trying to shift the entire problem of the dubious transactions onto him?

It may well have been a mixture of all these factors. Indeed, that the last reflection was not entirely unfounded is borne out by the unexpected comment of such a man as A.-E. Janssen: 'For us it's a good deal: the shit bin has been moved' ('Bonne affaire pour nous. Le bac à merde est déplacé') ${ }^{17}$. In his arguments, as well as in his subsequent letters, Plisnier regularly emphasized that he favoured joint action, which for him implied concessions by both sides. He never forgave the Banque d'Emission's founder-bankers for their abandonment of solidarity during the crisis.

\section{THE ARRANGEMENT OF 25 NOVEMBER 1942}

In Ingenbleek's view, the situation had become extremely critical. Without the knowledge of the founder-bankers, but with the approval of Goffin, he went to speak with Prack of the Bankaufsichtamt to sound him out about how the German authorities would react to the rigid standpoints now adopted by the Banque d'Emission and the Ministry of Finance ${ }^{18}$. Prack warned Ingenbleek that there would be severe sanctions if the monetary and financial leaders of the country were to carry their resistance to extremes: 'The Gestapo will reign without any restraint..., general von Falkenhausen will disappear' ${ }^{19}$. Ingenbleek began to fear that, as a counter-measure, the Germans might well take control of the Bank and the Banque d'Emission. He therefore continued

17 Quoted by Kauch: BNB, Archives, SD, Basyn Papers, dossier 6 g: letter of 12.01 .1942 from Kauch to Basyn, p. 9.

18 BNB, Archives, SD, 'enquête BEB': report of the Commission of Enquiry (published text, 1946), Chapter. 3, pp. 118-119.

19 BNB, Archives, $S D$, 2obis, clearing, dossier 8.11.10/23: nouvelles propositions du Commissariat (communication de M. le Vice-Gouverneur, 26.11.1942). During a later meeting with A.-E. Janssen, Ingenbleek said the following about his role in the acute crisis of that moment: 'c'est grâce à moi que les Allemands ne se sont pas installés en maîtres à la Banque Nationale pour y faire imprimer tous les milliards qu'ils désiraient se procurer, et que les hautes personnalités sont encore à la tête de leurs établissements' (BNB, Archives, Studiedienst, 5, dossier 01.02.01.70 (A 409/2 and A 267): Ingenbleek, aide-mémoire of 23-28.12.1942). 
to search for a compromise that would extract the Banque d'Emission from the impasse. To that end, he went to see Hofrichter, who had made an interesting suggestion the previous May. It had not been followed up then, although - as has been indicated - it had occasionally resurfaced, first in a letter written by Reeder on 29 October 1942 and later in a memorandum prepared by Berger during the meetings of the founderbankers on 3 and 4 November. Ingenbleek now proposed subtracting the commercial purchases made by troops in transit and the Feldpost transactions from the occupation costs and moving them to the clearing operations of the Banque d'Emission. The reduction in the occupation costs, realized in this way, would compensate for the monthly charge of 500 million Belgian francs, imposed by Reeder as an extra occupation cost upon the Ministry of Finance, if the Banque d'Emission refused to integrate it in its clearing system. The shift thus would amount to a zero operation for the Ministry and not entail any increase in occupation costs; for the Banque d'Emission, it would mean a purging of the clearing system. Hofrichter promised to look into the matter.

On 25 November, Hofrichter summoned Goffin and Cracco, and told them what the Bankaufsichtamt now proposed ${ }^{20}$. First of all, it had agreed to all dubious transactions of a political or military nature (including those involving the black market) being removed from the clearing system. As regards all normal commercial transactions, all the required information would be provided at the same time as payment orders were submitted. For blanket payment orders, the Wehrmachtverrechnungskassse would provide details for up to 90 per cent of the total amounts involved. Moreover, payments for commercial purchases made by troops in transit, and destined for another country, as well as payments for Feldpost transactions, would be withdrawn from occupation costs and would henceforth be settled via the clearing system. Lastly, the financing of dubious transactions would be transferred to occupation costs, but would not result in any rise in the overall amount.

Hofrichter went on to underline that the Military Government had now gone a long way to meeting Belgian wishes and that he therefore

20 BNB, Archives, $S D$, 2obis, clearing, dossier 8.11.10/23: nouvelles propositions du Commissariat (compte rendu de la séance, 25.11.1942). See also: ARA, Plisnier Papers, dossier 1: Banque d'Emission, aide-mémoire, 23-26.11.1942. 
expected immediate endorsement of the proposal by all parties concerned, adding that heavy sanctions would follow if full endorsement was not forthcoming. Should the Banque d'Emission reject the proposal, it would be required to make substantial sums available to the military commander; in case of refusal to act on the military commander's order, the board of directors and all other leaders of the Banque d'Emission and the Bank would be held jointly responsible for the refusal, and the private banks would be obliged to pay the sums demanded themselves.

At a meeting of the Banque d'Emission's founder-bankers that same day, Goffin and Cracco reported on their encounter with Hofrichter ${ }^{21}$. The bankers found that the proposal largely met what they were demanding and that there was no reason to refuse. However, Cracco felt that Plisnier ought to be informed in advance. Plisnier was pleased to hear that a favourable arrangement had been found for the Banque d'Emission and that there was to be no increase in occupation costs. Of course, he regretted that the proposed arrangement had shifted the problem of the irregular payments on to the Treasury, but the problem was not insurmountable. He would raise the question when next he had an opportunity to argue for the occupation costs to be reduced ${ }^{22}$. He finally expressed the hope that, with so much achieved, Berger and Van Nieuwenhuyse would withdraw their resignation.

On 3 December, Hofrichter travelled to Berlin to submit the arrangement to the government representatives for approval ${ }^{23}$. There appeared to be no great problem and by 7 December Reeder officially informed the Banque d'Emission that the agreement of 5 May 1942 was regarded as having been terminated and replaced by the arrangement of 25 November, coming into effect on 1 January 1943. Only the monthly lump sum of 50 million Belgian francs imposed by the May arrangement would remain ${ }^{24}$. Finally Reeder stated that there could be no favourable

21 BNB, Archives, SD, 2obis, clearing, dossier 8.11.10/23: nouvelles propositions du Commissariat (réunion des banquiers fondateurs, 25.11.1942).

22 NBB, SD, Basyn Papers, dossier 6 e: Basyn, relation des négociations consécutives au mémorandum du 3 octobre 1942 (17.12.1942), p. 31.

23 BNB, Archives, $D C$ NBB BEB, 03.12.1942.

24 In April 1943, this amount was increased to 75 million Belgian francs a month: BNB, Archives, $S D$, 'enquête BEB': report of the Commission of Enquiry (published text, 1946), Part 1, Chapter. 3, p. 127. 
response at the moment to the request for a reduction in occupation costs.

\section{THE QUESTION OF SUCCESSORS FOR BERGER AND VAN NIEUWENHUYSE}

Reeder's letter was followed by an abatement of the storm aroused by Plisnier's stance during the meetings of the previous weeks. A.-E. Janssen took the opportunity to convene a meeting on 19 December 1942 of the leaders of the Banque d'Emission, the Bank and the secretariesgeneral of the Ministries of Finance and of Economic Affairs. The attempt at reconciliation took place in Plisnier's private office. A.-E. Janssen opened the meeting with a plea for the united front to be restored: as negotiations were about to be resumed regarding the clearing system and the occupation costs between the Banque d'Emission and the Military Government, it would be useful if the Banque d'Emission and the Ministry of Finance could dovetail their approaches. Plisnier stated that he was ready to co-operate, Galopin responding that the Banque d'Emission would show complete solidarity with the secretary-general in his resistance to occupation costs being raised ${ }^{25}$.

The arrangement of 25 November and the restoration of the united front on 19 December prompted the members of the Bank's supervisory council to confirm that they would be remaining in office and not following the example of Berger and Van Nieuwenhuyse in resigning. Although not ideal, the arrangement of 25 November included important concessions on the part of the Germans and could be considered as ' $a$ serious attempt to purge the clearing" ${ }^{26}$. Nevertheless, the resignation of Berger and Van Nieuwenhuyse remained a source of great embarrassment. Most of the leading figures in the country, supported by public opinion, praised the two directors for acting courageously, but felt that, particularly after 25 November, they ought to reconsider their decision, the Military Government having met Belgian demands to a substantial degree ${ }^{27}$.

25 ARA, Plisnier Papers, dossier 1 h: réunion tenue au cabinet de M. Plisnier, 19.12.1942.

See also: BNB, Archives, RR, 30.12.1942; BNB, Archives, $B R$ BEB, 06.01.1943.

26 BNB, Archives, $R R, 30.12 .1942$.

27 BNB, Archives, $S D$, 2obis, clearing, dossier 8.11.10/ 24: réunion des banquiers fonda- 
On 3 December, Galopin spoke with the two directors for two hours in an attempt to convince them to change their minds, but to no avail. Both continued to insist that the resolutions of 16 October had to be accepted in their entirety by the occupier as a conditio sine qua non for further negotiations. As regards the upper limit, Berger showed himself a little more flexible, but for Van Nieuwenhuyse this point was also not negotiable: the limit represented a 'total and fixed' maximum. Galopin concluded that the two directors were so unbending and rooted in their prejudices that it was preferable to keep them out of the leadership. That same day, Goffin spoke with Hofrichter about the possibility of the two directors returning, and mentioned the unanimous resolution of his colleagues to request them to withdraw their resignation. Hofrichter found this unfortunate and pointed out that Reeder was highly displeased about the resignation and was looking to replace the two as quickly as possible. The Military Government was even considering blocking their eventual return ${ }^{28}$.

The question now arose of who was to replace them. Hofrichter suggested Cracco. In spite of feeling that Cracco was not an easy man to negotiate with, Hofrichter regarded him as intelligent, with a thorough grasp of his dossiers and behaving correctly during and after negotiations. Goffin found the suggestion acceptable and Cracco was sounded out. He agreed to have his name put forward and thus the first candidate had been discovered without too much discussion. Ingenbleek, on his part, proposed Kauch as the second candidate: he had been private secretary to the former governor, Janssen, and was a prominent member of the Research Department ${ }^{29}$. Kauch himself agreed directly, but speaking for the founder-bankers, A.-E. Janssen and de Munck vetoed his candidature, arguing that Kauch did not have a sufficient mastery of Dutch and that he also lacked the necessary competence. That was, at least, the official reason for the veto; it was, after all, a public secret that Kauch was not over-fond of private bankers; it was also a fact that

teurs, 09.12.1942; BNB, Archives, Studiedienst, 5, dossier 01.02.01.70 (A 409/2) and A 267): Ingenbleek, note (spring 1943).

28 BNB, Archives, BR BEB, 06.01.1943.

29 BNB, Archives, Studiedienst, 5, dossier 01.02.01.70 (A 409/2 and A 267): Ingenbleek, aide-mémoire, 23.12.1942 - 31.12.1942. 
the founder-bankers had a candidate of their own: Robert Vandeputte, secretary of the Belgian Banking Association.

Serious objections to Vandeputte's candidature were raised by a number of persons. The first was that, from a political point of view, his appointment would create an unacceptable imbalance within the leadership of the Bank and the Banque d'Emission, as he, too, like Cracco and the Bank's economic adviser, L.-H. Dupriez - not to mention its legal adviser, De Visscher - held a professorship at the University of Louvain. A second concerned his professional past, since he came from within the Belgian Banking Association and was thus a confidant of the private bankers. One of the aims of the reform of the Bank in 1937 had been to curb the influence of the private bankers within the Bank and for such a person to be brought into its management would be in conflict with the spirit of the law ${ }^{30}$. However, the Banque d'Emission's founders continued to support their candidate and carried the day.

The candidature and the status of the new directors was vigorously debated during the meetings of the Bank's supervisory council ${ }^{13}$ and of the Banque d'Emission's board of directors ${ }^{32}$. Within the supervisory council, Bekaert's proposal to appoint the new directors solely ad interim met with stiff opposition from the Banque d'Emission's founder-bankers. Ultimately, a compromise was reached, with Bekaert accepting the principle of an appointment, but only for the duration of hostilities $^{33}$. The government commissioner Smeers endorsed the compromise.

Cracco's appointment had meanwhile failed to win general approval within the Bank or the Banque d'Emission. Within the Bank, many perceived a contradiction in his attitude: it was, after all, his highly critical report of July 1942 regarding the clearing system that had spurred Berger and Van Nieuwenhuyse to adopt an aggressive stance towards the occupier. Sticking to principle had led them to resign, but now it appeared as though Cracco was using the situation to ease himself into a directorship. The first thought of the employees and staff of the Bank

30 BNB, Archives, RR, 06.02.1943.

31 BNB, Archives, $R R$, 30.12.1942, 06.01.1943.

32 BNB, Archives, $B R B E B$, 06.01.1943, 11.01.1943.

33 BNB, Archives, $S D$, 2obis, clearing, dossier 8.11.10/29: letter of 31.12.1942 from Bekaert to Goffin. 
and the Banque d'Emission was to meet Cracco's appointment with going on a 'sit-down strike' ('une grève des bras croisés'), but that would have been contrary to house tradition and was not pursued ${ }^{34}$.

34 Weekly newspaper Cassandre, 17.01.1943. 


\title{
Towards the End of the Occupation
}

\author{
THE TURN OF THE TIDE IN MILITARY AFFAIRS
}

The repercussions of the turn of the tide for the German armies since 1942 were also felt at the Bank and the Banque d'Emission. Their pressure to have a more effective say in clearing operations now found greater response from the Military Government, handicapped as it was by an increasing shortage of qualified German personnel ${ }^{1}$. Internally, the Bankaufsichtamt even agreed that it was pointless to oppose the growing resistance by threatening to close the two institutions ${ }^{2}$.

At the same time, however, the Berlin government began to take a much tougher line towards its own officials in Brussels. One of the first victims, not undeservedly, was von Becker, head of the Bankaufsichtamt and commissioner of the Bank and the Banque d'Emission, who in the autumn of 1943 was dismissed on suspicion of corruption. He was provisionally replaced by Dr. Jost, an insignificant figure ${ }^{3}$. Initially, after von Becker's departure, Hofrichter had probably hoped to step into von Becker's shoes, which he certainly merited, but events dictated otherwise. In Berlin, the Minister of Economic Affairs, Walther Funck, was himself under fire as someone who was too close to von Becker and he feared that Hofrichter had too much inside information. Hofrichter thus fell out of favour and, despite Reeder's persistent pleading, was also required to leave Brussels for Northern France. He returned to Brussels shortly thereafter, but declined to resume his function as

1 BNB, Archives, DC BEB, 17.04.1944.

2 BNB, Archives, Prack Papers, dossier 2: Jost, Abschluszbericht der Militärverwaltung und des Reichskommissars für Belgien und Nord-Frankreich, 01.01.1944 31.08.1944, pp. 4-5.

3 BNB, Archives, DC BEB 07.01.1944. 
deputy-commissioner as long as his position was not fully confirmed 4 . Consequently, he was sidelined, even before he disappeared for good from the Military Government in April 1944. Jost, for his part, was appointed as commissioner of both the Bank and the Banque d'Emission, with effect from 1 March $1944^{5}$.

All these changes at the top of the Military Government did nothing to make contacts any easier for the Belgians attempting to steer their country's affairs. Oddly, too, they seemed to look back with some regret to the earlier, familiar relationships with the Military Government, even though the encounters then were often confrontational and they had to give way more than once ${ }^{6}$.

The Military Government in Brussels itself had come into direct conflict with the Nazi government in Berlin, due to its strong disapproval of the ordinance in respect of forced labour, which in 1943 led to the large-scale deportation of Belgian workers to Germany and France. The Military Government had also hindered the requisitions of Fritz Sauckel's administration ${ }^{7}$ and vigorously opposed the efforts of the Berlin government to gain greater control over the Belgian economy. The rest was done by the SS's concoction of a corruption scandal among von Falkenhausen's confidants. Ultimately, Hitler decided to get rid of the Military Government in Belgium and Northern France, and replace it with a Civilian Administration. As this came into effect only on 13 July 1944, however, it was a little late in the day for such a change and the result was that Reeder stayed on as president of the Administration. Barely two months later, the country was liberated ${ }^{8}$.

Major changes had also taken place at the head of the Bank and the Banque d'Emission during this period. Since 16 January 1943, Goffin and Ingenbleek had been joined by Cracco and Vandeputte, both of whom were immediately very active. But Cracco was suddenly stopped

4 ARA, fonds Société Générale de Belgique, Direction, Nokin Papers: memorandum of February 1944.

5 BNB, Archives, DC, 08.03.1944.

6 BNB, Archives, SD, 22bis, clearing, 8.11.12/11: réunion des banquiers fondateurs, 17.04.1944.

7 Klemm, German Economic Policies in Belgium from 1940 to 1944, pp. 243-335. Fortunately, the Military Government was supported in this by Röchling, who had been sent specially by Albert Speer to Belgium to push up industrial production there for Germany.

8 Nefors, Economische collaboratie in België, pp. 223-224. 
short, when he was arrested by the Gestapo on 7 August $1943^{9}$. Cracco had received a sum of money from his brother, who was active in the Resistance. Through his office at the Bank, he was supposed to hand this to two Resistance members, the money being to aid Allied pilots who had gone into hiding after being shot down over Belgium. Information about this had leaked out and, after being arrested, Cracco was summoned before a military tribunal of the Luftwaffe. The military prosecutor demanded the death penalty, the normal punishment for a deed of that kind ${ }^{10}$, but the tribunal, probably after a great deal of lobbying, and to everyone's relief, sentenced Cracco on 12 November 1943 to eight years' hard labour and a fine of 62,00o Belgian francs or a year's additional jail ${ }^{11}$.

The conviction was confirmed in December, after appeal. Cracco was provisionally confined in the central prison at Leuven and transferred to Germany on 1 April $1944^{12}$. In the whole affair, the Bankaufsichtamt had done what it could and on 30 June 1944 Goffin was able to announce that a fresh appeal for clemency had been granted and that the punishment had been commuted from hard labour to straightforward imprisonment at Wittlich in Germany ${ }^{13}$. Cracco was eventually released in 1945 by American forces.

Cracco's arrest not only raised emotions throughout the Bank, but also did nothing to simplify the distribution of tasks within the managements of the Bank and the Banque d'Emission. At the beginning of February 1943, an eye complaint had obliged Ingenbleek to take a long leave of absence ${ }^{14}$. His work had been taken over by Vandeputte who, upon Cracco's arrest, was asked to take over his commitments. Vandeputte accepted, but was at the same time relieved of his responsibility for 'current matters' ${ }^{15}$.

9 BNB, Archives, DC, 07.08.1943.

10 BNB, Archives, DC, 14.11.1943: report of Vandeputte on his meeting with the jurist F. Eickhoff, a barrister at the Court of Appeal in Brussels and Cracco's defence lawyer.

11 BNB, Archives, SD, Cracco Papers: letter of 24.01.1986 from Prack to Cracco; BNB, Archives, DC, 14.11.1943.

12 BNB, Archives, BR BEB, 05.04.1944.

13 BNB, Archives, DC, 30.06.1944.

14 BNB, Archives, SD, 12, notes confidentielles diverses, dossier 8.11/2: letter of 01.02.1943 from Ingenbleek to Goffin.

15 BNB, Archives, DC, 07.08.1943. 
Vandeputte now emerged as the strong man in the Bank and the Banque d'Emission. He had the organizational talent of a real manager and the statements, memoranda and reports of that time bear the unmistakable imprint of his new approach. He bombarded the Bankaufsichtamt with critical comments about inadmissible payment orders from German agencies active in Belgium ${ }^{16}$.

There was, lastly, also a change in the cooperation between the Bank and the Banque d'Emission. The catalyst for this was certainly the tragic death of Galopin on 28 February 1944, who was murdered on his doorstep by members of a commando of a pro-German organization (DeVlag). His death came as a heavy blow to many and not least to the Banque d'Emission, whose founder-bankers were suddenly deprived of their figure-head and moral safeguard. The Bank's supervisory council and board of scrutineers had also had great confidence in him, even though he was not a member of either body. After his murder, the mood of confidence ebbed away and the alarming question of whether the leaders of the two institutions had got things right began to undermine their cohesion. A further point was that the Bank now had to prepare for the uncertain future that awaited it after the liberation without a strong personality such as Galopin.

Now that the end of the war was in sight, criticism from London and Belgian Resistance circles became more insistent, prompting the managing directors of the Banque d'Emission to be concerned about their responsibility for the clearing system. They asked the board of directors to what degree they regarded themselves co-responsible for the orders, which were being executed on their advice. During a meeting of the board on 8 May 1944 A.-E. Janssen stated that, strictly speaking, it was exclusively Goffin and Vandeputte who were responsible for the management of the Banque d'Emission. At the institution's creation, the board of directors had been given no more than an 'advisory role ${ }^{3_{17}}$. However, if after the liberation, an investigation committee were to ask the managing directors to justify their decisions during the war, it would be unforgivable for the directors not to share responsability with

16 BNB, Archives, SD, 2, Malaise Papers, dossier 9.5.11/ s. f. 2: note de Mlle Malaise, 03.12.1945.

17 вNB, Archives, SD, 24, clearing, dossier 8.11.14/25: la mission et l'organisation de la BEB (note, 03.05.1944, réunion des banquiers fondateurs, 08.05.1944). 
the managing directors. The other members of the meeting agreed with this view. In passing, it should be noted that, at the time, A.-E. Janssen was the only one who had contact with the government in London and who enjoyed its confidence.

\section{THE BELGIAN ECONOMY AT THE END OF THE OCCUPATION}

The final years of the occupation saw total war expenditure rising to what was an enormous amount for the time. Of the combined expenditure of the State and the Banque d'Emission just 38.5 per cent went directly to Belgium; the remaining 61.5 per cent going to the occupier.

The Banque d'Emission received the greater part of its resources from the Bank, which was covered by a State guarantee for money due from the Banque d'Emission. For its part, the State was only able to finance its money requirements in part from tax receipts, which in 19431944 covered barely 29 per cent of expenditure. The rest was funded by advances from the Bank in the form of transfers in its current account and in banknotes ( 37 per cent of expenditure), and by long-, medium- and short-term loans (34 per cent of expenditure). By 31 August 1944, the total circulation of banknotes had increased by 233 per cent in comparison with the situation at 8 May 1940. Belgium, though, got off

Table 19.1: Total means of payment in circulation, 1940-1944 (in millions of Belgian francs)

\begin{tabular}{lrrrrrr}
\hline $\begin{array}{l}\text { Situation } \\
\text { at the } \\
\text { beginning of } \\
\text { the month }\end{array}$ & $\begin{array}{r}\text { Banknotes } \\
\text { (BNB) }\end{array}$ & $\begin{array}{r}\text { Notes and } \\
\text { fractional } \\
\text { currency } \\
\text { (Treasury) }\end{array}$ & $\begin{array}{r}\text { Credit } \\
\text { balances } \\
\text { in current } \\
\text { account (BNB) }\end{array}$ & $\begin{array}{r}\text { Credit balances in } \\
\text { current account } \\
\text { (Postal Cheque } \\
\text { Office) }\end{array}$ & $\begin{array}{r}\text { Credit balances in } \\
\text { current account } \\
\text { (private banks) }\end{array}$ & Total \\
\hline 01.01.40 & 28,292 & 1,563 & 907 & 4,319 & 11,645 & 46,726 \\
08.05.40 & 29,806 & 1,607 & 909 & 4,668 & 13,620 & 50,610 \\
01.01 .41 & 35,453 & 2,302 & 1,779 & 5,311 & 14,151 & 58,996 \\
01.01 .42 & 48,942 & 3,420 & 2,348 & 7,401 & 17,788 & 79,899 \\
01.01 .43 & 68,638 & 3,918 & 4,563 & 7,714 & 22,283 & 107,116 \\
01.01 .44 & 84,156 & 4,365 & 5,646 & 8,884 & 32,220 & $\mathbf{1 3 5 , 2 7 1}$ \\
01.10 .44 & 99,216 & 5,468 & 3,719 & 10,674 & 37,380 & $\mathbf{1 5 6 , 4 5 7}$ \\
\hline
\end{tabular}

Source: BNB, Archives, AV, report by the board of scrutineers for the 1940-1944 financial years, prepared on behalf of the supervisory council, 1945, p. 11. 
fairly lightly in this respect, in comparison to her neighbours: between 1 January 1938 and 31 May 1944, the circulation of banknotes rose by 346 per cent in Belgium, compared with 498 per cent in France, 389 per cent in the Netherlands and 618 per cent in Germany.

Account has of course to be taken of more than just the banknotes. There were also the notes of 50, 20 and 5 Belgian francs issued by the Treasury. Their circulation likewise increased substantially, though not greatly, in comparison to the circulation of the banknotes.

Besides the Ministry of Finance's payment of occupation costs, the major cause of the rise in money circulation was the Banque d'Emission's financing of the clearing system. During 1943 and 1944, occupation costs held steady at their level of 1.5 billion Belgian francs a month, whereas the Banque d'Emission's total credit balances at the Verrechnungskasse in Berlin went up appreciably, particularly the balances vis-à-vis Germany (approximately 90 per cent of the total). Three factors are of importance in the analysis of the figures: the difference between balances arising from transactions in respect of goods, services and capital; the difference between direct and indirect payments in the clearing system; and the difference between balances at the end of the year and at the end of each month.

The Belgian clearing credit balances developed differently, depending on whether they arose from the supply of goods, services or capital. During 1943 and 1944, there was a clear weakening in percentage terms in the rise of the credit balance for goods, the prime reason for this being increasing difficulties in the industrial sector: air raids had inflicted serious damage to a number of factories and to the transport infrastructure, and had hindered the supply of raw materials, which were in any case becoming scarcer as the war dragged on. A second reason for the weakening was the stricter control exercised by the Banque d'Emission on the transactions that qualified for payment within the clearing system. On the other hand, the credit balance for services showed a very marked increase, which was chiefly the consequence of the forced labour in Germany, France and the Netherlands. 
Table 19.2: Belgian clearing credit balance at the Verrechnungskasse in Berlin, 1940-1944 (total balances and - between brackets - the Belgo-German clearing credit balances) (in millions of Belgian francs)

\begin{tabular}{lrrrr}
\hline As at 31 December & Goods & Services & Capital & Total balance \\
\hline 31.12 .1940 & 384 & 221 & 248 & 853 \\
& $(390)$ & $(173)$ & $(241)$ & $(743)$ \\
31.12 .1941 & 4,913 & 2,125 & 776 & 7,514 \\
& $(4,128)$ & $(2,151)$ & $(749)$ & $(7,028)$ \\
31.12 .1942 & 16,116 & 6,978 & 943 & $\mathbf{2 4 , 0 3 7}$ \\
& $(14,485)$ & $(6,614)$ & $(1,124)$ & $(\mathbf{2 2}, 223)$ \\
31.12 .1943 & 32,239 & 15,007 & 713 & 47,959 \\
& $(29,273)$ & $(13,808)$ & $(987)$ & $(44,068)$ \\
30.09 .1944 & 41,774 & 20,069 & -51 & 61,792 \\
& $(38,906)$ & $(18,243)$ & $(277)$ & $(57,426)$ \\
\hline
\end{tabular}

Source: BNB, Archives, AV, report by the board of scrutineers for the 1940-1944 financial years, prepared on behalf of the supervisory council, 1945, p. 16.

Payments in the clearing system can also be broken down according to direct or indirect transactions. The first category concerned amounts that the Banque d'Emission paid out to the beneficiaries directly; the second also concerned amounts that the Banque d'Emission paid out to the beneficiaries, but indirectly via the Wehrmachtverrechnungskasse, the Reichskreditkasse or German banks established in Belgium. For direct payments, the Banque d'Emission received immediate and fairly precise details about the beneficiaries and the nature of the transactions concerned, but that was less the case for indirect payments, details of which were provided only a posteriori, about two months after payment, and were not always particularly accurate. Furthermore, a proportion of the payments was exempt from the requirement to provide details. It is true that the arrangement of 25 November-7 December 1942 considerably reduced that proportion, but in April 1944 Reeder had raised the exempted monthly amount from 50 million to 75 million Belgian francs. All the while, vigilance remained the watchword in monitoring these arrangements.

In addition, much work had been done by Cracco and Vandeputte to get indirect payments reduced as much as possible in favour of direct, and they had been fairly successful in this until the spring of 1944 . From April of that year, however, indirect payments began to rise again 
in relative term $\mathrm{s}^{18}$. The two managing directors were also able to gain an improvement in the quality of the information provided: Cracco via the introduction of Banque d'Emission certificates, Vandeputte, later, via the tightening of control. They also succeeded in excluding dubious transactions from the payment system and even in claiming back some payments made erroneously.

Table 19.3: Payments in the clearing system, 1942-1944 (in per cent)

\begin{tabular}{lcr}
\hline Period & Indirect transactions & Direct transactions \\
\hline Fourth quarter 1942 & 62 & 38 \\
First quarter 1943 & 57 & 43 \\
Second quarter 1943 & 48 & $\mathbf{5 2}$ \\
Third quarter 1943 & 48 & $\mathbf{5 2}$ \\
Fourth quarter 1943 & 45 & 55 \\
First quarter 1944 & 31 & $\mathbf{6 9}$ \\
\hline
\end{tabular}

Source: ARA, fonds SG, executive committee, Nokin Papers, BEB, file 16: observations relatives au rapport de la Commission d'Enquête (ВEB) pour la période 15.01.194331.08.1944, p. 15 .

The post-war Commission of Enquiry was to be very strong in its condemnation of the many payments for unspecified transactions, which it regarded as payments bearing the stamp of political and military cooperation ${ }^{19}$. Cracco and Vandeputte would protest vigorously against this view and produced calculations showing that payments for unspecified transactions accounted for barely 7 per cent (3.9 billion Belgian francs) of the total amounts paid out in 1943 and 1944 (about 35 billion and 20 billion Belgian francs respectively). Included in that 7 per cent, moreover, was expenditure for the Feldpost and the transfers of banknotes to neighbouring countries for, among other things, the remuneration of Belgian workers. According to Cracco and Vandeputte, these could not be considered as transactions of a political or military nature. In addition, the two men argued that this in no way proved that all the transactions in respect of the exempted payments were of

18 BNB, Archives, DC BEB, 04.07.1944, 24.07.1944 (report of a meeting at the Bankaufsichtamt)

19 BNB, Archives, SD, Malaise Papers, 'enquête BEB': report of the Commission of Enquiry (published text, 1946), Part 1, pp. 139-140. 
a prohibited political or military nature: they were convinced that the opposite was the case ${ }^{20}$.

To indicate the burden that the clearing system imposed on the Belgian economy during the occupation, it is better to look at the average monthly increase in the clearing balance in Belgium's favour, rather than each year's final balance. That increase remained fairly limited until August 1941, but from then on began to accelerate to reach an overwhelming maximum in the last quarter of 1942, when it averaged 2.2 billion Belgian francs a month. The average remained at this high level throughout 1943, but dipped thereafter.

Table 19.4: Average monthly increase in the clearing balance in Belgium's favour, 19401944 (in millions of Belgian francs)

\begin{tabular}{lr}
\hline Period & Average monthly increase \\
\hline 01.08.1940-31.12.1940 & $\mathbf{1 8 2}$ \\
01.01.1941-31.12.1941 & 577 \\
01.01.1942-31.12.1942 & $\mathbf{1 , 4 1 0}$ \\
$(01.10 .1942-31.12 .1942)$ & $(\mathbf{2 , 2 0 0 )}$ \\
01.01.1943-31.12.1943 & $\mathbf{2 , 0 0 3}$ \\
01.01.1944-31.08.1944 & $\mathbf{1 , 7 0 1}$ \\
\hline
\end{tabular}

Source: Freiburg im Breisgau, Military archives, RW 36/277: Hofrichter, Abschluszbericht der Militärverwaltung in Belgien und Nord-Frankreich, 1940-1944, p. 14; ARA, fonds SG, executive committee, Nokin Papers, BEB file 16: observations relatives au rapport de la Commission d'Enquête, p. 20.

\section{ANXIOUS YEARS FOR THE STAFF AND FOR THE BANK}

The enormous expansion in the money supply had a fatal effect on prices: not so much on official prices as these were fixed and rose only very moderately, but on 'black market' prices, which went up by unfettered leaps and bounds. The underlying cause was official rationing, which was so strict that people were obliged to turn to the black market for their food, if they could pay the excessive prices being demanded. The situation was compounded by a tireless competitor on that market, the

20 ARA, fonds Société Générale de Belgique, Direction, Nokin Papers, BEB, dossier 16: observations relatives au rapport de la Commission d'Enquête, observations de M. Cracco. 
German purchasing agencies. In August 1944, for example, the index figure for a package of essential consumer goods purchased partly at official prices and partly at black market prices reached a maximum of 939, compared to the reference index of 100 in April $1940^{21}$.

Like the majority of the population, the staff of the Bank and the Banque d'Emission suffered badly from the price increases, made all the worse by the absence of any substantial adjustment to wages and salaries. The managements of the two institutions attempted to counter this by granting loans and advances that, in principle, had to be repaid after the war. They also increased the budget for charitable activities, which was now directed specifically at those of their own staff in need, including pensioners; in addition, they accelerated promotions, and continued to offer benefits in kind. Overall, it was an impressive effort on the part of the two institutions, which, in the spring of 1943, were employing more than 1,700 people.

A particular concern for management towards the end of the occupation was the drafting of staff for forced labour in Germany. Because of their close contacts with the Military Government and with the Bankaufsichtamt, the two institutions were initially spared the drafts ordered by the ordinance of 6 October 1942. At the beginning of 1943, however, the recruiting office (Werbestelle) began to exert significantly greater pressure on companies, including banks. In April of that year, Goffin consequently submitted a request to the secretary-general of the Ministry of Finance for the staff to obtain the same sort of identity card issued to the staff of government departments, State companies and semi-public organizations, which served as proof of employment and the means of exemption. Goffin's request was granted and the staff continued to escape being impressed.

However, fresh difficulties arose with the ordinance of 28 June 1943, which laid down that institutions assimilated to government departments would no longer enjoy exemption ${ }^{22}$. In September, the Werbestelle decided to draft Bank staff. Vandeputte was asked to submit detailed lists of employees born in 1920 and 1921, of whom there were about fifty.

21 Janssens, De Belgische frank, p. 303.

22 вNB, Archives, Contentieux, Miomandre Papers, dossier a: note pour le comité de direction, 07.07.1943. 
A sharp discussion arose among the leaders of the Bank about whether the lists should be handed over. Goffin and Vandeputte were in favour, although only the lists of those who had already received notice of call-up. They argued that handing over the lists could enable them to engage the Werbestelle in a discussion to have the departure of a number of employees postponed indefinitely or even cancelled. Their view prevailed. In November 1943, the Bank was requested to indicate sixteen of the group of those called up, just half of whom would be drafted. The management refused to comply, insisting that it would not give active assistance in impressment. This led to the Werbestelle, after deliberation with Vandeputte, dividing the staff called up into three groups, which would depart on 15 January, 15 February and 30 March 1944 respectively ${ }^{23}$.

An ordinance issued on 7 January 1944 tightened the forced labour measures even further, with drafting now being extended to take in young men born in 1922, 1923 and 1924. Fifty-one employees of the Bank were cited and the problem of submitting lists once again came to the fore. This time, Vandeputte allowed those involved to decide for themselves. Twenty-six, including nine who had already been called up, agreed to have their names submitted; eighteen asked for their names not to be given and the rest could no longer be contacted ${ }^{24}$. Ultimately, twenty of the staff were drafted to work in Germany, the rest - the majority - opted to go into hiding ${ }^{25}$. The Bank continued to pay virtually the full amount of their wages and salaries to their families ${ }^{26}$.

The rounding-up of labour that began at the end of 1942 in the occupied territories served to strengthen opposition to the Germans. The Resistance now no longer limited itself chiefly to passing on secret information, concealing escaped air-crew, discreet sabotage through goslow campaigns, and anti-German propaganda, but gradually extended

\footnotetext{
23 BNB, Archives, DC, 27.12.1943, 25.01.1944.

24 BNB, Archives, DC, 21.03.1944, 24.03.1944, 05.04.1944.

25 BNB, Archives, DC BEB, 16.05.1944.

26 Vandeputte had likewise ensured that the Bank granted subsidies to the rectors of the free universities of Louvain and Brussels to help students called up for labour in Germany, but who had refused to go and had gone into hiding: BNB, Archives, SD, 3, Malaise Papers, dossier 9.5.15/ s. f. 1, 'correspondance Mlle Malaise, 1953-1955' (draft declaration from Malaise in support of Vandeputte, 26.01.1953).
} 
its activities to armed attacks and to larger-scale sabotage ${ }^{27}$, which, of course, required greater financial resources. The Belgian government in London had been systematically sending us dollars with its agents that were being parachuted into Belgium, but the difficulties created by the clandestine exchange of dollars had forced this form of financing to be abandoned ${ }^{28}$. This led Raymond Scheyven, head of the 'Socrates' Resistance cell, to issue 'Socrates' certificates, many of which he was able to place with financial institutions and big companies through the mediation of his uncle, A.-E. Janssen, and which brought in a total of 176 million Belgian francs between mid 1943 and August 1944. After the liberation, the certificates were redeemed by the Bank on behalf of the State ${ }^{29}$. Other Resistance groups, too, received financial help from banks, holding companies and large businesses, but this aid was not so formalized as the Socrates-certificate system ${ }^{30}$. The Bank took no part in that system, but later organized its own means of financing the Belgian Resistance.

Some Resistance groups resorted to violence. Even the Bank itself was an occasional victim of hold-ups, sometimes with the secret cooperation of local branch managers. The general climate of unrest and of expectations about an imminent invasion prompted the Bank to take special precautionary measures. On 29 June 1943, for example, the Bank circulated instructions to all branch managers on how to safeguard their cash reserves in case of military operations or outbreaks

27 According to what Struye noted, it was only 1942 that the Belgian Resistance began to organize itself. Organized resistance expanded considerably from 1943 on: ARA, fonds Société Générale de Belgique, Défense, dossier 22: Struye, L’opinion publique en Belgique après vingt mois d'occupation (25.02.1942); Struye, L'opinion publique en Belgique après deux ans et demi d'occupation (31.12.1942).

28 ARA, Administrative services of the Prime Minister, dossier 74: letter of 21.10.1943 from de Staercke (London) to Gutt (London); letter of 26.10.1943 from Gutt (London) to de Staercke (London).

29 Bernard Ducarme, Le financement de la résistance armée en Belgique, 1940-1944 (CRISP, cahiers 476-477), 1970, $62 \mathrm{p}$.

30 At the beginning of June 1944, for example, the Bank's agent at Liège, on his own responsibility, handed over 4 million Belgian francs to representatives of the Secret Army (Het Geheime Leger): BNB, Archives, DC, 07.12.1944. In respect of aid to other Resistance groups, see: Fernand Strubbe, Geheime oorlog 40/45. De Inlichtings- en Actiediensten in België, Tielt, 1993. 
of disorder in their area ${ }^{31}$. The reason for the June instructions was to prepare, in case of an invasion, for the possibility - taken very seriously at the time - of the German forces withdrawing behind a defensive line along the river Meuse. Exactly what measures were to be taken was the subject of a sharp dispute between the Bank, the Ministry of Finance and the private bankers ${ }^{32}$. A front line along the river would serve to cut off the southern districts from the rest of the country and consequently threaten both the payment of the wages and salaries of public sector employees and the circulation of money. In the opinion of Plisnier and the private bankers, that particular crisis could be averted by giving the Bank's branches extra cash reserves, a move that would have the additional advantage of preventing a repetition of the chaotic situation of May 1940.

The Bank's directors were unimpressed by the suggestion and pointed out that, in the present state of unrest in the south of the country, additional cash reserves would only increase the risk of hold-ups and expose the staff to even greater threat. Moreover, there was also the possibility that German troops would simply confiscate the money. Lastly, as Goffin indicated, there was the problem of transport and insurance. The board argued further that the Bank had just four lorries and that the insurance companies had required a considerable reduction in the amount of money carried by each of them. As Plisnier was not prepared to provide a State guarantee to cover the risks of higher cash reserves and the attendant transport costs, the Bank could not disregard the conditions laid down by those companies. If the private bankers wished to have more cash resources at their disposition in Wallonia, the directors argued, they would have to put in more themselves.

The private bankers and the Secretary-general were not particularly happy about the Bank's standpoint and, at the beginning of 1944, resumed their offensive, supported this time by the Bankaufsichtamt ${ }^{33}$.

31 BNB, Archives, SD, 2, Malaise Papers, dossier 9.5.6: annexe à la circulaire du 29 juin 1943 (instructions aux agents en vue d'assurer la sécurité de leur encaisse en cas de troubles ou d'événements militaires).

32 BNB, Archives, SD, 14, Reichskreditkassenscheine, dossier 8.11/4: constitution d'encaisses spéciales en province, 20.09.1943; BNB, Archives, DC, 06.10.1943; BNB, Archives, $S D$, dossier 8.11/21: encaisses dans les agences (réunion des banquiers, 11.10.1943).

33 BNB, Archives, DC BEB, 07.01.1944. 
In April, Plisnier stated that, as State exchequer, the Bank was obliged to maintain substantial reserves in the provinces as well, in order to ensure the prompt payment of public sector wages and salaries, and to cover other current expenditure. Furthermore, he emphasized that his request for the cash reserves at the branches to be increased was to be considered as an instruction, which in May 1944 the board decided to endorse ${ }^{34}$.

\section{CRACCO'S EMISSIEBANK CERTIFICATES}

On 3 December 1942, shortly after the resignation of Berger and Van Nieuwenhuyse, Cracco submitted a memorandum to the Bank's board of directors, in which he set out a plan to subject clearing-system payments concerning exports of goods and services to stricter control. Payments by the Banque d'Emission would no longer be totally in cash; rather, 30 per cent would be in registered, non-negotiable certificates from the Banque d'Emission, redeemable once hostilities ceased. Besides serving to put a brake on the growth of the money supply and to counter price inflation, this procedure would provide a better insight into the indirect transactions being routed through the clearing system $^{35}$. This would at last be a way of drastically curbing payments for transactions on the black market and transactions of a political or military character.

Galopin insisted that Cracco should make contact with the leaders of the industrial groups via the Ministry of Economic Affairs, as he expected opposition from that quarter. A meeting was arranged and took place on 7 January 1943 at the ministry. As expected, Cracco's proposal came in for heavy criticism, the industrialists regarding the nonnegotiability of the certificates as an unacceptable obstacle, but in the end they gave in.

There was also opposition on the German side. Hofrichter proposed that, by way of experiment, the arrangement be applied initially solely to payments for direct clearing transactions and that there be an as-

34 BNB, Archives, DC, 04.05.1944, 10.05.1944.

35 The amount, corresponding to a payment with certificates, would be entered in the Banque d'Emission's books on an individual account of the beneficiary. 
sessment after two or three months' experience to determine whether it could also be extended to payments for indirect clearing transactions. It was only with great difficulty, and after major concessions, that Cracco was able to persuade Hofrichter to withdraw his counter-proposal ${ }^{36}$ and to issue in February 1943 an ordinance that adopted Cracco's original suggestions. However, the arrangement would cover only payment orders for the purchase of goods, not those for services. In addition, all payment orders for sums below 10,000 Reichsmarks (125,000 Belgian francs) would be automatically exempt and the Bankaufsichtamt would reserve the right to grant an exemption for higher amounts in exceptional cases. The Banque d'Emission would be similarly empowered and would also be able to grant advance redemption of the certificates to companies with liquidity problems ${ }^{37}$.

The system ran into difficulties right from the outset. Arguing that their profit margins were minimal, their activities loss-making or their liquidity position tight, the coal mines and the coke works immediately pushed for exemption, their example being followed by certain textile and steel firms ${ }^{38}$. The Banque d'Emission adopted a flexible stance and granted a number of exemptions, but all this led to a storm of criticism at the meeting of the board of directors in early April 1943. Cracco defended himself by pointing out that no less than 789 certificates had been issued for a total amount of 136.5 million Belgian francs, and these had been in favour of 455 enterprises. However, he had to admit that only 13.5 per cent of payments falling under the arrangement had been financed with certificates during that period, emphasizing that the Wehrmachtverrechnungskasse and the Reichskreditkasse were barely applying the arrangement at all ${ }^{39}$.

As April and May passed, criticism mounted. From Berlin came rumblings of displeasure about the decline in Belgian deliveries to

36 BNB, Archives, $S D$, 2obis, clearing, dossier 8.11.10/30: note relative aux récentes négociations au sujet des modalités de liquidation des ordres de paiement en clearing, 15.01.1943.

37 The Bank would cede Treasury certificates from its portfolio to the Banque d'Emission, as surety for and in proportion to Banque d'Emission certificates issued. The Bank would take back the Treasury certificates, as soon as the certificates had been paid out in cash: BNB, Archives, $D C B E B$, 01.07.1943.

38 BNB, Archives, DC, 05.03.1943.

39 BNB, Archives, $B R B E B$, 07.04.1943. 
Germany and the rise in Belgian export prices. Criticism was also rife within Belgium. Businessmen had no faith in the certificates and complained that exemptions were being granted arbitrarily, leading to widespread discrimination. As a result, the real dupes of the system were those who tried to run their businesses honestly ${ }^{40}$.

Cracco and Hofrichter began to negotiate possible amendments to the system. Hofrichter sought a gradual scaling-down, beginning with a reduction from 30 to 20 per cent of the payment percentage to be settled with certificates. Cracco demanded that the threshold for automatic exemption be lowered from 10,000 to 6,000 Reichsmarks and that there be stricter action regarding the German purchasing agencies. In the end, Hofrichter got his way in respect of the percentage, while Cracco had to be content with a promise that the agencies would be urged to apply the arrangement more effectively. The new arrangement took effect on 1 June $1943^{41}$.

The lowering of the percentage did nothing to quieten criticism on either the Belgian or the German side. In the opinion of the founderbankers the measure had totally failed to achieve its aims: there had been barely any reduction in the circulation of money and only a marginal improvement, at best, in the control over clearing transactions. Moreover, widespread irritation had been caused by the arbitrary handling of dossiers ${ }^{42}$. On the German side, the non-negotiability of the certificates came under heavy fire. Hofrichter and Cracco therefore sat down again to see how the system could be improved. The discussion with the bankers was anything but smooth ${ }^{43}$. They were not keen to take up the certificates, as they had no confidence in them. Indeed, they were prepared to grant advances with certificates as collateral only to companies that could present Treasury certificates from the Banque

40 BNB, Archives, $D C$ BEB, 07.05.1943, 22.05.1943; BNB, Archives, $S D$, 33, divers, dossier 8.11.27/ 1: divers (certificats de la BEB, note, 19.04.1943).

41 BNB, Archives, $S D, 21$, clearing, dossier 8.11.11/33: abaissement de la quotité de 30 à 20 procent (note du 15 mai 1943); BNB, Archives, $D C B E B, 01.06 .1943,02.06 .1943$; Belgian Official Gazette, 04-05.06.1943.

42 BNB, Archives, DC BEB, 16.06.1943, 21.06.1943, 24.06.1943.

43 BNB, Archives, $S D$, 21bis, clearing, dossier 8.11.11/35: réunion des fondateurs, 28.06.1943, 05.07.1943, 19.07.1943, 21.07.1943; BNB, Archives, DC BEB, 01.07.1943, 13.07.1943, 19.07.1943, 22.07.1943. 
d'Emission's portfolio as additional security. Cracco and Vandeputte pointed out the impossibility of this: the Bank's cession of Treasury certificates to the Banque d'Emission was a transaction for the public benefit and could not be changed. The bankers dug their heels in and demanded that they be allowed to discount bills payable at the Bank for the amount of the advances granted. They won and the certificates were made negotiable at the banks under these conditions ${ }^{44}$.

Meanwhile, repeated complaints from Berlin about the dwindling of Belgian deliveries to Germany had again antagonized the Bankaufsichtamt against the certificates ${ }^{45}$. German pressure became all the greater after Cracco's arrest on 7 August 1943 and Vandeputte responded by making a further reduction to 10 per cent in the payment percentage required to be settled with Banque d'Emission certificates ${ }^{46}$.

44 BNB, Archives, $S D$, 21bis, clearing, dossier, 8.11.11/36: réunion des banquiers fondateurs, 05.08.1943.

45 BNB, Archives, SD, 21bis, clearing, dossier 8.11.11/35: compte rendu de la réunion au commissariat, 20.07.1943; BNB, Archives, $S D$, 26, wVK, dossier 8.11.16/10: communications des membres du comité, 29.07.1943.

46 BNB, Archives, $D C$ BEB, 08.11.1943. 



\section{The Liberation in Sight}

\section{THE FINAL SKIRMISHES WITH THE BANKAUFSICHTAMT}

The fact that the relationship between the Bank and the Banque d'Emission, on the one hand, and the Bankaufsichtamt, on the other, remained tense, was due not so much to the occupying authority, which was inclined to adopt a more flexible line, but to the chief person on the Belgian side, namely the director Vandeputte. He was a stickler for the rules, never failed to spot an irregularity and subjected every dossier to the same perfectionist eye.

A major point of resentment continued to be the occupier's practice of requisitioning ${ }^{1}$. This had already been widespread in the early period of the occupation, but had expanded over the years to cover a broader range of goods. In January 1943, the Germans even turned to taking the bells from church towers as raw materials in their armaments factories. The method of recompense also differed widely. At first, recompense was made through the Ministry of Finance, partly in cash and partly in Treasury certificates, and was charged to occupation costs. Before long, however, it was being made via the clearing system. For the sake of appearances, however, the German authorities employed an increasing number of Belgian middlemen, so that the requisitioning could pass as a normal commercial contract ${ }^{2}$.

When the occupier began to use such contracts in April 1943 to buy up machinery and the entire plant of factories, and even to dismantle factories that were no longer operating, because their owners refused

1 BNB, Archives, $S D, 23$, clearing, dossier 8.11.13/16: paiement des réquisitions de l'occupant.

2 Vandeputte was very suspicious of this: BNB, Archives, $D C B E B, 16.12 .1943$; BNB, Archives, $S D$, 23, clearing, dossier 8.11.13/16: réquisitions, divers, textiles, 03.03.1944. 
to collaborate, there was reaction from the Belgian authorities ${ }^{3}$. They felt that the occupier was going too far and jeopardising the industrial infrastructure of the country. The managing directors of the Banque d'Emission therefore decided to refuse the execution of payment orders for such veiled requisitioning.

A second point of disagreement was the requisitioning of gold and foreign currency. At the end of 1942, the Germans began a fresh ploy. As explained above, the gold deposited by the Bank with the Banque de France had been transferred in 1941-1942 by the latter into the 'safekeeping' of the Reichsbank in Berlin. On 9 October 1942, however, without consultation or warning, the Reichsbank informed Governor Goffin via a letter from the Bankaufsichtamt in Brussels that the German government had requisitioned that gold and assessed remuneration at 2,784 Reichsmarks per kilogram of fine gold. The letter went on to ask how the Bank would like to receive that amount. Goffin answered that the Bank was not involved and did not want to be involved. As a result, the amount of $552,378,318.20$ Reichsmarks was lodged with the court in Berlin ${ }^{4}$.

In a further step, the Germans demanded that sterling held by private individuals and declared in 1940, but not commandeered, had now to be surrendered'. Writing on 23 February 1943 to the managing directors of the Banque d'Emission, von Becker ordered that the pounds were to be offered to the Banque d'Emission, purchased by it and channelled to the Reichsbank ${ }^{6}$. The handling of the dossiers went so slowly that the Bankaufsichtamt insisted on dealing with them more quickly. The managing directors refused, whereupon, on 30 June 1943, the Military Government issued an eleventh implementing ordinance, which transferred the handling from the Banque d'Emission to the Reichskreditkas$s e^{7}$. Even then the operation was not very successful. The total amount

$3 \mathrm{BZ}$, fonds $О B$, dossier 26: letter of 15.04.1943 from Goffin to Leemans; $\mathrm{BZ}$, fonds $О В$, dossier 27: letter of 23.10.1943 from Leemans to von Falkenhausen.

4 Cornu, L'or monétaire au vingtième siècle, pp. 182-184.

5 The measure applied not only to the pound sterling, but also to the South African, the Palestinian and the Egyptian pounds.

6 BNB, Archives, SD, enquête BEB, dossier 1-2, d: letter of 27.03.1943 from the Banque d'Emission to customers and banks.

7 Verordnungsblatt (German Official Gazette), 13.07.1943. 
of sterling involved was $£ 180,000$. About $£ 60$, o0o which belonged to Jews or to persons from territories hostile to the Germans had already been confiscated. No more than $£ 46$, ooo was ultimately sent to Berlin.

On 29 July 1943, the Military Government issued a twelfth implementing ordinance: gold, foreign currency and securities denominated in foreign currency that belonged to individuals or legal persons established in the Belgian Congo were required to be declared, offered and eventually surrendered to the Banque d'Emission ${ }^{8}$. The managing directors refused to co-operate. An additional order was received on 20 September to purchase all American and Swiss banknotes that had been declared in consequence of the twelfth ordinances. In a circular sent on 15 October 1943 to all foreign exchange banks holding such banknotes, the Banque d'Emission expressly emphasized that this was compulsory. The banks allowed the process of declaration to drag on, under the pretext of being unable to contact the depositors. The Bankaufsichtamt returned to the matter in August 1944, though by now the liberation was very much in the offing ${ }^{10}$.

A third major point of friction between the Banque d'Emission and the Bankaufsichtamt concerned the establishment of branches of German companies or new German companies in Belgium and the increase in the capital of German banks established in Belgium. All these developments were the direct consequence of Albert Speer taking charge of the German war economy. Speer was an architect, a confidant of Hitler and a highly skilled organizer. In answer to the devastating air attacks by the Allies on industrial areas in Germany, he had convinced the German authorities to transfer a proportion of production to the occupied territories ${ }^{11}$, arguing that greater dispersal would make mass destruction more difficult. Furthermore, doubtless the Allies would be reluctant to bomb a friendly nation. The German banks established in

8 The ordinance appeared in the Verordnungsblatt (German Official Gazette) of 09.08.1943.

9 ARA, fonds Société Générale de Belgique, Direction, BEB, dossier 22: note 'réquisition d'or et de devises', annex 3.

10 BNB, Archives, $S D$, clearing, dossier $8.11 .13 / 14$ bis: entretien au commissariat allemand, o8.08.1944.

11 Klemm, German Economic Policies in Belgium from 1940 to 1944, pp. 271-272, 283313 . 
Belgium had responded to this by increasing their capital in order to finance the extra activity ${ }^{12}$.

Setting up or expanding firms demanded the investment of capital and more operating funds in Belgium, the attendant transfers from Germany being arranged through the clearing system. In Vandeputte's view, the establishment of German subsidiaries and companies in Belgium meant a change in the industrial structure of the country, which was a matter of such public importance that it ought to involve the Ministries of Finance and Economic Affairs ${ }^{13}$. He was backed in this by the founder-bankers, who were naturally none too keen on German companies being set up in Belgium, although they admitted that this had served to cut the deportation of workers to Germany.

It so happened that relations between the Banque d'Emission and Secretary-general Plisnier were still tense at this time. Indeed, Plisnier wanted nothing more to do with Banque d'Emission affairs and was even refusing to answer letters ${ }^{14}$. He had the impression that the institution was attempting increasingly to shift its responsibility onto him as Secretary-general of the Ministry of Finance. Goffin went to see Plisnier, in order to smooth ruffled feathers: Plisnier assured him that he harboured no hostility towards or mistrust of the Banque d'Emission, he just did not want to be involved in its activities and decisions ${ }^{15}$. In a later discussion with Vandeputte, however, Plisnier agreed that applications for capital transfers should be examined jointly, case by case, and payment of them refused if the planned production in Belgium had a military character ${ }^{16}$.

A further point of resentment by the Banque d'Emission was the activity of the Wehrmachtverrechnungskasse, whose importance in clearing operations had rapidly increased after the arrangement of 7 December 1942. In order to facilitate its payments to the German agencies, it

12 BNB, Archives, $D C B E B, 14.12 .1943$; BNB, Archives, $S D$, 22bis, clearing, dossier 8.11.12/7: réunion du comité du clearing, 17.12.1943.

13 вNB, Archives, $S D$, 22bis, clearing, dossier 8.11.12/7.

14 BNB, Archives, DC BEB, 24.01.1944.

15 BNB, Archives, $S D$, 22bis, clearing, dossier 8.11.13/13: rapports avec le secrétaire général du Ministère des Finances, meeting between Goffin and Plisnier, 10.02.1944.

16 BNB, Archives, SD, 24, clearing, dossier 8.11.14/19: Betriebsmittel, meeting at the Bankaufsichtamt, 10.02.1944; meeting between Vandeputte and Plisnier, 03.03.1944. 
regularly requested the Banque d'Emission to transfer substantial sums to its account: at 31 October 1943, the overall provision for this totalled the considerable amount of 1,355 billion Belgian francs. As pointed out by Ingenbleek, the provisions boiled down to giving financial support to the enemy, which was punishable under article 115 of the Penal Code $^{17}$. In a memorandum of 15-17 November 1943 to the Bankaufsichtamt, the Banque d'Emission protested vehemently against such practices ${ }^{18}$. Reeder endorsed the protest and promised that a start would be made in November to scale down the provisions. He kept his word and by 31 December that year, the overall provision held by the Wehrmachtverrechnungskasse had shrunk to 831 million Belgian francs; by 31 May 1944, it was down to 216 million $^{19}$.

A fresh point of discussion arose when, in April 1944, indirect clearing operation $\mathrm{s}^{20}$ came to account again for two thirds of payments for all clearing operations. All that could be purchased in Belgium was now being bought up by the German agencies - even furniture, glassware, kitchenware and the like - to replace household goods destroyed in Germany by the Allied bombings. Belgium was also being used as a route to sell on large quantities of French wine and liqueurs to Germa$n^{21}$. In July-August, as the liberation became imminent, the managing directors resolved to postpone payments as much as possible and even to suspend them entirely.

\section{THE EXPORT OF BANKNOTES TO FRANCE}

As already indicated, the German army's purchase of Belgian goods destined for use in France had been the subject of strong protest by

17 BNB, Archives, $D C$ BEB, 16.11.1943.

18 вNB, Archives, Prack Papers, dossier 2: Jost, Abschluszbericht der Militärverwaltung des Reichskommissars für Belgien und Nord-Frankreich, 01.01.194430.08.1944, p. 35-36.

19 BNB, Archives, $S D$, 26, clearing, dossier 8.11.16/1: WVK (note, 01.07.1944).

20 BNB, Archives, $S D$, 23, clearing, dossier 8.11.12/11ter: réunion des banquiers fondateurs, 26.06.1944-09.08.1944.

21 BNB, Archives, SD, 26, clearing, dossier 8.11.16/ s. f. 2, 5, 7, 11: WVK (vins, note 10.08.1944). 
the Banque d'Emission in the course of 1942. The managing directors refused to agree that no goods could be obtained in return from France and that everything was to be settled through the Franco-Belgian clearing system. During negotiations about the problem in Paris in January $1943^{22}$, the Belgian delegation revived an earlier proposal for the credit balance arising from the sale of goods destined for France to be entered on a special account at the Banque de France that Belgium could use for the import of goods from France. Again, however, the proposal was firmly rejected.

A second point in the negotiations concerned the question of banknotes. The Banque de France requested the Banque d'Emission to cede its portfolio of French banknotes to France, declaring that it would have the equivalent value credited to the Belgian clearing balance in Berlin. The Banque d'Emission refused and the Banque de France then asked to be supplied with 100 million Belgian francs in banknotes, for which it would similarly repay Belgium through the clearing system. The banknotes were required to pay the wages of Belgian frontier workers in France and, increasingly, of Belgian workers in the French interior. Until then, the Banque de France had financed those payments with the Belgian banknotes that had been in its portfolio since the summer of 1940, when Belgian refugees were exchanging their money for French francs ${ }^{23}$. That stock was now all but exhausted and a fresh supply had to be obtained.

For various reasons, the Belgians were not at all happy with the request. In the first place, they were well aware of the fraud that was being practised in France with Belgian money: the exchange rate on the black market tended to be around 40 Belgian francs to 100 French, whereas the official rate was set at 62.5 Belgian francs to 100 French. Belgian workers, having their wages paid in Belgian money, exchanged that money into French on the black market in France and then had that French money exchanged for Belgian francs at par at Belgian banks ${ }^{24}$. A second cause for complaint was the manner in which the Banque de France made remuneration for the banknotes it purchased: the amount

22 BNB, Archives, RR, 27.01.1943.

23 BNB, Archives, SD, 24, clearing, dossier 8.11.14/31: note concernant la remise des francs français à la Banque de France, July 1943.

24 BNB, Archives, DC BEB, 06.05.1943. 
was registered as a Belgian credit item on the Belgian clearing account in Berlin. Ultimately, the Belgians gave in, agreeing to dispatch 100 million Belgian francs to the Banque de France and have the amount entered as a credit on the Belgian clearing account in Berlin. As a concession to the Belgians the French promised to institute stricter controls on the payment of the wages 25 .

A further round of negotiations took place in Paris on 9 and 10 September 1943, firstly to look at the question of the repayment of the Belgian loans of $1934^{26}$. Vandeputte, who had meanwhile replaced Cracco, attempted to have the 800 million French francs now held in banknotes by the Banque d'Emission applied to the repayment of those loans. The Banque de France refused, arguing that the banknotes had been brought into Belgium partly in 1940 and partly more recently fraudulently - for speculative purposes and therefore did not qualify for compensation.

The Belgian negotiators gained a point over wage payments; they would be organized more effectively through the introduction of a standardized pay slip. It was in respect of this concession that the Belgians finally accepted a French proposal for the Banque d'Emission to send 50 million Belgian francs in banknotes each month to the Banque de France to cover the payment of the wages of Belgians working in France. The Belgians also agreed that each monthly amount would be entered as a credit on the Belgian clearing account in Berlin.

The new arrangement came into effect on 1 December 1943 and the first monthly transfer of the 50 million francs took place on 4 February $1944^{27}$. Vandeputte nevertheless had difficulties with the arrangement. As soon as the landings had taken place in Normandy, he informed the Banque de France that the managing directors of the Banque d'Emission had resolved to halt the dispatches of Belgian banknotes with effect from 1 July $^{28}$. The Banque de France reacted sharply, but the breakthrough of the Allied troops in France soon served to break contacts between Paris and Brussels ${ }^{29}$.

\footnotetext{
25 BNB, Archives, RR, 27.01.1943.

26 BNB, Archives, BR BEB, 15.09.1943.

27 BNB, Archives, $D C B E B$, 04.02.1944.

28 BNB, Archives, $D C$ BEB, 14.06.1944.

29 BNB, Archives, $D C B E B$, 02.08.1944.
} 


\section{MONETARY DIFFERENCES AND DISPUTES WITH THE NETHERLANDS AND GERMANY}

In the autumn of 1943, the German General Staff was expecting an imminent Allied landing, possibly in the delta area of the rivers Scheldt, Meuse and Rhine, and had consequently sent a force of troops to Zeeland, besides having the Todt Organization build additional defence works in the south of the Netherlands. The purchase of provisions for those troops and of building materials was organized from Belgium and the Berlin government intended to make a similar financing arrangement to that for the purchase of goods in Belgium destined for France. To this end, Hofrichter instructed the Banque d'Emission on 17 September 1943 that, with effect from November, it was to finance military purchases in Belgium destined for the Netherlands. In return, a corresponding credit would be entered on the Belgian clearing account in Berlin $^{30}$. The managing directors could not agree to this procedure - it was not for Belgium to finance German military expenditure in the Netherlands $\mathrm{s}^{31}$ - and on 2 October the Bank informed the Military Government that it refused to execute the instruction of 17 September.

A second problem soon became acute. From the end of 1943, the Nederlandsche Bank had been urging the Banque d'Emission to transfer to Amsterdam the guilders it had received for exchange from Belgian workers in the Netherlands. In return, a corresponding credit would be entered on the Belgian clearing account at the Verrechnungskasse in Berlin ${ }^{32}$. The Banque d'Emission had always refused to countenance this, but the Nederlandsche bank continued to press the case, even to the point of Dutch employers being forbidden, to pay Belgian workers (mainly frontier workers) in guilders with effect from 1 July 1944, with the result that Belgian labour in the Netherlands was blocked. On 11 August 1944 the President of the Nederlandsche Bank, Rost van Tonningen, came in person to Brussels to push through the Dutch request with German help. In the end, the managing directors of the Banque

30 BNB, Archives, $S D$, 22, clearing, dossier 8.11.12/1: virements des RKK Hollande et Belgique, letter of 17.09.1943 from Hofrichter to Goffin.

31 BNB, Archives, DC BEB, 27.09.1943.

32 BNB, Archives, SD, 22, clearing, 8.11.12/1: virements des RKK Hollande et Belgique (meeting between Vandeputte and Hofrichter, 29.09.1943). 
d'Emission, being aware of the social implications for Belgian workers, gave in, accepting the procedure for a period of three months.

The Banque d'Emission's major dispute with the German Military Government in Brussels had also to do with payments for Belgian labour. The Belgians who left voluntarily during the early years of the occupation to work in Germany had never had any difficulty in converting their savings from Reichsmarks into Belgian francs in Germany, but this situation had been changed by the ordinance of 6 October 1942 on forced labour. The number of Belgian workers employed in Germany rose considerably. By the beginning of 1943 it was already approximately $300,000^{33}$; and by 1944 , it was even being put at between 425,000 and $450,0^{34}$. The dispatch of Belgian banknotes by the Reichskreditkasse from Brussels to Berlin now assumed unforeseen proportions, the average amount transferred each month between the end of 1942 and the spring of 1943 rising from 115 million to 300 million Belgian francs ${ }^{35}$.

However, suspicions were aroused at the Banque d'Emission that not all the banknotes were reaching the Belgian workers. This was conceded by the Military Government and the result was a circular letter of 26 May 1943 laying down that, with effect from 1 July 1943, Belgian workers in Germany were no longer permitted to exchange money in Germany when they took their holiday. All that they could do was to purchase Reisegutscheine issued by the Deutsche Bank, up to a maximum value of 300 Reichsmarks, which could be exchanged for Belgian francs in Belgium at all post offices and the local branches of the Reichskreditkasse ${ }^{36}$.

The new system resulted in a substantial reduction in the dispatches of Belgian banknotes to Germany, from a maximum of 300 million Belgian francs' worth a month in the spring of 1943 to between 100 and 125 million francs' worth by the end of the year ${ }^{37}$. But the system did not halt the consignments. The Bankaufsichtamt was then asked to explain

33 BNB, Archives, $S D$, 21, clearing, dossier 8.11.11/32: réunion des banquiers fondateurs, 01.04.1943.

34 BNB, Archives, $S D, 25$, travail à l'étranger, dossier 8.11.15/2: note sur les travailleurs à l'étranger, 31.05.1944; BNB, Archives, $B R B E B$, 07.06.1944.

35 BNB, Archives, $B R B E B, 16.02 .1944$.

36 BNB, Archives, $B R B E B$, 02.06.1943; BNB, Archives, $S D$, 25, travail à l'étranger, dossier 8.11.15/2: note sur les travailleurs belges à l'étranger, 31.05.1944.

37 BNB, Archives, $B R B E B, 16.02 .1944$. 
the purpose of the still considerable quantity of Belgian banknotes being sent to Germany by the Reichskreditkasse ${ }^{38}$. Hofrichter answered that, because of the air attacks and the resulting chaos in many German towns, workers returning on holiday to Belgium were finding it impossible to purchase Reisegutscheine and thus were attempting to exchange their German savings into Belgian money locally. Secondly, the wages of Belgian frontier workers were still being paid in Belgian francs ${ }^{39}$. Vandeputte was not satisfied with the explanation and Hofrichter ultimately had to admit that the banknotes were also being used to provide German troops in transit through Belgium with Belgian money ${ }^{40}$.

The Bankaufsichtamt then suggested that dispatches of banknotes to Germany be limited to a fixed amount of 50 million Belgian francs a month. The Banque d'Emission opposed this, being against the idea of a fixed payment. However, the Berlin government insisted, but qualified this by promising that the money would henceforth no longer be used to finance German troops in transit ${ }^{41}$.

A compromise was reached in February 1944, whereby the Banque d'Emission would continue to send 50 million Belgian francs' worth of banknotes each month to the Reichsbank, but just for a period of three months. After that, the matter would be reviewed. At that moment, the Bankaufsichtamt declared that the amount required had stabilized at around 40 million Belgian francs a month and that the money was being used chiefly to pay the frontier workers. The Banque d'Emission ultimately agreed to pay that amount ${ }^{42}$.

38 BNB, Archives, $S D$, 23, clearing, dossier 8.11.13/12bis: envoi de billets belges en Allemagne (letter of 17.08.1943 from Goffin to the Bankaufsichtamt); BNB, Archives, $B R$ $B E B, 20.10 .1943$ : BNB, Archives, $D C B E B, 25.11 .1943$.

39 BNB, Archives, $D C B E B, 14.12 .1943$.

40 BNB, Archives, RR, 29.12.1943 (letter of 20.12.1943 from the Bankaufsichtamt to Goffin).

41 BNB, Archives, $S D$, 23, clearing, dossier 8.11.13/12bis: envoi des billets belges en Allemagne (report of the meeting at the Bankaufsichtamt on 10.02.1944).

42 BNB, Archives, $S D$, 23, clearing, dossier 8.11.13/12bis: envoi des billets belges en Allemagne (RR, 10.05.1944, 31.05.1944, 07.06.1944). 
At quite an early stage during the occupation, the Bank turned its attention to the monetary and financial reform necessary to restore the internal and external stability of the pre-war years. The death of Georges Janssen brought this to a temporary halt, but a study group was set up in the course of 1942 by Dupriez, Cracco, Kauch and Vincent, another employee of the Bank, to examine post-war problems of exchange control. A much broader investigation got under way at the Bank at the beginning of 1943, to examine the entire question of post-war monetary recovery and the reform of public finances. For the sake of security, the Bank confined its research to a small study group, headed by the government commissioner Smeers. It met each Tuesday afternoon at the Bank, which is why it came to be called the Comité $d u$ Mardi ${ }^{43}$.

Within the study group, there was total agreement about a number of important general principles. First of all, the reform had not only to be pushed through rapidly, but also be exhaustive and fundamental. For this to be achieved, several measures would have to be taken immediately after the liberation. In addition, new banknotes would have to be issued, coupled with tax measures, to end the war-time inflation. Everyone was also agreed on a tax on war profits, the yardstick for which would be the growth in assets since 10 May 1940. However, because the proceeds from such a tax would be insufficient to compensate for the monetary dislocation during the war, supplementary tax measures were also necessary. Lastly, it was clear to everyone that exchange controls had to be renewed ${ }^{44}$.

Opinions differed on the question of the supplementary tax measures. Dupriez proposed that there should be just one supplementary measure, over and above the special tax on war profits, namely an immediate monetary tax to eliminate war-time inflation and reform the public finances ${ }^{45}$. The introduction of a new currency unit (the guilder

43 F. Cracco, 'Rond de monetaire hervorming van 1944', in: Tijdschrift van het personeel van de NBB, July-August 1977, p. 13.

44 BNB, Archives, SD, 48, dossier 8.13/10: rapports relatifs aux travaux de la commission d'études financières de Bruxelles (memorandum of 20.01.1944).

45 BNB, Archives, SD, 48, dossier 8.13/10: rapports relatifs aux travaux de la commission d'études financières de Bruxelles (memorandum from Dupriez, undated). 
in place of the franc) and the attendant issue of new banknotes and coins would provide the opportunity to levy a general monetary tax. All circulating banknotes and coins, all current and assimilated accounts at banks and the Postal Cheque Office would be converted at a rate of 50 per cent of their value into the new currency; the remaining 50 per cent going to pay off the State's debt to the Bank and the private bankers. In addition, all receivables, including insurance claims, savings, government and private sector bonds, and mortgage and commercial claims would be converted into the new currency at 75 per cent of their original value, the remaining 25 per cent also going to the State to redeem debt.

Dupriez's purpose was to place a rapid and drastic curb on the circulation of money and thereby immediately bring about deflation. The simplicity of the operation meant that potential loopholes would be avoided and red tape kept to a minimum. In his opinion, the proposal was also justified from a social and ethical point of view, as it was based on the assumption that notes and coins, as well as deposits on transfer accounts, were largely being held by those who had profited from the war. Lower income groups, on the contrary, no longer had any cash or savings and thus would not be hit by the monetary tax. In the business world, most companies had invested their liquid assets in private and public securities, which would be taxed at no more than 25 per cent, if at all, so that there would be only a minimal disturbance to the country's economic activity. For the same reason, the bank sector would be subject to only limited taxation, in order to make it easier for bridging loans to be provided to companies in temporary difficulty. However, companies, guilty of economic collaboration, or other companies, that had improperly enriched themselves, would be hit hard by the special tax on war profits.

The proposal was heavily criticized by Kauch and Franz De Voghel, Deputy-chairman of the Banking Commission ${ }^{46}$, their main point being the taxing of only one element of wealth, i.e. the monetary assets. Both offered an alternative proposal ${ }^{47}$ for reform in two phases. The first

46 BNB, Archives, Studiedienst, 9, dossier 01.02.01.70 (A 241/9, s. f. 3 and 6): résumé des observations présentées au cours de l'examen des projets d'assainissement monétaire; remarques de M. Kauch (undated).

47 BNB, Archives, Studiedienst, 9, dossier 01.02.01.70 (A 241/9, s.f. 3): proposition De 
phase would begin immediately after the liberation and be restricted to provisional reform: existing banknotes would be withdrawn from circulation and be replaced by a fresh issue. Each inhabitant would be permitted to exchange old banknotes for new, up to a maximum of 5,000 Belgian francs - an indicative amount - with the option of using current accounts for the purpose. The rest would be frozen, with the exception of what had been registered on 10 May 1940. The redemption of Treasury certificates would also be frozen.

The regulation regarding the frozen monies, credit balances and securities would be the subject of the reform's second phase and would be entrusted to a new, autonomous institution yet to be established, whose task would be to split the frozen assets into two equivalent parts, one subject to temporary freezing, the other to absolute or very long-term freezing. The assets in the first category would be released gradually, as required by the resumption of economic activity. Those in the second would be kept out of circulation indefinitely or at least for a very long period, having to be converted into a long-term, currency-reform loan. The proceeds of this loan would be applied to redeem short-term government debt.

The Kauch-De Voghel proposal likewise met with sharp criticism ${ }^{48}$. In particular, the operation planned for the second phase was thought to be too complex and would take too long to be effective: the current administration certainly lacked the competent manpower to bring such a difficult task to a successful conclusion within a reasonable time-span. It was also pointed out that the currency-reform loan would consolidate only part of the short-term government debt; consequently, debt to the Bank and the private bankers could not be fully redeemed. Kauch and De Voghel attempted to adjust their proposal in the light of the criticism, but even then failed to win the support of the entire study group. The final report therefore presented the two proposals - that of Dupriez and that of Kauch and De Voghel - as alternatives.

Dupriez had also thoroughly examined the problem of the post-war rate of exchange and for this purpose, too, submitted a proposal to the

Voghel-Kauch, observations et critiques (aides-mémoires, undated).

48 вNB, Archives, Studiedienst, 9, dossier 01.02.01.70 (A 241/9, s. f. 3): résultats des observations présentées au cours de l'examen des projets d'assainissement monétaire (undated). 
study group ${ }^{49}$. The exchange rate of the Belgian franc had to be linked to sterling, because Belgium would be dependent chiefly on sterling-area countries for her foreign trade after the war. A comparative analysis of prices and wages in Belgium and Great Britain led him to judge that a rate of 150 Belgian francs to 1 pound sterling would keep the purchasing power of the two countries in balance. However, the proposed rate implied a devaluation of the Belgian francs, which had been officially maintained at 123 Belgian francs to the pound during the war.

The final report of the Brussels study group included not only the general proposals for post-war reform, but also texts of draft laws designed to provide the proper legal basis for implementing the reform ${ }^{50}$. As early as March 1943, moreover, the engraver Jules Van Paemel had been commissioned to design a series of banknotes, and that year had also seen the declaration forms necessary for the administration of the entire reform process being printed in secret at the Bank.

No liberation came as expected in 1943. Pending it, this first series of proposals and texts with draft laws, together with the declaration forms, were locked away in the safe of the printing works, to which only the head of the works, had the key. During the summer of 1944, new proposals and new texts were worked out and added to the dossier ${ }^{51}$. On 11 September 1944, the chairman of the study group, Smeers, handed the dossier over to the Minister of Finance, Gutt, in the minister's private office in Brussels ${ }^{52}$.

49 Dupriez, Les réformes monétaires de Belgique, passim.

50 BNB, Archives, $S D$, 48, dossier 8.13/10: rapports relatifs aux travaux de la Commission d'études financières de Bruxelles (memorandum of 10.01.1944).

51 Simonis, 'Enkele korte, persoonlijke herinneringen aan de besluiten van 6 oktober 1944', in: Tijdschrift voor het personeel van de NBB, April 1977, p. 8.

52 BNB, Archives, Studiedienst, dossier 01.02.02.41 (A 254/2, 3 and 4): rapport relatif aux travaux de la Commission d'études financières de Bruxelles, 11.09.1944. During July and August 1944, the working-party developed new proposals and draft texts for laws regarding special taxes on war profits and assets. 


\section{THE FINAL DAYS OF THE OCCUPATION}

Events in 1944 were more than ever overshadowed by the approaching liberation. Some sceptics adopted a circumspect approach, but most Belgians - including those who had borne great responsibility during the occupation - looked forward with what, in retrospect, can be called amazing naivety to their country being freed from the yoke of occupation. Even Cracco, when he heard at the end of March 1944 that his imprisonment in Belgium was to be commuted into a deportation to Germany, wrote to Kauch to inform him that he was standing for reelection as a director at the general meeting of shareholders in August of that year ${ }^{53}$.

During the final days of the occupation, the Banque d'Emission was faced with urgent demands from German creditors to have their current accounts paid in cash $^{54}$. The managing directors resolved to put off meeting those demands as much as possible and were partially successful in this with the Werhrmachtverrechnungskasse, wholly successful with the German banks, though not with the purchasing agencies. On 4 September, however - the day that saw the liberation of Brussels all payments were henceforth suspended and the Banque d'Emission closed its doors 55 .

Unimaginable relief, great expectations and uncertainty dominated the days immediately following the liberation. The Bank itself was waiting for instructions from the government, unsure about what to do regarding money circulation and for the time being maintaining its refusal to accept banknotes from the public, save in redemption of debt.

53 BNB, Archives, dossiers officiels après 1945, dossier 111: affaire Cracco (arrestation, non-renouvellement de son mandat après la guerre).

54 BNB, Archives, DC BEB, 30.08.1944, 31.08.1944, 01.09.1944, 02.09.1944.

55 BNB, Archives, $D C B E B$, 06.09.1944. 



\section{Preparation in London for Post-War Belgium}

\section{THE ESTABLISHMENT AND START OF THE CEPAG}

By the late autumn of 1940, it had become evident to everyone in London that the Germans had lost the Battle of Britain, and hope had began to dawn that the final victory would be for the Allies. The Belgian government in exile now judged it opportune to start studying the post-war reform of Belgium's institutional structure, not only political reform, but also plans for a new socio-economic system ${ }^{1}$. Around the same time three prominent Belgian socialists who had fled to London - Jef Rens, Max Buset and Louis de Brouckère - had planned to set up a Belgian Committee for the Study of Post-war Problems (Commission belge pour l'Etude des Problèmes d'Après-Guerre - CEPAG) to prepare the return of the government after the country's liberation. Ideas, drawn from the pre-war statist thinking of Belgian public figures, such as Hendrik De Man and Paul Van Zeeland, were clearly in evidence, as well as new theories of the English economist John Maynard Keynes².

The government concurred with such a committee being set up, Gutt wanting this to be established in London ${ }^{3}$ with Rens as its secretarygeneral. Spaak insisted on Van Zeeland, the former Prime-Minister, being appointed as chairman. Both Gutt and Spaak got their way. The CEPAG was inaugurated on 27 June 1941, Van Zeeland having arrived

1 Dujardin and Dumoulin, Paul Van Zeeland, 1893-1973, p. 121..

2 Diane de Bellefroid, La Commission belge pour l'Etude des Problèmes d'AprèsGuerre (CEPAG), 1941-1944, (degree thesis, UCL, Department of History; supervisor: M. Dumoulin), Louvain- la-Neuve 1987, pp. 63-65.

3 ARA, Theunis Papers, 'correspondance Theunis-Gutt': letter of 17.01.1941 from Gutt (London) to Theunis (New York). 
from his residence in the United States for the occasion ${ }^{4}$. Sections seven in all - were set up for foreign policy, state reform, the economy, education, social affairs, colonial matters and reconstruction.

The section dealing with the economy held its first meeting in London on 16 July 1941, under the chairmanship of Van Zeeland. The occasion was taken to divide the section into four study groups to cover the 'state supervision of economic life', 'industrial restructuring', 'the relationship between industry and science' and 'international economic relationships'. The latter, which also included Van Zeeland and Ansiaux, was chaired by Baudewyns ${ }^{5}$.

In December 1941, Baudewyns was ready with his initial outline report - rapport préliminaire sur le problème du change ${ }^{6}$ - which demonstrated that the problem of the exchange rate had to be faced immediately after the liberation. It went on to state that the problem would be solved satisfactorily only if the government took effective and rapid action to end the monetary chaos of the war years. This supposed an immediate purging of the excess circulation of money, contrary to what had happened after the First World War. Setting a long-term exchange rate for the Belgian franc would therefore have to be postponed until after the liberation, as only then would it be possible to compare price levels in the sterling and dollar zones. The report went on to point out that, after the end of hostilities, strict exchange control would have to be maintained as long as internal and external price levels were not stabilized, although that control ought not to become an obstacle to the smooth resumption of Belgium's foreign trade or to the liberalization of trade relationships in general.

Baudewyns's report gained the particular attention of Gustave Joassart, the pre-war general manager of the FN armaments factory at Herstal, who had arrived in London from Belgium in November $1941^{7}$ and had joined the CEPAG as a member of the section dealing with the economy. After receiving the report, he contacted Baudewyns to examine certain aspects of it more deeply. What had impressed him most

4 Dujardin and Dumoulin, Paul Van Zeeland, 1893-1973, pp. 122-123.

5 Janssens, De Belgische frank, p. 311.

6 BNB, Archives, Commission belge pour l'Etude des Problèmes d'Après-Guerre (London): note préliminaire sur le problème du change, December 1941.

7 Crombois, Camille Gutt, 1940-1945, p. 145. 
was Baudewyns's practical approach, which contrasted with the empty rhetoric of the memoranda and reports of the other sections ${ }^{8}$, which, in Joassart's view, lacked substance and pragmatism?.

The study group was asked to develop the report into a comprehensive package of measures to guide monetary and financial reorganization after the liberation. Baudewyns finished revising his text on 20 March 1942 and submitted it to Van Zeeland as a preparatory draft. He argued for as limited a depreciation of the Belgian franc as possible against sterling and the us dollar. His standpoint was, no doubt, explained by Belgium's traumatic experience of monetary affairs after the First World War. During the early 1920 lax governmental policy had led to the Belgian franc going into free fall on the international exchange markets until it eventually stabilized in 1926 at a fifth of its pre-war value against both gold and sterling. Another catastrophe of such magnitude had to be avoided at all cost.

In the opening chapter, Baudewyns set out his suggestions to eliminate the uncontrolled expansion of the money supply. All banknotes in denominations of 100 Belgian francs and above would have to be surrendered within three days at a bank or at the Postal Cheque Office and withdrawn from circulation. Their value would be converted into credit balances on new or existing accounts, which would be in part consolidated into non-negotiable state securities to be held by the banks. Exempt from this would be all accounts up to an amount of 50,000 Belgian francs per household head or legal person. The accounts of the banks themselves would be exempt for their full value. Should domestic economic activity demand further resources, the percentage of the consolidated balances would be adjusted. In principle, exempt accounts and the non-consolidated portion of the other accounts would be freely accessible and new banknotes would be issued for the purpose.

8 Baudewyns Family Archives: letter of 15.10.1941 from Baudewyns (London) to his son (Oxford).

9 According to Jan-Albert Goris (a famous Belgian poet and novelist of Flemish origin and collaborator of Theunis in New York), it was a mistake to treat the Flemish problem within the CEPAG as purely a language problem and not to address the community question in Belgium, a political aspect that, in his view, could no longer be ignored. His remark drew no response (ARA, Theunis Papers, dossier $2 \mathrm{M}$, $\mathrm{n}^{\circ}$ 5: letter of 05.09.1941 from Goris (New York) to Theunis (New York)). 
The State securities Baudewyns referred to could be applied to the payment of tax on war profits, provided government approval was forthcoming. They could also be used as collateral to obtain bank loans, although only after approval by an Office du Crédit, yet to be established and integrated into the Bank. The proceeds from the special tax on war profits and from the revaluation of the Bank's gold reserves, together with the consolidated bank accounts, would be applied to redeeming the mass of short-term Treasury certificates held by banks and the public and to clearing government debt at the Bank. Furthermore, consumer goods would have to remain rationed some time to keep the level of domestic prices down, although there had to be flexibility in rationing of essential goods in recognition of all the hardships suffered during the war.

For Baudewyns, his entire plan centred on fixing the post-war rate of exchange. If the surplus money in circulation could be eliminated, lending placed under strict control, a tight rein kept on the price level, and public finances reformed, a 'limited' devaluation of the Belgian franc - as favoured by Baudewyns - would likely be sufficient and the purchasing power of wages and salaries not too seriously eroded. Nevertheless, setting the rate of exchange would have to take account also of the Belgian franc's competitiveness against sterling and the us dollar on the world market. It was a question of waiting to see how those two currencies performed, hence Baudewyns's circumspect suggestion that a 'provisional' rate of exchange be considered. However, one monetary question could be settled immediately, which was to restore the pre-war unity of the Belgian and Congolese francs.

\section{BAUDEWYNS' PROPOSAL BECOMES THE GUTT PLAN}

As chairman of the CEPAG, Van Zeeland had the task of synthesizing Baudewyns's draft and the discussions within the study group ${ }^{10}$. Certain of Baudewyns's suggestions Van Zeeland incorporated virtually unchanged into his report to the government. Others he altered completely according to his own view. In his draft, Baudewyns had sug-

10 CEPAG, Deuxième rapport de la Commission Belge pour l'Etude des Problèmes d'Après-Guerre, London, April 1942. 
gested that the Belgian franc's exchange rate ought to be as close as possible to its pre-war level and that the circulation of money and the level of prices should be adjusted accordingly. Van Zeeland disregarded this idea and substituted his own - that the Belgian franc's post-war exchange rate should be geared as much as possible to the level of prices at the time of the liberation.

One of the suggestions that Van Zeeland also adopted from Baudewyns's report was how to combat the threat of 'post-war' inflation. Only a few points of detail were changed. He proposed, for example, a tightening of the supervision of the activities of the banks and the stock markets, with two institutions being planned for the purpose, rather than one. Furthermore, the Bank itself needed to be integrated more into the apparatus of government and pursue a policy of flexible and inexpensive credit, in order to promote economic recovery and full employment. The same inspiration, deriving from the statist De Man Plan of 1933, was even more apparent in the other sections of Van Zeeland's report, which dealt with the general economy: after the war, 'organized freedom' ('La liberté organisée') had to be the guiding principle of economic activity in the country ${ }^{11}$.

Gutt was vexed with Van Zeeland's report. At the Cabinet meeting of 27 May, he stated that he could agree with 90 per cent of the proposals in respect of monetary reform immediately after the liberation, but not with the proposals for structural reform, which, in his view, were too dirigiste, too statist. The reaction pointed up the contrast between the economic views of the two men. For Gutt, the short-term monetary measures were more important than the long-term and priority should be given to monetary measures over economic policy. He was convinced that, immediately after the war, such measures would be sufficient to guarantee stable exchange rates and stable prices in a gradually recovering, open, liberal market economy, a context in which socio-economic progress would develop harmoniously. His model was 'la belle époque' of the end of the nineteenth century and the beginning of the twentieth. Van Zeeland, on the contrary, was convinced that this economic model was outdated: structural reform was now necessary. The government had to adopt a more prominent role; it had to organ-

11 Crombois, Camille Gutt, 1940-1945, pp. 442-443. 
ize the country's socio-economic activity, coordinate the economic activities and participate creatively in international cooperation to ensure balanced economic growth and a just distribution of incomes. Viewed in this context, monetary measures should not be a priority in themselves, but serve to underpin long-term structural reform.

Gutt, moreover, could not accept that Van Zeeland had adopted many of the elements of Baudewyns's proposal, without any attribution and, worse, that he had altered the proposal in such a way that the crucial point of departure regarding the exchange rate and its monetary implications no longer reflected the opinions of Baudewyns, the study group and the wider CEPAG section on the economy, but represented solely Van Zeeland's personal view ${ }^{12}$. In consequence, there was a move to curb his influence.

Consideration was given to reorganizing all CEPAG sections in such a manner that the reports would give way to studies more in keeping with the strategies championed by the Belgian government in London. Seven Comités d'Application were set up, each with a limited number of members selected by the government, their task being chiefly to flesh out the general reports, under government supervision. On 27 May 1942 and on Gutt's proposal, the government set up a Comité d'Application for the economy: Joassart was appointed to be its chairman, which is why it came to be known as the Joassart Committee. Notably, Van Zeeland was not a member ${ }^{13}$.

Gutt and Joassart shared Baudewyns's opinion that the moment had not yet come to give thought to setting a fixed gold parity for the Belgian franc, although they felt it desirable that there be some sort of anchor as a point of departure for a later solution. What they had in mind was a more-or- less fixed ratio of the Belgian franc to sterling. Consultations took place in June with the management of the Bank which led to the choice of a provisional rate of 176.625 Belgian francs to the pound. This appeared to be economically justified and also offered the

12 Baudewyns Family Archives: letter of 11.05 .1942 from Baudewyns (London) to his son (Oxford); BNB, Archives, SD, Ansiaux Papers, A 2, dossier 9.1/26, 'période de guerre, correspondance': letter of 15.06 .1942 from Ansiaux (London) to Theunis (New York).

13 ARA, Administrative services of the Prime Minister, CEPAG, dossier 527: letter of 01.06.1942 from Pierlot to Rens. See also: De Bellefroid, CEPAG, pp. 100 ff. 
advantage of re-establishing the links between the rates of the Belgian and Congolese francs ${ }^{14}$.

The first meeting of the Joassart Committee, on 8 June 1942, provided Baudewyns with the occasion to comment on the Van Zeeland report. He was cautious in his criticism, but pointed out clearly that the report was unacceptable in its present form. He proposed to set out a new and more comprehensive project ${ }^{15}$, taking his previous suggestions as the point of departure.

The new proposal that Baudewyns presented to the Joassart Committee on 1 July, in which Ansiaux was closely involved, repeated the ideas of his earlier plan, though this was set out in greater depth and was more detailed. He retained his earlier suggestions regarding rationing and the control of prices, exchange transactions and foreign trade. He also retained the suggestion that the Bank should take control of lending, though it was expanded to include Van Zeeland's proposal for two specific institutions to supervise short- and long-term lending respectively. But Baudewyns remained vehemently opposed to Van Zeeland's suggestions in respect of the exchange rate, being convinced that, by implementing rapid and radical monetary reform, the government could go far to curb war-time inflation and even head off a feared postwar inflation. A 'limited' devaluation of the Belgian franc against the major world currencies would thus be sufficient to reintegrate Belgium smoothly into the world economy. He also showed himself to be an opponent of any official integration of the Belgian franc into the sterling zone. In prevailing circumstances, this would serve only to deprive the Belgian government of freedom to act, without offering any concrete gain in return.

Baudewyns, furthermore, introduced a number of suggestions for structural reform within the Bank. He took the view that the law of 1937 required fundamental revision, because the proposals for monetary reform implied closer cooperation between the Bank and the government. The Bank's board of directors needed to be expanded, as control of lending and exchange operations would add appreciably to

14 ARA, Theunis Papers, 'correspondance Theunis-Gutt': letters of 26.06 .1942 and 10.08.1942.from Gutt (London) to Theunis (New York).

15 BNB, Archives, SD, Baudewyns Papers, A 2, dossier 9.1/26, 'période de guerre, correspondance': letter of 15.06.1942 from Ansiaux (London) to Theunis (New York). 
the Bank's activities and responsibilities. There had also to be arrangements for settling government debt vis-à-vis the Bank and for granting advances against the guarantee of state securities, as well as arrangements regarding discounting policy, exchange-rate policy, gold cover, the legal competence of the various management and administrative bodies of the Bank, the abolition of the Banking Commission, the acquisition of the assets and liabilities of the Banque d'Emission and the relationship with the Belgian Congo's note-issue authority. All this represented a mammoth programme that, however necessary, could not be implemented in a rush. Its implementation was thus put off to a later date $^{16}$. A final and important part of Baudewyns's report concerned post-war taxation policy and again he returned to the essential points of his earlier suggestions. Explicitly, he rejected any idea of introducing a wealth tax, preferring to tax income, more particularly the profits of limited companies.

Having discussed and approved Baudewyns's proposal, the Joassart Committee sent it to Gutt for comments, who gave it his approval later that same July ${ }^{17}$. On 3 August 1942, Baudewyns sent a summary of his plan to René Pleven of the Comité Français de la Libération Nationale and to his 'friends' at the Bank of England ${ }^{18}$. Gutt, for his part, put the proposal before the Cabinet on 6 October, where it was received quite favourably. 'It's a great, very great success', wrote Baudewyns to Theunis ${ }^{19}$.

\section{THE BELGIAN DISCUSSIONS ABOUT THE EXCHANGE RATE AND CURRENCY REFORM}

Van Zeeland was far from pleased at the way in which he had been kept out of the Joassart Committee, which meant that he was virtually

16 BNB, Archives, SD, Ansiaux Papers A 2, dossier 9.1/26, 'période de guerre, correspondance': letter of 28.06.1942 from Ansiaux (London) to Theunis (New York).

17 BNB, Archives, SD, 54A, Ansiaux Papers A 3, dossier 9.1/30, s. f. 1: meeting at the Ministry of Finance, 24.07.1942.

18 ARA, Administrative services of the Prime Minister, CEPAG (London): esquisse d'une solution des problèmes monétaires et économiques d'après-guerre, note Baudewyns pour Mr. Pleven et pour les amis de la Bank of England, 03.08.1942.

19 BNB, Archives, SD, London Archives, dossier 'accords monétaires': letter of 06.10.1942 from Baudewyns (London) to Theunis (New York). 
excluded from all discussion at governmental level about the monetary future of Belgium. He was no less annoyed at the way his report had been put to one side by the committee and replaced by the Baudewyns proposal, which in the meantime had become the Gutt Plan ${ }^{20}$.

At a meeting with Gutt on 10 November 1942, Van Zeeland repeated the arguments of his April report, claiming that his proposal was aimed at a stable transition from a wartime to a peacetime economy: 'no inflation, no deflation'. In his opinion, Baudewyns's proposal went much too far in combating inflation. Van Zeeland stated that he was certainly not opposed to monetary reform as such, but the reform had to be limited to the removal of surplus (chiefly 'hoarded') money, because that money would generate additional inflation if it was allowed to come into circulation after the liberation. The real price level at the time of the liberation had to be the point of departure for reform, besides providing the basis for determining the rate of exchange, where the level of prices in the dollar and sterling zones had to be taken into account. All this would probably cause the devaluation to be greater than in Baudewyns's proposal, but it would provide a boost to the business world and create opportunities for enterprising businessmen.

Van Zeeland's standpoint was clearly founded on his experiences during the 1930s, when the Belgian economy was thrown totally out of kilter by the deflationary policy pursued by the second Theunis government and was only returned to stability by the devaluation and the expansionary measures carried out under the Van Zeeland-De Man government in 1935. In taking those experiences into account, Van Zeeland was, in fact, also supporting the new Keynesian approach in economic policy. Baudewyns and Gutt, on the other hand, rested their views on events in Belgium during the 1920s, when the careless handling of converting German marks and the lax monetary policy of the first Theunis government led to prices skyrocketing and to a collapse in the exchange rate of the Belgian franc. It was only in 1926 that the currency was stabilized, although this was regarded at the time as an unpalatable reverse. As disciples of the traditional, quantity theory of money and of the clas-

20 ARA, Administrative services of the Prime Minister, CePAG (London): résumé d'une conversation entre M. Gutt et M. Van Zeeland, 10.11.1942; P. Van Zeeland, principes de politique monétaire, 25.11.1942. See also: H. Van Praag, L’opération Gutt, pp. 26-29. 
sical liberal model, Gutt and Baudewyns insisted that the money supply had to be drastically reduced if stability was to be restored to prices and the exchange rate; only in this way could the incomes of rentiers, wage-earners and salaried persons be protected. There appeared to be no reconciling the two standpoints, as they were based on diametrically opposed underlying concepts.

After his meeting with Van Zeeland, Gutt sent a letter to the Resistance Committee in Belgium, which was headed by Professor Charles De Visscher, with whom the London government was in clandestine contact $^{21}$. Gutt wanted to hear the opinion of the Belgian experts on post-war currency reform. In his letter he set out the two London standpoints in a fair amount of detail and as objectively as possible, naming them thesis A and thesis B for the sake of anonymity.

The early months of 1943 saw responses from Galopin, A.-E. Janssen, Dupriez, Frère and the economist Edouard Dervichian ${ }^{22}$. Regarding the exchange rate, all endorsed thesis A, being the Baudewyns-Gutt proposal. The reactions from Belgium were music to Gutt's ears. The exchange rate of around 176 Belgian francs to the pound sterling, his hobby horse, was about midway between the rate of around 150 francs recommended by certain experts in Belgium and the rate of 250-300 francs proposed by Van Zeeland.

Gutt appeared to have won, but Van Zeeland in the United States continued in early 1943 to push 'his' rate. He had access to the highest levels of the American administration, which made Gutt fear that the American authorities would get the impression that Van Zeeland's standpoint on the exchange rate was, in fact, the Belgian government's standpoint ${ }^{23}$. To prevent any misunderstanding, Gutt sent a memorandum, by way of Spaak and the Belgian Embassy, to the State Department in January of that year, in which it was made clear that only the

21 ARA, Administrative services of the Prime Minister, CEPAG (London): Gutt, note au sujet du problème monétaire (deux thèses sont en présence), 13.11.1942; V. Janssens, De Belgische frank, p. 314.

22 ARA, Theunis Papers, 'correspondance Theunis-Gutt': letter of 10.03.1943 from Gutt (London) to Theunis (New York); letter of 19.03.1943 from Baudewyns (London) to Theunis (New York); letter of 23.12.1945 from Gutt (London) to Theunis (New York). See also: H. Van Praag, L'opération Gutt, p. 29.

23 ARA, Theunis Papers, 'correspondance Theunis-Gutt': letter of 11.12.1942 from Gutt (London) to De Schryver (New York). 
Belgian government in London was competent to determine the exchange rate of the Belgian franc.

In London, Gutt found himself supported by Lord Keynes, who had circulated a memorandum in December 1942, setting out how the monetary reform ought to be conducted after the war: 'It seems to me that, in deciding the proper post-war rate of exchange, the primary consideration is neither the volume of notes nor the level (of prices). Apart from more fundamental considerations, a post-war rate of exchange, adjusted to the post-war level of wages, may represent a convenient middle course ${ }^{24}$. The position taken by Keynes ran counter to Van Zeeland's ideas and was clearly in line with the thinking of Baudewyns and Gutt. With Keynes's memorandum in mind, Gutt commissioned Paul Lévy, an economist who had made his way to London from Belgium, to make a detailed statistical study of the available data on British and Belgian wages and salaries, and use that to calculate a sensible rate of exchange. Lévy's calculation indicated a rate of about 176 Belgian francs to the pound. To add to this, Gutt received a well- documented memorandum in April from Galopin that contained a recommendation for a Belgian franc parity likewise close to his preferred level. Gutt was now convinced that his choice was the right one and, at the Cabinet meeting of the end of April 1943, proposed that the exchange rate be officially set at 176.625 Belgian francs to the pound sterling ${ }^{25}$.

The discussion in the Cabinet was particularly acerbic and revealed deep divisions among the government leaders ${ }^{26}$. Spaak, supported by Rens, was still under the sway of Van Zeeland's views and remained convinced that the rate proposed by Gutt was too high and would lead to unjustifiable socio-economic distortions. De Vleeschauwer was no less critical, pointing out that pressure groups in the Belgian Congo feared that unifying the Belgian and Congolese francs would result in too high an exchange rate for the colony's currency, in comparison with that for the currencies of neighbouring countries likewise exporting raw materials; hence their preference for the sort of monetary policy that Van Zeeland proposed. But, surprisingly, a majority of the Cabinet

24 Quoted by Crombois, Camille Gutt, 1940-1945, pp. 458-459.

25 Crombois, Camille Gutt, 1940-1945, pp. 457-461, 467-468.

26 ARA, Theunis Papers, 'correspondance Theunis-Gutt': letters of 25.04.1943 and 28.04.1943 from Gutt (London) to Theunis (New York). 
ultimately opted for a rate of around 162 francs to the pound and of about 41 francs to the dollar ${ }^{27}$.

These rates were, in fact, even higher than those proposed by Gutt. The reason for their being chosen can most probably be found in the wider situation regarding the French franc. At the time of the North African landing in November 1942, the Allied military leaders had unilaterally announced an exchange rate of 300 French francs to the pound sterling, but, at the insistence of the Comité Français de Libération Nationale in London, the American and British governments had decided on 2 February 1943 to change that to 200 French francs to the pound. The resulting cross-rate with the Belgian franc had consequently brought the rate of the Belgian franc to 150 to the pound. The majority of the Belgian ministers were probably looking for a rate in line with the rate of the French franc, the traditional monetary reference point for Belgium ${ }^{28}$. Gutt had to back down and ultimately accepted the compromise of rates around 162 Belgian francs to the pound and around 41 to the dollar, but only on condition that he would be able to increase those rates to respectively 176.625 and 43.827 francs - the levels he had originally suggested - if the British and American authorities rejected the rates of the compromise as being too high.

In July 1943 Gutt went to the British and American governments to clarify the Belgian decision: during the discussions both governments indicated that the rates, set by the Cabinet, were too high and that their preference was for Gutt's initial option. Ultimately the official rates were set at 176.625 and 43.827 Belgian francs to the pound sterling and the dollar respectively. All this may possibly have been an example of Gutt's diplomatic talent, but it ought not to be forgotten that, at the time, thought was being given in Washington and London to the approaching invasion of Europe: too strong an exchange rate for the currencies in the countries set for liberation would simply add to the cost of liberating them.

Once the matter of the exchange rate had been settled, the focus of discussion within the Belgian government switched to the overall pack-

27 BNB, Archives, SD, London Archives: letter of 02.09.1943 from Frazer (London) to Rowe Dutton (London).

28 ARA, Administrative services of the Prime Minister: letter of 12.02.1943 from Gutt (London) to Pierlot (London). 
age for currency reform. Spaak's criticism now was directed towards the fiscal aspects of the reform; in his view, to replace the wealth tax by a mandatory, long-term loan, as proposed, would burden the government budget to such an extent as to pose an unjustified threat to postwar social policy, the cornerstone of social recovery.

The discussions dragged on, with the result that the final draft texts on the currency reform were submitted to the Cabinet for approval only on 3 April 1944. All texts were finally approved, after a number of minor amendments had been made to them ${ }^{29}$. On 7 April, the problem of exchange rates was addressed and Spaak once more challenged the rates agreed on, remaining convinced that they were too high and would lead to deflation and thereby be detrimental to the socio-economic situation. Gutt reiterated his support for a strong currency, because Belgium would for a long time be reliant on mass imports of raw materials and capital goods for industry. Exports would not be a priority for the immediate future, whereas imports would be, as it was from imports that the post-war recovery had to generate the necessary capacity to reequip industry: indeed, they would be the linch-pin of that recovery ${ }^{30}$. Spaak only gave his assent after Gutt formally undertook to adjust the exchange rate if the level of 176.625 francs to the pound was effectively shown to be too high and an obstacle to economic growth.

This left just the draft decrees regarding fiscal and financial matters to be discussed and these were addressed on 14 April. Gutt feared rightly - that Spaak would be obstructive, as he remained an outspoken champion of a wealth tax, a measure that had not been included in the plan for reform. The expected attack materialized, with Spaak being supported by his Socialist colleague, the recently appointed Minister August Balthazar. They both upbraided Gutt for indefinitely postponing a decision about that tax, accusing him of looking to drop the measure altogether ${ }^{31}$. Making no concession, however, Gutt carried the day, and all the drafts were approved by the Cabinet on 27 April.

29 ARA, Theunis Papers, 'correspondance Theunis-Gutt': letter of 04.04.1944 from Gutt (London) to Theunis (New York).

30 ARA, Administrative services of the Prime Minister: report of a Cabinet meeting (London), 07.04.1944.

31 Crombois, Camille Gutt, 1940-1945, p. 46. 



\section{The Build-up to Post-War International Cooperation}

FROM THE DUTCH-BELGIAN-LUXEMBOURG MONETARY AGREEMENT TO BENELUX

Quite early during the war, Gutt, supported by Theunis, began to play with the idea of setting up a form of monetary and economic cooperation with the Netherlands. The idea first crystallized in discussions during the spring of 1941 between Gutt and Johannes van den Broek, head of the Dutch Economic Mission in the United States. Before the war, they had been members of the international tin cartel and their work together had engendered a mutual respect. Encountering each other in New York, and now with government responsibilities, their talks were chiefly about how the post-war economy in Europe ought to be organized. They shared the same underlying view that international cooperation was far preferable to the neo-mercantilism of the 1930s. Such cooperation held great promise, but could be realized only through an adequate political framework. Gutt thought that a first, modest step towards a wider international reorganization of the world economy could be a Belgo-Dutch agreement for cooperation, which he looked to achieve from within the Belgian government and via contacts with his Dutch colleagues in London.

Gutt was not interested solely in broad, overarching ideas; he saw very real advantages for Belgium in closer cooperation with the Netherlands, whose economic recovery after the war, together with that of her colonies, would guarantee a substantial market for Belgian exports. For the immediate future, moreover, positive cooperation would strengthen the two countries' hand in the impending discussions in Great Britain and the United States about the future orientation of the world economy ${ }^{1}$.

1 BNB, Archives, SD, 46, Ansiaux Papers, A 1: letter of 16.06.1942 from Ansiaux (London) to Theunis (New York). 
Within the Belgian government, there was little, if any, understanding of Gutt's ideas, both his colleagues and immediate advisers offering nothing but negative arguments. Spaak was worried about the British reaction and wondered whether association with the sterling area would not offer better prospects, given that Sir Anthony Eden, the British Foreign Secretary, had recently spoken of possible post-war monetary cooperation between the British Empire and Great Britain's European allies. Others took the view that there was too great a disparity in the political traditions of Belgium and the Netherlands and, moreover, that the two economies were no longer complementary, meaning that any union would serve only to sharpen competition between them. There was also a very sceptical reaction from the business world in Belgium, when it was consulted about the plans. A monetary union could never be viable without economic and even political union, and this last would throw up insoluble problems regarding the two royal houses and the respective colonies. Moreover, how would the French-speaking Belgians feel in a predominantly Dutch-speaking union? The argumentation was vague, but the resistance was manifest and Gutt was unable to drum up support, even within the ranks of his own government.

At the end of 1942, however, the situation changed, with the appointment of van den Broek as Dutch Minister of Finance and his move from New York to London, which immediately gave Gutt an influential ally within the Dutch government. The matter could now be discussed again and unexpectedly took a favourable turn, following what took place in North Africa in November 1942 regarding the unfavourable exchange rate of the French franc, unilaterally imposed by the AngloAmerican armies.

The incident prompted the European governments in exile in London to hold joint discussions and these served at once to bring the Dutch and Belgian governments closer together ${ }^{2}$. In February 1943, Gutt and

2 The Sous-Comité d'Experts pour l'étude des questions monétaires d'après-guerre, with representatives of the Comité Français de Libération Nationale and of the Dutch, Belgian, Luxembourg and Norwegian governments, met on 18.11 .1942 to discuss the incident. On 02.02.1943, in consequence of this and other reactions, the Anglo-American army leadership lowered the Algerian rate of the French franc from 300 to 200 French francs to the pound sterling: H. Van Praag, L'opération Gutt, p. 35 . 
van den Broek took advantage of the two governments' shift in attitude to resume discussion about monetary and economic cooperation ${ }^{3}$. For strategic and practical reasons, they now opted for a two-phase approach: during the first, a monetary agreement would be set up as rapidly as possible: and during the second, a customs union. Their hope was to have both in place before the liberation.

The reason for giving preference to a separate monetary agreement was linked to the talks taking place in Washington about a new world monetary system (including post-war exchange rates) and no less to the ambitious plans for the establishment of new, international institutions. For the small countries to avoid the diktat of their big allies in the determination of their post-war exchange rates and to be adequately represented in those institutions, mutual cooperation was crucial ${ }^{4}$.

Arguments of this nature struck a chord, even with the most critical opponents of Belgo-Dutch cooperation, and Gutt and van den Broek were given carte blanche to go ahead with their plans. By 14 March 1943 the two were ready with their proposal, which was approved in April by the respective governments 5 . In the first place this provided for fixed exchange rates between the Dutch, Belgian and Luxembourg currencies (including the currencies of the colonies), with none of the three countries being able to alter the rates without the assent of the other two. Furthermore, mutual lines of credit would be granted on favourable conditions, to be discussed and laid down in mutual agreements by the Bank and the Nederlandsche Bank. Lastly, the proposals also included the appointment of a group of experts to work out a plan for the establishment of a customs union. The actual agreement would be signed as soon as the parities between the currencies concerned were fixed. Van den Broek's opinion was that the agreement could be signed immediately, but certain of his Dutch colleagues thought that the parity should

3 ARA, Theunis Papers, 'correspondance Theunis-Gutt': letter of 10.03.1943 from Gutt (London) to Theunis (New York).

4 J.J. Polak, 'Financial relations between the Netherlands and Belgium: 1943 to 1993' in: A. Bakker et al., eds., Monetary Stability through International Cooperation. Essays in honour of André Szasz, Amsterdam, 1994, p. 184.

5 Ndl.mF, Archives, London settlement office, 1940-1948, dossier 539/ 1-2: letter of 14.03.1943 from van den Broek (London) to van Kleffens (London); meeting of 22.03.1943. 
depend on a monetary agreement under discussion with Great Britain, but not yet finalized ${ }^{6}$.

The postponement was an irritation to van den Broek and Gutt, as it frustrated their hope of being able to go to the monetary conference in Washington in May 1943 with an agreement in their pockets. They argued for a compromise, which was accepted just before the conference. It was that the Dutch and Belgian representatives in Washington would propose a provisional and informal fixed parity of 1 Dutch guilder to 16.52 Belgian francs?.

At last, after a few more delays, the Dutch-Belgian-Luxembourg monetary agreement was officially signed in London on 21 October $1943^{8}$. The exchange rate between the Dutch and Belgian currencies was set at the level agreed in May. Mutual lines of credit to the value of 1 billion Belgian francs were proposed, subject to monthly monitoring by the two central banks. No interest would be due on up to half the credit line; should more than half the credit line be drawn down, interest at the official discount rate would be charged. Debit balances above 1 billion francs would be liable for settlement in gold or a gold-based currency. It was also confirmed that the agreement was provisional. It came into force officially on 1 September 1945 , after the Netherlands and Belgium had been liberated and the two central banks had been able to make the necessary arrangements ${ }^{9}$.

Once the monetary agreement had been announced, the experts began their preparatory talks on the customs union. However, setting a common external tariff and working out transitional measures for the abolition of internal tariffs and quota restrictions took much more time than expected and it was only on 9 September 1944 that the customs union treaty between Belgium, the Netherlands and Luxembourg was

6 Polak, 'Financial relations between the Netherlands and Belgium', in: A. Bakker et al., eds., Monetary Stability through International Cooperation. Essays in honour of André Szasz, Amsterdam, 1994, p. 190.

7 Ndl.MF, Archives, London settlement office, 1940-1948, dossier 539/ 1-2: letter of 12.05.1943 from van den Broek (London) to van Kleffens (London).

8 BNB, Archives, SD, Ansiaux Papers, A 1, dossier 9.1/24: Dutch-Belgian-Luxembourg monetary agreement, 21.10.1943.

9 The discussions between the Bank and the Nederlandsche Bank were held in Brussels on 31.07.1945. The agreement was officially announced in the Belgian Official Gazette of 09.09.1945. 
signed in London, on the Belgian government's return to Brussels. The treaty went down in history books as 'the Benelux Treaty', and came into provisional effect on 10 May 1945, but had to wait until 1949 before taking definitive effect ${ }^{10}$.

The international press was laudatory: 'The two countries have set an excellent example of good-neighbourliness... it is a serious practical example of what could be done on a vast scale' (The Financial Times); 'The real important thing is that the agreement provides for coordinated action' (The Times); 'We look with sympathy on the efforts of two small and complementary countries to form a single trading area' (Manchester Guardian); 'The Low Countries plan a customs block as an example to post-war Europe' (New York Times). In fact, both the monetary agreement and the Benelux Treaty proved to be forerunners of wider alliances: the former was the prototype of more than one hundred similar, bilateral agreements after the war; the latter was a first, distant step towards the Treaty of Rome.

\section{THE FRANCO-BELGIAN AND ANGLO-BELGIAN MONETARY AGREEMENTS}

Upon the announcement of the monetary agreement of 21 October 1943, the Comité Français de Libération Nationale contacted Gutt in order to conclude a parallel Franco-Belgian monetary and economic cooperation agreement ${ }^{11}$, but Gutt, Theunis, Baudewyns and Ansiaux were not in favour ${ }^{12}$. First and foremost, the experience of recent years with France had been far too negative for them to have any desire to be drawn again into the French sphere of influence. In a letter to Spaak at a later date, Gutt wrote very bitterly: 'The French government likes Belgium very much on the condition that she follows its policy.... I have experienced these sympathies for 25 years : they never have prevented

10 Ndl.bz, London Archives, 1940-1945, dossier GA EZ/CHZ, F 78; Ndl.MF, Archives, London settlement office, 1940-1948, dossier 353: Belgo-Dutch-Luxembourg customs union.

11 BNB, Archives, SD, Ansiaux Papers, A 1, dossier 9.1/26: letter of 02.11.1943 from Ansiaux (London) to Theunis (New York); letter of 18.11.1943 from Theunis (New York) to Ansiaux (London).

12 Crombois, Camille Gutt, 1940-1945, pp. 429-433. 
treaties being abandoned, nor even treason....I fear that today we will have to deal with the same kind of men as we did before.... I know them ${ }^{13}$.

Secondly, the Belgians feared that economic recovery in France after the war would be very much an uphill struggle; with that in prospect, they could see no advantage in a monetary agreement, only future obligations. Thirdly, the Belgians wanted decisions about the Belgian franc's rate of exchange against sterling and the us dollar to be made by their own national decisions ${ }^{14}$. Lastly, and not unimportantly, they were infuriated by the deliberate vagueness of the promise of the Comite Français de Libération Nationale regarding restitution of the Bank's gold surrendered by France to Germany. That vagueness in a matter about which the Belgians in exile felt so strongly, closed the door on any talks about possible economic and monetary cooperation between the two countries.

The French made a fresh approach to Gutt and van den Broek in April $1944^{15}$. France and Great Britain had concluded their monetary agreement in February, inspired by the Dutch-Belgian-Luxembourg model. The Comité Français de Libération Nationale deemed the time was ripe to begin negotiating with the Benelux countries ${ }^{16}$. The negotiations dragged on, Gutt remaining all the while in close contact with van den Broek, but at last, on 1 September 1944, a draft agreement was tabled that both France and the Benelux countries could endorse. A provisional Belgo-French agreement was signed in London on 4 September, heralding a definitive version, once discussions in the liberated territories had clarified a number of matters. Mutual exchange rates were set on the basis of the cross-rates then in force against sterling ${ }^{17}$

13 BNB, Archives, Ansiaux Papers, dossier A 2, s. f., 'correspondance avec Gutt, Boël et autres': letter of 23.06.1944 from Gutt (Prestwick) to Spaak (London).

14 ARA, Theunis Papers, 'correspondance Theunis-Gutt': letters of 12.11 .1943 and 13.11.1943 from Theunis (New York) to Gutt (Atlantic City); letter of 16.11.1943 from Theunis (New York) to Spaak (Atlantic City).

15 Ndl.BZ, London Archives, 1940-1945, GA Ez/CHZ, dossier 2210, F 76: letter of 17.04.1944 from van den Broek (London) to van Kleffens (London).

16 BNB, Archives, SD, Ansiaux Papers A 2, dossier 9.1/26: letter of 17.05.1944 from Rens (London) to Ansiaux (Bretton Woods).

17 For Belgium and Luxembourg, this exercise resulted in a new rate of 100 Belgian francs to 113.25 French francs. 
and were to be adjusted in the future only after joint consultation. Additionally, mutual credit lines of 2 billion French francs and 1.765 billion Belgian francs were granted, the conditions being the same as those in the Benelux Treaty. The agreement would be implemented by the Bank and the Banque de France ${ }^{18}$ : and the two central banks agreed this provisionally on 10 October 1944.

Negotiations on the long-term agreement took place in Paris towards the end of October 1944. An attempt was made by the French representatives to have the line of credit increased to 3 billion French francs, but their proposal was rejected; otherwise, there was acceptance that settlement of debit balances exceeding the line of credit should be in gold. The permanent agreement was signed in Paris on 27 October 1944. It was very much in line with the provisional version and with it lapsed the virtually forgotten French-British-Belgian agreement of 7 July $1940^{19}$.

A similar monetary agreement was also concluded with Great Britain, but only after many difficulties had been overcome. At the end of 1943, Gutt had insisted with Sir David Waley of the Treasury that such an agreement be concluded, but - very diplomatically - the British had not reacted ${ }^{20}$. Following the agreement between France and Great Britain in February 1944, however, the Benelux countries felt that the time had come for a British agreement ${ }^{21}$ : Gutt and van den Broek therefore made a fresh approach to Waley. The Belgians and Dutch wanted to use fixed exchange rates to tie the franc and guilder zones (each with its colonial dependants) to sterling, thereby recognizing the supremacy of sterling as an international reserve currency. In return, Great Britain would confirm the independence and sovereignty of the Belgian franc and Dutch guilder and help to restore those currencies' pre-war posi-

18 Ndl.mF, Archives, London settlement office, 1940-1948, dossier N 537, letters of 29.08.1944; 01.09.1944; 05.09.1944 and 09.09.1944 from Gutt (London) to van den Broek (London).

19 Ndl.MF, Archives, London settlement office, 1940-1948, dossier 537: report of the meetings of 24, 25 and 26.10.1944.

20 Soma, Archives, Gutt Papers: letter of 05.12.1943 from Gutt (London) to Waley (London); Crombois, Camille Gutt, 1940-1945, pp. 414-415.

21 Ndl.BZ, London Archives, 1940-1945, dossier GA Ez/CHZ: F 76, report of the meeting of 29.02.1944; F 78, letter of 14.03.1944 from Beyen (London) to Crena de Iongh (Washington). 
tion in respect of international payments. The Belgians and Dutch also sought privileged access to the British market after the war, to be able to purchase - on credit, if need be - capital goods for the recovery of their economies ${ }^{22}$.

The Treasury and the Bank of England did not look kindly on the proposal. There could be no question of an Anglo-Benelux agreement, as that would lead to the transferability of sterling within the Benelux zone. Moreover, it could hinder the sterling area's accession to an international, multilateral arrangement. Lastly, any agreements could only apply to future commercial payments in current accounts: existing sterling balances would have to be dealt with separately ${ }^{23}$.

Ansiaux had been working since 26 February 1944 on an initial draft and this was presented to the Treasury on 4 March for discussion. Waley raised difficulties and remained critical, even when new, revised versions were later submitted that took account of points raised during the discussions. The negotiations dragged on without result ${ }^{24}$, despite the Belgians pointing out that an agreement would clearly be to Great Britain's advantage. It would peg the Belgian franc to sterling, which was tantamount to a Belgian vote of confidence in Great Britain's future, but if the British could see no virtue in that, Belgium would have to peg her currency to gold, independent of sterling ${ }^{25}$.

Waley would not be convinced: the enormous extent of sterling balances in the world meant that limits on transactions in sterling would in any case have to be retained. For the time being, therefore, it would not be possible to use existing and any new Belgian sterling balances, so that there was little sense in concluding an agreement that included the provision of mutual lines of credit. Baudewyns and Ansiaux answered that the proposal concerned essentially a monetary and not a

22 BEngl, Archives, Belgium, OV88, dossier 11: report of a meeting at the Treasury, 20.07.1944; further: notes on the Anglo-Belgian monetary agreement, 09.02.1945.

23 BEngl, Archives, Belgium, OV88, dossier 11, 'Siepman (Bank of England) to Waley (Treasury)': objections to monetary agreement with the Belgians and Dutch, 01.03.1944; BEngl, Archives, Gold, OV48: correspondence of April-May 1944 on the Anglo-Belgian monetary agreement.

24 BEngl, Archives, Belgium, OV88, dossier 11, 'Mutual Aid and General Monetary Agreements, March-September 1944'.

25 BNB, Archives, SD, London Archives, dossier 'or': projet d'accord monétaire anglobelge (report of 23.06.1944 from Baudewyns). 
credit agreement: it was more about the setting of a fixed exchange rate and, as far as credit was concerned, only about limited, mutual debit margins. Waley remained unmoved: the British government was only prepared to conclude an agreement if Belgium and the Netherlands agreed to continue to provide credit facilities to Great Britain, without any reciprocal obligation on the British side ${ }^{26}$.

Van den Broek and Gutt held consultations together in London in August 1944 to decide what the reaction to the British standpoint should be. In the first place, they thought that they should certainly recognise the problem of the sterling balances: these had increased enormously during the war and were set to rise even further in the immediate future - in the particular case of Belgium, via the Anglo-Belgian Financial and Mutual Aid agreements signed on 22 August 1944 ${ }^{27}$. The proper course for Belgium and the Netherlands would be to retain the balances arising from the war in escrow for the time being and, furthermore, to declare that they would not draw down the balances under the Financial and Mutual Aid scheme in gold or gold currency. With effect from a date to be determined, however, they argued that Belgium and the Netherlands would be allowed to apply those balances in annual tranches to purchases in the sterling zone. As regards the mutual provision of credit in the current account, the view of both Gutt and van den Broek was that there could be no derogation from the principle of reciprocity, though they declared themselves willing for the suggested credit margin of 10 million pounds to be reduced and for the life of the agreement to be cut from nine to three years ${ }^{28}$.

Consensus was ultimately reached on 22 September $^{29}$ and an AngloBelgian monetary agreement, incorporating the Belgian concessions over sterling balances, was at last signed on 5 October 1944 in London.

26 BEngl, Archives, Belgium, OV88, dossier 11: report of a meeting at the Treasury, 20.07.1944.

27 BEngl, Archives, Belgium, OV88, dossier 11: note of conversations at the Treasury regarding the Belgo-Dutch agreements, 04.09.1944; draft letter of 08.09.1944 to the Chancellor.

28 BNB, Archives, London Archives, dossier 'or': report of a meeting between Gutt and van den Broek, 18.08.1944.

29 BEngl, Archives, Belgium, OV88, dossier 11: memorandum of 16.09.1944 from Fraser to Waley; letter of 22.09.1944 from Fraser to Aarom (American embassy); definitive text of the agreement, 03.10.1944. 
The exchange rate for current commercial transactions was officially set at 1 pound sterling to 176.625 Belgian francs and the respective governments granted each other a credit line of 5 million pounds sterling. The actual implementation of the agreement would be taken care of by the Bank and the Bank of England ${ }^{30}$.

30 Ndl.Bz, London Archives, 1940-1945, GA Ez/CHZ, dossier 2210 F 76: monetary agreement between the government of the UK and the government of Belgium, London, 05.10.1944. 


\section{CHAPTER 23}

\section{Belgium and the New Economic World Order}

\section{BELGIUM AND THE BRETTON WOODS AGREEMENTS OF 22 JULY 1944}

The problems exercising the governments and central banks in London and Washington were much broader than the setting of new, more realistic exchange rates aimed at economic recovery in Western Europe after the war. In particular, there was the question of a new economic world order. Everyone was agreed that the ending of the war would provide a unique opportunity to rid the world of the pre-war monetary chaos and to harness international cooperation to achieving a stable and ordered system of free world trade and unhindered payment flows.

In June 1942, Gutt invited the famous English economist John Maynard Keynes to dinner, together with Baudewyns, Ansiaux, Jef Rens and Fernand Van Langenhove, to discuss post-war recover ${ }^{1}$. Since the Anglo-American discussions in 1941 about the Lend Lease Agreement, Keynes had been working on a comprehensive plan for the post-war organization of international payment flows; his underlying assumption was that any such plan ought to be to the benefit of the 'national economy', with full employment as the main priority. This did not mean that Keynes had no regard for the world economy; on the contrary, he was an ardent champion of greater openness and of broader international cooperation than had been the case during the inter-war years. In this, a dominant role would be played by the United States, in consequence of the enormous creditor position she had built up vis-à-vis the rest of the world, a position that would certainly continue to extend. The United States had by far the greatest gold reserves of any country and, after the war, would be the major supplier of both producer and

1 Crombois, Camille Gutt, 1940-1945, p. 364, footnote 17. 
consumer goods. This, Keynes foresaw, would lead to an exceptional scarcity of dollars for all countries after the war, irrespective of their side as a belligerent.

In view of this situation Keynes, with the support of the Treasury, had published a plan for setting up an International Clearing Union. The Union was presented as a type of international bank that would use a new unit of account, the bancor with a fixed, but adjustable gold parity. Each participating country would be allotted a quantity of bancors in proportion to its pre-war trade volume, population and gold reserves, criteria that were clearly to the advantage of Great Britain, whose Imperial Preference System and monetary policy had allowed her to sustain her foreign trade better than other countries during the 1930s. Moreover, the Union would adopt a multilateral clearing system. Where the total balance (credit or debit) exceeded the allotment of bancors, progressively rising interest rates would be applied as a sanction to countries both in surplus and deficit, thereby prompting all countries to work to achieve a new equilibrium in their balances of trade and payments ${ }^{2}$.

A plan was likewise being prepared in the United States by Harry Dexter White, a top official at the American Treasury Department. White had formulated some of its proposals at the beginning of 1941 and had developed them further when, in December of that year, the United States had joined the Allied camp. The proposals were published in April 1942 as the White Plan. White suggested the creation of two supranational institutions to guide the recovery of the world economy: a world bank for the provision of long-term credit and an international stabilization fund for the provision of short-term credit, the two to function within a context of fixed exchange rates, free world trade, and the free movement of money and capital. The stabilization fund would use multilateral offsetting to facilitate international payment flows. It would draw its resources from its members, whose contributions would be in gold and in their national currencies. The fund would thus act as a sort of international bank, where all participating countries would be able, on the most favourable conditions, to purchase foreign currency, in order to cope with temporary deficits in the balances of trade and

2 R. Skidelsky, John Maynard Keynes. Fighting for Britain, 1937-1946, London, pp. 179332. 
payments. This would serve to counter any brake on commercial expansion, brought about by balance-of-payment problems, and thereby help to correct the unequal distribution of gold reserves in the world3.

The two plans had a number of features in common, particularly that regarding an international, multilateral clearing system, which was very much on the lines of the Deutsche Verrechnungskasse set up by Hjalmar Schacht. However, there were also important differences. Keynes, for example, wished to place the burden of eliminating temporary balance-of-payments' disequilibria on countries in surplus and countries in deficit, White solely on countries in deficit ${ }^{4}$. Looking to achieve a political consensus, the two men negotiated intensively to harmonize their plans during the months that followed. They came up ultimately with a joint proposal that included the establishment of a World Bank and an International Monetary Fund, a proposal that was eventually discussed, amended and approved by the forty-five countries represented at the international conference at Bretton Woods in July 1944.

Theunis was distrustful of the joint proposal right from the outset, his ideology being too liberal to accept supranational organizations. A negative view of the two plans was also taken by Gutt's. These were not the sole voices raised in criticism. Ranged against the proposals were also the entire banking world in New York, the Republican Party (led by Senator Robert Taft), the Federal Reserve Bank of New York and the Federal Reserve Board in Washington. Each had its own specific motives, but together they created a formidable opposition. The American bankers feared competition from the World Bank and the Fund; the Federal Reserve institutions feared the loss of their strong grip on monetary policy; and the Republican Party was by tradition averse to the dirigiste slant of the New Deal inspiration that it detected in the White Plan and whose influence it feared in the subsequent joint proposals ${ }^{6}$.

3 J.K. Horsefield, The International Monetary Fund, 1945-1965. Twenty Years of International Cooperation, vol. 1, Chronicle, Washington, 1969; A. Van Dormael, Bretton Woods. Birth of a Monetary System, New York, 1978; R.N. Gardner, Sterling Dollar Diplomacy in Current Perspective, New York, $1988^{2}$; H. James, International Monetary Cooperation since Bretton Woods, Oxford, 1996.

4 H. Van der Wee, Prosperity and Upheaval. The World Economy, 1945-1980, p. 425435 .

5 Quoted by Crombois, Camille Gutt, 1940-1945, p. 375.

6 Ndl.MF, Archives, London settlement office, 1940-1948, dossier 6921: memorandum 
However, the project had the backing of the American president, and all its opponents consequently found themselves obliged to adjust to the new monetary landscape it introduced. In European circles the proposal immediately conjured up the spectre of a liberator reserving the right to set exchange rates unilaterally in the liberated territories, and preferably 'soft' rates that would give greater purchasing power to the pay of the invading forces ${ }^{7}$. Proper agreements about rates had therefore to be made, and made fairly quickly, because the invasion of Europe was believed to be imminent.

During the spring an summer of 1943 intense bilateral talks to evaluate the joint plan of White and Keynes began in Washington between representatives of the American Treasury and representatives of the European Ministers of Finance ${ }^{8}$. The Europeans thought that the problem of exchange rates would now be addressed, as it was integrally bound up with the plan. Furthermore, the European governments in exile wanted certainty about the exchange rates that would be applied by the Allied military command after the landings. Representing Belgium in the talks was Boël and he quickly received the impression that the American Treasury had weaker rates in mind for the Belgian franc than had been decided by the Belgian government in London. As mentioned above, the rates had been fixed at 162 and 42 Belgian francs to the pound and the us dollar respectively, but during the discussions with the Americans these rates were adjusted to 160 and 40, as the Americans preferred rounded figures.

At the beginning of October Boël himself came to the conclusion that the rates proposed by Belgium no longer corresponded to reality: the war was dragging on and clandestine sources were informing him that the issue of banknotes in Belgium was getting increasingly out of hand, so that the earlier calculations were no longer accurate. All this

of 03.10.1943 from the American Bankers Association, passed by Crena de Iongh to van den Broek; ARA, Theunis Papers, 'correspondance Theunis-Gutt', letters of 14.06.1944 and 22.06.1944 from Theunis (New York) to Gutt (London).

7 Ndl.mF, Archives, London settlement office, 1940-1948, dossier 6901: memorandum of early 1944 from Steenberghe (Washington) to Crena de Iongh (New York).

8 ARA, Administrative services of the Prime Minister: letter of 10.08.1943 from Gutt (London) to Pierlot (London) and Boël's reports of 26.07.1943 and 16.08.1943 on his discussions in Washington. 
convinced him that Gutt's preferred rates of 176.625 and 43.827 Belgian francs to sterling and the us dollar respectively were the correct ones?.

In January 1944, accompanied by Theunis, Ansiaux and Boël, Gutt conducted fresh exchange-rate negotiations in Washington with White $^{10}$, in which British, French, Dutch and Norwegian representatives were also involved. Calculations by Ansiaux and Boël indicated that Gutt's preferred rates were the most obvious ones to adopt; indeed, they were very much in line with the French and Dutch options. A margin of uncertainty nevertheless remained, as the future relationship of sterling to the us dollar remained unknown. White's initial reaction to the Belgian proposal was sceptical: he feared that the suggested rates were too high and would be an obstacle to Belgian exports, which would be a crucial factor in Belgium's post-war recovery.

Tradition has it that, towards the end of difficult talks, which had been continued by Ansiaux after Gutt's departure, White suddenly asked how much a female cloakroom assistant received in Belgium for her services, to which Ansiaux is supposed to have answered 'one franc'. After a few seconds' silence, White is then supposed to have declared that, in that case, he sympathized with the Belgian proposal. To everyone's relief, he closed the meeting with the redeeming statement that it was up to the Belgian government to determine its country's rates of exchange. Provided the rates were reasonable, the American government would agree to them ${ }^{11}$. At the Belgian Cabinet meeting of 7 April 1944 in London, Gutt once again tabled the proposal that he and Ansiaux had defended in Washington. This time his rates of respectively 176.625 and 43.827 were approved. He had good reason to be satisfied.

A final, major question remained to be resolved. The establishment of an International Stabilization Fund and a World Bank had still to be

9 ARA, Theunis Papers, 'correspondance Theunis-Gutt': letter of 07.10.1943 from Theunis (New York) to Gutt (London).

10 ARA, Theunis Papers, 'correspondance Theunis-Gutt': memorandum with a report of the meeting in White's office, 07.01.1944; letter of 24.01.1944 from Theunis (New York) to De Schryver (London).

11 BNB, Archives, London Archives, dossier 'Janssen': notes on a conversation with Ansiaux, 23.02.1944; BNB, Archives, $S D$, Ansiaux Papers, dossier 'période de guerre et immédiatement après-guerre' (letter of 03.05 .1985 from van Bellingen to Ansiaux, with the text of an announcement made by Ansiaux at a colloquium in London). 
proposed to the future member states and approved. During the winter of 1943-1944, White and Keynes had reached an accommodation and now submitted a joint project that by and large embodied the American plan. During the discussions, the interests of the Benelux countries were successfully defended by Boël, Crena de Iongh and Jacques J. Po$\mathrm{lak}^{12}$. Combining the membership quotas set for Belgium and the Netherlands meant that the two countries could jointly appoint an executive director in the executive committee of both the Fund and the Bank ${ }^{13}$.

Gutt, Theunis and Boël played a fairly important role at the Bretton Woods Conference (1-22 July 1944), at which they represented Belgium, together with Joseph Nisot, Baron de Gruben and Boris-Serge Chlepner ${ }^{14}$. Gutt was elected one of the four deputy-chairmen of the conference and, with Theunis, was asked to prepare the reports of the World Bank commission. During the discussion Boël drew attention to the principle of fixed exchange rates, which Keynes had previously succeeded in substantially watering down, while pushing through his own opinion of the problem, but the Belgian delegation was able to get the regulations for this important issue tightened up again.

Theunis and Gutt left the Bretton Woods Conference feeling relatively satisfied at the results that had been achieved. They were impressed by the unanimous will to work for international cooperation, so different and so new in comparison to the politics of the 1930s. For an export-oriented country like Belgium, it was extremely advantageous to see the emphasis being placed on the idea that the key to sustainable recovery of the world economy was an expansion of world trade ${ }^{15}$.

12 BNB, Archives, SD, Ansiaux Papers, A 1, dossier 0.1/30: letter of 25.05.1944 from Boël (Washington) to Gutt (London).

13 Polak, 'Financial Relations between the Netherlands and Belgium' in: A. Bakker et al., eds., Monetary Stability through International Cooperation. Essays in honour of André Szasz, Amsterdam, 1994, pp. 184-185.

14 Crombois, Camille Gutt, 1940-1945, p. 389.

15 ARA, Administrative services of the Prime Minister: letter of 24.07.1944 from Gutt (New York) to Pierlot (London); ARA, Theunis Papers, 'correspondance TheunisSpaak': letter of 03.08.1944 from Theunis (New York) to Spaak (London). 
THE BANKNOTES FOR THE ARMY OF LIBERATION AND FOR THE CURRENCY REFORM

As already indicated, financing the army of liberation became a thorny problem, in consequence of the landing of the Allies in North Africa at the end of 1942. Gutt therefore contacted the British Treasury at the beginning of 1943 and emphasized that the Allied troops landing in North-western Europe would have to respect certain elementary rules, one of which was that an army of liberation in Belgium would be required to settle its expenditure and pay its troops exclusively in Belgian francs. The Belgian government in London would make the requisite banknotes available at the appropriate moment ${ }^{16}$.

An agreement was reached in May 1943 with the British Treasury, according to which the Belgian government would instruct the Bank to deposit 750 million Belgian francs in banknotes with the Bank of England, for the account of the War Office. In a further agreement concluded on 29 October, that was increased to 4 billion Belgian francs and provision was made for a line of credit to be opened at the Bank for 1 billion Belgian francs. Repayment was to be made in sterling at a rate to be determined by the Belgian government in consultation with the British government, once Belgium had been liberated. The provision of services to the Allied armies would be borne by Belgium as a contribution towards the liberation of her territory ${ }^{17}$.

Thus, by December 1943 full preparations were being made for the issue of banknotes to be advanced to the Allied armies and the new banknotes to accompany the currency reform. Contrary to what he had achieved with the British, Gutt had still not been able to conclude a concrete agreement with the Americans. In an attempt to find a satisfactory arrangement, he had a fresh meeting in Washington on 29 December with White and his assistant Taylor. Irritated by Gutt's insistence, however, White rejected every proposal and declared that there could be no immediate solution for Belgium. In particular what was holding him back was the fact that the estimates for the cost of re-conquering Eu-

16 somA, Archives, Gutt Papers, dossier AA, 1624: letter of 15.04.1943 from Gutt (London) to Waley (London).

17 SOMA, Archives, Gutt Papers, dossier AA 1624: letter of 07.05.1943 from Gutt (London) to Waley (London) and Gutt's memorandum of 29.10.1943. 
rope still had to be endorsed by Congress, a delicate matter. White was, in fact, looking to integrate everything into a single package covering the entire operation of the landing and the re-conquest, and only when that had been done would it be possible for a specific arrangement to be made for Belgium. However, Gutt continued to press his point, arguing that, he, too, had budgetary obligations with regard to the Belgian people. Moreover, he could not see why, if Great Britain could come to an arrangement with Belgium, the United States still would not. It was all to no avail. White remained unmoved and closed the discussion with the vague promise that the United States would honour its obligations and proceed in due time to the reimbursement of all costs. However, a separate agreement between the two countries was at present out of the question ${ }^{18}$.

Further discussions took place in January and February 1944, but also without success ${ }^{19}$. At one moment, White even declared that he knew nothing of the Belgian banknotes being printed in Great Britain and that the us dollars (bearing a yellow seal) for the American troops to be landed in North-western Europe were ready. Ultimately, he agreed in principle to Gutt's demand for American military expenditure in liberated Belgium to be in Belgian banknotes.

During these difficult talks, Gutt, Ansiaux and Boël had held consultations with the French and the Dutch, to take joint action to get agreement from White about the amount of money held by the American army of liberation, but that did not lead directly to any formal agreement. Nevertheless, White gave the Belgian delegation a few guarantees. He would propose to Congress that the American army of liberation undertake to pay exclusively in Belgian francs in Belgium and would also attempt to have all military expenditure reimbursed within the framework of the Mutual Aid Agreement. Furthermore, he promised that the military command would keep accurate accounts of all expenditure $^{20}$. An agreement on those lines was ultimately signed on

18 soma, Archives, Gutt Papers, dossier AA 1624: report of the meeting in White's office in Washington, 29.12.1943.

19 ARA, fonds ministerie van Financiën: letter of 09.02.1944 from Gutt (Washington) to de Gruben (Washington); BNB, Archives, London Archives, dossier A.-E. Janssen: notes on a conversation with Ansiaux, 23.02.1944.

20 ARA, Theunis Papers, 'correspondance Theunis-Gutt': letter of 10.03 .1944 from Ansiaux or Boël (Washington) to Gutt (London). 
1 June 1944 with the Supreme Commander of the Allied forces ${ }^{21}$, and by 6 September, 1,840 crates of Belgian banknotes in denominations of 1,000, 500, 100, 50 and 10 francs were in the hands of the Supreme Headquarters Allied Expeditionary Force (SHAEF).

\section{THE ORGANIZATION OF THE BANK'S RETURN TO BELGIUM}

From the autumn of 1943 onwards, the Belgian government and the Bank's management in London and in New York began to prepare for their return to Belgium ${ }^{22}$. A memorandum with clear proposals was already on the table in $\mathrm{October}^{23}$. Authority would be delegated to one of the directors in London, who would follow closely behind the army of liberation and immediately assume control of the Bank's branches as they were liberated, as well as the head office in Brussels. The director would be accompanied by a small staff and, via the Belgian Military Mission, would also work with the Allied Supreme Commander, all the while retaining his independence. The government's choice for this task was Ansiaux, who received his appointment in the spring of $1944^{24}$.

In December 1943, Theunis began to look for a way to ditch the Bank's management in Brussels and turned to Nisot, his legal adviser in New York, to find one ${ }^{25}$. Nisot's proposal was ready by the beginning of January: the government was to issue a decree stating that, from the time of the liberation to the first subsequent general assembly, the management of the Bank was to be exercised exclusively by the Governor

21 BNB, Archives, London Archives, 1944: expéditions de billets par le SHAEFF.

22 In November-December 1943 Theunis was already preparing the great purging of the leaders of the Bank and the Banque d'Emission: 'Avez-vous déjà pensé à ce que vous ferez du faux gouverneur, du molasson Ingenbleek et des deux individus qui se sont introduits pour faire marcher à fond le clearing en faveur de l'Allemangne? Je suppose que votre réponse est: un coup de balai (BNB, Archives, London Archives, 1943: letters of 18.11.1943 and 28.12.1943 from Theunis (New York) to Baudewyns (London).

23 SOMA, Archives, Gutt Papers: memorandum of 25.10.1943 on the organization of the Bank during the re-conquest of the country (London).

24 SOMA, Archives, Gutt Papers: letter of 22.05.1944 from Gutt (London) to Frazer (London).

25 ARA, Theunis Papers, 'correspondance Theunis-Baudewyns': letter of 14.12.1943 from Theunis (New York) to Baudewyns (London). 
and the two directors from London. That same decree would invest Ansiaux with authority to act during the re-conquest of the country, which would automatically disqualify the Brussels management of the Bank from exercising any authority in the interim ${ }^{26}$.

In Baudewyns's opinion no special decree was required for the Brussels management to be purged after the country's liberation and for Ansiaux to be invested with the agreed authority, as both the organic law governing the Bank and the Bank's own bye-laws provided for such measures to be taken ${ }^{27}$. This became a point of dispute between Nisot and Baudewyns, and was ultimately resolved in Baudewyns's favour ${ }^{28}$.

The liberation was now at hand and Ansiaux joined the army of liberation as soon as it approached the Belgian border. Theunis in New York and Baudewyns in London, together with the government, began to organize their return to a liberated country. This came at the beginning of September 1944.

26 BNB, Archives, Ansiaux Papers, A 2: note de Nisot (New York) concernant la BNB, 03.01.1944.

27 BNB, Archives, London Archives, 1944: letter of 06.03.1944 from Baudewyns (London) to Theunis (New York) (statut juridique de la Direction de la BNB en prévision du retour).

28 вNB, Archives, $S D$, Ansiaux Papers, A 2, dossier 9.1/26; 'correspondance Gutt et autres': letters of 24.03.1944 and 30.03.1944 from de Selliers de Moranville (New York) to Ansiaux (London). 


\section{The Return from London}

\section{THE GREAT SETTLING OF SCORES}

When Brussels was liberated on 4 September 1944, the Bank's management had all the counters closed and waited for instructions from London. However, these did not arrive immediately and the Brussels board of directors found itself in a state of temporary paralysis. A degree of clarity was provided by Prime Minister Pierlot's address on the government's return to Belgium on 8 September, in which he declared that all appointments made in Belgium during the war were to be regarded as null and void. At the same time, he elucidated the measures taken by the government a few days earlier in London to safeguard the money supply and that were now of immediate effect in Belgium.

The following morning, Goffin was summoned to the Minister of Finance and, in an extremely short encounter, was requested to tender his resignation and quit the Bank's premises. He complied forthwith. Ingenbleek was then summoned to an even less friendly encounter, with Gutt reproving him for his lax, even collaborationist stance during the occupation and demanding his immediate resignation. With the alternative of immediate dismissal, Ingenbleek, too, complied forthwith'.

In a decree of 5 September 1944, the government had declared that all the measures regarding the Bank, announced on 27 November 1941, had now lapsed. More particularly, the Bank's registered office was brought back to Brussels, the board of directors would henceforth consist of six members, and all present directors, as well as the members of the supervisory council and the board of scrutineers, would have their mandates terminated on the day of the next general assembly meeting,

1 BNB, Archives, $D C$, 09.09.1944; BNB, Archives, SD, dossiers officiels après 1945, dossier 45: administration de la Banque (démissions): letter of 09.09.1944 from Ingenbleek to Gutt. 
when new elections would be taking place. On the government's return from London, Gutt (on Smeers's advice) had entrusted the management of the Bank to an interim management board consisting of Vandeputte, Ansiaux, Sontag and Basyn, ${ }^{2}$. The board met daily from 11 to 15 September and was replaced by a normally functioning board of directors on 16 September, the day of Governor Theunis's return from New York. This new board was chaired by the Governor and had five other members: the directors Baudewyns, Ansiaux and Vandeputte, the Treasurer Sontag and the Secretary Basyn ${ }^{3}$.

At the first meeting of the general council on 27 September Theunis announced the resignation of Goffin and Ingenbleek. The council immediately inferred that what had taken place was not 'resignation', but 'dismissal': the fact that Goffin had been 'removed' from office must thus have been due to a blameworthy attitude during the war. Even though the word was not uttered, some members of the council regarded Goffin's dismissal as a censure that also reflected on them, something they were not prepared to accept. The ensuing discussion was developed by Bekaert and Peltzer, members of the supervisory council, into an open defence of Goffin. They stressed that his appointment in 1941 as governor had been the only way to prevent a catastrophic German nominee. As governor, furthermore, they claimed that Goffin had always acted bravely, patriotically and with dignity. If his dismissal implied a censure, that censure fell on all members of the council. They went on to ask whether there was, perhaps, a secret agenda behind the decree of 5 September, and whether this was part of an attempt by the executives from London to get rid of all those present at the general council, on the pretext of their having adopted too lax an approach during the occupation ${ }^{4}$. Theunis climbed down, stating that Goffin's resignation in no way implied blame on the members of the council, and added that he rejoiced to be once more among his colleagues of the supervisory council and the board of scrutineers.

Theunis and Gutt were no doubt given food for thought by the critical reaction of the supervisory council to the less-than-elegant way in which they had treated Goffin. The incident during the meeting of the

2 BNB, Archives, $D C$, 09.09.1944.

3 BNB, Archives, DC, 16.09.1944.

4 BNB, Archives, AR, 27.09.1944. 
general council probably made them realize that they had not sufficiently assessed the difficulty in carrying out policy during the occupation. Indeed, Gutt was later to concede that the government in London had been very isolated during the war and that what information it had received about the policy being pursued in Belgium came from the few individuals who had fled to London and who themselves were poorly informed or had a biased view of what was taking place in the occupied territory ${ }^{5}$. Barely a couple of months after the dramatic events at the Bank, both Gutt and Theunis therefore felt morally obliged to make a gesture towards Goffin ${ }^{6}$. Following joint consultation and after seeking the jurist Marcq's opinion, Theunis proposed to the supervisory council that Goffin be granted a pension in recognition of services rendered', a proposal that was approved ${ }^{8}$.

However, Frère, elected Governor on 3 November, and the newly elected directors protested against the resolution to award a pension, pointing out that the bye-laws of 1937 forbad the members of the board of directors from receiving any remuneration from the Bank other than the salary allotted to them, which was deemed to be sufficient for them to make their own arrangements for their pensions or to cover other risks. On 2 March 1945 this standpoint was endorsed by the Minister of Finances.

The resignations at the Bank were not confined to the Governor and the Deputy-governor, but also involved the directors Vandeputte and Cracco. Vandeputte was convinced that he would be elected as director at the meeting of the general assembly on 3 November 1944. His view was that, during the past months, Gutt and Theunis had given him credit for what he had done during the final years of the war and had regarded him as a worthy colleague during the transitional months of September and October. Cracco, for his part, had managed at the last minute - just before his deportation to Germany - to put his name forward for election as a director and it was assumed that his candidature

5 ARA, Theunis Papers, 'correspondance Theunis-Gut': letter of 02.03.1947 from Gutt (Washington) to Theunis (Brussels).

6 NBB Archives, $R R, 2$ 29.11.1944; BNB, Archives, AR, 13.12.1944.

7 BNB, Archives, $S D$, Frère Papers: letter of 28.11.1944 from Goffin to Frère.

8 BNB, Archives, AR, 25.10.1944.

9 BNB, Archives, Frère Papers, dossier 'pension, Goffin': letter of 17.02.1945 from Frère to Eyskens; letter of 02.03.1945 Eyskens to Frère. 
would be accepted without demur. Particularly during the final months before his deportation, he had presented himself as an active defender of the Bank's interests. As a director, moreover, he had been regarded by the German authorities in Belgium as a sharp and difficult negotiator and had even earned their grudging respect. Now he had the aura of a member of the Resistance, held captive in a German prison. In the first flush of the liberation, was there anyone who could offer better credentials as a candidate for Bank director?

Gutt and Theunis had no problems with the two candidatures, but Berger and Van Nieuwenhuyse did and informally vetoed them ${ }^{10}$. They felt that, as 'members of the Resistance', they could demand to be reinstated on the board of directors themselves and refused to sit on it with Vandeputte and Cracco, though why this was so difficult for them remains an open question. Gutt and Theunis gave in. They had been suddenly catapulted out of their ivory towers in London and New York into reality or, rather, into the chaos of an unrecognisable country that appeared to be their fatherland. They wanted to adjust to circumstances far distant from those of the Belgium that they had left. If voices were raised against Vandeputte and even against Cracco, they felt that they had to take account of them.

The question of purging officials at the Bank also raised questions within the supervisory council. Although Peltzer had been arrested three times by the Germans during the occupation (a consequence of his patriotic stance and actions), he was detained on 9 July 1945 by the public prosecutor on suspicion of economic collaboration ${ }^{11}$. Within the

10 Report of Vandeputte's address to the meeting of the general council on 25.10.1944: 'Convoquéchez le Ministre des Finances dès la libération du territoire, M. Vandeputte s'est entendu dire par lui que l'on avait au sujet de son activité (comme directeur de la Banque) une opinion favorable. Le Ministre des Finances n'a pas manqué d'exprimer lui-même sa satisfaction sur la manière dont $M$. Vandeputte a défendu les intérêts $d u$ pays. M. Vandeputte a dans ces conditions continué à collaborer après la libération avec le Ministre des Finances pour la mise au point des arrêtés monétaires qui furent dans une très large mesure le fruit des travaux des commissions d'études qui ont siégé à la Banque Nationale sous l'occupation, aux travaux desquels il a régulièrement participé': BNB, Archives, AR, 25.10.1944.

11 The Bank's agent reported the 'grande émotion' that the detention of Peltzer excited in the region: 'aucun homme de bonne foi ne pouvait considérer André Peltzer comme un collaborateur volontaire de l'ennemi. L'intervention soudaine, et à mon avis regrettable, de l'auditorat militaire est généralement attribuée à la pression 
board of directors, Berger asked whether, under those circumstances, Peltzer could remain as a member of the supervisory council and stated that, in any case, no further credit should be granted to his companies. Ultimately the problem solved itself, with Peltzer being provisionally freed in August and all charges against him and his companies dropped shortly thereafter.

The purging was not restricted to members of the management, but also extended to members of the staff. Shortly after the liberation, the Bank set up a commission of enquiry whose task was to identify any anti-patriotic behaviour on the part of staff and to suggest appropriate sanctions to the management ${ }^{12}$. The commission completed its work in February 1945 and its investigations resulted in the immediate dismissal of eleven members of staff at head office; three others received notice of dismissal and one other was asked to resign. Out of a staff total of around 1,000, that is no bad score for a period that can be appropriately labelled repressive.

The purging turned lastly to the Banque d'Emission. Although the Bank and this institution had worked very closely together during the occupation, the Belgian government in London during the war and Governor Frère after the liberation attempted to make a fairly sharp distinction between the two. This harked back to Governor Janssen's conscious attempt to use a clear division of function between the two in order to delineate the specific character of each. He had managed to organize the distribution of responsibility in such a way that all financialeconomic activities directly concerned with the occupation as such, or manifestly linked to the exceptional circumstances of war, were shifted onto the Banque d'Emission, leaving the Bank, as far as possible, to pursue its pre-war activities. That division of function also proved helpful to the Belgian government in London, which was now able to secure the Bank from any possible suspicion of collaboration during the difficult

d'éléments communistes... Les employés et les ouvriers des usines sont déjà intervenus en faveur de leur patron'. In a telegram, Madame Jeanne Peltzer addressed herself directly to Frére: 'mon sang britannique est révolté par l'ingratitude montrée à l'égard de mon mari, qui a vu son devoir de rester auprès de ses ouvriers au lieu de suivre mon désir de rentrer dans mon pays l'Angleterre en 1942': BNB, Archives, SD, Frère Papers: dossier 'arrestation André Peltzer'.

12 BNB, Archives, DC, 29.09.1944. 
war years. The full odium of economic and financial collaboration was thus shifted onto the Banque d'Emission, which, after Janssen's death, was led by its founder-bankers, together with the boards of directors of the two institutions.

After the liberation, the lead in the country's overall purging was taken by the parties of the Left, particularly the Communist party, which had made its mark in the Resistance during the final years of the war. They accused the Banque d'Emission of having used the guise of the employment policy to help Belgian industrial and financial big business to legitimize collaboration. They claimed further that big business had done well out of the war and, with the support of the Banque d'Emission, had unjustifiably enriched itself. The fierce campaign that was consequently launched by the Left against the Banque d'Emission initially confirmed the suspicions of the government, recently returned from London.

As indicated, the Banque d'Emission had, with effect from 4 September 1944, closed its doors in Brussels. Pursuant to its bye-laws, the Banque d'Emission had to be liquidated on the cessation of hostilities, and its founder-bankers gathered on 18 September to review the matter. De Munck and others judged that liquidation could not take place until the Banque d'Emission's Belgian current accounts and certificates had been paid out, even if that required further advances from the Bank. Collin even took the view that the unpaid credit balances at the Verrechnungskasse in Berlin had to be settled first. Vandeputte, still a member of the Bank's board of directors, was better informed about the negative opinion held of the Banque d'Emission by the new Bank management and by the government, and therefore rejected the proposals as unrealistic, making it clear at the same time that the suggested approach to the Bank had no chance of success.

For these reasons, Vandeputte felt that it would be more advisable to prepare a general report for the Minister of Finance on the problem of liquidating the institution, a problem that was particularly acute in respect of the creditors and chiefly the Bank. On 20 September the board of directors agreed that Vandeputte should draw up such a report and also formulate a number of proposals for the settlement of certain priority liabilities, after their legitimacy had been determined ${ }^{13}$. Mean-

13 BNB, Archives, $S D$, 40, dossier 8.11.40/1: liquidation de la BEB (réunion des banquiers fondateurs, 25.09.1944; $B R B E B, 27.09 .1944)$. 
while, it had become clear that the situation was going to be reviewed through entirely different eyes, as the matter had been taken in hand by the military prosecutor's office (see infra).

\section{GOVERNOR THEUNIS IN BRUSSELS}

Theunis's spell as governor in Brussels was brief, lasting from 16 September to 3 November 1944 . The period may have been short, but exceptional circumstances made it one during which important and momentous steps were taken as regards not only the management of the Bank, but also the entire country. On 20 and 27 September, Theunis submitted a concise, provisional review to the supervisory council and the general council of the Bank's activities in London during the war years $\mathrm{s}^{14}$. He stated that, at the time of the German invasion, the major task entrusted by the management to the Bank's representatives abroad had been to secure the gold reserves. He took the view that the task had been more than admirably fulfilled, since the approximately 21 billion Belgian francs' worth of gold transferred abroad before and at the beginning of the invasion had been reduced by no more than 247 million francs' worth. It was true that the Banque de France had surrendered about 6.6 billion francs' worth to Nazi Germany, but he hoped that, thanks to the legal proceedings instituted in New York against the French central bank, this could be recouped in full.

Theunis also announced that, in exchange for Treasury certificates, the Bank had granted about 10 billion Belgian francs in interest-free advances to the Belgian government in London, which had used them in part to provide financial help to the Allied forces. The government had also used the money to set aside a substantial provision for the eventual redemption of the Treasury certificates that the Banque du Congo Belge had received during the war in exchange for the cession of gold and sterling. Lastly, Theunis reported that the Bank's own expenditure in London during the war had amounted to nearly 49 million Belgian francs, covering chiefly the cost of transporting Belgian gold from London to Ottowa in June 1940, the printing of new banknotes and the accommodation expenses of the Bank's staff in London during the war.

14 BNB, Archives, RR, 20.09.1944; BNB, Archives, AR, 27.09.1944. 
The preparations for the election of the six new directors on 3 November generated a great deal of tension within the Bank. In accordance with the bye-laws, it fell to the general council, on the advice of the governor, to propose the candidates for consideration to the general meeting of shareholders, but Theunis felt that the new governor, though not yet appointed, ought also to have a certain say in the composition of what was to be his board of directors. Additionally, pressure from Theunis and Gutt, coupled with the veto of Berger and Van Nieuwenhuyse, had led Vandeputte to withdraw his candidacy. During his final attendance at the meetings of the general council, though, he gave vent to his great disappointment, declaring that he had not sought his appointment in 1943, but that, in spite of the very substantial risks he knew it entailed, had ultimately accepted it at the urging of a number of prominent figures who had all reminded him of his patriotic duty ${ }^{15}$.

The directors appointed at the general meeting of 3 November were Ansiaux, Baudewyns, Berger, De Voghel, Smeers and Van Nieuwenhuyse. The Prince Regent of the country, Charles, appointed Frère as Governor and Baudewyns became Deputy-governor. Joseph Vanheurck, previously Director-general of the Treasury and the National Debt, became Government Commissioner, Sontag remained in his position as Treasurer and Basyn was confirmed in his previous function as Secretary.

Fresh difficulties arose at the beginning of 1945. It was still not possible for the considerable moneys due to the Bank from the State to be settled and there was nothing to indicate that there could be settlement within the foreseeable future The problem of the tax on war profits had not yet been entirely cleared up and it was equally uncertain what precisely should happen in respect of the revaluation of the gold reserves. Added to that was the very precarious situation of the Bank itself. There was still no certainty about whether the State would assume the enormous debt of 64.6 billion Belgian francs due to the Bank from the Banque d'Emission. On top of all this, the Socialist representative Lode Craeybeckx submitted a bill in March 1945 for the nationalization of certain sections of the Belgian economy, including the Bank. The board of directors felt that, under these circumstances, it would be both inopportune and impossible for the Bank's claims against the

15 BNB, Archives, AR, 25.10.1944. 
State to be settled in the short term, let alone for a radical reform of the Bank to be launched in the immediate future. In April, therefore, the Bank resolved to postpone both settlement and reform until a less tense moment ${ }^{16}$. It was thus only on 13 September 1948 that - in implementation of the law of 28 July 1948 - settlement and reform would finally be arranged ${ }^{17}$.

The obligation to submit the balance sheets and accounts for the 1940-1944 financial years before the end of June 1945 nevertheless remained. It was in fact met at an extraordinary general assembly meeting on 30 June 1945 at which, on behalf of the supervisory council, the board of scrutineers submitted them to the shareholders for discussion and approval ${ }^{18}$. The last balance sheet submitted set out the position of the Bank as at 31 December 1944. On the liabilities side, there was a directly payable amount of 46.3 billion Belgian francs, 42.7 billion of which in respect of new banknotes. On the assets side, the gold reserve was entered at a value of 32 billion Belgian francs, 10.5 billion of which (i.e. the increase in value, after the reserve's revaluation) was transferred to a blocked account in the name of the government, in order to redeem part of the State's short term debt to the Bank in a final settlement at a later date. At that moment the debt stood at 31.4 billion Belgian francs and would rise to nearly 41 billion in July 1945 .

\section{THE CLOSURE OF THE BELGO-FRENCH GOLD DOSSIER}

As indicated in Chapter 15, the legal proceedings that the Bank had instituted during the war in New York against the Banque de France had been suspended when the Germans had extended their occupation of France to the entire country, following the Allied landing in North Africa at the end of 1942. A second important consequence of the North African landing was the change in de Gaulle's position within the Allied camp. By joining the Americans in that landing, de Gaulle had

16 BNB, Archives, $D C$, 19.03.1945.

17 R. Simonis, 'Les règlements internationaux de 1939 à nos jours. Deuxième partie: la période de 1945 à 1950', in: Revue de la Banque, 48, 4/5, 1984 (special double issue), p. 53 .

18 BNB, Archives, AV, 30.06.1945, 27.08.1945. 
virtually supplanted the Vichy regime's General Giraud. He had also become the unchallenged leader of the Comité Français de Libération Nationale, which projected itself as the political organ of Free France against the Vichy government. The Belgian government in London was the first to recognize the Comité as the legitimate representative of Free France.

This was no coincidence. Since the beginning of 1943, the lawyers of the Bank and of the Banque de France had been prevented from conferring with the French government at Vichy and with the Banque de France at Clermont-Ferrand. Gutt consequently informed the French diplomat Hervé Alphand in the summer of that year that the Belgian government attached great importance to knowing what the Comités stance was regarding the matter of the Belgian gold. Alphand conveyed the message to Algiers, where the Comite then was, and on 5 October received a draft declaration in reply, to the effect that the Comité had no doubt that the Banque de France would restore the gold to the Bank after the war, as indeed had always been the central bank's intention. Moreover, the Comité promised to urge the future government of a liberated France to have the gold restored as soon as possible ${ }^{19}$.

Alphand passed the text of the reply to Spaak, who informed his government ${ }^{20}$. In December, the matter came up during two meetings between Gutt and Jean Monnet in New York, on the occasion of the conference establishing the United Nations Relief and Rehabilitation Administration (UNRRA) ${ }^{21}$. Gutt did not pull his punches and expressed his great disappointment with the French text, stating that a declaration of good will was wholly inadequate and that a more positive solution had to be offered. With Alphand and André Istel, and after consultation with Fuller in New York, Monnet drafted a new text in which the Comités undertaking was given more emphasis than in the original ${ }^{22}$.

19 BdFr, Archives, Secrétariat Général, dossier 1060.2001.01/41, 'or belge': projet, 04.10.1943; A/S: 'or belge', note (undated); $\mathrm{PB} / \mathrm{MI}$ : projet de déclaration (undated).

20 BdFr, Archives, Secrétariat Général, dossier 1060.2001.01/41, 'or belge': letter of 13.11.1943 from Valensi (Washington) to Guindey (Algiers).

21 BdFr, Archives, Secrétariat Général, dossier 1060.2001.01/41, 'or belge': letter of 14.12.1943 from Monnet (New York) to Comité de Libération (Algiers).

22 BdFr, Archives, Secrétariat Général, dossier 1060.2001.01/41, 'or belge': letter of 19.12.1943 from Monnet (New York) to Comité de Libération (Algiers). 
The Comité, backed by Jean Martial, who happened to be visiting Algiers at the time, was unable to agree with the draft, feeling that it went too far, and declared that the Comité itself had no legal competence to take measures regarding the disposal of assets of the Banque de France or to give an undertaking for their cession to the Bank. Monnet and Alphand refused to give up and asked Theunis for substantive details and suggestions that would correctly reflect the Belgian position on the matter and help in resolving the dispute. Theunis had Ansiaux draw up a memorandum, in which the whole story of the gold transfer to Berlin was set out with concrete data and figures. This was handed over to the French on 9 February $1944^{23}$.

In March 1944 Alphand and Monnet pressed the Comité to formulate more concrete proposals. The Comité now indicated its willingness to certify that the Bank would be reimbursed for all losses it had incurred regarding the gold deposited with the French central bank. Instructions were then given to Martial, who had meanwhile returned to New York, to work with Fuller to prepare a draft agreement on those lines ${ }^{24}$. The draft was completed in April and in it the Comité recognized the obligation of the French government to restore to the Bank after the war the crates of fine gold deposited in safe custody with the French central bank, or reimburse the equivalent in gold after the war $^{25}$.

It is likely that there was no immediate discussion of the draft. Martial fell seriously ill shortly thereafter and was given six months' sick leave; at the beginning of June, moreover, came the landings of the Allied forces on the coast of Normandy, which brought the prospect of the liberation of France and Belgium. Suddenly, there were other things occupying people's minds. Nevertheless, the question of the gold continued to concern the French and, in the course of June, the Comite - which had meanwhile become the Gouvernement Provisoire de la République Française - contacted the Belgian government directly in

23 BNB, Archives, Studiedienst, DS 13, dossier A 320/6: letter of 14.02.1944 from Nisot (New York) to Dulles (New York).

24 BdFr, Archives, Secrétariat de la direction, dossier 1060.2001.01/41, 'or belge': letter of 05.04.1944 from Massigli, Mayer and Mendès-France (Algiers) to Monnet (Washington).

25 BdFr, Archives, Secrétariat de la direction, dossier 1060.2001.01/41, 'or belge': letter of 15.04.1944 from Martial (New York) to Valensi (Washington). 
London, pressing for an amicable settlement ${ }^{26}$. Now, for the first time, Gutt reacted favourably. Spaak was fully supportive of Gutt's more positive attitude and was himself prepared to make a number of concessions ${ }^{27}$.

During the discussions, the provisional French government, represented by Pierre Mendès-France, initially kept to the draft text drawn up in April. Gutt sent the text to Theunis in New York for advice, who, in turn, passed it to his legal adviser, Nisot. His reaction was very negative: what were the actual conditions surrounding the guarantee of an eventual reimbursement by France? For how long could the legal proceedings be suspended ${ }^{28}$ ? In London, Ansiaux, too, had cast a critical eye over the proposal and he, too, saw it in a less than positive light. For him, it implied a change of debtor, which boiled down in legal terms to 'novation' - the substitution of a new contract in place of an old - whereby all the Bank's contractual rights vis-à-vis the Banque de France would lapse. Belgium had therefore absolutely to avoid recognizing a debtor other than the French central bank, certainly not the German government or the Reichsbank and certainly not the French government. Likewise, there could be no accepting the argument that, through force majeure, the Banque de France was freed from its responsibility. The Banque de France was the sole debtor and there could be no derogation from that underlying point. In addition, a suspension of the legal proceedings, as formulated in the proposal, could result in postponement sine die, which was a further risk to be avoided. In their assessment, the advisers were unanimous: the proposal had to be rejected $^{29}$.

During the Bretton Woods conference (15-22 July 1944) MendèsFrance organized an informal dinner, which was attended by the Belgians Gutt, Boël and Ansiaux, and the Frenchmen Istel, de Largentaye and Aglion. The purpose of the gathering was to seek a solution to the gold dispute, but talk also ranged over a Franco-Belgian monetary

26 Cornu, L’or monétaire au vingtième siècle, p. 188.

27 NBB, Archives SD, Ansiaux Papers, A2, s.f. 4: letter of 22.06.1944 from Ansiaux (London) to Theunis (New York).

28 BNB, Archives, SD, Ansiaux Papers, A 1: comments of 03.06.1944 by Nisot (New York) on Mendès-France's proposal to resolve the Belgo-French gold dispute.

29 BNB, Archives, SD, Ansiaux Papers, A 2: letter of 06.07.1944 from Ansiaux (London) to Gutt (London). 
agreement and, indeed, of a wider Franco-Belgian-Dutch economic cooperation agreement. Gutt - very soberly, as always - suggested that the last two points could better be discussed in London; as to the gold dispute, he stated frankly that the French proposal was unacceptable for three reasons. The first was that changing debtors was not customary practice between central banks and could not be permitted. The second was that he could not be satisfied with an undertaking from the provisional French government; there could be no certainty that a subsequent government would not dispute such an undertaking and simply ignore it. The third reason was that he regarded the proposed guarantee as empty and one that could remain on ice as long as the gold was not received back from Germany. Gutt's negative response came as a disappointment to Mendès-France, who now saw himself obliged, once again, to go through the long process of finding consensus among de Gaulle and the members of his provisional government for a new, viable formula ${ }^{30}$.

By 28 July, Mendès-France and Istel had come up with an amended proposal. The formula of the guarantee was replaced by the promise that, as soon as its head office was liberated, the Banque de France would make immediate payment of an advance to the value of the Belgian gold deposited with it. This would be guaranteed by the provisional government and the advance would be repayable only if the Bank was unable to recoup the gold from Germany. Naturally, the provisional government counted on the Bank suspending the legal proceedings in New York forthwith and cancelling them once the payment of the advance had been received. Gutt felt that the new proposal contained a number of important improvements: for example, the Banque de France now regarded itself as the debtor and the formula of the advance implied immediate and effective payment. However, he thought that it still needed more work ${ }^{31}$.

At the insistence of the French government, the matter was fasttracked as soon as Paris was liberated in August 1944. France was anx-

30 ARA, Administrative services of the Prime Minister, Pierlot Papers, dossier 6: letter of 21.07.1944 from Gutt (Bretton Woods) to Spaak (London).

31 BNB, Archives, SD, Ansiaux Papers, A 1: new proposal from Istel, with comments from Nisot, 28.07.1944. See also: BZ, Archives, dossier 12.318: letters of 04.08.1944 and 14.08.1944 from Gutt to Spaak. 
ious to start importing goods from the United States as soon as possible and was consequently looking to have the sequestration on her gold lifted. The acting governor of the Banque de France, Henri de Bletterie, informed the Belgian government in London that the French central bank had always recognized its liability towards the Bank and therefore desired as speedily as possible to meet its obligation to restore the gold, adding that the French Minister of Finance was in full agreement with this ${ }^{32}$.

Backed up by Baudewyns, Ansiaux and a few members of the Ministries of Finance and Foreign Affairs, Gutt immediately began negotiations in London with the Banque de France's representatives and a text was hammered out by the beginning of September that could meet with everyone's approval ${ }^{33}$. The Banque de France undertook to restore the Belgian gold as rapidly as possible and the provisional French government declared itself prepared to make immediate and full restoration if the gold was not back in the Bank's hands by 23 December 1944, the details of all this to be resolved between the two central banks. For its part, the Belgian government promised to press the Bank to suspend the legal proceedings until 23 December and to abandon them once the agreed restoration had taken place. Belgium would also make a special effort to track down the looted gold and would transfer any it recovered to the French central bank. In a letter to Theunis, Gutt expressed his great satisfaction with the proposal and was told in return that the reactions in New York were also highly favourable ${ }^{34}$.

The French Minister of Foreign Affairs, Georges Bidault, wrote to Spaak on 16 September 1944 that the Banque de France was prepared to restore the gold, so that no further negotiation at governmental level was necessary; this could now be taken over by the two central banks ${ }^{35}$. On 2 October, de Bletterie came personally from Paris to the Bank in

32 BNB, Archives, SD, Ansiaux Papers, A 1: memorandum of August 1944.

33 BdFr, Archives, Secrétariat Général, dossier 1060.2001.01/43, 'or belge': telegram of 08.09.1944 from the Banque de France (Paris) to the French embassy in London.

34 BNB, Archives, SD, Ansiaux Papers A 1: letter of 23.08.1944 from Gutt (London) to Theunis (New York); letter of 26.08.1944 from Spaak (London) to Gutt (London) and Theunis (New York).

35 BNB, Archives, SD, Ansiaux Papers, A 1: letter of 16.09.1944 from Bidault (Paris) to Spaak. 
Brussels to set the negotiations in train. With the instruction to be flexible, Bolgert and Sancery were delegated to continue discussions during the following days and bring them to a successful conclusion. In this respect, the Luxembourg gold (4,317 kilograms' worth) ought strictly to have been deducted from the amount of gold to be restored, as the Bank itself had ordered it to be surrendered to Germany, but the negotiators were given leeway to make a concession here, should the Bank take a rigid stance and require the Luxembourg gold to be included. The negotiators were also given a free hand regarding the actual place for the transfer, which the Bank preferred to be France and the Banque de France naturally preferred to be in a country where it held a stock of gold. A Belgian concession to the French on this point would, of course, save the French paying the transport costs, but the negotiators were free to meet the Bank's wishes. As regards the costs and fees involved in the legal proceedings in New York, the negotiators were required to suggest that each party bear its own costs and the fees for which it was liable. Should the Bank insist on a fifty-fifty arrangement, this could be accepted, but only in respect of costs, not fees ${ }^{36}$.

It appeared on the eve of the negotiations that an agreement would soon be struck ${ }^{37}$, but disillusionment rapidly set in, especially on the French side, the French delegation noting: 'The distrust and obstinacy shown by the Belgians since nearly four years have not at all softened ${ }^{38}$. During the first meeting, Theunis baldly announced that, in the absence of an agreement, the Bank would continue with the legal proceedings in New York and undoubtedly win the case. Then, on 6 October, Ansiaux joined the negotiators and stated that Gutt could not agree to the French proposal to exclude the Luxembourg gold from what was to be restored. In answer, the French delegation argued that it had been the Bank, the actual custodian of the Luxembourg gold, that had given the Banque de France express instructions during the war to send that

36 BdFr, Archives, Direction de la documentation, dossier 1397.1994.01/90, 'or belge': note pour le ministre, 29.09.1944.

37 BNB, Archives, DC, 02.10.1944, 03.10.1944, 04.10.1944.

38 In a comprehensive report, Bolgert set out the course of the negotiations in detail: BdFr, Archives, Direction de la documentation, dossier 1397.1994.01/89, 'or belge': compte-rendu des négociations qui se sont poursuivies à Bruxelles du 1er au 8 octobre 1944. 
gold to Luxembourg, from whence it had been transferred to Germany. It was therefore not the Banque de France, but the Bank that was liable to reimburse the Caisse d'Epargne du Luxembourg.

The tone of Ansiaux's reply was regarded by the French as being particularly virulent. His argument was that both the Banque de France and the French government had unacceptably ignored the royal decree of 2 February 1940. That decree had declared all Belgian officials in occupied territory to be incompetent to enter into any commitments abroad on behalf of the State or their institutions; consequently, the instructions of Janssen and Ingenbleek in respect of the Luxembourg gold were to be deemed invalid, and thus responsibility for the French central bank and the French government failing to take account of the decree could not be laid at the door of the Belgian government.

The French delegation forcibly rejected this argument, pointing out that, in July 1940, Janssen had returned to Brussels with the full authorization of the Belgian government and that all his actions until his death in June 1941 had been recognized as legally valid by the Belgian government in London. Why, the French questioned, should his action regarding the Luxembourg gold be specifically excluded from this? However, the Belgian negotiators stuck obstinately to their standpoint, which simply served to sour the negotiations.

During a meeting the next day between the French delegation and Gutt, the Minister, once again, demanded that the Luxembourg gold be included in what was to be restored to Belgium. According to the French, this could not be done immediately. In the first place, there had to be a formal request from the Caisse d'Epargne du Luxembourg; secondly, that institution would have to prove that, prior to the surrender of the gold to the Reichsbank, it had not received any reimbursement or compensation. However, Gutt continued to insist on his original demand until the French ambassador, also present at the meeting, gave an undertaking that his government would stand surety for the restoration of the Luxembourg gold to the Bank. Gutt now agreed to drop the demand for its immediate restoration and to have that take place at a later date. With this, the problems were straightened out and Gutt concluded with a special word of praise for the French gesture.

The agreement was signed on 8 October by Bolgert and Sancery for the Banque de France and was ratified a few days later by the institu- 
tion's acting governor, de Bletterie ${ }^{39}$. By the terms of the agreement, the French central bank undertook to transfer 198,434 kilograms of fine gold to the Bank before 23 December that year ${ }^{40}$. The agreement also laid down that the Bank could select the location for the transfer. After a little hesitation, the Bank opted for the Federal Reserve Bank of New York and restoration duly took place on 22 December $1944^{41}$. That same month, a proportion of the French gold held at the Federal Reserve Bank of New York and subject to the sequestration was released, the sequestration being lifted entirely the following month ${ }^{42}$.

Ultimately, everyone gained satisfaction from this result, the French delegation because the Banque de France's unimpeachable reputation had been confirmed and efforts could now be focused on getting the sequestration in New York lifted. It is true that the Belgian delegation had had to make a few concessions, but it, too, had cause to be satisfied with the result when it later heard from Dulles that, in essence, legal proceedings would have dragged on much longer than originally thought and that they might well have had to be settled by an international or even a French court of law ${ }^{43}$. The French central bank's promise to take the French banknotes still in the Banque d'Emission's portfolio was an additional reason for the Belgians to be very pleased with the outcome.

39 BNB, Archives, RR, 09.10.1944. BdFr, Archives, Secrétariat du Conseil Général et $d u$ Conseil de la politique monétaire, dossier 1069.1989.19/2, 'or belge': convention franco-belge, 8-9.10.1944..

40 The accounting department calculated the amount of gold to be restored as follows: on 10.05.1940, the Bank had entrusted a total of $245,503 \mathrm{~kg}$ of fine gold to the Banque de France (209,505 kg in deposit, 35,998 under dossier). Between 10 May and 4 June, $42,702 \mathrm{~kg}$ of this had been withdrawn, leaving a net balance of $202,801 \mathrm{~kg}$. The provision later granted by the Bank was regarded as cancelled. From the balance was deducted the amount of the Luxembourg gold deposited with the Bank $(4,317$ $\mathrm{kg}$ ) and the cession, later noted, of $50 \mathrm{~kg}$, leaving a final amount to be restored of $198,434 \mathrm{~kg}$ of fine gold.

41 BZ, Diplomatic Archives, dossier 12.318: letter of 20.10.1944 from Spaak to Gutt and Theunis; letter of 04.12.1944 from Frère to Spaak; BNB, Archives, RR, 06.12.1944; BNB, Archives, DC, 02.01.1945.

42 BdFr, Archives, Secrétariat Général, dossier 1060.2001.01/43, 'or belge': letter of 21.10.1944 from Guindey to Moninck; dossier 1060.2001.01/41, 'or belge': memorandum of 22.12.1944 for Martial.

43 BZ, Diplomatic Archives, dossier 12.318: telegram of 11.11.1944 from Nisot (New York) to Theunis. 



\section{CHAPTER 25}

\section{Back to Normality}

THE COMPLETION OF THE BELGO-FRENCH RECONCILIATION

Three major questions remained to be resolved with the Banque de France: the cost of the abandoned legal proceedings in New York; the decisions to be made when the Caisse d'Epargne du Luxembourg demanded the return of the gold it had deposited with the Bank; and the steps to be taken by the Banque de France to recover Belgian gold that might be found in Germany or elsewhere. The first question was resolved rapidly and satisfactorily. During the October negotiations, it had been agreed that, with the exception of lawyers' fees, legal costs would be shared between the two central banks'. However, there was also the delicate problem of the sheriff's fee. Originally the fee amounted to 2.5 million us dollars, but it had already been reduced to 256,000 us dollars. In the end the sheriff, under pressure of the American government, having reduced drastically a similar fee due by the Polish, also reduced the Belgian fee to 10,175 us dollars, to be paid half by the Bank and half by the Banque de France ${ }^{2}$.

With regard to the second question, the Luxembourg Minister of Finance, Pierre Dupong, informed the Bank on 21 March 1945 that his government was concerned about the gold deposited with the Bank by the Caisse d'Epargne du Luxembourg and enquired whether it was still available in Brussels ${ }^{3}$. This tardy request for information was undoubtedly due to von Rundstedt's Ardennes Offensive of December 1944, which meant that Luxembourg's institutions were able to begin functioning normally again only after the Offensive was broken. In reply to

1 ARA, Theunis Papers, 'correspondance Theunis-Nisot': letter of 03.10.1944 from Theunis to Nisot (New York).

2 BNB, Archives, DC, 25.06.1945.

3 BNB, Archives, DC, 21.03.1945. 
the enquiry, Governor Frère sent Dupong a detailed report of what had befallen the Luxembourg gold. Dupong reasoned that, on the basis of the report, the Caisse d'Epargne could claim a right to restoration. Frère replied he would take up the matter with the Banque de France, which in 1940 had received the Luxembourg gold in safe custody4.

Frère spent 12-15 July 1945 in Paris to discuss the Luxembourg problem with the new governor of the Banque de France, Emmanuel Monick. The talks went especially smoothly and, because the French government wished to fulfil its vague promise to Gutt the previous year, Monick was able to inform Frère that the Banque de France would answer for the restoration of the gold and, to that end, would deal directly with the Luxembourg government and the Caisse d'Epargne. In April 1946 an agreement for this was signed between the Banque de France, the Bank and the Caisse d'Epargne 5 .

The third major question concerned the steps to be taken by the Banque de France to recover Belgian gold that might be found in Germany or elsewhere after the war. The onus was, in fact, on the Bank, as the original owner, to demand its return - should any be found - and then transfer it to the French central bank. In April 1945, news came that the American Third Army had discovered a substantial quantity of gold bars and coins in the salt mines of Merkers in Germany. In line with the agreement of 8 October 1944, in which it had undertaken to spare no effort to help the Banque de France to track the gold down, the Bank immediately took steps in tandem with the French central bank to be able to participate in the identification of the find. However, the two banks were refused access, as the Americans were not allowing any civil officials into the area until the conquest of Germany had been completed ${ }^{6}$.

Following the German surrender in May 1945, matters could be taken further. Puhl, the former Deputy-president of the Reichsbank, was

4 BNB, Archives, RR, 11.07.1945.

5 BZ, Diplomatic Archives, dossier 12.318: letter of 30.04.1944 from Spaak to the French ambassador in Brussels. See also: BdFr, Archives, Secrétariat du Conseil Général et du Conseil de la politique monétaire, dossier 1069.1989.19/2: convention entre Banque de France, Banque Nationale de Belgique et Caisse d'Epargne du Grand Duché de Luxembourg, 20.02.1946, 23.02.1946, 02.03.1946.

6 BdFr, Archives, Secrétariat Général, dossier 1060.2001.01/43: rapport sur la récupération du Trésor à la mine de Kaiseroda à Merkers (Frankfurt, 18.04.1945). 
at Lindau under French supervision. Being questioned, he asserted that most of the Belgian gold had been melted down at the Prussian Mint and had been recast as Reichsbank gold bars, stamped with the years 1937 or 1938, but he did not say that they had been put back into circulation. According to what he remembered, nearly half of them had been used to pay for purchases from German allies and other friendly neutral countries7. In August 1945, the Bank's treasurer, Sontag, was given permission to travel with officials of the French central bank to Frankfurt, where the gold discovered at Merkers had been taken and inventoried. There were certainly indications that Belgian gold was probably among the gold bars, but no conclusive evidence ${ }^{8}$. It was only in January 1946 that proper identification could take place, when a Banque de France delegation was admitted to the archives of the Prussian Mint, which had been transferred to the headquarters of the Soviet army in the Russian zone of occupation in Berlin. The journals of the smelting-works for the 1938-1943 period provided detailed information about which numbered Belgian gold bars had been recast under a new Reichsbank number and with a fictitious date ${ }^{9}$. This identification enabled the destination of exported bars to be traced in certain instances. A considerable proportion of them, for example, had ended up in the Banque Nationale Suisse, in the central banks of Rumania, Portugal, Sweden and Spain ${ }^{10}$, and in the BIs at Basel ${ }^{11}$.

7 BdFr, Archives, Secrétariat Général, dossier 1060.2001.01/43: Puhl, la question de l'or belge (undated); letter of 21.06.1945 from Panouillot to the Minister of Finance (Paris).

8 BNB, Archives, AR, 22.08.1945: note pour le gouverneur (report of the Treasurer Sontag on his mission to Frankfurt, 10.08.1945-14.08.1945).

9 BNB, Archives, Schatbewaarder, T 2, dossier 02.03.02.05 (D 556/9): rapport de la mission de la Banque de France à Berlin, 02.01.1946-13.01.1946 (copy).

10 BNB, Archives, Hoofdkas, CC 1, dossier 25.17.02.00 (G 677): divers (note du chef de service du change (Brussels): or d'origine belge (refondu), retrouvé en Espagne, 26.04.1949).

11 During 1943-1944, the Reichsbank had gold to the value of 531.7 million Swiss francs transferred to its own deposit of gold with the Banque Nationale Suisse at Berne. Of this, 378.6 million francs' worth was delivered to the Banque Nationale Suisse itself, 98.4 million francs' worth to the Banco de Portugal, 35.6 million francs' worth to the Royal Bank of Sweden, 12.2 million francs' worth to the National Bank of Rumania and 6.8 million francs' worth to the BIs at Basel: Commission Indépendante d'Experts (Suisse: Seconde Guerre Mondiale), La Suisse et les transactions sur l'or pendant la Seconde Guerre Mondiale. Rapport intermédiaire, Berne (1997), annex 
Already at the beginning of 1945, the Banque de France and the French government had urged the Belgian government to accord special treatment to the Bank's rediscovered gold. Monetary gold was not to be considered as war booty, but to be returned intact to the central banks to which it rightfully belonged ${ }^{12}$. The Belgian government took steps to have this done, but the American government quickly made it known that it would not entertain any proposals to that effect, stating that, much as it would have liked to return monetary gold identified as Belgian to the Bank, the exceptional circumstances ruled out such a move. According to the Americans, to return the gold would, among other things, create a dangerous precedent. Virtually all the Austrian and Italian monetary gold had been found and identified, and it would not be fair that the central banks of Germany's allies - as Austria and Italy were - should be able to recover their gold in full simply because it had been kept intact by the Germans; the central banks of Western allies would be left in the cold, because none, or only a proportion, of their gold, whether plundered or recast, could be found. The American government was now certain that not all the plundered gold would be recovered, so that there would be insufficient for everyone to recoup their gold in full, and it was for this reason that the Americans were considering the formation of a pool from which recoupment could take place $^{13}$.

During the Paris conferences of 9 November and 21 December 1945 on reparations, the eighteen participating countries set up an Inter-Allied Reparation Agency and adopted the American proposal for a pool as the guiding principle for the distribution of reparation payments ${ }^{14}$. The agency requested the American, British and French governments themselves to solve the problem of reparations and to undertake the distribution of the attendant payments, as well as to begin negotiations with neutral countries, such as Switzerland, Sweden, Portugal and Spain, aimed at placing a claim on German assets there,

2, table 23. See also: Commission Indépendante d'Experts (Chairman : Professor Jean-François Berger) (Suisse: Seconde Guerre Mondiale), La Suisse, le nationalsocialisme et la Seconde Guerre Mondiale. Rapport final, Berne, 2002, pp. 224-238.

12 BNB, Archives, IS, dossier 39/1120: letter of 23.02.1945 from Moninck (Paris) to Frère.

13 BZ, Diplomatic Archives, DA, dossier 18: letters of 10.08.1945 and 14.08.1945 from Silvercruys (Washington) to Spaak.

14 Cornu, L’or monétaire du vingtième siècle, pp. 195-198. 
insofar as they qualified to be used for reparations ${ }^{15}$. On 26 September 1946, pursuant to their mandate, the three governments set up a Tripartite Commission for the Restitution of Monetary Gold, with its registered office in Brussels ${ }^{16}$. The method adopted by this commission was similar to that followed by the Inter-Allied Reparation Agency in December 1945: all plundered monetary gold found in Germany or elsewhere would be placed in a joint fund and each country involved would receive part of it, in proportion to the gold it had lost through German seizure during the period of occupation.

Requests for restitution had to be submitted to the commission before 15 September 1947 and the petitioning countries were Albania, Austria, Belgium, Czechoslovakia, Greece, Italy, Luxembourg, the Netherlands, Poland and Yugoslavia. The first distribution took place on 16 October 1947, Belgium receiving 90,650 kilograms of monetary gold and Luxembourg 1,930 kilograms ${ }^{17}$. Both transferred those amounts to France, as agreed. The commission remained active for a number of years and distributed a further amount of monetary gold, of which Belgium received just under 40,00o kilograms. France, thus, ultimately recovered about 64 per cent of the 198,434 kilograms of monetary gold that she had restored to Belgium ${ }^{18}$.

\section{THE GUTT OPERATION (6 OCTOBER 1944)}

Once Gutt's suggested exchange rates for the Belgian franc had been accepted by the American and British governments at the beginning of 1944, the time appeared ripe to incorporate the decisions into decrees.

15 Commission Indépendante d'Experts, La Suisse et les transactions sur l'or, p. 191.

16 BZ, Diplomatiek archief, DA, dossier 18: la restitution de l'or monétaire (note pour le ministre, 10.10.1947).

17 BZ, Diplomatic Archives, DA, dossier 18: la restitution de l'or monétaire (letter of 16.10.1947 from the Commission tripartite to the Belgian delegate of the inter-Allied agency).

18 Cornu, L'histoire de l'or au vingtième siècle, pp. 199-200. The French government reimbursed the Banque de France for the shortfall (about 70,00o kg), doing so in the form of a credit and at the official gold rate for the French franc in December 1944, though it was only in 1958 that the credit was paid out; in the meantime, the gold value of the French franc had fallen sharply, which resulted in the Banque de France, too, having to bear part of the loss. 
By a decree of 1 May 1944 the King and his government were empowered to fix the price of gold and the exchange rates of foreign currency in terms of the Belgian franc. At the same time, the decree abolished the franc's gold weight as promulgated in the royal decree of 1936, and empowered the government to set a new gold weight as soon as circumstances permitted. The same day, also by decree, the Cabinet officially fixed that weight as one kilogram of monetary gold to 49,318.0822 Belgian francs, which led to the following exchange rates: 176.625 francs to the pound sterling, 43.827 francs to the us dollar, 0.883 of a franc to the French franc and 16.52 francs to the Dutch guilder. The Belgian franc's devaluation against its pre-war gold weight amounted to 32.7 per cent and against the exchange rates of the other currencies in August 1939 to 30.29 percent against sterling, 48.65 per cent against the us dollar, 14.94 per cent against the French franc and 4.96 per cent against the Dutch guilder ${ }^{19}$.

The decree of 1 May 1944 was published in Brussels in the Belgian Official Gazette of 5 September 1944, together with other decrees drawn up in London, of which one amended the organic law of the Bank and another re-established the institution's registered office in Brussels. Lastly, a further five decrees were published instituting safeguarding measures regarding the prospective currency reform ${ }^{20}$.

The government's initial intention was to press ahead with monetary reform immediately upon returning from London at the beginning of September 1944, but the immediate operation envisaged was seen to be impossible. Printing the new banknotes had not yet been completed in London and, much worse, transport was lacking to get them to Belgium, exacerbated by the Allied Supreme Command's refusal to carry them in any of its warships. Meanwhile, Baudewyns had notified the board of directors that 23 billion Belgian francs' worth of new

19 Janssens, De Belgische frank, pp. 322-324.

20 For detailed information in respect of the Gutt Operation, see chiefly: H. Van Praag, L'opération Gutt: l'assainissement monétaire de la Belgique au lendemain de la seconde guerre mondiale (unpublished graduate thesis, ULB), Brussels, 1990; H. Van Praag, 'L'assainissement monétaire au lendemain de la seconde guerre mondiale. L'Opération Gutt en Belgique - La politique du Général de Gaulle en France', in: Revue de la Banque, February-March, 1996 (supplément historique), pp.3-37. See also: C. Chambre, L'expérience monétaire belge (unpublished Ph. D. thesis, University of Paris), 1950. 
banknotes were in London, waiting to be shipped, with a final batch of 3 billion francs' worth still being printed. This meant that there was a total stock of 26 billion francs' worth to be brought over. As soon as the shipments arrived, eight million inhabitants of Belgium would each be able to exchange 2000 old Belgian francs for new banknotes ${ }^{21}$.

Lastly, it was not until 11 September that the Brussels Comité $d u$ Mardi was ready with its report on currency reform (Rapport relatif aux travaux de la commission d'études financières, 1943-1944)22. The submission of the report led to Gutt setting up a small committee to work with a number of members of his private office to compare the draft bills from Brussels with those from London ${ }^{23}$. Despite scant contact between the two capitals, the texts exhibited a remarkable, underlying similarit ${ }^{24}$, although differences were also uncovered.

All the measures announced by Gutt in a radio address on 5 September and published that same day in the Belgian Official Gazette naturally bore the full London stamp, having already been promulgated as a decree on 1 May 1944 by the Belgian government in London. For the texts of the currency reform as such, however, it was seen that the drafts prepared in Brussels were much more in line with the daily life of the Belgian population on the eve of liberation. This was not surprising, given that the local experts had been able to continue fine-tuning their analyses up to that moment and had a much broader range of data to hand, enabling them to prepare more comprehensive and more accurate texts. These latter texts were generally preferred and in many cases adopted verbatim, or with only a minimum number of amendments, in the final versions. Gutt would acknowledge his debt to these texts, only several years later.

21 BNB, Archives, DC, 16.09.1944.

22 BNB, Archives, Studiedienst, DS 9, dossier 01.02.01.70 (A 241/9 s. f. 1): letter of 12.09.1944 from Smeers to Gutt.

23 BNB, Archives, $S D$, Ansiaux Papers, A 2, dossier 9.1/32, 'correspondance avec Gutt' (address of 03.11.1969 by Ansiaux).

24 Gutt spoke of 'une ressemblance quasi-miraculeuse', but this statement was clearly exaggerated. Dupriez's assessment is more qualified and probably closer to the truth, and account has been taken of it (BNB, Archives, Studiedienst, DS 12, dossier 01.02.02.70 (A 269/1): assainissement monétaire (review by Gutt at the end of 1948, beginning of 1949); Dupriez, Les réformes monétaires de la Belgique, Titre IV: la réforme monétaire de 1944). 
The postponement of the reform by one month had a number of adverse consequences. The imminence of reform was on everyone's minds and there was a resulting flight out of notes and coins, matched by a frantic rush into tangible goods. Inflated prices were paid for jewels, diamonds, coins and other objects in precious metal, for watches, stamp collections, paintings and antiques, and even for furs, pianos, bicycles, colonial goods, not forgetting household linen, bricks and window glass ${ }^{25}$. Stocks of postage and revenue stamps were bought up from post offices and there was even a run on tram and train season tickets. The reverse of this was that numerous farmers provisionally held their products back from sale, fearing that they would be saddled with virtually worthless banknotes ${ }^{26}$. And some speculators began to hoard 50and 20 -franc notes ${ }^{27}$.

Fortunately, at the end of September the government was able to profit from a suggestion made by an American naval officer and lay its hands on a number of landing-craft to ship the stock of new banknotes from Great Britain to Caen, from where they were taken by train and truck via Rouen, Paris and Liège to Brussels. At last, on 4 October, the Bank in Brussels had a stock of 20 billion francs' worth of new banknotes to hand, which it proceeded to distribute post-haste to its own branches, to the private banks and to the 1,300 post offices in the coun$\operatorname{try}^{28}$. The eight decrees in respect of the currency reform were promulgated on Friday 6 October and published the following day in the Belgian Official Gazette, finally clearing the way for the Gutt Operation to begin on Monday 9 October.

In a radio broadcast on 12 October, Minister Gutt addressed the population directly to explain the purpose of the operation. He pointed out that the immediate, two-thirds reduction in the circulation of notes and coins and deposits on transfer accounts, together with the mandatory declaration of moveable assets, would be a painful experience after four hard years of occupation, but that the measures were necessary for a variety of reasons. Only a drastic reduction of money in circulation

\footnotetext{
25 Janssens, De Belgische frank, p. 325.

26 Bz.Ndl, London Archives, 1940-1944, GA diplomatieke zaken, dossier (Dz) Ez/CHZ: report of the envoy van Harinxma thoe Slooten, 04.10.1944.

27 BNB, Archives, DC, 01.09.1944.

28 BNB, Archives, RR, 04.10.1944.
} 
could restore monetary stability to the country, eliminate war inflation and prevent post-war inflation, maintain the purchasing power of wage income and savings, and secure the viability of Belgian exports. Gutt also pointed out that the mandatory declaration of moveable assets was necessary for ethical reasons. Its purpose was to identify hidden, illegal German holdings and to expose the scandalous profits made by Belgian war-profiteers ${ }^{29}$.

The purpose of the currency reform was, in fact, both monetary and fiscal. On the monetary side, there was a series of measures to curb the circulation of notes and coins and replace the old banknotes in circulation with new. All banknotes of 100 Belgian francs and above in circulation were forthwith deprived of their power as legal tender and, with effect from Monday 9 October, had to be declared and surrendered within five days at one of the bank branches or post offices accredited for the purpose. In exchange, and against surrender of household ration coupon No. 12, each household head could receive an equal quantity of banknotes, with a maximum of 2,00o francs per household member; any balance being deposited in a special, blocked account. The monetary package also contained a series of measures to reduce deposits on transfer accounts. All current accounts at private commercial banks, private savings banks and the Postal Cheque Office, as well as all time deposit accounts with a term of two years or less, were frozen; no single-premium life-insurance contracts or other insurance contracts featuring capitalization were allowed; foreign currency transactions were subject to the approval of an Institut des changes established forthwith by decree. Lending by private banks was made subject to strict control, with all applications for loans above 1 million francs having to be submitted to the Bank for approval.

A number of exemptions were nevertheless built into the measures, allowing an additional quantity of new banknotes to be brought into circulation. From the outset, for example, exemption from any limitation on conversion was granted in respect of the cash stocks and current accounts of the State, provinces, municipalities, public and semi-public institutions, public and private banks, the Postal Cheque Office and the savings banks. Also qualifying for this exemption were monasteries

29 BNB, Archives, SD, Ansiaux Papers A 2, dossier 9.1/32, s. f. 5, 'correspondance avec Gutt' (draft text for a radio broadcast by Gutt, 10.10.1944; text of the broadcast, 12.10.1944). 
and convents, churches and cultural associations, because the decree of 18 October designated charitable and non-profit cultural organizations as public institutions. In addition, holders of frozen accounts were offered a series of specific exemptions: the first was to have immediate and unrestricted disposition of 10 per cent of their current account balance as of 8 October 1944 or immediate and unrestricted disposition of their entire current account balance as of 9 May 1940. Commercial, industrial and craft entrepreneurs were permitted to withdraw 1,00o francs per week per employee from their current account. Lastly, the Minister of Finance took it upon himself to decide before 9 November whether a certain amount of the balances on frozen accounts could qualify for an additional conversion into new banknotes. The matter was, in fact, settled by decree of 28 October 1944, whereby, for each household member, a maximum amount of 3,000 francs from the blocked accounts could be converted into new banknotes.

At the same time, Gutt announced an arrangement for the accounts remaining frozen after this second conversion operation. Henceforth, 40 per cent of the balances would be temporarily frozen and released in accordance with general government measures as economic activity in the country improved or in accordance with the decision of a special committee empowered to approve any applications for release. The remaining 60 per cent would be frozen indefinitely, with their ultimate disposition to be determined later. By decree of 14 October 1945, it was finally laid down that these frozen balances would become a compulsory long-term loan to the government at 3.5 per cent, whose certificates, though non-transferable, could be utilised for the payment of special war taxes.

First among the measures on the fiscal side was the obligation on those who held securities, whether domestic or foreign, to have them declared and stamped within fourteen days. Also to be declared were all time deposit accounts at banks at home and abroad, all long-term savings accounts, all other assets in Belgian and foreign currency, and all holdings of gold and other foreign exchange. To make the measure watertight, the exchange markets were closed until further notice; when at last they reopened - which was not until April 1945 - it was laid down that only declared securities could be traded and then only under restricted conditions. 
The fiscal regulations also contained measures designed to effect the reform of government finances. Gutt felt he could achieve this through the proceeds of a tax on the increase in wealth between 10 May 1940 and the beginning of September 1944; he was convinced that the tax would enable him to strike at all war-profiteers. Gutt's tax bill was approved by the government on 20 December 1944 and was then submitted to Parliament. When it came to be debated by the full Parliament, however, it met a storm of criticism; indeed, the opposition was so great that, in the turbulent sitting of 6 February 1945, the Pierlot government lost a vote of confidence and resigned the following day.

The Pierlot government was succeeded by the first Van Acker government, in which Gaston Eyskens was Minister of Finance. Eyskens prepared a new bill regarding war profits, which, submitted by his successor, Franz De Voghel, was approved by Parliament in three votes on 15, 16 and 17 October. The legislation provided for full confiscation of all profits and income derived from illegal transactions with the enemy and, in addition, imposed a heavy and progressive tax, ranging from 70 to 100 per cent, on all excess profits and income earned during the war. A final measure was a limited, one-off wealth tax of 5 per cent, levied on the most important components of wealth. As a rider to all this, the initial term of forty years set for the repayment of the compulsory currency-reform was reduced in 1951 by special legislation and repayment was completed by the end of 1971. 



\section{The End of an Era}

THE CURRENCY REFORM IN ACTION

The Gutt Operation was an extremely large-scale undertaking. At the 2,158 bank branches and post offices accredited for the purpose, no less than 1.3 million individuals applied to exchange old banknotes for new ${ }^{1}$. Between 9 and 12 October, a total of 14.4 billion Belgian francs' worth of banknotes were exchanged and a further 73.6 billion francs' worth of old banknotes were declared and deposited, but not exchanged. The Bank estimated the stock of banknote's held by banks, public, semipublic and assimilated institutions at 2.5-3 billion francs, meaning that an overall amount of 92.5-93 billion francs' worth of old banknotes had fallen into the net of exchange, declaration and deposit.

At the Bank, the staff was swamped by all the extra work. The tellers in the Head Cashier's Office simply could not cope, the more so as all transactions at that time were executed manually. In addition to handling the banknotes, there was also the more complex work involved with the current accounts: new accounts had to be opened to deal with the surplus of old banknotes that were not permitted to be exchanged for new, and, a little later, existing current accounts had to be split into temporarily and indefinitely frozen accounts, occasioning even more work. There was also the business of checking current account balances as at 9 May 1940 for those who had opted for the frozen balance exemption and no less time-consuming in respect of administration was the organization of the exchange control. At top level, moreover, contacts had to be re-established and maintained with other central banks.

1 Interview with W. Pluym. 
Table 26.1: Development of the money supply in Belgium (1936-1948) (in billions of Belgian francs)

\begin{tabular}{|c|c|c|c|c|c|c|c|c|}
\hline MONEY SUPPLY COMPONENTS & 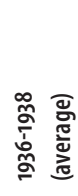 & 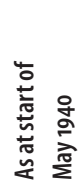 & 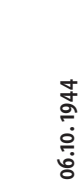 & 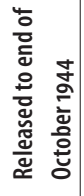 & 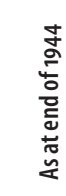 & 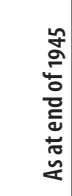 & 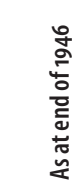 & 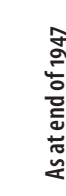 \\
\hline Treasury money & 1.6 & 1.6 & 6.4 & 6.4 & 6.3 & 6.8 & 5.5 & 4.4 \\
\hline BNB banknotes & 22.0 & 29.8 & 100.9 & 25.3 & 38.8 & 69.9 & 72.2 & 78.3 \\
\hline Current account balances & 3.7 & 0.9 & 3.6 & 3.6 & 3.8 & 3.5 & 6.3 & 5.9 \\
\hline Balances at the Postal Cheque Office & 2.9 & 4.7 & 11.0 & 6.7 & 10.7 & 16.5 & 18.3 & 20.2 \\
\hline Bank deposits & 12.8 & 13.5 & 42.7 & 15.4 & 14.6 & 34.8 & 43.3 & 42.5 \\
\hline Total & 43.0 & 50.5 & 164.6 & 57.4 & 74.2 & 131.5 & 145.6 & 151.3 \\
\hline
\end{tabular}

Source: Janssens, De Belgische frank, p. 334.

As indicated above, the economy had been in decline since the spring 1944, when the railways and other routes from Germany to France via Belgium began to be a particular target for Allied bombardment. During the re-conquest of the country at the beginning of September, the situation became even more dire. It is true that the liberation was taking place at an unanticipated speed, but this did not mean that the advance of the Allied armies was reducing the economic dislocation. The proposed currency reform further increased uncertainty and disquiet among many producers and sellers, who questioned whether the time was right to put goods onto the market.

The publication of the monetary decrees on 6 October 1944, nevertheless, came as a shock. At a stroke, they cut the circulation of banknotes (including Treasury money) from 107 billion to 23 billion Belgian francs. Despite the expansion to nearly 32 billion francs, following a decree of 28 October, this still represented an enormous contraction ${ }^{2}$. Including deposits on transfer accounts, the overall money supply was reduced drastically from 165 billion to 57.5 billion francs, which was not far from its level 50.5 billion francs in May 1940.

Gutt hoped that the radical monetary legislation would serve to bring prices down, but, to the general disappointment, this did not prove to

2 BNB, Archives, Studiedienst, SD 11, dossier 01.02.02.50 (B642): note concernant les résultats des mesures d'assainissement monétaire et la sitution de la circulation monétaire au 31 décembre 1944 (strictement confidentiel). 
be the case. He and his advisers had, in fact, got their estimates wrong about both supply and demand. The more flagrant miscalculation was on the supply side. The economy remained disorganized and few goods were reaching the market, even after 6 October. For the time being all Belgian imports of raw and ancillary materials were suspended and the port of Antwerp, the first port to fall virtually intact into Allied hands, was open only for military purposes. Consequently, no help was to be expected in the immediate future from America or from neutral countries, such as Sweden, Switzerland, Spain and Portugal. Moreover, there was a dire lack of coal: the Belgian mines were running at only half capacity, so that there were even restrictions on the use of gas and electricity ${ }^{3}$.

The supply-side crisis was exacerbated by what was initially a very strict campaign against economic and financial collaboration ${ }^{4}$. In circulars to his prosecutors and deputy-prosecutors, the chief military prosecutor, Ganshof-van der Meersch, demanded strict application of article 115 of the Penal Code; and the ministers in the final Pierlot government who were drawn from the Resistance organizations and from the Communist Party, were no less severe. It is therefore not surprising that more than 13,00o prosecution dossiers for economic collaboration were opened in Belgium, a vast difference to the 1,200 in neighbouring France. Furthermore, numerous companies were placed under sequestration by the deputy-prosecutors, which had the additional effect of temporarily paralysing a substantial level of production. In January 1945, the monthly average of industrial output was barely 16 per cent of the level in 1936-1938 and it failed to climb above the pre-war level until the beginning of $1947^{5}$.

3 BZ.Ndl, London Archives, 1940-1945, GA, diplomatieke zaken (DZ) EZ/CHZ: report of the envoy van Harinxma thoe Slooten (Brussels) to his minister, 20.10.1944; ARA, fonds Société Générale de Belgique, Direction, Nokin Papers, dossier 99, copy 550/1: letter of 23.01.1945 from Blaise to Major-general Erskine.

4 BEngl, Archives, Belgium, ov 88, dossier 36: letter of 05.10.1944 from Baudewyns (Brussels) to Siepman (London). In respect of what follows, see chiefly: D. Luyten, Burgers boven elke verdenking? Vervolging van economische collaboratie in België na de Tweede Wereldoorlog, Brussels, 1996.

5 V.A. De Ridder, 'The Belgian Monetary Reform', in: The Review of Economic Studies, 39 (XVI, 1), 1948-1949, p. 39-40. 
Reality fell short of expectations on the demand side, as well. To begin with, the government had assumed - naively, as it turned out that the liberation of the country would coincide with the end of the war and that Belgium would then be immediately able to import raw materials and goods a-plenty, and thereby amply satisfy market demand. The effect of the currency reform was also wrongly estimated, the government having assumed that the measures of 6 October 1944 would enable it to keep the money supply fully under control and that, as the economy gathered pace, it would be able gradually to liberalize the flow of money at the times and down to the last cent set out so meticulously in its plans. In practice, alas, things turned out quite differently, beginning with the fact that the liberation of Belgium did not coincide with a total cessation of hostilities. Against Field-Marshal Montgomery's judgement, General Eisenhower had decided that the Allied armies should over-winter in Belgium, before delivering the final attack on Germany. His decision was prompted by his experience of the Normandy beaches, which were far from equipped to handle the convoys required to supply the troops. He needed a port like Antwerp that could efficiently store and distribute the mass of material coming from overseas. Consequently, Antwerp had first to be liberated and then reequipped. All that would take time and also meant that a considerable proportion of the American, British and Canadian forces - more than a million men - would spend the entire winter in Belgium. The numbers were, in fact, increased after von Rundstedt began his offensive in the Ardennes in December 1944.

The troops temporarily stationed in Belgium naturally spent their money chiefly in the locations where they were quartered, thereby creating unexpected additional demand in a Belgium pursuing a strict monetary policy. The armies also had need of services and goods that they could not bring in from outside, and these also had to be purchased and paid for locally. In 1943 and again in 1944, the Belgian government in London and in Washington had spent days - weeks and months, even - negotiating with the Allies to get them to agree to pay their troops solely in Belgian money, once the country had been liberated. Their agreement had been obtained, but at no small price, as the government had made 16 billion Belgian francs in new banknotes available to the allied armies for the troops' pay alone, and a further 19 
billion francs had been transferred to them for the purchase of goods and services. Of course, these amounts were not fully taken up and the pay of American and Canadian troops would be reimbursed in full in hard currency by their countries, though this occurred only later (after the cessation of hostilities in Europe) and effectively only after October 1945. As agreed, the services provided to the Allied armies were charged to the liberated country concerned, as its share in the Allied war effort. Whether it was repaid or not, however, the monetary aid for the military liberation of Belgium resulted overall in a considerable injection of new banknotes into circulation, representing yet another check to the government's monetary plans at an untimely moment.

A second major factor disrupting monetary reform was the releasing earlier than planned the account balances temporarily frozen at banks and savings banks ${ }^{6}$. A campaign to have the balances released had begun in early November 1944 among the self-employed and the liberal professions 7 . Gutt's response to the campaign was an announcement on 18 November that he would address the problem very shortly, an announcement that was followed on 22 November by the issue of two ministerial decrees granting significant exemptions to industrial, commercial and craft businesses and to a number of citizens who had suffered war damage. From the beginning of 1945 on, exemptions were granted at an increasing rate by Gaston Eyskens and Franz De Voghel, Gutt's two immediate successors as Minister of Finances. The net result of this accelerated unfreezing was a further injection of new banknotes into circulation, again, much earlier than had been planned.

The government was itself partly responsible for the distortions in executing the monetary reform. After the liberation, the budget deficit expanded by leaps and bounds, reaching 35.8 billion Belgian francs in 1945 and 37.1 billion francs in $1946^{9}$. Only 12 billion francs of this could be covered by a long-term loan. A further proportion was financed by the private bank sector taking up short-term Treasury certificates and a further proportion by the Postal Cheque Office, which the Treasury

\footnotetext{
6 Van Praag, 'L’assainissement monétaire', pp. 23-25.

7 BNB, Archives, Studiedienst, DS 12, dossier 01.02.02.70 (A 269/1): assainissement monétaire (review by Gutt at the end of 1948, beginning of 1949, p. 9).

8 BNB, Archives, DC, 16.04.1945.

9 De Ridder, 'The Belgian Monetary Reform', 39, (xvi, 1), pp. 31-33.
} 
once now controlled. A final and not inconsiderable proportion of the deficit was covered by the Bank advancing new banknotes to the government.

The sharp rise of the deficit was due in part to payments to the Allied armies, but also to a steep increase of the government's own expenditures. Already in December 1944 the Social Pact, concluded during the war in secret between the trade unions and the employers' associations, was translated into concrete measures, such as the setting-up of the State Social Security system, whose costs were covered in part by the government ${ }^{10}$. The government also felt itself obliged to grant substantial subsidies to agriculture and the coal industry, in order to keep the prices of vital foodstuffs and coal low. At the same time, it faced urgent tasks of settling war damage claims, reconstructing the transport infrastructure in Antwerp, the Ardennes, and elsewhere amongst other commitments. Yet to fund all this tax receipts were limited: the economy was still dislocated despite all the efforts to restore its efficiency. Table 26.2 indicates how public debt, which had already risen appreciably during the war, continued to climb after September 1944, rather than declining, as planned.

Table 26.2: Trend of Belgian public debt (1940-1945) (in billions of Belgian francs)

\begin{tabular}{lrrrr}
\hline Components of public debt & 30 April 1940 & 30 September 1944 & 30 September 1945 & 31 December 1946 \\
\hline Consolidated debt: & & & & \\
- domestic debt & 35.3 & 41.7 & 42.2 & 104.7 \\
- foreign debt & 17.8 & 16.5 & 24.1 & 11.2 \\
\hline Total consolidated debt & 53.1 & 58.2 & 66.3 & $\mathbf{1 1 5 . 9}$ \\
\hline Short-term debt & 12.2 & 71.3 & 109.7 & 110.6 \\
Medium-term debt & 0.7 & 37.7 & 36.4 & 28.6 \\
\hline General total & $\mathbf{6 6 . 0}$ & $\mathbf{1 6 7 . 2}$ & $\mathbf{2 1 2 . 4}$ & $\mathbf{2 5 5 . 1}$ \\
\hline
\end{tabular}

Source: BNB Archives, sD, Smeers Papers, file 1: dette publique belge; De Ridder, 'The Belgian Monetary Reform', 39 (XVI, 1), p. 35.

As an orthodox central banker, Governor Frère was fully behind Gutt's currency reform, but he watched with disquiet as the money supply

10 BZ.Ndl, London Archives, 1940-1945, GA, diplomatieke zaken, (DZ) EZ/CHZ: report of the envoy van Harinxma thoe Slooten (Brussels) to his minister, 20.10.1944. 
rapidly expanded in terms of notes and coins. He soon began a counteroffensive, focusing on deposits on transfer accounts ${ }^{11}$. Starting at the beginning of December 1944, he concentrated on the necessity of curbing private bank lending in the form of advances in current account against the guarantee of temporarily and even indefinitely frozen account balances. This brought him into direct conflict with the business world, with Bekaert and Peltzer more than once sounding warnings at meetings of the supervisory council during the winter of 1944-1945. Bekaert stated that reserves in the business sector had been drained by the stagnating economy and that the over-drastic currency reform had not created any room for bridging the crisis. Businessmen hoped that the economic climate would shortly improve, but they were obliged to have recourse to bank credit in the meantime. By cutting back lending the Bank was putting the business world in an impossible position.

The continuing scarcity of goods became all the more acute during the winter months of $1944-1945^{12}$. The government therefore felt obliged to maintain the rationing of essential foodstuffs and even to reduce the allowance for certain goods, including coal, margarine and butter. The interplay of scarcity of goods with an uncontrolled increase in money circulation sent retail prices soaring, and no government's controls or subsidies were able to reverse the trend. In October 1944, the 'official' retail price index already stood at 260 (as against a pre-war level of 100). By September 1945, the index had risen to 387, staying at that peak level for a few months, but in the course of 1946 began to fall step-by-step, reaching a level of 331 in December of that year ${ }^{13}$.

May 1945 saw the import of foodstuffs, raw materials and other goods expanding again, initially in the wake of the special aid programmes, one of these being the Military Civil Program, which had been set up in November 1943 within the framework of the inter-Allied conference held at Atlantic City. No less effective in this respect, however, were the bilateral monetary agreements that provided Belgium with the oppor-

11 BNB, Archives, RR, 06.12.1944; DC, 09.12.1944, 20.12.1944, 08.01.1945; RR, 10.01.1945, 14.02.1945.

12 BEngl, Archives, Belgium, ov 88, dossier 36: letter of 05.10.1944 from Baudewyns (Brussels) to Siepman (London). See also: dossier 4: Cobbold, Impressions of a week in Belgium, 18.12.1944.

13 De Ridder, 'The Belgian Monetary Reform', 39 (XVI, 1), p. 37. 
tunity to purchase goods on credit, the most important of which were the Lend Lease and the Reverse Lend Lease agreements concluded with the Americans at the beginning of 1945, and the Financial and Mutual Aid cooperation agreement concluded with the British ${ }^{14}$.

Anticipating the liberation, the Belgian government in London had also purchased foodstuffs from Canada, Argentina and the Belgian Congo during the war. In addition, soon as circumstances permitted, a mission headed by the Minister of Supply, Paul Kronacker, was sent to the United States and Canada to procure goods outside the framework of the aid programmes and the other agreements ${ }^{15}$.

The recovery in industry and commerce was once more opening up the prospect of a growing market in commercial paper, in which the Bank had traditionally played an active part, and it was at this moment that the Banking Commission, headed by Eugène De Barsy, its new, dynamic and dirigiste chairman, gave the Bank the opportunity of renewing its grip on financial and monetary affairs. That came, in February 1946, with the Banking Commission's imposition of an obligation on the private banks to invest a high proportion of their deposits in Treasury certificates. By this the Bank saw a way to regain control of the volume of short-term money and credit and also to curb the too rapid expansion of deposits on transfer accounts ${ }^{16}$.

\section{CRITICISM AND EVALUATION}

High expectations that could not immediately be satisfied inevitably had a negative effect on public opinion. Indeed the Belgian population was already exhibiting disquiet, disappointment and irritation at the end of autumn 1944, only a few months after the liberation. In this respect, too, Gutt had miscalculated. During his visit to Washington at the beginning of 1944, he had already been warned by White of the American Treasury Department that his plan was too demanding and too harsh for a country just emerging from four years of occupation.

\footnotetext{
14 BNB, Archives, DC, 22.02.1945 ff. See also: De Staercke, pp. 147-148.

15 BNB, Archives, DC, 01.10.1945, 08.10.1945.

16 BNB, Archives, Studiedienst, DS 1, dossier 01.02.01 (A 262/2): le crédit à l'économie privée de 1940 à 1950.
} 
Unruffled, Gutt had replied that: 'I will make them accept the plan, because I will make them understand'. He even thought that the population would be behind him when the measure requiring moveable wealth to be declared was announced and that everyone would realize that justice was being done and that the hated war profiteers would be unmasked and punished.

The first negative reactions were directed at the monetary decrees ${ }^{17}$, which were claimed to be discriminatory. Why, for example, were Belgians living abroad (les émigrés) escaping scot-free? Why were there no exemptions for the lower income groups? The exemption for the funds of cultural associations, churches and other non-profit organizations also came under attack as opening the door to unsound practices and downright malpractice. Similar criticism was levelled at the exemption of 50- and 20-franc banknotes from declaration: inside knowledge had clearly led to abuses, and some of those in the know had salted away huge quantities of these small denominations before 6 October.

Uncertainty about what was ultimately to happen with the indefinitely frozen account balances likewise attracted a great deal of negative reaction, partly inspired by a number of economists who shared Van Zeeland's views and who had been sharply critical from the outset of what they termed the deflationary character of the currency reform. However, it was not only economists who ascribed the continuing economic stagnation mainly to the deflationary effects of Gutt's currency reform, but the business world, as well ${ }^{18}$.

Criticism gained momentum when, in December 1944, Gutt submitted his bill on the taxation of the increments in wealth, which was a logical consequence of the bill for the mandatory declaration of moveable assets, approved in the preceding October ${ }^{19}$. Bankers and stockbrokers looked askance at such measures, forecasting a drift into the doldrums for dealing in shares and government securities, if the intention to register all securities was maintained. However, the proposal to levy a tax

17 Van Praag, L'opération Gutt, pp. 79-82, 86-87.

18 BZ.Ndl, London Archives, 1940-1945, GA, diplomatieke zaken (DZ) EZ/CHZ: report of the envoy van Harinxma thoe Slooten to his minister, 03.11.1944.

19 BNB, Archives, Studiedienst, DS 11, dossier 01.02.02.50 (A 255/6): Mallien, The currency reform and the bill for an extraordinary tax on the growth of wealth. 
on the growth of wealth upset all members of the middle- and higherincome groups now feeling themselves threatened ${ }^{20}$.

Tax specialists, too, had their doubts about Gutt's reforms, regarding the tax on the increments in wealth as an inefficient way of punishing war profiteers. Moreover, collecting the tax would demand an extensive administrative apparatus, something that the tax authorities did not possess at that moment. Many people also found the tax fundamentally dishonest and immoral, as it targeted the growth of wealth from both reputable and disreputable activities: the bon-vivants who had blown their war profits were rewarded, whereas the careful savers were punished.

Worse still was the indefensible stipulation that the burden of proof regarding the extent of wealth as at 9 May 1940 lay with the tax subject. How could small entrepreneurs and those with a modest capital be expected to produce proof going back to May 1940 when they were not accustomed to keep accounts in those days and in many cases did not even have a bank account? For those with a large capital, there would be no problem in producing proof and those with really substantial fortunes would be untouchable, because their fortunes would have dated from before the war. Measures of this sort were regarded as unacceptable, discriminatory and anti-social, as well as dangerous in the turbulent social climate of a country only recently liberated.

These were all solid arguments, though there was more than once a hint of self-interest, depending on who was putting them forward. Reporting to his minister, Binnert Philip van Harinxma thoe Slooten, the Dutch ambassador to Belgium, made the ironic comment that: 'resistance (to the tax proposal) from the monied class is all the greater, as it has always been a matter of course to mislead the tax authorities by submitting inaccurate income returns....For many here, even if they had not profited at all from the war, (there is) a great discrepancy between their far too low income declarations before the war and what they have now been obliged to declare as wealth ${ }^{21}$. The ambassador had put his finger on the spot: the opposition to the bill was no longer a matter for learned economists offering an alternative approach to post-war policy. Rather,

20 Newspaper La Libre Belgique, 30.11.1944, quoted by Van Praag, L'opération Gutt, pp. 103-107.

21 BZ.Ndl, Londens archief, 1940-1945, GA, diplomatieke zaken, GA 194.45. 
it was a matter of every Belgian above the poverty line feeling targeted, which goes some way to explaining why, on 6 February 1945, Parliament passed a motion of no confidence in the Pierlot government. Gutt's successors, Eyskens and De Voghel, dropped the proposal and replaced it with one for three other taxes, including a moderate, one-off levy of 5 per cent on certain elements of wealth. These three new taxes were approved by Parliament in the autumn of 1945 and raised nearly 50 billion Belgian francs, a sum that was applied to reforming the public finances.

To assess the Gutt Operation meaningfully in the light of history, it must necessarily be examined from both an economic and a structural angle: in other words, from a short-term and from a long-term point of view. Taking the short term first, the decrees were already attracting a great deal of comment and discussion at the time of their actual implementation. As indicated, there were numerous politicians, businessmen and economists in Belgium who were critical of the deflationary effect of the drastic reduction in the money supply and who consequently held the reform responsible for the crisis that Belgium suffered during the first year after the liberation, the more so as the reform did not achieve its stated aim of an immediate fall in prices. That view was undoubtedly too one-sided. Unforeseen circumstances - and unforeseeable by anyone - combined to thwart a rapid recovery of the Belgian economy and were thus partially responsible for the economic crisis during the initial months following the liberation.

However, the government was itself responsible for some of the unfavourable circumstances. One in particular was the naivety with which, when still in London, it had regarded the post-war situation in Belgium, a naivety indicative of an ivory-tower mentality. Others were the chaos in the supply chain and the unnecessary boosting of the black market, a consequence of the immediate abolition of the German-inspired administrative system of rationing. There was also the months-long dislocation of industrial production, inter alia a consequence of the harsh attitude towards economic collaboration. In addition there were inconsistencies and miscalculations not only on the monetary side of the reform, but chiefly on the fiscal side; these served to generate too much emotional reaction and tension for the process of economic recovery to be set in train and pursued in an atmosphere of national solidarity and calm. Gutt's aim was a reform that respected distributive equality and 
restored a sense of morality through the selective punishment of war profiteers. In reality, his measures often produced the opposite result: on the monetary side, they proved anti-social in certain respects; while, fiscally, they left numerous loopholes for shrewd war profiteers and hit many in the mid-income bracket hard.

Despite the unfortunate circumstances and the mistakes that were made, many economists and politicians of the time took a positive view of the Gutt Operation. Belgian economists in the Liberal and Socialist camps, including Dervichian, Louis de Brouckère and Frère, the governor of the Bank, had defended the monetary reform from the start and continued to do so. Eyskens and Dupriez ${ }^{22}$ in the Christian-Democrat camp likewise remained fervent supporters of the monetary measures. However, everyone had to acknowledge that Gutt had not achieved his aim as regards prices and wages, though analysts argued that this failure did not alter the fact that his operation had clearly served to put a brake on inflation ${ }^{23}$.

Gutt's monetary reform was also positively received abroad. Seeking to reform his country's currency after the liberation, the Dutch Minister of Finance, Lieftinck, looked to the Belgian experiment for inspiration, though drawing the necessary conclusions from the Belgian experience and taking account in his bill of a number of errors and shortcomings that had come to light during the implementation of the Gutt Operation $^{24}$. Great interest in Gutt's plan had also been shown by MendèsFrance during his time with the Free French forces in London, where he was in contact with the Belgian government. It had prompted him to introduce a similar plan in Corsica, when the island was liberated in 1943. However, it was not approved of by De Gaulle, who, when France was liberated, set it aside in favour of the proposals of René Pleven, who felt that reform could be achieved more smoothly through a large-scale,

22 BNB, Archives, Studiedienst, dossier 01.02.02.70 (D 312): Dupriez, Etude critique de la politique des prix, 10.04.1945.

23 BNB, Archives, SD, De Voghel Papers, dossier c: presentation in the Chamber of Representatives of the bill on the war tax (written speech of 13.08.1945, with annotations by the minister). The allusion to 'l'impôt monétaire' refers to a proposal made at the time by Dupriez, but not taken into account (see above).

24 J. Barendregt, The Dutch Monetary Purge. The monetary consequences of German Occupation and their redress after Liberation, 1940-1952, Amsterdam, 1993. See also: Joh. De Vries, De Nederlandsche Bank, 1914-1948. Trips Tijdvak, 1931-1948, onderbroken door de Tweede Wereldoorlog, Amsterdam, 1994, pp. $426 \mathrm{ff}$. 
long-term Emprunt de la Libération (a liberation loan) and a one-off levy on wealth and on war profits ${ }^{25}$.

Once hostilities had finally ended in the summer of 1945, Gutt's reform was able to demonstrate that, in economic terms, the negative criticism of the early months had been exaggerated. What the reform had actually done was to lay the foundation for economic and financial stability, restoring confidence in the economic future of the country and creating the popular energy and optimism needed to tackle the task of reconstruction. No mean achievement. It has to be said, though, that the plan benefited from a number of fortunate circumstances. Belgium's industrial equipment and port infrastructure had not been dismantled or seriously damaged, contrary to what had occurred in neighbouring countries. Belgium was also able to share in the substantial stock of foreign currency built up in the Belgian Congo during the war, which consequently put her in a position to begin fairly quickly to import raw and ancillary materials from abroad, once peace had been restored in 1945, and even to purchase consumer goods in America. Furthermore, the government's liberal trading policy in a seller's market and the consequent growth of the country's gold and foreign currency reserves created ample scope for credit facilities to be granted to other countries within the framework of the monetary agreements on the Belgian model. These circumstances, too, aided economic recovery.

Looking back, it can be seen that there was a lot of truth in the claim that the financial reforms had produced a favourable economic result in the short term: their contribution to 'le miracle belge' of the 19461949 period was indeed highly significant. However, their effect over the long term is another question and one that has to be asked, because 'the miracle' had lost much of its lustre by the end of 1949. Statistics for all West-European countries from about 1950 on indicate high annual growth figures for each of them, with the exception of Great Britain and particularly Belgium. The weakening of the Belgian rate of growth during the 1950 s was so marked that the country came to be called 'the sick man of Europe'. The question then is whether there was any link between that weakening and the Gutt Operation, and the suggestion put forward here is that there probably was.

25 Van Praag, L'opération Gutt, pp. 120-141. 
In essence, the Belgian monetary reform was a monetary and financial operation conceived in purely technical terms, without any foundation in economic reality and without any integration into a longer-term plan for industrial reform. Gutt's traditional liberalism, in fact, was no longer relevant and most economists in Europe regarded it as outdated.

The era of the mixed economy had dawned. Through planning and direct intervention, governments now had to adapt the structure of their economies to the requirements of the coming new world order and the new world economy. In the Netherlands, the Minister of Finance, Lieftinck, integrated his restrictive monetary policy into the Tinbergen Plan, which was geared to a general restructuring of the Dutch economy. The Federal German Republic followed suit, albeit later in 1948, with the Minister of Economic Affairs, Ludwig Erhard, linking German currency reform to a structural economic reform known as 'Soziale Marktwirtschaft': this incorporated the planned dirigisme of the Nazi era into a market-oriented system, thereby initiating a particular version of the mixed economy for the long term. In France, a plan likewise aimed at restructuring the economy in a longer-term perspective - the 'Plan national de rééquipement et de modernisation', put forward by the General Commissioner of the Planning Office, Jean Monnet - was accepted by the French government and included in its political programme. A similarly long-term structural reform was pushed through in Italy by Luigi Einaudi, one aim of which was, among others, state-directed economic development of the south of the country. The monetary reforms undertaken at the same time in France and Italy met with failure, but the long-term economic component of their respective post-war policies put down firm roots and enabled both countries to enjoy a dynamic rate of growth during the 1950 os and 196os.

This long-term economic strategy was lacking in Belgian government circles in London. It was only in November 1946 that, in a confidential note from Washington to Belgium's Prince-Regent, Gutt gave an indication of his fear that something might be wrong with the way the Belgian economy was developing ${ }^{26}$. Of the two reasons he put forward for this, the first was that prices in Belgium were rising much too quickly in comparison with their rate of increase in the sterling zone,

26 De Staercke, Mémoires sur la Régence et la Question royale, pp. 367-372. 
which meant that Belgium's export position would in time come under threat. He reproached his successors Eyskens and De Voghel for this, claiming that they had pursued, within the framework of the Social Pact, too lax a wage policy, contrary to the situation in Great Britain and the Netherlands, where a policy of austerity was still in place.

The second reason advanced by Gutt was what he saw as the absence of a plan for re-equiping the Belgian economy. It so happened that Jean Monnet had just succeeded in selling such a plan in the United States, which had enabled him to win substantial long-term loans for France. Again, Gutt blamed his successors Eyskens and De Voghel for what he called their lack of structural vision, but the same could equally be said of him. Ought not the Belgian government in London, and particularly the Minister of Finance and Economic Affairs, to have prepared such a long-term plan for reforming the industrial structure of the country and to have integrated it within the plan of overall monetary reform that was launched in October 1944?

However, Gutt's personal, ideological makeup did not lend itself to such a vision. The concept of government-guided dynamic growth was foreign to him. He remained fundamentally true to his original liberal objective of static, microeconomic equilibrium and did not realize that a long-term industrial restructuring programme could be integrated into his monetary reform. Immediately after the liberation, the Belgian economy had been favourably influenced by external factors, but these had been transitory. Once their effect had worn off, the structural weaknesses of the Belgian economy were revealed and the rate of growth began to lag behind that of the country's more dynamic neighbours. It was a question of waiting for the laws promoting regional expansion, introduced by Gaston Eyskens in 1959, before any significant start could be made on industrial restructuring in Belgium. The establishment of the European Economic Community with effect from 1 January 1958 came at a timely moment to give the necessary boost to the Belgian restructuring to enable it to be anchored within the new, dynamic Europe. Numerous foreign companies then arrived to set up business and brought with them advanced technology and modern business techniques, introducing a spiral of expansion. The response to this appeared to be active and immediate in Flanders and the Brussels region, but much more muted in Wallonia, though this is a hypothesis 
that requires further research. Such research could contribute to a better insight into the complex, diverging Flemish-Walloon development within the Belgian economy after the Second World War. 


\title{
The Commission of Enquiry and the Legal Investigation
}

\author{
INSTALLATION AND START
}

The euphoria-inducing sound of Allied tanks rolling into the country had barely died away before the settling of scores began. The hour of repression had struck in Belgium and the hunt began for the culpable, for those deemed responsible for four wretched years of occupation and privation. In the dramatic one-liner later uttered by Ingenbleek: 'Les dieux avaient soif' ('The gods were thirsty')'.

On the proposal of the ministers returned from London, a decree was issued on 11 December 1944, whereby a Commission of Enquiry was set up with the specific task of examining and assessing as soon as possible (i.e. before the end of January 1945) the activity of the Banque d'Emission and the actions of its managing directors and board of directors during the occupation. ${ }^{2}$.

Information about the Banque d'Emission had also been assembled shortly after the liberation by the Military Prosecutor's Office and on 12 December the chief prosecutor resolved to transpose this dossier into an 'instruction', with a view to a possible indictment ${ }^{3}$. On 14 December, two deputy-prosecutors, accompanied by a representative of State Security and by three accounting experts appointed in the meanwhile, made their way to the Bank to seize the Banque d'Emission's archives and, with Governor Frère's permission, to inspect certain of the Bank's

1 BNB, Archives, SD, Ingenbleek Papers, I 1: Ingenbleek, La vie en Belgique sous l'occupation.

2 BNB, Archives, RR, 27.12.1944; ARA, fonds Société Générale de Belgique, BEB, dossier 25, copy 550/21: DC SG, 29.07.1952.

3 NBB, Archief, RR, 20.12.1944. 
own documents. At Frère's request, Goffin and Vandeputte were also present at the search of the premises, in order to explain the content and structure of the archives. In total, the archive material occupied two kilometres of shelf space ${ }^{4}$.

On 9 February 1945, in a further move, the deputy-prosecutors went to the Société Générale de Belgique to seize all documents regarding the establishment and operation of the Banque d'Emission, as well as all documents that had anything to do with the employment policy and the 'politique de moindre mal'. Finally, between 15 December 1944 and 28 November 1945, sixty-four reports were drawn up of the conversations of the deputy-prosecutors with various persons concerned with the setting-up of the Banque d'Emission and with its operations during the occupation'.

The deputy-prosecutors were apprehensive about the enormous extent of the investigation they had been charged with and therefore attempted to work together with the provisional administrators of the Banque d'Emission, appointed on 27 March 1945 by the government. For their part, the three accounting experts judged that the exact nature of the Banque d'Emission's transactions could be determined only by sifting carefully through the Belgian and German documents and identifying as many as possible of the Belgian individuals and companies paid directly or indirectly by the Banque d'Emission. However, this required both extensive examination and a prodigious amount of time ${ }^{6}$ - two and a half years, as it turned out.

For its part, the Commission of Enquiry was under great political pressure to produce rapid results, but this proved to be impossible. It was only at the end of January 1946 that the final report was ready in printed form and handed in confidence to the Minister of Justice. It remained for months a confidential document, but the matter leaked out at the beginning of 1947 and the report started to attract press attention, which determined the Minister to pass the report to the Senate Finance Committee and to the Secretariat of the Chamber of Representatives?

4 Newspaper Cité Nouvelle, 21.02.1947.

5 Krijgsauditoraat CI 47/44, BEB, dossier 4, s. f. 3: dossier d'instruction.

6 BNB, Archives, SD, enquête BEB, dossier 1-2: letter of 16.12.1946 from Ganshof-van der Meersch to the Minister of Justice.

7 Newspaper Le Soir, 30.01.1947. 


\section{THE COMMISSION'S REPORT}

In the report, a first and fairly brief section set out the Commission's opinion that there could be no disputing the legitimacy of the establishment of a bank of issue (the Banque d'Emission) during the confused early days of the occupation. The report's main attention then turned to the institution's activities during the four subsequent years and to what extent they were susceptible to criticism and dispute. In its evaluation, the Commission was equivocal, running with the hare and hunting with the hounds ${ }^{8}$. On the one hand, it expressed understanding for the difficult circumstances that the leaders of the Banque d'Emission had been faced with and the serious attempts made by them to resist. Consequently, the management of the Banque d'Emission could not be accused of open economic collaboration. On the other hand, the tone of the report's commentary was often critical and took on a sharp edge in respect of the management's stance.

In what follows, the attempt is made to review as objectively as possible the 'compromise' that the report ultimately became. In the view of the Commission, for example, it had been a mistake - with the benefit of hindsight - for the government to have authorized the return of Governor Janssen and the Bank's registered office to Brussels in July 1940, because this allowed the directors of the Banque d'Emission to claim that they had acted in accordance with the intentions of the government in London. However, the legitimacy that they were able to invoke during the early years of the occupation had lapsed with the proclamation of the decree of 27 November 1941, which made clear that the government had declared Goffin's appointment null and void and had transferred the Bank's registered office to London. The Commission found it a matter of regret that the directors of the Banque d'Emission had made no effort to find out the real intentions of the government in issuing the decree. On the other hand there was no exoneration for the government in London either, as, in letters to Galopin and to A.-E.

8 In respect of the analysis of the report of the Commission of Enquiry and of the analysis of the decision of the Krijgsauditoraat to drop the case, see chiefly the excellent work: D. Luyten, Burgers boven elke verdenking? See also the studies of E. Verhoeyen, België bezet, 1940-1944. Een synthese, Brussels, 1993, and P. Nefors, Industriële collaboratie in België. 
Janssen, it had never expressed any recrimination about the Banque d'Emission. There were, thus, shortcomings on both sides.

The Commission was much more critical about the clearing operations. It acknowledged the pressure exerted by the Germans and recognised their power and organization. There was agreement, too, about the resistance put up by the Banque d'Emission leaders, but their attempts at resistance from the end of 1941, and particularly from the end of 1942, were considered inadequate. It was also acknowledged that the arrangement of 7 December 1942 - arrived at after vehement discussion with the occupying power - had improved the situation. However, the concessions obtained had fallen far short of the stated goal and, even after this further trouncing - for it was nothing less - not one member of the management or the board of directors had resigned. In spite of all protests, the Belgian credit balance at the Deutsche Verrechnungskasse had risen to more than 64.5 billion Belgian francs. Even worse, this included a good 20 billion francs' worth of payments for which no details had been given and which could have hidden all kinds of dubious transactions.

The Commission emphasized the fact that the Banque d'Emission's leaders had never pursued a policy that was in any way aimed at providing direct aid to the enemy. It also pointed out that they had sought no direct advantage from their participation in the institution and that they had been honest in their conviction that concessions had to be made to the occupier, in order to safeguard certain national interests, such as avoiding dual money circulation, securing supplies, identifying those guilty of collaboration, and opposing the deportation of workers to Germany and France. The question facing the Commission was whether, in the light of what was achieved, the concessions were fully justified.

Although it was recognized that valid arguments could be advanced to do everything possible to prevent dual money circulation, the Commission was not convinced that - had it come about - this would have been an obstacle to financial reform after the war. With the lessons of 1918 still fresh in the memory, the government would certainly have dealt adequately with the problem after the liberation.

The Commission accepted that the argument for securing supplies had been valid at the beginning of the occupation, but pointed out that 
this was no longer the case from 1942, when the credit balance at the Verrechnungskasse had got out of hand. It also accepted that maintaining economic activity in order to prevent workers being deported was a valid argument for Belgian businessmen, but not a valid one for the leaders of the Banque d'Emission. On the contrary, their pursuit of such a policy implied a moral screen for collaboration. The strength of the argument regarding the identification of collaborators was likewise disputed. Had not the Banque d'Emission itself admitted that the details given were generally too summary for reliable lists of untrustworthy citizens to be drawn up? Moreover, had Banque d'Emission control actually held the extent of exports to Germany in check? The institution's leaders thought so and had pointed to declining figures towards the end of the war, but was that decline a consequence of Banque d'Emission action or rather of industrial activity having been brought to a standstill by bombardment or a lack of raw materials?

Turning to the moral aspect of the policy of maintaining a presence, the Commission stated that, in this instance, it was bound to imply co-operating with the enemy. Arranging money transfers from workers employed in Germany or France to their families in Belgium, making efforts on the industrial front to improve the provisioning of the population, or doing all that was possible to keep workers employed in Belgium all fell under the umbrella of 'providing social service', but did this not imply that the Banque d'Emission was thereby an instrument of economic exploitation of the country and its work force? The management of the Banque d'Emission was not blind to this implication, but in the dilemma between maintaining a presence and not doing so, it had opted for what it considered to be the more difficult policy of the lesser evil. The Commission had difficulty in endorsing this line of argument, because - as mentioned above - it was rather sceptical about the Banque d'Emission having played a positive role.

\section{REACTIONS}

Summing up its conclusions, the Commission stated that the Banque d'Emission had met its professional obligation in seeking all that was possible to safeguard not only the country's industrial and commercial 
equipment, but also its monetary system. The institution had also met its social obligation to do what it could to moderate the severity of the occupation. However, it had been found wanting in regards its political obligation to get occupied Belgium to participate as much as possible in the Allied struggle against Nazi Germany.

The founder-bankers had, in fact, expected the report to be more unfavourable and were consequently able to agree to some extent with its conclusions 9 . However, they were highly critical of certain aspects. In particular, they regarded as totally artificial the report's separation of the Bank and the Banque d'Emission, whereby only the latter and its leaders were held responsible for all the difficulties arising from the occupation: 'The Banque d'Emission had been a subsidiary of the Bank', they argued. It was on the Bank's authority and with the Bank's banknotes that the Banque d'Emission had executed all its transactions ${ }^{10}$. The bankers also remarked that the government commissioner, Smeers, could have exercised a right of veto over the banknotes made available by the Bank to the Banque d'Emission to finance its clearing operations; the fact that he did not do so, appeared to have been no hindrance to his being made a director of the Bank after the liberation. The bankers also noted that the appointment of Goffin as governor of the Bank after Janssen's death at the beginning of June 1941 had initially been accepted not only by the Belgian government in London, but also by Theunis in New York, who had even sent a congratulatory telegram to Goffin from there ${ }^{11}$.

The London decree of November 1941 had been regarded in Brussels as a measure underpinning the legal proceedings against the Banque de France and not as an expression of disapprobation of the two institutions. Indeed, the written communications between the government in London and the leaders of the Bank and the Banque d'Emission during the occupation had contained no criticism by that government of

9 ARA, fonds Société Générale de Belgique, BEB, dossier 25, copy 550/21: DC SG, 29.07.1952.

10 ARA, fonds Société Générale de Belgique, BEB, dossier 22 (copy 550/11): remarks on the report of the Commission of Enquiry, 15.03.1947.

11 ARA, De Vleeschauwer Papers, CRE, PD 40, dossier 598: Dubois-Pélerin to De Vleeschauwer (notes for the interpellation of Demany and letter of 16.06.1947). 
the 'activities' of both institutions ${ }^{12}$. The criticism of the Commission of Enquiry was, therefore, regarded as totally unfounded. The leaders of the Bank and the Banque d'Emission had remained at their posts solely to avoid any lackey of the Germans being placed at the helm ${ }^{13}$. In the Netherlands, where Trip had resigned as President of the Nederlandsche Bank, he was promptly replaced by the Germanophile Rost van Tonningen, to the great misfortune of the central bank and the country ${ }^{14}$.

The criticism that the Banque d'Emission had not resisted the occupier strongly enough over the clearing system, was also brushed aside. In fact, the increase in the Belgian credit balance at the Deutsche Verrechnungskasse in Berlin, brought about by the financial transfers, had been a priority concern of the Banque d'Emission from the outset and had been successfully held in check by the counter-measures taken by the institution ${ }^{15}$. As regards commercial transfers, everything possible had been done to rid the clearing system of dubious transactions.

Turning to the employment policy of 1940, involving exports to Germany and the clearing system, the founder-bankers pointed to the patriotism and moral integrity of Galopin, who had initiated the policy. In this policy Galopin had always been emphatically supported by Professor De Visscher, Chairman of the Belgian Resistance Committee, who maintained contact with London and via whom Galopin was also able to reach the government there : 'The policy of work resumption was the only feasable option in 1940: it implied, however, economic cooperation between Belgium and Germany, from which the Belgians could not withdraw ${ }^{316}$.

12 ARA, fonds Société Générale de Belgique, BEB, dossier 18, copy 550/5: letter of 10.09.1945 from A.-E. Janssen to Duquesne de la Vinelle; copy 550/14: Observations par la BEB sur la note du Comité d'Enquête portant sur les relations avec le gouvernement, 1945.

13 BNB, Archives, $S D$, 37, rapport BEB, dossier 8.11.34: remarques des banquiers fondateurs sur le rapport relatif à l'activité de la BEB.

14 In this respect, see the testimony of Goffin: Krijgsauditoraat CI 47/44, BEB, dossier 4, s. f. 3: dossier d'instruction (report of the testimony of Goffin).

15 ARA, fonds Société Générale de Belgique, BEB, dossier 19, copy 550/7: les transfers financiers.

16 SOMA, Archives, De Winter Papers, CRE, PD 34, dossier 652: quoted by Plisnier in his defence, following the decision of the administrative commission (o8.07.1948) that he should not be allowed to resume his function as secretary-general (among 
The founder-bankers also remarked that the Commission of Enquiry had presented a one-sided picture of the Belgian credit balance with the Deutsche Verrechnungskasse ${ }^{17}$. During the occupation, the total value of Belgian exports had amounted not to 64.5 billion Belgian francs, as indicated in the report, but to 98 billion. Besides exporting goods and services, Belgium had also imported goods to a total amount of 33.5 billion francs, chiefly for foodstuffs and raw materials that had helped to boost the population's food supply and employment. A further error had been made in the estimation of payments for which no transaction details had been given. The report spoke of a third of total exports, whereas the actual figure had been at most one tenth.

A final point made by the founder-bankers was that their policy of maintaining a presence had resulted in occupation costs being less onerous in Belgium than in neighbouring countries. If this was not so apparent in terms of absolute figures, it was certainly the case when the costs were placed in their correct context. On the eve of the Second World War, Belgium had been a country with a high level of industrialization, higher even than that in the Netherlands or France. Logically, therefore, the contribution to the war effort, imposed by the occupier, ought, in per capita terms, to have been much higher for Belgium than for her neighbours, but the figures showed that this had not been the case $^{18}$. The policy of maintaining a presence had thus clearly served to moderate Belgium's participation in those costs. In the opinion of the founder-bankers, this outcome was already sufficient justification for the stance they had adopted during the occupation.

other things imputed to him was 'qu'il avait commis une faute grave en s'associant à l'oeuvre de la Banque d'Emission'; moreover, his policy of maintaining a presence was condemned, because it had resulted in too many unacceptable compromises with the occupier). Plisnier was later to be rehabilitated.

17 BNB, Archives, SD, rapport BEB, dossier 8.11.34: notes des banquiers fondateurs (remarks by A.-E. Janssen, undated).

18 Even if the French per capita figures are lower than the Belgian, it should not be forgotten that the full occupation of France by the Germans took place more than two years after the Blitzkrieg. Consequently, spreading the total amount of occupation costs over the entire French population, even for the first years of occupation, distorts the comparison with other countries, including that with Belgium. 
Table 27.1: German levies on occupied territories, 1940-1944

\begin{tabular}{|c|c|c|c|c|}
\hline COUNTRY & $\begin{array}{r}\text { Gross amount levied } \\
\text { (in billions of } \\
\text { Reichsmarks) }\end{array}$ & $\begin{array}{l}\text { Number of } \\
\text { inhabitants } \\
\text { (in millions) }\end{array}$ & $\begin{array}{r}\text { Levy per capita } \\
\text { (in Reichsmarks) }\end{array}$ & $\begin{array}{r}\text { Adjusted GDP } \\
\text { figures - 1938 } \\
\text { (in Reichsmarks) }\end{array}$ \\
\hline France & 40.1 & 42.0 & 955 & 1,110 \\
\hline Netherlands & 14.5 & 8.7 & 1,667 & 1,667 \\
\hline Belgium & 10.3 & 8.4 & 1,226 & 1,333 \\
\hline Norway & 6.9 & 2.9 & 2,379 & 2,703 \\
\hline
\end{tabular}

Source, Klemann, Nederland, 1938-1948, p. 116.

\section{THE PROSECUTOR'S DECISION AND ITS AFTERMATH}

The Commission of Enquiry's report drew a quite different reaction from the media and certain political parties. A particularly aggressive line was taken by the Communist Party, which gave additional emphasis to the criticisms voiced in the report ${ }^{19}$. It pressurized the Minister of Justice to ask the chief military prosecutor, Ganshof-van der Meersch, to report as quickly as possible to him on the progress in the legal investigation. This the chief prosecutor did on 16 December 1946, hinting that, from the point of view of a criminal prosecution, there were insufficient elements in the Banque d'Emission dossier for the investigation to lead to charges being brought ${ }^{20}$.

Less propitious conclusions were drawn by the three accounting experts, who submitted their final report on 14 June 1947. They felt that the Banque d'Emission had gradually become an instrument for financing the enemy's economy. But at the same time they admitted that their report was made from a purely technical point of view and took no account of either the general context of the occupation or the difficult circumstances in which the leaders of the Banque d'Emission had to $\mathrm{act}^{21}$.

When rumours began that the military prosecutor was not going to act on the report and would halt the investigation, a fresh campaign was

19 Newspaper Le Drapeau Rouge, 04.02.1947; 05.02.1947; 08.02.1947.

20 BNB, Archives, $S D$, enquête BEB, dossier 1-2: letter of 16.12.1946 from Ganshof-van der Meersch to the Minister of Justice.

21 Luyten, Burgers boven elke verdenking?, pp. 232-233. 
whipped up, demanding sanctions against the Banque d'Emission and its leaders ${ }^{22}$. However, the military prosecutor remained unmoved by the new campaign and was not prepared to accept the negative conclusions of the experts. In an ordinance of 17 July 1947, he gave his decision that, in respect of possible breaches of articles 115 and 118bis of the Penal Code, the investigation regarding the Banque d'Emission and its leaders was dropped ${ }^{23}$. What was the prosecutor's justification for this decision? In the first place, he had looked into the circumstances surrounding the Banque d'Emission's establishment shortly after the beginning of the occupation. The departure of the Bank for France had created a monetary vacuum and, in accordance with the Hague Convention, the occupier had had a right in that case to set up its own issue institution. Founding a Belgian bank of issue was thus warranted because it had prevented both the establishment of a German institution and the attendant circulation of German marks.

In the second place, the prosecutor had looked into the manner in which the Banque d'Emission had operated, and had tested two aspects of that operation against articles 115 and 118bis of the Penal Code. The first aspect concerned the cession of gold and foreign currency belonging to individuals. Had the Banque d'Emission been seriously in error in the way it had responded to the German ordinance of August 1940 concerning gold and foreign currency? Investigation had shown that the majority of the gold (coins and bars) and foreign currency had been transferred to the Reichsbank in Berlin in 1940 and 1941 by the then Bank governor, Georges Janssen. The prosecutor felt that the transfer could be regarded as justified, because the governor had hoped, albeit in vain, that he would thereby have been able to finance imports of foodstuffs.

The second aspect had to do with the clearing system and here, too, no contravention of articles 115 and 118bis of the Penal Code could be determined. The payments made by the Banque d'Emission in return for credit balances with the Verrechnungskasse in Berlin could not be considered as financial aid to the enemy. Had the Banque d'Emission not undertaken the task, the occupier would have used other means

22 Newspaper Le Drapeau Rouge, 21.06.1947; newspaper La Libre Belgique, 22.06.1947. 23 Krijgsauditoraat, CI 47/44, BEB, dossier 4, s.f. 10: ordonnance de non-lieu, 17.07.1947. 
to settle the debts created by exports from Belgium to Germany. Indeed, nobody could have prevented the German authorities from using Reichskreditkassenscheine or Reichsmarks to pay Belgian suppliers and it was precisely the purpose of the Banque d'Emission payments to prevent such a dual or parallel circulation of money and maintain control over payments.

A final point was that, in the prosecutor's opinion, the managing directors and the board of directors of the Banque d'Emission had been convinced that their 'politique de présence' had been a means of preventing collaborators taking their places. The members of the two bodies had received no remuneration for their commitment and nowhere had any evidence been found that they had exploited their position at the Banque d'Emission to benefit their own companies.

During the investigation, the Commission of Enquiry had questioned whether the shareholders of the Banque d'Emission ought to be held liable for the Banque d'Emission's overall debt to the Bank, amounting - as indicated above - to 64.5 billion Belgian francs. Three eminent jurists had been consulted by the Commission on this matter and their scrutiny had led them to the conclusion that the legal liability of the Banque d'Emission's shareholders must remain limited to their share of the subscribed capital stock. After extensive deliberation, the Commission endorsed their opinion, an endorsement that, because of the State guarantee, boiled down to the State itself assuming liability for the remaining debt. The government acted on the endorsement at the beginning of $1948^{24}$ and thereby opened the way to the elucidation of the Bank's balance sheet that took place in the same year, together with the reform of the institution itself ${ }^{25}$.

However, the limitation of the shareholders' liability for the debts of the Banque d'Emission to the amount of capital they had subscribed continued to excite discussion ${ }^{26}$. At its establishment, the founderbankers of the institution had only partly paid up the capital to which they had subscribed and there was still a shortfall of 120 million Bel-

24 Newspaper Le Soir, 25.01.1948; newspaper Le Drapeau Rouge, 06.03.1948.

25 R. Brion and J.L. Moreau, La politique monétaire belge dans une Europe en reconstruction (1944-1958), Brussel, 2005.

26 ARA, fonds Société Générale de Belgique, BEB, dossier 25, copy 550/21: DC SG, 29.07.1952. 
gian francs. The matter remained unresolved until 16 July 1952 when the Belgian Parliament approved a government bill for the liquidation of the Banque d'Emission, which obliged the shareholders to pay up the capital in full.

The liquidation of the Banque d'Emission rang down the curtain on a troubled episode in the history of Belgian central banking. Jules Dubois-Pélerin, at that moment President of the Société Générale de Belgique, wrote in this respect: 'It is with great relief that the last phase of this sad adventure has been concluded. Our attitude and behaviour have been irreproachable from a political as well as from a moral and social point of view....Only one regret : our action was not always undertaken in an atmosphere of perfect unity, which during the occupation years was not only desirable but, still more, also indispensible ${ }^{27}$.

There was undoubtedly a subjective and partisan edge to DuboisPélerin's comments. The circumstances of war had been too complex for an exact distinction to be made between the respective areas of responsibility of the three parties concerned, i.e. the Bank, the Banque d'Emission and the Ministry of Finance; group interest and personal motives had also played a part, as indeed had the climate of repression at the time of the liberation, to which the government in London had made a considerable contribution. However, Dubois-Pélerin, in his comment, was correct in one thing: the united front during the occupation had not worked adequately; solidarity among the three parties had been lacking, and for this each of them bore a measure of blame.

27 ARA, fonds Société Générale de Belgique, BEB, dossier 25, copy 550/21: DC SG, 29.07.1952. 


\section{Epilogue}

Les livres ne sont pas faits pour être crus, mais pour être soumis à l'examen

(U. Eco, Au nom de la Rose)

This has been a lengthy book to write and its writing has taken many years of research, demanding close examination of countless items from the archives of prestigious institutions in Belgium and abroad. In their research, moreover, the authors were never shy of 'picking the brains' of eminent historians, politicians and journalists who, on paper or on tape, had recorded their fascination and knowledge about the Second World War. And yet the book leaves many questions still unanswered - essential questions to which the interested reader would no doubt have expected a clear answer. Could it be that, despite all the generous support they received from the National Bank of Belgium, the authors have fallen short of their goal?

To answer this particular question is also to ask what historians can and may do with the mass of information at their command. For the authors, the task of a historian is not to separate the good from the bad, as done so vividly in the mediaeval triptychs of the Last Judgement. Rather, it is, to the best of their ability and as objectively as possible, to set out the building blocks that have been uncovered in research and to leave the reader to make the final assessment. That is no simple task and was certainly not for the present book's two authors, who, as teenagers, experienced the war at first hand. Many might make light of this, but the impact on young people of their world exploding into war around them is not to be easily discounted. What that impact represented was a first hurdle that had to be overcome: no personal feelings could be allowed to intrude. In this respect, the authors have done their best to exclude any personal experience from this account. It remains for the reader to judge whether they have succeeded.

A specific question that might intrigue the reader is why the private bankers found it so necessary - and were so impatient - in June 1940 
to set up a bank of issue. One explanation might concern the degeneration of the democratic institutions in Belgium, particularly during the final inter-war years. Could it be, too, that the policy of neutrality, with King Leopold III and Spaak as its great advocates, offered an additional explanation for the lack of preparation for what everyone saw as an imminent world conflict, or should the emphasis rather be placed on the chaotic situation in the country during the first weeks after the German invasion? Perhaps the answer lies in a combination of all this. What is certain is that, after the German invasion, Belgium lay open like a wasteland for the enemy. Whether one now lays the emphasis on the thirst for profit of the bankers, who, in a spirit of revenge against the reforms of 1935 and 1937, saw a golden chance to regain their grip on the financial world in Belgium, or on attempts to assess the situation soberly and not in clichés, the fact remains that the mass flight of the political and monetary establishment left Belgium rudderless and a population dejectedly casting around for help. With the situation so chaotic, can the private bankers be reproached for having on their own initiative attempted to man the abandoned decks in their own country?

How did the government and the representatives of the Bank abroad assess the stance and actions of their counterparts in occupied Belgium? More particularly, why were Gutt and Theunis so full of understanding for the misjudgements and wrong decisions of Governor Janssen and so harsh and critical towards his successors? Georges Janssen was a person respected by all, unimpeachable and courageous, a man who radiated authority and decisiveness. However, the answer does not lie so much in the personality of the man as in the picture formed of him on the other side of the Channel and the assessement there of the situation in occupied Belgium. During the four years of their 'exile', the Belgian authorities in unoccupied territories changed markedly in their outlook. The clear vision with which they attempted to view their own country from London became clouded over the years and towards the end tended to darken very markedly.

Returning to the early months of the occupation, however, why was there no reaction from London to Janssen's initiative to conclude a convention with the Reichsbank, a convention that laid the legal basis for the derailing of the Belgo-German clearing system? When things came to be settled after the liberation, it was demonstrated with hard data 
how the clearing system had, in fact, been totally corrupted and had thereby been an additional tool in enabling the occupier to plunder the country. The leaders of the Bank and the Banque d'Emission at the time were held responsible for this, but there was not a word about Janssen. Nor was there any word about Janssen's unfortunate action over the Belgian and Luxembourg gold held by the French government, nor even about the misconceived decision in July 1940 to grant Ingenbleek exclusive competence to take all executive measures in unoccupied countries, a competence that for months paralysed the activities of the Bank in London and New York. Was the absence of any criticism a consequence of the defective lines of communication during the first months after the French cease-fire? Did the precarious situation of the Belgian government on its arrival in London also play a part? There was also no reaction from Baudewyns, the Bank's representative in unoccupied countries. Did the fact that he was a Bank man to the core mean that he saw matters solely through the eyes of Janssen?

The attitude of the Belgian government in London towards Galopin's policy of opting for the lesser evil also hardened as time passed. Initially, it was agreed by all on both sides of the Channel that a resumption of work was the only solution to the Allies' blockade, demanded by Churchill and supported by Roosevelt. Belgium had always been dependent on imports for her food supplies and if there was no possibility of organizing relief for Belgium on the lines of what had been done during the First World War, a resumption of work was the only alternative to keep the population fed: the deal was for manufactured goods in exchange for food, with the invoices settled through the clearing system in Berlin. In this matter, too, it appeared that all was well: Galopin's reputation was unassailable and Janssen, together with the Bank and the Banque d'Emission, fully supported the new strategy; the resumption of work would not only secure food for the population, but also jobs, thereby preventing an exodus of workers to Germany and the feared dismantling of industrial plant and equipment.

The occupying authority paid no heed to the agreements, and the Belgian credit balance on the clearing account in Berlin came to assume alarming proportions. Shortly after Janssen's death at the beginning of June 1941, the founder-bankers of the Banque d'Emission began systematically to take over decision-making and also within the Bank. 
By then, however, the policy of accommodation had already begun to slip into the grey area of economic collaboration and alarm bells had begun to ring in London. Deliveries to the occupier were no longer being offset by food imports and in the autumn of 1942 the signal was given for the feared deportation of Belgian labour to Germany and France. The entire structure upon which the policy of opting for the lesser evil rested had been eroded and the government in London now clearly distanced itself from the entire concept, the more so as sporadic news was being received of war collaborators enriching themselves. The fact that the Bank and the Banque d'Emission were involved in the financial settlement of transactions with Germany and France, through the clearing system, meant that charges of being guilty of collaboration were also levelled at them by London.

Were the accusations and the threats of sanctions after the war issued by the government in London and in even sharper terms by Theunis in New York against anyone who had borne monetary, financial or administrative responsibility - justified or had the Belgian authorities overseas generalized and magnified the sparse information that reached them about collaboration in their home country? As was to be expected, the opinions of contemporaries were sharply divided. The Bank and the Banque d'Emission were convinced that, under constant pressure from the occupier, they had demonstrated an unimpeachable sense of duty in carrying out their thankless task of balancing accommodation with resistance. They were even supported in that conviction by outsiders. Indeed, such people as De Visscher, Pholien and Dierkx, all belonging to the top echelon of the Resistance, were by no means happy with the hard line adopted by the 'Londoners' on their triumphant return. Sixty years on, however, and now that the fire of emotions has burnt low, how is the government's attitude on its return from London to be assessed?

In speaking of De Visscher, it has to be made clear that his favourable judgement of the policy of maintaining a presence in Belgium, as that policy unfolded after 1942, cannot be taken as endorsing a compliant attitude towards the occupier. He was unchanged in his view that those responsible for policy in Belgium were duty-bound to contest every unjustified demand from the Germans and to accede only when the demand was made into a formal order from the Military Government. 
What had irritated him during the occupation was the lack of solidarity between the Bank, the Banque d'Emission and the Ministry of Finance. He held to his belief that the united front that had so woefully collapsed during the crisis of 1942 could have continued to act as a buffer against the illegal demands made by the Germans - not that the plundering would have suddenly ceased, but because resistance in Belgium would thereby have been more effective. Was this a correct assessment of the situation? And who was actually responsible for the dramatic breach of the united front in 1942 ?

Although the various protagonists in the conflict continued to believe in the correctness of their own, individual courses of action, it was not so clear just what the limits were. The situation was very tense. The decrees issued in London on 27 November 1941 were already an unmistakeable signal to those responsible for policy in occupied Belgium that legal authority rested solely with the government in London and that it was there that strategies were determined and judgements made. Even though the decrees were designed primarily to support the Bank's legal proceedings in New York against the Banque de France, there was no misunderstanding the underlying messages. One of these was that disturbing questions were being asked in London regarding the policy of accommodation, the guiding principle determining the actions of the Bank, the Banque d'Emission, the private bankers and the industrialists - in short, the entire non-pro-German establishment in Brussels which they felt would vindicate their stance, if it was questioned.

Inevitably, the failure of Operation Barbarossa in Russia had an impact on the attitude of the Military Government in Brussels. If von Falkenhausen was to remain in Brussels and not bend under the pressure of the Nazi authorities in Berlin to have Belgium placed under a Civil Government, as was the case in the Netherlands, concessions would be necessary. The harder line now taken by the occupier was regarded as unacceptable by certain directors of the Bank and prompted their resignation. Was this pure opportunism or a matter of principle? Together with his administration, Secretary-general Plisnier faced the same dilemma. Who was to incur the odium and take responsibility for the monstrous policy represented by the clearing operations? Was it those who remained convinced that, without the Bank's and the Banque d'Emission's 'politique de présence', industrial collaboration would have 
got even further out of hand and that, however shaky, a Belgian hand controlling transactions with the enemy was better than no control at all? Or was it those who distanced themselves entirely from any participation in negotiations with the enemy? So far removed from the events we are describing, this may seem an academic question, but it was not so for the people at the time, who, after four years of occupation, urgently wanted an answer.

Moving on to the Gutt Operation, we see that it was praised by some and questioned by others. Indeed, two diametrically opposed views were already apparent during its preparation in London and Brussels. Baudewyns and Gutt restricted it to an orthodox reform and looked to reduce the money supply to its level of May 1940; in line with this, they opted for a fairly strong Belgian franc. Van Zeeland held out for a pragmatic approach limited to eliminating hoarded money and aimed at keeping the exchange rate low, with both elements serving to boost economic recovery after the liberation.

It was Gutt, the Minister of Finance, who got his way. From the outset, however, the operation ran up against an unforeseen difficulty, in that delivery of the new banknotes from Great Britain was held up for a month, which served to encourage fraud. Much worse, though, was the short-term deflationary effect of the reform. The economy failed to recover, prices continued to rise and the black market flourished. Meanwhile, unforeseen wintering of the Allied troops in Belgium in 1944-1945 brought about an increased demand for goods and services, so that the government was forced to resort to deficit spending to carry out the most urgent infrastructural work and to get the reconstruction of the country on track. Was the Gutt Operation therefore a failure?

It certainly appeared so to the average citizen during the first months after the liberation, but a definitive turning-point was reached in the summer of 1945. The worrying expansion of the money supply during the preceding winter, which had threatened to undermine the entire Gutt construction, ultimately turned out to be a blessing, because it created a reflationary climate that gave the Belgian economy the necessary breathing-space to begin recovering without falling into a vicious circle of post-war price inflation. It was just at that moment, in fact, that the braking effect of the deflationary shock of Gutt's monetary reform came into play, serving to stabilize prices, albeit at a much higher level 
than had been anticipated. That stabilization, in tandem with wage increases, in turn exercised a favourable effect on the real income of the great mass of those in waged and salaried employment. The reform long years in preparation - and a happy conjunction of circumstances ('chance', if you wish) combined to produce what came to be called 'the Belgian economic miracle' in the immediate post-war years.

However, the miracle proved to be short-lived: by the end of the 1940s, the Belgian economy was already in structural crisis. What caused this? How was it possible for the 'prodigy' to become in no time at all the 'sick man of Europe'? Could it have been that the currency reform was conceived in too exclusively monetary terms and took too little account of the complexity of post-war economic life? Everywhere, the emergence of the mixed economy had followed in the wake of the liberating armies; systematic cooperation between government and business had become a necessary condition for survival in a new and complex society. For the Belgian miracle of the immediate post-war years to endure, reform needed an economic component besides the monetary and the question is whether the Belgian currency reform had given sufficient attention to this. Neighbouring countries that had integrated monetary policy with wider structural reforms appeared later to have laid the foundations for a more durable recovery.

The development of Belgian financial and monetary policy during and immediately after the Second World War was not, thus, guided by an invisible hand; nor was it exclusively determined by chance and necessity. As is always the case in times of great tension, the dramatic years of 1940-1945 threw up remarkable characters, pivotal figures standing out sharply, in high relief, who set their stamp on the course of events and whose names continue to resonate in the collective memory. If, after nearly sixty years, a book such as this, can succeed in setting such dominant characters in their proper place under the arc light of history, its authors will feel themselves sufficiently rewarded.

In the Free World, Gutt - Minister of Finance of little Belgium stood head and shoulders above his fellow-countrymen and was, without doubt, the strong man of the government in exile in London. Calmly, but doggedly, step by step, he rebuilt his country's battered image. In Allied government circles, he came to be recognized - though not without difficulty - as the most respected defender of Belgian in- 
terests. Furthermore, his cooperation with the Dutch government in exile opened the way to important monetary agreements concluded in Europe after the war and even to wide-ranging initiatives for European cooperation and integration, though these paled into insignificance in the face of Gutt's burning passion during those years for the post-war recovery of his country.

Abused and occupied Belgium was at first no place for heroes, but it was a cockpit for fighters. A person like Governor Janssen may well have made errors, but no-one can question his courage and resoluteness in the struggle against the occupier. The same can be said of Cracco and Vandeputte, who followed him in confronting the occupier, though certainly not from opportunism, as it was already too late for that. A place of honour has also to be accorded to Galopin, who, supported by the éminence grise, A.-E. Janssen, subtly and in his own way maintained the struggle between occupier and occupied, until his calamitous murder drew an early line under what had been an immeasurable contribution. Many other participants in the tragedy of the occupation are not mentioned here; they were by no means secondary figures, but the part they played lay elsewhere, not immediately in the glare of the spotlights. It has been the authors' concern in this account to do justice to each of them, because the courage demonstrated by so many is a rare virtue and of all the more value because of that.

In respect of the occupier of Belgium, by way of postscript, it may be asked whether the Military Government was better than the Civil Government that eventually replaced it. Statisticians think it was. Was von Falkenhausen therefore right to charge Belgium with ingratitude after his conviction by the Military Tribunal in Brussels? No man of the party, he had - perhaps for personal reasons - fought to keep Belgium out of the grip of the Nazi party. Through endless discussion with Berlin, he was more or less successful in this until July 1944, when he was removed and the feared Civil Government took charge in Belgium, though too late to have much effect. Ought he, an enemy, to be included in the ranks, not of the heroes, but of the people of good will who attempted to make the suffering of World War Two more bearable? Or ought he simply to be lumped in with all the others who occupied, crushed and bled our country? Who is to say? 


\section{Sources}

\section{PUBLIC ARCHIVES}

\subsection{Archives of the National Bank of Belgium, Brussels}

Archives of the Central Administration

Accounting Department (Boekhouding)

Central Cashier's Office (Hoofdkas)

Treasurer's Office (Schatbewaarder)

Inspection Department (Inspectie)

Legal Department (Juridische Dienst)

Research Department (Studiedienst)

Archives of the Secretary's Office

Minutes of the General Assembly of the NBB, 1939-1946 (AV)

Minutes of the General Council of the NBB, 1939-1946 (AR)

Minutes of the Board of Directors of the NBB, 1939-1946 (DC)

Minutes of the Supervisory Council of the NBB, 1939-1946 (RR)

Minutes meetings Managing Directors of the BEB, 194O-1944 (DC BEB)

Minutes of the Board of Directors of the BEB, 1940-1944 (вн вЕВ)

Papers Georges Janssen

Papers Jules Ingenbleek

Papers Albert Goffin

Papers Adolphe Baudewyns

Papers Pierrre Berger

Papers François Cracco

Papers Robert Vandeputte

Papers Thomas Bassyn

Papers Hubert Ansiaux

Papers Herbert Prack

London Papers (Archives de Londres)

Committee of Enquiry BEB (Onderzoekscomité BEB)

Thematic Files 
Correspondence

Staff Inquiry вEB

Miscellaneous (Diversen)

1.2. General Archives of the Kingdom, Brussels (ARA)

Minutes of the Cabinet meetings in Brussels, 1936-1940

Papers Georges Theunis

Papers Albert de Vleeschauwer

Archives of the Prime Minister

Archives of the Ministry of Finance (Papers Plisnier)

Archives of the Société Générale de Belgique

1.3. Centre 'War and Contemporary Society', Brussels (soma)

Minutes of the Cabinet meetings in London,1940-1944 (copies)

Papers Camille Gutt

Papers Herbert Prack

Archives 'Centre d'Etude pour les Problèmes d'après-Guerre' (CEPAG)

1.4. Archives Société Générale de Belgique, Brussels (sG)

Directorate, Papers Alexandre Galopin

Directorate, Papers Max Nokin

Directorate, Papers Jules Dubois-Pélerin

Files 'Défense'

Dossier 'Banque d'Emission à Bruxelles' (вEB)

\subsection{Archives Royal Palace, Brussels}

Archives King Leopold III

Papers Robert Capelle (comte)

1.6. Archives Université Catholique de Louvain, Louvain-la-Neuve (UCL)

Papers Albert-Eduard Janssen

1.7. Archives Military Court, Brussels

Dossier Oscar Plisnier

Dossier 'Banque d'Emission à Bruxelles' (BEB)

Dossier Emile De Winter 


\subsection{Archives Ministry of Foreign Affairs, Brussels (Bz)}

Diplomatic records, 1939-1945

\subsection{Public Archives in The Netherlands}

General Archives of the Kingdom, The Hague (Ndl.ARA): 'Foreign Affairs'

Archives Ministry of Foreign Affairs, The Hague (Ndl.Bz)

Archives Ministry of Finance, The Hague (Ndl.MF)

Archives, Nederlandsche Bank, Amsterdam (Ndl.NB)

1.10. Archives in the U.S.A.

General Archives, Washington, D.C.: Files 'Belgium'

Hoover Institute, Stanford University, Palo Alto (CA): Files 'Belgium'

\subsection{Archives Banque de France, Paris}

Direction de la documentation et des publications économiques

Secrétariat Général

Secrétariat du Conseil Général et du Conseil de la politique monétaire

\subsection{Archives in Great-Brittain}

Archives Bank of England

Files 'Belgium'

Files 'Gold'

\subsection{Archives in Germany}

Archives Reichsbank (originals in Moscow, but copies at the Archives of the Deutsche Bank in Frankfurt am Main)

Military Archives, Freiburg im Bresgau: files 'Militärverwaltung Belgien' (copies at the Archives of the National Bank of Belgium)

Archives Deutsche Bank, Frankfurt am Main: files 'Société Générale de Belgique'

2. PRIVATE ARCHIVES (BELGIUM)

Family Papers Baudewyns

Family Papers Berger

Family Papers Ansiaux 
3. INTERVIEWS

Interviews with Gaston Eyskens, Fernand Collin, Robert Vandeputte, Tony Vandeputte 


\section{Bibliography}

Aly, G., Hitlers Volksstaat: Raub, Rassenkrieg und Nationaler Sozialismus, Stuttgart, 2005.

Ansiaux, H., 'L'or et les valeurs de la Banque Nationale dans la tourmente de 1940, I ; Eté 1940 : les vagabondages de l'or et du gouvernement belge, II; l'or belge : de l'été quarante à l'opération Gutt, III', in : Revue Générale, February, March, April 1985.

Ansiaux (baron), Souvenirs de Hubert Jacques Nicolas baron Ansiaux, 1908-1987, Brussels, 1990 (published privately).

Arnoult, P., Les finances de la France sous l'occupation, Paris, 1951.

Aron, R., Histoire de Vichy, 1940-1944, Paris, 1954.

Barendregt, J., The Dutch Monetary Purge. The Monetary Consequences of German Occupation and their Redress after Liberation, 1940-1952, Amsterdam, 1952.

Baudhuin, F., L'économie belge sous l'occupation, 1940-1944, Brussels, 1945.

Baudhuin, F., Collaboration économique', in: Revue Générale (July 1946), pp. 387-392.

Blom, J.C.H., Crisis, bezetting en herstel. Tien studies over Nederland, 1930-1950, Rotterdam, 1989.

Boehme, O., 'Academici en de revolutie van rechts tijdens het interbellum', in: Wetenschappelijke Tijdingen, 57, n 1 (1998), pp. 45-58.

Boehme, O., 'Voor de natie, tegen het nationalisme. Hendrik De Man (1885-1953) en de Vlaamse beweging', in: Wetenschappelijke Tijdingen, 57, $\mathrm{n}^{\circ} 4$ (1998), pp. 193-215. 
Boehme, O., 'Tussen de fronten. Het jong-conservatisme van Victor Leemans', in: Wetenschappelijke Tijdingen, 58, 1 (1999), pp. 131-153.

Bouthillier, Y., Le drame de Vichy, Paris, 1950-1951, 2 vols.

Brion, R. and Moreau J.-L., La Société Générale de Belgique, 1822-1997, Antwerp, 1998.

Brutsaert, S., La nuit ne durera pas toujours... Une biographie d' Oscar Plisnier (1885-1952) (graduate thesis, UCL, Louvain-la-Neuve), Louvain-la-Neuve, 1993.

Capelle, R. (comte), Au service du Roi (1940-1945), Brussels, 1949.

Carton de Wiart, F. and Jansens, G., eds., Joseph Pholien. Un homme d'état pour une Belgique en crise, Brussels, 2003.

CEPAG, Deuxième rapport de la Commission belge pour l'Etude des Problèmes d'Après-Guerre, Londen, 1942.

Chambre, C., L'expérience monétaire belge (PhD thesis, Sorbonne), Paris, 1950.

Chlepner, B.S., Belgian Banking and Banking Theory, Washington, D.C., 1943.

Collin, F., 'De politiek van tewerkstelling tijdens de bezetting', in: Mededelingen van de Koninklijke Academie voor Wetenschappen, Letteren en Schone Kunsten van België. Klasse der Letteren, 39, $\mathrm{n}^{\circ} 1$ (1977), Brussels.

Commission Indépendante d'Experts (Suisse-Seconde Guerre Mondiale), La Suisse et les transactions sur l'or pendant la Seconde Guerre Mondiale. Rapport intermédiaire, Bern, 1998.

Commission Indépendante d'Experts (Suisse-Seconde Guerre Mondiale), La Suisse, le national-socialisme et la Seconde Guerre Mondiale. Rapport final. Zurich, 2002.

Cornu, G., L'or monétaire au vingtième siècle. En marge de l'histoire de la Banque de France : aventures de l'or monétaire, Paris, 1981. 
Crombois, J.-F., 'Finance, économie et politique en Belgique à la veille de le Seconde Guerre Mondiale, 1939-1940', in: Bijdragen tot de Eigentijdse Geschiedenis, 5 (1998), pp. 171-206.

Crombois, J.-F., Camille Gutt, les finances et la guerre, 1940-1945, Brussels, 2000.

Dantoing, A. and Selleslagh, F., De verplichte tewerkstelling in Duitsland, 1942-1945, Brussels, 1993.

De Backer, A., Het proces von Falkenhausen en Reeder (graduate thesis, KU-Leuven), Leuven, 1990.

De Bellefroid, D., La Commission belge pour l'Etude des Problèmes d'Après-Guerre (CEPAG), 1941-1944 (graduate thesis, UCL, Louvain-laNeuve), Louvain-la-Neuve, 1987.

De Gaulle, Ch., Mémoires de guerre: l'Appel, 1940-1942, Paris, 1999.

De Keizer, M., et al., eds., Thuisfront. Oorlog en economie in de twintigste eeuw, Zutphen, 2003.

De Launay, J., Histoire de la diplomatie secrète de 1914 à 1945, Paris, Verviers, 1966.

De Lovinfosse, G., Au service de Leurs Majestés : histoire secrète des Belges à Londres. Strombeek-Bever, 1974.

Demany, F., On a volé 64 milliards: l'histoire de la Banque d'Emission, Brussels, 1947.

De Ridder, V.A., 'The Belgian Monetary Reform', in: The Review of Economic Studies, 38, XV, 2 (1947-1948), pp. 51-69; 39, XVI, 1 (1948-1949), pp. 25-40.

De Ridder, V.A., 'De recente monetair-financiële ontwikkeling in België in het licht van de economische theorie', in: Tijdschrift voor Sociale Wetenschappen, year 2, No. 4 (1957), pp. 227-266; year 3, Nos. 1-2 (1958), pp. 7-30.

De Schaepdrijver, S., "De Groote Oorlog”: het koninkrijk België tijdens de Eerste Wereldoorlog, Amsterdam, 1997. 
De Schryver, A., Uit de oorlogsdagboeken, 1940-1942, Tielt, 1999.

De Staercke, A., Tout cela a passé comme une ombre: Mémoires sur la Régence et la Question royale, Tielt, 2003.

De Strycker, C., La Banque Nationale de Belgique de 1914 à 1938, Brussels, 1939.

De Vlaminck, M., De wapenindustrie in België tijdens de bezetting, 1940-1944 (graduate thesis, KU-Leuven), Leuven, 1983.

De Vlaminck, M. and Devos, L., 'De Belgische industriëlen tijdens de bezetting 1940-1944. Collaboreren om de bezetter te schaden, produceren met het oog op de naoorlogse periode', in: Belgisch Tijdschrift voor Militaire Geschiedenis, June (1985), pp. 113-136; September (1985), pp. 211-221.

Devleeschouwer, R., Henri Rolin, 1891-1973: une voie singulière, une voix solitaire, Brussels, 1994.

De Vries, Joh., De Nederlandsche Bank van 1914 tot 1948: Trips tijdvak 1931-1948, onderbroken door de Tweede Wereldoorlog, Amsterdam, 1994.

De Voghel, F., La Banque Nationale de Belgique (1850-1950): activités et statuts, Brussels, 1955.

Dostert, P., 'L’or luxembourgeois spolié par l'Allemagne pendant la Seconde Guerre Mondiale ainsi que sa récupération à la fin des hostilités', in: Revue d'Histoire Luxembourgeoise, 1 (1998), pp. 1-34.

Ducarme, B., Le financement de la résistance armée en Belgique, 19401944 (CRISP, cahiers 476-477), Brussels, 1970.

Dujardin, V. and Dumoulin, M., Paul van Zeeland, 1893-1973, Brussels, 1997.

Dumoulin, M., Spaak, Brussels, 1999.

Dupriez, L.-H., Les réformes monétaires en Belgique (Titre IV : la réforme de 1944), Leuven, 1978. 
D’Ydewalle, P., De Memoires, 1912-1940, Tielt, 1994.

D’Ydewalle, P., Mijn oorlogsjaren, Tielt, 1997.

Eyskens, G., De Memoires (J. Smits, ed.), Tielt, 1993.

Ferguson, N., The Pity of War, London, 1999.

Fforde, J., The Bank of England and Public Policy, 1941-1958, Cambridge, 1992.

Ganshof-van der Meersch, W., 'Enkele juridische aspecten van de actie der regering tijdens de oorlog, 1940-1944', in: Veertig jaren Belgische politiek. Liber Amicorum A.E. De Schryver, Antwerp, 1968, pp. 393433.

Gardner, R.N., Sterling Dollar Diplomacy in Current Perspective, New York, 1988.

Gérard, M.-L., 'Une mission à Berlin en mars 1942', in: Revue Générale Belge, 1949, pp. 182-200.

Gérard-Libois, J. and Gotovitch, J., L’an 40. La Belgique occupée, Brussels, 1971.

Gérard-Libois, J. and Gotovitch, J., Léopold III de l'an 40 à l'effacement, Brussels, 1991.

Gijsen, M., De loopgraven van de Fifth Avenue: de oorlogsjaren in New York, Amsterdam, 1980.

Gillingham, J., Geld maken in oorlogstijd. Economische collaboratie, 1940-1945, Leuven, 1979.

Gotovitch, J., 'Des « magnats capitalistes » aux " patrons patriotes »: communistes et patronat sous l'occupation', in: S. Jaumain and K. Bertrams, eds., Patrons, gens d'affaires et banquiers (Hommages à Ginette Kurgan-van Hentenryk), Brussel, 2004, pp. 381-394.

Gotovitch, J. and Balace, Fr., 'Militärverwaltung', in: Jours de Guerre, Volume 5: jours de chagrin, 1, Brussels, 1991, pp. 81-101. 
Grosbois, Th., 'La naissance du Benelux, 1941-1944, in: Cahiers du Centre de Recherches et d'Etudes sur l'Histoire de la Seconde Guerre Mondiale, 15 (December 1992), pp. 53-100.

Grosbois, Th., 'Le renseignement économique et financier en Belgique occupée. L'exemple du Groupement d'études économiques', in: $L a$ Résistance et les Européens du Nord. Het verzet en Noord-Europa. Communications présentées lors du colloque de Bruxelles, 23-25 novembre 1994, vol. 1, Brussels, 1994.

Gutt, C., La Belgique au carrefour, 1940-1944, Paris, 1971.

Hardach, G., The First World War, 1914-1918, Harmondsworth, 1987.

Haupt, M.G., Der "Arbeitseinsatz" der belgischen Bevölkerung während des Zweiten Weltkrieges. $\mathrm{PhD}$ thesis, Bonn, 1970.

Hofmans, G., 'Het probleem van de economische collaboratie. De houding van de Groep de Launoit tijdens de Tweede Wereldoorlog', in: Bijdragen van het Navorsings- en Studiecentrum voor de Geschiedenis van de Tweede Wereldoorlog, 15, (December 1992), pp. 1-55.

Holtfrerich, C.-L., Reis, J. and Toniolo, G., eds., The Emergence of Modern Central Banking from 1918 to the Present, Aldershot, 1999.

Horsefield, J.K., The International Monetary Fund, 1945-1965. Twenty Years of International Cooperation: vol. 1. Chronicle, Washington, D.C., 1969.

Huyse, L. and Dhondt, S., Onverwerkt Verleden. Collaboratie en repressie in België, 1942-1952, Leuven, 1991.

James, H., Lindgren, H. and Teichova, A., The Role of Banks in the Interwar Economy, Cambridge, 1991.

James, H., 'The Deutsche Bank and the Dictatorship, 1933-1945', in: L. Gall, et al., The Deutsche Bank, 1870-1995, London, 1995, pp. 277308.

James, H., International Monetary Cooperation since Bretton Woods, Oxford, 1996. 
Janssens, V., De Belgische Frank. Anderhalve eeuw geldgeschiedenis, Brussels, 1976.

Janssens, V., De beheerders van ons geld. Negentien gouverneurs van de Nationale Bank van België, Tielt, 1997.

Kauch, P., De Nationale Bank van België, 1850-1918, Brussels, 1950.

Kauch, P., 'Histoire de la Banque Nationale', in: Histoire des finances publiques (Institut belge des Finances Publiques), Part 3, Brussels, 1955.

Kauch, P., Le vol de l'or de la Banque Nationale par les Nazis (1940-1943), Brussels, 1956.

Kauch, P., 'De gebouwen van de Bank. De eeuwfeestgebouwen', in: Tijdschrift voor het personeel van de NBB, 3 (1994), pp. 14-21; 4 (1994), pp. 22-28.

Klemann, H.A.M., Nederland, 1938-1948. Economie en samenleving in jaren van oorlog en bezetting, 1938-1948, Amsterdam, 2002.

Klemm, P.F., German Economic Policies in Belgium from 1940 to 1944 (PHD thesis, University of Michigan), Ann Arbor (Michigan), 1972.

Kurgan-van Hentenryk, G., Jaumain, S. and Montens, V., eds., Dictionnaire des patrons en Belgique. Les hommes, les entreprises, les réseaux, Brussels, 1996.

Kurgan-van Hentenryk, G., 'The Banque Nationale de Belgique and the Belgian Economy during the XXth Century', in: The Journal of European History (Special Issue: Financial Systems in Europe in the XXth Century), 2001, pp. 45-85.

Kwanten, G., August-Edmond De Schryver, 1898-1991. Politieke biografie van een gentleman-staatsman, Leuven, 2001.

Lepotier, R., La bataille de l'or, Paris, 1960.

Luyten, D., 'De "opdracht" van de regering aan het Galopin-Komitee op 15 mei 1940', in: Bijdragen van het Navorsings- en Studiecentrum voor de Geschiedenis van de Tweede Wereldoorlog, 16 (June 1994), pp. 163-171. 
Luyten, D., Burgers boven elke verdenking? Vervolging van de economische collaboratie in België na de Tweede Wereldoorlog, Brussels, 1996.

Luyten, D., Ideologie en praktijk van het corporatisme tijdens de Tweede Wereldoorlog in België, Brussels, 1997.

Luyten, D. and Vanthemsche, G., eds., Het Sociaal Pact van 1944. Oorsprong, betekenis, gevolgen, Brussels, 1995.

Luykx, Th., Politieke geschiedenis van België van 1789 tot heden, Amsterdam-Brussels, 1973.

Makart, J., Various unpublished notes concerning Jewish assets during the Second World War, 1940-1945, BNB, Brussels, 2002.

Margairaz, M., ed., Banques, Banque de France et Seconde Guerre Mondiale, Paris, 2002.

Margairaz, M., 'Introduction : 1. La Banque de France et l'occupation ; 2. La Banque de France et ses partenaires', in: M. Margairaz, ed., Banques, Banque de France et la Seconde Guerre Mondiale, Paris, 2002, pp. 1- 37.

Marquet, V., Bijdrage tot de geschiedenis van het Geheim Leger, 19401944, Brussels, 1991-1995, 6 vols.

Milward, A., The New Order and the French Economy, Oxford, 1970.

Milward, A., War, Economy and Society, 1939-1945, London, 1975.

Nationale Bank van België, Biografische nota's, NBB. Notices biographiques, BNB. 1850-1960, Brussels, 1960.

Nationale Bank van België, De fraaie frank. Belgische munten en biljetten sedert 1830, Brussels, 1989.

Nationale Bank van België, Speciale nummers van het personeelsblad 'Connect' uitgegeven ter gelegenheid van de $150^{\circ}$ verjaardag van de Bank. Various articles concerning the gold, the buildings, the banknotes, the annual reports, the governors, accounting machines, etc., Brussels, 2000. 
Nefors, P., 'Emissiebank en clearing: een aspect van het financieeleconomisch leven in het bezette België (1940-1944)', in: E. Aerts, et al., Studia Historica Oeconomica. Liber alumnorum Herman Van der Wee, Leuven 1993, pp. 303-310.

Nefors, P., Industriële collaboratie in België. De Galopin-doctrine, de Emissiebank en de Belgische industrie in de Tweede Wereldoorlog, Leuven, 2000.

Onderzoekscomité, Emissiebank te Brussel, De toestand en de verrichtingen der Emissiebank te Brussel tijdens de Duitsche bezetting: verslag van het onderzoekscomité, opgericht bij Besluitwet van 11 december 1944, Brussels, 1946, 4 vols.

Overy, R.J., War and Economy in the Third Reich, Oxford, 1994.

Plater-Zyberk (comtesse), Albert-Edouard Janssen, raconté par sa fille, Oyez, 1976.

Plisnier, O., 'L’or belge livré aux Allemands en 1940', in: Revue Générale Belge, 52, (February 1950), pp. 1-20.

Pluym, J., 'Rekeningen van verdwenen mensen. De Bank stelt de Joodse gemeenschap schadeloos voor verloren tegoeden tijdens Wereldoorlog II, in: 'Connect', Personeelsblad van de Nationale Bank van België, July-August 2002.

Polak, J.J., 'Financial Relations between the Netherlands and Belgium : 1942 to 1943', in: A. Bakker et al., eds., Monetary Stability through International Cooperation. Essays in honour of André Szasz, Amsterdam, 1994, pp. 183-199.

Pulinckx, R., L'assainissement monétaire et ses conséquences, (graduate thesis, RUCA, Antwerpen), Antwerp, 1946.

Quix, J., Een financieel-economische analyse van de Gutt-operatie (graduate thesis, KU-Leuven), Leuven, 1946.

Rehm, M., Eggert Reeder, 22. July 1894 - 22. November 1959: Preuszischer Regierungspräsident, Militärverwaltungschef, Staatsbürger, Nürtingen, 1976. 
Rens, J., Ontmoetingen, 1930-1942, Antwerp, 1984.

Ritschl, A.O., 'Nazi economic imperialism and the exploitation of the small: evidence from Germany's secret foreign balances, 1938-1940', in: The Economic History Review, 54, No. 2 (May 2001), pp. 324-345.

Schepens, L., De Belgen in Groot-Brittannië, 1940-1944: feiten en getuigenissen. Bruges, 1980 .

Scholliers, P., 'Strijd rond de koopkracht, 1939-1945', in: België 1940. Een maatschappij in crisis en oorlog, Brussels, 1993, pp. 245-276.

Simonis, R., Les règlements internationaux de 1939 à nos jours. I: les règlements internationaux pendant la seconde guerre mondiale (Centre d'Etudes Financières, cahier 23), Brussels, 1983.

Simonis, R., 'Les règlements internationaux de 1939 à nos jours. II : la période de 1945 à 1950', in: Revue de la Banque, 48, 4/5, (1984), pp. $1-88$.

Simonis, R., 'Enkele korte, persoonlijke herinneringen aan de besluiten van 6 oktober 1944', in: Tijdschrift voor het personeel van de NBB, (April 1977), pp. 7-9.

Simonis, R., 'Derrière les guichets. III : la période de la guerre, 19401945', in: Tijdschrift voor het personeel van de NBB, (April 1983), pp. 4-20.

Skidelsky, R., John Maynard Keynes. Fighting for Britain, 1937-1946, London, 2000.

Sluijter, P., De weg van het minste kwaad: economische collaboratie in België, 1940-1944 (graduate thesis, EHSAL, Brussel), Brussels, 1996.

Speer, A., Erinnerungen, Frankfurt-am-Main, 1969.

Stengers, J., Léopold III et le Gouvernement: les deux politiques belges de 1940, Gembloux, 1980.

Strubbe, F., Geheime oorlog, 1940-1945. De Inlichtings- en Actiediensten in België, Tielt, 1993. 
Struye, P. and Jacquemyns, G., La Belgique sous l'occupation allemande, 1940-1944 (édition préfacée et annotée par J. Gotovitch), Brussels, 2002.

Toniolo, G. and Clement, P., Central Bank Cooperation at the Bank for International Settlements, 1930-1973, Cambridge (UK), 2005.

Trepp, G., Die Bank für Internationalen Zahlungsausgleich im Zweiten Weltkrieg. Bankgeschäfte mit dem Feind: von Hitlers Europabank zum Instrument des Marshallplans, Zurich, 1993.

Truffaut, F.C., Sauver l'or belge: la mission du capitaine Georges Truffaut en Afrique occidentale (août-septembre 1940), Tubize, 1997.

Van de Burgt, Th.G.J.M., 'Nazi-goud: een tussenstand', in: Bank- en Effectenbedrijf, (January-February 1998), pp. 10-12.

Van den Wijngaert, M., Het beleid van het Comité van de secretarissengeneraal in België tijdens de Duitse bezetting, 1940-1944, Brussels, 1975.

Van den Wijngaert, M., Nood breekt wet. Economische collaboratie of accommodatie. Het beleid van Alexandre Galopin, gouverneur van de Société Générale tijdens de Duitse bezetting, 1940-1944, Tielt, 1990.

Van den Wijngaert, M., De Wever, B., Maerten, F., Luyten, D., Nefors, P., Vandeweyer, L., Beyen, M., België tijdens de Tweede Wereldoorlog, Antwerp, 2004.

Vanderlinden, J., Pierre Ryckmans, 1891-1959. Coloniser dans l'honneur, Brussels, 1994.

Van der Wee, H., Prosperity and Upheaval. The World Economy, 19451980, Berkeley, University Press, 1986.

Van der Wee, H., 'La Belgolaise et la Banque commerciale zaïroise, 19091995. Histoire de deux banques coloniales belges et de leur transformation après l'indépendance du Congo en 1960', in: M. Merger and D. Barjot, eds., Les entreprises et leurs réseaux: hommes, capitaux, techniques et pouvoirs (XIXe-XXe siècles). Mélanges en l'honneur de François Caron, Paris, 1998, pp. 471-484. 
Van der Wee, H. and Tavernier, K., La Banque Nationale de Belgique et la politique monétaire entre les deux guerres mondiales, Brussels, 1975.

Van der Wee, H. and Verbreyt, M., Mensen maken geschiedenis. De Kredietbank en de economische opgang van Vlaanderen, 1935-1985, Tielt, 1985.

Van der Wee, H. and Verbreyt, M., The Generale Bank, 1822-1997. A Continuing Challenge, Tielt, 1997.

Vandeputte, R., Abraham, J.-P. and Lempereur, C., Het Belgisch financiewezen. Deel 1: De publieke sector, Antwerp, 1981.

Van de Voorde, A., De penningmeesters van de Wetstraat. Het portret van vijf markante ministers van Financiën, voorafgegaan door een algemene terugblik op de titularissen van Financiën van 1931 tot nu, Tielt, 1993.

Van Dormael, A., Bretton Woods. Birth of a Monetary System, New York, 1978.

Van Houtte, J., 'Benelux in het wordend Europa', in: Veertig jaren Belgische Politiek. Liber Amicorum A.E. De Schryver, Antwerp, 1968, pp. 746-753.

Van Overstraeten (General), Léopold III prisonnier, Brussels, 1986.

Van Praag, H., L’opération Gutt: l'assainissement monétaire de la Belgique au lendemain de la Seconde Guerre Mondiale (graduate thesis, ULB), Brussels, 1990.

Van Praag, H., 'Lassainissement monétaire au lendemain de la seconde guerre mondiale: l'opération Gutt en Belgique - La politique du Général de Gaulle en France', in: Revue de la Banque, (FebruaryMarch, 1996), pp. 3-37.

Vanthemsche, G., 'De Bank van 1934 tot vandaag', in: H. Van der Wee, ed., De 'Generale Bank', 1822-1997, Tielt, 1997, pp. 342-378.

Vanthoor, W.F.V., De Europese monetaire eenwording in historisch perspectief, Amsterdam, 1994. 
Vanwelkenhuyzen, J. and Van der Wee, H., 'A propos de l'économie belge au cours de la seconde guerre mondiale', in: Revue belge de Philologie et d'Histoire, jg. 57 (1979), pp. 394-409.

Velaers, J. and Van Goethem, H., Leopold III: de koning, het Land, de Oorlog, Tielt, 1994.

Verhoeye, E., 'Les grands industriels belges entre collaboration et moindre mal', in: Cahiers du Centre de Recherche et d'Etude sur l'Histoire de la Seconde Guerre Mondiale, no 10 (1986), pp. 57-114.

Verhoeye, E., 'De Emissiebank', in: E. Verhoeye et al., eds., Het Minste Kwaad (België in de Tweede Wereldoorlog, $\mathrm{n}^{\circ}$ 9), Kapellen, 1990, pp. 23-31.

Verhoeye, E., België bezet, 1940-1944. Een synthese, Brussels, 1993.

Verduystert, F., 'Het Hollerith-systeem in de Nationale Bank van België', in: Tijdschrift voor het personeel van de $N B B, 1946, \mathrm{n}^{\circ}$ 5, pp. 1-5.

Williame, J.-C., 'Le Congo dans la guerre de co-operation économique belgo-alliée de 1940 à 1944', in : Le Congo belge durant la Seconde Guerre Mondiale. Recueil d'Etudes (Académie Royale des Sciences d'Outre-Mer), Brussels, 1983, pp. 213-252.

Willems H. and Buelens, F., 'De Tweede Wereldoorlog en de Belgische Beurzen', in: M. De Keizer, et al., eds., Thuisfront, Oorlog en Economie in de twintigste eeuw, Zutphen, 2003, pp. 149-162.

Willequet, J., La Belgique sous la botte : résistances et collaborations, Paris, 1986.

Witte, E., Craeybeckx, J. and Meynen, A., Politieke geschiedenis van België van 1830 tot heden, Brussels, 1997.

Witte, E., 'Achiel Van Acker: premier van "paarse" regeringen, 19451946, 1954-1958', in: M. Galle and S. Loccufer, eds., Facetten van 100 jaar politieke, economische en sociale geschiedenis. Herdenking geboorte Achiel Van Acker, 1898-1998, Brussels, 2000, pp. 47-75. 



\section{List of abbreviations}

$\begin{array}{ll}\text { AR } & \text { General Council, National Bank of Belgium } \\ \text { ARA } & \text { General Archives of the Kingdom, Brussels } \\ \text { AV } & \text { General Assembly, National Bank of Belgium } \\ \text { BdFr } & \text { Banque de France, Paris } \\ \text { BEB } & \text { Banque d'Emission à Bruxelles, Brussels } \\ \text { Bengl } & \text { Bank of England, London } \\ \text { HB BEB } & \text { Board of Directors, Banque d'Emission à Bruxelles } \\ \text { BIS } & \text { Bank for International Settlements, Basle } \\ \text { BZ } & \text { Ministry of Foreign Affairs, Brussels } \\ \text { DC } & \text { Board of Directors, National Bank of Belgium } \\ \text { DC BEB } & \text { Board of Directors, Banque d'Emission à Bruxelles } \\ \text { IS } & \text { Department 'Inspection', National Bank of Belgium } \\ \text { KP } & \text { Royal Palace } \\ \text { LLN } & \text { Catholic University of Leuven at Louvain-la-Neuve } \\ \text { NBB } & \text { National Bank of Belgium, Brussels } \\ \text { Ndl.ARA } & \text { General Archives of the Kingdom, The Hague } \\ \text { Ndl.BZ } & \text { Ministry of Foreign Affairs, The Hague } \\ \text { Ndl.MF } & \text { Ministry of Finance, The Hague } \\ \text { RR } & \text { Supervisory Council, National Bank of Belgium } \\ \text { SD } & \text { Secretary's Office, National Bank of Belgium } \\ \text { SG } & \text { Société Générale de Belgique, Brussels } \\ \text { SOMA } & \text { Centre: War and Contemporary Society, Brussels }\end{array}$





\section{Index}

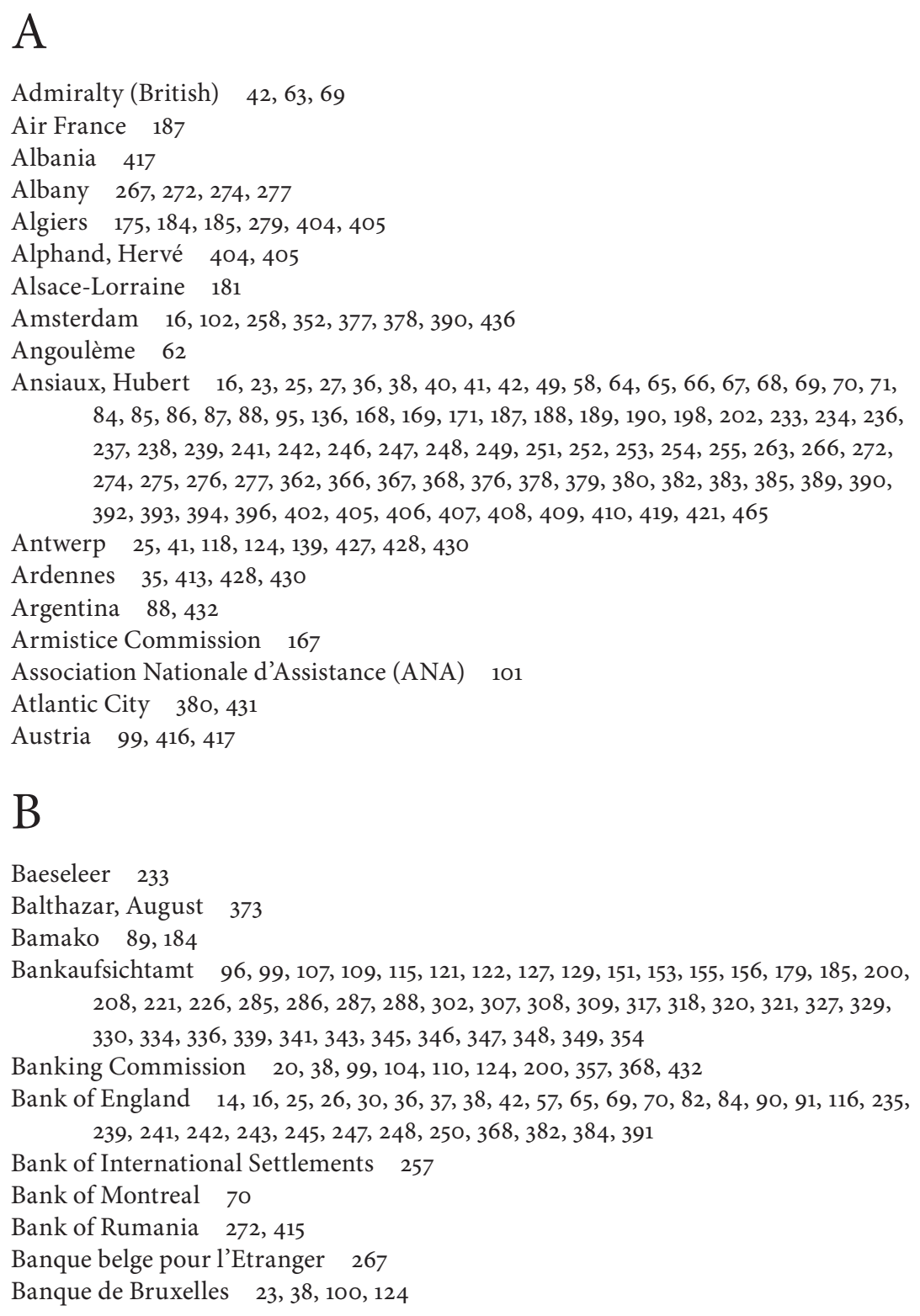


Banque de France $16,29,30,35,37,41,43,44,45,48,50,51,52,55,56,57,59,61,62$, $63,64,65,66,67,69,70,71,74,76,799,80,81,84,85,86,87,88,91,116,130,167$, $168,169,170,171, \frac{172}{173}, 174,175,176,177,178,179,180,181,182,183,185,186$, $\overline{187}, \overline{188}, \overline{189}, \overline{190}, \overline{191}, \overline{192}, \overline{193}, \overline{222}, \overline{224}, \overline{239}, 250,256,263,264,265,266, \overline{267}$, $\overline{268}, \overline{26}, \overline{270}, 271,272,273,275,276,277,278,279,280,281,282,318,346,350$, $351,381,401,403,404,405,406,407,408,409,410,411,413,414,415,416,417$, 446,457

Banque de la Société Générale $23,75,101,123$

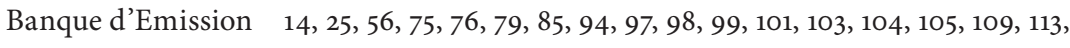
$114,115,116,117,118,119,120,121,122,123,124,125,126,127,128,129,130,131$, $\overline{132}, \overline{133}, \overline{138}, \overline{140}, \overline{141}, \overline{142}, \overline{144}, \overline{150}, 151,152, \overline{153}, \overline{154}, \overline{156}, \overline{157}, \overline{158}, \overline{159}, \overline{160}, \overline{161}$ $\overline{162}, \overline{163}, \overline{164}, \overline{165}, \overline{175}, \overline{179}, \overline{183}, \overline{195}, \overline{197}, \overline{198}, \overline{199}, \overline{200}, 209,211,212,214,215,216$, $\overline{217}, \overline{218}, \overline{219}, \overline{221}, \overline{222}, \overline{223}, 224,225,226,228,257,284,285,286,287,290,291$, 292, $293,294,295,297,298,299,300,301,302,303,305,306,307,308,311,312$, $\frac{313}{314}, 315,316,317,318,319,320,321,322,323,325,326,327,328,329,330,331$, $332,333,334,336,340,341,343,345,346,347,348,349,350,351,352,353,354$, $\frac{355}{359}, 368,393,399,400,402,411,441,442,443,444,445,446,447,448,449$, $450,451,452,455,456,457,458$

Banque du Congo belge 20 , 29

Banque Nationale Suisse $\underline{415}$

Barcelona 232

Basel $75,93,95,116,131,160,257,259,415$

Bastiné, Paul $43,51,57$

Basyn, Thomas $97,98,105,110,123,132,133,160,196,197,210,303,307,312,318,320$, $\underline{322}, \underline{396}, \underline{402}$

Bathurst 90

Baudewyns, Adolphe $16, \underline{35}, \underline{36}, \underline{38}, \underline{40}, \underline{41}, \underline{43}, \underline{44}, \underline{49}, 61,67,69,70,81, \underline{82}, \underline{83}, \underline{85}, \underline{86}$, 88, 90, 91, 95, 117, 121, $169,188,189,190,198,233,236,237,238,239,240,241$, $242,243,244,245,246,247,248,249,250,251,252,254,255,263,273,274,275$, $\frac{276}{279}, \frac{362}{363}, 364,365,366,367,368,369,370,371,379,382,383,385,393$, $\frac{394}{396}, \frac{302}{40}, 408,418,427,431,455,458$

Baudouin $\underline{87}, \underline{181}$

Bech 275

Bekaert, Léon 101, 117, 125, 257, 297, 298, 325, 396, 431

Belgian Banking Association 325

Belgian Navy $73,86,239$

Belgo-American Chamber of Commerce 267

Belgo-Luxembourg Economic Union 191

Bemelmans, Arthur 75, 253, 255, 256

Benelux 379, 380, 381, 382, 390

Berger, Pierre $\frac{16}{16}, \overline{118}, \overline{119}, 120,121,122,196,197,205,208,209,210,217,224,254,285$, $286,294,295,297,298,299,300,301,302,307,308,312,313,314,317,318,319$, $\overline{321}, 322,323,324,325,340,398,399,402,416$

Berlin $15,16,29,56,81,97,98,99,109,111,112,114,115,125,127,128,141,144,150,151$, $152,153,156,158,159,160,161,163,171,179,181,184,185,186,187,188,191,192$, $2 \mathrm{OO}, 201,2 \mathrm{O} 3,2 \mathrm{O} 5,212,214,218,220,221,222, \overline{224}, \overline{225}, \overline{226}, \overline{22} 7,228,229,230$, $\overline{276}, \overline{277}, \overline{281}, \underline{284}, \overline{285}, \overline{286}, \overline{287}, \overline{288}, \overline{289}, \overline{291}, \overline{293}, \overline{303}, \overline{305}, \overline{317}, \overline{322}, \underline{327}, \underline{328}$, 
$\underline{332}, \underline{333}, \underline{341}, \underline{343}, \underline{346}, \underline{347}, \underline{350}, \underline{351}, \underline{352}, \underline{353}, 354,400,405, \underline{415}, 447,450,455$, 457,460

Bermuda $\overline{266}$

Bernstein, E.M. $\quad 269,270,277$

Berryer 75

Beyen, Jan 381

Bidault, Georges 408

BIS 31, 75, 93, 95, $116,131,160,188,257,258,259,260,261,415$

Boël, René $65,85, \overline{86}, \overline{239}, 270,279,380,388,389,390,392,406$

Bolgert, J. $\quad 170,176,178,181,182,187, \frac{189}{29}, \frac{269}{409}, 410$

Bordeaux $29,48,52,54,56,61,64,65,66,67,69,73,74,75,76,115,239$

Bourem 184

Bouthillier 51, 53, 55, 63, 64, 66, 67, 68, 79, 80, 87, 171, 181, 182, 269

Brasseur, Robert 117

Bréart de Boisanger, Yvves $167,170,171,176,181,182,186,187,190,264,266,267,268$,

Brest $\frac{269}{62}, \frac{273}{63}, \frac{88}{6}$

Bretton Woods 380, 385, 387, 390, 406, 407

Brüsseler Treuhandgesellschaft 154

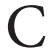

Caen 43,420

Caisse d'Epargne du Luxembourg 91, 274, 275, 276, 277, 278, 410, 413

Caisse Générale d'Epargne et de Retraite 101

Callens, Auguste 186

Campbell, Sir Ronald $\underline{53}$

Canada $26, \underline{63}, \underline{70}, \underline{74}, \underline{244}, \underline{432}$

Capelle, Robert (Comte) 195, 196, 227

Cartier de Marchienne, Emile $65, \overline{85}, 231,239$

Casablanca $\underline{63}, \underline{71}, \underline{88}, \underline{184}$

Cattier, Felicien $136,187,188,189,202,246,263$

Cayès 187

Charles (Prince-Regent of Belgium) $\quad \underline{438}$

China 96

Chlepner, Boris-Serge 20,390

Churchill, Sir Winston $\overline{68}, \overline{89}, 90,101,232,455$

Clermont-Ferrand $71,72,81,86,87,88,167,168,170,173,176,177,182,264,266,267$, $268,269,270,272,273,277,278,404$

Cobbold, Cameron $36,241,243,431$

Collin, Fernand $\quad 38, \overline{39}, \overline{100}, \overline{104}, \overline{111}, 124,160,198,202,257,400$

Colomb-Béchar $\overline{18} 4$

Comité d'Application $\underline{366}$

Comité du Mardi $355, \overline{419}$

Comité Français de Libération Nationale 372, 376, 379, 380, 404

Commission belge pour l'Etude des Problèmes d'Après-Guerre (CEPAG) 361, 362, $\underline{363}, \underline{364}, \underline{366}, \underline{368}, \underline{369}, \underline{370}$ 
Commission of Enquiry $\quad 75,76,85,94,106,109,113,116,117,150,151,154,156,159,160$, $161,162,164,165,196,255,301,302,307,319,320,322,334,441,442,443,446$, $\overline{447}, \overline{44} 8, \overline{449}, \overline{45} 1$

Committees for Public Assistance 94

Commonwealth 70

Compagnie Maritime Belge 28

Compagnie Transsaharienne $\overline{1} 84$

Congo (Belgian) 20, 29, 31, 50, 51, 52, 53, 58, 73, 91, 231, 232, 233, 234, 235, 236, 237, 241, $242,245,248, \underline{347}, \underline{368}, \underline{371}, \underline{401}, \underline{432}, \underline{437}$

Corsica 436

Coudert, Brothers \& $C^{\circ} \quad 265,267$

Cracco, François $\quad 20,98, \overline{119}, \overline{121}, 122,198,214,215,218,219,224,225,291,292,293$, $294,309,314,321,322,324,325,326,328,329,333,334,335,340,341,342,343$, $351,355,359,397,398,460$

Craeybeckx, Lode $\frac{17}{402}$

Czechoslovakia $\underline{63}, \underline{417}$

\section{$\mathrm{D}$}

d'Ambrière 66

Darlan, Jean $\overline{6_{3}}, 68,86$

Dartmouth $4 \overline{2}$

de Bletterie, Henri 408,411

de Brouckère, Louis $35,55,361,436$

de Gaulle, Charles 18, 89, 90, 237, 403, 407, 418

de Gruben, Hervé $\quad 390,392$

de Iongh, Crena $381,388,390$

de Largentaye 406

de Launoit, Paul 123, 198, 204, $\underline{317}$

Delmer, Alexandre 180

De Man, Hendrik 104, $361,365,369$

de Munck, Willy 23, 24, 34, 75, 101, 104, 105, 106, 107, 111, 112, 123, 198, 257, 312, 316,

Denmark 112,160

Deroy $66, \overline{67}$

Dervichian, Edouard 370,436

Desoer, Jacques 117

De Visscher, Fernand 297, 298, 299, 300, 308, 309, 314, 315, 316, 317, 318, 319, 325, 370, $\underline{447}, \underline{456}$

De Vleeschauwer, Albert $52, \underline{53}, \underline{57}, 58, \underline{72}, \underline{73}, \underline{74}, \underline{87}, \underline{92}, \underline{232}, \underline{233}, \underline{234}, \underline{235}, \underline{237}, \underline{240}$, $245,371,446$

De Voghel, Franz 20, 356, 357, 358, 402, 423, 429, 435, 436, 439

De Winter, Emile $\quad \overline{28} 7, \underline{447}$

Dierckx, Octave 314,319

Doing, Manlon B. $26 \overline{6}$

Dubois-Pélerin, Jules 201, 446, 452 
Dulles, John Foster 265, 266, 267, 269, 270, 271, 272, 273, 274, 276, 277, 278, 279, 281, 405, 411

Dumont de $\overline{C h}$ assart, Léopold $\underline{117}$

Dunkirk $\underline{42}$

Dupong, Pierre $274,276,413,414$

Dupriez, Léon-Hugo $\frac{20}{21}, 24,103,146,151,208,209,325,355,356,358,370,419,436$

Dussart, Georges $\quad 36, \overline{37}, \underline{46}, \underline{48}, \underline{77}$

E

Eden, Sir Anthony $\underline{235}, \underline{376}$

Einaudi, Luigi 438

Eisenhower, Dwight $\quad 265,428$

England 68, 69, 84, 86, $95, \overline{171}, 203,232,234,235,239,240,248$

Exchange Equalization Fund 50

Eyskens, Gaston $\quad \underline{397}, \underline{423}, \underline{429}, \underline{435}, \underline{436}, \underline{439}$

$\mathrm{F}$

Federal Reserve Bank of New York $\underline{69}, \underline{70}, \underline{71}, \underline{77}, 81,187,188, \underline{240}, \underline{243}, 244,245,255$, $259,261,267,270,271,272,387,411$

Federal $\overline{R e s e r v e} \overline{B o a r d}$ (Washington, $\overline{\text { D.C. }}$.) 387

Feldpost $312, \underline{321}, \underline{34}$

Financial and Mutual Aid (Anglo-Belgian) $383, \underline{432}$

Floor, Idesbald $\quad \underline{89}, \underline{90}, \underline{91}, \underline{92}$

Folkestone 42

Fonderies Nationales d' Herstal (FN) 362

Fonds de Stabilisation 50, 64

Fournier, Pierre $\underline{29}, \underline{30}, \underline{35}, \underline{48}, \underline{54}, \underline{55}, \underline{59}, \underline{61}, \underline{62}, \underline{64}, \underline{66}, \underline{67}, \underline{69}, \underline{70}, \underline{71}, \underline{74}, \underline{78}, \underline{81}, \underline{85}, \underline{86}$, $87,88,188, \frac{280}{28}$

France $2 \underline{6}, 29,30,31, \underline{35}, \underline{37}, 38,40,41,42,43,44,45,47,48,50,51,52,53,54,55,56,57$,

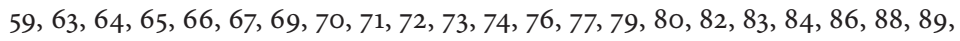
$\overline{92}, \overline{93}, \overline{95}, \overline{96}, \overline{97}, \overline{100}, \overline{104}, 112, \overline{115}, \overline{117}, \overline{118}, \overline{12} 6,127, \overline{131}, \overline{135}, \overline{140}, 141,142, \overline{156}$, $160,168,174,175, \overline{176}, 177,178,179,180, \overline{181}, \overline{182}, \overline{185}, 186, \overline{18} 7,188, \overline{189}, 190,191$, $\overline{192}, \overline{193}, \overline{201}, \overline{203}, \overline{214}, \overline{220}, 221,222,225,228,229,232,233,241,242,243,246$,

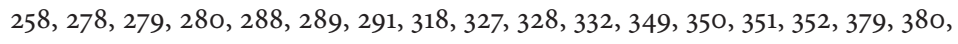
$\overline{381}, \overline{403}, \overline{404}, \overline{405}, \overline{406}, \overline{407}, 409,417,418,426,427,436,438,439,444,445,448$, $\overline{449}, \overline{450}, \overline{456}$

Franck, Louis 91,92

Frateur, Leopold $\frac{117}{77,178}$

Frédéricq, Louis $\quad \overline{77}, 178$

Freetown (Sierra Leone) 90, 91, 92

Frère, Maurice $99,124,125, \underline{200}, 261,370,397,399,402,411,414,416,430,436,441$, 442

Fuller, Paul 266, 267, 268, 269, 270, 272, 273, 274, 275, 277, 404, 405

Funck, Walther $\underline{228}, \underline{327}$ 
Galopin, Alexandre $\quad 38,39,75,76,77,83,95,100,101,102,104,107,111,112,115,116$, $120,122,123,124,126,135,136,137,138, \overline{161}, 164, \overline{168}, 196, \overline{197}, 198, \overline{199}, \frac{1200,}{201}$, $\overline{202}, 203,204,209,224,226,227,228,229,230,246,253,255,256,257,259,260$, $\overline{283}, \overline{287}, \overline{288}, 293,294,298,302,304,307,311,312,313,314,316,317,318,319,323$, $\overline{324}, \overline{330}, \overline{340}, \overline{370}, \overline{371}, \overline{443}, \overline{447}, \overline{455}, 4 \overline{460}$

Galopin Committee $101,102,104,107, \overline{136}, 137,138,161,164,168,293$

Gambia 90

Ganshof-van der Meersch, Walter-Jean 170, 195, $\underline{427}, \underline{442}, \underline{449}$

Gérard, Max-Léo 23, 38, 100, 107, 111, 112, 124, 198, 200, 204, 230, 287, 288, 302, 307, $308,311,314$

Gérard, Olivier $\frac{204}{214}$

Germany $20,25,27,54,68,73,74,89,95,102,103,105,123,134,135,136,137,138,141$, $142,153,156,158,159,160,162,163,181,183,185,199,201,202,204,206,212,214$, $216,220,221,225,228,229,230,231,232,246,247,263,283,284,286,289,291$, $\frac{298}{299}, \frac{300}{302}, 312, \frac{328}{329}, \frac{332}{33}, 36,337, \frac{342}{343}, \frac{347}{347}, \frac{349}{349}, \frac{352}{353}$, $\frac{354}{459}, 380,397,401,407,409,410,413,414,446,447,426,428,444,445,446$, $447,451,455, \frac{456}{103}$

Gillingham, John $\frac{103}{103}$

Giraud, Henri 404

Gironde 61, 65

Goering, Hermann 134,152

Goffin, Albert $\quad 38,40,77, \overline{81}, 100,101,104,105,107,111,112,114,115,116,117,119,120$, $122,146, \overline{155}, \overline{19} \mathrm{O}, 196, \overline{197}, \overline{198,}, \overline{204}, \overline{207}, \overline{210}, \overline{211}, \overline{212}, \overline{213}, \overline{220}, \overline{221}, 222,223,227$, $228,229,230,249,250,251,253,254,255,256,257,260,269,286,287,295,298$, $\overline{300}, 301, \frac{302}{305}, \frac{307}{308}, \frac{309}{317}, \frac{318}{320}, \frac{321}{321}, \frac{322}{324}, \frac{325}{328}, 3,329,330$,

$336,337,339,346,348,352,354,395,396,397,442,443,446,447$

Gouvernement Provisoire de la République Française $\underline{405}$

Grand-Duchy of Luxembourg 191, 216

Great Britain $26, \underline{27}, 28, \underline{35}, \underline{36}, \underline{37}, \underline{47}, \underline{50}, \underline{51}, \underline{52}, \underline{53}, \underline{58}, \underline{65}, 66,68,72,73,74,77,87,89$, $112,141,231,232,233,235,236,243,244,245,246,247,248,249,271,358,375$, $\overline{376}, \overline{378}, 380,381,382,383,386,392,420,437,439,458$

Greece 160,417

Gresham's Law 209

Gresham, Thomas 209

Gutt, Camille $17,18,19,24,27,28,29,30,36,37,38,39,41,44,45,46,47,49,50,51$, $52,53,54,55,57,59,60,63,64,65,66,67,68,69,71,72,73,74,75,76,77,79,80$, $\frac{81}{81}, \frac{32}{82}, \frac{83}{84}, \frac{86}{86}, \frac{87}{90}, \frac{91}{92}, \frac{101}{1118}, 136,168,187,189,190,195,201,202,209$, $232,233,234,235,236,237,238,239,241,244,245,246,247,248,249,250,251$, $\frac{252}{253}, \frac{254}{255}, \frac{256}{257}, \frac{258}{259}, \frac{260}{261}, \frac{264}{267}, \frac{270}{271}, \frac{272}{274}, \frac{275}{275}$, $\frac{279}{280}, \overline{281}, \overline{338}, \overline{358}, \overline{361}, \frac{262}{362}, \frac{254}{364}, \overline{365}, \overline{366}, \overline{367}, \overline{368}, \overline{369}, \overline{370}, \overline{371}, \overline{372}, \frac{273}{373}$, $\overline{375}, 376,377,378,379,380,381,387,3 \overline{385}, 387,388,389,390,391,392,393,394$, $\frac{395}{4396}, 397,398,402,404,406,407,408,409,410,411,414,417,418,419,420$, $\underline{421}, \frac{422}{423}, \underline{425}, \underline{426}, \underline{429}, \underline{430}, \underline{432}, \underline{433}, 434,435,436,437,438,4439,454,4,458$, $\underline{459}, \underline{460}$ 


\section{$\mathrm{H}$}

Hailey (Lord) 235

Halifax, Edward-Frederick (Lord) $\quad 68,90,231$

Hartlieb, Heinrich 176

Hayoit de Termicourt, Raoul $183,185,204,208,210,227,228$

Hemmen, Richard $167,170,17 \overline{1}, 172,174,176, \overline{178}, \overline{181}, \overline{182}, \overline{184}$

Heppner, Rudolf $10 \overline{0,106,109}$

Herstal 362

Hitler, Adolf $25, \underline{33}, \underline{69}, \underline{96}, \underline{227}, \underline{228}, \underline{328}, \underline{347}$

Hoboken 102

Hofrichter, $\overline{\text { Helmuth } \quad 51,91,96,98,99}, 109,112,115,117,119,121,139,150,154,167,168$, $169,171,172,173,174,175,176,178,180, \overline{182}, \overline{18} 5,191,196,201,204,210,217,222$, $223,230,284,285,286,288,289,290,304,305,307,308,317,321,322,324,327$, $\overline{335}, 340, \overline{341}, \overline{342}, \overline{352}, 354$

Hopkins, Harry Lloyd $\frac{248}{24}$

Hoppe, Hans 99

House of Lords (Great Britain) $\quad 68$

Huyssens, André 117

\section{I}

Ingenbleek, Jules $\underline{38}, \underline{41}, \underline{42}, \underline{43}, \underline{51}, \underline{52}, \underline{54}, \underline{55}, \underline{59}, \underline{61}, \underline{74}, \underline{75}, \underline{76}, \underline{77}, \underline{78}, \underline{79}, \underline{80}, \underline{81}, \underline{82}, \underline{84}$, $85,117,118,119,120,140,183,185,192,193,195,196,197,204,208,209,210,213$, $218,224,227,239,240,242,254,275,276,277,294, \overline{295}, 298, \overline{302}, 312, \overline{316}, 319$, $\overline{320}, \overline{321}, \overline{324}, \overline{328}, \overline{329}, \overline{349}, \overline{393}, 395, \overline{396}, \overline{410}, \overline{441}, \overline{455}$

International Clearing Union 386

International Monetary Fund (I $\overline{\mathrm{MF}}) \quad \underline{387}, \underline{438}$

International Stabilization Fund 390

Istel, André 404, 406, 407

Italy $160, \underline{416,}, \underline{417}, \overline{438}$

厂

Janssen, Albert-Edouard $22,23,24,25,26,27,28,29,30,35,37,38,39,40,41,44, \underline{45}$, $46,48,49,50,54,55,56,58,59,61,62,64,65,66,67,69,70,71,72,74,75,76,77$, $\underline{78}, \overline{79}, \frac{80}{80}, \frac{81}{82}, \frac{83}{84}, \frac{85}{85}, \frac{86}{86}, \overline{88}, \frac{94}{98}, \frac{101}{104}, 107,111,112,115,116,117,118$, $\overline{119}, 120,121,122,123,124,127,128,129,130,131,132, \overline{133}, 140, \overline{141}, 142,143,144$, $\overline{145}, \overline{150}, \overline{151}, \overline{152}, \overline{153}, \overline{156}, \overline{157}, 158,159,160,161,162,163,164,165,167,168,169$, $\overline{170}, \overline{171}, \overline{172}, \overline{173}, \overline{174}, \overline{175}, \overline{176}, \overline{177}, \overline{178}, \overline{179}, \overline{180}, \overline{183}, \overline{185}, \overline{186}, \overline{187}, \overline{188}, \overline{189}, \overline{190}$, $\overline{191}, 192,193,195,197,198,200,202,203,204,216,217,219,234,236,239,240$, $241,242,243,244,246,247,249,250,259,263,275,278,280,301,314,318,320$, $\underline{323}, 324,330,331,338,355,370,389,392,399,400,410,443,444,446,447,448$,

Japan $\overline{96}$ $\underline{450}, \underline{454}, \underline{455}, \underline{460}, \underline{473}$

Jaspar, Marcel-Henri $\quad 21,22,72,73,234$ 
Jewish register 154

Joassart Committee $\quad 366,367,368$

Joassart, Gustave $362,363,366,367,368$

Jost, Helmuth $\quad 98, \overline{167}, \underline{327}, \underline{328}, \underline{349}$

\section{$\mathrm{K}$}

Kauch, Pierre $\quad 20,21,22, \underline{23}, 24,25, \underline{34}, \underline{35}, \underline{36}, \underline{37}, \underline{38}, \underline{43}, \underline{46}, \underline{47}, 48, \underline{49}, \underline{51}, \underline{52}, \underline{53}, \underline{54}, \underline{56}$, $57,59,60,64,70,75,77,80,89,100,104,109,112,113,114,115,121,128,130,132$, $\frac{133}{13}, 146,149,150,152,158,160,164,170,174,176,177,178,184,186,187,188,189$, $\overline{190}, \overline{191}, \overline{193}, \overline{195}, \overline{197}, \overline{198}, \overline{205}, \overline{208}, \overline{209}, \overline{211}, \overline{212}, \overline{213}, 226,236,242,249,263$, $303,312,320,324,325,355,356, \overline{357}, \overline{358}, 359$

Keynes, John Maynard (Lord) 361, 371, 385, 386, 387, 388, 390

Kiewitz, Werner 69, 227

Kortrijk 93

Kredietbank 16, 38, 100, 118, 124, 161, 202

Kronacker, Paul $\underline{432}$

$\mathrm{L}$

Laloux, Georges 117

Lamoureux, Félicien 36

Landfried, Friedrich $\overline{22} \mathrm{O}, 284$

Laval, Pierre 181,182

League of Nations $\overline{99}$

Leemans, Victor $125,126,199,201,220,226,286,287,288,289,290,294,295,301$, $\underline{302}, \underline{313}, \underline{317}, \underline{346}$

Le Havre $41,42,43$

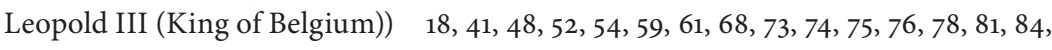
$94,95,96,181,195,196,227,253,254,454$

Leopoldville $18,19, \underline{92}, \underline{233}, \underline{235}$

Le Perthus $87,232,233$

Leuven 15, 20, $95,101,121,329,337$

Lévy, Paul $\overline{371}$

Libourne $29,48,66$

Lieftinck, Pieter $\underline{436}, \underline{438}$

Liège $\quad \underline{33}, \underline{94}, \underline{101}, \underline{102}, \underline{122}, \underline{139}, \underline{338}, \underline{420}$

Limburg 102

Lindau 415

Lippens, Maurice 204

London $16,18,25, \overline{26}, 28,29,30,33,36,42,44,45,47,48,49,62,63,64,65,67,68,69$, $70, \overline{71}, 72,73,74,78, \overline{82}, \overline{83}, 84,85,86,87,88,90,91,92,95,102,117,120,121,122$, $123,124,125,136,152,167,168,169,170,171,174,177,178,179,180,183,186,187$, $\overline{188}, \overline{189}, \overline{190}, \overline{192}, \overline{193}, \overline{195}, \overline{197}, \overline{198}, \overline{202}, 203,210,214,231,232,233,234,235,236$, $237,238,239,240,241,242,243,244,245,246,247,248,249,250,251,252,253$, $254,255,256, \overline{257}, 258,260, \overline{261}, 264,265, \overline{268}, 269,270,271,272,273,274,275$, 
$276,277,279,330,331,338,361,362,363,364,366,367,368,369,370,371,372$, $\frac{373}{375}, \frac{376}{376}, \frac{377}{378}, \frac{379}{379}, \frac{380}{381}, \frac{382}{383}, \frac{384}{385}, \frac{386}{386}, \frac{388}{389}, \frac{390}{390}, \frac{391}{391}$ $\frac{392}{493}, 394,395,396,397,398,399,400,401,404,406,407,408,410,418,419$, $\underline{420}, \underline{427}, 428,430,431, \underline{432}, \underline{433}, \underline{435}, \underline{436}, \underline{438}, \underline{439}, \underline{441}, \underline{443}, 446, \underline{447}, 452,454$, $455,456,457,458,459$

Lorient $\frac{62}{6}, 63, \overline{67}, 88$

Luxembourg $9 \overline{6}, 97,161,191,192,193,216,274,275,276,277,376,377,378,379,380$, $\underline{381}, \underline{409}, \underline{410}, \underline{411}, \underline{413}, \underline{414}, \underline{417}, \underline{455}$

\section{$\mathrm{M}$}

Mahieu, Louis-Jean $\quad \underline{25}, \underline{117}$

Malmédy 33

Marcq, René 142, 143, 179, 183, 185, 190, 202, 207, 210, 213, 254, 255, 269, 287, 297, 298, $300,305,308,309,315,318,319,397$

Marocco 184

Marseilles $175,176,180,181,184$

Martial, Jean $2 \overline{64}, \overline{266}, \overline{267}, \overline{269}, 272,273,278,405,411$

McKittrick, Thomas $75,716, \overline{259}, \overline{260}, \frac{261}{406}$

Mendès-France, Pierre $\underline{405}, \underline{406}, \overline{407}, \underline{436}$

Merkers 414, 415

Mers-el-Kébir $\underline{88}, \underline{167}$

Middle East $\underline{96}$

Möckel, Helmut 100, 109

Moevus 62, $6 \underline{3}$

Monick, Emmanuel $\underline{414}$

Monnet, Jean 280, 404, $\underline{405}, \underline{438}, \underline{439}$

Mons 34, 40

Mont-de-Marsan $\underline{43}, \underline{48}, \underline{52}, \underline{54}, \underline{59}, \underline{61}, \underline{70}, \underline{75}, \underline{76}, 77,79,80,81,82,84,85,116,117,119$, $120,127,239,242,254,256$

Montgomery, Bernard Law (Lord) $\quad \underline{428}$

Moreton 71,72

Mulier, Arthur $\underline{117}$

$\mathrm{N}$

Navy (British) $65,66,90$

Navy (French) $\overline{62}, \overline{64}, \overline{67}, 70,86,266$

Nederlandsche Bank $1 \overline{16}, 102, \overline{140}, \overline{163}, 164,201,292,318,352,353,377,378,436,447$

New York $19,26,28,29, \overline{30}, 63,65, \overline{69}, \overline{70}, \overline{71,77}, \overline{81}, \overline{82}, 83,85,86, \overline{87}, \overline{88}, 91,118,187$, $188,189,190,198,237,238,239,240,241,243,244,245,246,247,248,249,250$, $\overline{251}, \overline{254}, \overline{255}, \overline{256}, \overline{259}, \overline{260}, \overline{261}, \overline{263}, \overline{264}, \overline{265}, \overline{266}, \overline{267}, \overline{268}, \overline{269}, \frac{270}{271}, \overline{272}$, $\frac{273}{274}, \frac{275}{276}, \frac{277}{278}, \frac{279}{280}, \frac{281}{361}, \frac{363}{3666}, 367,368,370,371,373$, $\underline{375}, 376,377,379,380,387,388,389,390,393,394,396,398,401,403,404,405$, $406,407,408,409,411,413,446,455,456,457$

Nieuwpoort $\underline{42}$ 
Nisot, Joseph $\quad 251,263,267,268,273,275,276,279,390,393,394,405,406,407,411$,

Nivelles $\stackrel{413}{40}$

Normandy $351,405,428$

Norman, Montagu 66, 70, 243

North Africa $63,28 \overline{0}, 376, \overline{391}, 403$

Northern France $35,96,97,100,112,135,141,142,200,203,221,327,328$

Norway $63,112,160,449$

Nuyens, Leopold $\overline{117}$

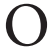

Onslow $\underline{65}, \underline{66}, \underline{67}, \underline{68}$

Oran $18 \overline{4,187}$

Ostend $\underline{31}, \overline{38}, \underline{39}, \underline{40}, \underline{41}, \underline{42}, \underline{43}, \underline{44}, \underline{65}, \underline{233}$

Ottawa $26,70,244$

Oujda $\underline{184}$

$\mathrm{P}$

Paris $16,29,35,36,41,43,44,47,49,53,59,61,62,64,71,72,78,84,88,125,126,167$, $170,172,173,176,177,179,181,184,187, \overline{188}, 189,190,221,232,241,264, \overline{265}, 268$, $\overline{269}, \overline{273}, \overline{277}, 281,350,351,352,381,407,408,414,415,416,418,420$

Patoor, Walter 43

Pearl Harbor $2 \overline{70}$

Peltzer, André $\quad \frac{257}{297}, 396,398,399,431$

Pétain, Philippe $63,68,72,85,88$

Pholien, Joseph $\quad 314, \overline{319}, 456$

Pierlot, Hubert $17,18,19,27,29,44,48,72,73,74,84,87,94,190,233,237,249,250$, $254,271, \underline{366}, \underline{372}, \underline{388}, \underline{390}, \underline{395}, \underline{407}, \underline{423}, \underline{427}, \underline{435}$

Pirsoul 114

Pleven, René $\quad 368, \underline{436}$

Plisnier, Oscar $20,45,61,64,71,77,80,81,82,107,111,112,113,114,117,120,124,125$, $140,141, \overline{142}, \overline{143}, \overline{144}, 145,151, \overline{155}, \overline{157}, 162,165,168,169,170, \overline{171}, \overline{180}, \overline{181}, \overline{185}$, $\overline{195}, \overline{196}, \overline{198}, \overline{199}, 203,204,205,210,211,212,213,214,218,223,224,226,227$, $228,229,230,249,250,254,255,256,259,286,287,288,289,295,301,302,304$, $307,308,312,313,314, \underline{315}, 316, \underline{317}, 318,319,320,321,322,323,339,340,348,447$, $448, \frac{457}{42}$

Plymouth $\underline{42}, 65$

Poitiers $44, \underline{48}, 61,64$

Polak, Jacques J. $377,378,390$

Poland 19, 21, 22, 89, $96,98,99,109,417$

Portugal $84,260,415,416,427$

Postal Cheque Office $23,38,91,93,94,106,129,132,139,331,356,363,421,426,429$

Prack, Herbert $96,97,98,99,117,119,120,121,122,123,124,125,129,130,176,180,197$, 198, 200, 204, 205, 206, 212, $320,327,329,349$ 
Prussian Mint 415

Puhl, Emile 114, 152, 229, 230, 414, $\underline{415}$

\section{$\mathrm{R}$}

Reeder, Eggert $\quad 96,97,126,130,134,140,141,143,144,145,180,201,203,205,212,214$, $220,223,226,227,230,286,288,294,301,302,303,304,305,306,311,312,313$, $315,316,317,318, \underline{321}, \underline{322}, \underline{323}, \underline{324}, \underline{327}, 328,333,349$

Reichsbank $31,75,81,98,99,100,109,110,112,114,127,150,151,152,154,158,159,160$, $163,18 \overline{0}, 181, \overline{18} 2,183,185,188,191,192,216,229,259,264, \overline{265}, \overline{275}, \overline{276}, \overline{277}, \overline{278}$,

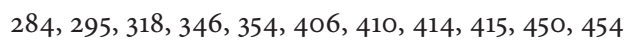

Reichskreditkasse (scheine) $56,79,110,140,149,216,217,218,221,222,223,290,291$, $300,303,333,341,346, \underline{353}, 354$

Rens, Jef $361,366,371,380,385$

Reynaud, Paul $\frac{35}{36}, \frac{37,48}{48}$

Reynaud-Simon monetary agreement 35,36

Rhineland-Westphalia $\underline{96}, 97$

Rochat 87

Rolin, Hēnri $\quad 24,25,94,104,127,142,143,151,153,179,183,193,255,279$

Roosevelt, Franklin Delano 248,455

Rost van Tonningen, Meinaud $\overline{\mathrm{M}} . \overline{16}$, 353, 447

Rouen 420

Rueff, Jacques $\quad 56,67,88$

Rumania $160,272,415$

Ryckmans, Pierre 73, 231, 234, 236

S

Sainte-Adresse 43

Sancery $264,26 \overline{6}, 267,409,410$

Sauckel, Fritz $\underline{328}$

Saumur 61

Sauveterre-en-Guyenne $\quad \underline{61}, 64$

Schacht, Hjalmar $284,38 \overline{7}$

Schäfer, Carl $167, \overline{172}, 176,179,181,182,269$

Scheyven, Hubert $\underline{113}, \underline{338}$

Schleswig 97

Schlumprecht, Karl 228, 229, 230

Senate $\frac{442}{89}$

Senegal $\frac{49}{89}, 167$

Siepmann, Arthur $243,244,248$

Sierra Leone 90, 91

Smeers, Leopold $\underline{45}, 54,61,64$, 84 $, \underline{92}, 119,146,157,213,314,315,325,355,358, \underline{396}$, $402,419,430,446$

Snoy et d'O ppuers, Jean-Charles 126

Société Belge de Banque 123 
Société Coopérative d'Avances et de Prêts 101 Société française de banque et de dépôts 155

Société Générale $\quad 23,34,38,39,75,94,100,101,102,103,105,114,122,123,132,136$, $146,151,186,187,201,202,203,209,246,255,303,316,328,335,338,437,4,427$, $441,442,446,447,451,452$

Socrates (Belgian Resistance cell) 338

Sontag, Henri 25, 26, 38, 40, 114, 396, 402, 415

South African Reserve Bank $\overline{30}, \overline{69}, \frac{91}{36}$

Spaak, Paul-Henri 18, 19, 29, $36,36,39,53,57,84,87,101,189,233,235,237,273,281$, $361,370,371,372,373,376, \underline{379}, \underline{380}, \underline{390}, \underline{404}, 406,407,408,441,4414,446,4$

Spain $\frac{415}{416}, \underline{427}$

Speer, Albert 328,347

State Department $\overline{266}, 269,370$

Struye, Paul $93,95,103, \overline{131}, 142,143,283,338$

Sudan 89,184

Sudetenland 21

Sullivan \& Cromwell 265

Supreme Headquarters Allied Expeditionary Force (SHAEF) $\quad 393$

Sweden 160, 415, 416, 427

Switzerland $\underline{26}, \underline{77,}, \underline{160}, \underline{255}, \underline{260}, \underline{416}, \underline{427}$

$\mathrm{T}$

Taft, Robert 387

Tarbes $43,48,52,59,71,84,85,172,177$

Taylor (US-Treasury) 391

The Hague 16, 102

Theunis, Georges $19,49, \underline{44}, \underline{57}, 63,65,68,69,76,82,83,118,168,187,189,190,192$, $233,237,238,239,240,241,242,244,245,246,247,248,250,251,252,253,254$, $\frac{255}{257}, \frac{260}{261}, \frac{263}{264}, \overline{265}, \overline{266}, \overline{270}, \frac{271}{272}, \frac{273}{274}, 275, \frac{276}{277}, \frac{279}{27}$, $\overline{280}, \overline{281}, \overline{361}, \overline{363}, \overline{366}, \overline{367}, \overline{368}, \overline{369}, \overline{370}, \overline{371}, \overline{373}, 375, \overline{376}, \overline{377}, 379, \overline{380}, \overline{387}$, $\overline{388}, \overline{389}, 390,392,393,394,396,397,398,401,402,405,406,408,409,411,413$, $446,454,456$

Thiès $\overline{88,89}$

Tinbergen $\overline{\operatorname{Plan}} \quad 438$

Todt, Fritz 283, 289,352

Todt Organization $2 \overline{289}, 352$

Toulouse $43,48, \underline{42}, \underline{59}, \underline{84}, \underline{85}, \underline{172}, \underline{177}, \underline{187}, 263$

Trip, L.J.A. $140,164,447$

Truffaut, Georges J.

Tschoffen, Paul 101, 104, 111, 114, 196

U

United Nations Relief and Rehabilitation Administration (UNRRA) 404

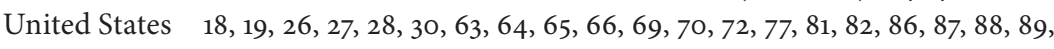


$101,169,185,187,188,236,244,249,263,264,270,271,274,279,280,283,362$, $\overline{370}, \overline{375}, \overline{385}, \overline{386}, \overline{392}, \overline{40}, \overline{432}, 439$

Université Libre de Bruxelles $\frac{20}{121}, \frac{125}{125}$

University of Louvain $124, \underline{325}$

$\mathrm{V}$

van den Broek, Johannes $375,376,377,378,380,381,383,388$

Vandeputte, Robert 15, 98, 122, 325, 328, 329, 330, 333, 334, 336, 337, 343, 345, 348, 351, $352,354,396,397,398,400,402,442,460$

Van Dievoet, Emile 101, 207

Van Goethem, Fernand $\underline{18}, \underline{48}, 68,73,75,95,96,117,181$

van Harinxma thoe Slooten, Binnert Philip $\underline{44}, \underline{48}, \underline{95}, \underline{420}, \underline{427}, 430,433$

Van Langenhove, Fernand 385

Van Nieuwenhuyse, Jean $\quad 20,43,84,85,117,118,119,120,121,122,196,197,224,254$, $294,295,297,298,299,300,301,302,303,309,313,314,317,318,319,322,3,3$, $324,325,340,398, \frac{302}{402}$

Van Paemel, Jules 358

Van Zeeland, Paul 18 , 232, 251, 252, 361, 362, 363, 364, 365, 366, 367, 368, 369, 370, 371, $\underline{433}, \underline{458}$

Vaxelaire, Raymond (baron) 101

Velge, Henri 39

Verrechnungskasse 110, 128, 156, 158, 159, 160, 161, 163, 165, 214, 221, 222, 225, 291, 292, $293,332,333,352,387,400,444,445,447,448,450$

Vichy $\quad 45,58,61,70,71,76,77,79,80,81,82,84,75,86,87,88,89,95,116,118,123,168$, $169,171,181,185,232,233,234,236,241,242,264,266,269,273,277,278,279$, 404

Vienna 99,119

Vincent, Jean-Jacques $20,105,146,208,355$

von Becker, Hans $96,9 \overline{8}, 109,111,112,114,115,117,130,133,141,150,151,161,163,164$, $167,168,169,170,171,172,173,174,176,178,179,180,182,183,198,218,221,224$, $\overline{285}, \overline{286}, \overline{302}, 308,327,346$

von Craushaar, Harry $96,141,223,225$

von Falkenhausen, Alexander $\overline{77}, \overline{96}, 97,99,134,180,183,196,201,203,205,213,218$, $228,284,286,289,290,303,320,328,346,457,460$

von Lumm, $\overline{\text { Karl }} \overline{97}$

von Ribbentrop, Joachim 181

von Rundstedt, Karl, Rudolf, Gerd $\quad \underline{413}, \underline{428}$

$\mathrm{W}$

Waley, Sir David S. $36,91,245,246,248,381,382,383,384,391$

Washington (D.C.) $\overline{16}, \overline{19}, \overline{26}, 2 \overline{66}, 2 \overline{69}, 270,272,274,277,278,279,372,377,378,381$, $385, \underline{387}, 388,389, \underline{390}, \underline{391}, \underline{392}, \underline{397}, \underline{40}, \underline{405}, \underline{416}, \underline{428}, \underline{432}, \underline{438}$

Wauters, Joseph 234

Wehrmachtverrechnungskasse $\underline{305}, \underline{306}, \underline{313}, \underline{333}, \underline{341}, \underline{348}, \underline{349}$ 
Werbestelle 336, 337

White, Harry Dexter $386,387,388,389,390,391,392,432$

White Plan 386, 387

Wiesbaden Convention 176, 179, 182, 183

Witt 107

Wittlich 329

Wood, Sir Kingsley 4 47, 245, 247, 249

World Bank 387, 390

Y

Young, Norman E. $\quad 66, \underline{67}, \underline{68}, \underline{257}$

Young Plan $\underline{257}$

Yugoslavia $\underline{160}, \underline{417}$ 